\title{
AVALIAÇÃO DA DUCTILIDADE DE PILARES DE CONCRETO ARMADO, SUBMETIDOS À FLEXO- COMPRESSÃO RETA COM E SEM ADIÇÃO DE FIBRAS METÁLICAS
}

\author{
Tese apresentada à Escola de \\ Engenharia de São Carlos, da \\ Universidade de São Paulo, como \\ parte dos requisitos para a obtenção \\ do título de Doutor em Engenharia \\ de Estruturas.
}

Orientador: José Samuel Giongo

Departamento de Engenharia de Estruturas

Escola de Engenharia de São Carlos Universidade de São Paulo

São Carlos, Maio de 2003 
"Sou fio das mata, cantô da mão grossa, Trabáio na roça, de inverno e de estio. A minha chupana é tapada de barro, Só fumo cigarro de páia e de mio...

...Não tenho sabença, pois nunca estudei, Apenas eu sei o meu nome assiná. Meu pai, coitadinho! vivia sem cobre, E o fio do pobre não pode estudá.

Meu verso rastêro, singelo e sem graça, Não entra na praça, no rico salão, Meu verso só entra no campo e na roça Nas pobre paioça, da serra ao sertão.

...Eu canto o vaquêro vestido de côro, Brigando com o tôro no mato fechado, Que pega na ponta do brabo novio, Ganhando lugio do dono do gado.

Eu canto o mendigo de sujo farrapo, Coberto de trapo e mochila na mão, Que chora pedindo o socorro dos home, E tomba de fome, sem casa e sem pão.

E assim, sem cobiça dos cofre luzente, Eu vivo contente e feliz com a sorte, Morando no campo, sem vê a cidade, Cantando as verdade das coisa do Norte."

Patativa do Assaré

Aos milhões de Brasileiros que jamais tiveram $e$ terão acesso a SABENÇA, e que mesmo assim são os sábios do nosso país;

Aos meus pais, Humberto C. Lima e Maria Zelma M. Lima;

Aos meus irmãos, Maurício Lima e Márcia Lima; e

E em especial à minha esposa Michele Lima. 


\section{AGRADECIMENTOS}

A Deus que sempre se fez presente nesta longa caminhada, que é a vida.

Ao Povo Brasileiro que por intermédio da CAPES e FAPESP financiou este trabalho.

Ao Professor José Samuel Giongo pela orientação, dedicação e amizade desenvolvida ao longo deste trabalho.

Aos meus pais e irmãos que mesmo na distância me acompanharam e que sempre serão merecedores de todo o meu carinho

À Michele Lima, o grande amor de minha vida, que com carinho e dedicação sempre se fez presente.

A todos meus amigos do SET, em especial à: Rodrigo, Fernando, Romel, Reginaldo, Joel, Ricardo Dias e Ricardo Carrazedo.

Aos funcionários e amigos do Laboratório de Estruturas, Amauri, Fabiano, Jorge, Mário, Mauri, Valdir e Luiz, que foram indispensáveis na realização dos ensaios experimentais deste trabalho.

A todos os funcionários do Departamento de Engenharia de Estruturas da Escola de Engenharia de São Carlos - USP, em especial a Maria Nadir Minatel.

Aos professores do Departamento de Estruturas da EESC.

Aos professores da Área de Estrutura da Universidade Estadual do Oeste do Paraná que colaboraram para o meu afastamento para doutoramento, em especial ao Professor e Amigo Fabio Luis Willrich.

Às empresas: Camargo Corrêa Cimentos S.A., Belgo Mineira Bekaert Arames Finos Ltda. e a Reax Industria e Comercio Ltda., pela doação de material essencial ao desenvolvimento da pesquisa. 
Lista de figuras

Pág.

Lista de tabelas

VII

Lista de símbolos

$\mathrm{XX}$

Resumo

XXII

Abstract

XXVI

XXVIII

Capítulo I - Introdução

1.1. CONSIDERAÇÕES INICIAIS

1.2. OBJETIVO

1.3. JUSTIFICATIVA

4

1.4. CONTEÚDO DA TESE

5

6

Capítulo II - Modelos para o concreto confinado 10

2.1. INTRODUÇÃO

2.2 FATORES QUE INFLUENCIAM NO COMPORTAMENTO DOS PILARES DE $C A R$

2.2.1. Resistência do concreto

2.2.2. Cobrimento

2.2.3. Geometria, taxa, diâmetro e espaçamento da armadura transversal

2.2.4. Taxa e diâmetro da armadura longitudinal

2.2.5. Tensão de escoamento da armadura transversal

2.3. COMPORTAMENTO DO CONCRETO À COMPRESSÃO CENTRADA 18

2.3.1. Histórico

2.3.2. Equações constitutivas do concreto confinado e nãoconfinado

2.3.3. Modelos para o concreto de alta resistência

2.3.4. Modelo de Cusson e Paultre (1995) 27

2.4. COMPORTAMENTO DO CONCRETO À COMPRESSÃO EXCÊNTRICA

Capítulo III - Concreto reforçado com fibra de aço 39

3.1. CONSIDERAÇÕES INICIAIS 39

3.2. FATORES QUE INFLUENCIAM AS PROPRIEDADES MECÂNICAS DO CRFA 40

3.2.1. Fatores relacionados às matrizes cimentícias 40

3.2.2. Fatores relacionados às fibras de aço $\quad 42$

3.3. COMPORTAMENTO À COMPRESSÃO DO CRFA 47

3.4. COMPORTAMENTO À TRAÇÃO DO CRFA

3.5. COMPORTAMENTO À FLEXÃO DO CRFA 
Capítulo IV - Implementações computacionais, metodologias de avaliação da ductilidade e modelagens

4.1. PROGRAMA COMPUTACIONAL

4.1.1. Procedimentos de implementação das leis constitutivas do material

4.1.2. Leis constitutivas para o concreto confinado

4.1.3. Leis constitutivas para o concreto não-confinado

4.1.4. Leis constitutivas para a armadura

4.2. METODOLOGIAS DE QUANTIFICAÇÃO DA DUCTILIDADE

4.2.1. Metodologia proposta 68

4.3. MODELAGEM À COMPRESSÃO DO CRFA

Capítulo $\boldsymbol{V}$ - Estudos paramétricos $\quad 75$

5.1. COMENTÁRIOS INICIAIS

5.2. LIMITE MÍNIMO DE DUCTILIDADE PARA OS CAR 76

5.2.1. Variação da ductilidade com a resistência do concreto 77

5.2.2. Variação da ductilidade com a resistência do concreto, a taxa de armadura transversal, a taxa de armadura longitudinal $e$ geometria da seção transversal

5.2.3. Variação da ductilidade com o índice de reforço da adição de fibras

5.2.4. Comportamento à flexo-compressão dos pilares confinados 96

5.3. PRINCIPAIS OBSERVAÇÕES DOS ESTUDOS PARAMÉTRICOS 100

Capítulo VI - Programa experimental 102

6.1. PLANEJAMENTO EXPERIMENTAL 102

6.2. MATERIAIS UTILIZADOS 104

6.2.1. Concreto 104

6.2.2. Fibras de aço 107

6.2.3. Aço das armaduras $\quad 108$

6.3. METODOLOGIA EMPREGADA 109

6.3.1. Condições de contorno dos pilares $\quad 109$

6.3.2. Ensaios à compressão centrada $\quad 114$

6.3.3. Ensaios à compressão excêntrica 119

Capítulo VII - Análise e discussão dos resultados dos pilares 125

7.1 CARACTERÍSTICAS DO CONCRETO

7.1.1. Comportamento geral $\quad 125$

7.1.2. Diagrama tensão vs. deformação do concreto 126

7.2.PILARES SUBMETIDOS À COMPRESSÃO CENTRADA 132

7.2.1. Comportamento global dos pilares $\quad 132$

7.2.2. Forças últimas dos pilares e variação da tensão no concreto 136

7.2.3. Deformações na armadura transversal 144

7.2.4. Avaliação do modelo de Cusson e Paultre (1995) 148 
7.2.5. Avaliação da ductilidade dos pilares

151

7.3.MODIFICAÇÃO DO MODELO DE CUSSON E PAULTRE (1995)

156

7.3.1.Avaliação da deformação na armadura transversal 162

7.3.2. Procedimento para modelagem do pilares $\quad 165$

7.4.CONCLUSÕES PARCIAIS 168

Capítulo VIII - Análise e discussão dos resultados dos pilares 170 ensaiados à compressão excêntrica

8.1.CONSIDERAÇÕES INICIAIS 170

8.2. CARACTERÍSTICAS DO CONCRETO 170

8.2.1. Comportamento à compressão $\quad 170$

8.2.2. Comportamento à tração $\quad 175$

8.3.PILARES SUBMETIDOS À COMPRESSÃO EXCÊNTRICA 177

8.3.1. Comportamento global dos pilares $\quad 177$

8.3.2. Avaliação do sistema de apoio 181

8.3.3. Armadura longitudinal $\quad 185$

8.3.4. Deformações na armadura transversal 186

8.3.5. Avaliação da capacidade resistente dos pilares $\quad 191$

8.3.6. Avaliação da ductilidade dos pilares 201

8.4.EFEITO DA FLEXÃO NO CONFINAMENTO DO CONCRETO

8.5. CONCLUSÕES PARCIAIS

$\begin{array}{ll}\text { Capítulo IX - Conclusões } & 217\end{array}$

Referências Bibliográficas $\quad 223$

Apêndice A 240

Apêndice B 292 
Figura 2.1 - Comportamento esquemático dos pilares de concreto de alta resistência sob compressão centrada (ACI-441, 1997).

Figura 2.2 - Mecanismo de destacamento do cobrimento (Foster et alii, 1998).

Figura 2.3 - Áreas efetivas de confinamento (Park e Paulay, 1975).

Figura 2.4 - Distribuição das tensões de confinamento nas seções transversais e ao longo do pilar.

Figura 2.5 - Modelo proposto por Chan (1955).

Figura 2.6 - Modelo proposto por Roy e Sozen (1964).

Figura 2.7 - Modelo proposto por Sargin et alii (1971).

Figura 2.8 - Modelo proposto por Kent e Park (1971).

Figura 2.9 - Modelo proposto por Sheikh e Uzumeri (1982). 22

Figura 2.10 - Modelo proposto por Saatcioglu e Rasvi (1992). 22

Figura 2.11 - Distribuição da tensão de confinamento no concreto.(Sheikh e Uzumeri, 1982)

Figura 2.12 - Diagrama tensão vs. deformação para o concreto confinado proposto por Cusson e Paultre (1995).

Figura 2.13 - Distribuição da pressão lateral promovida pela armadura de confinamento para pilares submetidos à compressão excêntrica (a) e centrada (b).

Figura 2.14 - Distribuição das pressões laterais das vigas $2(a), 3(b)$ e 4 (c), calculadas por Delalibera (2002).

\section{Capítulo III}

Figura 3.1 - Planos direcionais dos alinhamentos das fibras conforme a direção da vibração. (Bentur e Mindess, 1990)

Figura 3.2 - Efeito do comprimento e da tensão de aderência na energia de arrancamento da fibra e na eficiência do reforço da fibra.

Figura 3.3 - Comparação entre o modelo de Ezeldin e Balaguru (1992) e dados experimentais.

Figura 3.4 - Comportamento do modelo sugerido por Balaguru e Shah (1992) para o CRFA submetido à tração.

Figura 3.5 - Diagrama esquemático do equilíbrio de forças em uma seção transversal de um modelo submetido à flexão. (Armelin e Banthia, 1997)

Figura 3.6 - Valores das constantes $A, B, C$ e Ep para diversos ângulos de orientação das fibras. (Armelin e Banthia, 1997)

Figura 3.7 - Comparação o modelo de proposto por Armelin e Banthia (1997) e resultados experimentais. 


\section{Capítulo IV}

Figura 4.1 - Elemento finito utilizado e sistemas de coordenadas naturais (a) e auxiliar (b).

Figura 4.2 - Algoritmo utilizado pelo programa para a análise de uma estrutura em uma etapa de carregamento.

Figura 4.3 - Detalhes do sistema de coordenada local.

Figura 4.4 - Domínio de integração da seção transversal analisada.

Figura 4.5 - Parametrização de um segmento da poligonal.

Figura 4.6 - Diagramas de concretos com e sem adição de fibras (Lima Jr. e Giongo, 2001).

Figura 4.7 - Metodologia de avaliação da ductilidade proposta por Laurent (1989).

Figura 4.8 - Metodologia do índice de ductilidade pós-pico.

Figura 4.9 - Convalidação do modelo proposto para modelar o comportamento do CRFA à compressão.

Figura 4.10 - Convalidação do modelo proposto para modelar o comportamento do CRFA à compressão.

\section{Capítulo $V$}

Figura 5.1 - Curvas dos índices de ductilidade vs. resistência do concreto, FIB-CEB.

Figura 5.2 - Curvas dos índices de ductilidade vs. resistência do concreto, Popovics.

Figura 5.3 - Disposição da armadura de confinamento do CAR para a fase 1 .

Figura 5.4 - Curvas paramétricas tensão vs. deformação do concreto para resistência C60.

Figura 5.5 - Curvas paramétricas tensão vs. deformação do concreto para resistência C80.

Figura 5.6 - Curvas paramétricas tensão vs. deformação do concreto para resistência C100.

Figura 5.7 - Disposição da armadura de confinamento do CAR para fase 2.

Figura 5.8 - Curvas paramétricas tensão vs. deformação do concreto para seção transversal com $b / h=1,0$.

Figura 5.9 - Curvas paramétricas tensão vs. deformação do concreto para seção transversal com $b / h=1,5$.

Figura 5.10 - Curvas paramétricas tensão vs. deformação do concreto para seção transversal com $b / h=2,0$.

Figura 5.11 - Curvas paramétricas tensão vs. deformação do CRFA com resistência à compressão de 60MPa.

Figura 5.12 - Curvas paramétricas tensão vs. deformação do CRFA com resistência à compressão de 80MPa.

Figura 5.13 - Curvas paramétricas tensão vs. deformação do CRFA com resistência à compressão de $100 \mathrm{MPa}$. 
Figura 5.14 - Curvas paramétricas tensão vs. deformação do CRFA com adição de taxas volumetrias ótimas e do C30 sem adição de fibras.

Figura 5.15 - Curvas vvs. $\mu$ para diferentes resistências de concreto.

Figura 5.16 - Curvas $v$ vs. $\mu$ para resistência do concreto de 60MPa e espaçamento entre estribo de $15 \mathrm{~cm}$ e $5 \mathrm{~cm}$.

Figura 5.17 - Curvas v vs. $\mu$ para resistência do concreto de 80MPa e espaçamento entre estribo de $15 \mathrm{~cm}$ e $5 \mathrm{~cm}$.

Figura 5.18 - Pilares ensaiados por Lloyd e Rangan (1996).

Figura 5.19 - Diagrama vvs. $\mu$ para os pilares ensaiados.

Figura 5.20 - Curva parametrizada força vs. deslocamento dos pilares ensaiados experimentalmente segundo o modelo FIB (1999)-CEB (1990).

\section{Capítulo VI}

Figura 6.1 - Diagrama de dosagem para o concreto de alta resistência. 106

Figura 6.2 - Diagrama de dosagem para o concreto de resistência usual. 107

Figura 6.3 - Diagrama tensão vs. deformação do aço com diâmetro de $6,3 \mathrm{~mm}$.

Figura 6.4 - Diagrama tensão vs. deformação do aço com diâmetro de $12,5 \mathrm{~mm}$.

Figura 6.5 - Características da montagem do mecanismo de apoio.

Figura 6.6 - Características do mecanismo de apoio - Peça 1.

Figura 6.7 - Características do mecanismo de apoio - Peça 2.

Figura 6.8 - Características do mecanismo de apoio - Peça 3.

Figura 6.9 - Características do mecanismo de apoio - Peça 4.

Figura 6.10 - Características do mecanismo de apoio - Peça 5.

Figura 6.11 - Características do mecanismo de apoio - Peça 6.

Figura 6.12 - Características geométricas das armaduras dos pilares.

Figura 6.13 - Características geométricas das fôrmas dos pilares ensaiados à compressão centrada (medidas em $\mathrm{mm}$ ).

Figura 6.14 - Detalhes da instrumentação dos pilares ensaiados à compressão centrada.

Figura 6.15 - Características das armaduras dos pilares ensaiados a flexocompressão.

Figura 6.16 - Planta das fôrmas dos pilares ensaiados a flexo-compressão (medidas em $\mathrm{mm}$ ).

Figura 6.17 - Detalhes da instrumentação dos pilares ensaiados à flexocompressão.

Figura 6.18 - Detalhes da instrumentação dos pilares ensaiados à flexocompressão

Figura 6.19 - Detalhes do ensaio à compressão excêntrica

\section{Capítulo VII}

Figura 7.1 - Detalhes dos ensaios de compressão dos corpos-de-prova cilíndricos e do prisma de concreto simples

Figura 7.2 - Diagramas tensão vs. deformação do concreto com resistência $40 \mathrm{MPa}$ 
Figura 7.3 - Diagramas tensão vs. deformação do concreto com resistência $60 \mathrm{MPa}$ e $V_{f}=0,0 \%$

Figura 7.4 - Diagramas tensão vs. deformação do concreto com resistência $60 M P$ a e $V_{f}=0,5 \%$

Figura 7.5 - Diagramas tensão vs. deformação do concreto com resistência $60 \mathrm{MPa}$ e $V_{f}=1,0 \%$

Figura 7.6 - Diagramas tensão vs. deformação do concreto com resistência $80 \mathrm{MPa}$ e $V_{f}=0,0 \%$

Figura 7.7 - Diagramas tensão vs. deformação do concreto com resistência $80 \mathrm{MPa}$ e $V_{f}=0,5 \%$

Figura 7.8 - Diagramas tensão vs. deformação do concreto com resistência $80 M P$ a e $V_{f}=1,0 \%$

Figura 7.9 - Detalhes das extremidades dos pilares durante e após ensaio

Figura 7.10 - Detalhes do descolamento dos cobrimentos nos pilares com e sem adição de fibras de aço

Figura 7.11 - Plano de cisalhamento de ruptura dos pilares

Figura 7.12 - Variação do coeficiente $k_{2}$ com a resistência do concreto de acordo com o ACI (1989), NBR (1989) e Fusco (1989

Figura 7.13 - Diagramas deformação na armadura transversal vs. deformação dos pilares com concretos com resistência de 60MPa

Figura 7.14 - Diagramas deformação na armadura transversal vs. deformação dos pilares com concretos com resistência de $80 \mathrm{MPa}$

Figura 7.15 - Diagramas tensão no concreto vs. deformação dos pilares sem adição de fibra

Figura 7.16 - Diagramas paramétricas tensão no cocreto vs. deformação dos pilares com concretos com resistência média de 60MPa

Figura 7.17 - Diagramas paramétricas tensão no cocreto vs. deformação dos pilares com concretos com resistência média de 80MPa

Figura 7.18 - Variação de $k_{22}$ em relação ao índice de reforça da adição de fibra de aço

Figura 7.19 - Variação de $k_{22}$ em relação a pressão efetiva de confinamento

Figura 7.20 - Variação do ganho de resistência em relação ao índice de confinamento

Figura 7.21 - Variação do ganho de deformação ec0,5fcf em relação ao indice de reforço

Figura 7.22 - Comportamento esquemático dos pilares de concreto de alta resistência sob compressão centrada (ACI-441, 1997)

Figura 7.23 - Variação da deformação na armadura transversal em relação ao índice de confinamento, para o ponto A no diagrama força vs. deslocamento axial dos pilares

Figura 7.24 - Procedimento de modelagem por meio do modelo modificado de Cusson e Paultre (1995)

Figura 7.25 - Modelagem dos pilares ensaiados na presente tese com $60 M P a$, por meio do modelo modificado de Cusson e Paultre (1995)

Figura 7.26 - Modelagem dos pilares ensaiados na presente tese com 60MPa, por meio do modelo modificado de Cusson e Paultre (1995) 


\section{Capítulo VIII}

Figura 8.1 - Diagramas tensão vs. deformação do concreto com resistência $40 \mathrm{MPa}$

Figura 8.2 - Diagramas tensão vs. deformação do concreto com resistência $60 M P$ a e $V_{f}=0,0 \%$

Figura 8.3 - Diagramas tensão vs. deformação do concreto com resistência $60 \mathrm{MPa}$ e $V_{f}=0,5 \%$

Figura 8.4 - Comparação entre os diagramas tensão vs. deformação do concreto com resistência 40MPa com o modelo proposto

Figura 8.5 - Comparação entre os diagramas tensão vs. deformação do concreto com resistência 60MPa com o modelo proposto

Figura 8.6 - Comparação entre os diagramas tensão vs. deformação do concreto com resistência $60 \mathrm{MPa}$ e $V_{f}=0,5 \%$ com o modelo proposto

Figura 8.7 - Detalhes do ensaio à flexão do concreto

Figura 8.8 - Diagramas tensão de tração vs. deformação do concreto com resistência 40MPa

Figura 8.9 - Diagramas tensão de tração vs. deformação dos concreto com resistência 60MPa e, com e sem adição de fibras

Figura 8.10 - Detalhes do modo de colapso dos pilares submetidos à compressão excêntrica

Figura 8.11 - Detalhes do descolamento dos cobrimentos nos pilares com e sem adição de fibras de aço e submetidos à compressão excêntrica

Figura 8.12 - Diagramas forçca vs. momentos fletores dos pilares com concretos $C 60$ e $V_{f}=0,0 \%$, e submetidos a excentricidades de $1 \mathrm{~cm}$ e $2 \mathrm{~cm}$

Figura 8.13 - Diagramas forçca vs. momentos fletores dos pilares com concretos $C 60$ e $V_{f}=0,5 \%$, e submetidos a excentricidades de $1 \mathrm{~cm}$ e $2 \mathrm{~cm}$

Figura 8.14 - Disposição dos extensômetros na armadura transversal

176

180

Figura 8.15 - Diagramas força paramétrica $v$ s. excentricidade relativa dos pilares submetidos à flexo-compressão

Figura 8.16 - Diagramas força paramétrica vs. excentricidade relativa para pilares com concretos de 20MPa e 40MPa segundo o FIB (1999)

Figura 8.17 - Diagramas momento vs. curvatura dos pilares com $f_{c j}=60$, $s=15 \mathrm{~cm}$ e $V_{f}=0 \%$, e modelados pelo FIB (1999)

Figura 8.18 - Diagramas momento vs. curvatura dos pilares com $f_{c j}=60$, $s=5 \mathrm{~cm}$ e $V_{f}=0 \%$, e modelados pelo FIB (1999)

Figura 8.19 - Diagramas momento vs. curvatura dos pilares com $f_{c j}=60$, $s=15 \mathrm{~cm}$ e $V_{f}=0,5 \%$, e modelados pelo FIB (1999)

Figura 8.20 - Diagramas momento vs. curvatura dos pilares com $f_{c j}=60$, $s=5 \mathrm{~cm}$ e $V_{f}=0,5 \%$, e modelados pelo FIB (1999)

Figura 8.21 - Diagramas momento vs. curvatura dos pilares com $f_{c j}=60$, $s=15 \mathrm{~cm}$ e $V_{f}=0 \%$, e modelados pelo modelo proposto para o CRFA

Figura 8.22 - Diagramas momento vs. curvatura dos pilares com $f_{c j}=60$, $s=5 \mathrm{~cm}$ e $V_{f}=0 \%$, e modelados pelo modelo proposto para $o$ CRFA

Figura 8.23 - Diagramas momento vs. curvatura dos pilares com $f_{c j}=60$, $s=15 \mathrm{~cm}$ e $V_{f}=0,5 \%$, e modelados pelo modelo proposto para o CRFA 
Figura 8.24 - Diagramas momento vs. curvatura dos pilares com $f_{c j}=60$, $s=5 \mathrm{~cm}$ e $V_{f}=0,5 \%$, e modelados pelo modelo proposto para o CRFA

Figura 8.25 - Diagramas momento vs. curvatura dos pilares com $f_{c j}=60$, $s=15 \mathrm{~cm}$ e $V_{f}=0 \%$, e modelados pelo modelo de Cusson e Paultre (1995)

Figura 8.26 - Diagramas momento vs. curvatura dos pilares com $f_{c j}=60$, $s=5 \mathrm{~cm}$ e $V_{f}=0 \%$, e modelados pelo modelo de Cusson e Paultre (1995)

Figura 8.27 - Diagramas momento vs. curvatura dos pilares com $f_{c j}=60$, $s=15 \mathrm{~cm}$ e $V_{f}=0,5 \%$, e modelados pelo modelo de Cusson e Paultre (1995)

Figura 8.28 - Diagramas momento vs. curvatura dos pilares com $f_{c j}=60$, $s=5 \mathrm{~cm}$ e $V_{f}=0,5 \%$, e modelados pelo modelo de Cusson e Paultre (1995)

Figura 8.29 - Diagramas forçca vs. deformação de pilares com alturas diferente (Cusson et alii, 1996)

Figura 8.30 - Diagramas força vs. deslocamento longitudinal dos pilares com concretos $f_{c j}=60, V_{f}=0,0 \%$, e $s=15 \mathrm{~cm}$

200

200

203

Figura 8.31 - Diagramas força vs. deslocamento longitudinal dos pilares com concretos $f_{c j}=60, V_{f}=0,0 \%$, e $s=5 \mathrm{~cm}$

Figura 8.32 - Diagramas força vs. deslocamento longitudinal dos pilares com concretos $f_{c j}=60, V_{f}=0,5 \%$, e $s=15 \mathrm{~cm}$

Figura 8.33 - Diagramas força vs. deslocamento longitudinal dos pilares com concretos $f_{c j}=60, V_{f}=0,5 \%$, e $s=5 \mathrm{~cm}$

Figura 8.34 - Hipótese da distribuição de forças na armadura transversal

Figura 8.35 - Elemento finito e discretização utilizados no estudo da distribuição das tensões de confinamento nos pilares ensaiados a flexocompressão

Figura 8.36 - Distribuições das tensões nas direções $x$, y e $z$, na face menos comprimida dos pilares com espaçamento entre estribos de $15 \mathrm{~cm}$

Figura 8.37 - Distribuições das tensões nas direções $x$, y e $z$, na face menos comprimida dos pilares com espaçamento entre estribos de $5 \mathrm{~cm}$

204

204

205

208

209

Figura 8.38 - Distribuição da pressão lateral promovida pela armadura de confinamento para pilares submetidos à compressão excêntrica e centrada (parte dessa figura foi adaptada de Cusson e Paultre, 1995)

Figura 8.39 - Diagramas momento vs. curvatura dos pilares com $f_{c j}=60$, $s=15 \mathrm{~cm}$ e $V_{f}=0 \%$, e modelados pelo modelo modificado de Cusson $e$ Paultre (1995)

Figura 8.40 - Diagramas momento vs. curvatura dos pilares com $f_{c j}=60$, $s=5 \mathrm{~cm}$ e $V_{f}=0 \%$, e modelados pelo modelo de Cusson e Paultre (1995) 214 modificado

Figura 8.41 - Diagramas momento vs. curvatura dos pilares com $f_{c j}=60$, $s=15 \mathrm{~cm}$ e $V_{f}=0,5 \%$, e modelados pelo modelo de Cusson e Paultre (1995) modificado

Figura 8.42 - Diagramas momento vs. curvatura dos pilares com $f_{c j}=60$, $s=5 \mathrm{~cm}$ e $V_{f}=0,5 \%$, e modelados pelo modelo de Cusson e Paultre (1995) 214 modificado 


\section{Apêndice A}

Figura A.1 - Diagramas forças parciais vs. deformação do pilar, do concreto e da armadura longitudinal

Figura A.2 - Diagramas força aplicada vs. deformação lida por cada LVDT

Figura A.3 - Diagramas força aplicada vs. deformação lida pelos extensômetros na armadura longitudinal

Figura A.4 - Diagramas força aplicada vs. deformação lida pelos extensômetros na armadura transversal

Figura A.5 - Diagramas forças parciais vs. deformação do pilar, do concreto e da armadura longitudinal

Figura A.6 - Diagramas força aplicada vs. deformação lida por cada LVDT

Figura A.7 - Diagramas força aplicada vs. deformação lida pelos extensômetros na armadura longitudinal

Figura A.8 - Diagramas força aplicada vs. deformação lida pelos extensômetros na armadura transversal

Figura A.9 - Diagramas forças parciais vs. deformação do pilar, do concreto e da armadura longitudinal

Figura A.10 - Diagramas força aplicada vs. deformação lida por cada LVDT

Figura A.11 - Diagramas força aplicada vs. deformação lida pelos extensômetros na armadura longitudinal

Figura A.12 - Diagramas força aplicada vs. deformação lida pelos extensômetros na armadura transversal

Figura A.13 - Diagramas forças parciais vs. deformação do pilar, do concreto e da armadura longitudinal

Figura A.14 - Diagramas força aplicada vs. deformação lida por cada LVDT

Figura A.15 - Diagramas força aplicada vs. deformação lida pelos extensômetros na armadura longitudinal

Figura A.16 - Diagramas força aplicada vs. deformação lida pelos extensômetros na armadura transversal

Figura A.17 - Diagramas forças parciais vs. deformação do pilar, do concreto e da armadura longitudinal

Figura A.18 - Diagramas força aplicada vs. deformação lida por cada LVDT

Figura A.19 - Diagramas força aplicada vs. deformação lida pelos extensômetros na armadura longitudinal

Figura A.20 - Diagramas força aplicada vs. deformação lida pelos extensômetros na armadura transversal

Figura A.21 - Diagramas forças parciais vs. deformação do pilar, do concreto e da armadura longitudinal

Figura A.22 - Diagramas força aplicada vs. deformação lida por cada LVDT 
Figura A.23 - Diagramas força aplicada vs. deformação lida pelos extensômetros na armadura longitudinal

Figura A.24 - Diagramas força aplicada vs. deformação lida pelos extensômetros na armadura transversal

Figura A.25 - Diagramas forças parciais vs. deformação do pilar, do concreto e da armadura longitudinal

Figura A.26 - Diagramas força aplicada vs. deformação lida por cada LVDT

Figura A.27 - Diagramas força aplicada vs. deformação lida pelos extensômetros na armadura longitudinal

Figura A.28 - Diagramas força aplicada vs. deformação lida pelos extensômetros na armadura transversal

Figura A.29 - Diagramas forças parciais vs. deformação do pilar, do concreto e da armadura longitudinal

Figura A.30 - Diagramas força aplicada vs. deformação lida por cada LVDT

Figura A.31 - Diagramas força aplicada vs. deformação lida pelos extensômetros na armadura longitudinal

Figura A.32 - Diagramas força aplicada vs. deformação lida pelos extensômetros na armadura transversal

Figura A.33 - Diagramas forças parciais vs. deformação do pilar, do concreto e da armadura longitudinal

Figura A.34 - Diagramas força aplicada vs. deformação lida por cada LVDT

Figura A.35 - Diagramas força aplicada vs. deformação lida pelos extensômetros na armadura longitudinal

Figura A.36 - Diagramas força aplicada vs. deformação lida pelos extensômetros na armadura transversal

Figura A.37 - Diagramas forças parciais vs. deformação do pilar, do concreto e da armadura longitudinal

Figura A.38 - Diagramas força aplicada vs. deformação lida por cada LVDT

Figura A.39 - Diagramas força aplicada vs. deformação lida pelos extensômetros na armadura longitudinal

Figura A.40 - Diagramas força aplicada vs. deformação lida pelos extensômetros na armadura transversal

252

253

253

254

254

255

255

256

256

257

257

258

258

259

Figura A.41 - Diagramas forças parciais vs. deformação do pilar, do concreto e da armadura longitudinal

Figura A.42 - Diagramas força aplicada vs. deformação lida por cada LVDT

Figura A.43 - Diagramas força aplicada vs. deformação lida pelos extensômetros na armadura longitudinal

Figura A.44 - Diagramas força aplicada vs. deformação lida pelos extensômetros na armadura transversal

Figura A.45 - Diagramas forças parciais vs. deformação do pilar, do concreto e da armadura longitudinal 
Figura A.46 - Diagramas força aplicada vs. deformação lida por cada LVDT

Figura A.47 - Diagramas força aplicada vs. deformação lida pelos extensômetros na armadura longitudinal

Figura A.48 - Diagramas força aplicada vs. deformação lida pelos extensômetros na armadura transversal

Figura A.49 - Diagramas forças parciais vs. deformação do pilar, do concreto e da armadura longitudinal

Figura A.50 - Diagramas força aplicada vs. deformação lida por cada LVDT

Figura A.51 - Diagramas força aplicada vs. deformação lida pelos extensômetros na armadura longitudinal

Figura A.52 - Diagramas força aplicada vs. deformação lida pelos extensômetros na armadura transversal

Figura A.53 - Diagramas forças parciais vs. deformação do pilar, do concreto e da armadura longitudinal

Figura A.54 - Diagramas força aplicada vs. deformação lida por cada LVDT

Figura A.55 - Diagramas força aplicada vs. deformação lida pelos extensômetros na armadura longitudinal

Figura A.56 - Diagramas força aplicada vs. deformação lida pelos extensômetros na armadura transversal

Figura A.57 - Diagramas forças parciais vs. deformação do pilar, do concreto e da armadura longitudinal

Figura A.58 - Diagramas força aplicada vs. deformação lida por cada LVDT

Figura A.59 - Diagramas força aplicada vs. deformação lida pelos extensômetros na armadura longitudinal

Figura A.60 - Diagramas força aplicada vs. deformação lida pelos extensômetros na armadura transversal

Figura A.61 - Diagramas forças parciais vs. deformação do pilar, do concreto e da armadura longitudinal

Figura A.62 - Diagramas força aplicada vs. deformação lida por cada LVDT

Figura A.63 - Diagramas força aplicada vs. deformação lida pelos extensômetros na armadura longitudinal

Figura A.64 - Diagramas força aplicada vs. deformação lida pelos extensômetros na armadura transversal

Figura A.65 - Diagramas forças parciais vs. deformação do pilar, do concreto e da armadura longitudinal

Figura A.66 - Diagramas força aplicada vs. deformação lida por cada LVDT

Figura A.67 - Diagramas força aplicada vs. deformação lida pelos extensômetros na armadura longitudinal

Figura A.68 - Diagramas força aplicada vs. deformação lida pelos extensômetros na armadura transversal 
Figura A.69 - Diagramas forças parciais vs. deformação do pilar, do concreto e da armadura longitudinal

Figura A.70 - Diagramas força aplicada vs. deformação lida por cada LVDT

Figura A.71 - Diagramas força aplicada vs. deformação lida pelos extensômetros na armadura longitudinal

Figura A.72 - Diagramas força aplicada vs. deformação lida pelos extensômetros na armadura transversal

Figura A.73 - Diagramas forças parciais vs. deformação do pilar, do concreto e da armadura longitudinal

Figura A.74 - Diagramas força aplicada vs. deformação lida por cada LVDT

Figura A.75 - Diagramas força aplicada vs. deformação lida pelos extensômetros na armadura longitudinal

Figura A.76 - Diagramas força aplicada vs. deformação lida pelos extensômetros na armadura transversal

Figura A.77 - Diagramas forças parciais vs. deformação do pilar, do concreto e da armadura longitudinal

Figura A.78 - Diagramas força aplicada vs. deformação lida por cada LVDT

Figura A.79 - Diagramas força aplicada vs. deformação lida pelos extensômetros na armadura longitudinal

Figura A.80 - Diagramas força aplicada vs. deformação lida pelos extensômetros na armadura transversal

Figura A.81 - Diagramas forças parciais vs. deformação do pilar, do concreto e da armadura longitudinal

Figura A.82 - Diagramas força aplicada vs. deformação lida por cada LVDT

Figura A.83 - Diagramas força aplicada vs. deformação lida pelos extensômetros na armadura longitudinal

Figura A.84 - Diagramas força aplicada vs. deformação lida pelos extensômetros na armadura transversal

Figura A.85 - Diagramas forças parciais vs. deformação do pilar, do concreto e da armadura longitudinal

Figura A.86 - Diagramas força aplicada vs. deformação lida por cada LVDT

Figura A.87 - Diagramas força aplicada vs. deformação lida pelos extensômetros na armadura longitudinal

Figura A.88 - Diagramas força aplicada vs. deformação lida pelos extensômetros na armadura transversal

Figura A.89 - Diagramas forças parciais vs. deformação do pilar, do concreto e da armadura longitudinal

Figura A.90 - Diagramas força aplicada vs. deformação lida por cada LVDT

Figura A.91 - Diagramas força aplicada vs. deformação lida pelos extensômetros na armadura longitudinal 
Figura A.92 - Diagramas força aplicada vs. deformação lida pelos extensômetros na armadura transversal

Figura A.93 - Diagramas forças parciais vs. deformação do pilar, do concreto e da armadura longitudinal

Figura A.94 - Diagramas força aplicada vs. deformação lida por cada LVDT

Figura A.95 - Diagramas força aplicada vs. deformação lida pelos extensômetros na armadura longitudinal

Figura A.96 - Diagramas força aplicada vs. deformação lida pelos extensômetros na armadura transversal

Figura A.97 - Diagramas forças parciais vs. deformação do pilar, do concreto e da armadura longitudinal

Figura A.98 - Diagramas força aplicada vs. deformação lida por cada LVDT

Figura A.99 - Diagramas força aplicada vs. deformação lida pelos extensômetros na armadura longitudinal

Figura A.100 - Diagramas força aplicada vs. deformação lida pelos extensômetros na armadura transversal

Figura A.101 - Diagramas forças parciais vs. deformação do pilar, do concreto e da armadura longitudinal

Figura A.102 - Diagramas força aplicada vs. deformação lida por cada LVDT

Figura A.103 - Diagramas força aplicada vs. deformação lida pelos extensômetros na armadura longitudinal

Figura A.104 - Diagramas força aplicada vs. deformação lida pelos extensômetros na armadura transversal

\section{Apêndice B}

Figura B.1 - Diagramas forças vs. deslocamento vertical do pilar

Figura B.2 - Diagramas força vs. deslocamento transversal do pilar

Figura B.3 - Diagramas força vs. deformação na armadura longitudinal

Figura B.4 - Diagramas força vs. deformação na armadura transversal

Figura B.5 - Diagramas força vs. deformação no concreto

Figura B.6 - Diagramas forças vs. deslocamento vertical do pilar

Figura B.7 - Diagramas força vs. deslocamento transversal do pilar

Figura B.8 - Diagramas força vs. deformação na armadura longitudinal

Figura B.9 - Diagramas força vs. deformação na armadura transversal

Figura B.10 - Diagramas força vs. deformação no concreto

Figura B.11 - Diagramas forças vs. deslocamento vertical do pilar 297

Figura B.12 - Diagramas força vs. deslocamento transversal do pilar 297

Figura B.13 - Diagramas força vs. deformação na armadura longitudinal 298

Figura B.14 - Diagramas força vs. deformação na armadura transversal 298

Figura B.15 - Diagramas força vs. deformação no concreto 299

Figura B.16 - Diagramas forças vs. deslocamento vertical do pilar 299

Figura B.17 - Diagramas força vs. deslocamento transversal do pilar $\quad 300$

Figura B.18 - Diagramas força vs. deformação na armadura longitudinal 300 
Figura B.19 - Diagramas força vs. deformação na armadura transversal

301

Figura B.20 - Diagramas força vs. deformação no concreto

301

Figura B.21 - Diagramas forças vs. deslocamento vertical do pilar

Figura B.22 - Diagramas força vs. deslocamento transversal do pilar

Figura B.23 - Diagramas força vs. deformação na armadura longitudinal

Figura B.24 - Diagramas força vs. deformação na armadura transversal

Figura B.25 - Diagramas força vs. deformação no concreto

Figura B.26 - Diagramas forças vs. deslocamento vertical do pilar

Figura B.27 - Diagramas força vs. deslocamento transversal do pilar

Figura B.28 - Diagramas força vs. deformação na armadura longitudinal

Figura B.29 - Diagramas força vs. deformação na armadura transversal

Figura B.30 - Diagramas força vs. deformação no concreto

Figura B.31 - Diagramas forças vs. deslocamento vertical do pilar

Figura B.32 - Diagramas força vs. deslocamento transversal do pilar

Figura B.33 - Diagramas força vs. deformação na armadura longitudinal

Figura B.34 - Diagramas força vs. deformação na armadura transversal

Figura B.35 - Diagramas força vs. deformação no concreto

Figura B.36 - Diagramas forças vs. deslocamento vertical do pilar

Figura B.37 - Diagramas força vs. deslocamento transversal do pilar

Figura B.38 - Diagramas força vs. deformação na armadura longitudinal

Figura B.39 - Diagramas força vs. deformação na armadura transversal

Figura B.40 - Diagramas força vs. deformação no concreto

Figura B.41 - Diagramas forças vs. deslocamento vertical do pilar

Figura B.42 - Diagramas força vs. deslocamento transversal do pilar

Figura B.43 - Diagramas força vs. deformação na armadura longitudinal

Figura B.44 - Diagramas força vs. deformação na armadura transversal

Figura B.45 - Diagramas força vs. deformação no concreto

Figura B.46 - Diagramas forças vs. deslocamento vertical do pilar

Figura B.47 - Diagramas força vs. deslocamento transversal do pilar

Figura B.48 - Diagramas força vs. deformação na armadura longitudinal

Figura B.49 - Diagramas força vs. deformação na armadura transversal

Figura B.50 - Diagramas força vs. deformação no concreto

Figura B.51 - Diagramas forças vs. deslocamento vertical do pilar

Figura B.52 - Diagramas força vs. deslocamento transversal do pilar

Figura B.53 - Diagramas força vs. deformação na armadura longitudinal

Figura B.54 - Diagramas força vs. deformação na armadura transversal

Figura B.55 - Diagramas força vs. deformação no concreto

Figura B.56 - Diagramas forças vs. deslocamento vertical do pilar

Figura B.57 - Diagramas força vs. deslocamento transversal do pilar

Figura B.58 - Diagramas força vs. deformação na armadura longitudinal

Figura B.59 - Diagramas força vs. deformação na armadura transversal

Figura B.60 - Diagramas força vs. deformação no concreto

Figura B.61 - Diagramas forças vs. deslocamento vertical do pilar

Figura B.62 - Diagramas força vs. deslocamento transversal do pilar

Figura B.63 - Diagramas forças vs. deslocamento vertical do pilar

Figura B.64 - Diagramas força vs. deslocamento transversal do pilar
302

302

303

303

304

304

305

305

306

306

307

307

308

308

309

309

310

310

311

311

312

312

313

313

314

314

315

315

316

316

317

317

318

318

319

319

320

320

321

321

322

322

323

323 
Figura B.65 - Diagramas forças vs. deslocamento vertical do pilar 324

Figura B.66 - Diagramas força vs. deslocamento transversal do pilar 
Tabela 5.1 - Valores dos índices de ductilidade para os concretos com resistências de 20MPa à 80MPa de acordo com o modelo do FIB-CEB

Tabela 5.2 - Valores dos índices de ductilidade para os concretos com 78 resistências de 20MPa à 80MPa de acordo com o modelo de Popovics

Tabela 5.3 - Valores dos índices de ductilidade $\varepsilon_{0.5 f d} \mathcal{\varepsilon}_{c o}:$ Fase 1

Tabela 5.4 - Valores dos índices de ductilidade ID Pós: Fase 1

Tabela 5.5 - Análise de variância para os valores de $\varepsilon_{0.5 f_{c}} / \mathcal{E}_{c o}$ : Fase 1

Tabela 5.6 - Análise de variância para os valores de ID Pós: Fase 1

Tabela 5.7 - Valores dos índices de ductilidade $\varepsilon_{0.5 f_{c}} \mathcal{E}_{\text {co }}$ : Fase 2

Tabela 5.8 - Valores dos índices de ductilidade ID Pós: Fase 2

Tabela 5.9 - Análise de variância para os valores de $\varepsilon_{0.5 f d} / \varepsilon_{c o}:$ Fase 290

Tabela 5.10 - Análise de variância para os valores de ID Pós: Fase 290

Tabela 5.11 - Valores dos índices de ductilidade $\varepsilon_{0.5 f c} / \varepsilon_{\text {co }}$ do CRFA 93

Tabela 5.12 - Valores dos índices de ductilidade ID ${ }_{\text {Pós }}$ do CRFA

Tabela 5.13 - Análise de variância para os valores de $\varepsilon_{0.5 f_{c}} \mathcal{E}_{\text {co }}$ do CRFA 94

Tabela 5.14 - Análise de variância para os valores de ID Pós do CRFA 94

Tabela 5.15 - Taxas volumétricas ideais para diversas resistências de 95 concreto

\section{Capitulo VI}

Tabela 6.1 - Estudo de dosagem para o concreto com resistência de alta resistência

Tabela 6.2 - Estudo de dosagem para o concreto com resistência de $30 \mathrm{MPa}$

Tabela 6.3 - Propriedades físicas e mecânicas das armaduras

Tabela 6.4 - Características físicas dos pilares ensaiados à compressão centrada

Tabela 6.5 - Características físicas dos pilares ensaiados à compressão excêntrica

\section{Capítulo VII}

Tabela 7.1 - Características dos concretos utilizados na moldagem dos pilares

Tabela 7.2 - Características das curvas tensão vs. deformação dos concretos

Tabela 7.3 - Forcas últimas dos pilares com espaçamento entre estribos de $15 \mathrm{~cm}$

Tabela 7.4 - Forcas últimas dos pilares com espaçamento entre estribos de $5 \mathrm{~cm}$ 
Tabela 7.5 - Forcas últimas para os pilares de Lima (1997) e Queiroga (1999)

Tabela 7.6 - Valores experimentais de $k_{2}$ para os pilares ensaiados

Tabela 7.7 - Análise de variância para os valores experimentais de $k_{2} \quad 144$

Tabela 7.8 - Valores das deformações dos estribos correspondente a força máxima do pilar $\left(\mathcal{E}_{t c c}\right)(\% \circ)$

Tabela 7.9 - Análise de variância para os valores das deformações dos estribos

Tabela 7.10 - Comparação entre os valores teóricos e experimentais de $\left(\varepsilon_{t c c}\right)$

Tabela 7.11 - Variáveis de avaliação do modelo de Cusson e Paultre (1995)

Tabela 7.12 - Valores dos índices de ductilidade $I D_{\text {pós }}$ para os pilares

Tabela 7.13 - Valores dos índices de ductilidade $\varepsilon_{0.5 f c c / \varepsilon c c}$ para os pilares

Tabela 7.14 - Análise de variância para os valores de $I D_{\text {pós }}$

Tabela 7.15 - Análise de variância para os valores de $\varepsilon_{0.5 f c c / \varepsilon c c}$

\section{Capitulo VIII}

Tabela 8.1 - Características dos concretos utilizados na moldagem dos pilares

Tabela 8.2 - Características das curvas tensão vs. deformação dos concretos

Tabela 8.3 - Índices de ductilidade obtidos com o modelo proposto

Tabela 8.4 - Deformação na armadura transversal para 95\% da força máxima no trecho ascendente

Tabela 8.5 - Deformação na armadura transversal para força máxima

Tabela 8.6 - Deformação na armadura transversal para $85 \%$ da força máxima no trecho descendente

Tabela 8.7 - Capacidade resistente dos pilares ensaiados à flexocompressão segundo FIB(1999)

Tabela 8.8 - Capacidade resistente dos pilares ensaiados à flexocompressão segundo o modelo para CRFA

Tabela 8.9 - Capacidade resistente dos pilares ensaiados à flexocompressão segundo Cusson e Paultre(1995)

Tabela 8.10 - Valores dos índices de ductilidade $I_{\text {pós }}$ para os pilares

Tabela 8.11 - Valores dos índices de ductilidade $\varepsilon_{0.5 f c c / \varepsilon c c}$ para os pilares

Tabela 8.12 - Análise de variância para os valores de ID pós

Tabela 8.13 - Análise de variância para os valores de $\varepsilon_{0.5 f c c / \varepsilon c c}$ 


\section{LISTA DE SÍMBOLOS}

\section{Letras romanas minúsculas}

a Deflexão máxima localizada no ponto médio ao longo da altura do pilar

$\boldsymbol{a}_{\exp }$ Deflexão máxima experimental localizada no ponto médio ao longo da altura do pilar

$a_{1} \quad$ Constante obtida através de análise de regressão e que caracteriza a inclinação do trecho descendente do diagrama tensão vs. deformação do concreto que é expressa pela Eq.(2.5)

$\boldsymbol{b} \quad$ Base da seção transversal do pilar

$\boldsymbol{b}_{1} \quad$ Constante obtida através de análise de regressão e que caracteriza o valor da tensão para deformação nula na Eq.(2.5)

$\boldsymbol{c}_{\boldsymbol{x}}$ e $\boldsymbol{c}_{\boldsymbol{y}} \quad$ Larguras do núcleo do pilar, nas direções $x$ e $y$, respectivamente

$\boldsymbol{e} \quad$ Excentricidade da força

$\boldsymbol{e}_{2}(\boldsymbol{x}) \quad$ Excentricidade de segunda ordem

$f_{0}, f_{22,5}$, Funções das forças de arrancamento para fibras inclinadas de $0^{\circ}, 22,5^{\circ}$,

$f_{45}, f_{67,5} \quad 45^{\circ}, 67,5^{\circ}$ e $90^{\circ}$, respectivamente

e $f_{90}$

$f_{c j} \quad$ Resistência à compressão média do concreto, obtida por ensaios de corpos-de-prova cilíndricos, dada em (MPa) na idade $\mathrm{j}$

$f_{c} \quad$ Resistência à compressão do concreto na estrutura, dada em (MPa)

$f_{c c} \quad$ Resistência do concreto confinado

$f_{c c f} \quad$ Resistência do concreto confinado e/ou com adição de fibras

$f_{c f} \quad$ Resistência do concreto com adição de fibras

$f_{c m o} \quad$ Coeficiente igual a $70 \mathrm{MPa}$

$f_{c t m} \quad$ Resistência à tração do concreto

$f_{\text {hook }}$ Função que leva em consideração o comprimento de embebimento de cada fibra nas proximidades da fissura

$f_{i} \quad$ Força de arrancamento de uma fibra $i$

$f_{l} \quad$ Tensão lateral nominal de confinamento

$f_{l e} \quad$ Pressão efetiva de confinamento

$f_{\text {tcc }} \quad$ Tensão na armadura transversal de confinamento

$\boldsymbol{f}_{\boldsymbol{t} \text { CRFA }}$ Tensão de tração aplicada ao CRFA

$f_{\text {tuCRFA }}$ Máxima tensão de tração suportada pelo CRFA

$\boldsymbol{f}_{\boldsymbol{y}} \quad$ Tensão de escoamento do aço

$\boldsymbol{h} \quad$ Altura da seção transversal do pilar

$\boldsymbol{k} \quad$ Coeficiente de que correlaciona a resistência do concreto medida em corpos-de-prova com a resistência de projeto da estrutura

$\boldsymbol{k}_{11} \quad$ Constante obtida através de análise de regressão e que caracteriza inclinação do trecho descendente do diagrama da Eq.(2.6)

$\boldsymbol{k}_{22}$ Constante obtida através de análise de regressão e que caracteriza curvatura do trecho descendente do diagrama da Eq.(2.6)

$\boldsymbol{k}_{\boldsymbol{l}} \quad$ Coeficiente que leva em conta o acréscimo de resistência do concreto após 28 dias 
$\boldsymbol{k}_{2} \quad$ Coeficiente que correlaciona a resistência do concreto obtida por meio de corpos-de-prova cilíndricos e a resistência do concreto na estrutura

$\boldsymbol{k}_{3} \quad$ Coeficiente que considera a diminuição da resistência do concreto para ações de longa duração

ln Logaritmo neperiano

$\ell \quad$ Comprimento da fibra de aço

$\ell_{\mathrm{c}} \quad$ Comprimento crítico da fibra

$r^{2} \quad$ Coeficiente de correlação

$\boldsymbol{s} \quad$ Distância de centro a centro entre estribos ao longo do eixo do pilar

$\boldsymbol{w}_{f i} \quad$ Abertura da fissura na posição de cada fibra

$\boldsymbol{w}_{\boldsymbol{i}} \quad$ Espaços entre as armaduras longitudinais

$\boldsymbol{y}$ Distancia da face superior do modelo a um ponto qualquer

\section{Letras romanas maiúsculas}

$\boldsymbol{A} \quad$ Área da seção transversal do pilar

$\boldsymbol{A}_{0,5 f c c} \quad$ Área abaixo do diagrama tensão vs. deformação do concreto confinado, da origem até a deformação $\varepsilon_{0,5 f c c}$

$\boldsymbol{A}_{\boldsymbol{c}} \quad$ Área do núcleo de concreto da seção transversal do pilar

$\boldsymbol{A}_{\boldsymbol{c}} \quad$ Área de concreto da seção transversal do pilar

$\boldsymbol{A}_{\boldsymbol{s}} \quad$ Área da armadura longitudinal do pilar

$\boldsymbol{A}_{s \boldsymbol{n}} \quad$ Área da barra $n$ da armadura

$\boldsymbol{A}_{\text {stx }}$ e Áreas da seção transversal das armaduras de confinamento, paralelas

$\boldsymbol{A}_{\text {sty }} \quad \operatorname{aos}$ eixos $x$ e $y$, respectivamente

$\boldsymbol{B}$ Constante auxiliar utilizada em algumas equações obtida por análise de regressão

C Constante auxiliar utilizada em algumas equações obtida por análise de regressão

$C^{\prime} \quad$ Distância da linha neutra de uma viga de CRFA até a face superior do modelo

$\boldsymbol{E}_{\boldsymbol{c}} \quad$ Módulo de elasticidade do concreto não confinado

$\boldsymbol{E}_{\boldsymbol{c o}} \quad$ Módulo de elasticidade secante do concreto

$\boldsymbol{E}_{\boldsymbol{c t} \boldsymbol{C R F A}}$ Módulo de elasticidade à tração do CRFA

$\boldsymbol{E}_{\boldsymbol{f}} \quad$ Módulo de elasticidade da fibra.

$\boldsymbol{E}_{\boldsymbol{s}} \quad$ Módulo de elasticidade do aço

$\boldsymbol{E}_{\text {secc }} \quad$ Módulo de elasticidade secante no ponto de máxima tensão do concreto confinado

$\boldsymbol{F}_{\text {teo }} \quad$ Força teórica resistente do pilar calculadas com a seção transversal íntegra

$\boldsymbol{F}_{\text {teo-nuc }}$ Força teórica resistente do pilar calculadas com a seção transversal do núcleo do pilar

$\boldsymbol{F}_{\text {exp }} \quad$ Força experimental resistente do pilar

$\boldsymbol{G}_{\boldsymbol{k}, \boldsymbol{m}} \quad$ Integral de contorno do j-ésimo segmento da poligonal

I Momento de inércia

$\boldsymbol{I D}_{\boldsymbol{p o ́ s}} \quad$ Índice de ductilidade pós-pico

$\boldsymbol{I D}_{\text {pré }} \quad$ Índice de ductilidade pré-pico

$\boldsymbol{K}_{\boldsymbol{e}} \quad$ Coeficiente de confinamento efetivo que representa a taxa da área do 
concreto menos confinada, que se localiza na região média entre dois estribos consecutivos

$\boldsymbol{L} \quad$ Comprimento de flambagem do pilar

$M_{\xi} \quad$ Momento resistente por uma seção transversal de um pilar

$\boldsymbol{M}_{\boldsymbol{S}} \quad$ Momento externo aplicado ao pilar

$\boldsymbol{M}_{\boldsymbol{R}} \quad$ Momento interno resistido pelo pilar

$N \quad$ Número de fibras existente em uma seção transversal

$N_{\xi} \quad$ Esforço normal resistente por uma seção transversal de um pilar

$\mathbf{S G}$ Extensômetro elétrico i disposto na armadura

$\boldsymbol{R} \quad$ Índice de reforça da adição de fibra

$\boldsymbol{T} \quad$ Temperatura do ambiente

$\boldsymbol{U} \quad$ Umidade do ambiente

$\boldsymbol{V}_{\boldsymbol{f}} \quad$ Taxa volumétrica de adição de fibra

$\boldsymbol{W} \quad$ Trabalho médio para arrcamento da fibra da matriz cimentícia

$\boldsymbol{X}_{\boldsymbol{i}} \quad$ Denominação dos fatores principais utilizados na anaálise de variância

\section{Letras gregas}

$\alpha \quad$ Ângulo de inclinação do plano de ruptura dos pilares

$\alpha_{\beta} \quad$ Coeficiente que depende do tipo de agregado graúdo que constitui o concreto

$\alpha_{e} \quad$ Coeficiente igual a 21500MPa.

$\alpha_{i} \quad$ Angulo de inclinação de cada fibra em relação ao plano da fissura

$\beta \quad$ Constante função do módulo de elasticidade tangente do concreto nãoconfinado e do módulo de elasticidade secante do concreto confinado que caracteriza a Eq.(2.3)

$\varepsilon_{0,5 f c}$ Deformação correspondente a $50 \%$ da resistência do concreto não confinado no trecho descendente do diagrama tensão vs. deformação de compressão

$\varepsilon_{0,5 f c c}$ Deformação correspondente a $50 \%$ da resistência do concreto confinado no trecho descendente do diagrama tensão vs. deformação de compressão

$\varepsilon_{0,5 c c f}$ Deformação correspondente a $50 \%$ da resistência do concreto confinado e/ou com adição de fibras, no trecho descendente do diagrama tensão vs. deformação de compressão

$\varepsilon_{0,85 f c}$ Deformação correspondente a $85 \%$ da resistência do concreto não confinado no trecho descendente do diagrama tensão vs. deformação de compressão

$\varepsilon_{0,85 f c c}$ Deformação correspondente a $85 \%$ da resistência do concreto confinado no trecho descendente do diagrama tensão vs. deformação de compressão

$\varepsilon_{c} \quad$ Deformação de compressão do concreto

$\varepsilon_{c}(x)$ Deformação do compósito em um determinado ponto

$\varepsilon_{c 2} \quad$ Deformação última de avaliação da ductilidade

$\varepsilon_{c c}$ Deformação correspondente à tensão máxima $f_{c c}$ do concreto confinado

$\varepsilon_{c c f}$ Deformação correspondente à tensão máxima $f_{c c f}$ do concreto confinado

$\varepsilon_{c f}$ Deformação correspondente à tensão máxima $f_{c f}$ do concreto com adição 


$\begin{array}{ll} & \text { de fibras } \\ \varepsilon_{c o} & \begin{array}{l}\text { Deformação correspondente à tensão máxima } f_{c} \text { do concreto não } \\ \text { confinado }\end{array} \\ \varepsilon_{c t} & \text { Deformação de tração do concreto } \\ \varepsilon_{c u} & \text { Deformação de compressão última do concreto } \\ \varepsilon_{s} & \text { Deformação na armadura metálica } \\ \varepsilon_{t c c} & \text { Deformação da armadura de confinamento } \\ \varepsilon_{t C R F A} & \text { Deformação de tração do CRFA em um ponto do diagrama tensão vs. } \\ & \text { deformação } \\ \varepsilon_{y} & \text { Deformação de escoamento do aço } \\ \eta & \text { Ordenada de um ponto qualquer da seção no sistema de coordenada } \\ & \text { local } \\ \eta_{n} & \text { Ordenada da barra } n \text { da armadura } \\ \phi_{f} & \text { Diâmetro da fibra de aço } \\ \phi_{t} & \text { Diâmetro dos estribos } \\ \gamma_{c} & \text { Massa específica do concreto } \\ \mu & \text { Momento fletor reduzido } \\ \nu & \text { Esforço normal reduzido } \\ v & \text { Coeficiente de Poisson do concreto } \\ \rho_{l} & \text { Taxa de armadura longitudinal } \\ \rho_{w} & \text { Taxa de armadura transversal } \\ \sigma_{s}(\varepsilon) & \text { Tensão na armadura } \\ \sigma_{c}(\varepsilon) & \text { Tensão no concreto } \\ \sigma_{c}(y) & \text { Tensão de compressão no concreto em um ponto y qualquer } \\ \sigma_{f u} & \text { Tensão de ruptura da fibra } \\ \tau & \text { Tensão de aderência entre a matriz e a fibra } \\ \tau_{f u} & \text { Tensão de aderência média última entre a matriz e a fibra } \\ \xi & \text { Abscissa de um ponto qualquer da seção no sistema de coordenada local } \\ \zeta & \text { Coeficiente função do módulo de elasticidade e das deformações do } \\ & \text { concreto }\end{array}$

\section{Siglas}

ACI American Concrete Institute

$\boldsymbol{A S C E}$ American Society of Civil Engineering

$\boldsymbol{C E B}$ Comité Euro Internationale du Béton

$\boldsymbol{C A R}$ Concreto de alta resistência

$\boldsymbol{C R F A}$ Concreto reforçado com fibras de aço

$\boldsymbol{C R} \boldsymbol{U}$ Concreto de resistência usual

Eq. Equação

FIB Fédération Internationale du Béton

JSCE Japan Society of Civil Engineers

$\boldsymbol{L V D T}$ Linear variable different ional transformer

NBR Norma Brasileira

SG Strain gage 
LIMA JÚNIOR, H. C. Avaliação da ductilidade de pilares de concreto armado, submetidos à flexo-compressão reta com e sem adição de fibras metálicas. Tese de doutorado - Escola de Engenharia de São Carlos, Universidade de São Paulo, São Carlos, 2003.

Este trabalho tem como objetivo investigar o comportamento pós-pico de pilares com concretos de alta resistência confinados com e sem adição de fibras metálicas, submetidos à flexo-compressão. Para tanto, realizou-se inicialmente uma extensa revisão bibliográfica sobre o tema, na qual, elencaram-se os principais fatores que influenciam o comportamento pós-pico desses elementos estruturais. Em seguida, desenvolveram-se estudos paramétricos com o intuito de estabelecer os modos de influência de cada fator.

Com base nesses estudos preliminares, um programa experimental, dividido em duas fases, foi proposto. Na primeira fase, ensaiaram-se vinte e seis pilares de concreto armado e 14 pilares de concreto simples. Três fatores foram estudados: a taxa de adição de fibras metálicas, a taxa de armadura transversal e a resistência à compressão do concreto. Os pilares possuíam seções transversais quadradas com dimensões $15 \mathrm{~cm} x 15 \mathrm{~cm}$ e altura de $50 \mathrm{~cm}$ e foram ensaiados à compressão centrada com controle de deslocamento. Observou-se que os três fatores analisados influenciam diretamente a ductilidade desses elementos estruturais e que, por meio de adição de fibras metálicas, é possível garantir índices de ductilidade aceitáveis para os pilares com concreto de alta resistência. Outrossim, analisando-se os diagramas força vs. deformação dos pilares, observou-se que para o primeiro pico de força, toda a seção resiste a esforços de compressão e que a adição de fibras melhora o trabalho conjunto entre o cobrimento e o núcleo do pilar. Finalizando esta fase, propuseram-se modificações para o modelo para concreto confinado de Cusson e Paultre (1995), de modo que, 
permitisse ao mesmo modelar o comportamento do concreto confinado com e sem adição de fibras metálicas.

$\mathrm{Na}$ segunda fase do programa experimental, quinze pilares de concreto armado foram ensaiados a compressão excêntrica. Essa fase teve como objetivo investigar a influência da excentricidade, da taxa de armadura transversal e da taxa de adição de fibras metálicas no comportamento pós-pico desses elementos estruturais. Os pilares, nessa fase, possuíam seção transversal quadrada com dimensões de $15 \mathrm{~cm}$ x $15 \mathrm{~cm}$ e altura de $170 \mathrm{~cm}$. Para realização dos ensaios foi confeccionado um par de rótulas unidirecionais, as quais apresentaram excelente desempenho, conseguindo transferir integralmente o momento externo aplicado ao pilar. Observou-se que, tanto a flambagem das barras da armadura longitudinal, quanto a perda de massa de concreto nesses pilares ocorrem de modo bem mais crítico que nos pilares submetidos à compressão centrada. Constatou-se, ainda, que quando os valores dos três fatores analisados são elevados, a ductilidade desses elementos estruturais é melhorada. Finalmente, foi observado que o efeito da flexão faz com que as tensões de confinamento se distribuam de modo diferenciado dentro da seção transversal dos pilares; contudo, observou-se que a tensão de confinamento na região comprimida da seção transversal pouco é modificada.

Palavras-chave: pilar, concreto de alta resistência, fibras metálicas, confinamento, excentricidade de força. 
LIMA JÚNIOR, H. C. Evaluation of the reinforced concrete columns' ductility, under combined axial load and bending, with or not steel fibres addition. Ph.D. thesis - Engineering School at São Carlos, São Paulo University, São Carlos, 2003.

This thesis aims to investigate the ductility of high strength concrete columns, with confinement and/or with steel fibre addition, under combined axial load and bending. For this, an extensive survey was performed, and the main factors, which influence the column ductility, were pointed out. Then, parametric studies were done, aiming to establish the mode of influence of each factor.

Based on these preliminaries studies, an experimental investigation, divided in two steps, was proposed. In the first part, twenty-six reinforced concrete columns and fourteen concrete columns were tested and three factors were analysed: the ratio of fibre addition, the transversal reinforcement ratio and the concrete compressive strength. The columns have $15 \mathrm{~cm} \times 15 \mathrm{~cm}$ square cross section and were $50 \mathrm{~cm}$ high. They were tested under concentric load with displacement control. It was observed that all factors interfere in the columns' ductility, and that, by adding fibre in the concrete, is possible to provide acceptable ductility index to high strength concrete columns. The load vs. column strain diagrams were studied and it was verified that for the first load peak, all the column cross section resists the axial load. Besides that, it was observed that the fibre addition improves the work together between the cover and the column core. Finally, several modifications to the concrete confinement model of Cusson and Paultre (1995) were proposed to allow this model to analyse the compressive behaviour of the confined concrete with or/not fibre addition. 
In the second part of the experimental program, fifteen reinforced concrete columns were tested under eccentric load. The effects of the load eccentricity, the ratio of steel fibre addition and the transversal reinforcement ratio on the column ductility were investigated. The columns have $15 \mathrm{~cm} \times 15 \mathrm{~cm}$ square cross section and were $170 \mathrm{~cm}$ high. A pair of unidirectional hinges was design, which presented exceptional performance, transferring integrally the external applied moment to the columns. A most critical model of longitudinal reinforcement buckling and mass lost was observed. In addition, it was verified that when the values of all factors were increased, the column ductility was improved. Finally, a different distribution mode of the confinement pressure on the column cross section was observed, when combined axial load and bending is applied. Nevertheless, the confinement pressure on the compressive region of the column cross section is not modified.

Key words: column, high strength concrete, steel fibre, confinement and load eccentricity. 


\section{INTRODUÇÃO}

\subsection{CONSIDERAÇÕES INICIAIS}

Nos últimos anos, um crescente aumento do uso dos concretos de alto desempenho $(C A D)$ e das pesquisas sobre o tema vem sendo relatado nas Literaturas nacional e internacional. A busca incessante por novos materiais e técnicas para a fabricação do $C A D$ firma-se a cada dia, objetivando melhorar as propriedades desse material, dentre as quais, destaca-se a resistência à compressão do concreto.

A busca por concretos com resistências à compressão mais elevadas iniciou-se entre as décadas de 50 e 60 (Aïticin, 2000). Nesse período, as dificuldades principais para elevação da resistência do concreto residiam na qualidade do cimento, na qualidade dos materiais pozolânicos e no tipo de redutores de água utilizados. Desse modo, as resistências características dos concretos encontravam-se entre $10 \mathrm{MPa}$ e $20 \mathrm{MPa}$. Os cimentos da época apresentavam grãos bem mais grossos dos que os atuais, o que dificultava a sua hidratação. Além disso, iniciava-se a utilização dos materiais pozolânicos adicionados aos concretos, cuja qualidade e consistência ainda era questionada. Os redutores de água apresentavam elevada dispersão em composição e pureza e eram baseados em lignossulfonatos, que apresentam forte tendência em incorporar ar e retardar a pega do cimento, quando usados em quantidades elevadas.

A partir da década de 70, com o surgimento dos redutores de água de alto desempenho (Mayer, 1981), a introdução da sílica ativa (Malhotra et alii, 1987) e o desenvolvimento da indústria cimentícia (Aïticin, 2000), as pesquisas sobre os concretos de alta resistência tomaram novos rumos. Concretos com resistências da ordem de 70MPa (edifício River Plaza, em Chicago, construído em 1976), 80MPa (edifício Prudential Plaza, em Chicago, construído em 1988) e 110MPa (edifício 
Gateway Towert, em Seattle, construído em 1990) tornaram-se exeqüíveis, abrindo novos caminhos para as estruturas de concreto (Aïticin, 2000).

Atualmente, observa-se que resistências de concreto entre $50 \mathrm{MPa}$ e 100MPa são alcançadas sem maiores dificuldades. Contudo, tais resistências estão fora dos padrões de projetos nacionais, seja por falta de conhecimento e normalização das propriedades mecânicas deste novo material (Projeto de Revisão da Norma Brasileira NBR 6118, 2001), seja por resistências da ordem de 30MPa ainda suprirem as necessidades estruturais da maioria das edificações brasileiras.

Aïticin (2000) sugere que os concretos de alta resistência sejam classificados em cinco classes, em faixas de resistências que variam por incrementos de 25MPa: Classe I, entre 50MPa e 75Mpa; Classe II, entre 75MPa e $100 \mathrm{Mpa}$; Classe III, entre 100MPa e 125Mpa; Classe IV, entre $125 \mathrm{MPa}$ e 150Mpa; e Classe V, acima de 150MPa. No Brasil, conforme a NBR 8953:1992, os concretos de alta resistência estão agrupados em apenas uma classe, correspondente à Classe II, na qual a resistência do concreto varia entre $55 \mathrm{MPa} \mathrm{e}$ $80 \mathrm{MPa}$.

Apesar das inúmeras vantagens apresentadas pelos concretos de alta resistência em relação aos concretos de resistências usuais, pesquisas têm mostrado que esses materiais apresentam algumas características diferenciadas, que necessitam de maiores estudos. Entre essas características, destaca-se a baixa ductilidade do concreto de alta resistência à compressão simples. Ao contrário do concreto de resistência usual, o concreto de alta resistência apresenta um diagrama tensão vs. deformação de compressão bem mais linearizado, com sua parte ascendente praticamente linear até à tensão máxima e sua parte descendente bastante inclinada.

Uma das principais aplicações estruturais do concreto de alta resistência é em pilares de edifícios altos, cujo comportamento estrutural é governado pelas propriedades mecânicas do concreto. Esse fato torna a ductilidade desses elementos estruturais bem mais sensível ao tipo de concreto utilizado e ao seu respectivo diagrama tensão vs. deformação. Observa-se, assim, que, quando o concreto de alta resistência é aplicado a pilares, a ductilidade desses elementos 
estruturais é reduzida e sua ruptura fica caracterizada por pequenas deformações. Deste modo, a redistribuição de esforços capaz de evitar o colapso de uma edificação, quando da ruptura de um pilar, é comprometida. Em países onde existe o risco de abalos sísmicos, esse comportamento torna-se ainda mais preocupante, pois variações bruscas de ações podem levar uma edificação ao colapso sem nenhum aviso prévio.

Para solucionar tal problema, diversos pesquisadores, no Brasil e no mundo, vêm estudando o comportamento dos pilares de concreto de alta resistência, visando ao melhoramento da capacidade de absorção de energia dessas estruturas. Entre esses estudos, destacam-se os trabalhos internacionais de Bjerkeli et alii (1990); Cusson e Paultre (1994); Ibrahim e MacGregor (1996); Samaan, Mirmiran e Shahawy (1998); Diniz e Frangopol (1998); e Razvi e Saatacioglu (1999-b). Além desses, merecem destaque trabalhos experimentais nacionais, como, por exemplo, o de Agostini (1992); Paiva (1994); Perdão Júnior (1994) e Fernandes (1997), todos estes desenvolvidos na Faculdade de Engenharia Civil da UNICAMP, e Lima (1997); Queiroga (1999); Vanderlei (1999); e Guimarães (1999), realizados na Escola de Engenharia de São Carlos - USP.

A grande maioria dos trabalhos citados acima se baseia no aumento da capacidade de absorção de energia dos pilares, por meio da técnica de confinamento da seção transversal. Esta técnica traduz-se, basicamente, em se adotar altas taxas de armadura transversal (seja por estribos ou encamisamento por chapas de aço ou materiais compósitos), de modo a gerar um confinamento passivo capaz de controlar o processo de fissuração e a expansão lateral do concreto e, desse modo, aumentar a ductilidade desses elementos estruturais.

A técnica de confinamento da seção transversal mostra-se eficiente para pilares submetidos à compressão centrada. Contudo, pesquisas vêm mostrando que essa metodologia perde eficiência, quando os pilares são submetidos à flexocompressão (Sheikh e Yeh, 1990; Saatacioglu et alii, 1995 e ACI-441, 1997). Esse problema torna-se ainda mais grave, uma vez que a grande maioria dos pilares de concreto presente nas estruturas é submetida à flexo-compressão. 
Outra técnica de comprovada eficiência, que também vem sendo estudada, é a adição de fibras de aço à massa do concreto (Taerwe, 1992; Hsu e Hsu, 1994; Nataraja et alii, 1999; e Guimarães, 1999). Quando adicionadas ao concreto, as fibras geram um tipo de "confinamento" que mantém o concreto íntegro, mesmo para elevadas deformações, aumentando de forma considerável a ductilidade deste material. A grande vantagem do tipo de "confinamento" gerado por essa metodologia é que ele é imune aos efeitos da flexo-compressão.

A utilização de fibras em materiais frágeis, buscando ganho de ductilidade, data de tempos remotos. Contudo, aplicada ao concreto, essa técnica é bastante recente, apresentando ainda vários problemas a serem solucionados, tais como: problemas com a trabalhabilidade do concreto fresco e desconhecimento das taxas ideais de adição de fibras.

Dentro desse contexto, este trabalho tem como proposta a avaliação do comportamento dos pilares de concreto de alta resistência submetidos à flexocompressão reta. Para tanto, investigou-se a ductilidade dos pilares submetidos à compressão centrada e à flexo-compressão reta, com adição de fibras de aço e/ou aumento das taxas de armadura transversal. Em seguida, taxas mínimas ideais de adição de fibras e/ou de armadura transversais foram buscadas, de modo a garantir a capacidade mínima de absorção de energia por estes elementos.

\subsection{OBJETIVO}

Esta tese tem como proposta principal o estudo da ductilidade e do comportamento de pilares de concretos de altas resistências submetidos à flexocompressão reta. Objetiva-se, inicialmente, quantificar e modelar matematicamente o ganho de ductilidade dos pilares de concreto de alta resistência com a adição de fibras de aço com ganchos nas extremidades e/ou com confinamento da seção transversal por meio de estribos. Para tanto, um estudo experimental foi realizado para calibração dos modelos propostos. Em seguida, com o modelo matemático calibrado com os resultados experimentais, realizaramse simulações que conduziram a determinação de taxas mínimas de armadura transversal e de índices de reforços ideais de adição de fibras ao concreto, capazes 
de proverem aos pilares de CAR os mesmos índices de ductilidade dos pilares de concreto de resistência usual, dimensionados segundo o Projeto de Revisão de Norma da NBR 6118 (2001).

Na parte principal desse trabalho, fez-se a avaliação do efeito da flexão sobre as tensões de confinamento geradas pela armadura transversal. Buscou-se qualificar e quantificar a dissipação dessas tensões, bem como o efeito resultante na ductilidade dos pilares de $C A R$.

Finalmente, incorporaram-se todos os modelos matemáticos propostos ao programa ANAPROT, que se baseia no Método dos Elementos Finitos e é capaz de analisar pórticos planos de concreto armado e protendido. Após a incorporação dos modelos, o programa foi utilizado para simular o comportamento de alguns pilares de $C A R$, almejando-se a criação de critérios iniciais de dimensionamento dessas estruturas, com índices de ductilidade aceitáveis.

\subsection{JUSTIFICATIVA}

$\mathrm{O}$ advir do concreto de alta resistência permitiu aos engenheiros o dimensionamento de edificações com maior durabilidade, maior rigidez e maior disponibilidade de espaços. Contudo, observa-se que a utilização desse material na construção civil brasileira é extremamente restrita e agravada pela falta de conhecimento sobre suas propriedades e de uma normalização nacional específica para o seu emprego em estruturas de concreto armado.

O Projeto de Revisão da Norma Brasileira NBR 6118 (2001), que regulamenta as metodologias de dimensionamento das estruturas de concreto armado, restringirá os projetos de estruturas às resistências características de concreto inferiores a 50MPa. Observa-se, ainda, que a extrapolação dos conceitos desse projeto de norma (op. cit.), para estruturas com concretos com resistências superiores a 50MPa, pode gerar situações contrárias à segurança, uma vez que, os modelos de cálculo utilizados não se aplicam às estruturas de concreto de alta resistência. Desse modo, tem-se observado que os poucos projetos nacionais, que utilizaram e estão utilizando o concreto de alta resistência, foram embasados em normas internacionais, que, na grande maioria, não são condizentes aos materiais 
e nem à realidade brasileira. Diante dos fatos expostos, faz-se necessária, com certa urgência, a criação de normas nacionais sobre o tema.

Tentado colaborar para o melhor entendimento das propriedades mecânicas do concreto de alta resistência e gerar informações necessárias para uma futura normalização de seu emprego em estruturas de concreto armado, várias pesquisas foram realizadas no Brasil, conforme citado no item 1.1 deste capítulo. Diversos problemas já foram elucidados; contudo, outros pontos ainda requerem maiores estudos e análises.

Visando dar continuidade às investigações sobre o tema, o presente trabalho procurou estudar a ductilidade dos pilares de concreto de alta resistência, com adição de fibras metálicas, submetidos à compressão centrada e à flexocompressão. Como parte de um projeto maior, não se objetivou a compilação dos resultados e das revisões bibliográficas dos trabalhos anteriores, mas, sim, a utilização destes apenas como referências norteadoras para se atingir os objetivos propostos.

Finalmente, dentro da realidade exposta, observa-se que todos os esforços que visam a gerar subsídios para a normalização do uso do CAR adquirem relevância.

\subsection{CONTEÚDO DA TESE}

A presente tese foi dividida em nove capítulos e dois apêndices. No primeiro capítulo, são apresentados os comentários iniciais, os objetivos, as justificativas e a relevância do estudo aqui desenvolvido.

No segundo capítulo, apresentam-se, inicialmente, as principais características dos pilares de concreto de alta resistência e os fatores que influenciam o seu comportamento mecânico. Em seguida, um breve histórico dos modelos para o concreto confinado submetido à compressão centrada é realizado e, então, são apresentadas as equações matemáticas mais utilizadas para descrever esse comportamento. Apresenta-se, ainda, uma discussão sobre os modelos matemáticos, existentes na Literatura, que se propõem a descrever o comportamento à compressão do concreto de alta resistência com confinamento 
por armadura transversal, constituída por estribos metálicos. Nessa discussão, esses modelos matemáticos são comparados, suas vantagens e desvantagens levantadas e a sua eficiência em representar com exatidão o comportamento real dos pilares é avaliada. Baseado nesta avaliação, o modelo de Cusson e Paultre (1995) foi escolhido para ser utilizado nesta tese. Finalmente, discute-se o comportamento do concreto confinado submetido à flexo-compressão reta.

No capítulo três, é apresentada a revisão bibliográfica sobre o concreto reforçado com fibras de aço $(C R F A)$. Os principais fatores que influenciam o comportamento mecânico do CRFA são elencados e discutidos. Em seguida, discute-se o efeito das fibras de aço no comportamento à compressão do concreto e a eficiência dos principais modelos matemáticos que tentam descrever o problema. Concluindo o capítulo, são discutidos os comportamentos à tração e à flexão do $C R F A$ e os modelos que tentam descrevê-los.

No capítulo quatro, é apresentado o programa computacional utilizado para modelar os pilares de concreto de alta resistência. São apresentadas as principais hipóteses, os procedimentos de cálculo e o elemento finito que esse programa utiliza. Em seguida, apresentam-se as leis constitutivas dos materiais, que foram incorporadas ao programa, e a metodologia utilizada para essa incorporação. Ainda, são discutidas as metodologias para avaliação e quantificação da ductilidade dos concretos, e um modelo é proposto. Finalmente, propõe-se um modelo matemático para descrever o comportamento do $C R F A$ à compressão com fibras de aço com ganchos nas extremidades. O modelo é válido para resistência do concreto entre $30 \mathrm{MPa}$ e $90 \mathrm{MPa}$ e foi proposto a partir da análise de regressão de 75 diagramas experimentais de CRFA com resistência do concreto entre $30 \mathrm{MPa}$ e $90 \mathrm{MPa}$, taxas volumétricas de fibras entre $0 \%$ e $2 \%$, e fatores de forma da fibra entre 50 e 114.

No quinto capítulo, é realizado um estudo paramétrico da influência da resistência do concreto, da taxa da armadura longitudinal e transversal, da geometria da seção transversal, do índice de reforço da adição de fibras e da excentricidade do carregamento na ductilidade do concreto de alta resistência. São 
estabelecidos, ainda, limites mínimos de ductilidade aceitáveis, para os concretos de alta resistência.

No sexto capítulo, é apresentado o programa experimental realizado. São descritos os materiais utilizados, as metodologias empregadas na preparação dos pilares e na execução dos ensaios.

No sétimo capítulo, são apresentadas, inicialmente, as observações gerais do programa experimental referente aos ensaios dos pilares submetidos à compressão centrada. São descritos e analisados os resultados dos ensaios desses pilares de concreto de alta resistência, com diferentes resistências, índices de reforço da adição de fibras e taxas de armadura transversal. Análises de variância são realizadas para quantificar a influência dos fatores analisados nas resistências do concreto no pilar, nas deformações da armadura transversal e nos índices de ductilidade desses elementos. Realiza-se um estudo comparativo entre o modelo de Cusson e Paultre (1995) e os resultados experimentais. Em adição, são sugeridas modificações para o modelo de Cusson e Paultre (1995) para que o mesmo seja capaz de modelar o comportamento de pilares com concretos de alta resistência com confinamento e/ou adição de fibras de aço. Para tanto, análises de regressões não-lineares são realizadas e novas equações matemáticas são sugeridas. Também, por meio de análises de regressões não-lineares, são apresentadas equações que garantem a ductilidade mínima para os pilares com CAR

No oitavo capítulo, são apresentadas as principais observações referentes aos ensaios dos pilares submetidos à compressão excêntrica. Inicialmente, é realizada uma análise da eficiência das condições de contorno utilizadas e, em seguida, avaliam-se os efeitos das variáveis estudadas (excentricidade de força, taxa de adição de fibras e taxa de armadura transversal) na capacidade de carga, nas deformações das armaduras e nos índices de ductilidade dos pilares. Finalmente, conduz-se um estudo sobre a modelagem do comportamento dos pilares à flexo-compressão. Nesse estudo, são comparados os resultados experimentais com os fornecidos pelos modelos de Cusson e Paultre (1995), FIB 
(1999) e do modelo proposto para o CRFA no Capítulo 5. Finalmente, a dissipação das tensões de confinamento devido à flexão é discutida e quantificada.

Por fim, no nono capítulo, são apontadas e discutidas as principais conclusões do trabalho e alguns aspectos correlatos ao tema, que demandam futuros estudos.

Posteriormente aos nove capítulos, apresentam-se as referências bibliográficas citadas e os dois apêndices com as informações complementares dos ensaios experimentais. 


\section{MODELOS PARA O CONCRETO CONFINADO}

\subsection{INTRODUÇÃO}

Um aspecto que tem levantado bastante discussão no meio técnicocientífico é a fragilidade do concreto de alta resistência, quando comparado aos concretos de resistências usuais. Em uma análise rápida e visual entre os diagramas tensão vs. deformação desses concretos, observa-se que a parte ascendente do diagrama torna-se cada vez mais linear, a deformação correspondente à tensão de pico eleva-se e a capacidade de carga no trecho descendente diminui, quando da elevação da resistência à compressão. Essas diferenças nos diagramas são explicadas pela mudança da estrutura interna do concreto, que ocorre com o aumento da resistência à compressão. Observa-se que, com a elevação da resistência, a interface pasta-agregado torna-se mais resistente, a porosidade diminui e a relação entre a rigidez do agregado e da pasta aproximase da unidade. A superfície de ruptura, que antes era caracterizada pela propagação das fissuras dentro da pasta e na interfase pasta-agregado, passa a ser caracterizada, também, pelo secionamento dos agregados. Esse fato torna a distribuição interna das tensões mais uniforme, e o processo de fissuração só é iniciado quando as tensões de compressão atingem cerca de $90 \%$ da resistência do concreto, provocando uma linearização do trecho ascendente do diagrama. Ainda, por conta do reduzido processo de fissuração, a redistribuição de esforços dentro da massa do concreto fica comprometida, provocando um comportamento póspico bastante frágil e que é refletido na elevada inclinação do trecho descendente do diagrama tensão vs. deformação do concreto de alta resistência (Aïticin, 2000).

Tem-se verificado, porém, que a ductilidade de uma estrutura não depende apenas da ductilidade dos materiais que a constituem, mas também de diversos outros fatores, bem mais complexos, tais como: geometria do elemento estrutural, 
condições de contorno, tipo de carregamento, disposição das armaduras, taxa volumétrica das armaduras, interação entre os materiais constituintes, etc (Mendes, 1993). Assim, não é correto afirmar que uma estrutura de concreto de alta resistência irá se comportar de modo frágil.

Richart et alii (1928 ${ }^{1}$ apud MacGregor, 1997) observaram que, quando submetido a um estado de compressão tri-axial, o concreto pode apresentar comportamento quase frágil, plástico com softening ou plástico com hardening, dependendo das intensidades das três tensões principais. Esse efeito é provocado pelas tensões de compressão, que controlam o processo de propagação das fissuras e, conseqüentemente, a ductilidade do concreto.

Nos pilares, o concreto pode ser submetido a um estado tri-axial de tensões, por meio do confinamento por armaduras transversais. Essas armaduras podem ser formadas por estribos com pequeno espaçamento, por tubos metálicos, ou ainda por tubos de materiais compósitos. Em todos esses casos, as armaduras transversais geram um confinamento passivo. Assim, para baixas intensidades de carregamento, a expansão lateral do concreto é desprezível; conseqüentemente, a armadura transversal é praticamente não-solicitada e o comportamento do concreto é semelhante ao do não-confinado. Com a elevação do carregamento para níveis da resistência uniaxial do material, o processo de microfissuração se intensifica, a expansão lateral do material atinge o valor máximo e, então, a armadura transversal é solicitada intensamente, confinando, desse modo, o concreto (Park e Paulay, 1975 e Chen, 1982).

Ensaios de pilares de concreto de alta resistência, confinados e submetidos à compressão centrada, têm mostrado que o comportamento mecânico desses elementos apresenta características diferenciadas das dos pilares de concreto de resistência usual (Cusson e Paultre, 1994; Foster et alii, 1998; Raszvi e Saatacioglu, 1999a; e Liu et alii, 2000). Os ensaios mostram ainda que o

${ }^{1}$ RICHART, F. E.; BRANDTZAEG, A e BROWN, R. L.. A study of the failure of concrete under combined compressive stress. Bull. n. 185, Engineering Experimental Station, University of Illinois, Urbana, Ill, 1928. 
comportamento mecânico dos pilares de CAR é influenciado por diversos fatores, dentre os quais destacam-se: a resistência do concreto; o cobrimento; a geometria, a taxa, o diâmetro e o espaçamento da armadura transversal; e, por fim, a tensão de escoamento da armadura de confinamento.

O Comitê 441 do Instituto Americano do Concreto (ACI-441, 1997) mostra que o comportamento dos pilares de CAR é diretamente influenciado pelo confinamento e pode ser resumido esquematicamente na Figura 2.1. Observa-se que o trecho ascendente do diagrama é praticamente linear até $90 \%$ da carga correspondente ao ponto A. Nesse trecho, a armadura de confinamento tem pouco ou nenhum efeito e trabalha com tensões inferiores a $50 \%$ da sua tensão de escoamento (Cusson e Paultre, 1994). O ponto A corresponde ao descolamento do cobrimento, que ocasiona uma perda brusca de resistência, conduzindo o diagrama ao ponto B. A diferença entre as cargas correspondentes aos pontos A e B é influenciada diretamente pela espessura do cobrimento e pela quantidade de armadura transversal, e varia, aproximadamente, entre $10 \%$ e $15 \%$. Após o ponto B, a expansão lateral do concreto atinge o seu valor máximo e o comportamento do pilar torna-se função da armadura de confinamento. Segundo Bjerkeli et alii (1990) e Cusson e Paultre (1994), é possível aumentar a resistência dos pilares de CAR em até $150 \%$ da calculada pelas previsões do ACI 318-89. Além disso, podem-se obter altos índices de ductilidade, quando o índice de confinamento for alto.

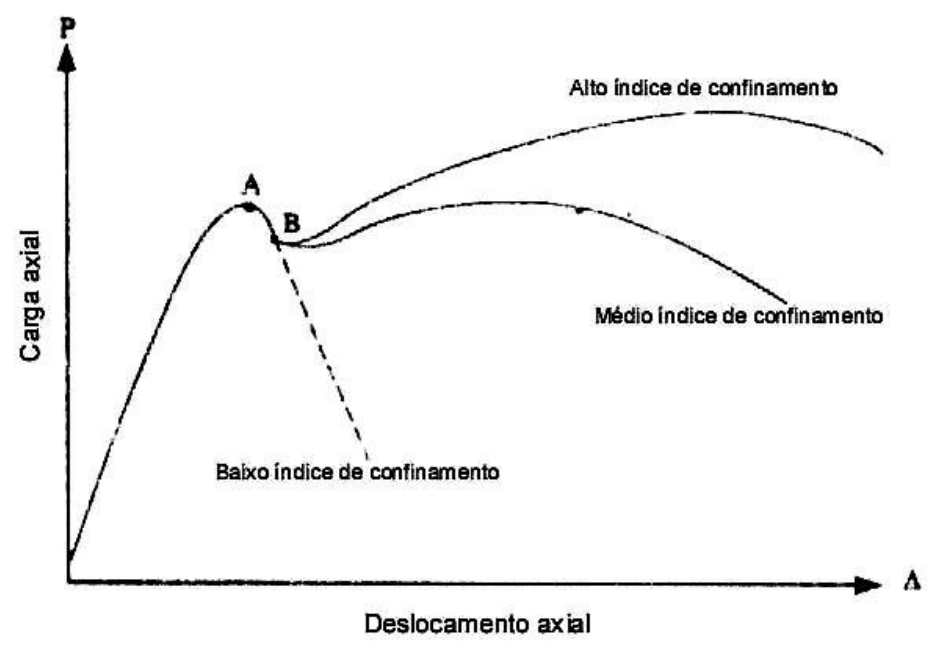

Figura 2.1 - Comportamento esquemático dos pilares de concreto de alta resistência sob compressão centrada (ACI-441, 1997) 


\subsection{FATORES QUE INFLUENCIAM NO COMPORTAMENTO DOS PILARES DE CAR}

\subsubsection{Resistência do concreto}

A influência da resistência do concreto está relacionada a dois fatores: ao coeficiente de Poisson e à ductilidade do concreto. Durante a fase elástica dos diagramas tensão de compressão vs. deformação, os coeficientes de Poisson, dos concretos de resistências usual e alta, são da mesma ordem de grandeza. Entretanto, próximo à ruptura, o CAR apresenta coeficiente de Poisson menor, isto é, menor expansão lateral, devido à sua menor microfissuração interna. Desse modo, a armadura transversal só é solicitada para valores elevados de deformações, superiores aos do concreto de resistência usual, reduzindo, assim, a eficiência do confinamento (Bjerkeli et alii, 1990 e Cusson e Paultre, 1994). Segundo Ahmad e Shah (1987), para a intensidade de tensão relativa à resistência do concreto, o coeficiente de Poisson é dado pela Eq.(2.1):

$$
\nu=6,85 \cdot f_{c j}^{-0,77}
$$

na qual $f_{c j}$ é a resistência à compressão média do concreto, obtida por ensaios de corpos-de-prova cilíndricos, dada em (MPa). Por outro lado, verifica-se que os concretos menos resistentes apresentam maior ductilidade, sendo necessária uma taxa de confinamento relativamente menor para se atingir uma ductilidade préestabelecida (Park e Paulay, 1975).

\subsubsection{Cobrimento}

Ao contrário do que ocorre nos pilares de concreto de resistência usual, é observado que o cobrimento dos pilares de CAR se destacam antes que a capacidade de carga axial teórica do elemento seja atingida (ACI-441, 1997). Como já mencionado, esse fato é refletido no diagrama carga axial vs. deslocamento axial do pilar, pela perda de resistência correspondente ao trecho A$\mathrm{B}$ do diagrama (Figura 2.1). O descolamento prematuro do cobrimento, segundo alguns autores (Park et alii, 1982; Razvi e Saatacioglu, 1994; Claeson et alii, 1996 e Liu e Foster, 1998), é provocado pelo alto volume de armadura transversal, que 
interrompe a continuidade entre o concreto do núcleo e do cobrimento, gerando desse modo, uma linha preferencial de falha, que é agravada quando o espaçamento entre os estribos é pequeno.

Por outro lado, Sargin et alii (1971) sugerem que a presença de altas taxas de armadura transversal prejudica a compactação do concreto do cobrimento e, assim, uma maior concentração de ar e água localiza-se nesta região. Esses fatores fazem com que a resistência do concreto do cobrimento seja inferior ao do núcleo, colaborando para sua ruptura prematura.

Collins et alii (1993) explicam que, em virtude da baixa permeabilidade do CAR, a secagem do cobrimento ocorre primeiro do que a do concreto do núcleo. Esse fenômeno gera um gradiente de tensões dentro da massa do concreto, que resulta na formação de planos de ruptura responsáveis pelo destacamento.

Foster et alii (1998), por meio de análise com Elementos Finitos, mostraram que as deformações laterais do núcleo são inferiores às do cobrimento, uma vez que a amadura transversal impede a expansão lateral do núcleo (ver Figura 2.2). Esse gradiente de deformações gera tensões de tração entre o núcleo e o cobrimento, que, quando atinge a resistência à tração do concreto, ocasiona o surgimento de fissuras na interfase núcleo-cobrimento, as quais ocasionam a separação entre as duas partes. Ainda segundo os autores citados, para acontecer o destacamento do cobrimento é preciso não só o surgimento das fissuras, mas também outros mecanismos, como a flexão e a expansão da armadura longitudinal, e a instabilidade lateral que fica sujeito o cobrimento devido a sua baixa esbeltez.

A fissuração na interface núcleo-cobrimento também ocorre nos pilares de concreto de resistência usual, porém, o destacamento não acontece de forma brusca, imediatamente após o início da fissuração. O cobrimento perde sua capacidade de carga de forma gradual durante a ativação do confinamento passivo, não sendo observado o segmento A-B no diagrama carga axial vs. deslocamento axial (Sheike e Uzumeri, 1980). 

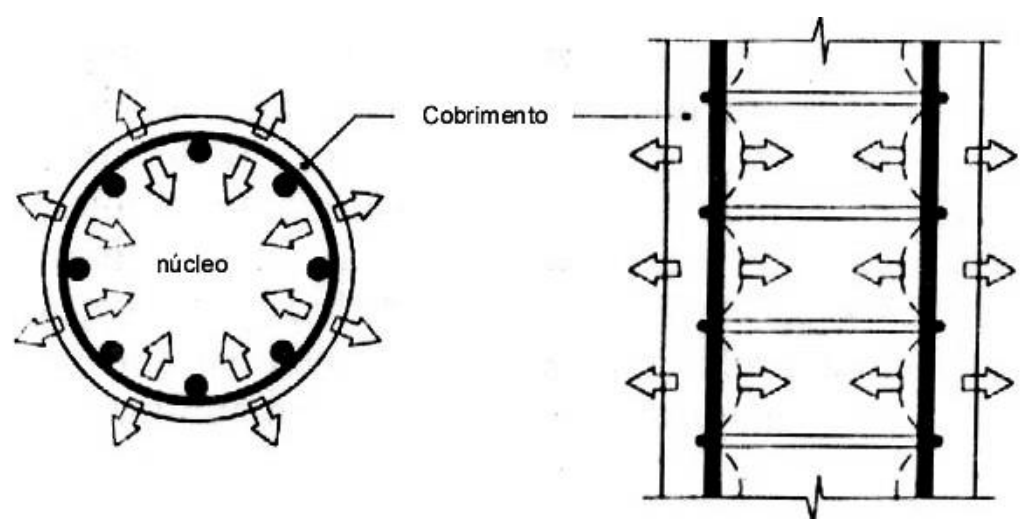

Figura 2.2 - Mecanismo de destacamento do cobrimento (Foster et alii, 1998)

\subsubsection{Geometria, taxa, diâmetro e espaçamento da armadura transversal}

Richart et alii (1928) observaram que o comportamento do concreto com confinamento, por meio de armadura transversal circular helicoidal, é semelhante ao confinamento exercido pela pressão hidrostática através de fluidos, tanto qualitativamente, quanto quantitativamente. Porém, ao contrário do caso anterior, o confinamento do concreto por estribos retangulares é bem menos eficiente (Bertero e Felippa, 1964² apud Park e Paulay, 1975). A razão para essa ineficiência reside na configuração geométrica da armadura transversal. Trabalhando como armadura de confinamento, os estribos circulares helicoidais são submetidos apenas a esforços de tração e, assim, conseguem transmitir de modo uniforme a tensão de confinamento para o concreto. Já os estribos retangulares, além dos esforços de tração, também são submetidos a esforços de flexão, que provocam o arqueamento de seus ramos e, conseqüentemente, a dissipação de parte das tensões de confinamento. Desse modo, apenas as regiões de concreto próximas às quinas e ao centro da seção permanecem efetivamente confinadas. Esse fenômeno agrava-se ainda mais, quando a relação entre a maior e a menor dimensão dos estribos retangulares é elevada, pois o efeito de arqueamento se intensifica. Na Figura 2.3 apresentam-se maiores detalhes deste fenômeno. Apesar desse fato, pesquisas apontam que os estribos retangulares

\footnotetext{
2 BERTERO, V.V. e FELIPPA, C. Discussion of "Ductility of concrete" by Roy, H.E.H. and Sozen, M.A., International Symposium on flexural mechanics of reinforced concrete, ASCE-ACI, Miami, 1964, p.227-234.
} 
aumentam significativamente a ductilidade do concreto, contudo, a resistência pouco é modificada.

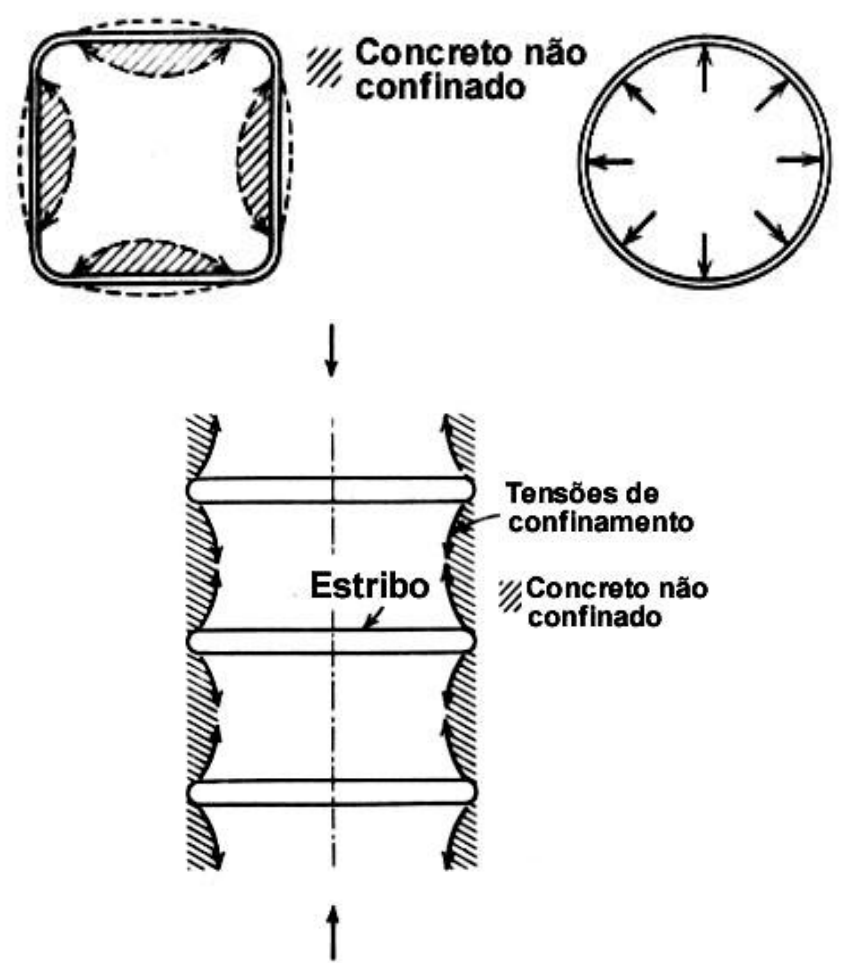

Figura 2.3 - Áreas efetivas de confinamento (Park e Paulay, 1975)

Diversos pesquisadores relatam que a tensão lateral de confinamento aplicada ao concreto está diretamente relacionada com a taxa de armadura transversal (Fafitis e Shah, 1985; Bjerkeli et alii, 1990; Cusson e Paultre, 1994; e Mau et alii, 1998). Xie et alii (1997) mostrou que, quando o espaçamento da armadura transversal é mantido constante e a taxa volumétrica dessa armadura é elevada ocorre o aumento da tensão de confinamento e, conseqüentemente, o incremento da capacidade pós-pico dos pilares.

Claeson e Gyltoft (1998) observaram por meio de ensaio de pilares de seção quadrada, que quanto menor for o espaçamento entre estribos mais eficiente torna-se o confinamento, melhorando, assim, a ductilidade dos elementos. Contudo, os autores não observaram melhora na capacidade de carga dos pilares quando o espaçamento dos estribos era reduzido. Apesar desse fato, Cusson e Paultre (1992) observaram melhora, tanto na ductilidade, como também na 
capacidade resistente dos pilares, quando o espaçamento dos estribos era reduzido. O fato é explicado, uma vez que a distribuição das tensões de confinamento longitudinalmente, entre estribos, se dá em forma de arco. Desse modo, quando o espaçamento é elevado, um grande volume de concreto permanece não-confinado e, durante o carregamento da estrutura, este pode se desprender da peça, em virtude do gradiente interno de tensões (ver Figura 2.4).
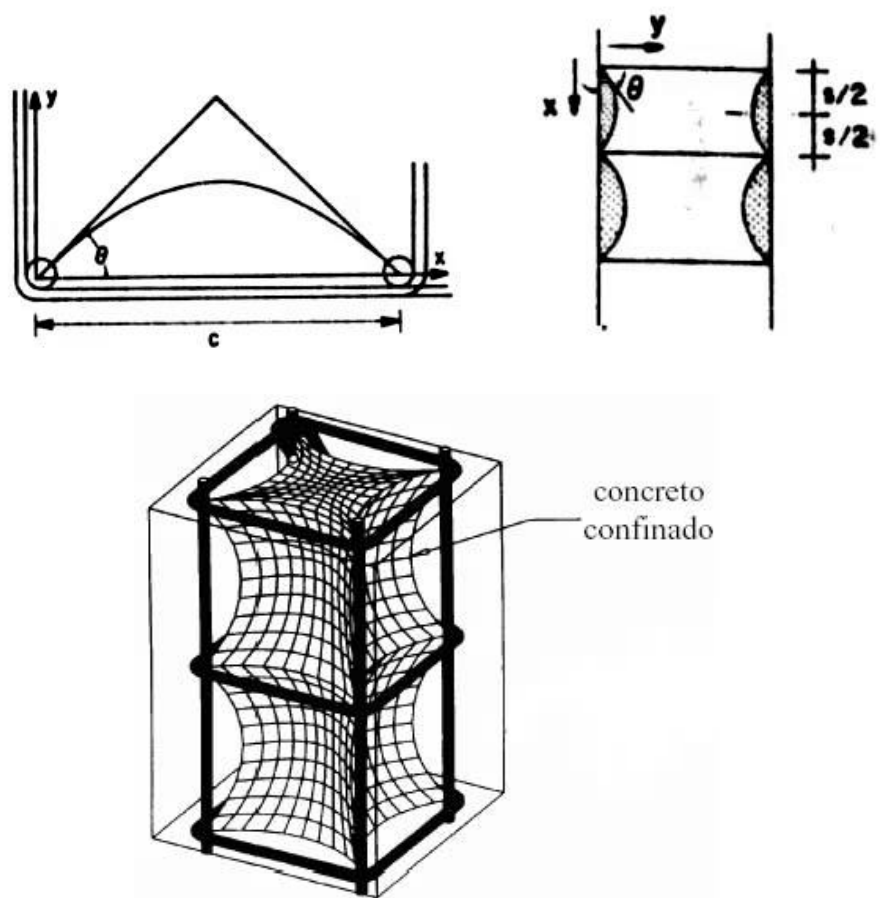

Figura 2.4 - Distribuição das tensões de confinamento nas seções transversais e ao longo do pilar

O diâmetro da armadura transversal também é fator importante, quando a geometria do estribo é retangular, pois, devido a maior rigidez dos estribos com maior diâmetro, o efeito do arqueamento é minorado e a distribuição das tensões de confinamento na seção transversal torna-se mais uniforme, melhorando a eficiência do confinamento (Park e Paulay, 1975).

\subsubsection{Taxa e diâmetro da armadura longitudinal}

A armadura longitudinal também colabora no confinamento do concreto nos pilares de CAR. Verifica-se que elevadas taxas e diâmetros da armadura 
longitudinal melhoram a eficiência do confinamento, aumentando o ganho na capacidade de carga e ductilidade dos elementos (Razvi e Saatacioglu, 1999a e Cusson e Paultre, 1992). A distribuição da armadura longitudinal ao longo do perímetro do núcleo deve ser uniforme e o espaçamento entre as barras pequeno. $\mathrm{O}$ contato entre as barras da armadura longitudinal e os estribos da armadura transversal deve ser garantido, de modo a impedir qualquer movimento de corpo rígido das barras longitudinais (Sheikh e Uzumeri, 1982).

\subsubsection{Tensão de escoamento da armadura transversal}

A tensão de escoamento da armadura transversal determina o limite superior da pressão de confinamento aplicada ao núcleo do pilar. Desse modo, era esperado que estribos com elevada tensão de escoamento melhorassem a eficiência do confinamento, porém, Cusson e Paultre (1992) e El-Dash e Ahmad (1994) observaram que, para os estribos desenvolverem toda a sua capacidade resistente, é necessário que os pilares de CAR sejam bem confinados, com elevadas taxas volumétricas e arranjos das armaduras transversais adequados.

\subsection{COMPORTAMENTO DO CONCRETO À COMPRESSÃO CENTRADA}

\subsubsection{Histórico}

O início dos estudos da modelagem do concreto confinado por estribos retangulares data da década de 50, quando Chan $\left(1955^{3}\right.$ apud Sheikh, 1982) propôs equações para avaliar a resistência do concreto confinado e a correspondente deformação. As equações propostas eram baseadas em testes de pilares submetidos à compressão com pequena excentricidade de dimensões: $152 \mathrm{~mm} \times 152 \mathrm{~mm} x 292 \mathrm{~mm}$ e $152 \mathrm{~mm} \times 92 \mathrm{~mm} x 1321 \mathrm{~mm}$. Chan (op. cit.) sugeria que o trecho ascendente do diagrama tensão vs. deformação do concreto confinado fosse modelado por um diagrama tri-linear, no qual a inclinação dos segmentos de

\footnotetext{
${ }^{3}$ CHAN, W. W. L.. The ultimate strength and deformation of plastic hinges in reinforced concrete framework. Magazine of Concrete Research, v. 7, n. 21, 1955, p. 121-132.
} 
reta diminuía em função de um coeficiente $\lambda_{i}$ que multiplica o módulo de elasticidade tangente na origem do concreto (ver Figura 2.5).

Nove anos após o trabalho de Chan ter sido publicado, Roy e Sozen $\left(1964^{4}\right.$ apud Sheikh, 1982) propuseram um modelo no qual o comportamento do concreto confinado era representado por um diagrama bi-linear. Os autores estudaram, experimentalmente, pilares com dimensões de $127 \mathrm{~mm} x 127 \mathrm{~mm}$ e $635 \mathrm{~mm}$, constituídos por concretos com resistência não superior a $25 \mathrm{MPa}$, submetidos à compressão axial, e concluíram que o confinamento por meio de estribos retangulares não era capaz de promover aumento de resistência, sendo este fato incorporado ao modelo. Roy e Sozen (op. cit.) ainda sugeriram que a avaliação da ductilidade pós-pico do concreto confinado fosse realizada por meio da deformação correspondente à tensão igual $50 \%$ da tensão máxima suportada por este material, conforme Figura 2.6.

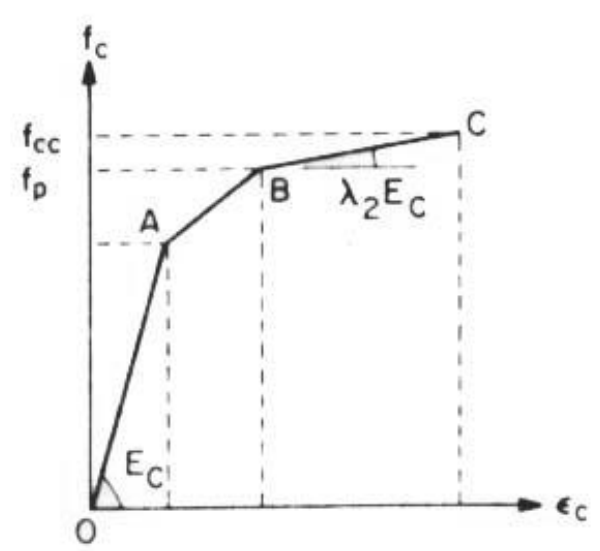

Figura 2.5 - Modelo proposto por Chan (1955)

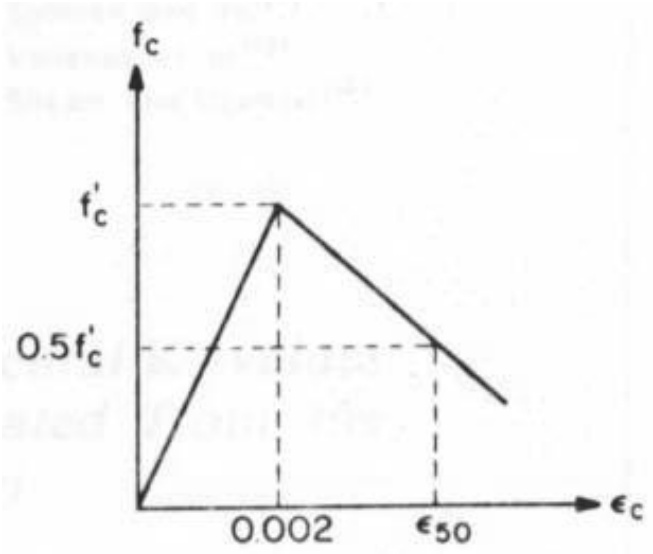

Figura 2.6 - Modelo proposto por Roy e Sozen (1964)

Já na década de 70, Sargin et alii (1971) apresentaram quatro equações para modelar o comportamento do concreto confinado. Três dessas equações eram utilizadas para calcular a tensão máxima do concreto confinado e a respectiva deformação. Essas equações foram obtidas por meio da análise de regressão dos resultados experimentais de ensaios realizados em pilares com dimensões $127 \mathrm{~mm}$

\footnotetext{
${ }^{4}$ ROY, H. E. H. e SOZEN, M. A.. Ductility of concrete. American Concrete Institute SP-12, Detroit, 1965, p. 213-224.
} 
$x 127 \mathrm{~mm} x$ 635mm, submetidos à compressão centrada e excêntrica. O trecho ascendente do diagrama era descrito pela equação proposta por Sargin (op. cit.), atualmente uma das mais utilizadas para descrever esse trecho do diagrama do concreto confinado e não-confinado, e que será discutida posteriormente. $\mathrm{Na}$ Figura 2.7, é apresentado o diagrama tensão vs. deformação para o concreto confinado proposto pelos autores.

No mesmo ano, Kent e Park (1971) propuseram um modelo para o diagrama tensão vs. deformação do concreto confinado, que consistia de um polinômio do segundo grau para o trecho ascendente e duas equações lineares para o trecho descendente. Nesse modelo, o efeito do confinamento era caracterizado pelo ajuste da inclinação da curva do trecho descendente do diagrama e não considerava o aumento da resistência provocado pelo confinamento. O modelo proposto pelos autores foi obtido por análise de regressão dos resultados experimentais de Solima e Yu (1967) e Roy e Sozen (1964) e é apresentado na Figura 2.8.

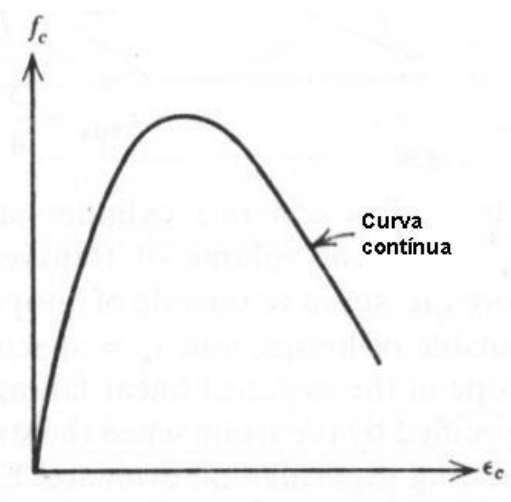

Figura 2.7 - Modelo proposto por Sargin et alii (1971)

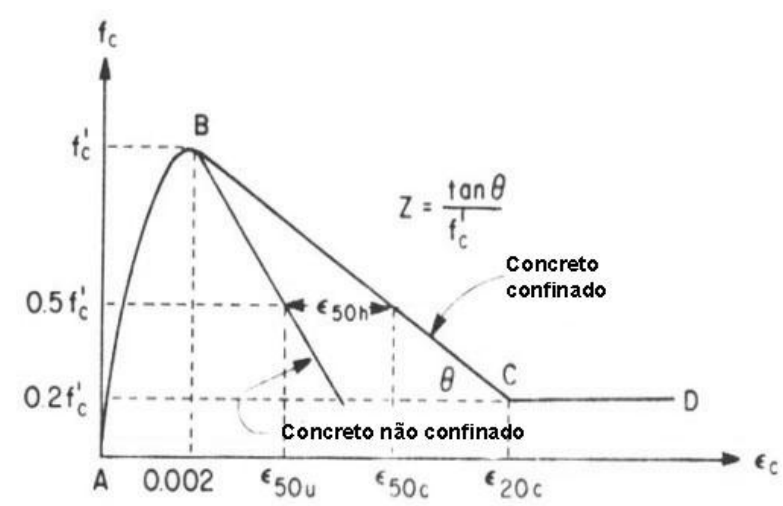

Figura 2.8 - Modelo proposto por Kent e Park (1971)

Park et alii (1982) ajustaram o modelo de Kent e Park (1971) e introduziram o aumento da resistência do concreto provocado pelo confinamento; assumiram, ainda, que o efeito do confinamento era proporcional à taxa volumétrica de armadura de confinamento. Nesse mesmo ano, Sheikh e Uzumeri (1982) desenvolveram um modelo no qual o efeito do confinamento era incorporado, pelo ajuste da tensão máxima, ao diagrama tensão vs. deformação do 
concreto não-confinado, e sugeriram um coeficiente que media a eficiência do confinamento. O comportamento descendente do diagrama tensão vs. deformação do modelo em questão era similar ao de Park et alii (1982). O grande avanço desse último modelo é a consideração da influência da armadura longitudinal e do arranjo da armadura transversal. Novamente, todo o equacionamento foi obtido através da análise de regressão de dados experimentais. Na Figura 2.9, é apresentado o diagrama tensão vs. deformação para o concreto confinado, proposto por Sheikh e Uzumeri (1982).

Na década de 90, Saatcioglu e Razvi (1992) estabeleceram um modelo no qual o diagrama tensão vs. deformação para o concreto confinado era modelado por um polinômio do segundo grau, para o trecho ascendente, e um do primeiro grau, para o trecho descendente. A equação para o trecho descendente era função do ponto correspondente a $85 \%$ da tensão de pico (ver Figura 2.10). O modelo segue a linha do modelo de Sheikh e Uzumeri (1982) e utiliza um coeficiente para determinação da pressão equivalente de confinamento. Um ponto importante no modelo de Saatcioglu e Razvi (1992) é a consideração, na sua formulação, da forma das seções retangulares, na qual a pressão equivalente de confinamento é calculada para a direção da maior e menor dimensão separadamente. Ainda, seguindo a linha de todos os modelos já citados, esse modelo baseia-se em um extenso programa experimental.

Todos os modelos anteriormente citados foram desenvolvidos para concreto com resistência usual e não são adequados para modelar o comportamento dos pilares de CAR, uma vez que superestimam a ductilidade e não levavam em consideração a perda prematura do cobrimento, que acontece de modo mais acentuado nos pilares de concreto de alta resistência (Cusson e Paultre, 1993). Apesar desses fatos, os modelos para concretos de resistência usual com confinamento vêm servindo como base para formulação de novos modelos para o CAR. O procedimento consiste na introdução de coeficientes obtidos da análise estatística de resultados experimentais de concreto de alta resistência com confinamento e/ou introdução de novas equações (Cusson e Paultre, 1995; Attard e Setunge, 1996; Diniz e Frangopol, 1997; Foster et alii, 1998; e Razvi e 
Saatcioglu, 1999b). Desse modo, observa-se que a maioria desses novos modelos utiliza quase sempre as mesmas equações para modelar o diagrama tensão vs. deformação do CAR confinado. Apesar desse fato, observa-se que, quando utilizados para descrever um dado pilar com confinamento, as respostas tensão vs. deformação de cada modelo apresentam diferenças consideráveis. Essas diferenças são explicadas, uma vez que as amostras de ensaios experimentais utilizadas para calibração dos modelos seguem padrões diferenciados de ensaios (Quintana, 2001).

A seguir, apresentam-se as equações mais utilizadas para modelar o comportamento dos concretos de CAR, com e sem confinamento.

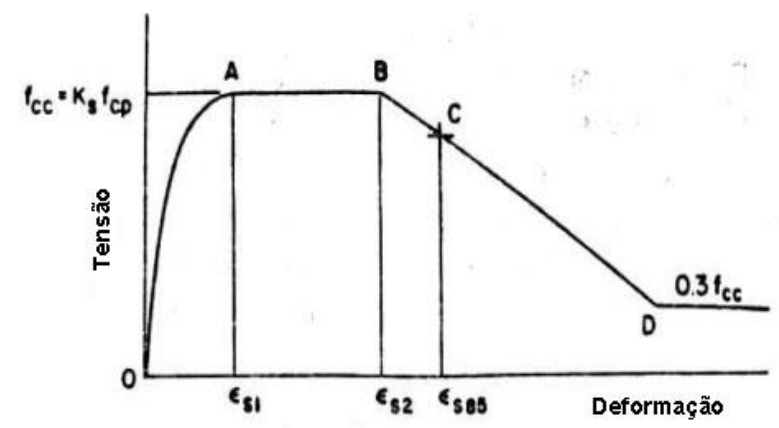

Figura 2.9 - Modelo proposto por Sheikh e Uzumeri (1982)

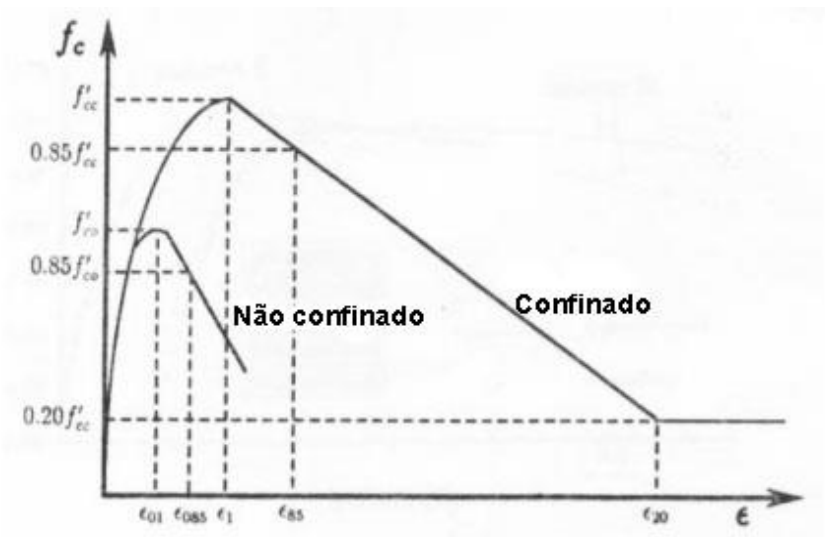

Figura 2.10 - Modelo proposto por Saatcioglu e Rasvi (1992) 


\subsubsection{Equações constitutivas do concreto confinado}

O comportamento ascendente do diagrama tensão de compressão vs. deformação do concreto confinado é comumente modelado pela equação proposta por Sargin (1971), que é expressa pela Eq.(2.2):

$$
\frac{\sigma_{c}}{f_{c c}}=\frac{A \cdot\left(\frac{\varepsilon_{c}}{\varepsilon_{c c}}\right)+(B-1) \cdot\left(\frac{\varepsilon_{c}}{\varepsilon_{c c}}\right)^{2}}{1+(A-2) \cdot\left(\frac{\varepsilon_{c}}{\varepsilon_{c c}}\right)+B \cdot\left(\frac{\varepsilon_{c}}{\varepsilon_{c c}}\right)^{2}}
$$

na qual $\varepsilon_{c}$ é a deformação do concreto, $\varepsilon_{c c}$ é a deformação correspondente à tensão máxima $f_{c c}, \sigma_{c}$ é a tensão no concreto, e $A$ e $B$ são constantes funções das propriedades mecânicas do concreto. Os valores de $A, B, \mathcal{E}_{c c}$ e $f_{c c}$ são definidos de modo diferente pelos autores, em cada modelo proposto.

Outra equação bastante utilizada para definir o ramo ascendente do diagrama tensão de compressão vs. deformação do concreto confinado foi proposta por Popovics (1973) e é descrita pela Eq.(2.3):

$$
\frac{\sigma_{c}}{f_{c c}}=\frac{\beta \cdot\left(\frac{\varepsilon_{c}}{\varepsilon_{c c}}\right)}{(\beta-1)+\left(\frac{\varepsilon_{c}}{\varepsilon_{c c}}\right)^{\beta}}
$$

na qual $\beta$ é definido pela Eq.(2.4):

$$
\beta=\frac{\mathrm{E}_{\mathrm{c}}}{\mathrm{E}_{\mathrm{c}}-\left(f_{c c} / \varepsilon_{c c}\right)}
$$

nesta última, $E_{c}$ é o módulo de elasticidade do concreto não-confinado.

Para o ramo descendente do diagrama tensão vs. deformação do concreto confinado, as equações mais utilizadas são a equação polinomial de grau um, inicialmente proposta por Roy e Sozen (1964), e a exponencial, proposta por Fafitis e Shah (1985), e que podem ser expressas pelas Eq.(2.5) e Eq.(2.6), respectivamente: 


$$
\begin{aligned}
& \frac{\sigma_{c}}{f_{c c}}=a_{1} \cdot \varepsilon_{c}+b_{1} \\
& \frac{\sigma_{c}}{f_{c c}}=\exp \left(k_{11} \cdot\left(\varepsilon_{c}-\varepsilon_{c c}\right)^{k_{22}}\right)
\end{aligned}
$$

nas quais os valores de $a_{1}, b_{1}, k_{11}$ e $k_{22}$ são definidos de modo diferente pelos autores, em cada modelo proposto.

É essencial que exista continuidade entre os diagramas do concreto confinado e do não-confinado. Desse modo, é comum os modelos adotarem as mesmas equações do concreto confinado para o não-confinado, substituindo apenas as variáveis $\varepsilon_{c c}$ e $f_{c c}$ por $\varepsilon_{c o}$ e $f_{c}$, considerando que $\varepsilon_{c o}$ é a deformação correspondente à tensão de compressão do concreto não-confinado $f_{c}$ na estrutura.

\subsubsection{Modelos para o concreto de alta resistência}

A partir de 1980, diversos modelos vêm sendo propostos para modelar o comportamento à compressão do concreto de alta resistência, dentre os quais destacam-se: o modelo de Park et alii (1982), que foi calibrado com ensaios de pilares nos quais a resistência do concreto variava de $20 \mathrm{MPa}$ a $60 \mathrm{MPa}$; o modelo de Fafitis e Shah (1985), calibrado com concretos com resistências entre 26MPa e 66MPa; o modelo de Yong et alii (1988), calibrado com resistências de concreto que variavam de $84 \mathrm{MPa}$ a 94MPa; o modelo de Bjerkeli et alii (1990), calibrado com resistências de concreto que variavam de 50MPa a 97MPa; o modelo de Nagashima et alii (1992 5 apud Kappos e Konstantinidis, 1999), calibrado com concretos de resistências entre 60MPa e 118MPa; o modelo de EL-Dash e Ahmad (1994), calibrado com concretos de resistências entre 30MPa e 100MPa; o modelo de Cusson e Paultre (1995), calibrado com concretos de resistências entre 60MPa e 120MPa; Ibrahim e MacGregor (1996a), calibrado com concretos com

\footnotetext{
${ }^{5}$ NAGASHIMA, T., SUGANO, S., KIMURA, H. and ICHIKAWA, A. Monotonic axial compression test on ultra-high-strength concrete tied columns. Tenth world conference on earthquake engineering, Rotterdan: 1992, p. 2983-2988.
} 
resistências entre 60MPa e 129MPa; e, por fim, o modelo de Razvi e Saatcioglu (1999b), calibrado com concretos com resistências entre 60MPa e 124MPa.

Dentre todos os modelos citados acima, apenas os modelos de Cusson e Paultre (1995) e o modelo de Razvi e Saatcioglu (1999b) levam em consideração que a tensão na armadura transversal de confinamento pode ser diferente da tensão de escoamento, quando o núcleo do concreto atinge a sua resistência, e apresentam equações para predizer o valor da tensão real na armadura. Todos os outros consideram que para este ponto a armadura transversal está escoando.

Kappos e Konstantinidis (1999) realizaram um estudo estatístico, visando a avaliar a eficiência de dez modelos numéricos para concreto de alta resistência confinado. Dentre os modelos citados anteriormente, apenas os modelos de ELDash e Ahmad (1994) e Razvi e Saatcioglu (1999b) não se encontram inclusos na análise. Para o estudo, os autores utilizaram os dados experimentais de 108 pilares de CAR, com seção transversal quadrada, ensaiados com força centrada, com concretos cujas resistências variavam entre $50 \mathrm{MPa}$ e $125 \mathrm{MPa}$, armadura transversal composta por aços, com tensão de escoamento variando entre $340 \mathrm{MPa}$ e $1390 \mathrm{MPa}$, e taxa volumétrica de armadura transversal entre $0,8 \%$ e $5 \%$. Os autores avaliaram a precisão dos modelos em predizer seis parâmetros: a resistência do concreto confinado $\left(f_{c c}\right)$; a deformação axial correspondente à resistência do concreto confinado $\left(\varepsilon_{c c}\right)$; a deformação no trecho descendente do diagrama tensão vs. deformação, correspondente a $85 \%$ da resistência do concreto não-confinado $\left(\varepsilon_{0,85 f c}\right)$; a deformação no trecho descendente do diagrama tensão vs. deformação, correspondente a $50 \%$ da resistência do concreto confinado $\left(\varepsilon_{0,5 f c c}\right)$; a área abaixo do diagrama tensão vs. deformação, da origem até a deformação $\varepsilon_{c c}\left(A_{f c c}\right)$; e a área abaixo do diagrama tensão vs. deformação, da origem até a deformação $\varepsilon_{0,5 f c c}\left(A_{0,5 f c c}\right)$.

Kappos e Konstantinidis (1999) concluíram que, quanto à resistência $f_{c c}$, todos os modelos apresentaram bom comportamento. Os autores justificam o resultado, afirmando que esse parâmetro é de fácil modelagem. Os melhores resultados foram obtidos com os modelos de Nagashima et alii (1992), seguidos 
pelo de Cusson e Paultre (1995), apesar de a metodologia de cálculo de Cusson e Paultre (1995), para a tensão na armadura transversal, correspondente à resistência do concreto, ser conservativa.

Com relação à deformação $\varepsilon_{c c}$, foi observada elevada discrepância entre os resultados experimentais e os resultados dos modelos. Esse fato deve-se à alta influência do comprimento utilizado para a medição das deformações axiais sobre o valor de $\varepsilon_{c c}$. Novamente, os resultados mais uniformes foram obtidos com os modelos de Nagashima et alii (1992) e Cusson e Paultre (1995). A maioria dos modelos apresentou elevada variação na avaliação das deformações $\varepsilon_{0,85 f c}$ e $\varepsilon_{0,5 f c c}$, sendo o modelo de Ibrahim e MacGregor (1996) o que apresentou melhor desempenho. Os resultados mostraram elevada discrepância na predição da área $A_{f c c}$ pelos modelos estudados, sendo os melhores resultados obtidos com os modelos de Nagashima et alii (1992) e Cusson e Paultre (1995). Quanto à avaliação da área $A_{0,5 f c c}$, também foi observada alta discrepância entre os modelos, sendo o modelo de Ibrahim e MacGregor (1996) o mais preciso. Finalmente, os resultados da análise de Kappos e Konstantinidis (1999) indicam que o modelo de Nagashima et alii (1992) apresentou o desempenho mais satisfatório com relação a todos os parâmetros, seguido pelo modelo de Cusson e Paultre (1995).

Quintana (2001) realizou estudo comparativo entre diversos modelos para concreto confinado e não-confinado. Nesse estudo, foram avaliados todos os modelos citados, com exceção dos modelos de Fafitis e Shah (1985) e Nagashima et alii (1992). A autora concluiu que as curvas tensão vs. deformação para o concreto confinado e não-confinado, sugeridas pelos diversos modelos, podem apresentar grandes diferenças entre si, para um mesmo pilar. Ela informa, ainda, que essas diferenças são mais elevadas no ramo descendente do diagrama e que, para o concreto não-confinado, elas são provocadas pelos diferentes tipos de corpos-de-prova, características dos concretos e procedimentos usados nos ensaios, os quais foram utilizados para calibrar os modelos. E, segunda a autora, para o caso do concreto confinado, tem-se ainda a interferência das características das armaduras utilizadas nos pilares. 
Quintana (2001) também comparou as tensões na armadura transversal, correspondentes à resistência do concreto confinado, calculadas segundo Cusson e Paultre (1995) e Razvi e Saatcioglu (1999b) e as experimentais. A autora concluiu que os valores fornecidos por Cusson e Paultre (1995) sempre foram iguais ou menores que os de Razvi e Saatcioglu (1999b). Além disso, ela observa que estes valores podem diferir expressivamente dos experimentais. Finalmente, a autora realizou um estudo comparativo entre os modelos e resultados experimentais de pilares de seção quadrada, retangular e circular, com resistências do concreto entre $25 \mathrm{MPa}$ e $130 \mathrm{MPa}$, tensão de escoamento da armadura transversal entre $250 \mathrm{MPa}$ e $700 \mathrm{MPa}$ e taxa volumétrica de armadura transversal entre $0,4 \%$ e $5 \%$. Para os pilares de seção quadrada, a autora observou que as curvas fornecidas pelos modelos apresentaram-se bastante discrepantes das experimentais e sempre os melhores modelos eram aqueles que incluíram as curvas experimentais em sua calibração. Para seções retangulares, o modelo que apresentou melhor comportamento foi o de EL-Dash e Ahmad (1994), e para seções circulares o de Razvi e Saatcioglu (1999b). A autora concluiu que, dentre os modelos estudados, os que conseguem melhor representar o comportamento do concreto com confinamento passivo são os modelos de EL-Dash e Ahmad (1994) e Cusson e Paultre (1995).

Baseado nos estudos apresentados nos parágrafos anteriores, optou-se por utilizar o modelo de Cusson e Paultre (1995) como modelo base para este trabalho. A seguir, é apresentada uma descrição mais detalhada do modelo em questão.

\subsubsection{Modelo de Cusson e Paultre (1995)}

O modelo proposto por Cusson e Paultre (1995) é baseado na análise estatística de resultados experimentais de ensaios à compressão centrada de 50 pilares de concreto de alta resistência, dentre os quais 30 foram executados pelos próprios autores e 20 por Nagashima et alii (1992). No modelo, são utilizados conceitos e equações de diversos outros modelos encontrados na Literatura e já 
citados anteriormente neste trabalho. Desse modo, os autores partem do trabalho de Richart et alii (1928), que observaram que, quando submetido a um estado bidimensional de tensões de compressão, o concreto atinge a ruptura com força superior àquela do estado uniaxial. Assim, Richart et alii (1928) propuseram que a tensão máxima de compressão do concreto confinado pode ser calculada pela Eq.(2.7):

$$
f_{c c}=f_{c}+4,1 \cdot f_{l}
$$

na qual $f_{c}$ é a resistência à compressão do concreto na estrutura e $f_{l}$ é a tensão lateral nominal de confinamento. A tensão lateral nominal de confinamento apenas pode ser aplicada em regiões nas quais o efeito do confinamento se desenvolve completamente, o que não é o caso das seções retangulares com armadura transversal constituídas por estribos.

Cusson e Paultre (1995), utilizando o equilíbrio das tensões laterais do núcleo do concreto e as forças na armadura de confinamento, obtiveram que a tensão lateral nominal de confinamento pode ser expressa pela Eq.(2.8):

$$
f_{l}=\frac{f_{t c c}}{s} \cdot\left(\frac{A_{s t x}+A_{s t y}}{c_{x}+c_{y}}\right)
$$

na qual $f_{t c c}$ é a tensão na armadura transversal de confinamento; $s$ é a distância de centro a centro entre estribos; $A_{s t x}$ e $A_{s t y}$ são as áreas da seção transversal das armaduras de confinamento, paralelas aos eixos $x$ e $y$, respectivamente; e $c_{x}$ e $c_{y}$ são as larguras do núcleo do pilar, nas direções $x$ e $y$, respectivamente. O valor de $f_{t c c}$ é obtido pela deformação da armadura de confinamento, que é dada pela Eq.(2.9):

$$
\varepsilon_{t c c}=\boldsymbol{v} \cdot \varepsilon_{c c}-\left(\frac{f_{l e}-\boldsymbol{v} \cdot f_{l e}}{E_{s e c}}\right)
$$

na qual $v$ é o coeficiente de Poisson do concreto confinado, no ponto correspondente à máxima tensão; $E_{\text {secc }}$ é o módulo de elasticidade secante no ponto de máxima tensão do concreto confinado; e $f_{l e}$ é a pressão efetiva de confinamento, dada pela Eq.(2.10): 


$$
f_{l e}=K_{e} \cdot f_{l}
$$

Nesta última, por sua vez, $K_{e}$ é o coeficiente de confinamento efetivo e representa a taxa da área do concreto menos confinada, que se localiza na região média entre dois estribos consecutivos (ver Figura 2.11), assumindo que a distribuição da tensão de confinamento se dá em forma de arco. O conceito do coeficiente $K_{e}$ foi proposto por Sheikh e Uzumeri (1982) e, posteriormente, modificado por Mander et alii (1988), que adotaram que a distribuição da tensão de confinamento se dá em forma de arco e pode ser aproximada por uma parábola com tangente inicial igual a $45^{\circ}$. Assim, pode-se escrever o coeficiente $K_{e}$ pela Eq.(2.11):

$$
K_{e}=\frac{\left(1-\frac{\sum_{i} w_{i}^{2}}{6 \cdot c_{x} \cdot c_{y}}\right) \cdot\left(1-\frac{\left(s-\phi_{t}\right)}{2 \cdot c_{x}}\right) \cdot\left(1-\frac{\left(s-\phi_{t}\right)}{2 \cdot c_{y}}\right)}{1-\rho_{l}}
$$

na qual $w_{i}$ são os espaços entre as armaduras longitudinais; $\phi_{t}$ é o diâmetro dos estribos; $s$ é o espaço de centro a centro de estribo; e $\rho_{l}$ é a taxa de armadura longitudinal, em relação ao núcleo do pilar.

Richart et alii (1928) propuseram que a relação entre a tensão máxima do concreto confinado e sem confinamento pode ser expressa pela Eq.(2.12):

$$
\frac{f_{c c}}{f_{c}}=A+B \cdot\left(\frac{f_{l e}}{f_{c}}\right)^{C}
$$

na qual $A, B$ e $C$ são constantes obtidas por análise de regressão. Cusson e Paultre (1995) realizaram a análise de regressão para o concreto de alta resistência confinado e obtiveram, para $A, B$ e $C$, os valores de 1,0, 2,1 e 0,7, respectivamente. O coeficiente de correlação $\left(r^{2}\right)$ obtido pelos autores foi de $83 \%$. 

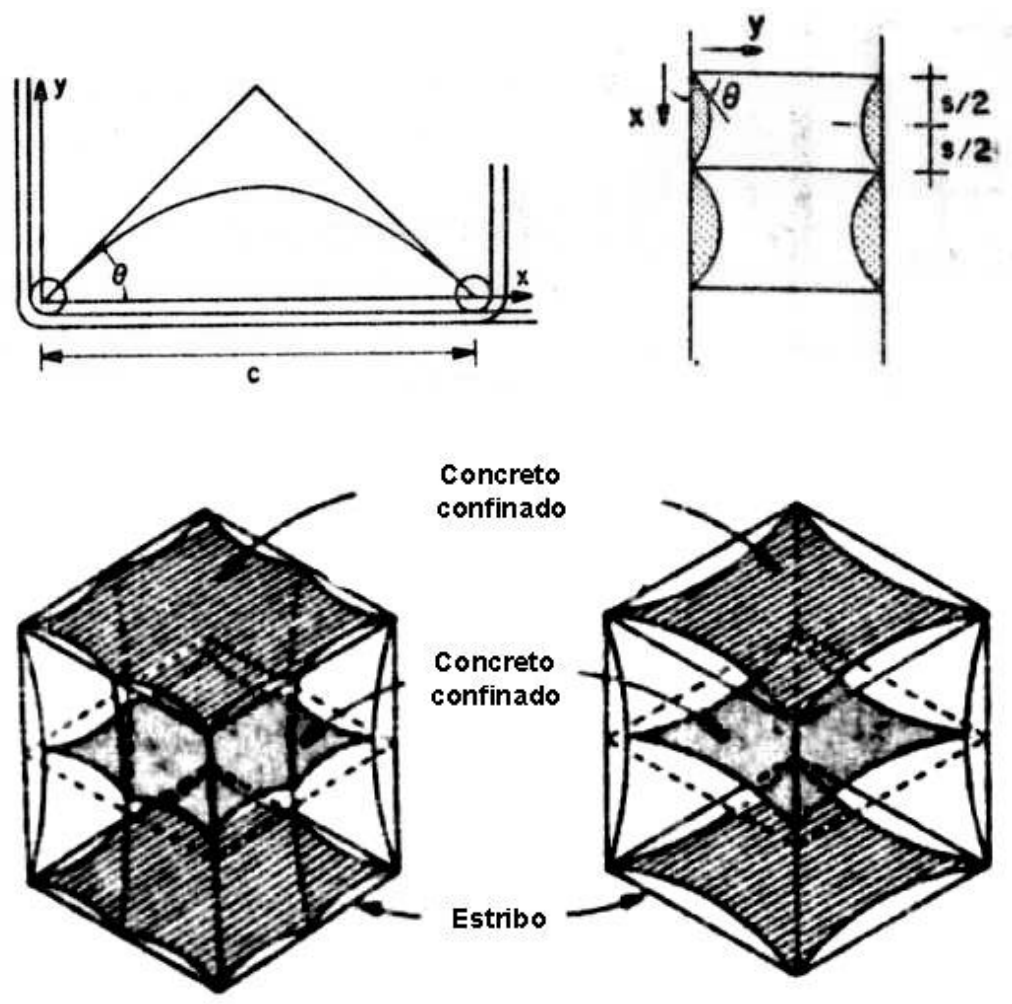

Figura 2.11 - Distribuição da tensão de confinamento no concreto.(Sheikh e Uzumeri, 1982)

A determinação do ganho de deformação de pico e de ductilidade foi também realizada por análise de regressão. Os autores consideraram a deformação no trecho descendente do diagrama tensão vs. deformação, correspondente a 50\% da tensão máxima, como parâmentro de análise da ductilidade. Assim, obtiveram as Eq.(2.13) e Eq.(2.14) :

$$
\begin{aligned}
& \varepsilon_{c c}-\varepsilon_{c o}=0,21 \cdot\left(\frac{f_{l e}}{f_{c}}\right)^{1,7} \\
& \varepsilon_{0,5 f c c}-\varepsilon_{0,5 f c}=0,15 \cdot\left(\frac{f_{l e}}{f_{c}}\right)^{1,1}
\end{aligned}
$$

nas quais $\varepsilon_{0,5 f c}$ é a deformação no trecho descendente do diagrama tensão vs. deformação do concreto não-confinado, correspondente a $50 \%$ da tensão máxima, e pode ser adotada como 4\%o. As Eq.(2.13) e Eq.(2.14) apresentaram coeficiente de correlação $\left(r^{2}\right)$ de $89 \%$ e $85 \%$, respectivamente. Para o cálculo do valor de 
$\mathcal{E}_{0,5 f c c}$, deve-se tomar $f_{t c c}$ igual à tensão de escoamento da armadura de confinamento.

Analisando as equações de Eq.(2.7) a Eq.(2.14) observa-se que estas estão inter-relacionadas e que só podem ser solucionadas iterativamente. Assim, podese, inicialmente, supor a tensão $f_{t c c}$ como sendo a resistência de escoamento da armadura transversal. Em seguida, trabalha-se com as equações citadas. Verificase se a deformação $\varepsilon_{t c c}$, calculada pela equação Eq.(2.9), é compatível com a tensão inicialmente adotada para $f_{t c c}$, considerando a curva tensão vs. deformação do aço utilizado; caso não exista compatibilidade entre os dois valores, refaz-se o procedimento com um novo valor para $f_{t c c}$.

Cusson e Paultre (1995) utilizaram, para a representação numérica do ramo ascendente do diagrama tensão vs. deformação do concreto confinado, a expressão sugerida por Popovics (1973) - Eq. (2.3).

Para o ramo descendente do diagrama, Cusson e Paultre (1995) utilizaram a equação proposta por Fafitis e Shah (1985) - Eq.(2.6), com $k_{11}$ sendo o coeficiente que controla a inclinação do trecho descendente do diagrama e tendo sido obtido impondo-se que a curva passa pelo ponto $\left(\varepsilon_{0,5 f c c}, 0,5 f_{c c}\right)$; e $k_{22}$ sendo o coeficiente que controla a curvatura do trecho descendente do diagrama e tendo sido obtido por análise de regressão de resultados experimentais, apresentando um coeficiente de correlação de $88 \%$. Os coeficientes $k_{11}$ e $k_{22}$ podem ser expressos, respectivamente, pela Eq.(2.15) e Eq.(2.16):

$$
\begin{aligned}
& k_{11}=\frac{\ln (0,5)}{\left(\varepsilon_{0,5 f c c}-\varepsilon_{c c}\right)^{k_{22}}} \\
& k_{22}=0,58+16 \cdot\left(\frac{f_{l e}}{f_{c}}\right)^{1,4}
\end{aligned}
$$

Na Figura 2.12, é apresentado o comportamento da curva tensão vs. deformação para o concreto confinado, proposto por Cusson e Paultre (1995). 


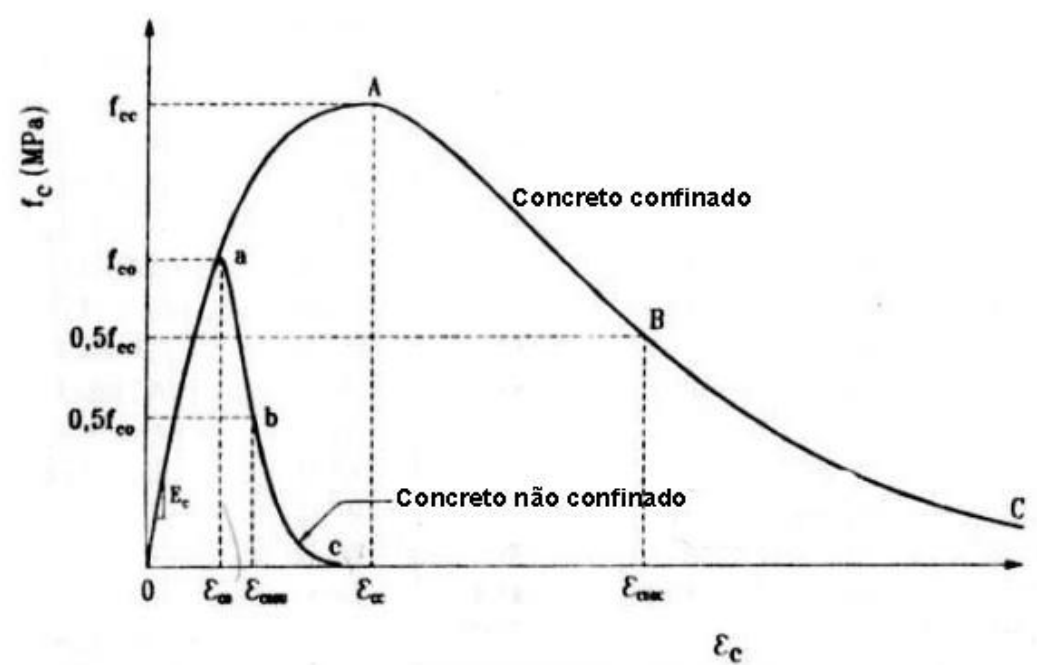

Figura 2.12 - Diagrama tensão vs. deformação para o concreto confinado proposto por Cusson e Paultre (1995)

\subsection{COMPORTAMENTO DO CONCRETO À COMPRESSÃO EXCÊNTRICA}

O número de trabalhos experimentais sobre o efeito do gradiente de deformação axial no confinamento do concreto é bastante limitado, sendo o assunto ponto de controvérsias e discussões entre os pesquisadores (Saatacioglu et alii, 1995 e ACI-441, 1997).

Em 1965, Sturman et alii (1965) realizaram um dos primeiros estudos sobre o efeito do gradiente de deformações no comportamento tensão vs. deformação do concreto, e observaram que, quando o concreto é submetido à carga excêntrica, a deformação e a tensão de pico do diagrama são incrementados em $50 \%$ e 20\%, respectivamente, quando comparados com o diagrama do concreto sob carga centrada. Apesar deste fato, Karsan e Jirsa (1970) realizaram ensaios em pilares de concreto simples de resistência usual sob compressão excêntrica e observaram que o diagrama tensão vs. deformação do concreto é, essencialmente, o mesmo do concreto sob compressão centrada. A única discrepância observada foi que o trecho descendente do diagrama era menos inclinado; contudo, os valores da deformação e a tensão de pico eram os mesmos.

Soliman e Yu (1967) ensaiaram 16 pilares de concreto de resistência usual, com armadura de confinamento e submetidos à flexo-compressão, e indicam que o 
comportamento da pressão provida pelo confinamento é modificado, quando da presença da flexão.

Kent e Park (1971) estudaram o comportamento do diagrama momento fletor vs. curvatura de pilares de concreto com resistência usual, com confinamento e submetidos à flexo-compressão, e observaram que a curvatura última é incrementada, quando da presença do confinamento. Os autores justificam que esse incremento pode ter sido promovido, uma vez que a armadura de confinamento garantiu que a armadura longitudinal comprimida flambasse apenas para curvaturas bem superiores, comparadas com as dos pilares sem a presença desta armadura. Sheikh e Uzumeri (1982) também observaram aumento de ductilidade em pilares de concreto de resistência usual, devido ao gradiente de deformação, e propuseram um modelo calibrado com resultados de ensaios de pilares com concreto confinado e submetidos à compressão centrada. Os autores utilizaram esse modelo para predizer o diagrama momento fletor vs. curvatura de pilares submetidos à compressão excêntrica e obtiveram bons ajustes entre as curvas experimentais e teóricas.

Park et alii (1982) afirmam que os modelos numéricos formulados a partir de dados de ensaios de pilares de concreto de resistência usual, com confinamento e sob compressão concêntrica, podem ser aplicados para pilares submetidos a carregamento excêntrico, uma vez que o gradiente de deformação não afeta o diagrama tensão vs. deformação do concreto.

Sheikh e Yeh (1986) estudaram o comportamento do concreto de resistência usual, confinado por estribos retangulares e carregamento excêntrico, e estenderam o uso de um modelo para concreto confinado sob compressão concêntrica para excêntrica. Os autores concluem que, até aquele momento, não existiam dados experimentais suficientes para garantir que o gradiente de deformação axial na seção transversal aumente a resistência do concreto. Entretanto, afirmam que a ductilidade é elevada na presença da flexão e que a deformação correspondente à tensão de pico é função da relação entre a largura da seção transversal e a profundidade da linha neutra. 
Sheikh e Yeh (1990) realizaram ensaios experimentais em 15 pilares de concreto de resistência usual, com confinamento lateral e submetidos à compressão excêntrica. Os autores observaram que, tanto as distribuições das armaduras longitudinais, quanto transversais são de extrema importância no comportamento dos pilares submetidos à flexo-compressão. Como observado por Kent e Park (1971), um maior número de estribos impede a flambagem das barras longitudinais, melhorando a ductilidade e a capacidade resistente à flexão dos pilares. Além disso, o confinamento mantém o núcleo de concreto íntegro para grandes curvaturas, aumentando a ductilidade e resistência dos pilares. Os autores concluem que o efeito do confinamento na presença da flexão é complexo e que nenhum modelo, até aquela época, seria capaz de representar com precisão o comportamento dos pilares sob flexo-compressão.

Sheikh et alii (1994) estudaram o comportamento de 4 pilares de concreto de alta resistência, submetidos à flexo-compressão, e observaram que a capacidade de absorção de energia dos pilares parecia ser proporcional à taxa de armadura transversal. Contudo, a capacidade resistente da seção à flexão não seguia esta proporcionalidade, apesar de o confinamento proporcionar incrementos de $120 \%$ a $150 \%$, no momento fletor resistente da seção. Os autores observaram que, mesmo na flexo-compressão, os pilares de CAR apresentavam menor ductilidade do que os pilares de concreto de resistência usual, com as mesmas características, e que este problema podia ser corrigido através do confinamento da seção transversal.

Saatacioglu et alii (1995) ensaiaram 12 pilares de concreto de resistência usual, submetidos à compressão excêntrica, e investigaram o efeito do gradiente de deformação no confinamento do concreto. Os pilares foram ensaiados sob carregamento monotônico com taxas de excentricidade $e / h$ entre 0,28 e 0,36. Eles foram compostos por concretos com resistência variando entre $25 \mathrm{MPa}$ e $35 \mathrm{MPa}$, taxa longitudinal de armadura entre $1,8 \%$ e $2,8 \%$, e taxa volumétrica de armadura de confinamento entre $1,27 \%$ e $2,98 \%$. Os resultados indicaram que, mesmo na presença da flexão, incrementos nas taxas de armadura transversal implicaram em aumento da ductilidade e resistência dos pilares. Maiores excentricidades de carregamento aumentaram a ductilidade desses elementos. 
Saatacioglu et alii (1995) explicam que, quando os pilares de concreto confinado são submetidos à flexo-compressão, a seção transversal fica submetida a um gradiente de deformações axiais que pode conter apenas deformações de compressão ou deformações de compressão e tração, dependendo do grau da excentricidade do carregamento. Nesse contexto, observa-se que o lado da seção transversal mais comprimido apresenta expansão lateral igual ou superior às encontradas nas seções transversais dos pilares sob compressão concêntrica. Entretanto, o lado menos comprimido da seção transversal pode apresentar expansão lateral bem inferior a esse valor, podendo anular-se, quando da presença de tração.

Desse modo, a armadura de confinamento é solicitada de forma não uniforme, gerando pressões laterais de confinamento, cuja distribuição é variável ao longo da seção transversal. Os autores assumem que esta variação pode ser considerada linear, o que gera diagramas tensão vs. deformação distintos entre as áreas das faixas 1, 2 e 3 (Figura 2.13). Explicam ainda que, quando são utilizados os modelos propostos para o concreto sob compressão centrada com o diagrama tensão vs. deformação da faixa 1, para toda a seção transversal, o erro cometido é pequeno, uma vez que a super-estimativa da pressão lateral nas faixas 2 e 3 é compensada pela baixa estimativa na faixa 1. Os autores utilizaram o modelo proposto por Saatacioglu e Razvi (1992), para modelar o comportamento de diversos pilares sob compressão excêntrica, e obtiveram precisão razoável.

Lloyd e Rangan (1996) estudaram 36 pilares esbeltos de concreto de alta resistência, com armadura de confinamento e submetidos a carregamentos com excentricidade $e / h$ entre 0,08 e 0,4 . Os autores observaram que os pilares sob pequena excentricidade atingiram a ruína, apresentando baixíssimo índice de ductilidade e sendo caracterizados pela perda explosiva do cobrimento. Já os pilares com elevada excentricidade apresentaram altos índices de ductilidade. $\mathrm{O}$ efeito do confinamento foi considerado desprezível pelos autores e, através da teoria da estabilidade, eles tentaram modelar o comportamento dos pilares. Os autores obtiveram bom comportamento para o ramo ascendente dos diagramas; contudo, o modelo não conseguiu representar o ramo descendente com exatidão. 


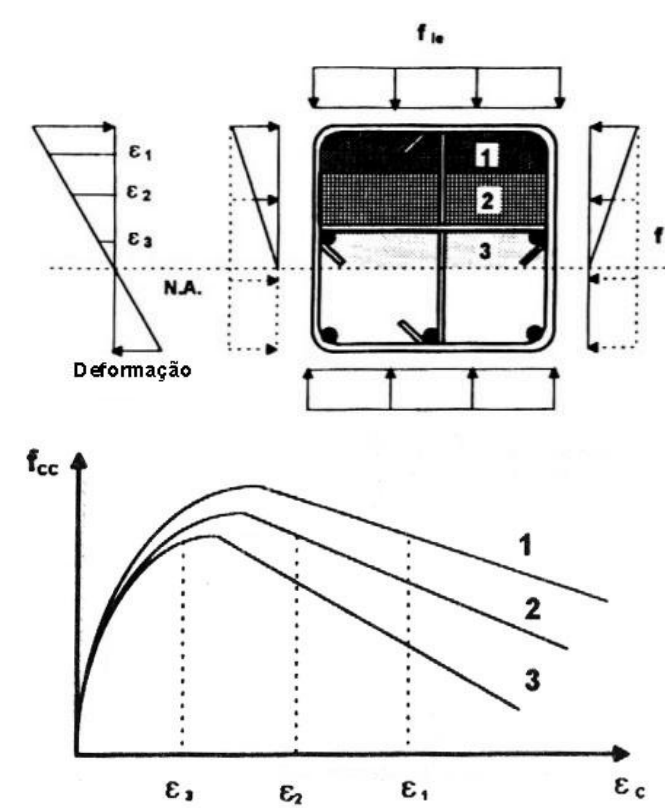

(a)
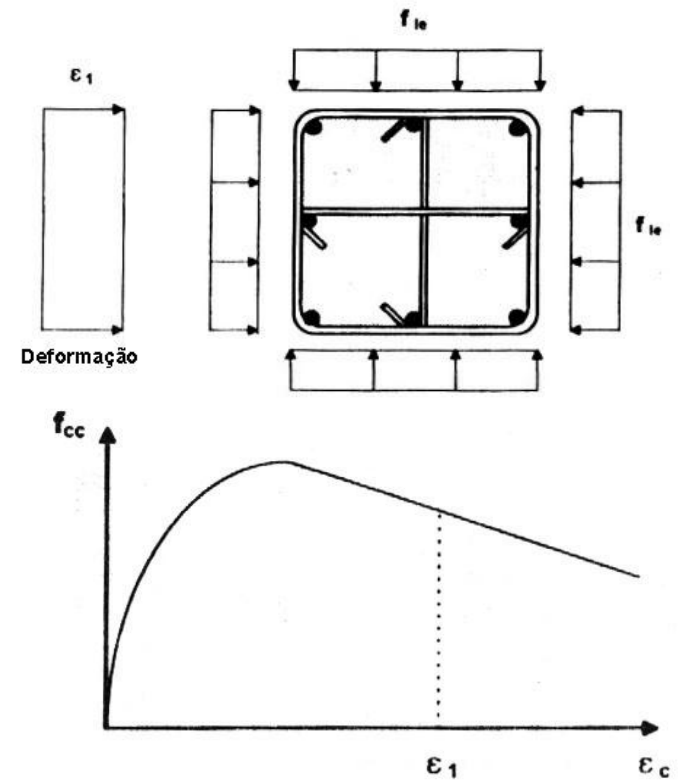

(b)

Figura 2.13 - Distribuição da pressão lateral promovida pela armadura de confinamento para pilares submetidos à compressão excêntrica $(a)$ e centrada (b)

Azizinamini e Kebraei (1996) ensaiaram 6 pilares de concreto de alta resistência, confinados e submetidos à flexo-compressão, e observaram que a capacidade resistente dos pilares era superestimada, quando calculada segundo o ACI-318 (1995). Os autores sugeriram a utilização de um diagrama triangular de tensões, para o cálculo da capacidade resistente à flexo-compressão dos pilares de CAR. Utilizando o mesmo procedimento de ensaio dos autores anteriormente citados, Ibrahim e MacGregor (1996) ensaiaram 20 pilares de concreto de alta resistência, confinados e submetidos à compressão excêntrica. Os autores observaram que nenhum modelo conseguia descrever com exatidão o comportamento do ramo descendente do diagrama carga vs. deformação, e sugeriram alguns ajustes no modelo de Bjerkeli et alii (1990), para um melhor ajuste aos resultados experimentais. Apesar disto, Lee e Son (2000) ensaiaram 32 pilares de concreto de alta resistência com confinamento e não observaram grandes discrepâncias entre as forças axiais e momentos fletores resistentes, calculados segundo o ACI -318 (1995), e os dados experimentais obtidos.

Delalibera (2002) ensaiou 4 vigas de concreto de resistência usual e no domínio de deformações 4 (NBR 6118:1978). O autor estudou a variação da 
ductilidade dos elementos, em função da armadura de confinamento disposta apenas na região comprimida da seção transversal. Na primeira viga não foi disposta armadura de confinamento. Na segunda, terceira e quarta o autor dispôs estribos quadrados de 5,0mm de diâmetro, apenas na região comprimida da seção transversal, espaçados a cada $15 \mathrm{~cm}, 10 \mathrm{~cm}$ e $5 \mathrm{~cm}$, respectivamente. No instante em que foi atingida a carga máxima em todas as vigas, os estribos se encontravam totalmente dentro da zona comprimida da seção transversal. O autor observou que mesmo na presença do gradiente de deformação, a armadura de confinamento aumentou consideravelmente a ductilidade das vigas, porém não foi observado aumento de resistência das vigas. A variação das pressões laterais de confinamento foi considerada linear e, para a análise dos resultados, o núcleo foi dividido em 3 faixas, nas quais a pressão confinante foi calculada e considerada constante em cada uma delas. A distribuição das tensões laterais das vigas 2, 3 e 4, para a carga máxima, obtidas pelo autor, é apresentada na Figura 2.14. Observa-se que essa distribuição coincide com a sugerida por Saatacioglu e Razvi (1995).

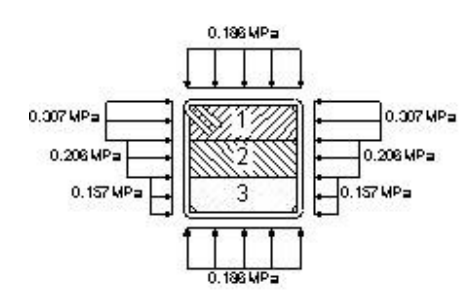

(a)

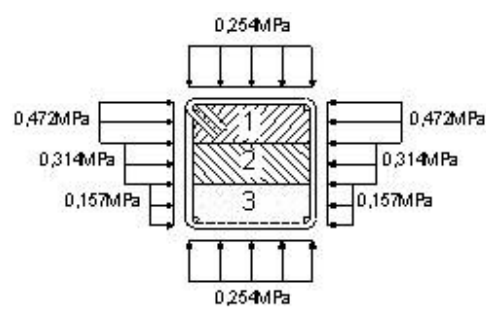

(b)

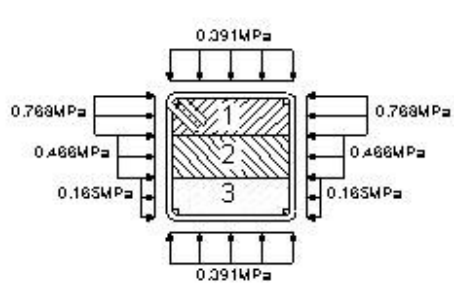

(c)

Figura 2.14 - Distribuição das pressões laterais das vigas 2 (a), 3 (b) e 4 (c), calculadas por Delalibera (2002)

Baseado no exposto nos parágrafos anteriores, são observadas diversas opiniões contraditórias sobre o efeito do gradiente de deformação no comportamento do concreto confinado. Apesar deste fato, a maioria dos autores concorda que o confinamento melhora a ductilidade do concreto, mesmo que este esteja submetido à flexo-compressão. Outro ponto de concordância é que elevadas taxas de armadura transversal, distribuídas com pouco espaçamento, garantem a não-flambagem prematura da armadura longitudinal do lado da seção transversal mais comprimido, melhorando, assim, o comportamento do diagrama momento 
fletor vs. curvatura dos pilares. Finalmente, observa-se que se fazem necessários maiores estudos teórico-experimentais sobre o assunto, para permitir um melhor entendimento do problema e para garantir dados suficientes para a formulação de um modelo numérico preciso, que contribua para a análise do concreto confinado sob a presença do gradiente de deformação. 


\section{CONCRETO REFORCADO COM FIBRAS DE AÇO}

\subsection{CONSIDERAÇÕES INICIAIS}

Nas duas últimas décadas, a utilização do concreto reforçado com fibras de aço (CRFA) intensificou-se devido ao seu grande potencial para diversas aplicações estruturais (Committee 544 do ACI, 1988). Esse material é um compósito, cuja matriz é o concreto de cimento Portland e a segunda fase é constituída por fibras descontínuas de aço distribuídas aleatoriamente.

Os primeiros estudos sobre o CRFA datam da década de 60 (Romuadi e Baston, 1963). No início, apenas fibras retas eram utilizadas, com teores que variavam de $90 \mathrm{~kg} / \mathrm{m}^{3}$ à $120 \mathrm{~kg} / \mathrm{m}^{3}$, e relação comprimento/diâmetro de 60 a 100. Entretanto, problemas com dificuldade de mistura e trabalhabilidade obrigavam a utilização de agregados com diâmetros limitados. Esses problemas só foram minimizados com o desenvolvimento das fibras com ancoragem e das fibras coladas (Ramakrishman et alii, 1981) e mais tarde com a criação dos aditivos redutores de água (Balaguru e Shah, 1992).

A adição de fibras de aço aprimora diversas propriedades mecânicas do concreto e argamassa, destacando-se: a resistência ao impacto, resistência à flexão, ductilidade, e a capacidade de controle do processo de fissuração e perda de massa. As propriedades mecânicas dos CRFA estão intimamente relacionadas à interação entre a fibra e a matriz cimentícia. Estudos mostram que esta interação é influenciada por diversos fatores (Bentur e Mindess, 1990), tais como: a resistência da matriz e as dimensões dos agregados que a compõem; geometria, orientação, distribuição e taxa volumétrica das fibras. A seguir, discute-se a influência desses fatores e as principais propriedades mecânicas do CRFA. 


\subsection{FATORES QUE INFLUENCIAM AS PROPRIEDADES MECÂNICAS DO CRFA}

\subsubsection{Fatores relacionados às matrizes cimentícias}

Não existe nenhuma restrição quanto ao tipo de cimento para uso nos concretos com adição de fibras. Balaguru e Shah (1992) recomendam, entretanto, que o tipo de cimento deva estar de acordo com a utilização do CRFA e a resistência requerida.

Os agregados utilizados no CRFA são os mesmos utilizados no concreto comum, deve-se, porém, ter cuidados com o correto proporcionamento destes, uma vez que a adição de fibras aumenta de forma considerável a coesão do concreto, comprometendo a sua trabalhabilidade. Isto ocorre porque as fibras apresentam elevada área superficial, que aumenta o atrito entre os constituintes do concreto, restringindo a fluidez e mobilidade da mistura. Assim, faz-se necessário o uso de misturas mais ricas em teores de argamassa, sendo sugerido pelo ACI (1988) o valor mínimo de 50\%. A fluidez da matriz é outro ponto importante. Bentur e Mindess (1990) sugerem que a matriz de concreto tenha abatimento no tronco de cone $60 \mathrm{~mm}$ maior que aquela especificada para o concreto com fibras.

Outro aspecto relevante é a geometria do agregado graúdo. Agregados com dimensões muito maiores que o comprimento das fibras prejudicam o comportamento pós-fissuração do compósito. Esse fato é explicável, pois, quando as fissuras interceptam os agregados, estas se propagam preferencialmente junto da interface pasta-agregado nos concretos de resistências usuais, o que compromete o efeito favorável do uso da fibra. O ACI (1993) sugere que o diâmetro máximo do agregado graúdo não seja superior a $19 \mathrm{~mm}$ e que as fibras devam ter comprimento igual a pelo menos duas vezes o diâmetro do agregado. Para o concreto de alta resistência, o caminho preferencial de propagação de fissura junto à interface pasta-agregado deixa de existir, sendo o agregado graúdo normalmente seccionado pelas fissuras. Desse modo, fibras de comprimento menores que as dimensões do agregado graúdo seriam mais aconselháveis para o CAR, uma vez que, para uma mesma taxa volumétrica de fibras, o número de 
fibras existente é maior quando seu comprimento é menor, e a probabilidade de mais fibras costurarem as fissuras aumenta. Apesar dessa observação, o número de estudos sobre o assunto é insipiente, não existindo consenso entre os estudiosos (Aïticin, 2000).

A utilização de aditivos redutores de água é comum no concreto com adição de fibras. Recomenda-se apenas que aditivos contendo cloretos sejam evitados. A utilização de adições minerais, como a sílica ativa, também se tem tornado comum nos CRFA. A presença de sílica ativa torna a matriz mais densa, melhorando a interface fibra-matriz e, por conseguinte, as propriedades mecânicas do compósito.

Diversos trabalhos vêm mostrando que o aumento da resistência do concreto diminui a tenacidade dos concretos reforçados com fibras (Balaguru et alii, 1997; Banthia e Trottier, 1994 e Armelin e Banthia, 1997). Esse fato é explicado, uma vez que as matrizes de concreto de alta resistência possuem uma zona de transição fibra-matriz menos porosa e sem a presença dos cristais de hidróxido de cálcio. Esses dois fatores promovem um aumento da resistência de aderência entre a fibra e a matriz, e, conseqüentemente, a força necessária para o arrancamento da fibra durante o processo de fissuração do compósito é elevada. Desse modo, as fibras ficam sujeitas a maiores tensões de tração, que podem provocar as suas rupturas. Como a energia gasta no processo de ruptura de uma fibra é inferior àquela correspondente ao seu arrancamento, a tenacidade dos CRFA com concretos de alta resistência tende a ser menor.

Outro ponto importante é que as fibras inclinadas em relação ao plano de fissura nas matrizes de CAR tendem a sofrer flexão, ao invés de promover o esmagamento da pasta do concreto (Armelin e Banthia, 1997). Devido a esse fato, tensões adicionais de cisalhamento são desenvolvidas. Essas tensões contribuem no processo de escorregamento entre os sistemas cristalinos da fibra de aço, o que provoca a diminuição da tensão de escoamento e de ruptura da fibra, favorecendo a possibilidade de ruptura prematura da mesma (Banthia e Trottier, 1994). 


\subsubsection{Fatores relacionados às fibras de aço}

As fibras de aço utilizadas no CRFA são, geralmente, monofilamentos discretos, fabricados com ligas metálicas ou aços carbônicos. Elas são descontínuas e apresentam comprimentos que variam de $19 \mathrm{~mm}$ a $76 \mathrm{~mm}$. As resistências à tração, apresentadas pelas fibras, variam entre $345 \mathrm{MPa}$ e $2100 \mathrm{MPa}$, e as deformações últimas, entre $0,5 \%$ e $35 \%$, dependendo do processo e do material empregado na produção destas. As fibras são fabricadas em diversas geometrias. As fibras de seção transversal circular, por exemplo, são produzidas pelo corte de arames e podem apresentar diâmetro entre $0,25 \mathrm{~mm}$ e $1 \mathrm{~mm}$. As fibras com seção retangular são obtidas pelo corte de chapas de aço e podem apresentar largura entre $0,15 \mathrm{~mm}$ e $0,50 \mathrm{~mm}$ e espessura entre $0,25 \mathrm{~mm}$ e $0,90 \mathrm{~mm}$. As fibras, podem, ainda, se apresentarem coladas umas às outras, por meio de cola solúvel em água, agrupadas de 10 a 30 unidades. Essa forma de apresentação objetiva facilita o manuseio e a mistura (Bentur e Mindess, 1990).

Como mencionado, dois dos principais fatores relacionados às fibras e que interferem nas propriedades mecânicas dos compósitos são o teor e a geometria das fibras. A influência da geometria da fibra esta ligada ao fator de forma (relação comprimento/diâmetro). Valores elevados do fator de forma intensificam a tendência de embolamento das fibras e a diminuição na trabalhabilidade do compósito, sendo que elevados teores de fibras também provocam estes problemas.

De modo a evitar esses efeitos, Ramakrishnan et alii (1981) recomendam a utilização de teores de fibras inferiores a $2 \%$ e fator de forma inferior a 100 . A definição de fator de forma foi inicialmente criada para fibras retas; apesar disso, ela vem sendo utilizada, também, para as fibras com ganchos nas extremidades. Diversos pesquisadores questionam a importância deste fator para as fibras com ancoragem; contudo, pesquisas vêm mostrando que o fator de forma influencia diretamente a tenacidade dos CRFA com fibras com ancoragem nas extremidades (Ceccatto e Torneri, 1997). É comum que os pesquisadores agrupem as influências do fator de forma e da taxa volumétrica de fibra em um fator único, denominado 
índice de reforço, e que é definido pelo produto da taxa volumétrica de fibras pelo fator de forma (Johnston, 1974), conforme exposto na equação Eq.(3.1):

$$
R=\frac{V_{f} \cdot \ell}{\phi_{f}}
$$

na qual $\phi_{f}$ é o diâmetro da fibra, $V_{f}$ é taxa volumétrica de adição de fibra e $\ell$ é o comprimento da fibra.

Outro aspecto que merece destaque é a orientação e distribuição das fibras dentro do compósito. Uma distribuição perfeitamente uniforme e aleatória é difícil de ser atingida (Bentur e Mindess, 1990). Esse comportamento torna-se ainda mais grave em estruturas que apresentam alguma dimensão com comprimento inferior ao da fibra (efeito de borda). Nesse caso, as fibras distribuem-se preferencialmente em um arranjo bidimensional. Para minimizar esses problemas, a JSCE (1984) recomenda que os corpos-de-prova e os elementos estruturais devem apresentar a menor dimensão com comprimento maior que três vezes o comprimento da fibra e que cuidados sejam tomados durante a vibração. $\mathrm{O}$ arranjo bidimensional pode, também, ser provocado em elementos com maior espessura, por meio de vibração ou compactação, com as fibras tendendo a se alinharem em planos ortogonais à direção de vibração. $\mathrm{Na}$ Figura 3.1, são apresentados detalhes do plano de alinhamento das fibras segundo a direção da vibração.

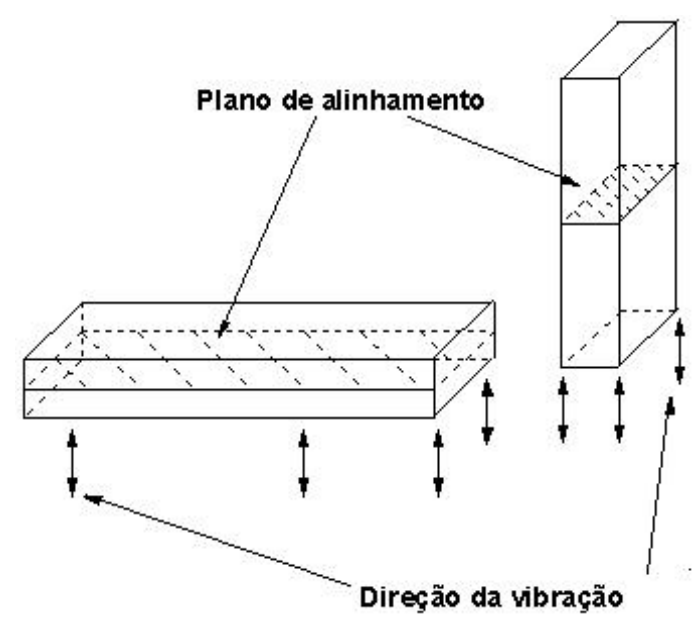

Figura 3.1 - Planos direcionais dos alinhamento das fibras conforme a direção da vibração. (Bentur e Mindess, 1990) 
Por conta desses problemas com relação ao adensamento, a JSCE (1984) recomenda a utilização de vibração externa, tomando-se apenas o cuidado com relação ao plano de alinhamento das fibras. Por outro lado, o ACI (1982) afirma que, em obras, a vibração externa não é de simples execução e por isso sugere o uso de vibração interna no CRFA. A fluidez da matriz é outro ponto importante, pois, durante a vibração, pode ocorrer a sedimentação das fibras na parte inferior dos elementos de CRFA. Não é recomendada a utilização de concretos com fluidez excessiva.

A capacidade de absorção de energia e a resistência do CRFA estão diretamente relacionadas com o comprimento das fibras de aço. O efeito do comprimento das fibras nessas propriedades é comumente analisado em função do mecanismo de transferência de tensões entre a fibra e a pasta do concreto. Para tanto, define-se um parâmetro de análise, que é denominado de comprimento crítico da fibra. O comprimento crítico da fibra é definido como sendo o dobro do comprimento mínimo, o qual tem de estar embebido na pasta do cimento para que as tensões de aderência sejam capazes de solicitar a fibra a uma tensão igual à tensão de ruptura desta. Desse modo, pode-se expressar o comprimento crítico pela Eq.(3.2):

$$
\ell_{c}=\frac{\phi_{f} \cdot \sigma_{f u}}{2 \cdot \tau_{f u}}
$$

na qual $\sigma_{f u}$ é a tensão de ruptura da fibra e $\tau_{f u}$ é tensão de aderência média última entre a matriz e a fibra. Analisando a equação Eq.(3.2) observa-se que, quando a tensão de aderência atingir o seu valor máximo, se a fibra apresentar comprimentos inferiores à $\ell_{\mathrm{c}}$, essa irá deslizar dentro da massa do concreto, e, quando o comprimento for superior, ocorrerá a ruptura da fibra, caso a fissura corte as fibras em seu ponto médio. 
Law (1971 ${ }^{1}$, apud Katz e Bentur, 1991) realizou um estudo sobre a eficiência das fibras em matrizes frágeis. Nesse estudo, o autor observou que, em função das baixas deformações apresentadas por essa matriz, antes da fissuração, as fibras não são solicitadas suficientemente para modificar as propriedades mecânicas das matrizes. Entretanto, após a fissuração, as fibras trabalham mais eficientemente, dando ao compósito propriedades mecânicas bem superiores às das matrizes. Laws (1971) também sugeriu que, mesmo tendo comprimento superior ao $\ell_{\mathrm{c}}$, as fibras só atingem a ruptura se uma fissura interceptar a fibra no seu ponto médio. A partir dessa suposição, Law (op. cit.) mostrou que a probabilidade de uma fibra escorregar dentro da matriz pode ser expressa pela Eq.(3.3):

$$
\theta=\frac{E_{f} \cdot \varepsilon_{c f}(x) \cdot \phi_{f}}{\tau_{f u} \cdot \ell \cdot 2}
$$

na qual $E_{f}$ é o módulo de elasticidade da fibra e $\varepsilon_{c f}(x)$ é a deformação do compósito em um determinado ponto.

Seguindo a linha do estudo de Laws (op. cit.), Kelly (1973² apud Katz e Bentur, 1991) dividiu o estudo da eficiência das fibras em duas partes: resistência do compósito e tenacidade do compósito. Na primeira parte do seu estudo, Kelly mostrou que, para atingir 90\% de eficiência com relação à resistência, o comprimento da fibra tem que apresentar um valor de 5 a 10 vezes o comprimento crítico. Essa eficiência pode ser atingida variando-se a geometria da fibra ou o valor de $\tau_{f u}$.

Para estudar o efeito da absorção de energia do compósito em relação ao comprimento da fibra, Kelly (op. cit.) considerou que a energia consumida na ruptura da fibra é desprezível, quando comparada com a energia absorvida durante o processo de arrancamento da fibra. Desse modo, compósitos caracterizados por ruptura das fibras terão um comportamento frágil. Utilizando princípios básicos de

\footnotetext{
${ }^{1}$ LAW, V.. The efficiency f fibrous reinforcement of brittle matrices. J. Phys. D. Appl. Phsys, No. 4, 1971, p. $1737-1746$.

${ }^{2}$ KELLY, A.. Strong solids. Oxford University press, 1973.
} 
trabalho e energia, Kelly (1973) mostrou que o trabalho médio no processo de arrancamento das fibras pode ser expresso pela Eq.(3.4):

$$
\begin{array}{ll}
\bar{W}=\frac{\pi \cdot \phi_{f} \cdot \tau_{f u} \cdot \ell^{2}}{24} & \ell<\ell_{c} \\
\bar{W}=\frac{\pi \cdot \phi_{f} \cdot \tau_{f u} \cdot \ell_{c}^{3}}{24 \cdot \ell} & \ell>\ell_{c}
\end{array}
$$

Trabalhando com as equações Eq.(3.2) a Eq.(3.4), Bentur e Mindess (1990) desenvolveram relações entre o trabalho necessário no processo de arrancamento das fibras em função da tensão de aderência. Essas equações podem ser escritas pela Eq.(3.5):

$$
\begin{array}{ll}
\bar{W}=\frac{\tau \cdot \sigma_{f u} \cdot V_{f} \cdot \ell}{24 \cdot \tau_{f u}} & \tau<\tau_{f u} \\
\bar{W}=\frac{\tau_{f u}^{2} \cdot \sigma_{f u} \cdot V_{f} \cdot \ell}{24 \cdot \tau^{2}} & \tau>\tau_{f u}
\end{array}
$$

nas quais $\tau$ é a tensão de aderência entre a fibra e o concreto, e a representação gráfica das equações Eq.(3.4) e Eq.(3.5), que são apresentadas na Figura 3.2. Observa-se que a máxima tenacidade é obtida quando o comprimento da fibra é exatamente igual ao comprimento crítico. Observa-se, ainda, que existe uma contradição entre o comportamento da resistência e da tenacidade. Quando elevase o comprimento da fibra para uma maior resistência do compósito, perde-se em tenacidade.

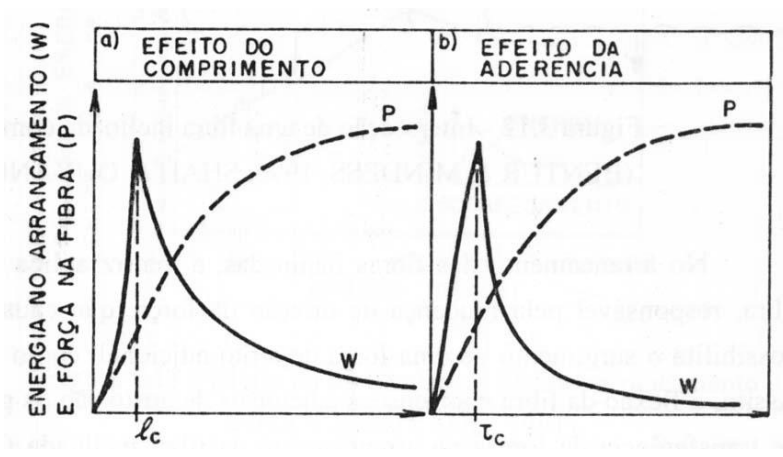

Figura 3.2 - Efeito do comprimento e da tensão de aderência na energia de arracamento da fibra e na eficiencia do reforço da fibra. (Bentur e Mindess, 1990) 


\subsection{COMPORTAMENTO À COMPRESSÃO DO CRFA}

A adição de fibras à massa do concreto, em taxas inferiores a $2 \%$ em volume, pouco altera a resistência à compressão, o módulo de elasticidade e a deformação relativa à tensão máxima desse material. Observa-se que o comportamento do trecho ascendente do diagrama tensão vs. deformação do concreto não sofre mudanças significativas (Fanella e Naaman, 1985; e Soroushian e Lee, 1987). Entretanto, é observado um aumento substancial na ductilidade pós-fissuração e na capacidade de absorção de energia pós-pico do concreto (Nataraja et alii, 1999). Esses aumentos traduzem-se basicamente na diminuição da inclinação do trecho descendente do diagrama tensão vs. deformação do concreto.

O aumento da ductilidade à compressão do CRFA é função, basicamente, do tipo, da taxa volumétrica e do fator de forma da fibra. Desse modo, é comum analisar o comportamento à compressão do CRFA em função do índice de reforço da fibra (Soroushian e Lee, 1987). Geralmente, altos índices de reforço fazem com que o concreto apresente elevada ductilidade e capacidade de absorção de energia; entretanto, índices de reforço muito elevados também podem comprometer a trabalhabilidade do compósito e, conseqüentemente, as propriedades mecânicas do material endurecido.

Craig et alii (1984) mostraram que a adição de fibras pode controlar de forma satisfatória o colapso frágil do concreto, quando este é submetido a esforços de compressão e cisalhamento, simultaneamente. Os mesmos autores apontaram também a necessidade de se determinar índices de reforço ideais para os concretos submetidos à compressão.

Fanella e Naaman (1985) estudaram a variação da tenacidade dos concretos submetidos à compressão em função do índice de reforço e apontaram que a capacidade de absorção de energia à compressão do concreto com adição de fibras de aço é função linear do índice de reforço. Porém, observa-se, nos resultados desses autores, uma grande dispersão entre os resultados experimentais, em relação à função linear. Recentemente, Nataraja et alii (1999), estudando a 
modelagem do diagrama tensão vs. deformação do CRFA, mostraram, por meio de análise de regressão, que o índice de tenacidade para os concretos com resistências até $50 \mathrm{MPa}$ submetidos à compressão é realmente uma função linear do índice de reforço da fibra, obtendo um coeficiente de correlação $r^{2}$ de $73 \%$.

Mangat e Azarit (1984) avaliaram a influência da adição de fibras metálicas no processo de fratura do concreto com resistências entre $20 \mathrm{MPa}$ e $45 \mathrm{MPa}$. Os autores observaram que, até a tensão última, as fibras se comportam similarmente aos agregados graúdos. Contudo, a adição de fibra é capaz de aumentar o valor do coeficiente de Poisson do concreto em até 50\%, em relação ao do concreto simples. Os autores explicam que os concretos, mesmo antes de serem carregados, apresentam microfissuras e vazios provenientes do processo de retração e do fluxo da água, durante o processo de endurecimento do material. Tanto as microfissuras e os vazios tendem a se concentrar nas interfases entre os agregados graúdos e a pasta de cimento. As fibras de aço utilizadas para reforço no concreto apresentam elevada área superficial, muito maior do que a apresentada por um mesmo volume de agregado graúdo. Além disso, as fibras apresentam rigidez superior à dos agregados. Desse modo, a união desses dois fatores promove um aumento considerável no volume de vazios e microfissuras na massa do concreto e, conseqüentemente, o aumento do coeficiente de Poisson. Os autores acrescentam que, após a tensão máxima, as fibras criam pontes de tensões entre as fissuras, as quais amarram a massa do concreto e impedem que esta se fragmente de modo rápido. Nesse estágio, as fibras mobilizam de forma efetiva as tensões de cisalhamento na interfase pasta-fibra, causadas pelo atrito e adesão, e, deste modo, controlam a dissipação de energia armazenada no material.

Rotásy e Hartwich (1985) estudaram o comportamento do concreto de resistência de $25 \mathrm{MPa}$, com adições volumétricas de fibras entre $0,75 \%$ e 1,5\%, submetido à compressão excêntrica. Os autores relatam um aumento de até $50 \%$ na deformação correspondente à máxima tensão, em relação à mesma deformação na compressão uniaxial. Adicionam ainda que, nas regiões mais comprimidas, ao contrário do que ocorre no concreto simples, no qual é observado desprendimento de grandes massas de material, as fibras geram um tipo de "confinamento" que 
mantém o concreto íntegro, mesmo para elevados níveis de deformação. Finalmente, concluem que a adição de fibra garante ao concreto um elevado aumento na capacidade de absorção de energia.

Mangat e Azari (1985) avaliaram experimentalmente a variação da capacidade de absorção de energia de pilares de concreto armado com adições de fibras e armadura transversal composta por estribos. Os pilares ensaiados apresentavam dimensões de $15 \mathrm{~cm}$ x $15 \mathrm{~cm}$ x $75 \mathrm{~cm}$. Os autores utilizaram fibras fabricadas por meio de extração por fundição (melt extraction fiber). A resistência do concreto variou entre $26 \mathrm{MPa}$ e $37 \mathrm{MPa}$, e o índice de reforço das fibras entre 0 e 1,86. A armadura transversal foi composta por estribos de dois ramos, com $6 \mathrm{~mm}$ de diâmetro, espaçados de $12,5 \mathrm{~cm}, 18,7 \mathrm{~cm}$ e $37,5 \mathrm{~cm}$. Os autores relatam aumento da ordem de $30 \%$ na capacidade de absorção de energia dos pilares, quando são adicionadas taxas de fibras com índices de reforço da ordem de 0,9. Observaram também que índices de reforço da ordem de 0,93 são capazes de prover, aos pilares com $37,5 \mathrm{~cm}$ de espaçamento entre estribos, a mesma capacidade de absorção de energia dos pilares sem adições de fibras e com $12,5 \mathrm{~cm}$ de espaçamento. Os autores ainda relatam aumento do coeficiente de Poisson com o aumento da taxa volumétrica de fibra, e o efeito favorável das fibras em impedir o desprendimento de massa no concreto.

Kosaka, Tanigawat e Hatanaka (1985) compararam, através de ensaios experimentais, o efeito do estado tri-axial de tensões e da adição de fibras de aço no comportamento do diagrama tensão vs. deformação do concreto. A resistência do concreto estudada foi de $30 \mathrm{MPa}$, os índices de reforço das fibras variaram entre 0 e 1,5, e a pressão lateral imposta variou entre 0 e 1,6MPa. Os autores apontam que adições de fibras com índices de reforço de 0,75 e 1,5 equivalem a impor ao concreto uma pressão lateral de confinamento de $0,4 \mathrm{MPa}$ e $0,8 \mathrm{MPa}$, respectivamente.

Soroushian e Lee (1987) também estudaram e compararam a ductilização do concreto por meio de adição de fibra e por confinamento com armadura transversal. Os autores estudaram concretos com resistências da ordem de 40MPa e fibras de aço retas com índices de reforço entre 0 e 2. Eles mostram que adições 
de fibras com índices de reforço de 1 e 2 podem prover ao concreto os mesmos índices de ductilidade providos por taxas volumétricas de armadura transversal de $0,5 \%$ e $1 \%$, respectivamente. Essas taxas de armaduras transversais são equivalentes a armar um pilar com seção transversal quadrada de $20 \mathrm{~cm}$ por $20 \mathrm{~cm}$, com estribos de $6,3 \mathrm{~mm}$ de diâmetro espaçados a cada $11 \mathrm{~cm}$ e $5,5 \mathrm{~cm}$, respectivamente. Os autores ainda realizaram um estudo comparativo entre o custo da ductilização por estribo e por adição de fibras e concluíram que, para a época, a relação entre o custo de $0,5 \%$ de taxa volumétrica de armadura transversal e adições de fibras com índice de reforço de 1 era igual a um, e entre $1 \%$ de armadura transversal e adições com índice de reforço de 2 era igual a 0,64.

Taerwe (1992) estudou e comparou a tenacidade dos concretos de baixas, médias e altas resistências submetidos à compressão axial. Nesse estudo, o autor, em questão, utilizou concretos com resistências de 35MPa, 50MPa e 95MPa e observou que as adições de fibras com índices de reforço entre 0,4 e 0,76 eram capazes de promover, aos concretos de médias e altas resistências, índices de tenacidade semelhantes aos concretos de resistências usuais.

A modelagem do comportamento tensão vs. deformação à compressão do CRFA vem sendo investigada por alguns pesquisadores (Hughes e Fattuhi, 1977; Fanella e Naaman, 1985; Balaguru e Shah, 1992; Hsu e Hsu, 1994; Nataraja et alii, 1999). Entretanto, devido às características intrínsecas desse material, tais como a geometria e o tipo da fibra de aço, a orientação da fibra na massa do concreto e a resistência à compressão do concreto, a modelagem do comportamento se torna complexa. Assim, alguns autores têm restringido seus modelos para características previamente definidas do CRFA. Semelhantemente à modelagem do concreto confinado, faz-se necessário que estes modelos comportem-se continuamente com a variação da taxa volumétrica de fibra e do fator de forma da fibra, isto é, o modelo deve ser capaz de modelar de modo satisfatório tanto o concreto simples, quanto o concreto com adições de fibras.

Dentre os modelos com características pré-definidas do CRFA, destaca-se o proposto por Elzedin e Balaguru (1992). Os autores utilizaram a curva tensão vs. deformação para o concreto sem adição de fibras, proposta por Popovics (1973), 
conforme exposto na Eq.(2.3), para modelar tanto o trecho ascendente, quanto o descendente do diagrama tensão de compressão vs. deformação do CRFA. E, através de análise de regressão sobre dados experimentais, obtiveram duas equações para o coeficiente $\beta$ da Eq.(2.3), que podem ser expressas pelas Eq.(3.6) e Eq.(3.7):

$$
\begin{aligned}
& \beta=1,093+0,7132 \cdot R^{-0,926} \\
& \beta=1,093+7,4818 \cdot R^{-1,387}
\end{aligned}
$$

A equação Eq.(3.6) só é válida para fibras com extremidades com acoragem e a Eq.(3.7), para fibras retas. Ainda, as equações Eq.(3.6) e Eq.(3.7) são válidas apenas para concretos com dispersão aleatória de fibra e frações volumétricas de fibras abaixo de 1,5\%. Analisando essas duas equações, observase que, quando $R$ tende a zero, o valor de $\beta$ tende ao infinito, e, conseqüentemente, o comportamento da equação Eq.(2.3), após a tensão máxima, tende a ser uma reta com inclinação de $90^{\circ}$. Assim, é esperado que o modelo apresente-se inconsistente para teores de fibras próximos de zero. Apesar desse fato, Balaguru e Shah (1992) especificam a utilização desse modelo para qualquer taxa volumétrica de fibra entre $0 \%$ e 2\%. Na Figura 3.3, é apresentada uma comparação entre os diagramas tensão de compressão vs. deformação experimentais e os obtidos com o modelo de Ezeldin e Balaguru (1992). Observa-se que, para concretos com baixo teor de fibras, o modelo não consegue representar de forma satisfatória o comportamento à compressão do concreto, o que já era esperado; porém, esse modelo apresentou bom comportamento para concreto com $60 \mathrm{MPa}$ e índice de reforço de 0,8 .

Nataraja et alii (1999), baseando-se no trabalho de Elzedin e Balaguru (1992), realizaram estudo semelhante para fibras onduladas e resistência do concreto até $50 \mathrm{MPa}$. E sugerem uma expressão para o coeficiente $\beta$, dada pela Eq.(3.8):

$$
\beta=0,5811+1,93 \cdot R^{-0,7406}
$$

a qual é válida apenas para índices de reforço entre 0,9 e 2,7. 
Baseado no exposto, faz-se necessária a reformulação dos modelos citados, de modo que eles possam vir a modelar tanto o concreto simples, quanto o CRFA.
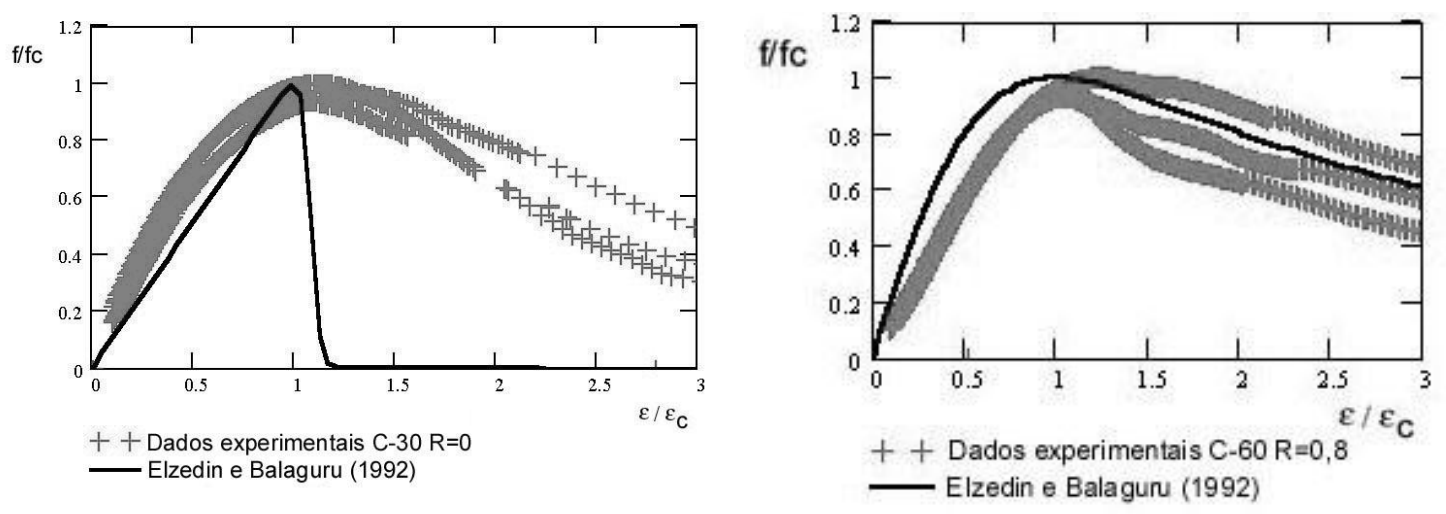

Figura 3.3 - Comparação entre o modelo de Ezeldin e Balaguru (1992) e dados experimentais

\subsection{COMPORTAMENTO À TRAÇÃO DO CRFA}

Para taxas de adição de fibras inferiores a 2\%, o comportamento à tração do CRFA é semelhante ao observado na compressão. Observa-se que as variações na resistência à tração do concreto, no módulo de elasticidade e na deformação correspondente à máxima tensão, são praticamente desprezíveis. Porém, observase uma elevada melhora no comportamento pós-fissuração do concreto, que é traduzida, basicamente, na diminuição da inclinação do trecho descendente do diagrama tensão à tração vs. deformação do concreto.

Segundo Balaguru e Shah (1992), diversos modelos são apresentados na Literatura para CRFA com mais de $2 \%$ de adição de fibras. A maior parte desses modelos é baseada em teorias da Mecânica da Fratura. Contudo, modelos matemáticos para concretos reforçados com taxas de fibras inferiores a $2 \%$ são praticamente inexistentes. Balaguru e Shah (1992) sugerem a utilização de um modelo matemático simples para o comportamento tensão de tração vs. deformação do CRFA. Neste modelo é considerado que a deformação correspondente à máxima tensão é igual a $0,2 \%$. O trecho ascendente do diagrama é considerado linear até à máxima tensão e pode ser expresso pela Eq.(3.9): 


$$
f_{t C R F A}=E_{c t C R F A} \cdot \varepsilon_{t C R F A} \quad \varepsilon_{t}<0,2 \%
$$

na qual $E_{C t C R F A}$ é o módulo de elasticidade à tração do CRFA e $\varepsilon_{t C R F A}$ é a deformação em um ponto do diagrama tensão vs. deformação. O trecho descendente do diagrama pode ser expresso por uma função exponencial dada pela Eq.(3.10):

$$
f_{t C R F A}=f_{\text {tuCRFA }} \cdot e^{-B \cdot \varepsilon_{t}} \quad \varepsilon_{t}>0,2 \%
$$

na qual $f_{\text {tuCRFA }}$ é a máxima tensão de tração suportada pelo CRFA e $B$ é um coeficiente que depende do índice de reforço da fibra e da resistência do concreto, podendo ser obtido através da análise de regressão de dados experimentais. $\mathrm{Na}$ Figura 3.4, apresenta-se o diagrama correspondente ao modelo proposto para o comportamento à tração do CRFA.

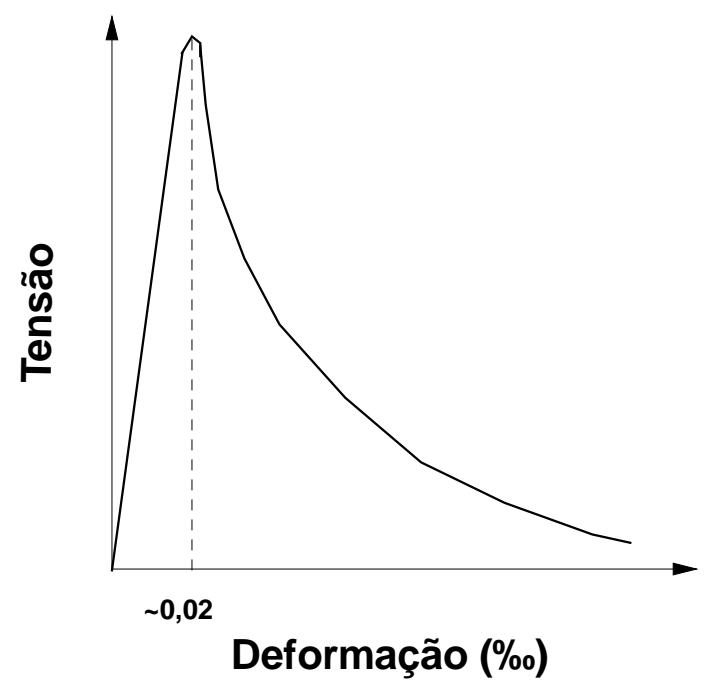

Figura 3.4 - Comportamento do modelo sugerido por Balaguru e Shah (1992) para o CRFA submetido à tração

\subsection{COMPORTAMENTO À FLEXÃO DO CRFA}

Seguindo a mesma linha de comportamento mecânico à compressão e à tração axial, a adição de fibras à massa do concreto com taxas inferiores a 2\% não aumenta de modo significativa a resistência desse material à flexão. A grande vantagem da adição de fibras dessa ordem de grandeza, reside no melhoramento 
do comportamento pós fissuração do compósito. Isso porque as fibras compõem uma ponte de ligação entre as fissuras e, por meio do processo de deslizamento, controlam as deformações, aumentando, assim, da capacidade de absorção de energia do compósito (Banthia e Trottier, 1995).

Muitos pesquisadores vêm tentando correlacionar os resultados experimentais do ensaio de arrancamento das fibras com a tenacidade à flexão do CRFA, através de modelos matemáticos (Banthia e Trottier, 1995; e Armelin e Banthia, 1997). Porém, tem-se observado algumas dificuldades devido às inconsistências itrínsecas ao CRFA. Por exemplo, esperava-se que, ao se duplicar a percentagem de fibras da matriz, o número de fibras remanescente em uma seção fissurada também duplicasse, porém, observa-se que esse processo não é linear. Além desse problema, a distribuição aleatória das fibras em diferentes planos e inclinações dificulta ainda mais o problema.

Devido às dificuldades expostas, durante a modelagem de estruturas de CRFA que trabalham a flexão, muitos pequisadores costumam desprezar completamente a resistência à tração do CRFA, ou modelá-la segundo o modelo sugerido por Balaguru e Shah (1992), apresentado no item 3.1.3 deste capítulo (Hsu, He, Elzedin, 1992).

Recentemente, Armelin e Banthia (1997) apresentaram um modelo baseado nos resultados experimentais de ensaios de arrancamento e que se mostrou bastante satisfatório. O modelo considera o Método de Confiabilidade de Primeira Ordem e utiliza variáveis estocásticas para a análise. Segundo esse modelo, o equilíbrio da seção transversal é função da força de arracamento individual de cada fibra, conforme expresso pela Eq.(3.11):

$$
\begin{aligned}
& \sum F_{x}=0 \Rightarrow\left(\int_{0}^{c^{\prime}} \sigma_{c}(y) \cdot b \mathrm{dy}\right)+\sum_{i}^{N} f_{i}=0 \\
& \sum M=0 \Rightarrow M_{e}=\left(\int_{0}^{x} \sigma_{c}(y) \cdot b \cdot y \mathrm{dy}\right)+\sum_{i}^{N}\left(f_{i} \cdot y_{i}\right)
\end{aligned}
$$


na qual $C^{\prime}$ é a distância da linha neutra até a face superior do modelo, $N$ é o número de fibras existente na seção transversal, $y$ é a distancia da face superior do modelo a um ponto qualquer, $b$ é a largura do modelo, $\sigma_{c}(y)$ é a tensão de compressão no concreto em um ponto y qualquer, e $f_{i}$ é a força de arrancamento de uma fibra $i$. Na Figura 3.5, é apresentado um diagrama esquemático do equilíbrio de forças da seção transversal de um modelo fletido. O comportamento à compressão do CRFA pode ser modelado pelos modelos sugeridos no item 3.1.2 deste capítulo.

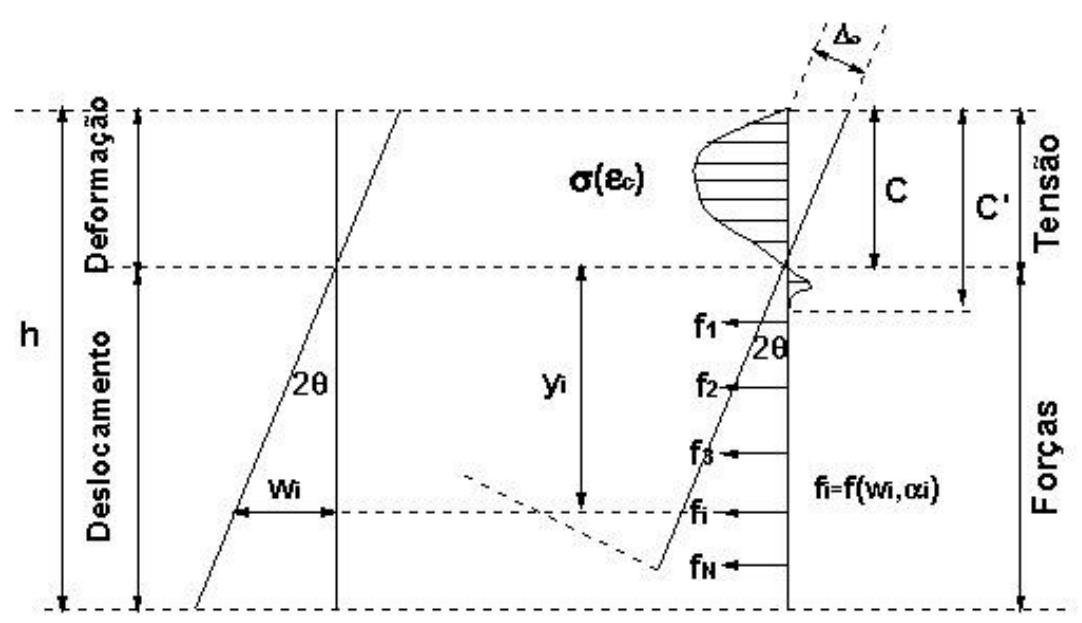

Figura 3.5 - Diagrama esquemático do equilíbrio das forças em uma seção transversal de um modelo submetido à flexão. (Armelin e Banthia, 1997)

As forças de arrancamento $f_{i}$ podem ser expressas analiticamente como uma função do ângulo de inclinação de cada fibra, em relação ao plano da fissura $\left(\alpha_{i}\right)$ e da abertura da fissura na posição de cada fibra $\left(w_{f i}\right)$; desse modo pode-se escrevê-la como na Eq.(3.12):

$$
f_{i}\left(w_{f i}, \alpha_{i}\right)=E_{p} \cdot w_{f i} \cdot\left\{A+\frac{1-A}{\left[1+\left(B \cdot w_{f i}\right)^{C}\right]^{1 / C}}\right\}
$$

na qual $A, B, C$ e $E_{p}$ são constantes obtidas por análise de regressão de resultados experimentais de arracamento, para diversas inclinações de fibras. Os valores dessas constantes são apresentados na Figura 3.6. 


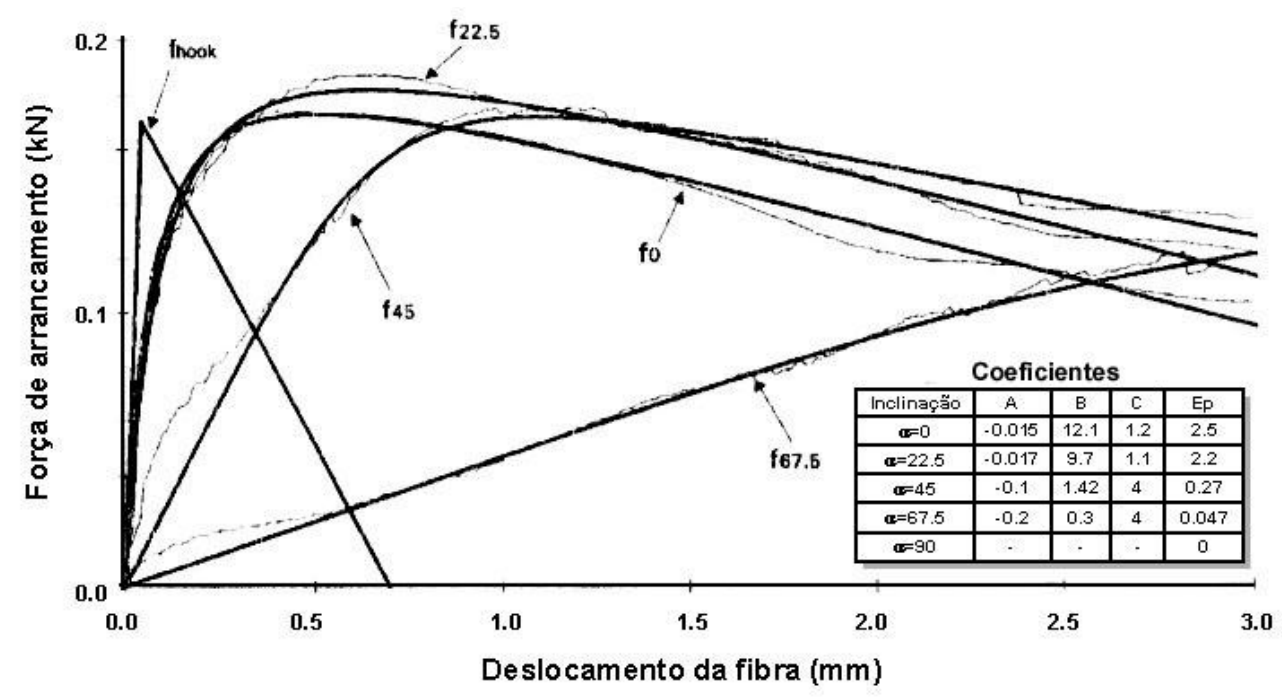

Figura 3.6 - Valores das constantes $A, B, C$ e $E_{p}$ para diversos ângulos de orientação das fibras. (Armelin e Banthia, 1997)

A força de arrancamento média em uma dada seção transversal pode ser expressa pela Eq.(3.13):

$$
\bar{f}=\frac{\sum_{i}^{N} f_{i}}{N}
$$

Para se calcular o valor médio da força de arrancamento assumindo uma distribuição randômica das fibras é necessário computar todas as possíveis combinações de inclinações e de comprimento de embebimento das fibras. Desse modo, assumindo que todas as combinações têm a mesma probabilidade de ocorrer, isto é, obdecendo a uma distribuição uniforme, pode-se escrever que a força média de arrancamento é expressa pela Eq.(3.14):

$$
\begin{aligned}
\bar{f}(w) & \cong \frac{1}{2} \cdot\left\{\left[\left(\frac{f_{0}(w)}{2}+f_{22,5}(w)+f_{45}(w)+f_{67,5}(w)+\right.\right.\right. \\
& \left.\left.\left.+\frac{f_{90}(w)}{8}\right)\right]+f_{\text {hook }}(w)\right\}
\end{aligned}
$$

na qual $f_{0}, f_{22,5}, f_{45}, f_{67,5}$ e $f_{90}$ são as funções das forças de arrancamento para fibras inclinadas de $0^{\circ}, 22,5^{\circ}, 45^{\circ}, 67,5^{\circ}$ e $90^{\circ}$, respectivamente, e $f_{\text {hook }}$ é a função que 
leva em consideração o comprimento de embebimento de cada fibra nas proximidades da fissura.

Para a análise do modelo, Armelin e Banthia (1997) acoplaram-no a um programa de análise de confiabilidade. Assim, foi possível obter, além do comportamento estocástico médio da variação da carga para uma dada deflexão, o intervalo de confiabilidade do problema (limites superiores e inferiores do intervalo de predição). Na Figura 3.7, é apresentada uma comparação entre os resultados do modelo proposto e os obtidos experimentalmente, na qual se observa um comportamento bastante satisfatório do modelo. Armelin e Banthia (1997) ainda sugerem que o modelo pode ser acoplado a um programa baseado no Método dos Elementos Finitos, para a análise de estruturas de CRFA submetidos à flexão.

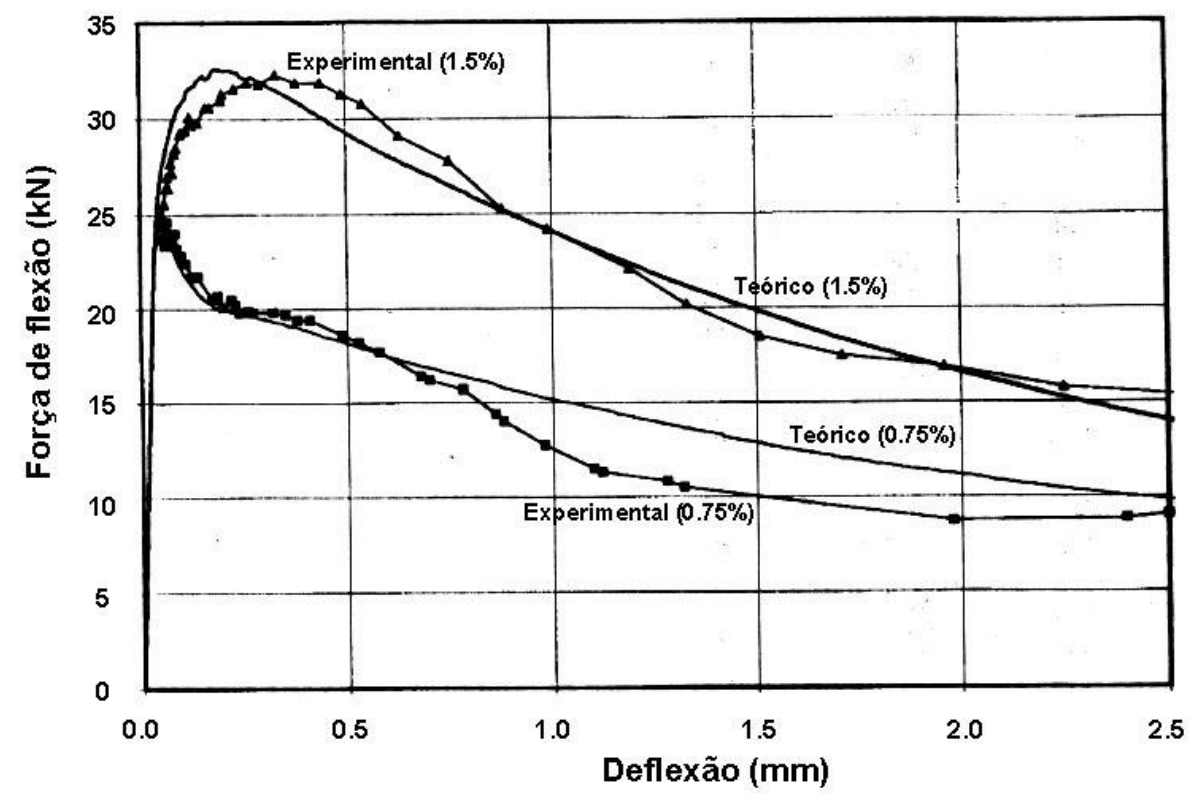

Figura 3.7 - Comparação o modelo de proposto por Armelin e Banthia (1997) e resultados experimentais 


\section{IMPLEMENTAÕES COMPUTACIONAIS, METODOLOGIAS DE AVALIAÇÃO DA DUCTILIDADE E MODELAGENS}

\subsection{PROGRAMA COMPUTACIONAL}

O programa utilizado neste trabalho foi o ANAPROT. Esse programa é fruto de uma linha de pesquisa desenvolvida pelos prof. Ney Augusto Dumont e Giuseppe Barbosa Guimarães, da Pontifícia Universidade Católica do Rio de Janeiro, e foi composto por quatro teses de mestrado (Ferreira, 1986; Musso, 1987, Krüger, 1989; e Campos, 1993). O código fonte do programa foi cedido ao presente estudo, para que fosse possível o acoplamento das sub-rotinas aqui desenvolvidas a ele. O programa foi desenvolvido para análise de pórticos planos de concreto armado e protendido; ele utiliza o método dos elementos finitos e leva em consideração as não-linearidades físicas do material e as geométricas da estrutura. A teoria utilizada é a teoria de vigas de Bernoulli-Kirchhoff e o elemento finito utilizado é o de viga, que é inicialmente descrito em um sistema natural de coordenadas. Em seguida, este é transformado para um sistema auxiliar de coordenadas, cujas coordenadas de deslocamentos são dispostas segundo as coordenadas globais do pórtico e permitem a descrição de deslocamentos de corpo rígido. Logo após, ocorre a transformação para o sistema global de coordenadas e, a partir daí, segue-se o método da rigidez direta. Na Figura 4.1 é apresentado o elemento finito utilizado e os sistemas de coordenadas.
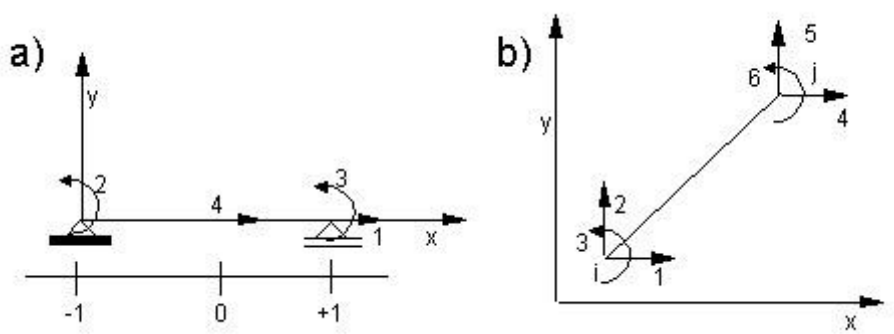

Figura 4.1 - Elemento finito utilizado e sistemas de coordenadas natural (a) e auxiliar (b) 
A resolução do sistema não-linear de equações, necessário para cada etapa do processo incremental, pode ser feita segundo alguns métodos, a depender do usuário: método de controle do trabalho das forças externas; método das normas dos deslocamentos; e método de Newton Raphson, com controle de força ou deslocamento. O programa consegue representar os fenômenos de snap-through e snap-back e, independentemente do método utilizado para a resolução do sistema não-linear de equações, ele segue o algoritmo de análise da estrutura numa etapa do carregamento apresentado na Figura 4.2.

\subsubsection{Procedimento de implementação das leis constitutivas do material}

Foram implementadas sub-rotinas em Linguagem Fortran, que continham as leis constitutivas do concreto confinado e com adições de fibras. Em seguida, essas sub-rotinas foram acopladas ao programa ANAPROT. Para tanto, foram realizadas pequenas modificações no código do programa original, para que este pudesse se comunicar com as sub-rotinas. O procedimento de integração numérica utilizado foi o mesmo para todas as sub-rotinas e será descrito a seguir.

Definidas as leis constitutivas dos materiais e a seção transversal do elemento estrutural de concreto armado, podem-se obter os esforços resistentes, utilizando um sistema local de coordenada $(\xi, \eta, \zeta)$, que passa pelo centro de gravidade da seção transversal, por meio da integração das tensões definidas para o concreto e para o aço, em função das curvas tensão-deformação de cada material. Os esforços resistentes podem ser descritos pelas equações Eq.(4.1) e Eq.(4.2)

$$
\begin{aligned}
& M_{\xi}=-\left(\int_{A_{c}} \sigma_{c}(\varepsilon) \cdot \eta \cdot d A+\sum_{n} A s_{n} \cdot \sigma_{s}(\varepsilon)_{n} \cdot \eta_{n}\right) \\
& N_{\xi}=-\left(\int_{A_{c}} \sigma_{c}(\varepsilon) \cdot d A+\sum_{n} A s_{n} \cdot \sigma_{s}(\varepsilon)_{n}\right)
\end{aligned}
$$


Capítulo IV - Implementações computacionais, metodologias de avaliação da ductilidade e 60 modelagens.

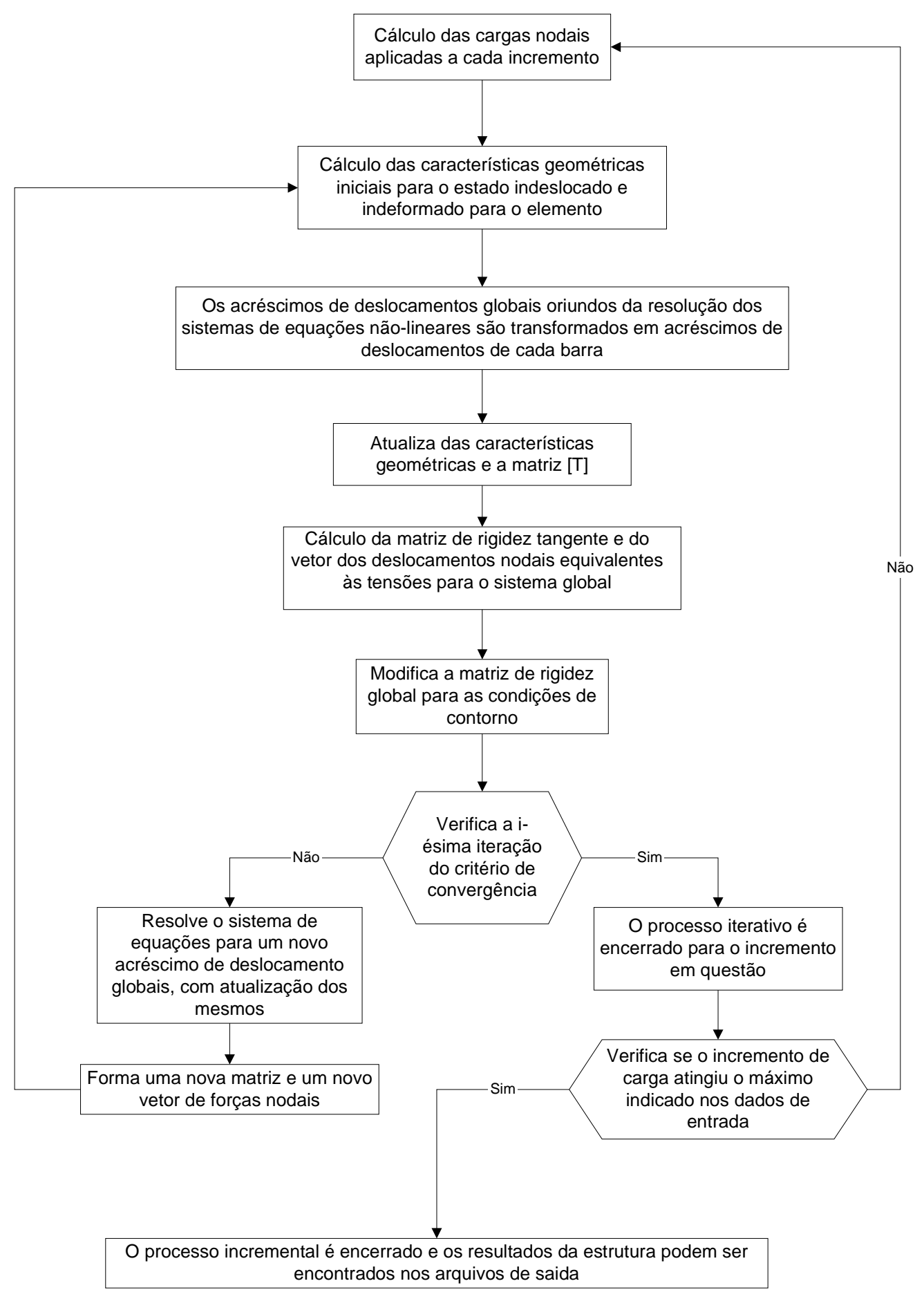

Figura 4.2 - Algoritmo utilizado pelo programa para a análise de uma estrutura em uma etapa de carregamento

nas quais $\sigma_{c}(\varepsilon)$ e $\sigma_{s}(\varepsilon)$ são as tensões no concreto e na armadura, respectivamente; $A_{c}$ é a área do concreto; $\eta$ é a ordenada de um ponto qualquer da seção no sistema de coordenada local; $A_{s n}$ e $\eta_{n}$ são a área e a ordenada da barra $n$ da armadura, 
respectivamente. Na Figura 4.3 apresentam-se detalhes do sistema de coordenada local.

Analisando as equações Eq.(4.1) e Eq. (4.2), observa-se que os esforços resistentes contêm tanto contribuição da armadura quanto do concreto. Observa-se ainda que, para quantificar a parcela atribuída ao concreto, é necessária a resolução das integrais presentes nestas equações. O processo numérico utilizado para resolução das integrais consiste em transformar as integrais de superfície sobre o domínio em integrais de linha ao longo do contorno. Para tanto, aplica-se o teorema de Green no plano. Uma seção transversal qualquer é definida como uma poligonal fechada, percorrida no sentido anti-horário, sendo que, em caso de aberturas internas, essas são definidas por uma orientação horária. Na Figura 4.4 apresenta-se a definição do domínio de integração (Krüger, 1989).

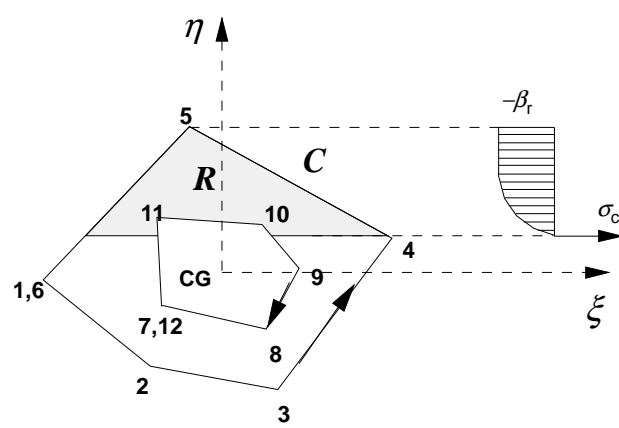

Figura 4.3 - Detalhes do sistema de coordenada local

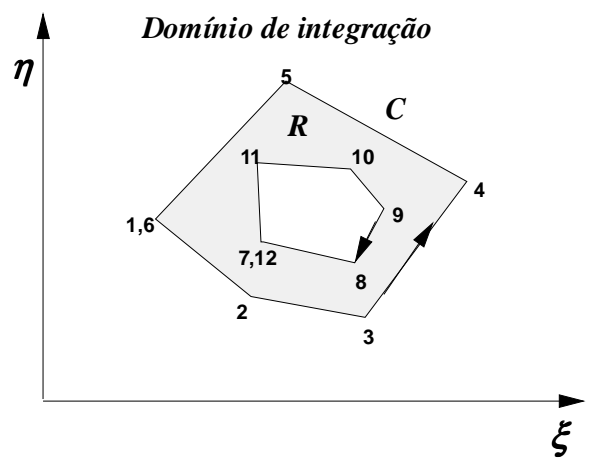

Figura 4.4 - Domínio de integração da seção transversal analisada

Pela aplicação do teorema de Green no plano, a expressão de um termo genérico de um polinômio transformado para uma integral de contorno é expressa pela Eq.(4.3):

$$
\int_{R} \xi^{k} \cdot \eta^{m} d A=\int_{C} \frac{\xi^{k+1} \cdot \eta^{m}}{k+1} d \eta=\sum_{j=1}^{N} G_{k, m}
$$

na qual $N$ representa o número de segmentos e $G_{k, m}$ a integral de contorno do jésimo segmento da poligonal, definido pelos vértices $i$ e $i+1$, como apresentado na Figura 4.5. As integrais $G_{k, m}$ podem ser expressas pela Eq.(4.4): 


$$
G_{k, m}=\frac{1}{k+1} \cdot \int_{\eta_{i}}^{\eta_{i+1}} \xi^{k+1} \cdot \eta^{m} d \eta
$$

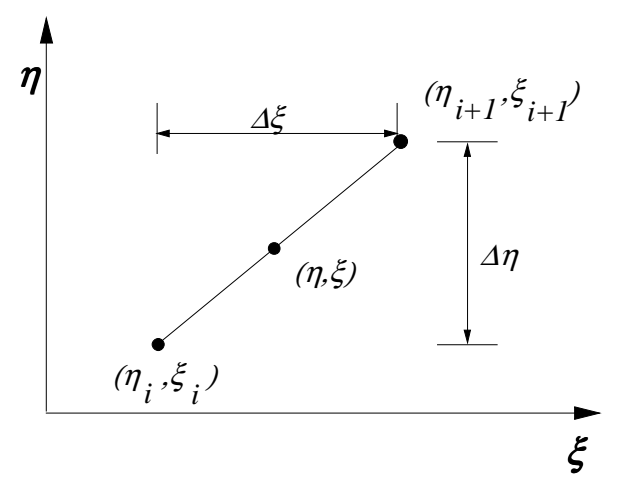

Figura 4.5 - Parametrização de um segmento da poligonal

Considerando $\omega$ um incremento qualquer na ordenada $\eta$, pode-se escrever a equação Eq.(4.5):

$$
\begin{aligned}
& \eta=\eta_{i}+\omega \\
& \xi=\xi_{i}+\frac{\Delta \xi}{\Delta \eta} \cdot \omega
\end{aligned}
$$

Substituindo a equação Eq.(4.5) na Eq.(4.4), obtém-se a equação Eq.(4.6):

$$
G_{k, m}=\frac{1}{k+1} \cdot \int_{0}^{\Delta \eta}\left(\xi_{i}+\frac{\Delta \xi}{\Delta \eta} \cdot \omega\right)^{k+1} \cdot\left(\eta_{i}+\omega\right)^{m} d \omega
$$

na qual $\Delta \eta$ e $\Delta \xi$ são dados pela equação Eq.(4.7):

$$
\begin{aligned}
& \Delta \eta=\eta_{i+1}-\eta_{i} \\
& \Delta \xi=\xi_{i+1}-\xi_{i}
\end{aligned}
$$

Utilizando o procedimento descrito acima, as equações Eq.(4.1) e Eq.(4.2) tornam-se um somatório de várias parcelas, funções de $G_{k, m}$. Após o cálculo dessas funções, segue-se o procedimento usual de utilização da integração numérica Gaussiana para resolução das matrizes de rigidez do sistema.

\subsubsection{Leis constitutivas para o concreto confinado}

O modelo de Cusson e Paultre (1995), descrito no capítulo dois, item 2.3.4, foi implementado e acoplado ao programa ANAPROT. Observou-se que os 
autores não apresentaram equações para o cálculo da deformação $\varepsilon_{c o}$ correspondente à tensão de pico do concreto sem confinamento e nem para o cálculo do módulo de elasticidade do concreto. Baseado no exposto, optou-se por utilizar as expressões sugeridas pelo FIB (1999) para a deformação $\varepsilon_{c o}$ e o módulo de elasticidade do concreto, e que são expressos pelas Eq.(4.8) e Eq.(4.9), respectivamente:

$$
\begin{aligned}
& \varepsilon_{c o}=-0,0017-0,0010\left(\frac{f_{c}}{f_{c m o}}\right) \\
& E_{c}=\alpha_{e} \cdot \alpha_{\beta} \cdot\left[f_{c} / f_{c m o}\right]^{1 / 3} \quad(M P a)
\end{aligned}
$$

nas quais $f_{c m o}$ é igual a 70MPa, $\alpha_{e}$ é igual a $21500 \mathrm{MPa}$ e $\alpha_{\beta}$ é um coeficiente que depende do tipo de agregado graúdo que constitui o concreto - para o agregado basáltico, $\alpha_{\beta}$ é igual a 1,2 .

O comportamento à tração do concreto confinado é considerado semelhante ao do concreto sem confinamento; assim, foi utilizado o modelo do FIB (1999) sem nenhuma modificação e cuja tensão de tração pode ser expressa pelas equações Eq.(4.10) e Eq.(4.11):

$$
\begin{gathered}
\sigma_{c t}=E_{c} \cdot \varepsilon_{c t} \sigma_{c t} \leq 0,9 \cdot f_{c t m} \\
\sigma_{c t}=f_{c t m}-\frac{0,1 \cdot f_{c t m}}{0,00015-\frac{0,9 \cdot f_{c t m}}{E_{c}}} \cdot\left(0,00015-\varepsilon_{c t}\right) \\
0,9 \cdot f_{c t m} \leq \sigma_{c t} \leq f_{c t m}
\end{gathered}
$$

nas quais $f_{c t m}$ é a resistência à tração do concreto e $\varepsilon_{c t}$ é a deformação à tração, deformação à qual o concreto está submetido.

\subsubsection{Leis constitutivas para o concreto não-confinado}

Para a análise do concreto não-confinado pode ser utilizado o modelo de Cusson e Paultre (1995), considerando que a taxa de armadura de confinamento é nula. Contudo, o programa ANAPROT já disponibilizava as leis constitutivas do CEB (1990). A única modificação realizada no modelo do CEB (op. cit.) foi alterar o valor da deformação $\varepsilon_{c o}$, que é sugerido como 0,0022 , para o valor 
calculado pela Eq.(4.8). Segundo o CEB (op. cit.), a tensão no concreto nãoconfinado pode ser expressa pelas Eq.(4.12) e Eq.(4.13):

$$
\begin{gathered}
\sigma_{c}=\left[\frac{\left(\frac{E_{c}}{E_{c o}}\right) \cdot\left(\frac{\varepsilon_{c}}{\varepsilon_{c o}}\right)-\left(\frac{\varepsilon_{c}}{\varepsilon_{c o}}\right)^{2}}{1+\left(\left(\frac{E_{c}}{E_{c o}}\right)-2\right) \cdot\left(\frac{\varepsilon_{c}}{\varepsilon_{c o}}\right)}\right] \cdot f_{c} \quad \varepsilon_{c} \leq \varepsilon_{c u} \\
\sigma_{c}=\left[\begin{array}{l}
\left(\frac{1}{\left(\frac{\varepsilon_{c}}{\varepsilon_{c o}}\right)} \cdot \zeta-\frac{2}{\left(\frac{\varepsilon_{c}}{\varepsilon_{c o}}\right)^{2}}\right) \cdot\left(\frac{\varepsilon_{c}}{\varepsilon_{c o}}\right)^{2}+ \\
\left(\frac{4}{\left(\frac{\varepsilon_{c}}{\varepsilon_{c o}}\right)}-\zeta\right) \cdot\left(\frac{\varepsilon_{c}}{\varepsilon_{c o}}\right)
\end{array}\right] \cdot f_{c} \quad \varepsilon_{c} \geq \varepsilon_{c u}
\end{gathered}
$$

nas quais $E_{c o}$ é o módulo de elasticidade secante do concreto, $E_{c}$ é o módulo de elasticidade do concreto calculado pela Eq.(4.9), $\varepsilon_{c u}$ é a deformação última do concreto e $\zeta$ é um coeficiente função do módulo de elasticidade e das deformações do concreto. Essas variáveis podem ser expressas pelas equações Eq.(4.14), Eq.(4.15) e Eq.(4.16), respectivamente:

$$
\begin{aligned}
& E_{c o}=\frac{f_{c}}{\varepsilon_{c o}} \quad(\mathrm{MPa}) \\
& \frac{\varepsilon_{c u}}{\mathcal{E}_{c o}}=\frac{1}{2} \cdot\left(\frac{1}{2} \cdot \frac{E_{c}}{E_{c o}}+1\right)+\sqrt{\frac{1}{4} \cdot\left(\frac{1}{2} \cdot \frac{E_{c}}{E_{c o}}+1\right)^{2}-\frac{1}{2}} \\
& \zeta=\frac{4 \cdot\left[\left(\frac{\varepsilon_{c u}}{\varepsilon_{c o}}\right)^{2} \cdot\left(\frac{E_{c}}{E_{c o}}-2\right)+2 \cdot\left(\frac{\varepsilon_{c u}}{\varepsilon_{c o}}\right)-\left(\frac{E_{c}}{E_{c o}}\right)\right]}{\left[\left(\frac{\varepsilon_{c u}}{\varepsilon_{c o}}\right) \cdot\left(\frac{E_{c}}{E_{c o}}-2\right)+1\right]^{2}}
\end{aligned}
$$


As leis constitutivas do concreto não-confinado submetido à tração sugeridas pelo CEB (1990) são semelhantes às do FIB (1999) e expressas pelas equações Eq.(4.10) e Eq.(4.11).

\subsubsection{Leis constitutivas para a armadura}

O programa já continha as leis constitutivas para aços classe A e aços classe B. Todavia, utilizaram-se apenas os aços classe A neste trabalho, uma vez que a nova norma NBR-7480:1996 especifica apenas os aços classe A para o reforço de elementos de concreto armado. Segundo essa norma, a tensão na armadura é expressa pela equação Eq.(4.17):

$$
\begin{array}{ll}
\sigma_{s}=E_{s} \cdot \varepsilon_{s} & \mathcal{E}_{s} \leq \varepsilon_{y} \\
\sigma_{s}=f_{y} & \varepsilon_{s} \geq \varepsilon_{y}
\end{array}
$$

na qual $E_{s}$ é o módulo de elasticidade do aço, $f_{y}$ é a tensão de escoamento do aço, $\varepsilon_{y}$ é a deformação de escoamento do aço e $\varepsilon_{s}$ é a deformação imposta à armadura metálica.

\subsection{METODOLOGIAS DE QUANTIFICAÇÃO DA DUCTILIDADE}

Um dos grandes problemas para quantificar a ductilidade do material concreto e das estruturas compostas por este material reside no mau entendimento do que seja essa propriedade. É comum, na literatura, a troca da definição de ductilidade pela de tenacidade, o que leva alguns pesquisadores à formulação de índices inconsistentes ou inadequados para a avaliação daquela.

Segundo Van Vlack (1982), ductilidade é uma medida de deformação que indica a capacidade de um corpo deformar-se inelasticamente, sem perder de forma brusca a sua capacidade resistente. Já tenacidade é a medida de energia que quantifica a capacidade de um corpo absorver energia elástica ou inelástica até chegar à ruptura. Desse modo, é possível um material ser altamente tenaz, porém frágil, ou altamente dúctil, porém pouco tenaz.

Um aspecto que tem levantado bastante discussão no meio técnicocientífico é a fragilidade do concreto de alta resistência, quando comparado com 
os concretos comuns. Isso porque, quando do ensaio à compressão em corpos-deprova, a ruína se dá de modo mais frágil do que nos concretos comuns. Como já enfatizado e explicado no decorrer desse texto.

No estudo da ductilidade, é comum a utilização de três abordagens: a nível do material, a nível do elemento estrutural e a nível da estrutura. Neste trabalho, restringir-se-á aos dois primeiros níveis: ductilidade do material e ductilidade do elemento estrutural.

A ductilidade dos concretos é comumente avaliada por meio do diagrama tensão vs. deformação, obtido em ensaios de corpos-de-prova submetidos à compressão. Já a ductilidade dos pilares de concreto submetidos à compressão concêntrica é normalmente avaliada através, do diagrama tensão vs. deformação do concreto, obtido pela subtração, em cada incremento de carga, da força total resistida pelo pilar pela parcela de carregamento suportada pela armadura longitudinal, e, em seguida, pelo cálculo da tensão à qual o concreto está submetido. Quando os pilares são submetidos à flexo-compressão, utiliza-se o diagrama momento vs. rotação, para realizar a avaliação da ductilidade.

É observada, na Literatura, uma grande controvérsia quanto à metodologia de avaliação da ductilidade do concreto e dos pilares de concreto armado, submetidos à compressão concêntrica, o que leva alguns pesquisadores a se restringirem a apenas à avaliação qualitativa dos diagramas tensão vs. deformação. Outros pesquisadores costumam utilizar apenas o trecho descendente do diagrama tensão vs. deformação para quantificar a ductilidade do concreto, uma vez que, tanto o confinamento moderado, quanto a adição de fibras só aumentam a ductilidade do trecho descendente do diagrama (Ahmad e Shah, 1982; Martinez et alli, 1984; Razvi e Saatcioglu, 1999b; e Cusson e Paultre, 1995). Porém, essa metodologia recebe críticas por desprezar a deformação plástica no trecho ascendente do diagrama, a qual, no caso dos concretos de resistência usual, é significativa.

Um outro ponto de discordância é a escolha do ponto a ser utilizado para quantificar a deformação plástica no trecho descendente do diagrama. Alguns pesquisadores consideram o ponto correspondente a $85 \%$ da tensão máxima como 
ponto ideal (Martinez et alli, 1984), outros, 50\% (Cusson e Paultre, 1995). A discordância reside no fato de que a avaliação da ductilidade realizada através de pontos do diagrama próximos da tensão máxima pode fornecer resultados imprecisos. Outro fato é que, devido à parametrização do diagrama, utilizada nessas metodologias, a avaliação em apenas um ponto do diagrama também pode gerar resultados conflitantes, como é mostrado na Figura 4.6, na qual, utilizando um ponto entre $80 \%$ e $100 \%$ da tensão máxima, os concretos C30 e C60 com 1\% de adição de fibras iriam apresentar o mesmo índice de ductilidade. O mesmo acontece para os concretos C30 e C60 com 0,5\% de adição, quando o ponto correspondente a $35 \%$ da tensão máxima é utilizado.

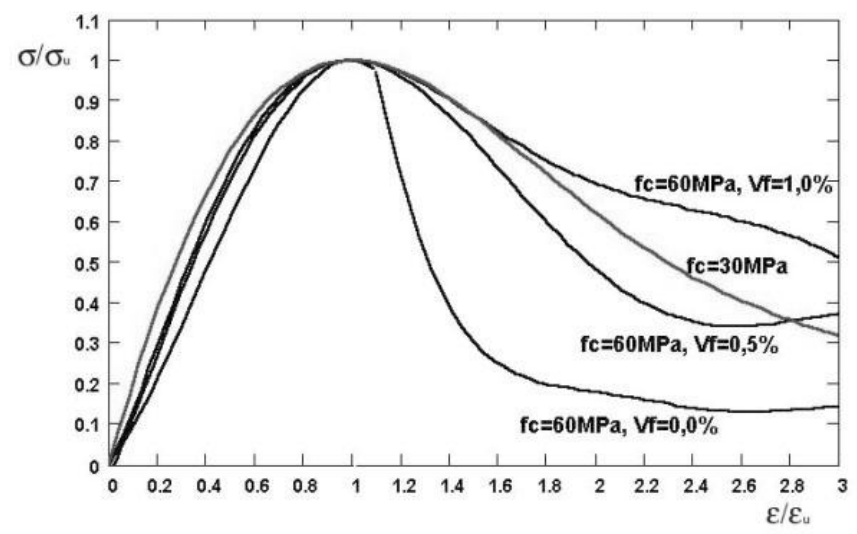

Figura 4.6 - Diagramas de concretos com e sem adição de fibras (Lima Jr. e Giongo, 2001)

Apesar do exposto acima, uma metodologia bastante aceita no meio científico é a proposta por Laurent (1989 ${ }^{1}$ apud Mendes, 1993) ${ }^{2}$. O autor define, como índice de ductilidade do trecho ascendente ( $I d_{\text {pré}}$ ), a relação entre a deformação correspondente à máxima tensão e a deformação elástica equivalente, sendo esta última dada pela razão entre a resistência do concreto e o módulo de elasticidade tangente na origem. Define, ainda, como ductilidade do trecho descendente, a relação entre a deformação do trecho descendente correspondente a

\footnotetext{
${ }^{1}$ LAURENT, N.. Frgilité des éléments comprimés en béton à hautes et très hautes performances et pourcentages minimaux d'armatures. Université Blaise Pascal - Clermont Fd. II, juin 1989, p.72.

${ }^{2}$ Essa metodologia é utilizada no modelo de Cusson e Paultre (1995) para concreto confinado.
} 
$50 \%$ da tensão máxima e a deformação correspondente à máxima tensão. $\mathrm{Na}$ Figura 4.7, é apresentada esquematicamente a metodologia de Laurent.

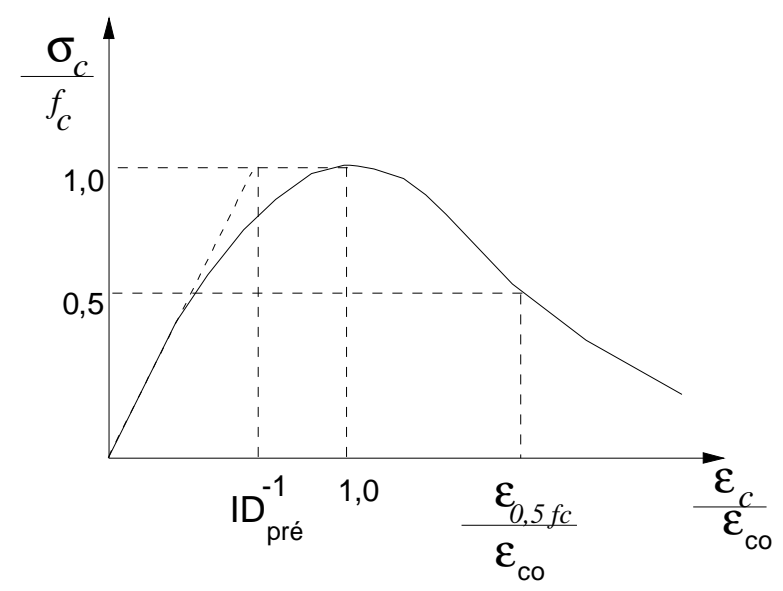

Figura 4.7 - Metodologia de avaliação da ductilidade proposta por Laurent (1989)

\subsubsection{Metodologia proposta}

Com o objetivo de minimizar os problemas observados nas metodologias de avaliação da ductilidade dos concretos simples, com confinamento e com adição de fibras, propõe-se neste item um procedimento para analisar essa propriedade. Esse procedimento estabelece dois índices de ductilidade: um para o ramo ascendente do diagrama tensão vs. deformação e outro para o ramo descendente. $\mathrm{O}$ índice correspondente ao ramo ascendente é denominado índice de ductilidade pré-pico e é definido pela Eq. (4.18):

$$
I D_{\text {Pré }}=\frac{\frac{2 \cdot \int_{0}^{\varepsilon_{c o}} \sigma_{c}\left(\varepsilon_{c}\right) d \varepsilon_{c}}{f_{c}}-\frac{f_{c}}{E_{c}}}{\varepsilon_{c o}}
$$

na qual $\sigma_{c}\left(\mathcal{E}_{c}\right)$ é a função tensão do concreto, $f_{c}$ é a tensão máxima resistida pelo concreto, $E_{c}$ é o módulo de elasticidade tangente na origem do concreto e $\varepsilon_{c o}$ é a deformação correspondente à tensão máxima resistida pelo concreto.

O índice de ductilidade correspondente ao ramo descendente do diagrama foi denominado de índice de ductilidade pós-pico e foi definido como sendo o comprimento da base de um retângulo de altura unitária e área igual à área abaixo 
do ramo descendente do diagrama parametrizado tensão vs. deformação do concreto (ver Figura 4.8). Assim, o índice de ductilidade pós-pico pode ser escrito pela Eq.(4.19):

$$
I D_{p o ́ s}=\frac{\int_{\varepsilon_{c o}}^{\varepsilon_{c 2}} \sigma_{c}\left(\varepsilon_{c}\right) d \varepsilon_{c}}{\varepsilon_{c o} \cdot f_{c}}
$$

na qual $\sigma_{c}\left(\varepsilon_{c}\right)$ é a função tensão do concreto e $\varepsilon_{c 2}$ é a deformação última de avaliação da ductilidade. Ensaios experimentais mostram que, mesmo com máquinas de ensaio de compressão, com mecanismo de controle de deslocamento, é difícil obter o comportamento do concreto simples, confinado e com adição de fibras, após a deformação correspondente a quatro vezes a deformação correspondente à tensão máxima. Esse fato ocorre porque, a partir dessa deformação, tensões de flexão, fendilhamento e cisalhamento surgem na massa do material. Além disso, o grau de fissuração do concreto é tão elevado que já não se pode considerar o material um meio contínuo. Desse modo, considerou-se, no presente trabalho, a deformação última como sendo o valor relativo a três vezes a deformação correspondente a tensão máxima. Van Mier (1997) utiliza este valor igual a $10 \%$, o que é aproximadamente igual ao valor adotado neste trabalho.

A grande vantagem dessa metodologia é que ela leva em consideração todos os pontos do ramo ascendente e descendente do diagrama tensão vs. deformação dos diversos concretos.
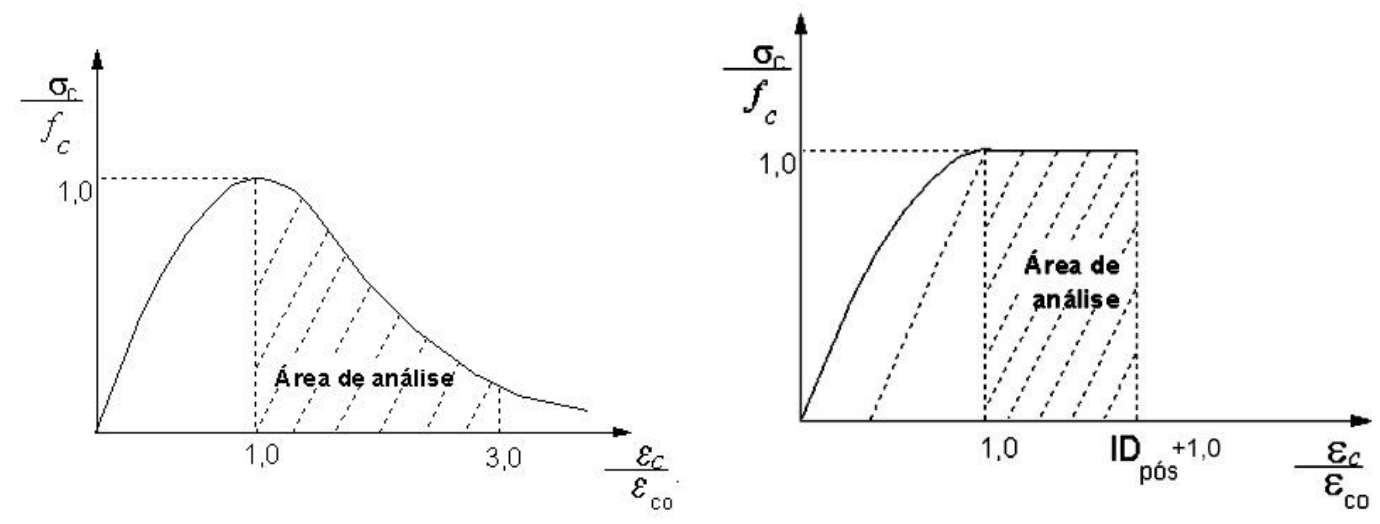

Figura 4.8 - Metodologia do índice de ductilidade pós-pico 
Neste trabalho utilizar-se-á apenas o índice de ductilidade pós-pico proposto, uma vez que, tanto o confinamento moderado, quanto a adição de fibras não interferem no ramo ascendente do diagrama tensão vs. deformação do concreto. Apesar das restrições, o índice de ductilidade proposto por Laurent (1989) também será utilizado, pois o modelo para o concreto confinado proposto por Cusson e Paultre (1995) é baseado na metodologia sugerida por aquele autor.

\subsection{MODELAGEM À COMPRESSÃO DO CRFA}

Como discutido no capítulo 3, item 3.4, desta tese, a modelagem do comportamento tensão vs. deformação à compressão do CRFA é influenciada por alguns fatores que a tornam complexa e levam alguns pesquisadores a restringirem seus modelos para características previamente definidas do CRFA. Observou-se também que os modelos mais utilizados não eram capazes de modelar de forma contínua o comportamento do CRFA com taxas de fibras variando de $0 \%$ a $2 \%$. Com o objetivo de solucionar esse problema, o modelo proposto por Elzedin e Balaguru (1992) foi reformulado. O novo modelo foi calibrado através de análise estatística de 75 diagramas tensão vs. deformação de concretos reforçados com fibras de aço com ancoragens nas extremidades. As resistências dos concretos variaram entre $30 \mathrm{MPa}$ e $90 \mathrm{MPa}$, a taxa volumétrica de fibras entre $0 \%$ e $2 \%$, e o fator de forma entre 50 e 114. As curvas foram selecionadas dos seguintes trabalhos: quatorze curvas de Taerwe (1992), três curvas de Hsu e Hsu (1994), duas curvas de Huges e Fattuhi (1977), 36 curvas de Guimarães (1999), quatro curvas de Balaguru e Shah (1992), quatro curvas de Elzedin e Balaguru (1992) e doze curvas de Lima Jr. e Giongo (2001). Além dos 75 diagramas de CRFA, utilizou-se também o modelo do FIB (1999) como base para os diagramas dos concretos sem adições de fibras.

O modelo proposto utiliza a equação Eq.(2.3), proposta por Popovics (1973) para o trecho ascendente do diagrama, substituindo-se a resistência do concreto confinado e a deformação correspondente a essa resistência pela resistência do CRFA e a deformação correspondente à tensão máxima do CRFA. Desse modo, a equação da tensão pode ser re-escrita pela Eq.(4.20): 


$$
\frac{\sigma_{c}}{f_{c f}}=\frac{\beta \cdot\left(\frac{\varepsilon_{c}}{\varepsilon_{c f}}\right)}{(\beta-1)+\left(\frac{\varepsilon_{c}}{\varepsilon_{c f}}\right)^{\beta}}
$$

na qual $f_{c f}$ é a resistência do concreto com adição de fibras e $\varepsilon_{c f}$ é deformação correspondente a essa resistência. A deformação correspondente à tensão máxima do CRFA $\varepsilon_{c f}$ foi obtida adicionando-se mais um termo à equação Eq.(4.8), sugerida pelo FIB (1999) para concretos simples. O termo adicional é uma função linear do índice de reforço obtido por análise de regressão com coeficiente de correlação $\left(r^{2}\right)$ de $71,63 \%$. Assim, pode-se expressar o valor de $\varepsilon_{c f}$ pela Eq.(4.21):

$$
\varepsilon_{c f}=-0,0017-0,0010\left(\frac{f_{c f}}{f_{c m o}}\right)-0,00032 \cdot R
$$

O coeficiente $\beta$ também foi calculado através de análise de regressão, utilizando o modelo do FIB (1999) e os diagramas experimentais mencionados. Observou-se que a influência do índice de reforço no trecho ascendente do diagrama pode ser desprezada, e que o valor de $\beta$ pode ser expresso pela Eq.(4.22):

$$
\beta=1,6186+0,06294 \cdot f_{c f}-0,0002175 \cdot f_{c f}^{2}
$$

na qual o coeficiente de correlação obtido $\left(r^{2}\right)$ foi de $92,52 \%$.

Para o ramo descendente do diagrama tensão vs. deformação do CRFA foi utilizada a equação Eq.(2.6), proposta por Fafitis e Shah (1985). Nesta, a tensão de pico $f_{c c}$ e a deformação $\varepsilon_{c c}$ foram substituídas por $f_{c f}$ e $\varepsilon_{c}$, respectivamente, resultando na Eq.(4.23):

$$
\frac{\sigma_{c}}{f_{c f}}=\exp \left(k_{11} \cdot\left(\varepsilon_{c}-\varepsilon_{c f}\right)^{k_{22}}\right)
$$

na qual os coeficiente $k_{11}$ e $k_{22}$ são funções da resistência do concreto e do índice de reforço da fibra. Os valores de $\varepsilon_{c}$ e $\varepsilon_{c f}$ devem ser expressos em (\%o). Esses coeficientes foram calculados por meio de análise de regressão, utilizando as 75 curvas de CRFA. Os coeficientes de correlação $\left(r^{2}\right)$ para os coeficientes $k_{11}$ e $k_{22}$ 
foram $82,19 \%$ e $81,11 \%$, respectivamente, e podem ser escritos pelas Eq.(4.22) e Eq.(4.23), respectivamente:

$$
\begin{aligned}
k_{11}= & -0,394-2,883 \cdot 10^{-3} \cdot f_{c f}+0,106 \cdot \ln (1,018+160,351 \cdot R) \quad \text { Eq.(4.24) } \\
k_{22}= & 0,674+3,468 \cdot 10^{-3} \cdot f_{c f}+1,759 \cdot 10^{-2} \cdot \ln (1,029+877,455 \cdot R)+ \\
& +0,396 \cdot \mathrm{R}
\end{aligned}
$$

Para verificar a eficiência do modelo proposto, foram modeladas 20 curvas experimentais de CRFA, que são apresentadas nas Figura 4.9 e Figura 4.10.

Observa-se que o modelo conseguiu representar de forma satisfatória todas as curvas experimentais analisadas.

Finalmente, deve-se enfatizar que o modelo é adequado apenas para CRFA com fibras com ancoragens nas extremidades, taxas de fibras de $0 \%$ a $2 \%$, fator de forma entre 50 a 120 e resistência do concreto entre 20MPa e 100MPa. Esse modelo também foi implementado e acoplado ao programa ANAPROT, utilizando-se o procedimento exposto no item 4.1.1. 
Capítulo IV - Implementações computacionais, metodologias de avaliação da ductilidade e 73 modelagens.
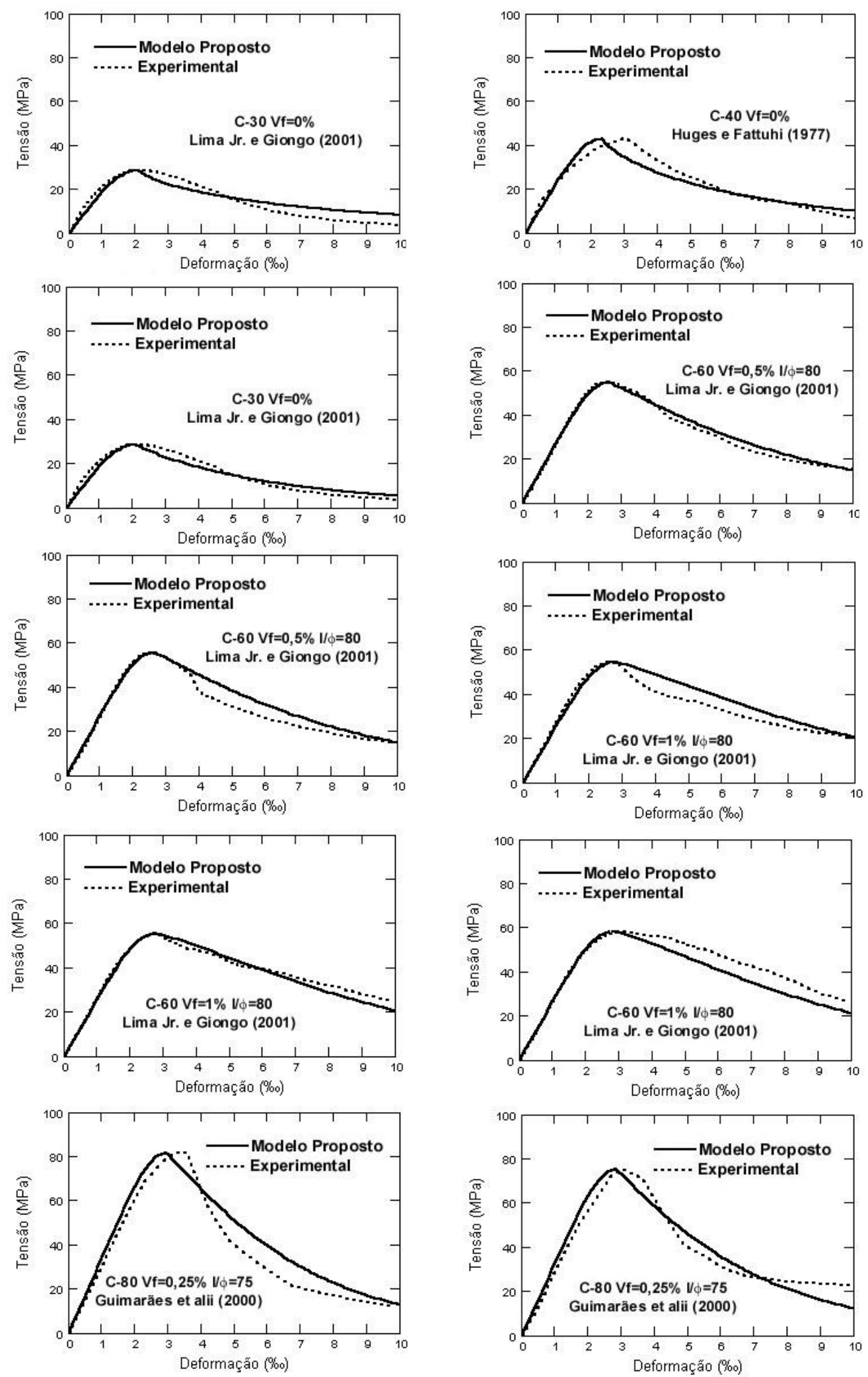

Figura 4.9 - Convalidação do modelo proposto para modelar o comportamento do CRFA à compressão 
Capítulo IV - Implementações computacionais, metodologias de avaliação da ductilidade e 74 modelagens.
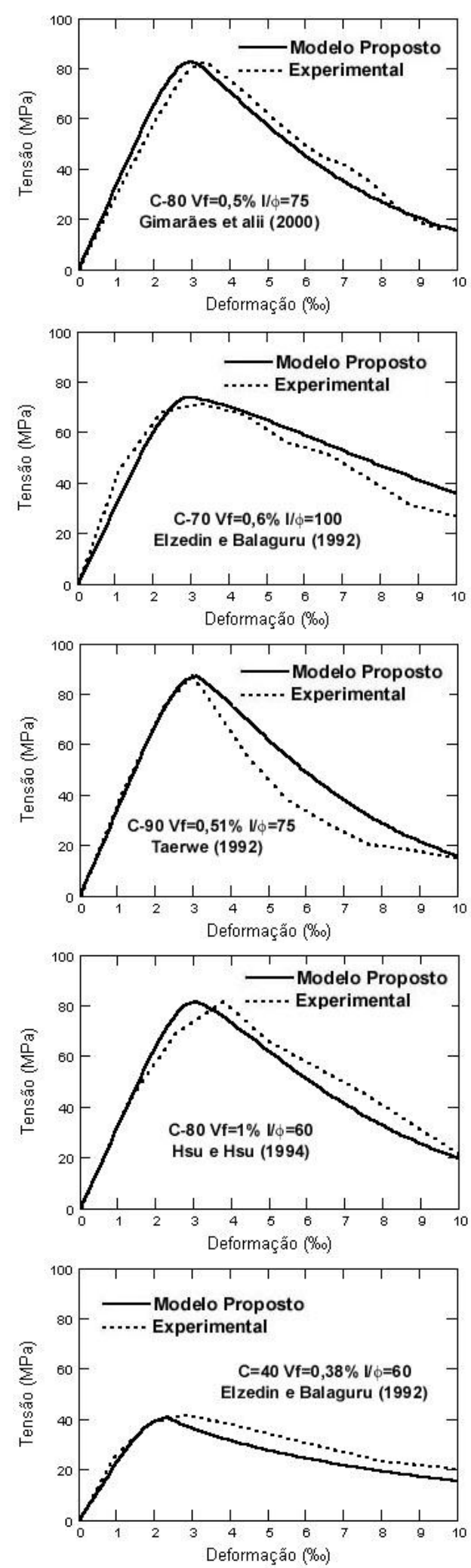
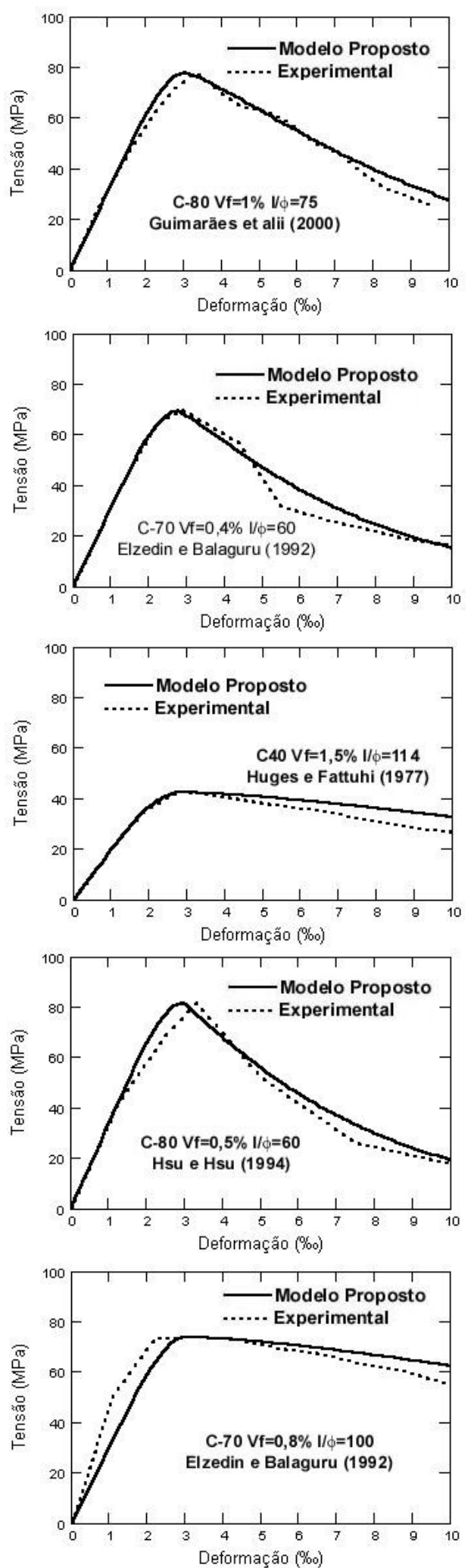

Figura 4.10 - Convalidação do modelo proposto para modelar o comportamento do CRFA à compressão 


\subsection{COMENTÁRIOS INICIAIS}

Neste capítulo, são realizados estudos paramétricos que visam a quantificar e a verificar a influência dos principais fatores na ductilidade dos pilares de concreto de alta resistência. Esses estudos têm como principal premissa gerar subsídios norteadores para o planejamento experimental do presente trabalho. Assim, com base na revisão bibliográfica realizada nos capítulos 2 e 3 , listaram-se os seguintes fatores de influência:
a) Resistência do concreto à compressão simples;
b) Taxa de armadura longitudinal;
c) Taxa de armadura transversal;
d) Geometria da seção transversal;
e) Índice de reforço da adição de fibras; e
f) Excentricidade do carregamento.

Observa-se, contudo, que, além do conhecimento a respeito de como varia a ductilidade dos pilares de CAR com os fatores listados acima, é essencial estabelecer um limite mínimo aceitável para a ductilidade dos pilares de CAR. Desse modo, apresentam-se e se discutem a seguir: um limite mínimo para a ductilidade do concreto de alta resistência para ser empregado em pilares; e os estudos paramétricos realizados. 


\subsection{LIMITE MÍNIMO DE DUCTILIDADE PARA OS CAR}

Tanto a norma brasileira para Projetos e Execução de Obras de Concreto Armado (NBR 6118: 1978) como o seu Projeto de Revisão (NBR 6118, 2001) não apresentam critérios para a consideração da ductilidade em pilares. Essas estabelecem apenas taxas mínimas de armadura transversal e longitudinal para os pilares e os limites para a resistência mínima e máxima do concreto (estes iguais a 20MPa e 50MPa). Estabelecem ainda que, em pilares não cintados e não sujeitos a esforços de torção e cisalhamento, esta armadura transversal mínima tem apenas a função de conter a flambagem lateral das barras da armadura longitudinal, antes que elas atinjam o escoamento, bem como que a taxa mínima de armadura longitudinal tem a função de preservar a seção transversal íntegra quanto à presença de flexões não consideradas no cálculo.

Uma crítica com relação à NBR 6118:1978 e o seu Projeto de Revisão (NBR 6118, 2001) que pode ser levantada, se refere à consideração de concretos com resistência característica de 50MPa como concretos de resistência usual. Em ensaios de laboratório, observa-se que, à compressão - tanto de corpos-de-prova, como de pilares -, o concreto de resistência de 50MPa já apresenta um comportamento pós-pico bastante frágil, muito semelhante ao de resistência $60 \mathrm{MPa}$ (Willrich et alii, 2002). Sendo, deste modo, considerado como concreto de alta resistência em diversos países europeus e pelo Estados Unidos da América.

Camara et alii (2003) estudou experimentalmente a influência da resistência do concreto e da geometria da seção transversal no comportamento de pilares pouco esbeltos dimensionados segundo os critérios do Projeto de Revisão da Norma NBR 6118 (2001). Os autores, em questão, observaram que os pilares rompem em um plano cisalhante com inclinação média de $59^{\circ}$, sempre perpendicular a sua menor dimensão. Quanto à capacidade de carga desses elementos ela é influenciada pela resistência do concreto e pela geometria da seção transversal dos pilares com um grau de confiabilidade de $99 \%$. Contudo, não detectaram interferência do acoplamento desses dois fatores. Observaram, ainda, que, elevando a resistência do concreto, a capacidade de carga paramétrica dos pilares aumenta de modo linear, porém, quando a relação entre $h / b$ é elevada, 
essa capacidade decresce linearmente. Já, quanto ao coeficiente de segurança global dos pilares, detectaram que este sofre influência dos dois fatores analisados, como também do acoplamento desses, para um grau de confiabilidade de $99 \%$. Essa influência se dá de forma não-linear, devido à interferência do acoplamento dos fatores. Ainda, que apenas a resistência à compressão do concreto influencia a ductilidade dos pilares de concreto armado. Essa influência apresenta um comportamento linear e a variação da ductilidade desses elementos estruturais é inversamente proporcional aos valores da resistência do concreto. Finalmente, os autores confirmaram que as armaduras transversais calculadas segundo o Projeto de Revisão da Norma (op. cit.) têm apenas a função de evitar a flambagem das barras da armadura longitudinal antes que o pilar atinja a sua máxima capacidade de carga.

Apesar do exposto, observa-se que os pilares dimensionados com resistência do concreto entre 20MPa e 40MPa e segundo os critérios da NBR 6118 (1978) - que são os mesmos do Projeto de Revisão acima mencionado apresentam ductilidade aceitável para as condições sísmicas brasileiras. Desse modo, desprezando o efeito favorável das armaduras desses pilares sobre a ductilidade do concreto, pode-se considerar, como índice mínimo aceitável de ductilidade para os concretos de alta resistência, a média entre os índices de ductilidade dos pilares com concretos com resistência de 40MPa. Camara et alii (2003) obtiveram os seguintes valores médios: $\varepsilon_{0.5 f c d} \mathcal{E}_{c c}=1,775$ e $I D_{p o ́ s}=0,958$.

\subsubsection{Variação da ductilidade com a resistência do concreto}

Como já discutido no capítulo 2, existem diversos modelos matemáticos para descrever o comportamento à compressão do concreto, que podem diferir entre si em diversos aspectos (Quintana, 2001). Assim, para realizar uma análise qualitativa e quantitativa da variação dos índices de ductilidade dos concretos, com relação à resistência do concreto, foram selecionados dois modelos já discutidos: FIB (1999) e Popovics (1973). Como o FIB (1999) apresenta equações que apenas são válidas até a deformação correspondente a cinqüenta por cento da tensão máxima no trecho descendente do diagrama tensão vs. deformação do 
concreto, as equações do CEB (1990) foram utilizadas para complementar o diagrama a partir da deformação em questão. A expressão do FIB (1999) para a deformação correspondente à tensão de pico também foi utilizada no modelo de Popovics (1973).

Na Tabela 5.1 e na Tabela 5.2, apresentam-se os valores dos índices de ductilidade para os concretos com resistência entre 20MPa e $80 \mathrm{MPa}$, enquanto na Figura 5.1 e na Figura 5.2, as curvas referentes aos índices de ductilidade vs. a resistência do concreto. Uma análise de regressão polinomial não-linear foi realizada, objetivando-se obter uma equação que representasse o comportamento dos dados (ver Figura 5.1 e Figura 5.2). Em todos os casos, foram obtidas equações lineares com coeficientes de correlações $\left(r^{2}\right)$ superiores a $88 \%$. Observase que com o aumento da resistência ocorre uma redução nos valores dos índices de ductilidade do concreto, que essa redução se comporta linearmente e que, como esperado, para a mesma resistência os valores dos índices diferem entre os modelos. Nota-se que, se aumentada a resistência do concreto de $20 \mathrm{MPa}$ para $80 \mathrm{MPa}$, os índices de ductilidade reduzem-se da ordem de $50 \%$.

Tabela 5.1 - Valores dos índices de ductilidade para os concretos com resistências de 20MPa à 80MPa de acordo com o modelo do FIB-CEB

\begin{tabular}{cccccccc}
\hline Índices & \multicolumn{7}{c}{ Resistência $(\mathrm{MPa})$} \\
\cline { 2 - 8 } & 20 & 30 & 40 & 50 & 60 & 70 & 80 \\
\hline$\frac{\varepsilon_{0.5 f c}}{\mathcal{E}_{c o}}$ & 2,107 & 1,826 & 1,670 & 1,569 & 1,499 & 1,448 & 1,409 \\
$I D_{P o ́ s}$ & 1,174 & 0,943 & 0,792 & 0,686 & 0,609 & 0,551 & 0,506 \\
\hline
\end{tabular}

Tabela 5.2 - Valores dos índices de ductilidade para os concretos com resistências de 20MPa à 80MPa de acordo com o modelo de Popovics

\begin{tabular}{cccccccc}
\hline Índices & \multicolumn{7}{c}{ Resistência $(\mathrm{MPa})$} \\
\cline { 2 - 8 } & 20 & 30 & 40 & 50 & 60 & 70 & 80 \\
\hline $\boldsymbol{\varepsilon}_{0.5 f c}$ & 2,412 & 2,094 & 1,915 & 1,801 & 1,722 & 1,666 & 1,624 \\
$\mathcal{E}_{c o}$ & 1,329 & 1,169 & 1,041 & 0,940 & 0,860 & 0,798 & 0,749 \\
\hline$D_{P o s}$ & 1090
\end{tabular}




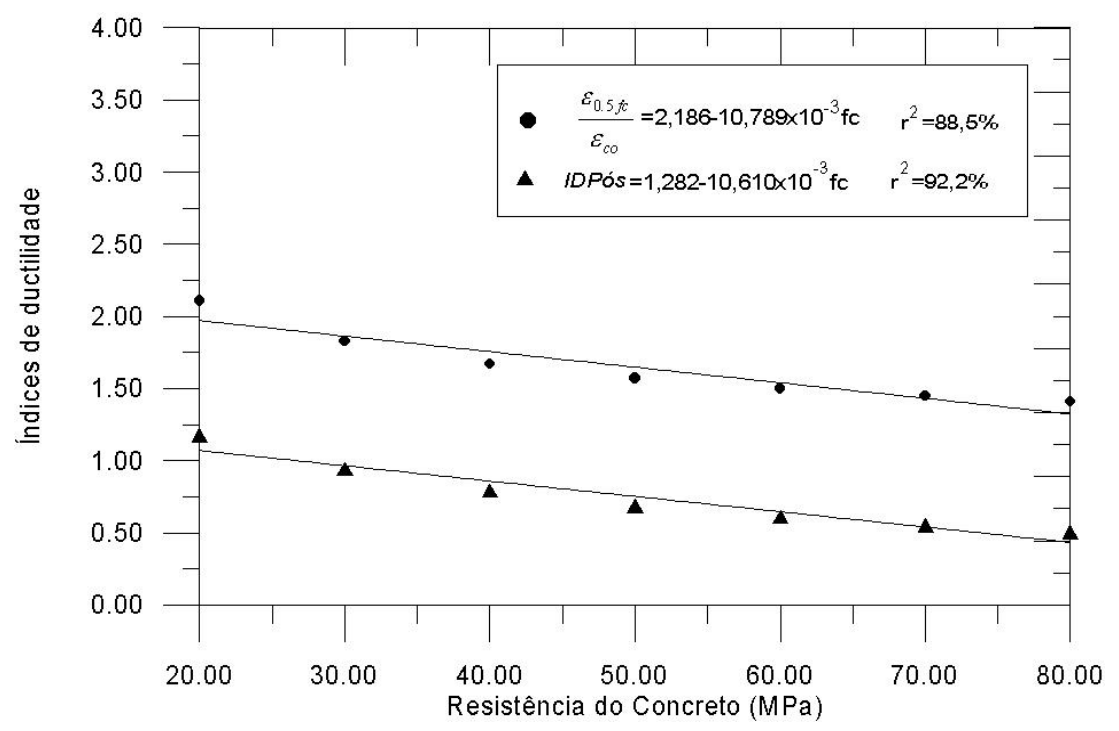

Figura 5.1 - Curvas dos índices de ductilidade vs. resistência do concreto, FIB-CEB

Devido à diferença dos índices de ductilidade entre os modelos do FIB (1999) e de Popovics (1973), foi adotado, como índice mínimo aceitável de ductilidade para os concretos de alta resistência, a média entre os índices de ductilidade dos dois modelos em questão, majorada de 10\%, para a resistência estabelecida no item 5.1.1 deste capítulo (40MPa). Assim, os valores ideais para os índices $\varepsilon_{0.5 f d} / \varepsilon_{c o}$ e $I D_{P o ́ s}$ são 1,972 e 1,008 , respectivamente. Observa-se que estes valores concordam com os obtidos por Camara et alii (2003).

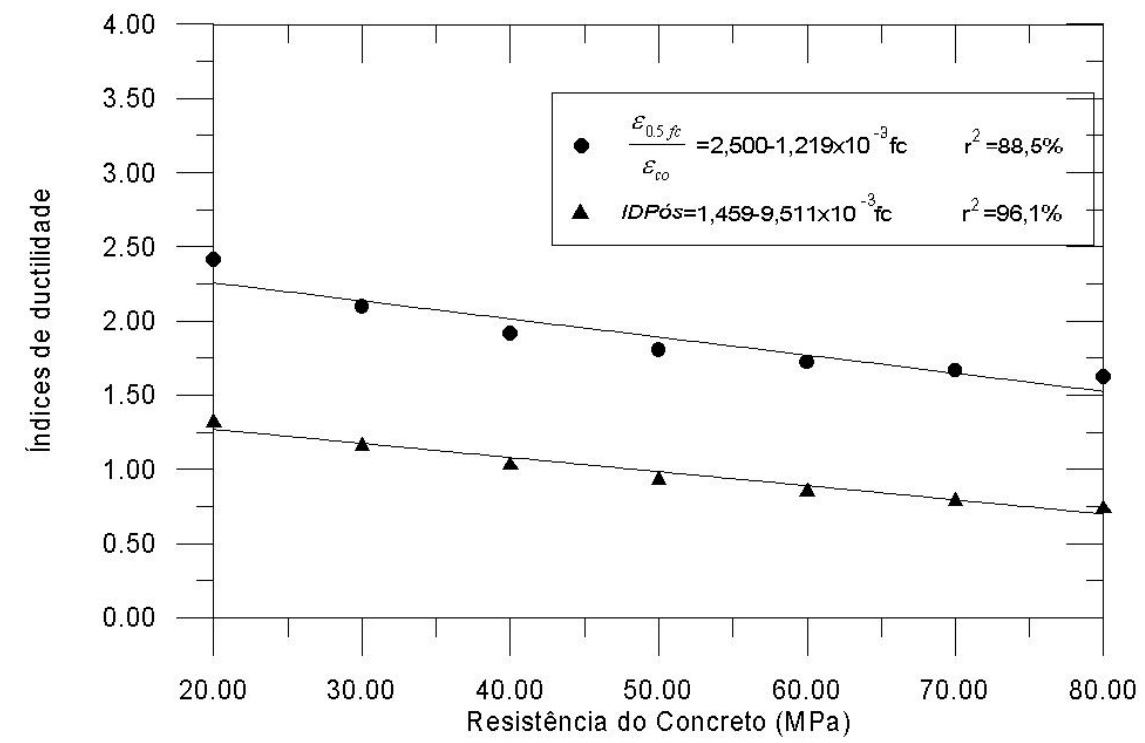

Figura 5.2 - Curvas dos índices de ductilidade vs. resistência do concreto, Popovics 


\subsubsection{Variação da ductilidade com a resistência do concreto, a taxa de armadura transversal, a taxa de armadura longitudinal e geometria da seção transversal}

O estudo paramétrico dos índices de ductilidade do CAR confinado foi dividido em duas partes: a primeira, na qual foram analisadas as influências da resistência do concreto, da taxa de armadura longitudinal e da taxa de armadura transversal; e a segunda, na qual foram avaliadas as influências da geometria da seção transversal, da taxa da armadura longitudinal e transversal.

Para a primeira fase, foram idealizadas 27 condições de concretos confinados e, em seguida, essas condições foram estudadas numericamente, aplicando-se o modelo de Cusson e Paultre (1995). As condições idealizadas apresentavam concretos com resistências de 60MPa, 80MPa e $100 \mathrm{MPa}$, e taxas de armadura longitudinal de $1,227 \%, 2,454 \%$ e $3,681 \%$. As armaduras transversais foram compostas por estribos de dois ramos, com diâmetro de 6,3mm, dispostos a cada $15 \mathrm{~cm}, 10 \mathrm{~cm}$ e $5 \mathrm{~cm}$. As seções transversais foram consideradas quadradas, com dimensões de $20 \mathrm{~cm}$ x $20 \mathrm{~cm}$ e a presença de cobrimento foi desprezada. $\mathrm{Na}$ Figura 5.3 são apresentados os detalhes das armaduras de confinamento.

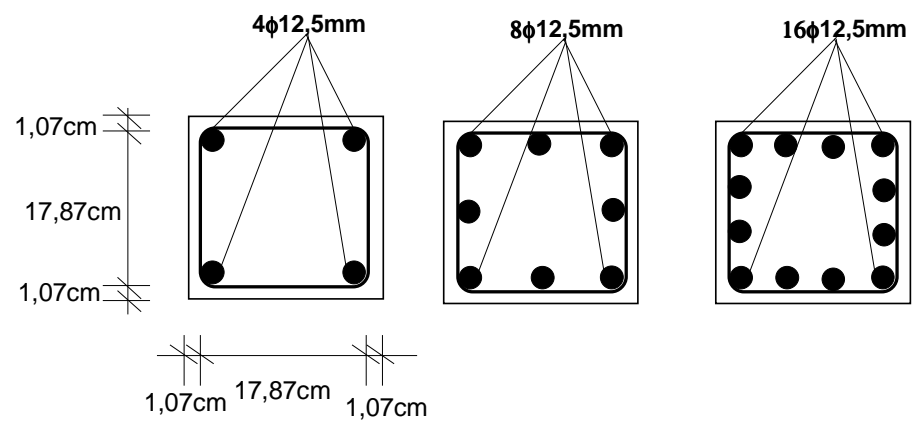

Figura 5.3 - Disposição da armadura de confinamento do CAR para a fase 1

Na Figura 5.4, na Figura 5.5 e na Figura 5.6, são apresentadas as curvas tensão vs. deformação do concreto, para as diversas combinações de armadura e resistências dos concretos, e, na Tabela 5.3 e na Tabela 5.4, os valores dos índices de ductilidade para os concretos confinados. Como esperado, observa-se que os aumentos das taxas de armadura transversal e longitudinal elevam os índices de 
ductilidade do concreto, mesmo quando da elevação da resistência deste. Observase também que, para certas combinações de armadura longitudinal e transversal, é possível atingir os índices de ductilidade dos concretos de resistências usuais.

Para quantificar a influência de cada variável sobre os índices de ductilidade, foi realizada uma análise de variância. Os graus de significância dos efeitos de cada variável foram testados para graus de confiabilidade de $90 \%$ e $95 \%$, usando o F teste. Nessa análise, a variável taxa de armadura longitudinal foi denominada de fator $X 1$, a resistência do concreto, de fator $X 2$, e a taxa de armadura transversal, de fator X3. A taxa de armadura transversal foi definida segundo a Eq.(5.1):

$$
\rho_{t}=\frac{\left(A_{s t x}+A_{s t y}\right)}{s \cdot\left(c_{x}+c_{y}\right)} \cdot 100 \%
$$

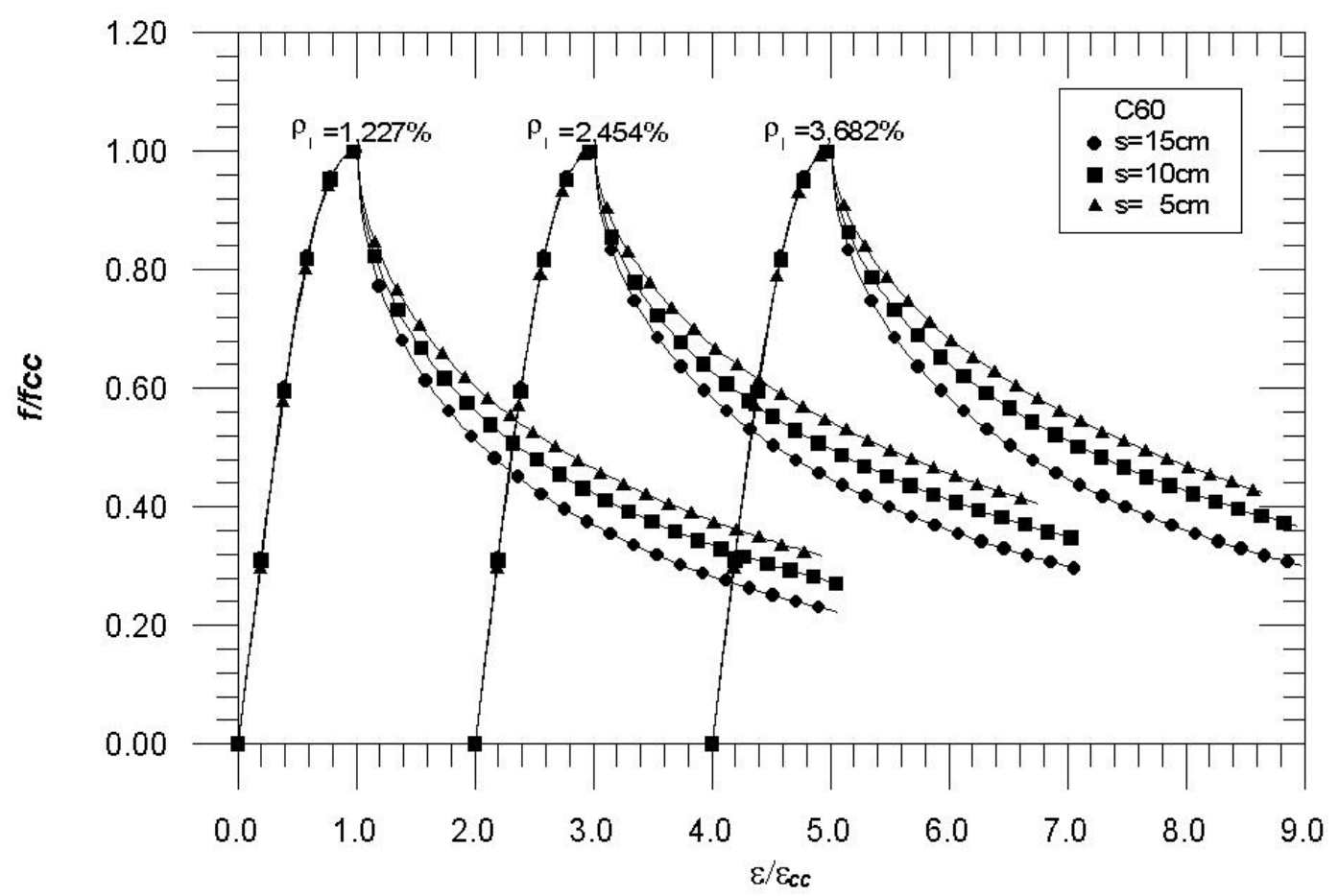

Figura 5.4 - Curvas paramétricas tensão vs. deformação do concreto para resistência C60 


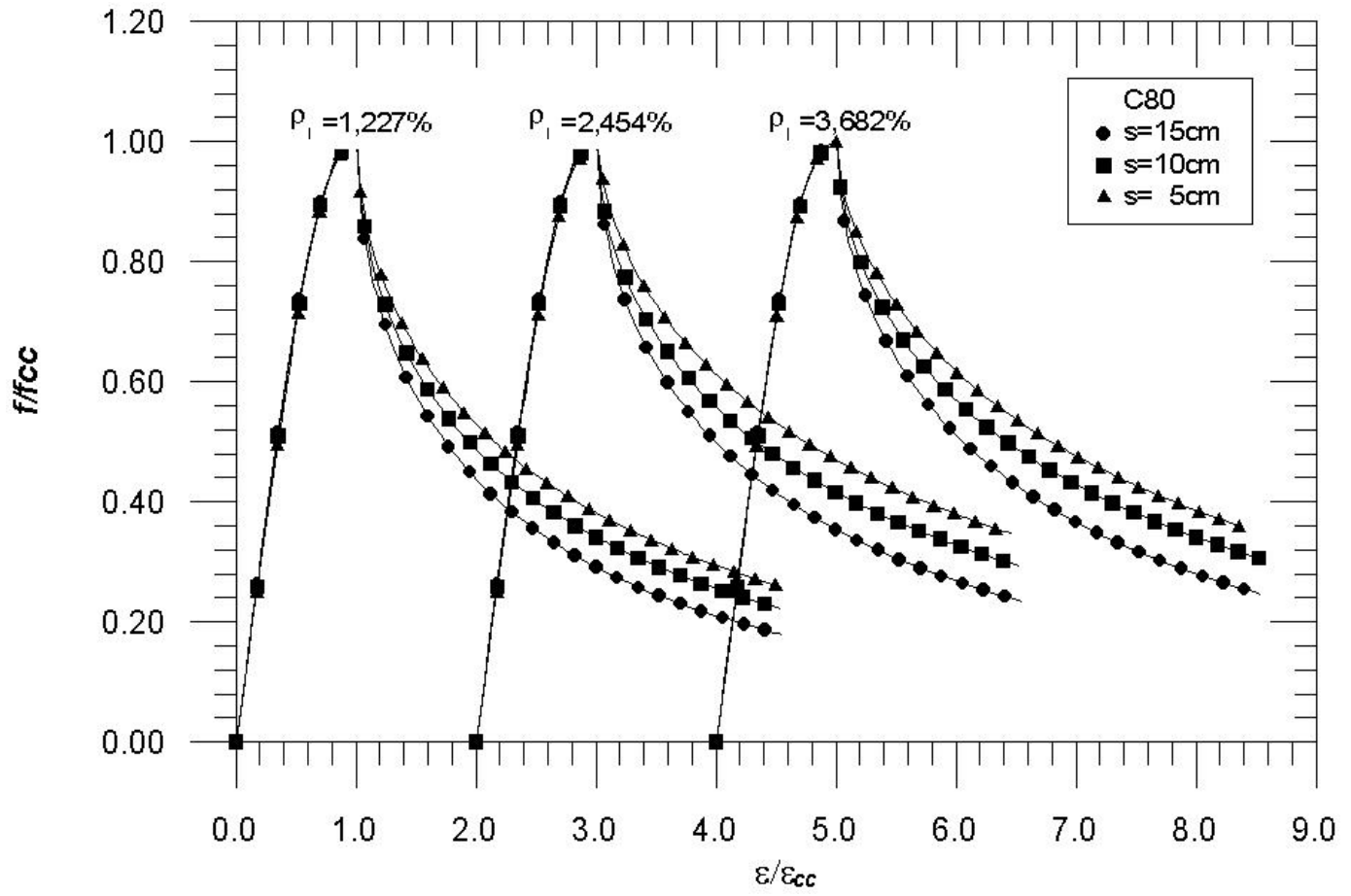

Figura 5.5 - Curvas paramétricas tensão vs. deformação do concreto para resistência $C 80$

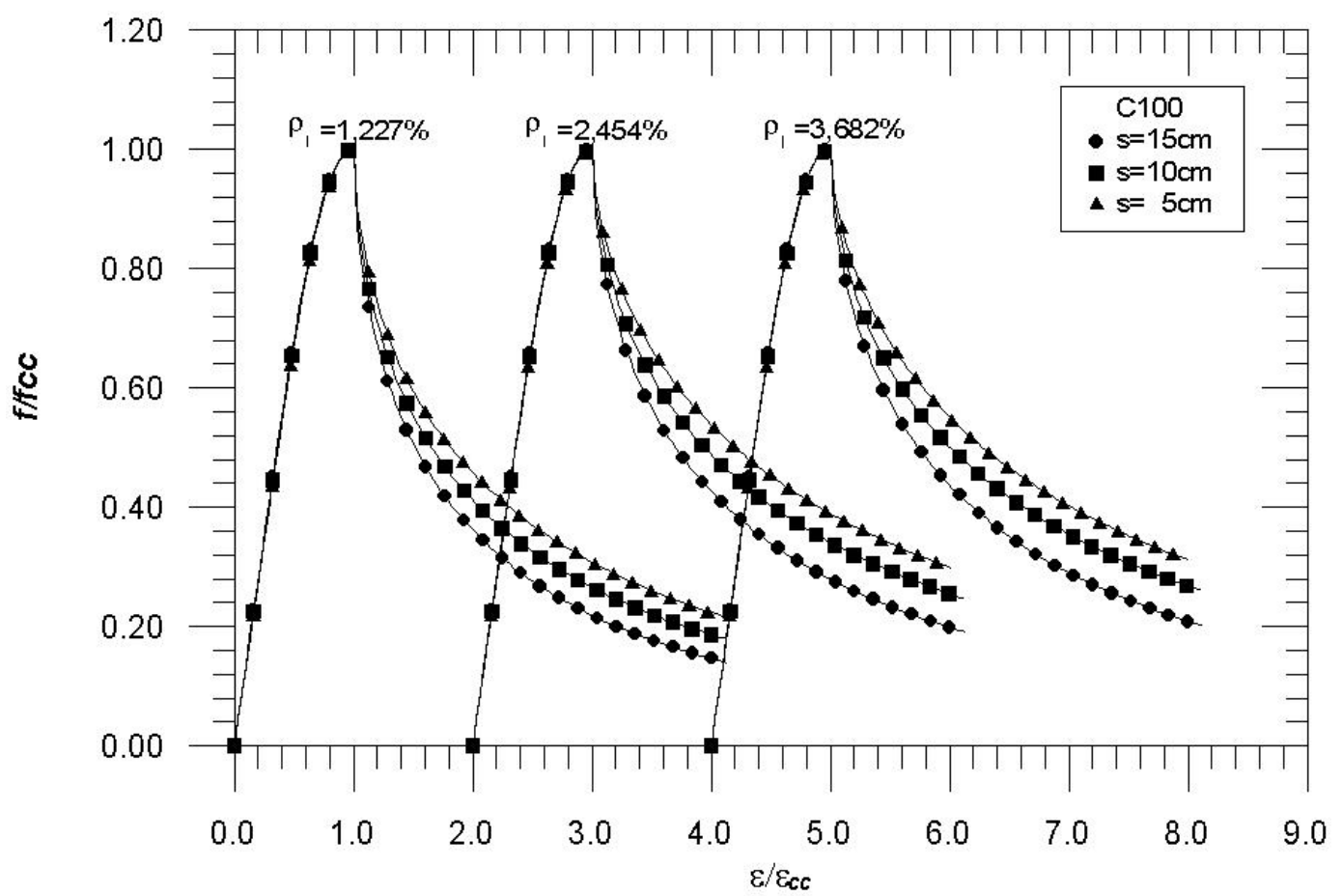

Figura 5.6 - Curvas paramétricas tensão vs. deformação do concreto para resistência $C 100$ 
Tabela 5.3 - Valores dos indices de ductilidade $\boldsymbol{\varepsilon}_{0.5 f c d} / \boldsymbol{\varepsilon}_{c c}:$ Fase 1

\begin{tabular}{|c|c|c|c|c|c|c|c|c|c|}
\hline \multirow{4}{*}{$X_{l}(\%)$} & \multicolumn{9}{|c|}{$X_{2}(M P a)$} \\
\hline & \multicolumn{3}{|c|}{60} & \multicolumn{3}{|c|}{80} & \multicolumn{3}{|c|}{100} \\
\hline & \multicolumn{9}{|c|}{$X_{3}(\%)$} \\
\hline & 0,623 & 0,312 & 0,208 & 0,623 & 0,312 & 0,208 & 0,623 & 0,312 & 0,208 \\
\hline 1,227 & 2,694 & 2,369 & 2,074 & 2,156 & 1,936 & 1,741 & 1,815 & 1,655 & 1,516 \\
\hline 2,454 & 3,466 & 2,979 & 2,465 & 2,688 & 2,338 & 1,998 & 2,102 & 1,942 & 1,699 \\
\hline 3,682 & 3,615 & 3,106 & 2,548 & 2,794 & 2,423 & 2,053 & 2,282 & 2,003 & 1,738 \\
\hline
\end{tabular}

Tabela 5.4 - Valores dos índices de ductilidade ID $_{\text {Pós: }}$ Fase 1

\begin{tabular}{|c|c|c|c|c|c|c|c|c|c|}
\hline \multirow{4}{*}{$X_{I}(\%)$} & \multicolumn{9}{|c|}{$X_{2}(M P a)$} \\
\hline & \multicolumn{3}{|c|}{60} & \multicolumn{3}{|c|}{80} & \multicolumn{3}{|c|}{100} \\
\hline & \multicolumn{9}{|c|}{$X_{3}(\%)$} \\
\hline & 0,623 & 0,312 & 0,208 & 0,623 & 0,312 & 0,208 & 0,623 & 0,312 & 0,208 \\
\hline 1,227 & 1,263 & 1,187 & 1,101 & 1,129 & 1,050 & 0,963 & 0,998 & 0,915 & 0,824 \\
\hline 2,454 & 1,392 & 1,310 & 1,210 & 1,266 & 1,180 & 1,074 & 1,145 & 1,053 & 0,940 \\
\hline 3,682 & 1,412 & 1,330 & 1,228 & 1,288 & 1,201 & 1,094 & 1,169 & 1,076 & 0,961 \\
\hline
\end{tabular}

na qual $A_{s t x}$ e $A_{s t y}$ são as áreas da seção transversal das armaduras transversais perpendiculares aos eixos $x$ e $y$, respectivamente; $s$ é o espaçamento da armadura transversal; e $c_{x}$ e $c_{y}$ são as larguras do núcleo do pilar nas direções $x$ e $y$, respectivamente.

$\mathrm{Na}$ Tabela 5.5 e na Tabela 5.6, são apresentados os resultados da análise. Com base nestes resultados, pode-se observar que, para os dois índices de ductilidade, o fator de influência mais importante é a resistência do concreto, seguido pela taxa de armadura transversal e pela taxa de armadura longitudinal. Esses fatores são significantes em um grau de confiabilidade de $99 \%$. Um fato interessante observado é que os graus de influência das taxas de armadura longitudinal e transversal são da mesma ordem de grandeza. Observa-se ainda que todos os acoplamentos também apresentam significância em um grau de confiabilidade de 99\%. Contudo, os graus de influência dos acoplamentos são extremamente inferiores aos graus dos fatores principais, o que significa que estes podem ser desconsiderados na análise de regressão. 
Tabela 5.5 - Análise de variância para os valores de $\boldsymbol{\varepsilon}_{0.5 f c c} / \boldsymbol{\varepsilon}_{c c}$ : Fase 1

\begin{tabular}{|c|c|c|c|c|c|c|}
\hline \multirow{2}{*}{$\begin{array}{l}\text { Variável } \\
\text { Fatores principais }\end{array}$} & \multirow[t]{2}{*}{$\begin{array}{l}\text { Soma dos } \\
\text { quadrados }\end{array}$} & \multirow[t]{2}{*}{$\begin{array}{l}\text { Graus de } \\
\text { liberdade }\end{array}$} & \multirow[t]{2}{*}{$\begin{array}{l}\text { Média dos } \\
\text { quadrados }\end{array}$} & \multirow[t]{2}{*}{ Fator $\left(F_{o}\right)$} & \multicolumn{2}{|c|}{$\begin{array}{c}\text { Mínimo fator de } \\
\text { significância requerido } \\
\left(F_{0.05, n, 26}\right) \text { e }\left(F_{0.01, n, 26}\right)\end{array}$} \\
\hline & & & & & & \\
\hline$X_{1}$ & 1,328 & 2 & 0,664 & 458,481 & 3,37 & 5,53 \\
\hline$X_{2}$ & 4,135 & 2 & 2,068 & 1428,213 & 3,37 & 5,53 \\
\hline$X_{3}$ & 1,856 & 2 & 0,928 & 641,007 & 3,37 & 5,53 \\
\hline \multicolumn{7}{|l|}{ Interações } \\
\hline$X_{1} \times X_{2}$ & 0,127 & 4 & 0,032 & 21,882 & 2,74 & 4,14 \\
\hline$X_{1} \times X_{3}$ & 0,094 & 4 & 0,024 & 16,273 & 2,74 & 4,14 \\
\hline$X_{2} \times X_{3}$ & 0,175 & 4 & 0,044 & 30,247 & 2,74 & 4,14 \\
\hline Erro & 0,012 & 8 & 0,001448 & -- & & \\
\hline Total & 7,727 & 26 & -- & -- & & \\
\hline
\end{tabular}

Tabela 5.6 - Análise de variância para os valores de ID $_{\text {Pós: }}$ Fase 1

\begin{tabular}{|c|c|c|c|c|c|c|}
\hline \multirow{2}{*}{$\begin{array}{l}\text { Variável } \\
\text { Fatores principais }\end{array}$} & \multirow[t]{2}{*}{$\begin{array}{l}\text { Soma dos } \\
\text { quadrados }\end{array}$} & \multirow[t]{2}{*}{$\begin{array}{l}\text { Graus de } \\
\text { liberdade }\end{array}$} & \multirow[t]{2}{*}{$\begin{array}{l}\text { Média dos } \\
\text { quadrados }\end{array}$} & \multirow[t]{2}{*}{ Fator $\left(F_{o}\right)$} & \multicolumn{2}{|c|}{$\begin{array}{c}\text { Mínimo fator de } \\
\text { significância requerido } \\
\left(F_{0.05, n, 26}\right) \text { e }\left(F_{0.01, n, 26}\right)\end{array}$} \\
\hline & & & & & & \\
\hline$X_{I}$ & 0,115 & 2 & 0,057 & 19506,679 & 3,37 & 5,53 \\
\hline$X_{2}$ & 0,307 & 2 & 0,154 & 52189,584 & 3,37 & 5,53 \\
\hline$X_{3}$ & 0,155 & 2 & 0,077 & 26283,886 & 3,37 & 5,53 \\
\hline \multicolumn{7}{|l|}{ Interações } \\
\hline$X_{1} \times X_{2}$ & 0,000235 & 4 & 0,000059 & 19,925 & 2,74 & 4,14 \\
\hline$X_{1} \times X_{3}$ & 0,000768 & 4 & 0,000192 & 65,245 & 2,74 & 4,14 \\
\hline$X_{2} \times X_{3}$ & 0,000294 & 4 & 0,000073 & 24,943 & 2,74 & 4,14 \\
\hline Erro & 0,000024 & 8 & 0,0000029 & -- & & \\
\hline Total & 0,578 & 26 & -- & -- & & \\
\hline
\end{tabular}

Com o objetivo de obter equações que correlacionem os índices de ductilidade com as variáveis estudadas, foram realizadas análises de regressão múltipla não-linear, com os dados apresentados na Tabela 5.5 e na Tabela 5.6. As equações obtidas apresentaram coeficiente de correlação $\left(r^{2}\right)$ de $97,4 \%$ e $98,5 \%$, e são expressas pelas Eq.(5.2) e Eq.(5.3), respectivamente:

$$
\begin{aligned}
& \varepsilon_{0.5 \cdot f c c} / \varepsilon_{c c}=3,151-0,024 \cdot f_{c}+1,427 \cdot \rho_{t}+0,208 \cdot \rho_{l} \\
& I D_{\text {Pos }}=1,359-0,007 \cdot f_{c}+0,406 \cdot \rho_{t}+0,060 \cdot \rho_{l}
\end{aligned}
$$


Analisando as equações Eq.(5.2) e Eq.(5.3), observa-se que todos os índices variam linearmente com a resistência do concreto, com a taxa de armadura longitudinal e a taxa de armadura transversal. Esse comportamento também foi observado por Quintana (2001).

Como já discutido, a ductilidade ótima (para a realidade sísmica brasileira) dos CAR pode ser estabelecida como sendo àquela que apresenta o mesmo índice do CRU com 40MPa. Desse modo, utilizando as equações Eq.(5.2) e Eq.(5.3) e os índices do CRU calculados no item 4.3.1, deste trabalho, podem-se calcular taxas de armadura transversal ideais para cada resistência do concreto e para cada taxa de armadura longitudinal. Assim, para um pilar com seção transversal quadrada de $20 \mathrm{~cm} \times 20 \mathrm{~cm}$, estribos de dois ramos, resistência do concreto de 70MPa e taxa de armadura longitudinal de 1\%, obtém-se que a taxas de armadura transversal ideais, segundo as Eq.(5.2) e Eq.(5.3), são 0,205\% e 0,195\%, o que equivale a estribos de $5,0 \mathrm{~mm}$ de diâmetro espaçados a cada $10,65 \mathrm{~cm}$ e $11,20 \mathrm{~cm}$, respectivamente. $\mathrm{Na}$ Figura 5.7, apresentam-se as curvas tensão vs. deformação paramétricas do concreto para o pilar descrito acima e com as duas taxas de armadura transversal. Em adição, apresenta-se a curva do mesmo pilar, porem com resistência de 40MPa e obtida por meio do mesmo modelo de Cusson e Paultre (1995). Observase que as avaliações da ductilidade dos pilares pelos dois índices de ductilidade utilizados apresentaram o mesmo resultado.

Para a segunda fase do estudo, também foram idealizadas 27 condições de concretos confinados e estudadas, numericamente, através do modelo de Cusson e Paultre (1995). Os concretos apresentavam resistências de $80 \mathrm{MPa}$ e foram confinados por armaduras transversais compostas por estribos com diâmetro de $6,3 \mathrm{~mm}$, dispostos a cada $15 \mathrm{~cm}, 10 \mathrm{~cm}$ e $5 \mathrm{~cm}$. As taxas de armadura longitudinal foram de $1,227 \%, 2,454 \%$ e $3,681 \%$. As seções transversais estudadas eram retangulares, com relações entre as dimensões largura/altura $(b / h)$ de $1,1,5$ e 2; a presença de cobrimento foi desprezada. A mesma taxa de armadura transversal, calculada segundo a Eq.(5.1), foi garantida para as três seções transversais. Na Figura 5.8 são apresentados os detalhes das seções transversais estudadas. 


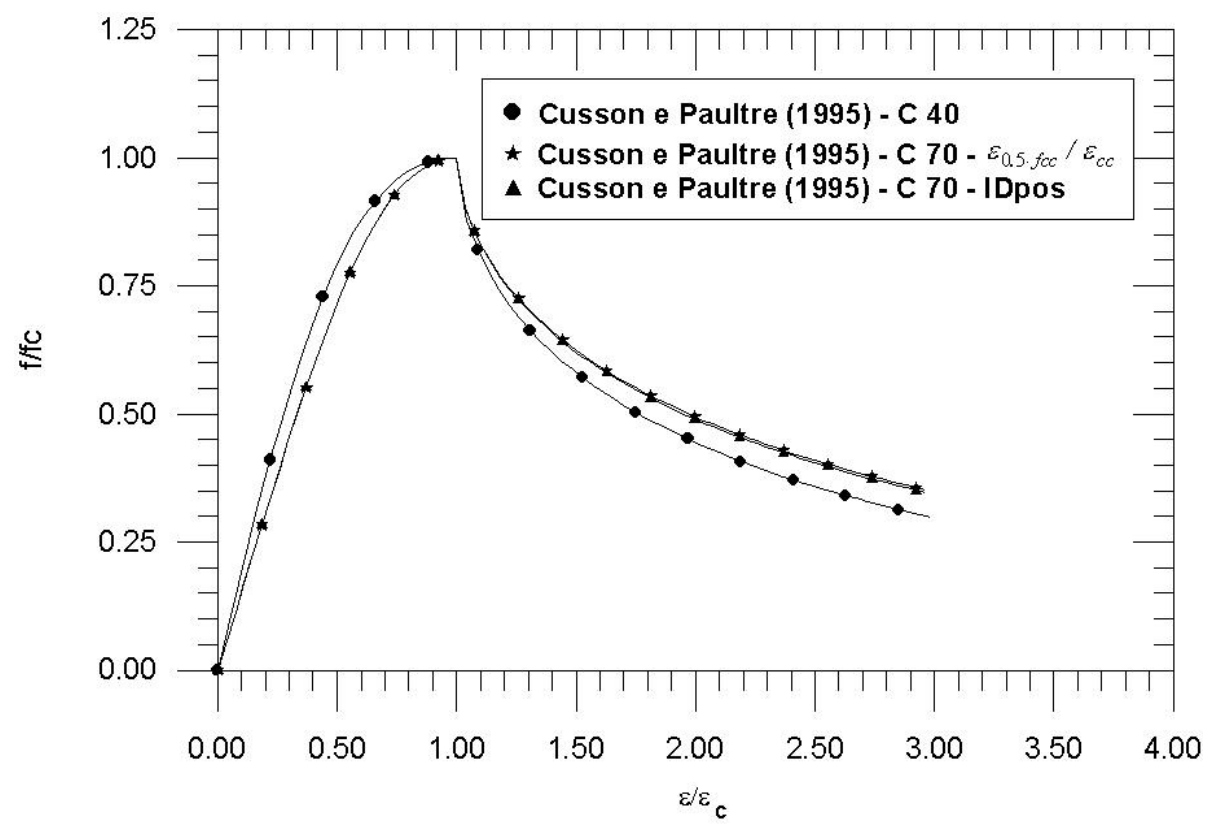

Figura 5.7 - Curvas paramétricas tensão vs. deformação do concreto C40 e C70 fornecidas para resistência C100

Na Figura 5.9, na Figura 5.10 e na Figura 5.11 são apresentadas as curvas tensão vs. deformação do concreto para as diversas combinações de armadura de confinamento e seções transversais, e, na Tabela 5.7 e na Tabela 5.8, os valores dos índices de ductilidade para os concretos confinados. Observa-se que, com os aumentos das taxas de armadura transversal e longitudinal, os índices de ductilidade do concreto se elevam. Verifica-se também que, com o aumento da relação $b / h$ e mantendo-se a mesma taxa de armadura longitudinal e transversal, os índices de ductilidade aumentam. Lima Jr. e Giongo (2000) concluíram que, quando a relação $b / h$ era incrementada, a configuração geométrica da armadura transversal mantida e apenas o diâmetro do estribo elevado, para garantir a mesma taxa de armadura transversal, a ductilidade do concreto diminuía. Esse fato ocorre uma vez que, apesar de garantida a mesma taxa de armadura transversal, o efeito do arqueamento do ramo do estribo de maior dimensão não é eliminado. Desse modo, observa-se que adições de ramos extras de estribo na direção perpendicular à maior dimensão da seção transversal são fundamentais. 


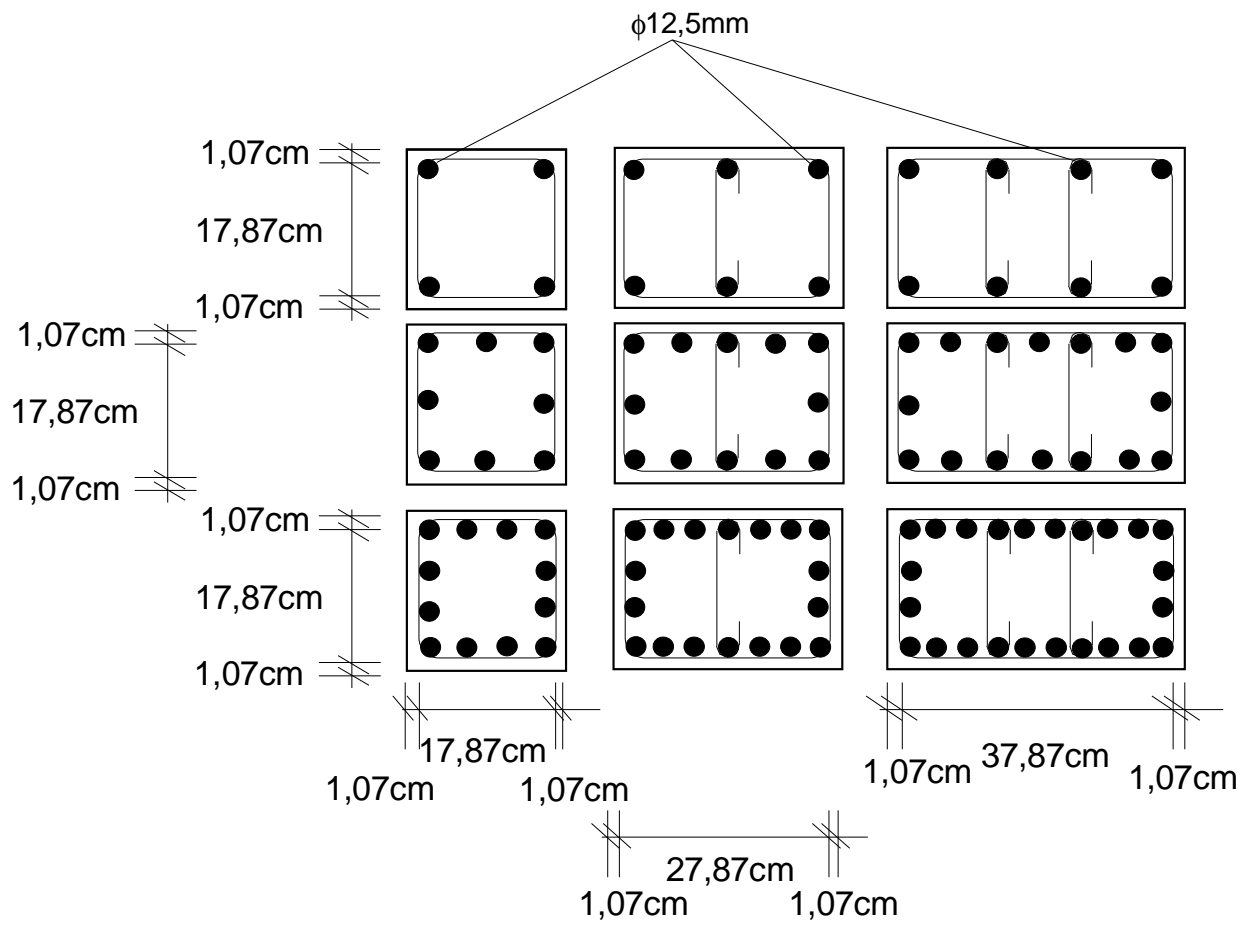

Figura 5.8 - Disposição da armadura de confinamento do CAR para fase 2

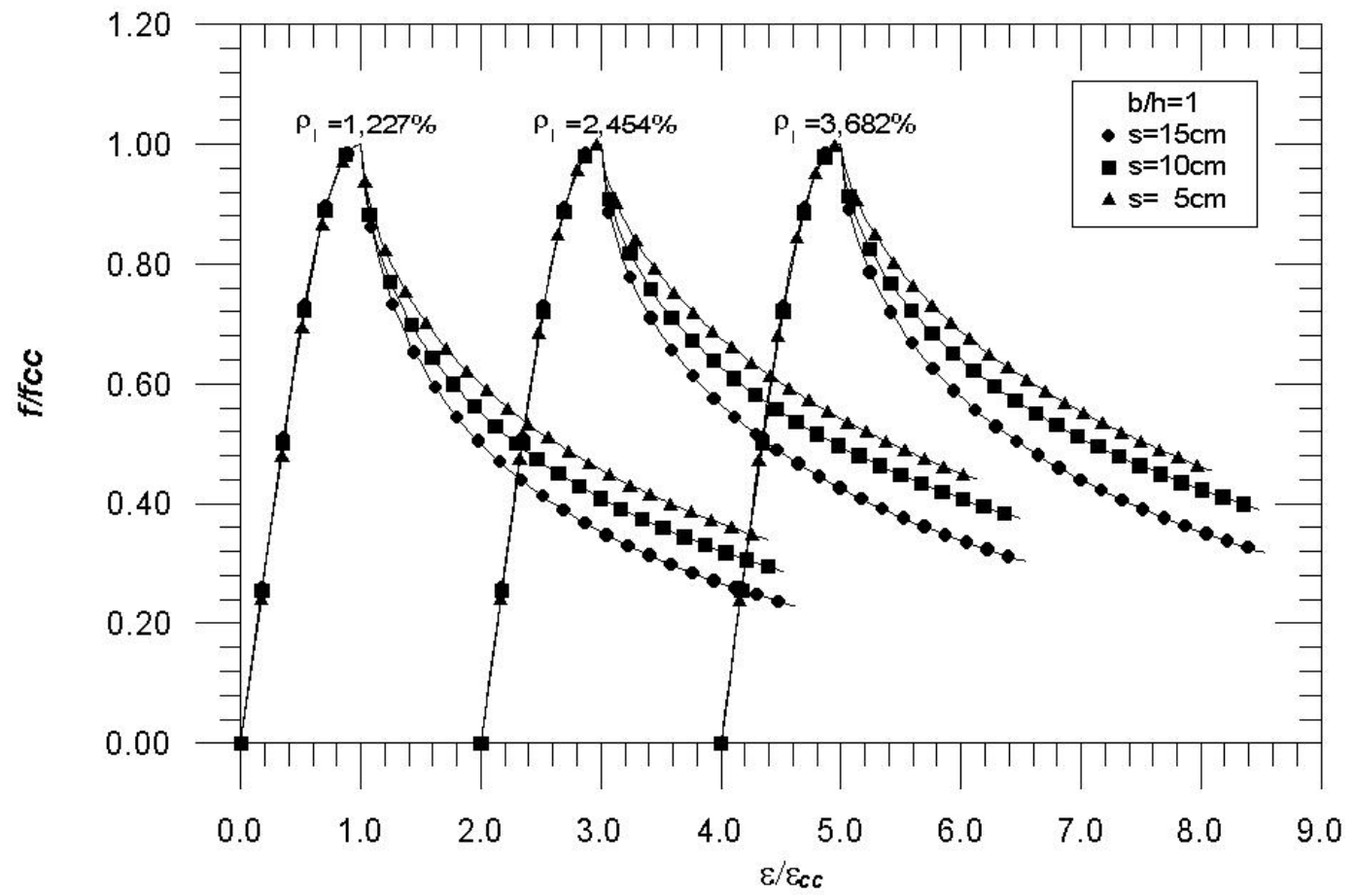

Figura 5.9 - Curvas paramétricas tensão vs. deformação do concreto para seção transversal com $b / h=1,0$ 


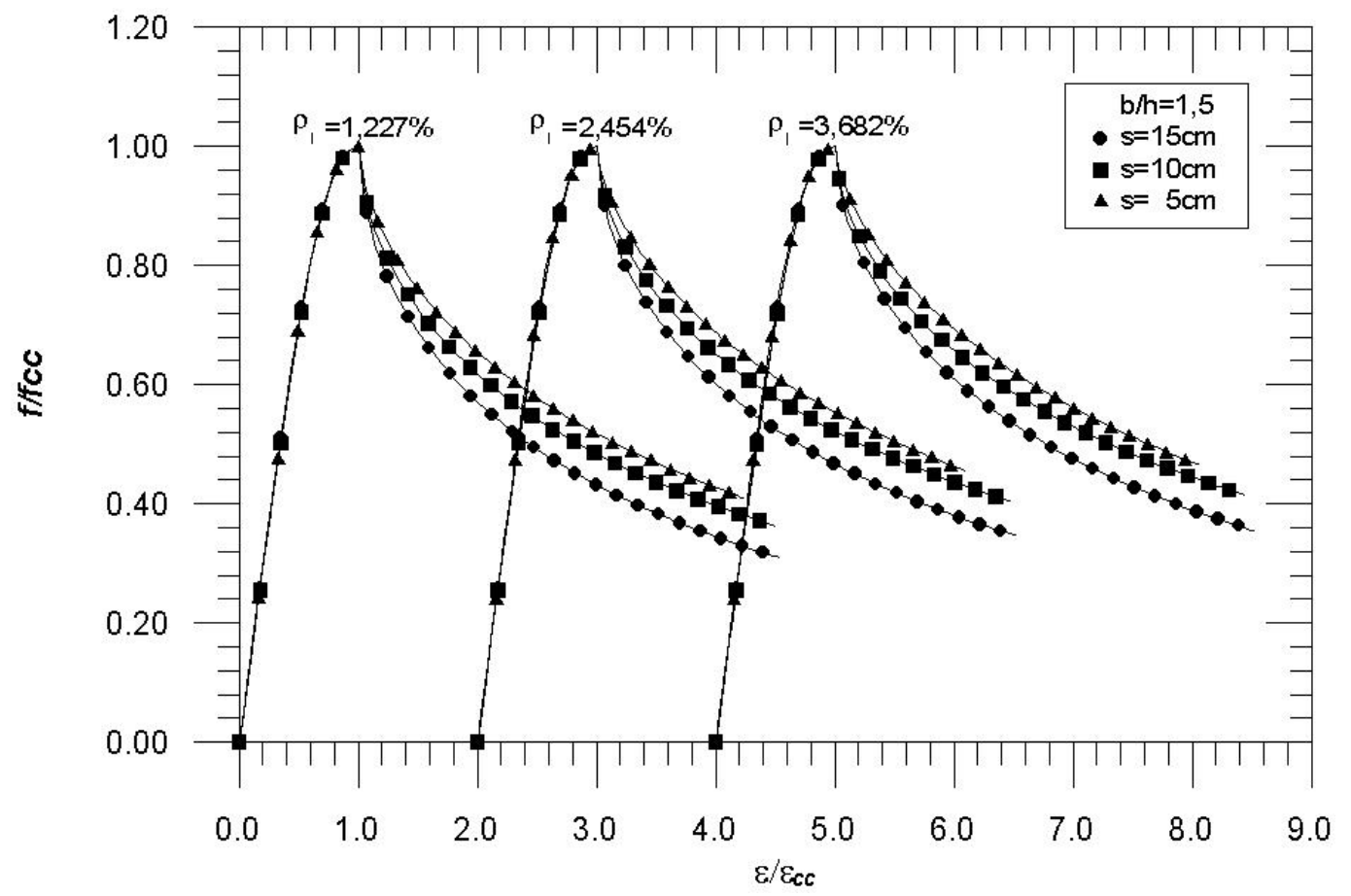

Figura 5.10 - Curvas paramétricas tensão vs. deformação do concreto para seção transversal com $b / h=1,5$

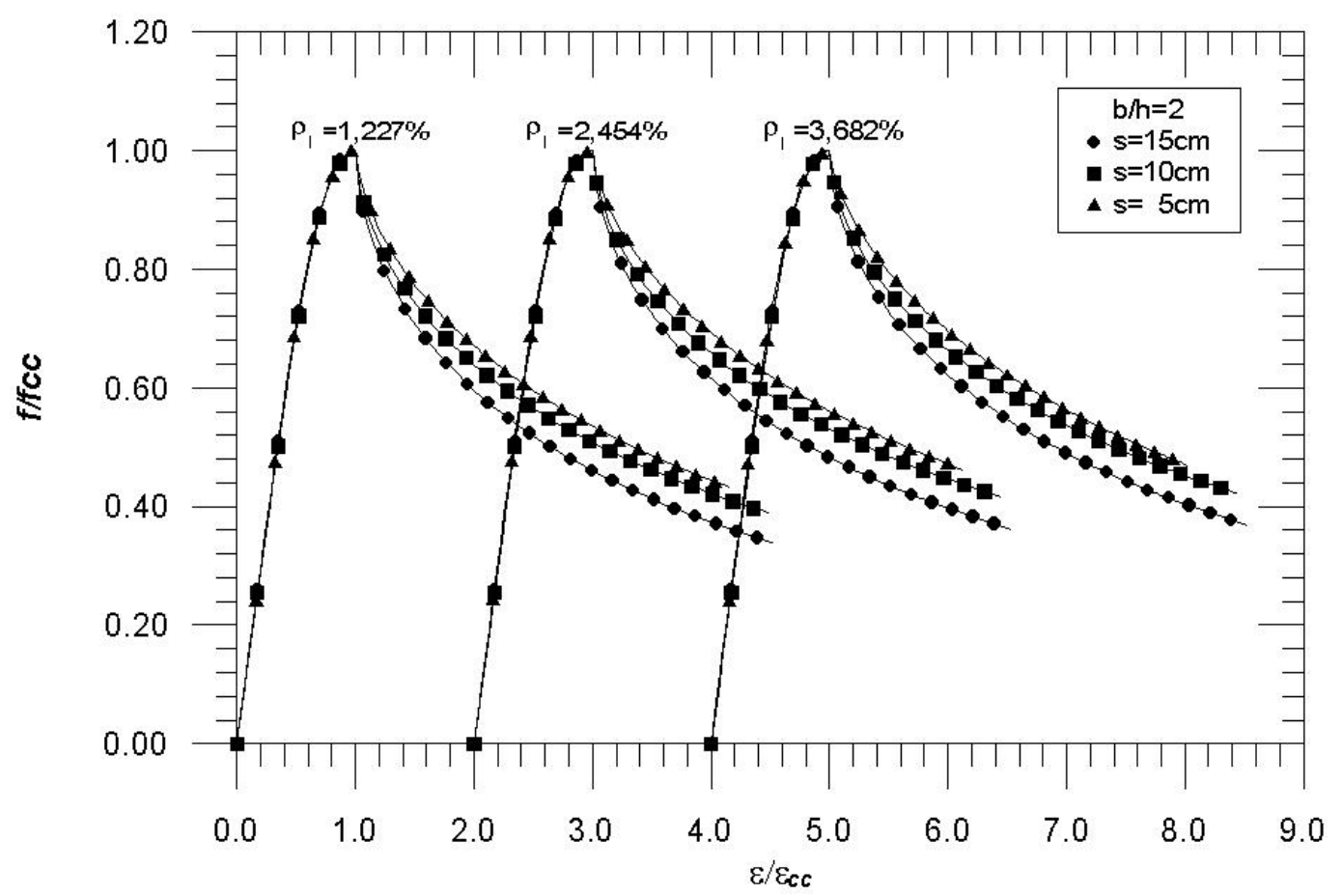

Figura 5.11 - Curvas paramétricas tensão vs. deformação do concreto para seção transversal com $b / h=2,0$ 
Tabela 5.7 - Valores dos índices de ductilidade $\boldsymbol{\varepsilon}_{0.5 f c d} \mathcal{\varepsilon}_{c c}:$ Fase 2

\begin{tabular}{|c|c|c|c|c|c|c|c|c|c|}
\hline \multirow{4}{*}{$X_{l}(\%)$} & \multicolumn{9}{|c|}{$X_{2}$} \\
\hline & \multicolumn{3}{|c|}{1,0} & \multicolumn{3}{|c|}{1,5} & \multicolumn{3}{|c|}{2,0} \\
\hline & \multicolumn{9}{|c|}{$X_{3}(\%)$} \\
\hline & 0,623 & 0,312 & 0,208 & 0,623 & 0,312 & 0,208 & 0,623 & 0,312 & 0,208 \\
\hline 1,227 & 2,626 & 2,291 & 1,969 & 3,178 & 2,850 & 2,434 & 3,354 & 3,074 & 2,645 \\
\hline 2,454 & 3,409 & 2,954 & 2,400 & 3,548 & 3,221 & 2,705 & 3,639 & 3,327 & 2,838 \\
\hline 3,682 & 3,550 & 3,093 & 2,491 & 3,628 & 3,309 & 2,770 & 3,648 & 3,395 & 2,890 \\
\hline
\end{tabular}

Tabela 5.8 - Valores dos índices de ductilidade $\boldsymbol{I D}_{\text {Pós: }}$ Fase 2

\begin{tabular}{|c|c|c|c|c|c|c|c|c|c|}
\hline \multirow{4}{*}{$X_{l}(\%)$} & \multicolumn{9}{|c|}{$X_{2}$} \\
\hline & \multicolumn{3}{|c|}{1,0} & & \multicolumn{3}{|c|}{2,0} \\
\hline & & & & & $X_{3}(\%)$ & & & & \\
\hline & 0,623 & 0,312 & 0,208 & 0,623 & 0,312 & 0,208 & 0,623 & 0,312 & 0,208 \\
\hline 1,227 & 1,253 & 1,167 & 1,063 & 1,358 & 1,290 & 1,203 & 1,387 & 1,327 & 1,249 \\
\hline 2,454 & 1,395 & 1,308 & 1,195 & 1,417 & 1,349 & 1,261 & 1,425 & 1,364 & 1,286 \\
\hline 3,682 & 1,417 & 1,330 & 1,216 & 1,429 & 1,362 & 1,273 & 1,432 & 1,373 & 1,295 \\
\hline
\end{tabular}

Novamente foi realizada uma análise de variância para quantificar a influência de cada variável sobre os índices de ductilidade. Os graus de significância do efeito de cada variável foram testados para graus de confiabilidade de $90 \%$ e $95 \%$, usando o F teste. Nessa análise, a variável taxa de armadura longitudinal foi denominada de fator $X 1$, a relação $b / h$, de fator $X 2$, e a taxa de armadura transversal, de fator $X 3$.

Na Tabela 5.9 e na Tabela 5.10 são apresentados os resultados da análise. Com base nestes resultados, pode-se observar que, para os dois índices de ductilidade, o fator de influência mais importante é a taxa de armadura transversal, seguida pela taxa de armadura longitudinal e pela relação $b / h$. Esses fatores são significantes em um grau de confiabilidade de $99 \%$. Para o índice $\varepsilon_{0.5 f_{c}} / \mathcal{E}_{c o}$, apenas os acoplamentos $X 1 x X 2$ e $X 1 x X 3$ apresentam significância em um grau de confiabilidade de 99\%. Contudo, os graus de influência desses são bem menores que os dos fatores principais. Para o índice $I D_{P o ́ s}$, apenas os acoplamentos $X 1 x X 2 \mathrm{e}$ $X 2 x X 3$ apresentam significância em um grau de confiabilidade de $99 \%$. Todavia, seus valores também são bem inferiores aos dos fatores principais. Baseado no exposto, podem-se desprezar os efeitos dos acoplamentos. 
Tabela 5.9 - Análise de variância para os valores de $\boldsymbol{\varepsilon}_{0.5 f c c} / \boldsymbol{\varepsilon}_{c c}:$ Fase 2

\begin{tabular}{|c|c|c|c|c|c|c|}
\hline \multirow{2}{*}{$\begin{array}{l}\text { Variável } \\
\text { Fatores principais }\end{array}$} & \multirow[t]{2}{*}{$\begin{array}{l}\text { Soma dos } \\
\text { quadrados }\end{array}$} & \multirow[t]{2}{*}{$\begin{array}{l}\text { Graus de } \\
\text { liberdade }\end{array}$} & \multirow[t]{2}{*}{$\begin{array}{l}\text { Média dos } \\
\text { quadrados }\end{array}$} & \multirow[t]{2}{*}{ Fator $\left(F_{o}\right)$} & \multicolumn{2}{|c|}{$\begin{array}{c}\text { Mínimo fator de } \\
\text { significância requerido } \\
\left(F_{0.05, n, 26}\right) \text { e }\left(F_{0.01, n, 26}\right)\end{array}$} \\
\hline & & & & & & \\
\hline$X_{1}$ & 1,207 & 2 & 0,604 & 239,179 & 3,37 & 5,53 \\
\hline$X_{2}$ & 0,954 & 2 & 0,477 & 189,039 & 3,37 & 5,53 \\
\hline$X_{3}$ & 3,105 & 2 & 1,553 & 615,288 & 3,37 & 5,53 \\
\hline \multicolumn{7}{|l|}{ Interações } \\
\hline$X_{1} \times X_{2}$ & 0,197 & 4 & 0,049 & 19,484 & 2,74 & 4,14 \\
\hline$X_{1} \times X_{3}$ & 0,039 & 4 & 0,009 & 3,815 & 2,74 & 4,14 \\
\hline$X_{2} \times X_{3}$ & 0,021 & 4 & 0,005 & 2,116 & 2,74 & 4,14 \\
\hline Erro & 0,020 & 8 & 0,002 & -- & & \\
\hline Total & 5,543 & 26 & -- & -- & & \\
\hline
\end{tabular}

Tabela 5.10 - Análise de variância para os valores de ID $_{\text {Pós: }}$ Fase 2

\begin{tabular}{|c|c|c|c|c|c|c|}
\hline \multirow{2}{*}{$\begin{array}{l}\text { Variável } \\
\text { Fatores principais }\end{array}$} & \multirow[t]{2}{*}{$\begin{array}{l}\text { Soma dos } \\
\text { quadrados }\end{array}$} & \multirow[t]{2}{*}{$\begin{array}{l}\text { Graus de } \\
\text { liberdade }\end{array}$} & \multirow[t]{2}{*}{$\begin{array}{l}\text { Média dos } \\
\text { quadrados }\end{array}$} & \multirow[t]{2}{*}{ Fator $\left(F_{o}\right)$} & \multicolumn{2}{|c|}{$\begin{array}{c}\text { Mínimo fator de } \\
\text { significância requerido } \\
\left(F_{0.05, n, 26}\right) \text { e }\left(F_{0.01, n, 26}\right)\end{array}$} \\
\hline & & & & & & \\
\hline$X_{1}$ & 0,044416 & 2 & 0,022208 & 6345,174 & 3,37 & 5,53 \\
\hline$X_{2}$ & 0,038017 & 2 & 0,019008 & 5430,984 & 3,37 & 5,53 \\
\hline$X_{3}$ & 0,121018 & 2 & 0,060509 & 17288,222 & 3,37 & 5,53 \\
\hline \multicolumn{7}{|l|}{ Interações } \\
\hline$X_{1} \times X_{2}$ & 0,012973 & 4 & 0,003243 & 926,635 & 2,74 & 4,14 \\
\hline$X_{1} \times X_{3}$ & 0,000020 & 4 & 0,000005 & 1,397 & 2,74 & 4,14 \\
\hline$X_{2} \times X_{3}$ & 0,002759 & 4 & 0,000689 & 197,063 & 2,74 & 4,14 \\
\hline Erro & 0,000028 & 8 & 0,000004 & -- & & \\
\hline Total & 0,219230 & 26 & -- & -- & & \\
\hline
\end{tabular}

Seguindo o procedimento realizado na fase 1, equações que correlacionam os índices de ductilidade com as variáveis estudadas foram obtidas por meio de análises de regressão múltipla não-linear. As equações obtidas apresentaram coeficiente de correlação $\left(r^{2}\right)$ de $95,5 \%$ e $95,1 \%$, e são expressas pelas Eq.(5.4) e Eq.(5.5), respectivamente:

$$
\begin{aligned}
& \varepsilon_{0.5 \cdot f c c} / \varepsilon_{c c}=1,174+0,477 \cdot b / h+1,785 \cdot \rho_{t}+0,197 \cdot \rho_{l} \\
& I D_{P o s}=0,952+0,088 \cdot b / h+0,356 \cdot \rho_{t}+0,038 \cdot \rho_{l}
\end{aligned}
$$


Analisando as equações Eq.(5.4) e Eq.(5.5), observa-se novamente que todos os índices variam linearmente, com a taxa de armadura longitudinal, a taxa de armadura transversal e a relação $b / h$.

\subsubsection{Variação da ductilidade com o índice de reforço da adição de fibras}

Para estudar a ductilidade dos CRFA de alta resistência, foram selecionadas duas variáveis: resistência do concreto e índice de reforço, sendo estas avaliadas em 3 e 7 níveis de estudos, respectivamente. Os concretos apresentavam resistências de $60 \mathrm{MPa}, 80 \mathrm{MPa}$ e $100 \mathrm{MPa}$ e os índices de reforço foram $0,0,3,0,4,0,5,0,6,0,8$ e 1,0. Para gerar os diagramas tensão vs. deformação do CRFA, foi utilizado o modelo proposto no item 4.2 do Capítulo 4 deste trabalho.

Na Figura 5.12, na Figura 5.13 e na Figura 5.14, são apresentadas as curvas tensão vs. deformação parametrizadas dos CRFA para as diversas combinações entre resistências do concreto e índices de reforço, e na Tabela 5.11 e Tabela 5.12 na os valores dos índices de ductilidade. Observa-se que, com o aumento dos valores dos índices de reforço, a ductilidade do concreto é elevada, atingindo valores semelhantes aos concretos confinados com altas taxas de armadura transversal (ver Tabela 5.3 e Tabela 5.4).

Seguindo o mesmo procedimento dos estudos anteriores, realizou-se uma análise de variância, com o objetivo de determinar os graus de influência das variáveis estudadas no comportamento dos índices de ductilidade do CRFA. Os graus de significância do efeito de cada variável foram testados para graus de confiabilidade de $90 \%$ e $95 \%$, usando o F teste. Por se tratar de uma análise nãobalanceada, uma vez que foram utilizados números de níveis de estudos diferentes para cada variável, foi necessária a aplicação do teorema de Tukey na análise (Montgomery, 1997). A variável resistência do concreto foi denominada de fator $X 1$ e o índice de reforço, de $X 2$. 


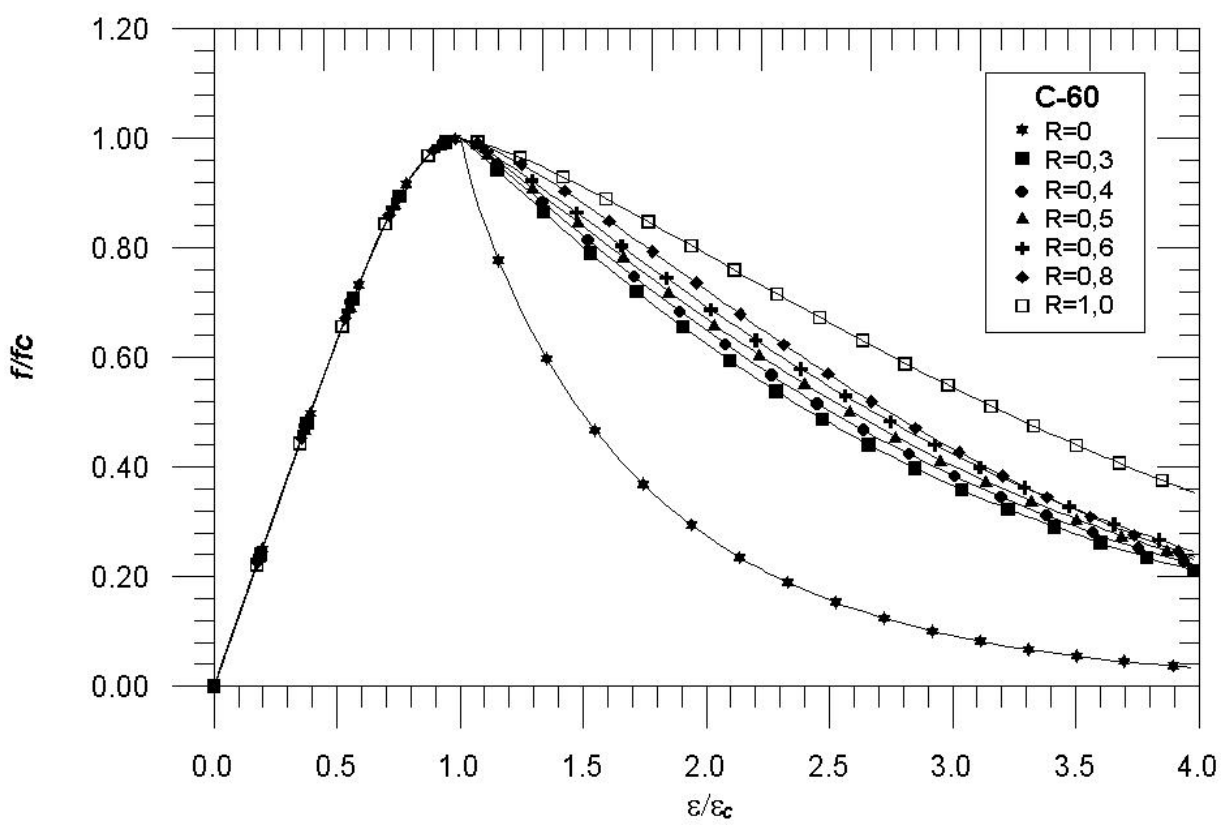

Figura 5.12 - Curvas paramétricas tensão vs. deformação do CRFA com resistência à compressão de 60MPa

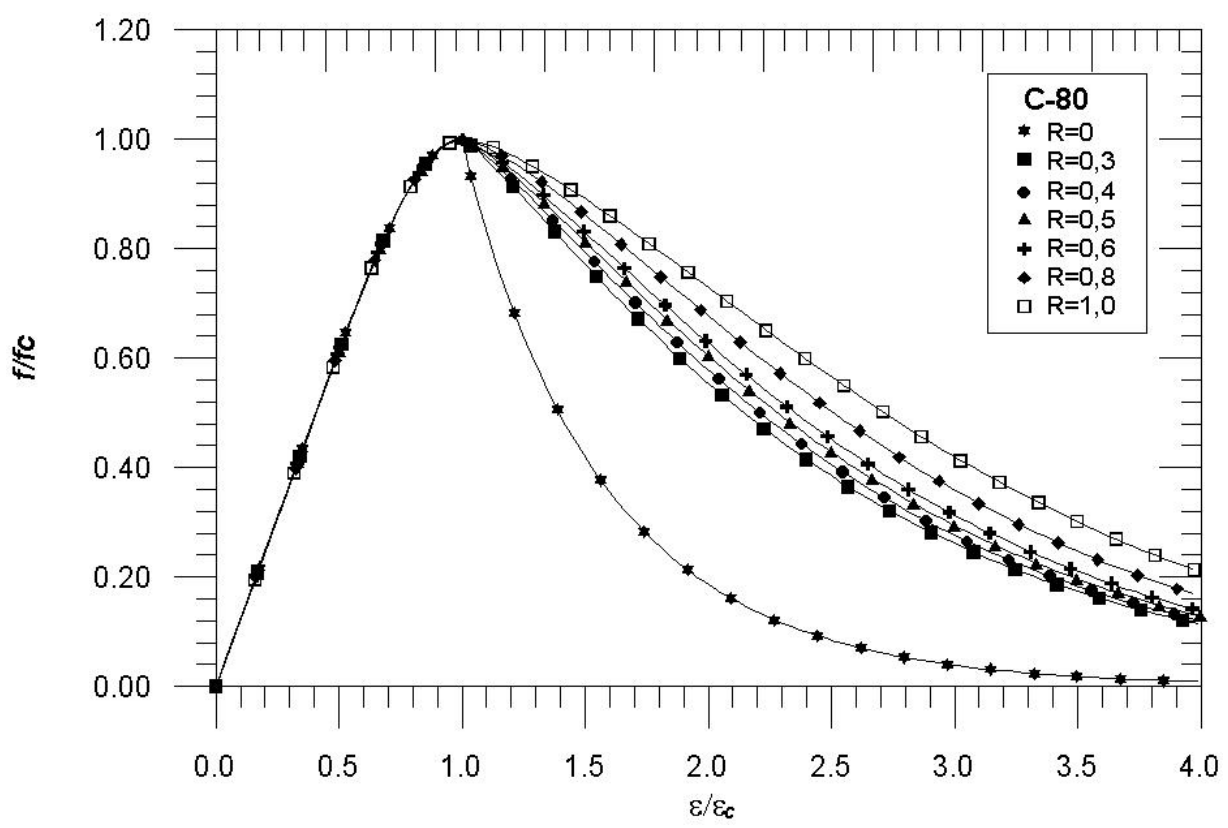

Figura 5.13 - Curvas paramétricas tensão vs. deformação do CRFA com resistência à compressão de $80 \mathrm{MPa}$ 


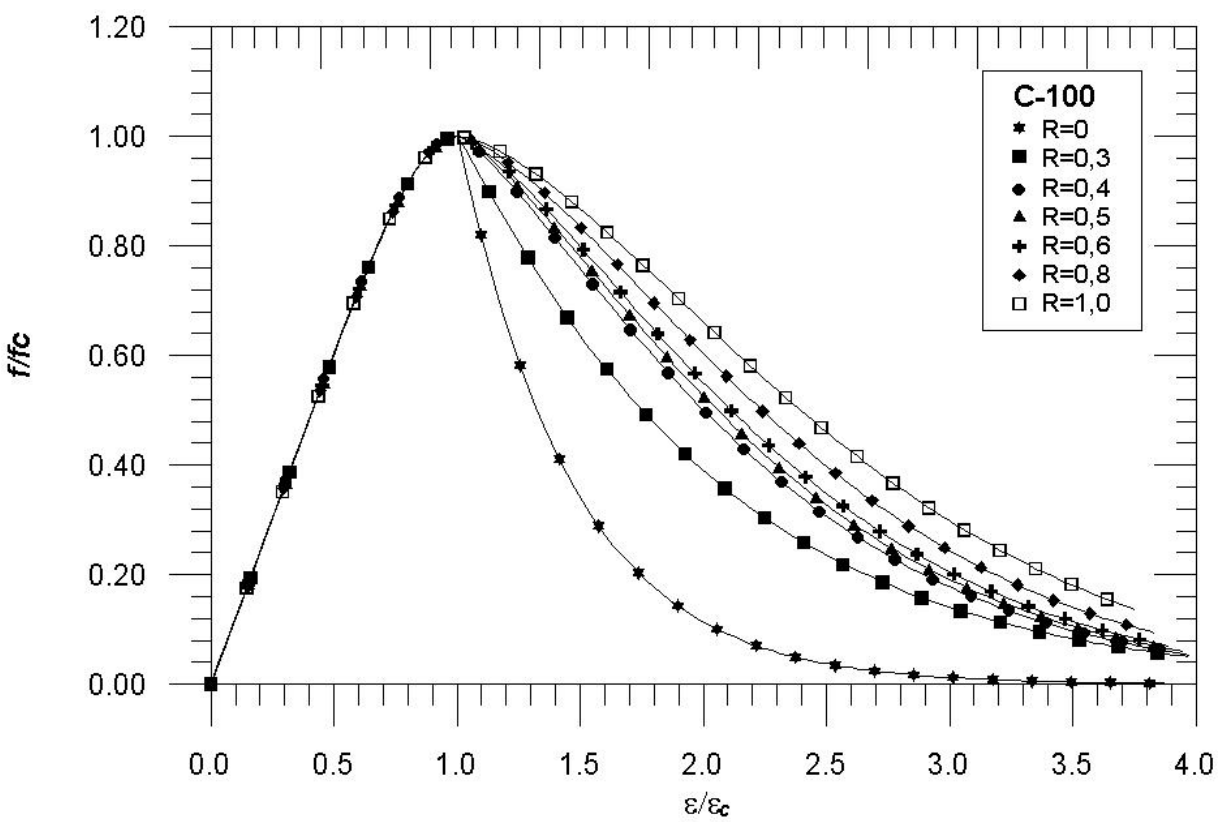

Figura 5.14 - Curvas paramétricas tensão vs. deformação do CRFA com resistência à compressão de $100 \mathrm{MPa}$

Tabela 5.11 - Valores dos índices de ductilidade $\boldsymbol{\varepsilon}_{0.5 f c} / \mathcal{\varepsilon}_{c f}$ do CRFA

\begin{tabular}{cccccccc}
\hline & \multicolumn{7}{c}{$X_{2}$} \\
\cline { 2 - 7 }$X_{I}(\mathrm{MPa})$ & 0,00 & 0,30 & 0,40 & 0,50 & 0,60 & 0,80 & 1,00 \\
\hline 60 & 1,493 & 2,480 & 2,674 & 2,866 & 3,067 & 3,567 & 4,447 \\
80 & 1,394 & 1,939 & 2,014 & 2,077 & 2,132 & 2,227 & 2,315 \\
100 & 1,325 & 1,665 & 1,703 & 1,732 & 1,755 & 1,787 & 1,809 \\
\hline
\end{tabular}

Tabela 5.12 - Valores dos índices de ductilidade ID $_{\text {Pós }}$ do CRFA

\begin{tabular}{cccccccc}
\hline & \multicolumn{7}{c}{$X_{2}$} \\
\cline { 2 - 7 }$X_{I}(\mathrm{MPa})$ & 0,00 & 0,30 & 0,40 & 0,50 & 0,60 & 0,80 & 1,00 \\
\hline 60 & 0,703 & 1,313 & 1,388 & 1,453 & 1,513 & 1,630 & 1,755 \\
80 & 0,566 & 1,037 & 1,087 & 1,128 & 1,162 & 1,221 & 1,275 \\
100 & 0,457 & 0,797 & 0,828 & 0,849 & 0,865 & 0,886 & 0,898 \\
\hline
\end{tabular}

Na Tabela 5.13 e na Tabela 5.14 , são apresentados os resultados da análise. Nota-se que, para os dois índices, a resistência do concreto é o fator primordial, seguido pelo índice de reforço, e que esses fatores apresentaram significância, em um grau de confiabilidade de $99 \%$. O acoplamento dos dois fatores apresentou elevado grau de influência e significância, em um grau de confiabilidade de $99 \%$. 
Tabela 5.13 - Análise de variância para os valores de $\varepsilon_{0.5 f c t} \mathcal{\varepsilon}_{c f}$ do CRFA

\begin{tabular}{|c|c|c|c|c|c|c|}
\hline Variável & $\begin{array}{l}\text { Soma dos } \\
\text { quadrados }\end{array}$ & $\begin{array}{l}\text { Graus de } \\
\text { liberdade }\end{array}$ & $\begin{array}{l}\text { Média dos } \\
\text { quadrados }\end{array}$ & Fator $\left(F_{o}\right)$ & $\begin{array}{r}\text { Mínimo } \\
\text { significânc } \\
\left(F_{0.05, n, 20}\right)\end{array}$ & $\begin{array}{l}\text { ator de } \\
\text { requerido } \\
\left(F_{0.01, n, 20}\right)\end{array}$ \\
\hline \multicolumn{7}{|l|}{ Fatores principais } \\
\hline$X_{1}$ & 5,968896 & 2 & 2,984448 & 131,598 & 3,49 & 3,87 \\
\hline$X_{2}$ & 3,660121 & 6 & 0,61002 & 36,985 & 2,60 & 5,85 \\
\hline \multicolumn{7}{|l|}{ Interações } \\
\hline $\begin{array}{c}X_{1} \times X_{2} \\
\text { Não aditivo }\end{array}$ & 1,927421 & 1 & 1,927421 & 116,860 & 4,35 & 8,10 \\
\hline Erro & 0,1814272 & 11 & 0,001898 & -- & & \\
\hline Total & 11,737866 & 20 & -- & -- & & \\
\hline
\end{tabular}

Tabela 5.14 - Análise de variância para os valores de ID Pós $_{\text {do CRFA. }}$

\begin{tabular}{|c|c|c|c|c|c|c|}
\hline \multirow{2}{*}{$\begin{array}{l}\text { Variável } \\
\text { Fatores principais }\end{array}$} & \multirow[t]{2}{*}{$\begin{array}{l}\text { Soma dos } \\
\text { quadrados }\end{array}$} & \multirow[t]{2}{*}{$\begin{array}{l}\text { Graus de } \\
\text { liberdade }\end{array}$} & \multirow[t]{2}{*}{$\begin{array}{l}\text { Média dos } \\
\text { quadrados }\end{array}$} & \multirow[t]{2}{*}{ Fator $\left(F_{o}\right)$} & \multicolumn{2}{|c|}{$\begin{array}{c}\text { Mínimo fator de } \\
\text { significância requerido } \\
\left(F_{0.05, n, 20}\right) \text { e }\left(F_{0.01, n, 20}\right)\end{array}$} \\
\hline & & & & & & \\
\hline$X_{1}$ & 1.248537 & 2 & 0.624269 & 564.933 & 3,49 & 3,87 \\
\hline$X_{2}$ & 1.049605 & 6 & 0.174934 & 217.672 & 2,60 & 5,85 \\
\hline \multicolumn{7}{|l|}{ Interações } \\
\hline $\begin{array}{c}X_{1} \times X_{2} \\
\text { Não aditivo }\end{array}$ & 0.103321 & 1 & 0.103321 & 128.563 & 4,35 & 8,10 \\
\hline Erro & 0.008840 & 11 & 0.000804 & -- & & \\
\hline Total & 2.410304 & 20 & -- & -- & & \\
\hline
\end{tabular}

Uma análise de regressão múltipla não-linear foi realizada e as equações obtidas apresentaram coeficiente de correlação $\left(r^{2}\right)$ de $98,09 \%$ e $97,82 \%$, e são expressas pelas Eq.(5.6) e Eq.(5.7), respectivamente:

$$
\begin{gathered}
\varepsilon_{0.5 \cdot f c f} / \varepsilon_{c f}=1,636+6,021 \cdot R-1,477 \cdot 10^{-3} \cdot f_{c}- \\
\quad-5,836 \cdot 10^{-2} \cdot R \cdot f_{c} \\
I D_{\text {Pos }}=1,344+1,819 \cdot R-7,484 \cdot 10^{-3} \cdot f_{c}- \\
\quad-1,444 \cdot 10^{-3} \cdot R \cdot f_{c}
\end{gathered}
$$

Analisando as equações acima, observa-se que todos os índices variam linearmente com o índice de reforço e a resistência do concreto. Contudo, devido à presença do acoplamento entre o índice de reforço e a resistência do concreto as equações Eq.(5.6) e Eq.(5.7), variam não linearmente. Nota-se, ainda, que as equações Eq.(5.6) e Eq.(5.7) podem ser utilizadas para calcular as taxas de fibras 
ideais para uma dada resistência do concreto e um tipo de fibra, considerando os índices de ductilidade ideais do item 5.2.1, deste capítulo. Na Tabela 5.15 são apresentadas as taxas ideais para resistências de concreto, variando entre $50 \mathrm{MPa}$ e 100MPa, e fibras de aço com gancho nas extremidades, com $60 \mathrm{~mm}$ de comprimento e $0,75 \mathrm{~mm}$ de diâmetro, e na Figura 5.15 as curvas tensão vs. deformação paramétricas dos CRFA com resistências 60MPa e taxas de fibras ótimas e dos C60 e C40 sem adição de fibras.

Tabela 5.15 - Taxas volumétricas ideais para diversas resistências de concreto

\begin{tabular}{cccccccccccc}
\hline $\begin{array}{c}\text { Resistência } \\
(\mathrm{MPa})\end{array}$ & 50 & 55 & 60 & 65 & 70 & 75 & 80 & 85 & 90 & 95 & 100 \\
\hline$V_{f}(\%)-I D p o ́ s$ & 0.05 & 0.10 & 0.15 & 0.22 & 0.29 & 0.38 & 0.50 & 0.63 & 0.81 & 1.05 & 1.38 \\
$V_{f}(\%)-\varepsilon_{0.5 f c} \mathcal{E}_{c f}$ & 0.16 & 0.18 & 0.21 & 0.24 & 0.28 & 0.34 & 0.42 & 0.44 & 0.61 & 1,00 & 2.62 \\
\hline
\end{tabular}

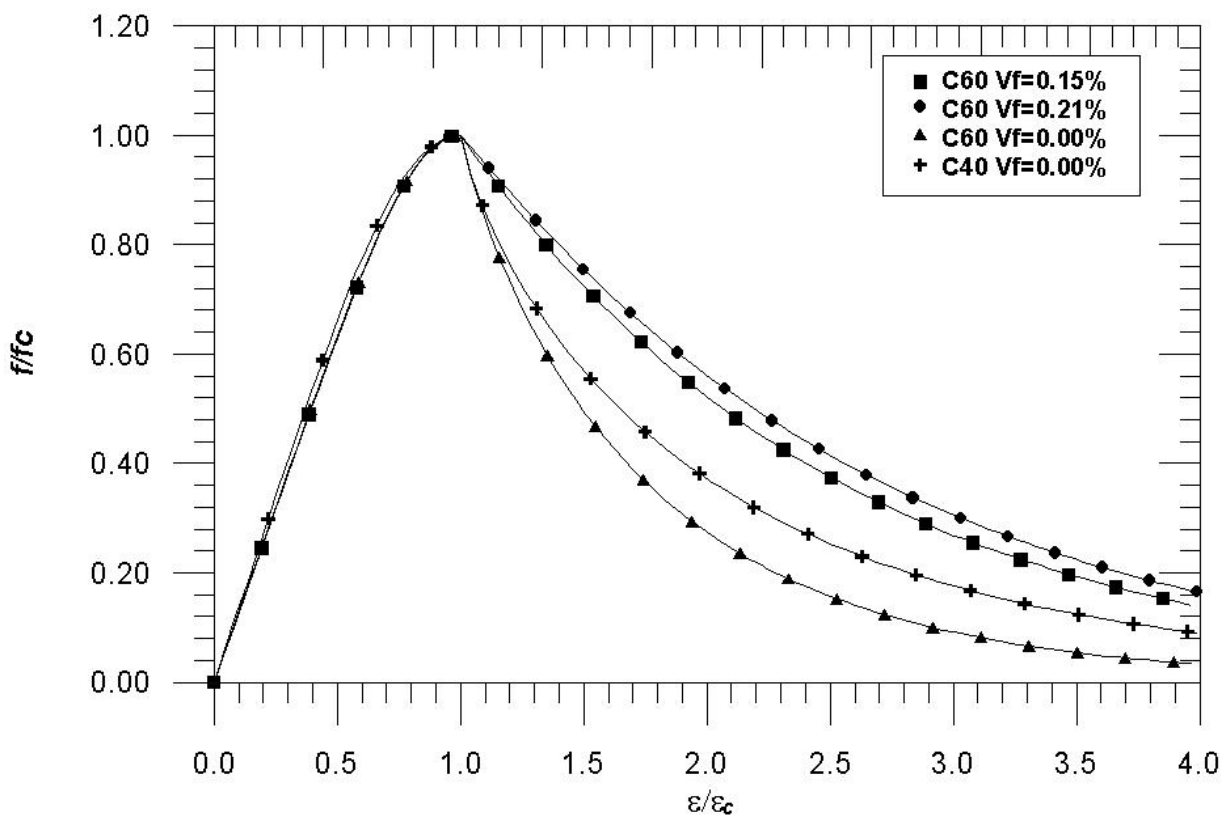

Figura 5.15 - Curvas paramétricas tensão vs. deformação do CRFA C60 com adição de taxas volumetrias ótimas e do C60 e C40 sem adição de fibras 


\subsubsection{Comportamento à flexo-compressão dos pilares confinados}

Para realizar o estudo paramétrico dos pilares submetidos à flexocompressão, não foi considerada a dissipação das tensões de confinamento, provocada pela flexão. Desse modo, optou-se por analisar todas as variáveis através dos modelos do FIB (1999) e do Cusson e Paultre (1995), uma vez que os valores exatos das análises encontram-se no intervalo entre os valores fornecidos pelos dois modelos citados.

Para a análise, foram introduzidos dois parâmetros adimensionais, denominados de momento fletor reduzido e esforço normal reduzida, e que são expressos pelas equações Eq.(5.8) e Eq.(5.9), respectivamente:

$$
\begin{gathered}
\mu=\frac{M}{b \cdot h^{2} \cdot f_{c}} \\
\nu=\frac{N}{b \cdot h \cdot f_{c}}
\end{gathered}
$$

nas quais $M$ e $N$ são o momento fletor e a força normal aplicada ao pilar; $b$ é a dimensão da seção transversal perpendicular ao plano de flexão; $h$ é a dimensão da seção transversal paralela ao plano de flexão; e $f_{c}$ é a resistência média à compressão do concreto que constitui o pilar.

Com o intuito de verificar a variação do diagrama esforço normal reduzido vs. momento reduzido, com relação apenas à resistência do concreto, foi analisado numericamente um pilar de seção transversal quadrada de $20 \mathrm{~cm}$ x $20 \mathrm{~cm}$, com armadura longitudinal constituída por quatro barras de $12,5 \mathrm{~mm}$ e armadura transversal calculada segundo o Projeto de Norma da NBR 6118 (2000), que indica estribos de $6,3 \mathrm{~mm}$ espaçados $15 \mathrm{~cm}$ uns dos outros. Três resistências de concreto foram analisadas: 60MPa, 70MPa e 80MPa. Para realizar esta avaliação, foi utilizado o modelo numérico do FIB (1999). Na Figura 5.16 apresentam-se as curvas $v$ vs. $\mu$, para as três resistências de concreto analisadas. Observa-se uma pequena diferença entre as três curvas, pois, com a diminuição da resistência à compressão do concreto, ocorre um aumento dos momentos fletores e esforços normais resistentes reduzidos da seção. Esse fato é explicado, uma vez que o 
esforço normal resistente da seção transversal $N$ é constituído pelo somatório entre a força resistida pelo concreto e as parcelas de forças de cada barra da armadura longitudinal. Assim, quando, nas Eq.(5.8) e Eq.(5.9), divide-se $N$ pela resistência do concreto, a parcela referente à armadura também é dividida e, conseqüentemente, quanto maior for a resistência do concreto, menor será a contribuição dessa parcela. Assim, os valores dos esforços normais e momentos fletores reduzidos diminuem com o aumento da resistência.

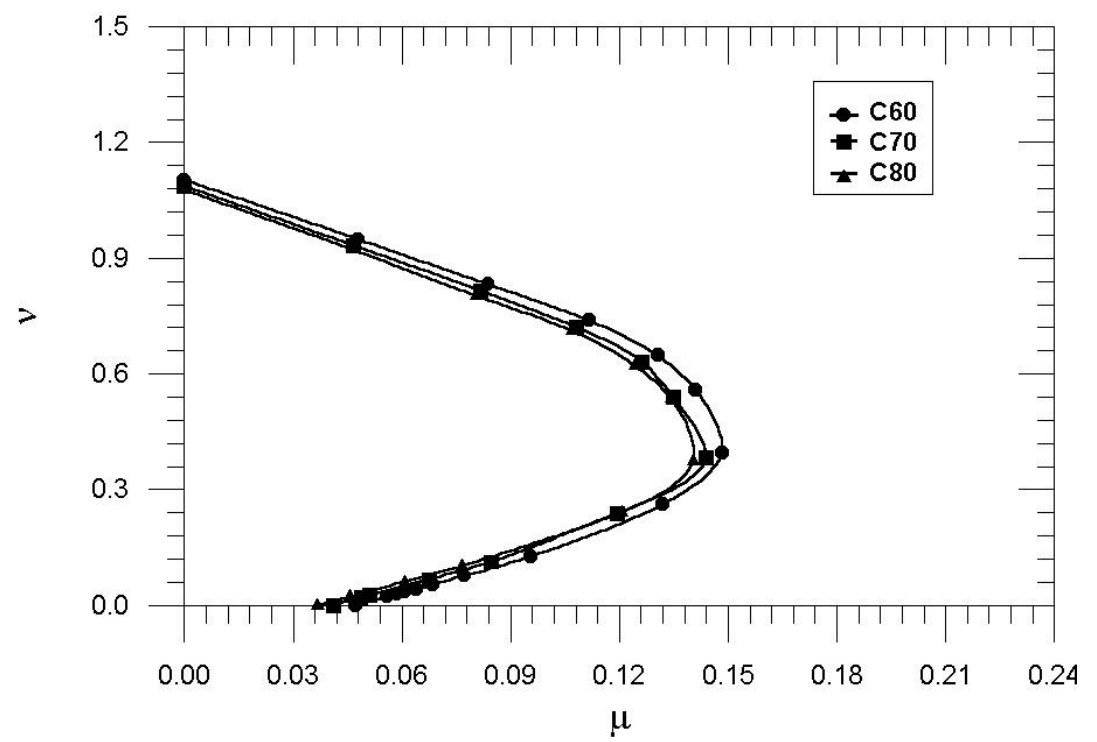

Figura 5.16 - Curvas $v$ vs. $\mu$ para diferentes resistências de concreto

Objetivando-se analisar a influência do confinamento no diagrama $v$ vs. $\mu$ dos pilares com concreto de alta resistência, analisou-se numericamente o pilar anteriormente estudado, variando-se o espaçamento entre os estribos da armadura transversal de $15 \mathrm{~cm}$ para $5 \mathrm{~cm}$, e a resistência do concreto de $60 \mathrm{MPa}$ para $80 \mathrm{MPa}$. Neste estudo foi utilizado o modelo de Cusson e Paultre (1995) e do FIB (1999). Os novos diagramas são apresentados na Figura 5.17 e na Figura 5.18. Observa-se que, com o aumento da taxa de armadura transversal, ocorre uma elevação no esforço normal e momento fletor reduzido, o que já era esperado, uma vez que o confinamento aumenta a resistência do concreto, e esta, por sua vez, aumenta a capacidade resistente da seção transversal. 


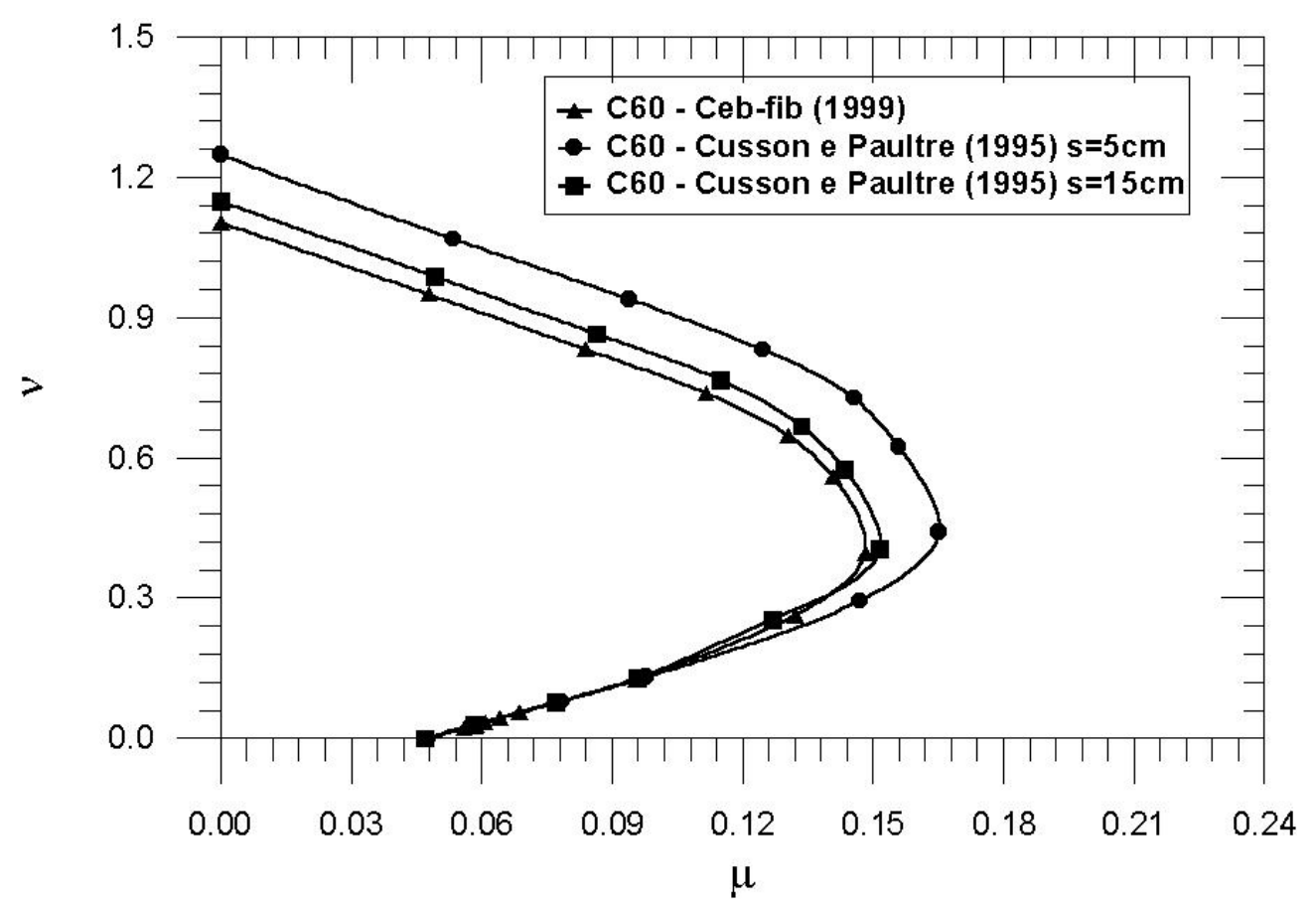

Figura 5.17 - Curvas vvs. $\mu$ para resistência do concreto de 60MPa e espaçamento entre estribo de $15 \mathrm{~cm}$ e $5 \mathrm{~cm}$

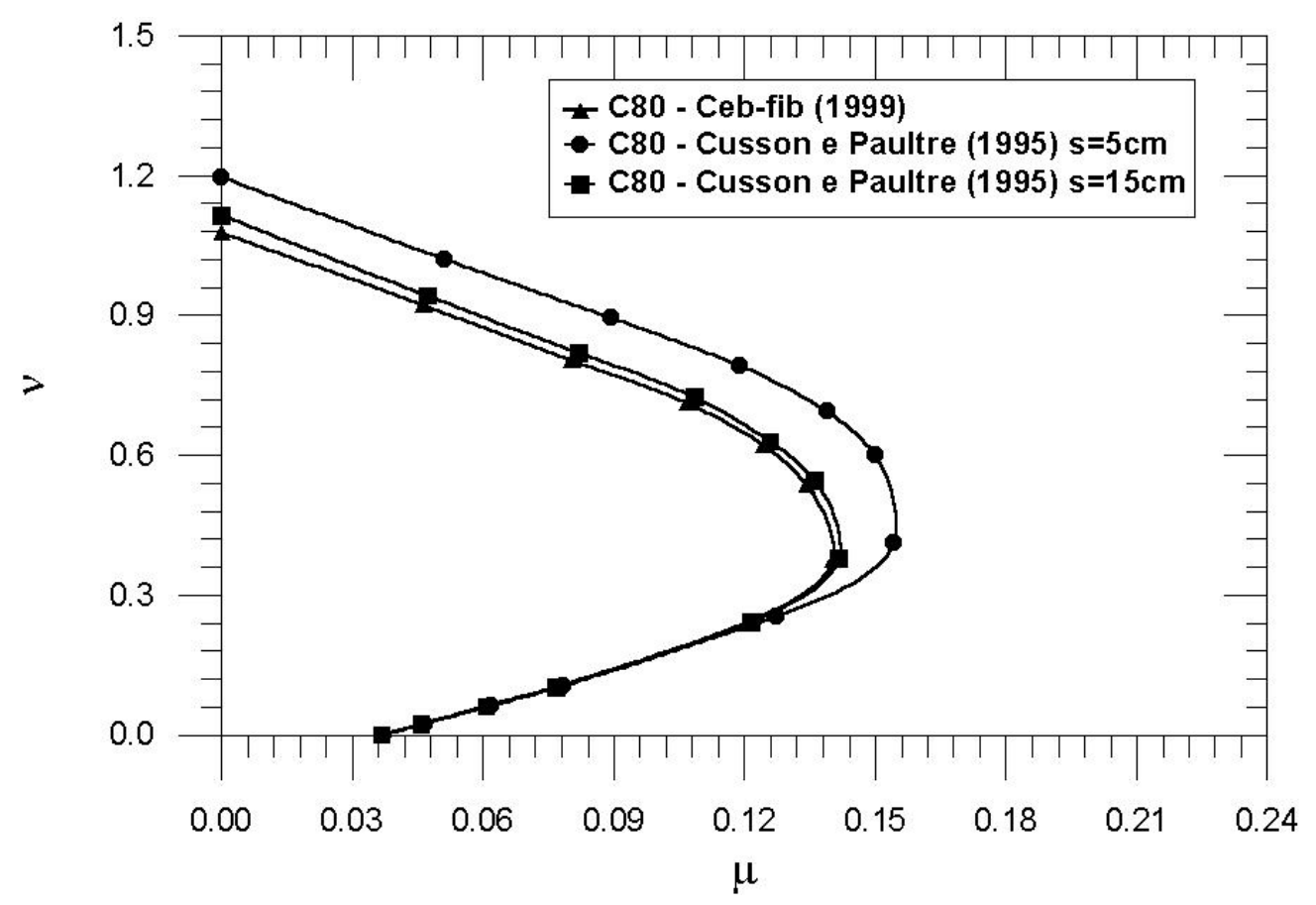

Figura 5.18 - Curvas $v$ vs. $\mu$ para resistência do concreto de 80MPa e espaçamento entre estribo de $15 \mathrm{~cm}$ e $5 \mathrm{~cm}$ 
Seguindo o estudo paramétrico, buscou-se verificar, no presente trabalho, a precisão do modelo de Cusson e Paultre (1995) em predizer o comportamento dos pilares de CAR submetidos à flexo-compressão reta. Para tanto, foram estudados aqui os comportamentos de 12 pilares de CAR ensaiados à flexo-compressão reta por Lloyd e Rangan (1996). Os pilares analisados eram bi-rotulados, com comprimento de flambagem de $168 \mathrm{~cm}$ e foram ensaiados com excentricidades de força de $15 \mathrm{~mm}, 50 \mathrm{~mm}$ e $65 \mathrm{~mm}$ (seções transversais quadradas) e $10 \mathrm{~mm}$, 30mm e 40mm (seções transversais retangulares). Além disso, eles foram constituídos por duas resistências de concreto: $58 \mathrm{MPa}$ e $92 \mathrm{MPa}$; duas taxas de armadura longitudinal: $2,15 \%$ e 1,44\%; e estribos espaçados a cada $6 \mathrm{~cm}$ (ver Figura 5.19). Na Figura 5.20 são apresentados os diagramas obtidos da análise numérica, $v$ vs. $\mu$, para os pilares em questão, e os correspondentes valores experimentais. Observa-se que, para grandes excentricidades, a concordância entre o diagrama e os valores experimentais é razoável, contudo, para pequenas excentricidades os valores experimentais divergem do diagrama. Observa-se ainda que a geometria da seção transversal, a taxa de armadura longitudinal e a resistência do concreto têm influência significativa na conformação do diagrama, isso porque estes fatores influenciam diretamente na tensão de confinamento gerada pela armadura transversal.

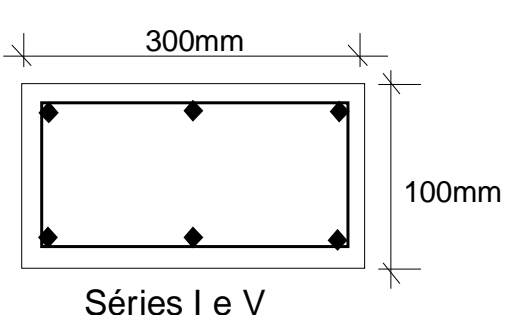

Séries I e V

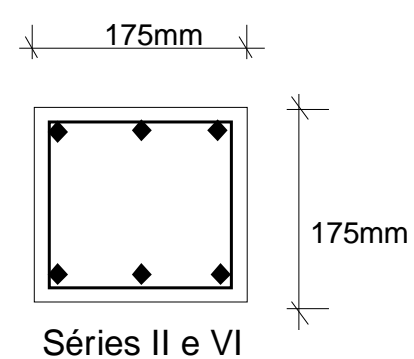

Séries II e VI

Séries I e II = 58MPa

Séries V e VI = 92MPa

Figura 5.19 - Pilares ensaiados por Lloyd e Rangan (1996) 

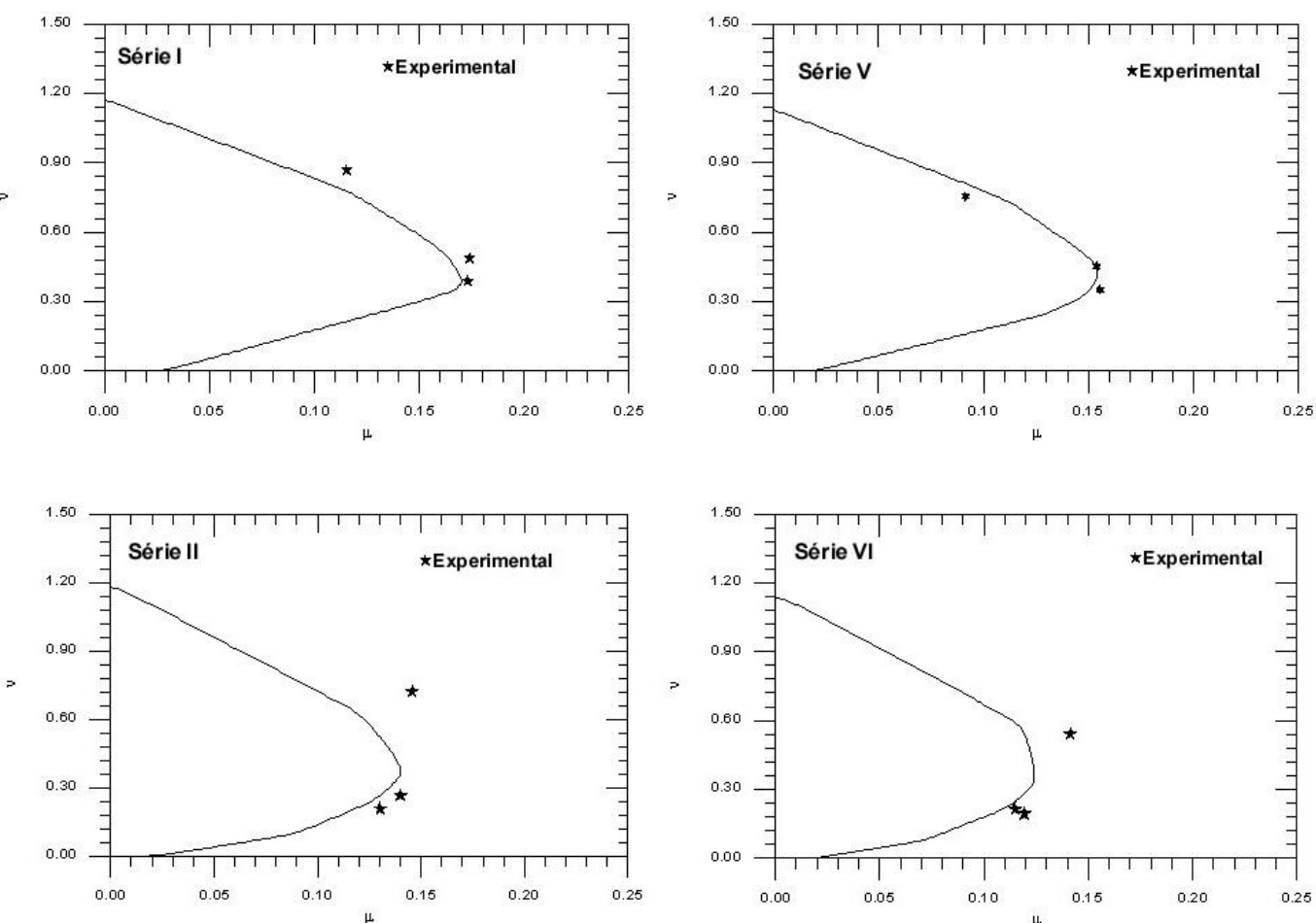

Figura 5.20 - Diagrama $v$ vs. $\mu$ para os pilares ensaiados por Lloyd e Rangan (1996)

\subsection{PRINCIPAIS OBSERVAÇÕES DOS ESTUDOS PARAMÉTRICOS}

Os resultados obtidos com as simulações de pilares submetidos a compressão centrada mostraram que os fatores de $\boldsymbol{a}$ à $\boldsymbol{e}$, listados nas considerações iniciais deste capítulo, influenciam na ductilidade dos pilares de concreto de alta resistência. Esses resultados mostraram ainda, que os índices de ductilidade variam linearmente com esses fatores e que apenas o acoplamento entre as resistências dos concretos e os índices de reforço da adição de fibras tem influência significativa sobre os índices de ductilidade dos pilares.

O modelo do Cusson e Paultre (1995), quando utilizado para modelar pilares submetidos à flexo-compressão, apenas apresentou valores adequados para os momentos resistentes dos pilares submetidos a grandes excentricidades. Contudo, para pequenas excentricidades, a discrepância entre os valores do modelo e dos resultados experimentais foi considerável. Isso vem a comprovar que a flexão interfere no comportamento do concreto confinado e que se faz necessária uma avaliação experimental mais detalhada deste efeito. Não foi 
possível avaliar o comportamento pós-pico dos pilares submetidos à flexocompressão, uma vez que não foi encontrado na Literatura nenhum trabalho que apresentasse esse comportamento.

Resultados de diversos pesquisadores indicam que, elevando-se a excentricidade, a ductilidade dos pilares é melhorada e que esse comportamento, aparentemente, é não-linear. 


\subsection{PLANEJAMENTO EXPERIMENTAL}

O estudo experimental desenvolvido neste trabalho foi baseado em uma programação fatorial de experimento, a qual foi dividida em duas fases: a primeira, que consistiu no estudo da ductilidade dos pilares de CAR submetidos à compressão concêntrica e com e sem adições de fibras de aço e confinamento por armadura transversal; e a segunda, na qual foi analisado o comportamento dos pilares de CAR submetidos à flexo-compressão reta e com adições de fibras de aço e/ou confinamento por armadura transversal.

Para a primeira fase do programa experimental foram selecionados três fatores de influência: a resistência do concreto, a taxa volumétrica de armadura transversal e o índice de reforço de adição de fibras. Com base nos estudos paramétricos realizados no Capítulo 5 desta tese, observou-se que a ductilidade dos pilares de CAR varia linearmente com a resistência do concreto e a taxa volumétrica de armadura transversal. Ainda, que esta propriedade varia linearmente com a resistência do concreto e o índice de reforço de adição de fibras; porém, essa variação torna-se não-linear em virtude do acoplamento desses dois últimos fatores. Desse modo, para compor as características físicas dos pilares a serem estudados, foram selecionadas duas resistências de concreto: $60 \mathrm{MPa}$ e $80 \mathrm{MPa}$; duas taxas volumétricas de armaduras transversais, calculadas segundo a equação Eq.(5.1): 0,32\% e 0,96\%; e três índices de reforço de adição de fibras: $0,0,4$ e 0,8. Foram utilizadas duas réplicas para cada combinação de variáveis, resultando em um projeto fatorial de $2 \times 2 \times 3 \times 2=24$ pilares (Montgomery, 1997).

A segunda fase do programa experimental constituiu-se do estudo dos pilares de CAR submetidos à compressão excêntrica. Para essa fase, foram 
também selecionados três fatores de influência: o índice de reforço de adição de fibras, a taxa volumétrica da armadura transversal e a excentricidade de força. A resistência do concreto foi tomada constante para todos os pilares ensaiados e foi igual a 60MPa. Com a resistência do concreto constante, a não-linearidade da variação da ductilidade dos pilares de CAR, com relação ao acoplamento da resistência do concreto e do índice de reforço de adição de fibras, deixa de existir. Assim, foi possível utilizar apenas dois índices de reforço para compor as características físicas dos pilares a serem ensaiados à flexo-compressão reta: 0 e o índice ótimo para a resistência média de $60 \mathrm{MPa}$ obtido na primeira fase experimental, e que será discutido posteriormente. Foram utilizadas as mesmas duas taxas volumétricas de armadura transversal utilizada na primeira fase: $0,32 \%$ e $0,96 \%$.

Quanto ao fator excentricidade de força, não foi possível pré-estabelecer o modo de resposta da variação da ductilidade dos pilares de CAR com relação a este fator, a partir da revisão bibliográfica e dos estudos paramétricos. Com isso, foi admitido que essa variação é não-linear, implicando, assim, a necessidade de pelo menos três níveis de estudo para esse fator. Baseando-se no exposto, foram selecionadas quatro excentricidades paramétricas $(e / h)$ para os ensaios: 0\%, $6,67 \%, 13,33 \%$ e $20 \%$. Entretanto, como é possível, utilizando os dados obtidos na primeira fase do programa experimental, para estabelecer o comportamento dos pilares de CAR para a excentricidade nula, foram ensaiados apenas pilares submetidos às excentricidades paramétricas de força de 6,67\%, 13,33\% e $20 \%$. Para esta fase não foram utilizadas réplicas, resultando em um projeto fatorial de 2x2x4=16 pilares (Montgomery, 1997).

Nas duas fases do programa experimental, foram adicionados pilares com resistência do concreto de $40 \mathrm{MPa}$ e armadura transversal calculadas segundo o Projeto de Revisão da Norma Brasileira NBR 6118 (2001). Esses pilares foram ensaiados segundo os mesmos procedimentos utilizados, em cada fase, para os pilares de CAR. Os comportamentos dos pilares com resistência do concreto de 40MPa serviram como parâmetros de avaliação dos resultados das duas fases do estudo experimental. 


\subsection{MATERIAIS UTILIZADOS}

\subsubsection{Concreto}

As resistências do CAR foram escolhidas baseando-se na capacidade máxima de força da máquina de ensaio disponível. Assim, optou-se por trabalhar com resistências média de concreto de 60MPa e 80MPa. Além dessas resistências, como já mencionado, foi utilizado um concreto com 40MPa para a confecção dos pilares de referência. As matrizes utilizadas nos concretos para os diversos teores de fibras, em uma mesma série de ensaio, apresentavam as mesmas características. Este procedimento teve como objetivo evitar a interferência dos efeitos da variação das propriedades da matriz no comportamento pós-fissuração dos concretos (Nunes, 1998). Em todo o estudo foram utilizados corpos-de-prova cilíndricos $15 \mathrm{~cm}$ x $30 \mathrm{~cm}$ para a avaliação da resistência à compressão do concreto.

O cimento utilizado foi o cimento Portland de alta resistência inicial, CP V ARI da marca Ciminas. A Sílica Ativa utilizada foi de origem nacional da marca SILMIX, de fabricação da Camargo Corrêa Cimentos S.A. Esta sílica se apresentava não densificada, com massa específica de $2,22 \mathrm{~kg} / \mathrm{dm}^{3}$ e diâmetro das

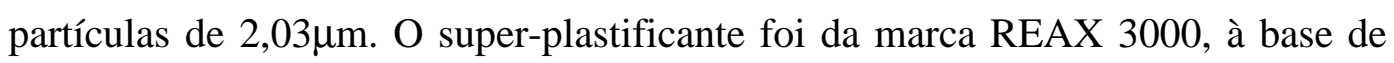
melamina sulfonada, apresentava densidade de $1,16 \mathrm{~g} / \mathrm{cm}^{3}$, e produzido pela Fosroc Reax.

O agregado miúdo utilizado foi a areia quartzosa proveniente do rio MogiGuaçu. Este agregado apresentou módulo de finura de 2,11, diâmetro máximo de $2,4 \mathrm{~mm}$ e massa específica aparente de $2,65 \mathrm{~kg} / \mathrm{dm}^{3}$ (NBR 7217:1987 e NBR 9776:1987). Utilizou-se agregado graúdo de origem basáltica, da região de São Carlos, com módulo de finura de 6,8 e massa específica de $2,90 \mathrm{~kg} / \mathrm{dm}^{3}$ (NBR 7217:1987 e NBR 9776:1987).

Para a determinação das porcentagens dos materiais para os concretos de altas resistências, foi realizado um estudo experimental de dosagem. $\mathrm{O}$ traço foi definido a partir de curva de dosagem, seguindo a metodologia apresentada por Helene e Terzian (1992). O teor de argamassa utilizado foi de 57\%, seguindo recomendação do ACI (1993) e ACI (1988), que sugerem teor mínimo de 50\%. O 
teor de água/materiais secos foi fixado em 10\% para um abatimento de tronco de cone de $120 \mathrm{~mm} \pm 10 \mathrm{~mm}$. Para determinação da massa específica e das resistências das proporções bases foi utilizada a média de 3 corpos-de-prova.

A metodologia para determinação das porcentagens dos materiais para o concreto com 40MPa foi a mesma utilizada para o CAR. O teor de argamassa utilizado foi de $52 \%$ e o teor de água/materiais secos foi fixado em $10 \%$, para um abatimento de tronco de cone de $200 \mathrm{~mm} \pm 10 \mathrm{~mm}$. Novamente, foi utilizada a média de 3 corpos-de-prova para a determinação da massa específica e das resistências dos concretos das proporções bases.

Na Tabela 6.1 é apresentado o estudo experimental do concreto de alta resistência, e, na Figura 6.1, a curva de dosagem para esse concreto. Com a análise do diagrama de dosagem do CAR, e partindo-se da resistência média de $60 \mathrm{MPa}$ obtém-se a seguinte dosagens em massa: 1: 2,14: 2,37; consumo de cimento de $400,71 \mathrm{~kg} / \mathrm{m}^{3}$; teor de argamassa de $57 \%$; relação água/cimento de 0,54 ; relação água/materiais secos de $10 \%$; teor de sílica ativa de $10 \%$ em relação à massa do cimento; e teor de super-plastificante de $2,5 \%$ da massa do cimento. Ainda, partindo-se da resistência média de 80MPa obtém-se: 1: 1,13: 1,61; consumo de cimento de $604,09 \mathrm{~kg} / \mathrm{m}^{3}$; teor de argamassa de $57 \%$; relação água/cimento de 0,38; relação água/materiais secos de $10 \%$; teor de sílica ativa de $10 \%$ em relação à massa do cimento; e teor de super-plastificante de $2,5 \%$ da massa do cimento. Para confirmação das resistências dos traços acima, realizaram-se concretagens de 3 corpos-de-prova para cada traço, os quais apresentaram resistências médias de 60,68MPa e 78,95MPa, respectivamente, e abatimentos no tronco de cone de $11,5 \mathrm{~cm}$ e $9,5 \mathrm{~cm}$, respectivamente.

Na Tabela 6.2, é apresentado o estudo experimental do concreto de resistência usual, e, na Figura 6.2, a curva de dosagem para esse concreto. A partir do diagrama de dosagem do CRU, obteve-se a seguinte dosagem para o concreto com resistência de 40MPa: 1: 1,96: 2,84; consumo de cimento de $418 \mathrm{~kg} / \mathrm{m}^{3}$; teor de argamassa de 51\%; relação água/cimento de 0,58; relação água/materiais secos de $10 \%$. Novamente, realizou-se uma concretagem de 3 corpos-de-prova para 
avaliação da resistência do referido traço, a qual apresentou-se igual a 39,95MPa, com abatimento no tronco de cone de $19 \mathrm{~cm}$.

Tabela 6.1 - Estudo de dosagem para o concreto com resistência de alta resistência

\begin{tabular}{lcccc}
\hline \multirow{2}{*}{ Traço em massa } & Número & CAR-3 & CAR-4 & CAR-5 \\
\cline { 2 - 5 } & $1: \mathrm{m}$ & $1: 3$ & $1: 4$ & $1: 5$ \\
\cline { 2 - 5 } & $1: \mathrm{a}: \mathrm{p}$ & $1: 1,28: 1,72$ & $1: 1,85: 2,15$ & $1: 2,42: 2,58$ \\
\hline Teor de argamassa $(\%)$ & 57,00 & 57,0 & 57,00 \\
Consumo de cimento $\left(\mathrm{kg} / \mathrm{m}^{3}\right)$ & & 562,91 & 437,84 & 372,69 \\
Relação água cimento & 0,40 & 0,5 & 0,59 \\
Abatimento no tronco de cone (mm) & 120,00 & 140,0 & 160,00 \\
Água/materiais secos & 10,00 & 10,0 & 10,00 \\
Resistência aos 14 dias (MPa) & 77,30 & 64,6 & 55,60 \\
Sílica ativa (\% massa cimento) & 10,00 & 10,0 & 10,00 \\
Superplastificante $(\%$ massa cimento) & 2,50 & 2,50 & 2,50 \\
\hline
\end{tabular}

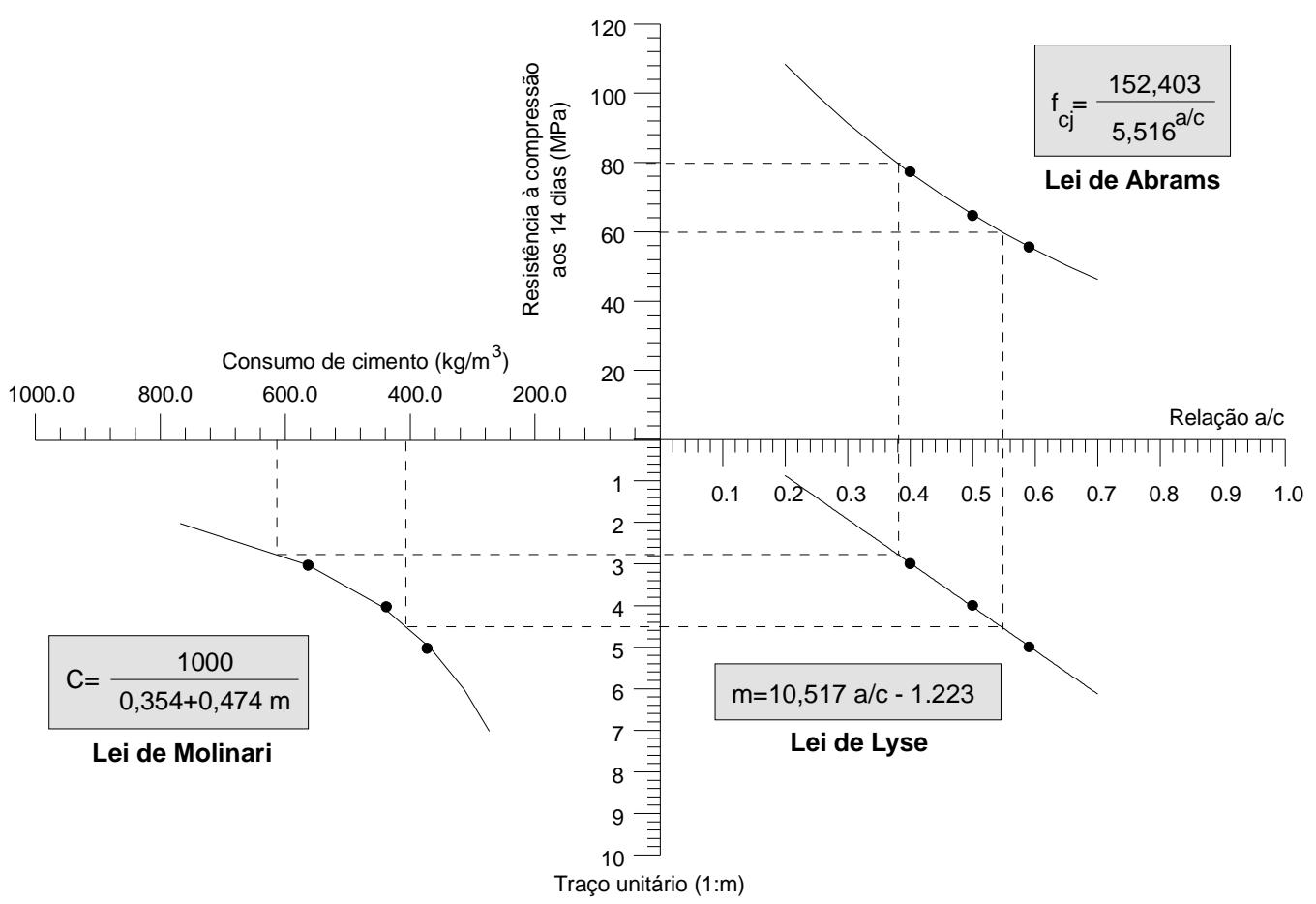

Figura 6.1 - Diagrama de dosagem para o concreto de alta resistência.

Tabela 6.2 - Estudo de dosagem para o concreto com resistência de 40MPa

\begin{tabular}{lcccc}
\hline \multirow{3}{*}{ Traço em massa } & Número & CAR-3,5 & CAR-5,0 & CAR-6,5 \\
\cline { 2 - 5 } & $1: \mathrm{m}$ & $1: 3,5$ & $1: 5,0$ & $1: 6,5$ \\
\cline { 2 - 5 } & $1: \mathrm{a}: \mathrm{p}$ & $1: 1,30: 2,20$ & $1: 2,06: 2,94$ & $1: 2,83: 3,67$ \\
\hline Teor de argamassa (\%) & 51 & 51 & 51 \\
Consumo de cimento $\left(\mathrm{kg} / \mathrm{m}^{3}\right)$ & 505,00 & 378,75 & 303,03 \\
Relação água cimento & 0,45 & 0,60 & 0,75 \\
Abatimento no tronco de cone (mm) & 205 & 200 & 200 \\
Água/materiais secos & 10 & 10 & 10 \\
Resistência aos 14 dias (MPa) & 51,7 & 39,3 & 28,7 \\
\hline
\end{tabular}




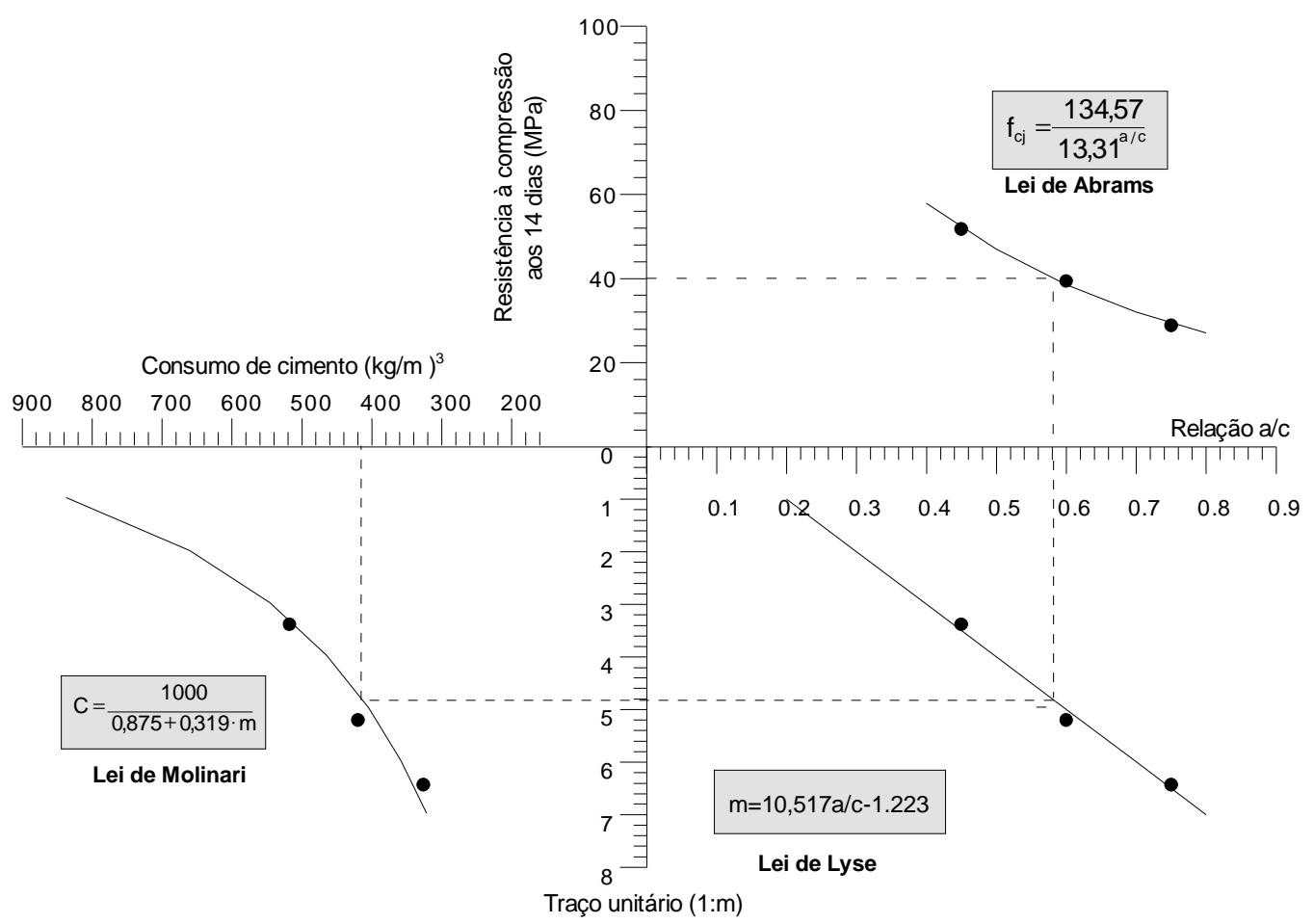

Figura 6.2 - Diagrama de dosagem para o concreto de resistência usual.

\subsubsection{Fibra de aço}

Banthia e Trottier (1994) avaliaram o comportamento da tensão de arrancamento de fibras metálicas com diferentes geometrias e inclinações em três matrizes de concreto com resistências de $40 \mathrm{MPa}, 52 \mathrm{MPa}$ e $85 \mathrm{MPa}$. Neste estudo, os autores utilizaram fibras de aço com extremidades com gancho e propriedades mecânicas e geométricas semelhantes às encontradas no Brasil, fabricadas pela N.V. BEKAERT S.A.. Os autores obtiveram que a resistência de aderência dessas fibras para a matriz de concreto com resistência de $52 \mathrm{MPa}$ era $4,81 \mathrm{MPa}$ e para a matriz com resistência $85 \mathrm{MPa}$ era 5,10MPa. Desse modo, utilizando a equação Eq.(3.1), a resistência à tração das fibras de aço, fornecidas pela N.V. BEKAERT S.A. e igual a $\sigma_{f u}=1015 \mathrm{MPa}$, e as resistências de aderência obtidas por Banthia e Trottier (1994), podem-se estimar os fatores de forma ideais das fibras para a máxima ductilidade para os concretos de altas resistências com $60 \mathrm{MPa}$ e $80 \mathrm{MPa}$, que são: 105 e 99, respectivamente. 
Como já mencionado, o ACI (1993) sugere que o diâmetro máximo do agregado graúdo não seja superior a $19 \mathrm{~mm}$ e que as fibras devam ter comprimento equivalente a pelo menos duas vezes o diâmetro do agregado, isto é, $38 \mathrm{~mm}$.

Buscaram-se, no mercado brasileiro, fibras de aço com fatores de forma e comprimento mínimo das fibras semelhantes aos valores acima mencionados; contudo, fibras com essas características não foram encontradas. Desse modo, optou-se pelas fibras que apresentassem características geométricas próximas às exigidas. Sendo assim, foi utilizada a RC-80/60-CN, de fabricação da N.V. BEKAERT S.A., com fator de forma igual a 80, seção transversal circular com $\phi_{f}=0,75 \mathrm{~mm}$, comprimento de $60 \mathrm{~mm}$ e ganchos nas extremidades.

\subsubsection{Barras de aço das armaduras}

Foram utilizadas barras de aço com diâmetro de $12,5 \mathrm{~mm}$, para compor a armadura longitudinal, e de $6,3 \mathrm{~mm}$, para a armadura transversal. Três amostras de $80 \mathrm{~cm}$ de comprimento, de cada diâmetro, foram coletadas para ensaio de tração uniaxial. Os corpos-de-prova foram pesados em balança com precisão de $0,01 \mathrm{~g}$, tiveram o comprimento medido e, em seguida, foram calculados as áreas transversais e os respectivos diâmetros, considerando a massa específica do aço igual a $7850 \mathrm{~kg} / \mathrm{m}^{3}$. Após o cálculo dos diâmetros, os corpos-de-prova foram instrumentados com clip gage e ensaiados em uma máquina universal de ensaios. As propriedades mecânicas das armaduras são apresentadas na Tabela 6.3, e os diagramas tensão vs. deformação dos aços com 6,3mm e 12,5mm, nas Figura 6.3 e Figura 6.4, respectivamente.

Tabela 6.3 - Propriedades físicas e mecânicas dos corpos-de-prova das armaduras

\begin{tabular}{rcccc}
\hline Aço & Área $-S_{d}\left(\mathrm{~cm}^{2}\right)$ & $\phi_{s}-S_{d}(\mathrm{~mm})$ & $E_{s}-S_{d}(\mathrm{GPa})$ & $f_{y}-S_{d}(\mathrm{MPa})$ \\
\hline$\phi$ de 0,63 & $0,312-0,002$ & $0,630-0,002$ & $200,867-4,141$ & $655,900-14,508$ \\
$\phi$ de 1,25 & $1,192-0,006$ & $1,231-0,003$ & $197,75-15,226$ & $597,533-13,800$ \\
\hline
\end{tabular}

Nota: $S_{d}$ é o desvio padrão da amostra de 3 amostras; $\phi_{s}$ é o diâmetro da barra de aço; $E_{s}$ é o módulo de elasticidade do aço e $f_{y}$ é a tensão de escoamento do aço. 


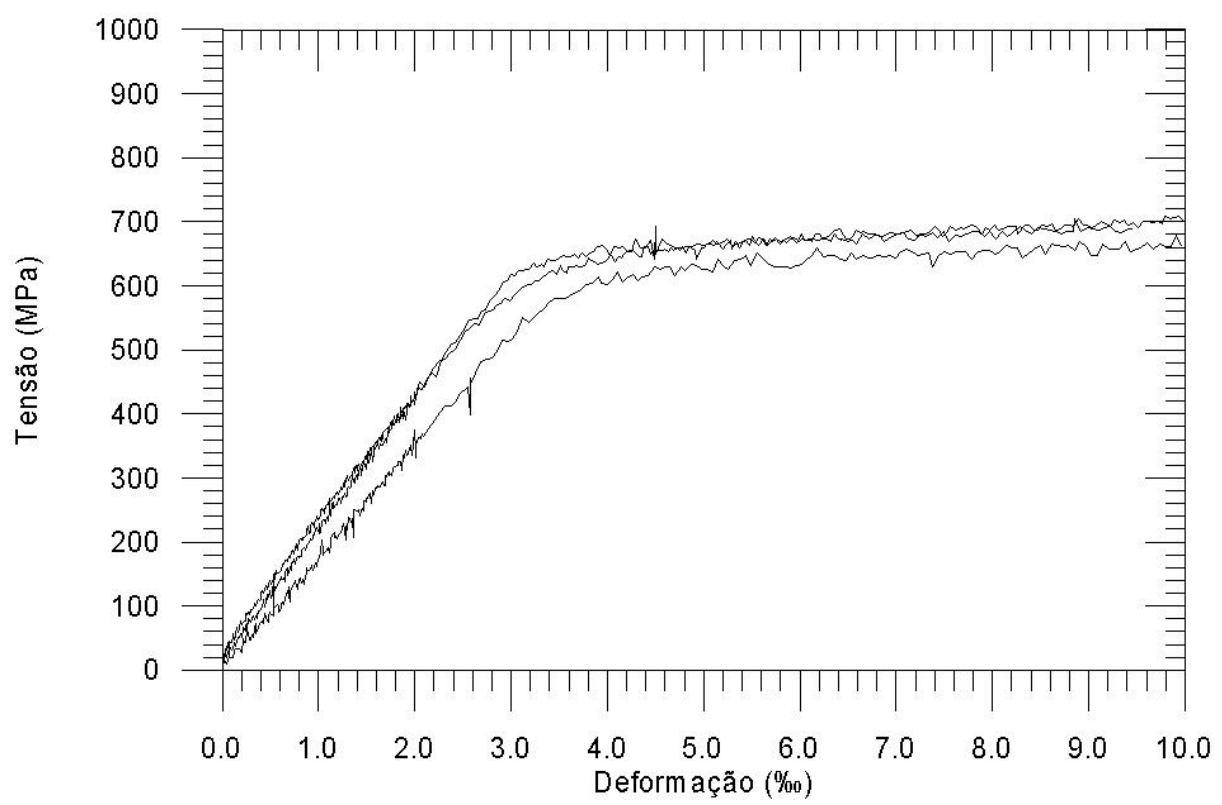

Figura 6.3 - Diagrama tensão vs. deformação do aço com diâmetro de 6,3mm

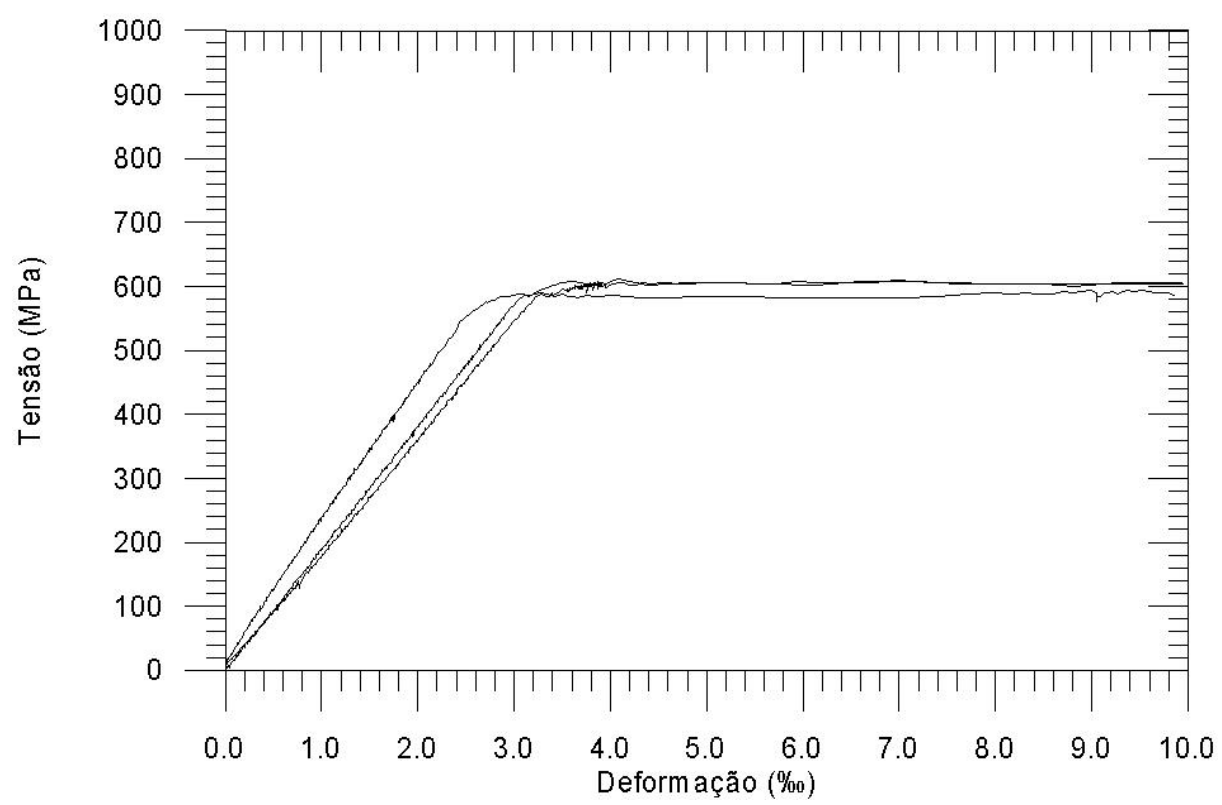

Figura 6.4 - Diagrama tensão vs. deformação do aço com diâmetro de 12,5mm

\subsection{METODOLOGIA EMPREGADA}

\subsubsection{Condições de contorno dos pilares}

A principal dificuldade na execução dos ensaios de pilares submetidos à compressão excêntrica reside na obtenção das condições de contorno ideais, capazes de permitir rotações livres nas extremidades dos pilares e a aplicação precisa de momentos ou excentricidades de carregamento. No caso do ensaio de pilares de concreto de alta resistência, esse problema se agrava em função da 
elevada intensidade de força exigida, da ordem de $3000 \mathrm{kN}$. Na literatura pesquisada, foram encontradas basicamente cinco metodologias para o ensaio de pilares à compressão excêntrica, as quais foram desenvolvidas e/ou aprimoradas por Hognestad et alli (1955), Sturman et alli (1965), Ibrahim e MacGregor (1996), Karsan e Jirsa (1970) e Lloyd e Rangan (1996). Após análise detalhada de cada metodologia, optou-se por aquela apresentada por Lloyd e Rangan (1996), em virtude da facil exeqüibilidade e à elevada precisão.

A metodologia de Lloyd e Rangan (1996) é uma aprimoração da apresentada por Sturman et alli (1965) e consiste em submeter os pilares a uma força pontual excêntrica, por meio de dois sistemas especiais, de rótulas unidirecionais, dispostos nas extremidades dos pilares e denominados de knife bearings (apoio de faca) (ver Figura 6.5). Depois de contatado, o Professor B. Vijaya Rangan, da School of Civil Engineering da University of Technology Perth, Austrália, prontamente cedeu o projeto dos sistemas de apoios, no qual foram realizadas pequenas alterações para que os mecanismos pudessem ser acoplados à máquina de ensaios Instron, existente no Laboratório de Estruturas do SET - EESC - USP, e para que eles se adequassem aos aços brasileiros.

As rótulas foram projetadas para uma força de $2000 \mathrm{kN}$. Os aços que as compõem são o aço 1020, para as peças 3 a 6, e o aço VC - 131, para as peças 1 e 2 (ver Figura 6.5). As peças 1 e 2 foram tratadas termicamente, atingindo dureza de 62 na escala Rockwell e uma resistência à tração mínima de $2090 \mathrm{MPa}$. As tensões nas peças 1 e 2 foram verificadas, utilizando-se Funções de Tensões e a Teoria da Elasticidade para sólidos de revolução, apresentada por Timoshenko (1970). Por meio da formulação referenciada, obteve-se que as máximas tensões para a força de projeto, eram: $\sigma_{z}=-505 \mathrm{MPa}, \sigma_{r}=-359 \mathrm{MPa}, \sigma_{\theta}=-359 \mathrm{MPa}$ e $\tau_{\max }=179 \mathrm{MPa}$, valores bem inferiores à resistência do material. Da Figura 6.6 à Figura 6.11, apresentam-se as dimensões das peças que compõem os mecanismos de apoio. O sistema pode ser montado de forma a gerar excentricidade de força entre $0 \mathrm{~cm}$ e $6 \mathrm{~cm}$, e permite rotações livres da ordem de $15^{\circ}$ para cada lado.

As rótulas acima discutidas foram apenas utilizadas na fase dois do programa experimental. $\mathrm{Na}$ fase um, os pilares tiveram a face inferior apoiada na 
base da máquina de ensaio (sem rotulação) e a face superior apoiada à rótula bidirecional da própria máquina de ensaio.
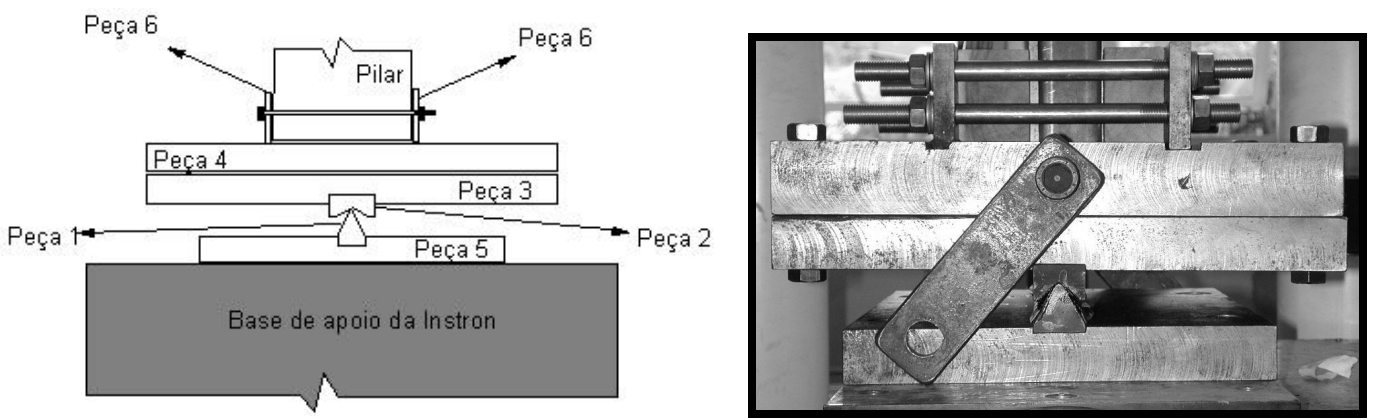

Figura 6.5 - Características da montagem do mecanismo de apoio
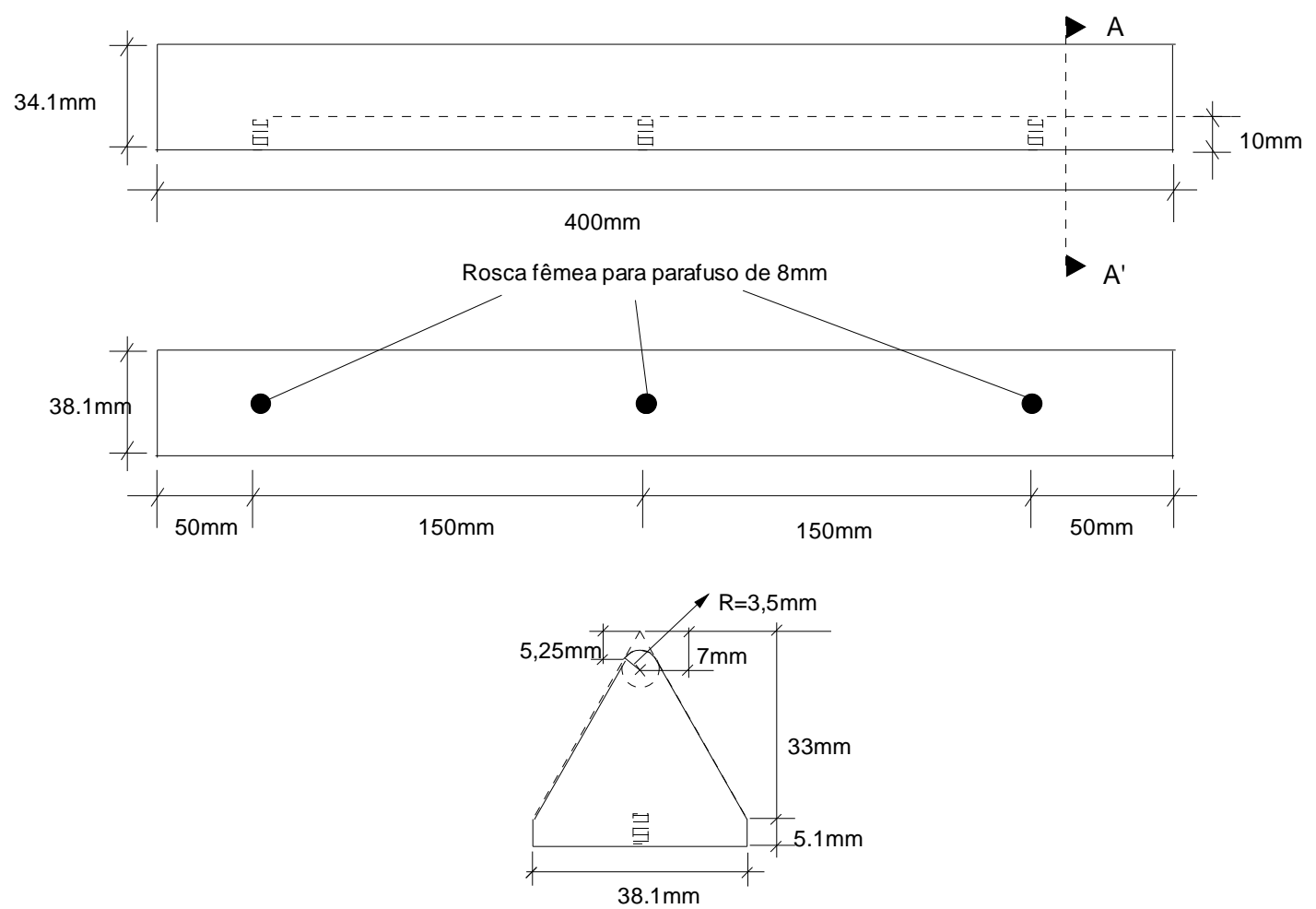

Corte A-A'

Figura 6.6 - Características do mecanismo de apoio - Peça 1 

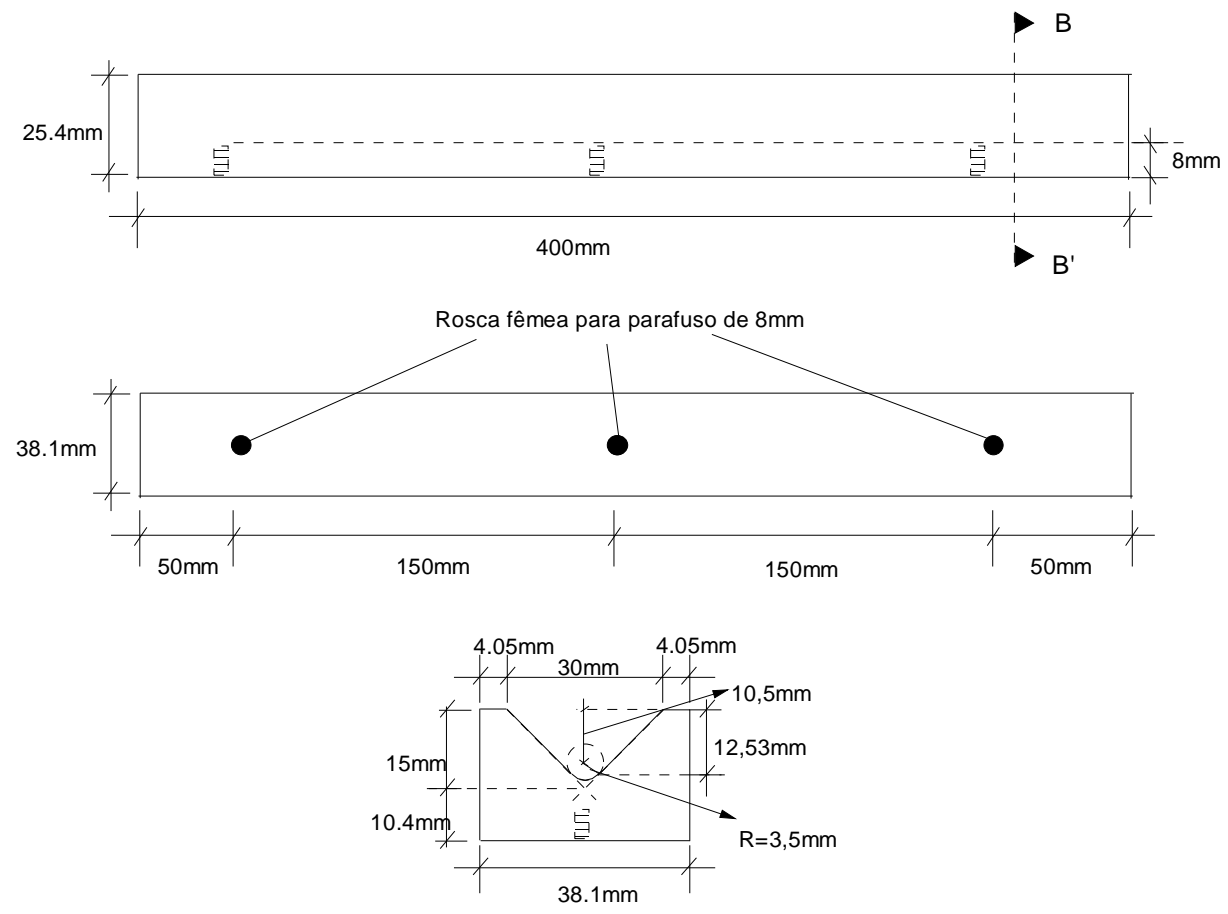

Corte B-B'

Figura 6.7 - Características do mecanismo de apoio - Peça 2
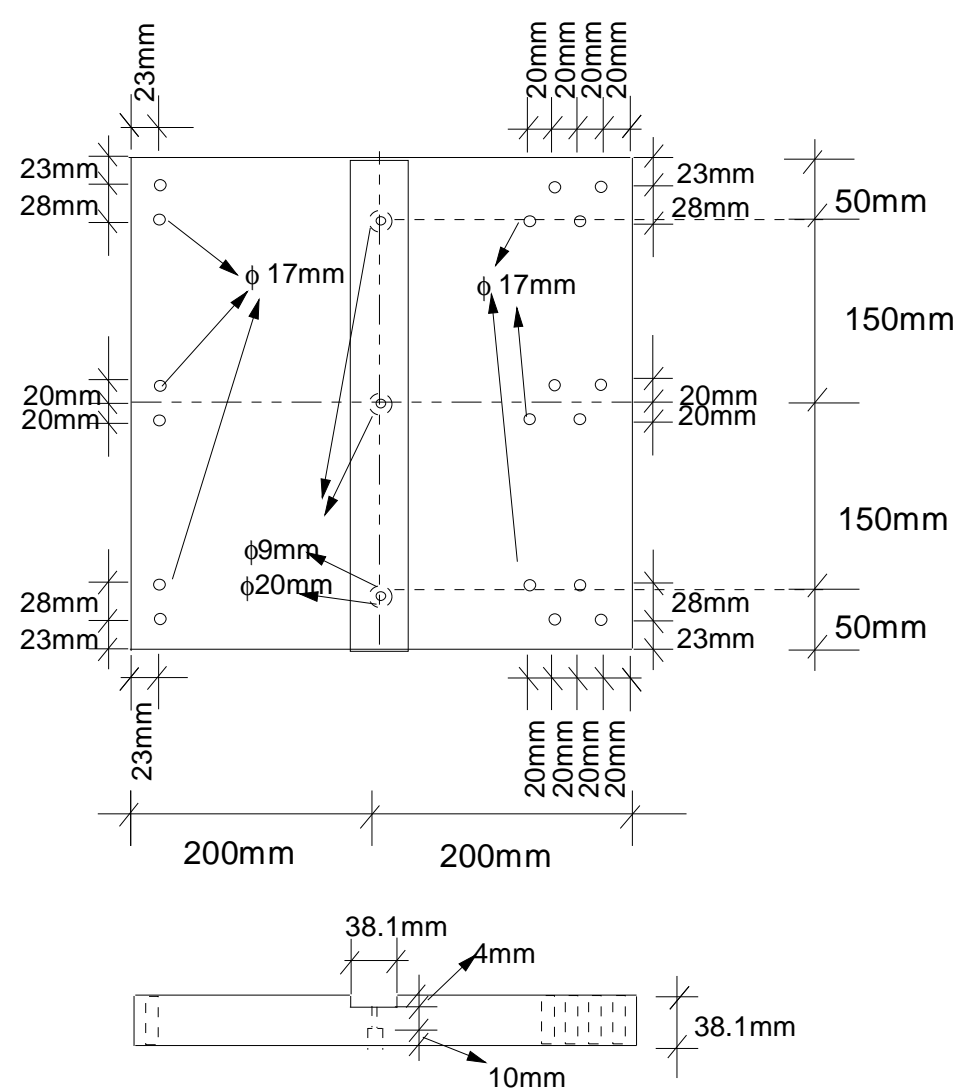

Figura 6.8 - Características do mecanismo de apoio - Peça 3 


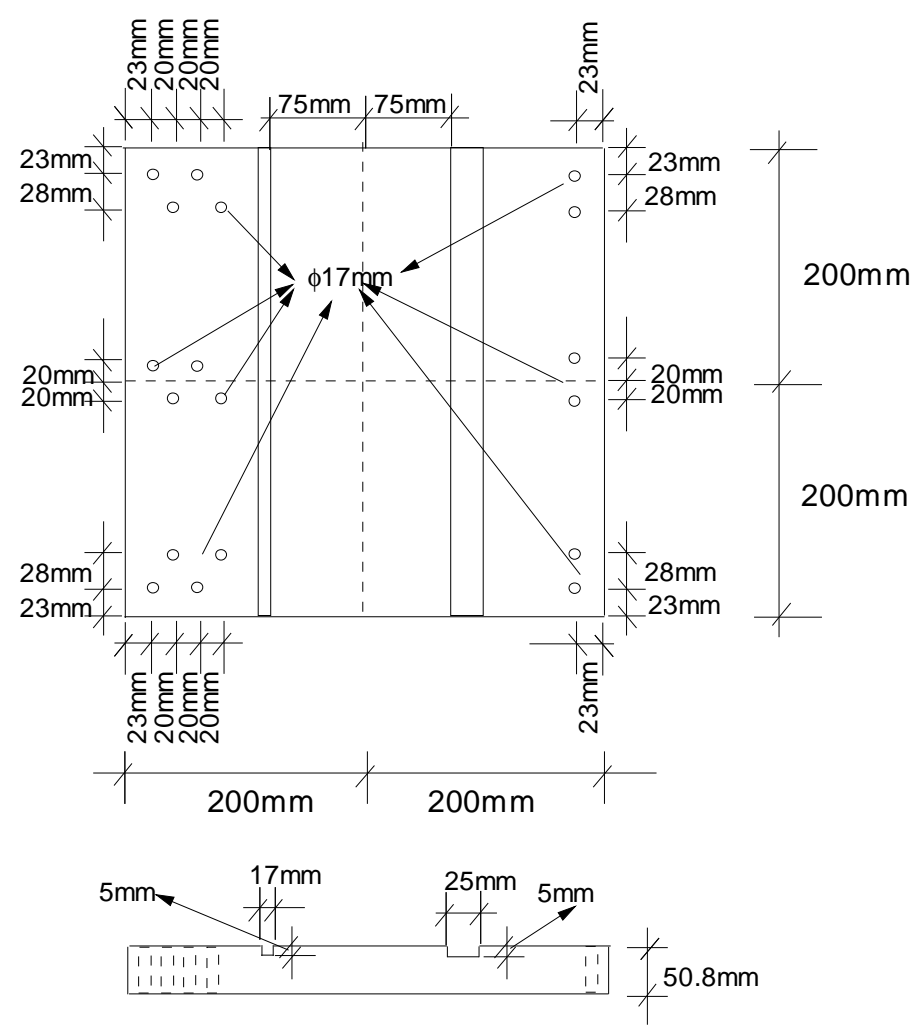

Figura 6.9 - Características do mecanismo de apoio - Peça 4
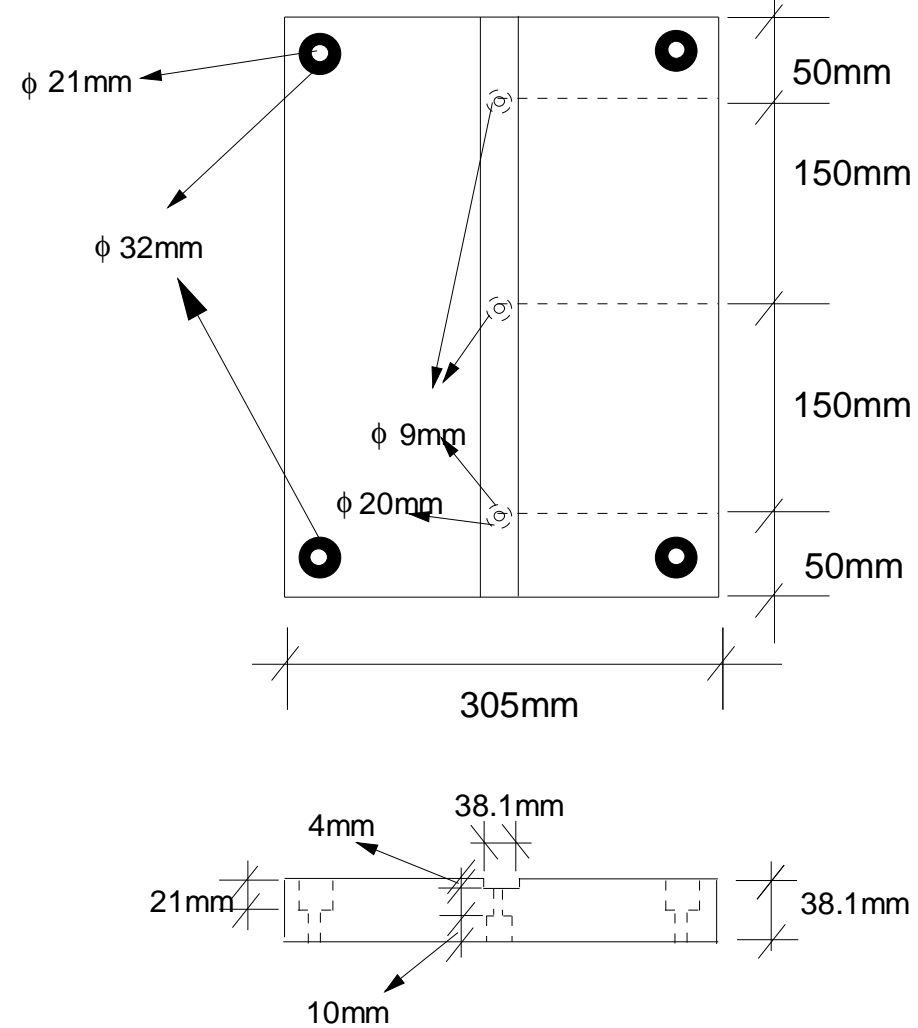

Figura 6.10 - Características do mecanismo de apoio - Peça 5 


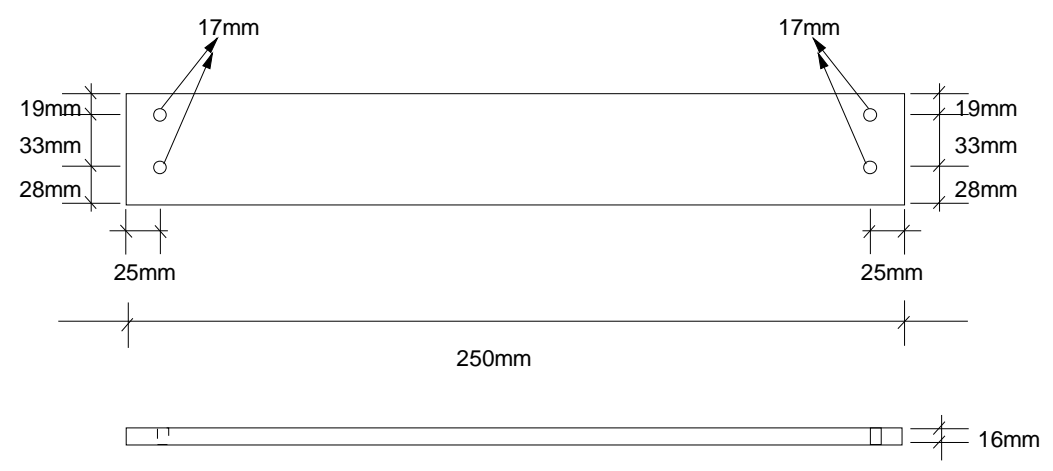

Figura 6.11 - Características do mecanismo de apoio - Peça 6

\subsubsection{Ensaios à compressão centrada}

A fase um consistiu no estudo de pilares de CAR com adição de fibras e/ou confinamento submetidos à compressão centrada. Nessa fase, foi investigada, experimentalmente, a variação da ductilidade do concreto em relação à taxa de adição de fibras e/ou ao confinamento. Foram ensaiados 40 prismas de concreto com dimensões de $50 \mathrm{~cm}$ de altura, seção transversal quadrada de $15 \mathrm{~cm} \times 15 \mathrm{~cm}$ e índice de esbeltez da ordem de 6. Dentre estes, 24 apresentavam a mesma armadura longitudinal, que era composta por 4 barras de $12,5 \mathrm{~mm}$ de diâmetro. Três taxas de adição de fibras foram investigadas: $0,0 \%, 0,5 \%$ e 1,0\%; duas resistências de concreto, $60 \mathrm{MPa}$ e $80 \mathrm{MPa}$; e duas taxas de armadura transversal, $0,32 \%$ e $0,96 \%$. Doze pilares foram moldados sem a presença das armaduras transversal e longitudinal, sendo dois pilares para cada combinação de resistência e taxa de adição de fibras. Finalmente, quatro pilares foram moldados com concreto com resistência de $40 \mathrm{MPa}$, sendo dois deles sem armaduras e dois com quatro barras de $12,5 \mathrm{~mm}$ de diâmetro, compondo a armadura longitudinal, e estribos de dois ramos de $6,3 \mathrm{~mm}$ de diâmetros e espaçados a cada $15 \mathrm{~cm}$, a transversal.

Os pilares foram nomeados segundo suas características físicas de $P-N-X-$ $Y$-Z, onde $N$ corresponde ao número da réplica, $X$ à resistência do concreto, $Y$ ao espaçamento entre estribos e $Z$ à taxa volumétrica de adição de fibras. Deste modo, o pilar com o código P160150, significa que é o primeiro pilar com $60 \mathrm{MPa}$ de resistência do concreto, com estribos espaçados à cada $15 \mathrm{~cm}$ e $0 \%$ de adição de fibras. Na Tabela 6.4 apresentam-se a descrição física de todos os pilares ensaiados com os respectivos códigos. 
Tabela 6.4 - Características físicas dos pilares ensaiados à compressão centrada

\begin{tabular}{lcccccc}
\hline Código & $f_{c j}(\mathrm{MPa})$ & $b \times h(\mathrm{~cm})$ & Altura $(\mathrm{cm})$ & $\begin{array}{c}\text { Armadura } \\
\text { longitudinal }\end{array}$ & $\begin{array}{c}\text { Armadura } \\
\text { transversal }\end{array}$ & $V_{f}(\%)$ \\
\hline $\begin{array}{l}P 14015 \\
P 24015\end{array}$ & 40 & $15 \times 15$ & 50 & $4 \phi 12,5 \mathrm{~mm}$ & $\phi 6,3 \mathrm{~mm}-\mathrm{c} 15 \mathrm{~cm}$ & 0,0 \\
\hline $\begin{array}{l}P 160150 \\
P 260150\end{array}$ & 60 & $15 \times 15$ & 50 & $4 \phi 12,5 \mathrm{~mm}$ & $\phi 6,3 \mathrm{~mm}-\mathrm{c} 15 \mathrm{~cm}$ & 0,0 \\
\hline $\begin{array}{l}P 16050 \\
P 26050\end{array}$ & 60 & $15 \times 15$ & 50 & $4 \phi 12,5 \mathrm{~mm}$ & $\phi 6,3 \mathrm{~mm}-\mathrm{c} 5 \mathrm{~cm}$ & 0,0 \\
\hline $\begin{array}{l}P 1601505 \\
P 2601505\end{array}$ & 60 & $15 \times 15$ & 50 & $4 \phi 12,5 \mathrm{~mm}$ & $\phi 6,3 \mathrm{~mm}-\mathrm{c} 15 \mathrm{~cm}$ & 0,5 \\
\hline $\begin{array}{l}P 160505 \\
P 260505\end{array}$ & 60 & $15 \times 15$ & 50 & $4 \phi 12,5 \mathrm{~mm}$ & $\phi 6,3 \mathrm{~mm}-\mathrm{c} 5 \mathrm{~cm}$ & 0,5 \\
\hline $\begin{array}{l}P 160151 \\
P 260151\end{array}$ & 60 & $15 \times 15$ & 50 & $4 \phi 12,5 \mathrm{~mm}$ & $\phi 6,3 \mathrm{~mm}-\mathrm{c} 15 \mathrm{~cm}$ & 1,0 \\
\hline $\begin{array}{l}P 16051 \\
P 26051\end{array}$ & 60 & $15 \times 15$ & 50 & $4 \phi 12,5 \mathrm{~mm}$ & $\phi 6,3 \mathrm{~mm}-\mathrm{c} 5 \mathrm{~cm}$ & 1,0 \\
\hline $\begin{array}{l}P 180150 \\
P 280150\end{array}$ & 80 & $15 \times 15$ & 50 & $4 \phi 12,5 \mathrm{~mm}$ & $\phi 6,3 \mathrm{~mm}-\mathrm{c} 15 \mathrm{~cm}$ & 0,0 \\
\hline $\begin{array}{l}P 18050 \\
P 28050\end{array}$ & 80 & $15 \times 15$ & 50 & $4 \phi 12,5 \mathrm{~mm}$ & $\phi 6,3 \mathrm{~mm}-\mathrm{c} 5 \mathrm{~cm}$ & 0,0 \\
\hline $\begin{array}{l}P 1801505 \\
P 2801505\end{array}$ & 80 & $15 \times 15$ & 50 & $4 \phi 12,5 \mathrm{~mm}$ & $\phi 6,3 \mathrm{~mm}-\mathrm{c} 15 \mathrm{~cm}$ & 0,5 \\
\hline $\begin{array}{l}P 180505 \\
P 280505\end{array}$ & 80 & $15 \times 15$ & 50 & $4 \phi 12,5 \mathrm{~mm}$ & $\phi 6,3 \mathrm{~mm}-\mathrm{c} 5 \mathrm{~cm}$ & 0,5 \\
\hline $\begin{array}{l}P 180151 \\
P 280151\end{array}$ & 80 & $15 \times 15$ & 50 & $4 \phi 12,5 \mathrm{~mm}$ & $\phi 6,3 \mathrm{~mm}-\mathrm{c} 15 \mathrm{~cm}$ & 1,0 \\
\hline$P 28051$ & 80 & $15 \times 15$ & 50 & $4 \phi 12,5 \mathrm{~mm}$ & $\phi 6,3 \mathrm{~mm}-\mathrm{c} 5 \mathrm{~cm}$ & 1,0 \\
\hline $\begin{array}{l}P 18051 \\
P\end{array}$ & 150 & 50 & 50 & 50 \\
\hline
\end{tabular}

De cada traço, foram retirados nove corpos-de-prova cilíndricos, para obtenção da curva tensão vs. deformação do concreto. Tais curvas foram posteriormente confrontadas com as obtidas a partir dos pilares prismáticos sem armadura. Junto às cabeças dos pilares foi disposta uma armadura de fretagem, composta por estribos de dois ramos de $6,3 \mathrm{~mm}$ de diâmetro, espaçados a cada 2,25cm. Na Figura 6.12, são apresentados os detalhes da armadura longitudinal e transversal dos modelos analisados.

Os pilares foram concretados três a três, na vertical, em fôrma de madeira compensada, escorada por sarrafo de pinus, sendo o concreto lançado através da face superior das mesmas, e vibrado mecanicamente por meio de vibrador de agulha. Foram confeccionadas duas fôrmas para permitir a concretagem de 6 pilares por etapa, sendo dois com estribos a cada $15 \mathrm{~cm}$, dois a cada $5 \mathrm{~cm}$ e dois prismas sem armaduras. As concretagens foram divididas em 7 baterias de acordo com resistência do concreto e a taxa de fibra adicionada. Inicialmente foram 
moldados os pilares com concreto $C 60$ e $V_{f}=0,5 \%$. Entretanto, depois de endurecido o concreto esfarelava-se ao toque e a resistência à compressão não ultrapassou 10MPa aos 14dias. Não tendo uma explicação plausível para o que havia acontecido, a bateria foi refeita. Contudo, o problema persistiu, com o agravante que o concreto expandiu cerca de 5\%. Após uma analise detalhada, constatou-se que o cobrimento de zinco das fibras reagia quimicamente com o super-plastificante, liberando gazes que geravam a redução da resistência e a expansão do concreto. Com o problema identificado, trocou as fibras de aço com cobrimento de zinco, por fibras de aço com as mesmas características, contudo, sem esse cobrimento, solucionando-se assim o problema. Em seguida, seguiu-se o seguinte cronograma de moldagens: 1 - $C 60$ e $V_{f}=0 \%$; 2- $C 40$ e $V_{f}=0 \%$; 3- $C 60$ e $V_{f}=1 \%$; 4- $C 80$ e $V_{f}=0 \%$; 5- $C 80$ e $V_{f}=0,5 \%$; 6- $C 60$ e $V_{f}=0,5 \%$; e $7-C 80$ e $V_{f}=1 \%$.
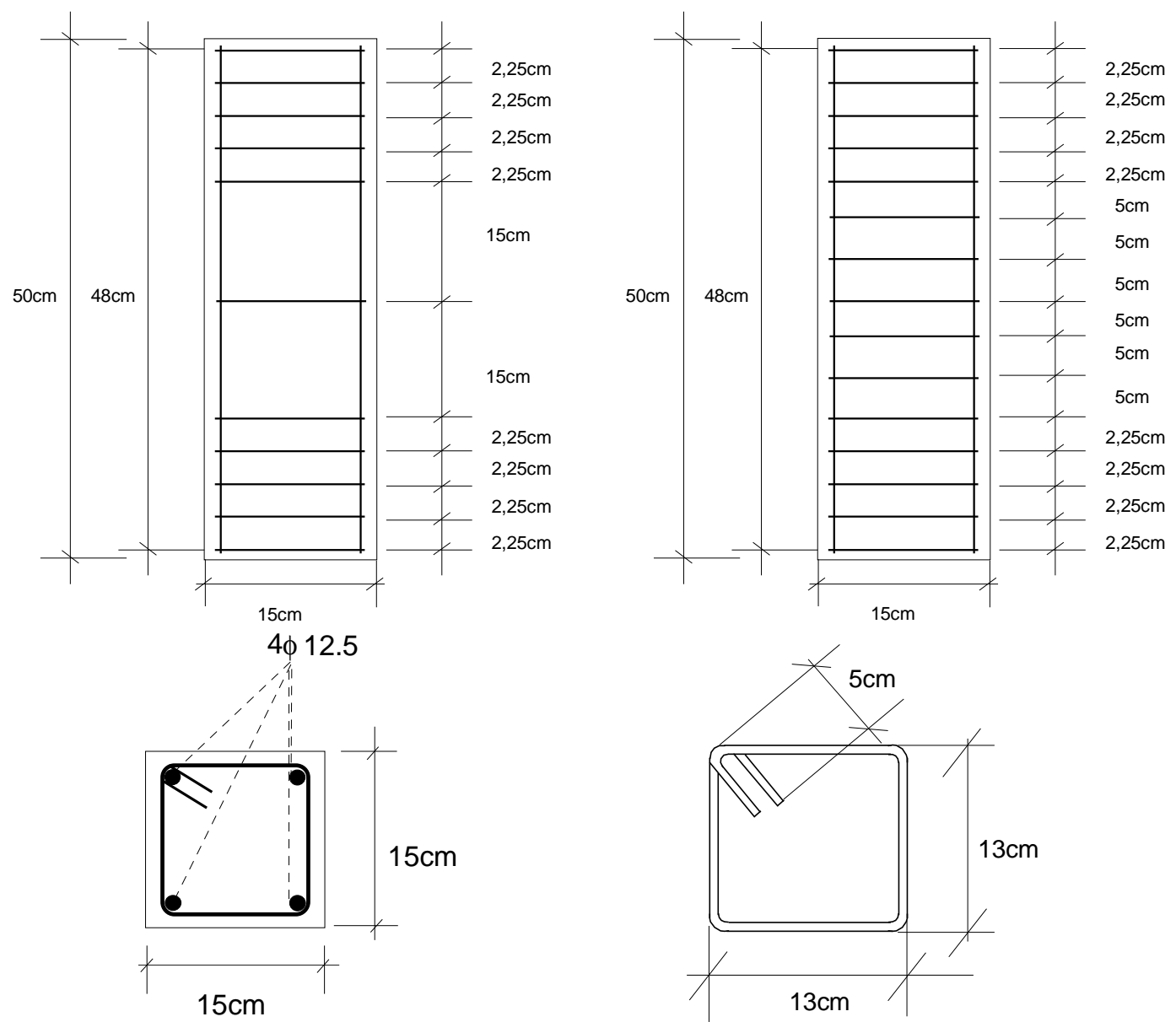

Figura 6.12 - Características geométricas das armaduras dos pilares 
Na Figura 6.13, são apresentadas as características das formas dos pilares ensaiados à compressão centrada. Após a concretagem, os pilares permaneceram nas fôrmas por um período de $24 \mathrm{~h}$. Durante esse período, foram dispostas nas extremidades expostas dos pilares espumas umidificadas. Após o período de $24 \mathrm{~h}$, os pilares foram desenformados e levados a uma câmara úmida, onde permaneceram por sete dias.
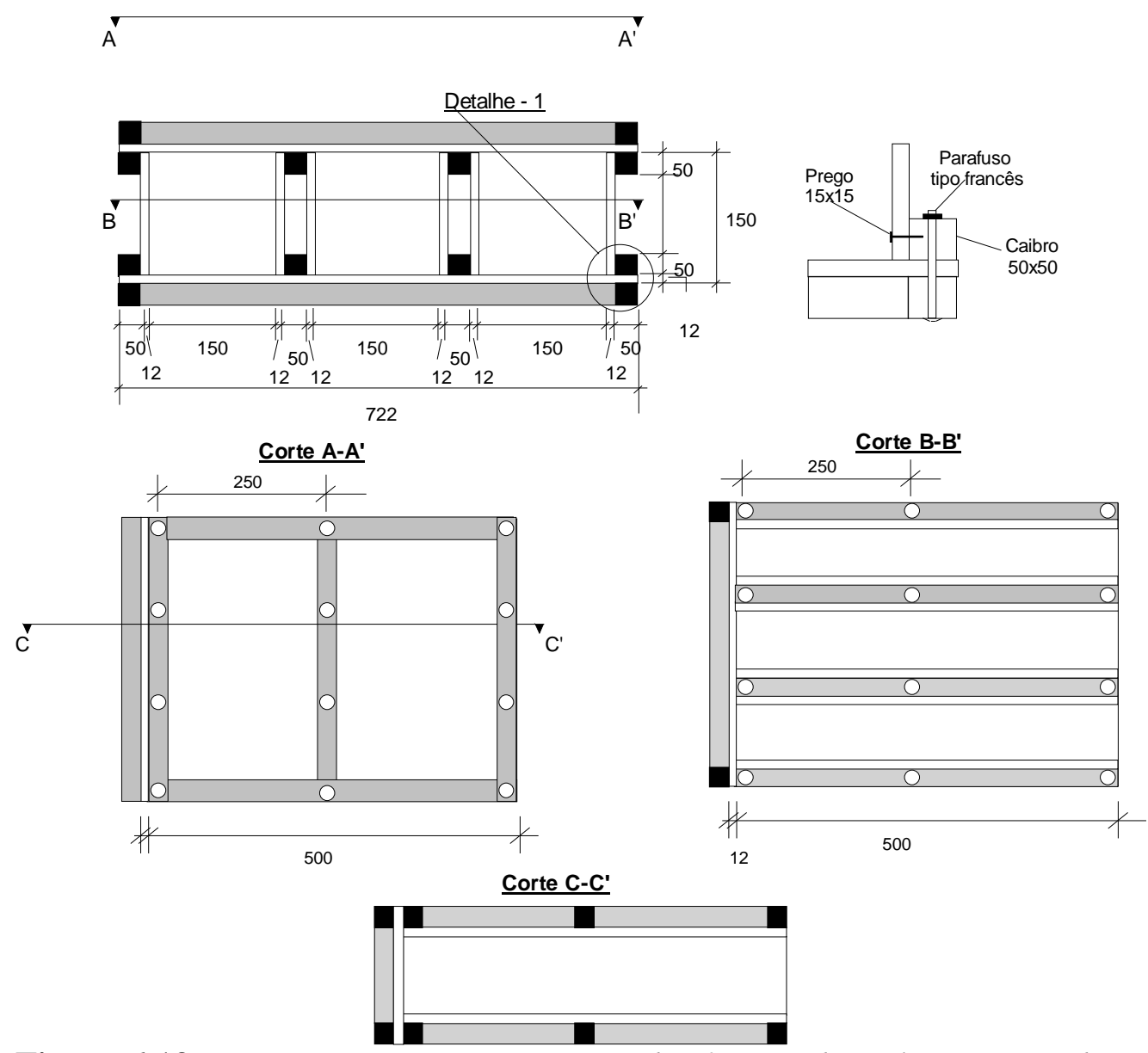

Figura 6.13 - Características geométricas das fôrmas dos pilares ensaiados à compressão centrada (medidas em $\mathrm{mm}$ )

Ao término do período de cura, os pilares foram retirados da câmara úmida e tiveram suas extremidades capeadas com enxofre, de modo a corrigir pequenas imperfeições e garantir o paralelismo das mesmas.

A instrumentação dos pilares foi composta por dois extensômetros de resistência, dispostos em dois ramos do estribo e localizados no ponto médio ao 
longo da altura do modelo; dois extensômetros de resistência posicionados em duas barras da armadura longitudinal, também localizados próximos à seção transversal média ao longo da altura do modelo; e 4 LVDTs posicionados um em cada face dos pilares, presos a colares de aço de alta resistência. Esses colares, além de servirem de suporte para a instrumentação, proveram um confinamento adicional às extremidades dos pilares. Os colares foram fixados aos pilares por meio de 4 parafusos de $19 \mathrm{~mm}$ de aço de alta resistência, utilizando-se torque elevado. Na Figura 6.14, são apresentados maiores detalhes da instrumentação utilizada.

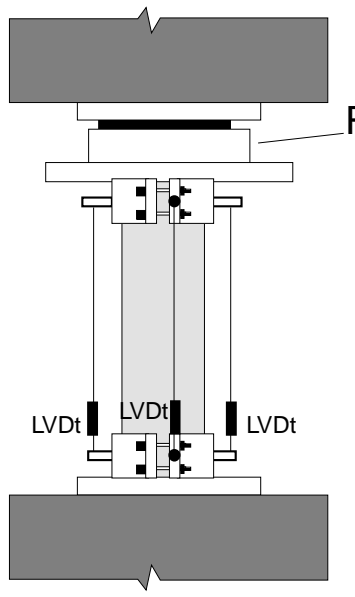

Vista Lateral

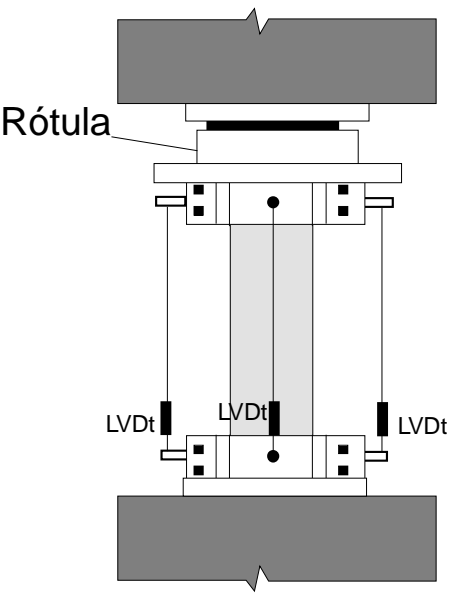

Vista Frontal

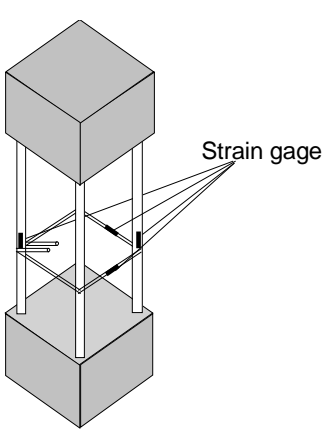

Detalhe da instrumentação da armadura

Figura 6.14 - Detalhes da instrumentação dos pilares ensaiados à compressão centrada

Os pilares foram ensaiados em um equipamento com controle de deslocamento. A força foi aplicada de modo quase estático, controlada através da deformação imposta ao pilar; esta correspondeu a aproximadamente $0,005 \mathrm{~mm} / \mathrm{m}$.s (RILEM TC 148-SSC, 2000) até o ponto correspondente a $70 \%$ da força máxima, localizado no trecho descendente do diagrama força vs. deformação e de $0,01 \mathrm{~mm} / \mathrm{m}$.s para o resto do ensaio. O ensaio era finalizado quando a deformação do pilar atingia cerca de 1,5\%. O tempo aproximado de duração de cada ensaio foi de 30min. As leituras dos instrumentos foram realizadas automaticamente na freqüência de 10Hz. Na Figura 6.15 apresentam-se detalhes do ensaio à compressão centrada. 


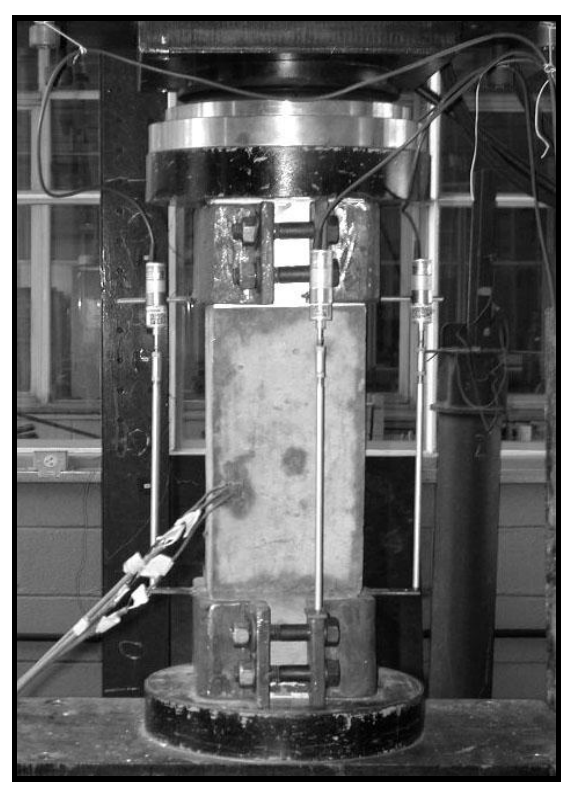

Figura 6.15 - Detalhes do ensaio à compressão centrada

\subsubsection{Ensaios à compressão excêntrica}

A fase dois consistiu do ensaio de 15 pilares submetidos à flexocompressão. Nessa fase, buscou-se avaliar a variação da ductilidade dos pilares de CAR em função da excentricidade de força, da taxa de adição de fibras e da armadura transversal. O concreto de alta resistência utilizado nessa fase apresentava 60MPa de resistência à compressão, e foram utilizadas duas taxas de fibras: $0 \%$ e a taxa de fibra ótima obtida nos ensaios de compressão centrada para o concreto com 60MPa. Os pilares apresentavam seção transversal quadrada de $15 \mathrm{~cm} \times 15 \mathrm{~cm}$ e altura de $170 \mathrm{~cm}$. Quando posicionados nos sistemas de apoios, os pilares apresentavam índice de esbeltez da ordem de 45. A armadura transversal foi composta por estribos de $6,3 \mathrm{~mm}$ espaçados a cada $15 \mathrm{~cm}$ e $5 \mathrm{~cm}$. A armadura longitudinal foi formada por 4 barras de $12,5 \mathrm{~mm}$ de diâmetro, e os pilares foram submetidos a excentricidades de $1 \mathrm{~cm}, 2 \mathrm{~cm}$ e $3 \mathrm{~cm}$. As excentricidades foram escolhidas de modo que, no primeiro caso a força permanecesse dentro do núcleo central, no segundo, a força ficasse próxima do limite do núcleo central, e no último, fora desta região. Foi analisado apenas um pilar para cada combinação de fatores.

Além dos 12 pilares de CAR, foram ensaiados à flexo-compressão três pilares com concreto de resistência média de 40MPa e mesma geometria. A 
armadura longitudinal desses pilares foi composta por 4 barras de $12,5 \mathrm{~mm}$ de diâmetro e armadura transversal por estribos de dois ramos de $6,3 \mathrm{~mm}$ de diâmetro, espaçados a cada $15 \mathrm{~cm}$ (ver Tabela 6.5). Foi disposta, nas extremidades dos pilares, uma armadura de fretagem formada por estribos de dois ramos de $6,3 \mathrm{~mm}$ de diâmetro, espaçados a cada $2,25 \mathrm{~cm}$. Na Figura 6.16, são apresentados maiores detalhes da armadura dos pilares.
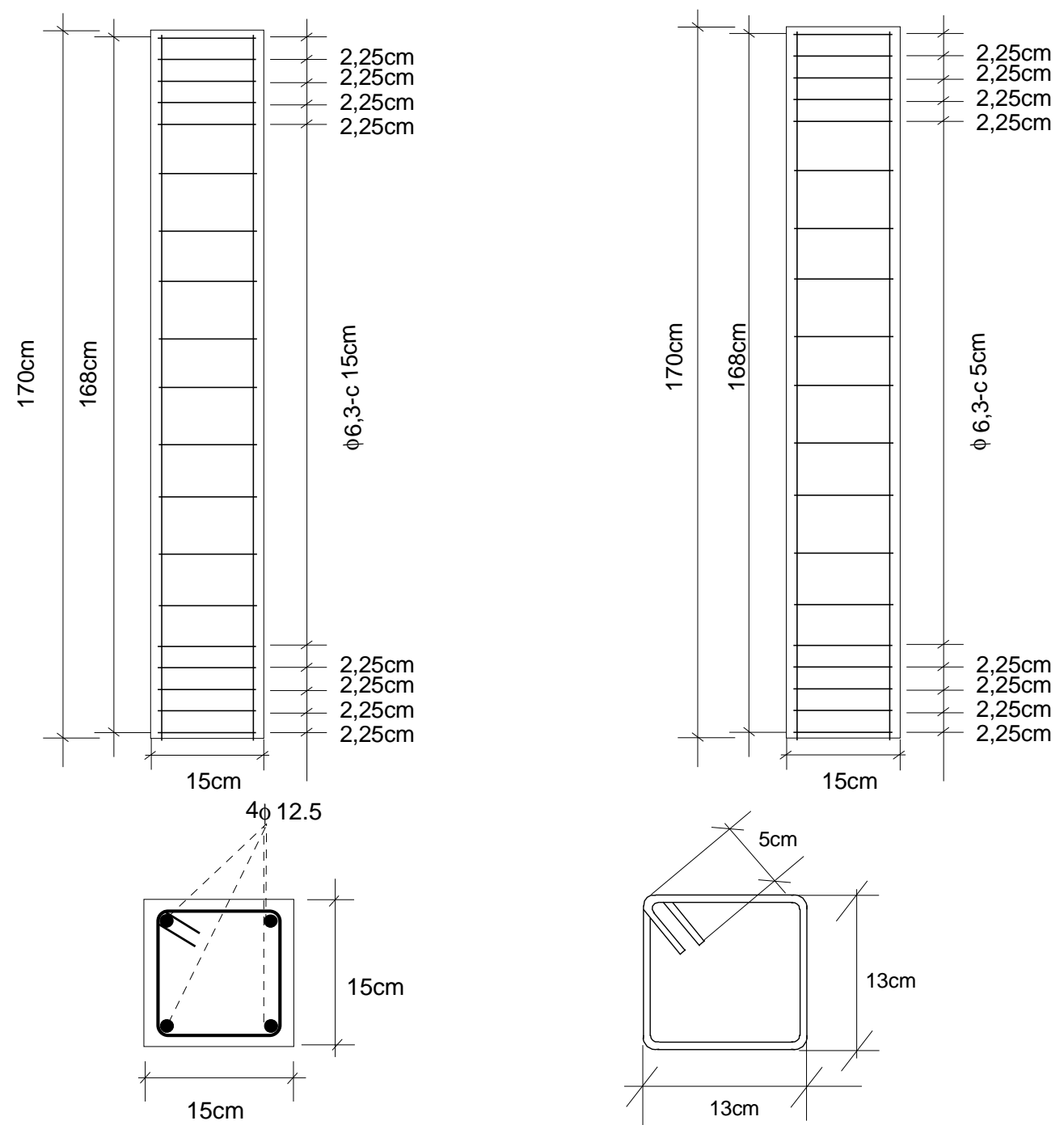

Figura 6.16 - Características das armaduras dos pilares ensaiados à flexo-compressão 
Seguindo o mesmo procedimento adotado para os pilares ensaiados à compressão centrada, nomearam-se os pilares ensaiados a compressão excêntrica segundo suas características físicas de $P-E-X-Y-Z$, onde $E$ corresponde a excentricidade de força imposta ao pilar, $X$ à resistência do concreto, $Y$ ao comprimento do espaçamento dos estribos e $Z$ à taxa volumétrica de adição de fibras. Deste modo, o pilar com o código P160150, significa que ele foi ensaiado com uma excentricidade de $1 \mathrm{~cm}$, possuía resistência do concreto igual a $60 \mathrm{MPa}$, estribos espaçados à cada $15 \mathrm{~cm}$ e $0 \%$ de adição de fibras. Na Tabela 6.5, apresentam-se a nomenclatura e as características de cada pilar.

Tabela 6.5 - Características físicas dos pilares ensaiados à compressão excêntrica

\begin{tabular}{lccccccc}
\hline Código & $\begin{array}{c}f_{c j} \\
(\mathrm{MPa})\end{array}$ & $\begin{array}{c}b \times h \\
(\mathrm{~cm})\end{array}$ & $\begin{array}{c}\text { Altura } \\
(\mathrm{cm})\end{array}$ & $\begin{array}{c}\text { Armadura } \\
\text { longitudinal }\end{array}$ & $\begin{array}{c}\text { Armadura } \\
\text { transversal }\end{array}$ & $V_{f}(\%)$ & $\begin{array}{c}e \\
(\mathrm{~cm})\end{array}$ \\
\hline$P 140$ & 40 & $15 \times 15$ & 170 & $4 \phi 12,5 \mathrm{~mm}$ & $\phi 6,3 \mathrm{~mm}-\mathrm{c} 15 \mathrm{~cm}$ & 0,0 & 1,0 \\
$P 240$ & 40 & $15 \times 15$ & 170 & $4 \phi 12,5 \mathrm{~mm}$ & $\phi 6,3 \mathrm{~mm}-\mathrm{c} 15 \mathrm{~cm}$ & 0,0 & 2,0 \\
$P 340$ & 40 & $15 \times 15$ & 170 & $4 \phi 12,5 \mathrm{~mm}$ & $\phi 6,3 \mathrm{~mm}-\mathrm{c} 15 \mathrm{~cm}$ & 0,0 & 3,0 \\
$P 160150$ & 60 & $15 \times 15$ & 170 & $4 \phi 12,5 \mathrm{~mm}$ & $\phi 6,3 \mathrm{~mm}-\mathrm{c} 15 \mathrm{~cm}$ & 0,0 & 1,0 \\
$P 260150$ & 60 & $15 \times 15$ & 170 & $4 \phi 12,5 \mathrm{~mm}$ & $\phi 6,3 \mathrm{~mm}-\mathrm{c} 15 \mathrm{~cm}$ & 0,0 & 2,0 \\
$P 360150$ & 60 & $15 \times 15$ & 170 & $4 \phi 12,5 \mathrm{~mm}$ & $\phi 6,3 \mathrm{~mm}-\mathrm{c} 15 \mathrm{~cm}$ & 0,0 & 3,0 \\
$P 16050$ & 60 & $15 \times 15$ & 170 & $4 \phi 12,5 \mathrm{~mm}$ & $\phi 6,3 \mathrm{~mm}-\mathrm{c} 5 \mathrm{~cm}$ & 0,0 & 1,0 \\
$P 26050$ & 60 & $15 \times 15$ & 170 & $4 \phi 12,5 \mathrm{~mm}$ & $\phi 6,3 \mathrm{~mm}-\mathrm{c} 5 \mathrm{~cm}$ & 0,0 & 2,0 \\
$P 36050$ & 60 & $15 \times 15$ & 170 & $4 \phi 12,5 \mathrm{~mm}$ & $\phi 6,3 \mathrm{~mm}-\mathrm{c5cm}$ & 0,0 & 3,0 \\
$P 1601505$ & 60 & $15 \times 15$ & 170 & $4 \phi 12,5 \mathrm{~mm}$ & $\phi 6,3 \mathrm{~mm}-\mathrm{c} 15 \mathrm{~cm}$ & 0,5 & 1,0 \\
$P 2601505$ & 60 & $15 \times 15$ & 170 & $4 \phi 12,5 \mathrm{~mm}$ & $\phi 6,3 \mathrm{~mm}-\mathrm{c} 15 \mathrm{~cm}$ & 0,5 & 2,0 \\
$P 3601505$ & 60 & $15 \times 15$ & 170 & $4 \phi 12,5 \mathrm{~mm}$ & $\phi 6,3 \mathrm{~mm}-\mathrm{c} 15 \mathrm{~cm}$ & 0,5 & 3,0 \\
$P 160505$ & 60 & $15 \times 15$ & 170 & $4 \phi 12,5 \mathrm{~mm}$ & $\phi 6,3 \mathrm{~mm}-\mathrm{c} 5 \mathrm{~cm}$ & 0,5 & 1,0 \\
$P 260505$ & 60 & $15 \times 15$ & 170 & $4 \phi 12,5 \mathrm{~mm}$ & $\phi 6,3 \mathrm{~mm}-\mathrm{c} 5 \mathrm{~cm}$ & 0,5 & 2,0 \\
$P 360505$ & 60 & $15 \times 15$ & 170 & $4 \phi 12,5 \mathrm{~mm}$ & $\phi 6,3 \mathrm{~mm}-\mathrm{c5cm}$ & 0,5 & 3,0 \\
\hline
\end{tabular}

Os pilares foram concretados três a três, na vertical, em fôrma de madeira compensada, escorada por sarrafo de pinus, sendo o concreto, também, lançado através da face superior das mesmas, e vibrado mecanicamente por meio de vibrador de agulha. Foi confeccionada apenas uma fôrma, e, em cada etapa, foram concretados 3 pilares por vez, sendo esta, reutilizada cinco vezes. Na Figura 6.17, são apresentadas as características das fôrmas dos pilares ensaiados à compressão excêntrica. Após a concretagem, os pilares permaneceram nas fôrmas por um período de 24horas. Durante esse período, foram dispostas espumas umidificadas nas extremidades expostas dos pilares. Ao término desse período, os pilares foram desenformados e tiveram suas extremidades capeadas com resina epoxídica. Em 
seguida, foram dispostos na horizontal, molhados e envoltos em lona plástica, onde permaneceram por mais 7 dias.
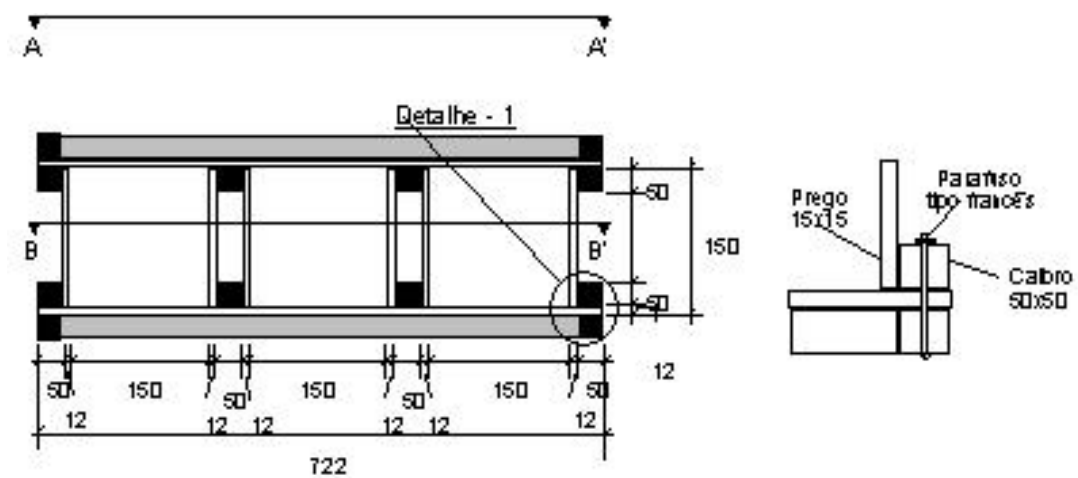

722

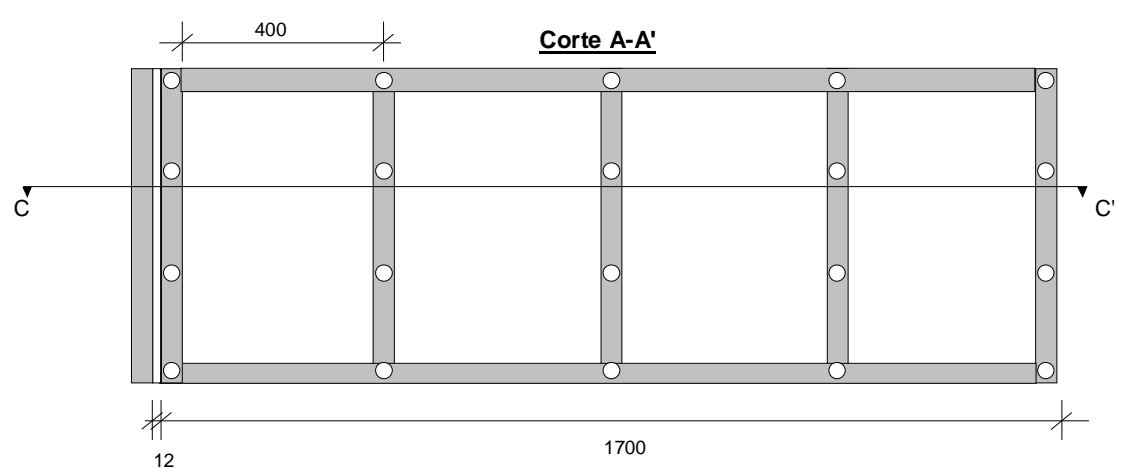

12400
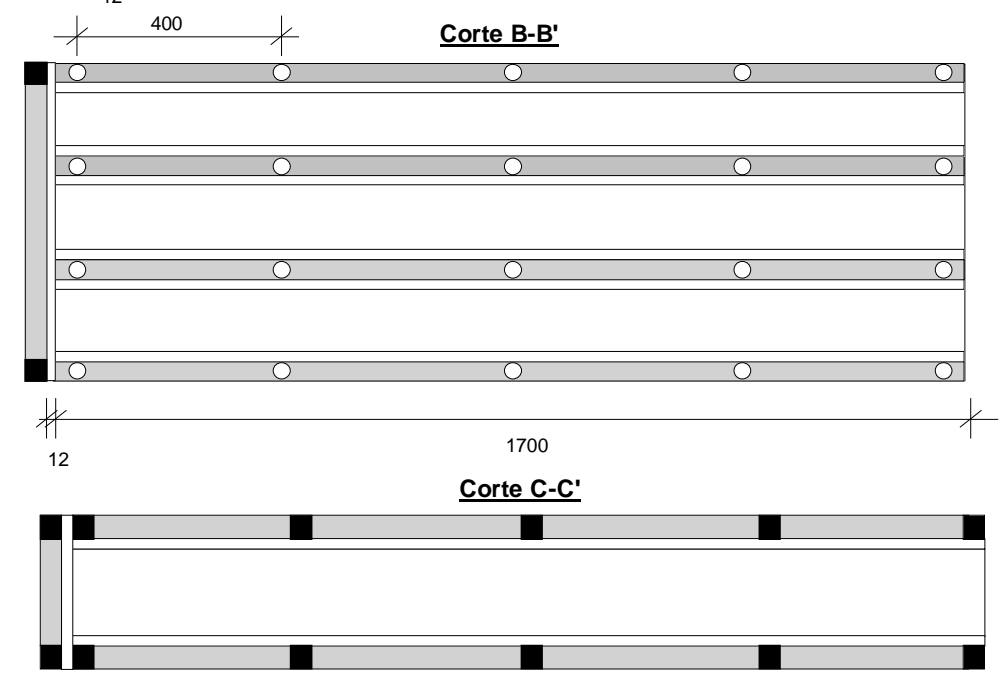

Figura 6.17 - Planta das fôrmas dos pilares ensaiados à flexo-compressão (medidas em $\mathrm{mm}$ )

A instrumentação dos pilares foi composta por 4 extensômetros de resistência dispostos no estribo localizado no ponto médio ao longo da altura do pilar, um em cada ramo do estribo. Ainda, foram dispostos 4 extensômetros de resistência nas barras que compõem a armadura longitudinal, sendo estes 
posicionados próximos ao estribo instrumentado. Um extensômetros de resistência foi posicionado na face mais comprimida dos pilares, próximo ao estribo instrumentado, com o intuito de se verificar a deformação do concreto no instante em que era atingida a força máxima resistida por esses elementos. Finalmente, dois LVDT foram posicionados verticalmente, conectados às rótulas, e três horizontalmente a uma das faces dos pilares. Os LVTD possuíam curso máximo de $100 \mathrm{~mm}$ e sensibilidade de $0,01 \mathrm{~mm}$. Na Figura 6.18, são apresentados maiores detalhes da instrumentação utilizada.

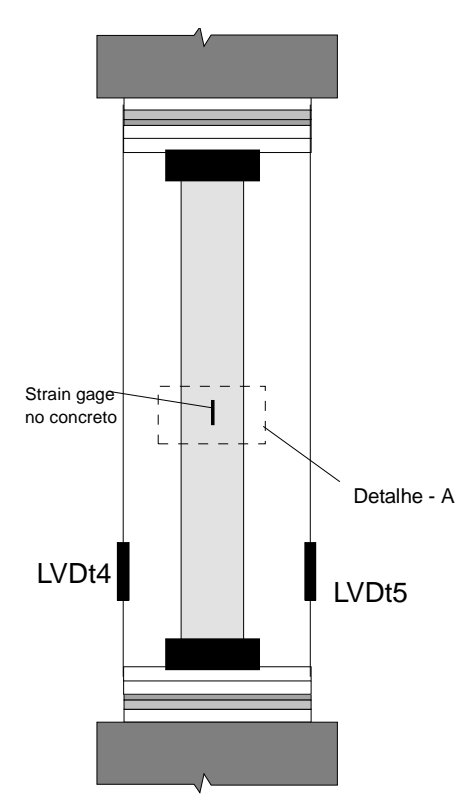

Vista Frontal

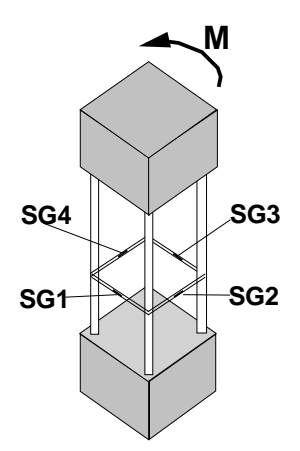

Detalhe - A

Extensômetros na armadura transversal

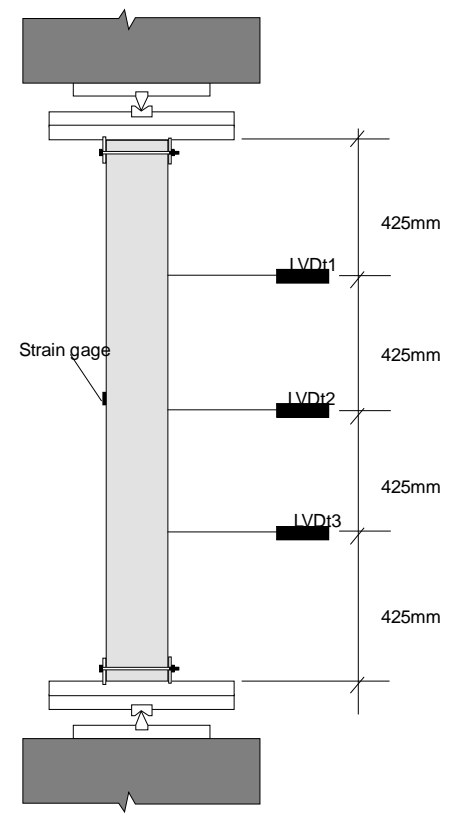

$\underline{\text { Vista Lateral }}$

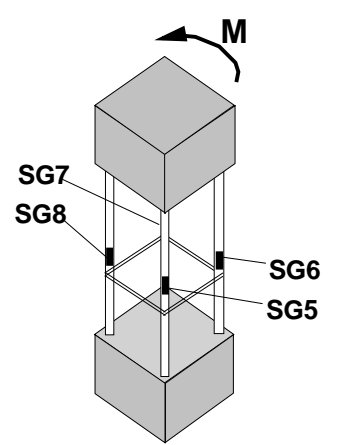

Detalhe - A

Extensômetros na armadura longitudinal

Figura 6.18 - Detalhes da instrumentação dos pilares ensaiados à flexocompressão 
Os procedimentos de ensaio foram semelhante aos dos pilares submetidos a compressão centrada. Utilizou-se o mesmo equipamento com controle de deslocamento, sendo o carregamento também aplicado de modo quase estático, controlado através da deformação imposta ao pilar. A taxa de deformação imposta foi de aproximadamente $0,005 \mathrm{~mm} / \mathrm{m}$.s até o ponto correspondente a $70 \%$ da carga máxima, localizado no trecho descendente do diagrama carga vs. deformação, e de $0,01 \mathrm{~mm} / \mathrm{m}$.s para o resto do ensaio. $O$ ensaio era finalizado quando o deslocamento lateral máximo atingia o valor de $100 \mathrm{~mm}$. A freqüência de leituras de toda a instrumentação foi realizada em $10 \mathrm{~Hz}$. O tempo aproximado de duração de cada ensaio foi de $60 \mathrm{~min}$.

Para os pilares ensaiados à compressão excêntrica, utilizaram-se os aparelhos de apoio descritos no item 6.3.1 deste capítulo. Os pilares foram fixados a estes aparelhos por meio de colares metálicos e quatro parafusos de alta resistência de 19mm de diâmetro. Na Figura 6.19 apresentam-se os detalhes do ensaio.
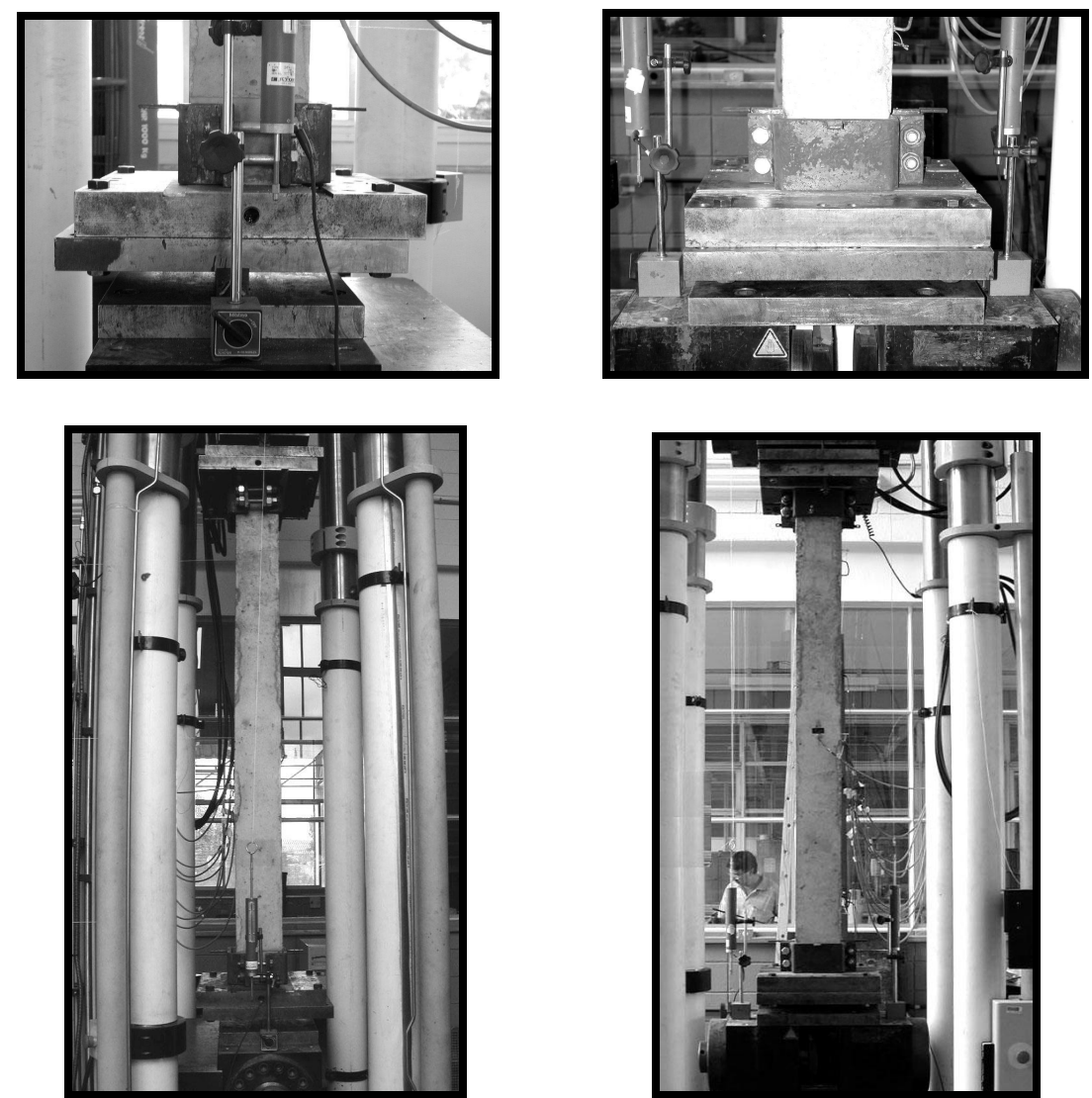

Figura 6.19 - Detalhes do ensaio à compressão excêntrica 


\section{ANÁLISE E DISCUSSÃO DOS RESULTADOS DOS PILARES ENSAIADOS À COMPRESSÃO CENTRADA}

\subsection{CARACTERÍSTICAS DO CONCRETO}

\subsubsection{Comportamento geral}

Na Tabela 7.1, são apresentadas as características dos concretos utilizados na moldagem dos pilares. Todos os concretos apresentaram elevada trabalhabilidade e fácil moldagem. A adição de fibras metálicas correspondentes à taxa volumétrica de $1 \%$ reduziu o abatimento no tronco de cone em cerca de $50 \%$. Entretanto, não se observaram maiores dificuldades durante a moldagem, uma vez que, com a vibração, os concretos apresentaram elevada fluidez. Observou-se que o concreto $\operatorname{com} f_{c j}=80 \mathrm{MPa}$ com $V_{f}=1 \%$ perdeu trabalhabilidade rapidamente. Esse fato pode ter sido ocasionado pelas más condições atmosféricas do dia, quando se observou temperatura média de $33^{\circ} \mathrm{C}$ e umidade de $65 \%$, durante a concretagem dos pilares. A temperatura ambiente, durante as concretagens, variou entre $23^{\circ} \mathrm{C} \mathrm{e}$ $33^{\circ} \mathrm{C}$, e a umidade relativa do ar entre $68 \%$ e $80 \%$.

Tabela 7.1- Características dos concretos utilizados na moldagem dos pilares

\begin{tabular}{ccccccccc}
\hline $\begin{array}{c}\text { Concreto } \\
f_{c j}\end{array}$ & $\begin{array}{c}V_{f} \\
(\%)\end{array}$ & $\begin{array}{c}\text { Slump } \\
(\mathrm{mm})\end{array}$ & $\begin{array}{c}T \\
\left({ }^{\circ} \mathrm{C}\right)\end{array}$ & $\begin{array}{c}U \\
(\%)\end{array}$ & $\begin{array}{c}\gamma_{c} \\
\left(\mathrm{~kg} / \mathrm{m}^{3}\right)\end{array}$ & $\begin{array}{c}f_{c j 3} \\
(\mathrm{MPa})\end{array}$ & $\begin{array}{c}f_{c j 7} \\
(\mathrm{MPa})\end{array}$ & $\begin{array}{c}f_{\text {cjensaio }} \\
(\mathrm{MPa})\end{array}$ \\
\hline 40 & 0,0 & 190 & 23,0 & 68 & 2380 & 22,70 & 39,04 & 43,03 \\
60 & 0,0 & 145 & 23,5 & 80 & 2494 & 46,13 & 56,23 & 66,85 \\
60 & 0,5 & 100 & 24,5 & 76 & 2518 & 51,17 & 57,56 & 69,63 \\
60 & 1,0 & 70 & 24,0 & 75 & 2526 & 48,57 & 60,15 & 68,07 \\
80 & 0,0 & 120 & 25,0 & 71 & 2480 & 78,68 & 80,68 & 97,50 \\
80 & 0,5 & 100 & 26,0 & 74 & 2508 & 77,10 & 80,28 & 93,85 \\
80 & 1,0 & 65 & 33,0 & 65 & 2527 & 62,50 & 76,15 & 80,28 \\
\hline
\end{tabular}

Todos os concretos de alta resistência apresentaram massas específicas da ordem de $2500 \mathrm{~kg} / \mathrm{m}^{3}$, mesmo aqueles sem adição de fibras. Ainda, como esperado, a adição de fibras metálicas elevou os valores das massas específicas dos concretos. 
Dos nove corpos-de-prova cilíndricos moldados durante a concretagem, três foram ensaiados aos três dias, três aos sete dias e três no dia do ensaio dos pilares. Apenas os corpos-de-prova do dia do ensaio dos pilares foram ensaiados em equipamento com controle de deslocamento. Aos três dias os concretos apresentaram resistência média de cerca de $76 \%$ da resistência do concreto no dia do ensaio e, aos sete dias, de $86 \%$.

Por causa de avaria na máquina de ensaio, após a concretagem da segunda bateria de pilares, o cronograma dos ensaios teve que ser alterado. Deste modo, apenas os pilares com resistência do concreto de 40MPa foram ensaiado aos 14 dias, todos os outros foram ensaiados aos 23 dias. Conseqüentemente, observa-se que as resistências dos concretos nos dias dos ensaios apresentaram-se superiores às estabelecidas previamente.

Finalmente, observa-se que a adição de fibras não interferiu na resistência à compressão dos concretos. Observa-se, entretanto, que a resistência média à compressão do último concreto $\left(f_{c j}=80 \mathrm{MPa}\right.$ e $\left.V_{f}=1 \%\right)$ apresentou valor médio bem inferior aos dos outros concretos $\operatorname{com} f_{c j}=80 \mathrm{MPa}$. Esse fato, como já mencionado, pode ter sido ocasionado pelas condições atmosféricas durante a concretagem, que provocou uma rápida perda de trabalhabilidade do concreto e, possivelmente, micro-fissura em virtude da secagem rápida.

\subsubsection{Diagrama tensão vs. deformação do concreto}

Para a avaliação dos diagramas tensão de compressão vs. deformação de cada tipo de concreto, ensaiaram-se, com controle de deslocamento, três corposde-prova cilíndricos $15 \mathrm{~cm} \times 30 \mathrm{~cm}$ e dois prismas de concreto simples, com dimensões de $15 \mathrm{~cm} \times 15 \mathrm{~cm} \times 50 \mathrm{~cm}$. As deformações nos corpos-de-prova cilíndricos foram avaliadas por meio de três LVDT, com sensibilidade de $0,001 \mathrm{~mm}$, dispostos de forma triangular em pontos eqüidistantes, tendo como comprimento de avaliação todos os $30 \mathrm{~cm}$ da altura dos corpos-de-prova.

A metodologia utilizada para o ensaio dos prismas de concreto foi igual a utilizado para os pilares. Foram dispostos colares metálicos nas extremidades dos 
prismas, aos quais foram acoplados 4 LVDT com sensibilidade de 0,001mm, um em cada face. O comprimento de avaliação das deformações foi de $30 \mathrm{~cm}$. $\mathrm{Na}$ Figura 7.1, apresentam-se detalhes dos ensaios.
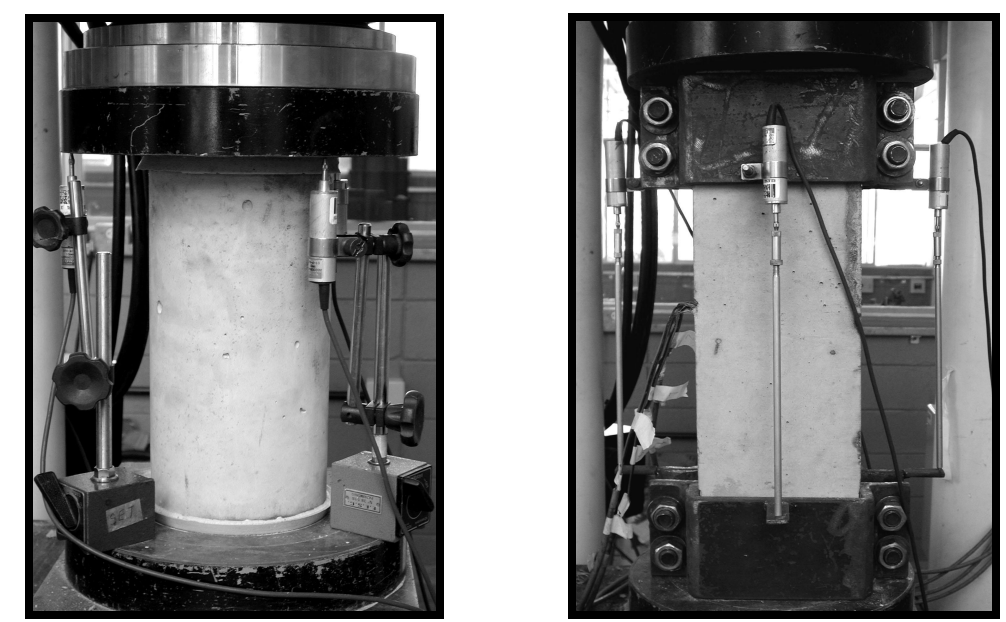

Figura 7.1 - Detalhes dos ensaios de compressão dos corpos-de-prova cilíndricos e do prisma de concreto simples

Durante o ensaio, tentou-se utilizar a taxa de deformação sugerida pelo RILEM TC 148-SSC (2000), de 0,005mm/m.s. Contudo, por causa da baixa rigidez da máquina de ensaio, os corpos-de-prova rompiam bruscamente logo após ser atingida a tensão máxima. Conseqüentemente, decidiu-se pela redução da taxa de deslocamento imposta, sendo utilizada a menor taxa permitida pelo equipamento de ensaio, que é de $0,001 \mathrm{~mm} / \mathrm{s}$. Essa taxa de deslocamento corresponde a uma taxa de deformação de $0,0033 \mathrm{~mm} / \mathrm{m}$.s e $0,002 \mathrm{~mm} / \mathrm{m}$.s para os corpos-de-prova cilíndricos e os prismas de concreto simples, respectivamente. Mesmo com a redução da velocidade de ensaio, não foi possível obter o trecho descendente do diagrama tensão vs. deformação de alguns concreto.

Para obtenção dos diagramas tensão vs. deformação de cada ensaio, adotou-se, como deformação do corpo-de-prova, a deformação média entre a aquelas calculadas com as leituras dos deslocamentos de cada LVDT.

Foram calculados dois diagramas tensão vs. deformação para cada concreto: um obtido por meio dos ensaios dos três corpos-de-prova cilíndricos e outro por meio dos ensaios dos dois prismas de concreto simples. Para tanto, 
utilizou-se regressão polinomial não-linear sobre os dados dos três corpos-deprova cilíndricos e sobre os dados dos dois prismas. Todas as curvas obtidas apresentaram coeficientes de correlação, $r^{2}$, superior a 93\%. Nas Figura 7.2 a Figura 7.8 apresentam-se os diagramas dos concreto obtidos com os corpos-deprova cilíndricos e os prismas de concreto simples.

Comparando-se os diagramas obtidos com os corpos-de-prova cilíndricos e os prismas, observam-se comportamentos diferenciados, principalmente nos trechos descendentes dos diagramas. Em todos os casos, as resistências dos prismas foram inferiores às dos cilíndricos, o que concorda com Leonhardt (1977a), o qual sugere que o coeficiente de correlação entre as resistências do prisma e do cilindro é da ordem de 0,92, quando ambas as esbeltezes do prisma $(h / b)$ e do cilíndrico $(h / d)$ são iguais a 2 . Observa-se, entretanto, que a esbeltez do prisma utilizado é igual a 3,33. Apesar deste fato, era esperado que o coeficiente de correlação entre os corpos-de-prova cilíndricos e os prismas utilizados fossem próximos ao valor sugerido pelo autor anteriormente citado, uma vez que os colares metálicos dispostos nas extremidades dos prismas geram um elevado grau de confinamento que compensa a maior esbeltez desses últimos.

Na Tabela 7.2 é apresentado os valores dos coeficientes de correlação obtidos para os diversos concretos. Observa-se que, para os concretos com resistência à compressão de $40 \mathrm{MPa}$ e $60 \mathrm{MPa}$, os valores dos coeficientes apresentaram-se muito próximos ao sugerido por Leonhardt (1977a). Todavia, para os concretos com resistência à compressão de $80 \mathrm{MPa}$, os valores dos coeficientes se apresentaram inferiores. Observa-se, ainda, que os concretos de $80 \mathrm{MPa}$ e taxas de adição de fibras de $0 \%$ e $1 \%$ apresentaram valores dos coeficientes de correlação quase semelhantes, da ordem de 0,85 , porém, o concreto com mesma resistência e taxa de adição de fibra de 0,5\% apresentou valor $12 \%$ inferior. 


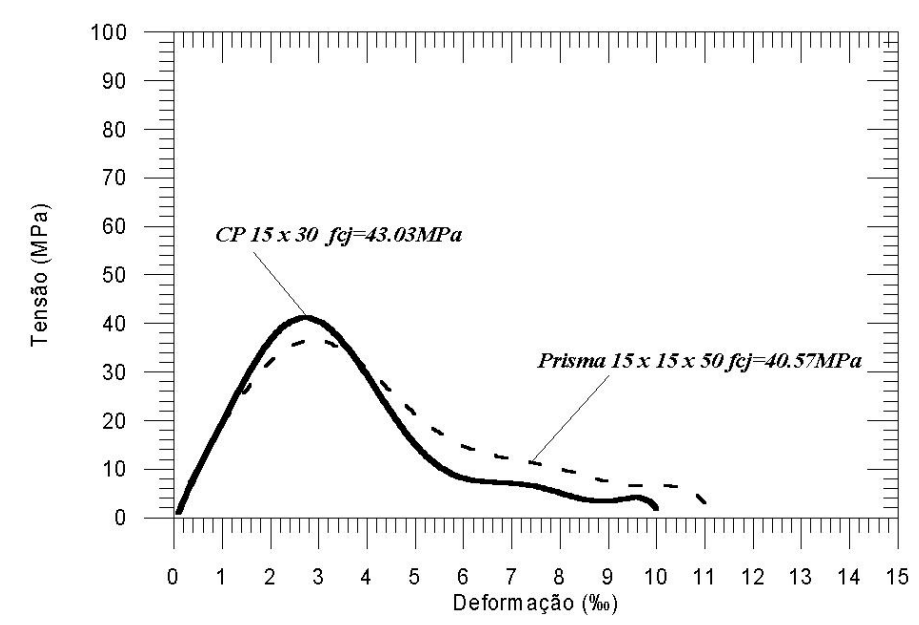

Figura 7.2 - Diagramas tensão vs. deformação do concreto com resistência 40MPa

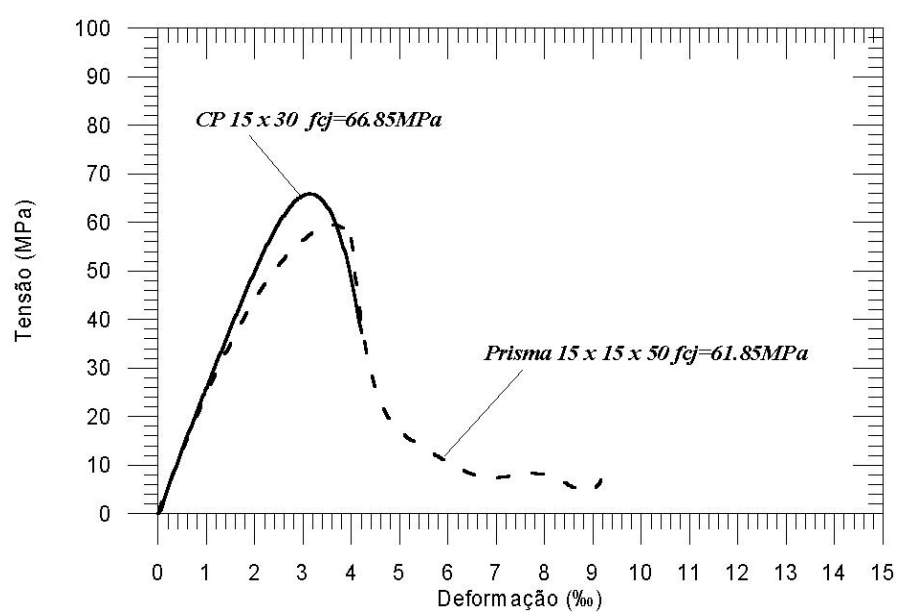

Figura 7.3 - Diagramas tensão vs. deformação do concreto com resistência 60MPa e $V_{f}=0,0 \%$

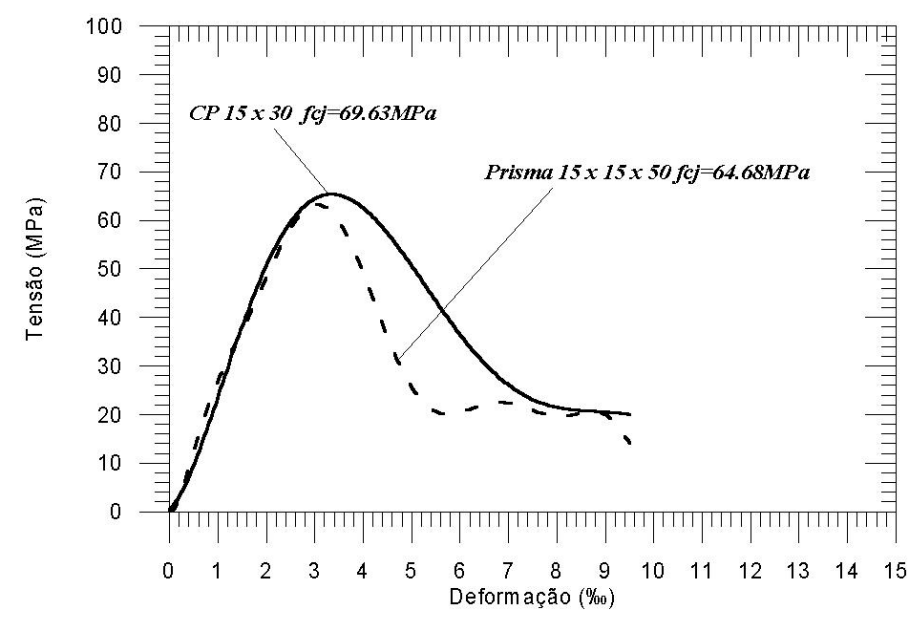

Figura 7.4 - Diagramas tensão vs. deformação do concreto com resistência 60MPa e $V_{f}=0,5 \%$ 


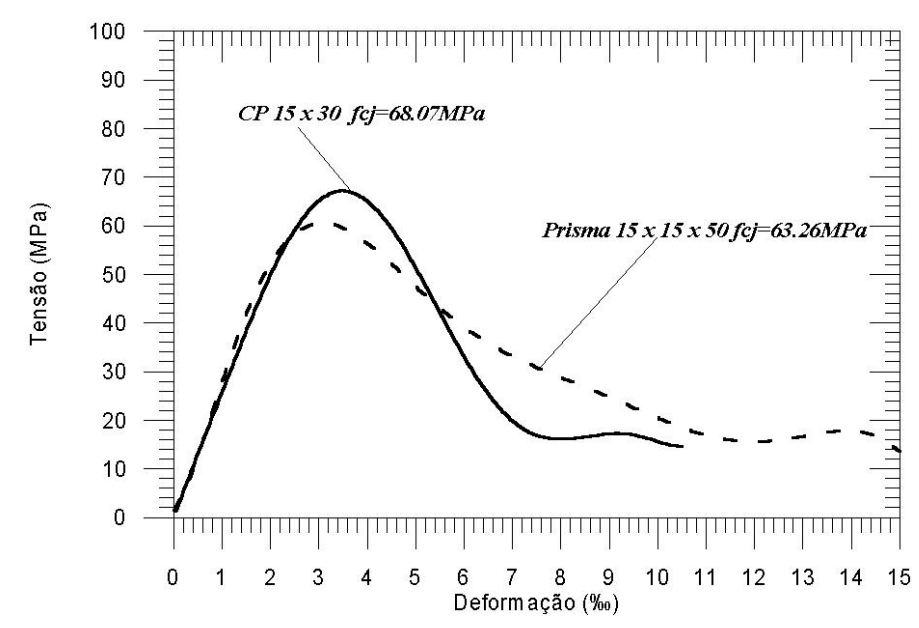

Figura 7.5 - Diagramas tensão vs. deformação do concreto com resistência 60MPa e $V_{f}=1,0 \%$

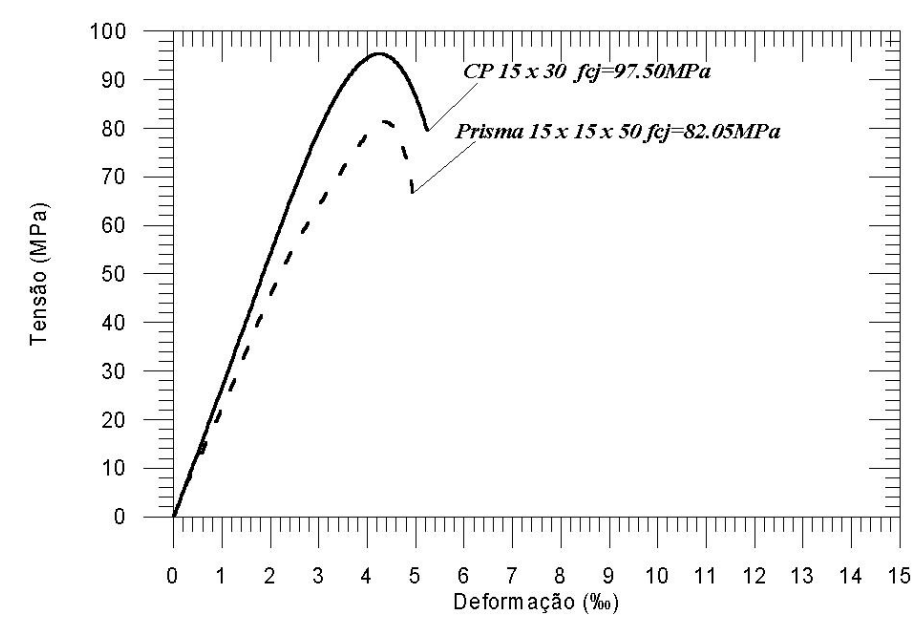

Figura 7.6 - Diagramas tensão vs. deformação do concreto com resistência 80MPa e $V_{f}=0,0 \%$

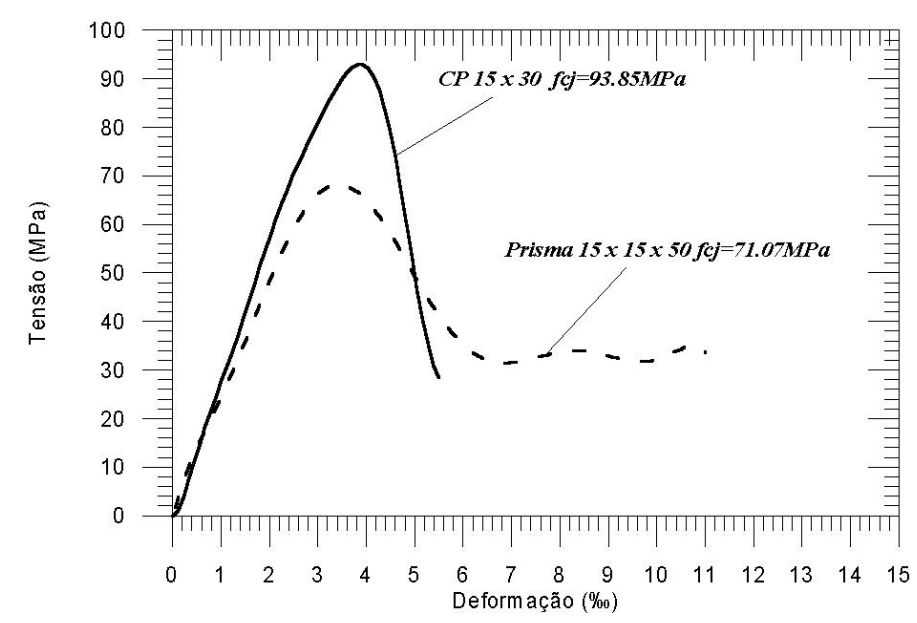

Figura 7.7 - Diagramas tensão vs. deformação do concreto com resistência 80MPa e $V_{f}=0,5 \%$ 


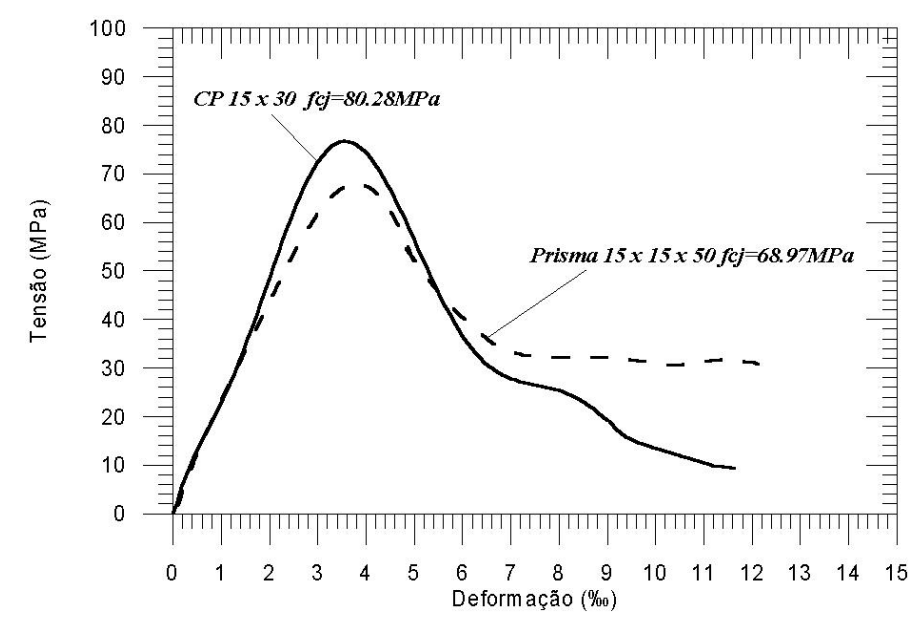

Figura 7.8 - Diagramas tensão vs. deformação do concreto com resistência 80MPa e $V_{f}=1,0 \%$

Tabela 7.2- Características das curvas tensão vs. deformação dos concretos

\begin{tabular}{|c|c|c|c|c|c|c|c|c|}
\hline $\begin{array}{c}\text { Concreto } \\
f_{c j}\end{array}$ & $\begin{array}{c}V_{f} \\
(\%)\end{array}$ & $\begin{array}{r}f_{c j p r i s m a} \\
(M P a)\end{array}$ & $\begin{array}{r}f_{c j \text { c cilindro }} \\
(M P a)\end{array}$ & $\frac{f_{c j \text { prisma }}}{f_{c j \text { cilincdro }}}$ & $\begin{array}{l}\mathcal{E}_{0.5 f c / c c o} \\
\text { prisma }\end{array}$ & $\begin{array}{c}I D_{p o ́ s} \\
\text { prisma }\end{array}$ & $\begin{array}{c}\mathcal{E}_{0.5 \mathrm{ff} / \varepsilon \mathrm{\varepsilon co}} \\
\text { cilinddro }\end{array}$ & $\begin{array}{l}I D_{\text {pós }} \\
\text { cilindro }\end{array}$ \\
\hline 40 & 0,0 & 40,57 & 43,03 & 0,943 & 1,621 & 0,884 & 1,695 & 0,853 \\
\hline 60 & 0,0 & 61,85 & 66,85 & 0,925 & 1,186 & 0,533 & 1,166 & $\approx 0,269^{*}$ \\
\hline 60 & 0,5 & 64,68 & 69,63 & 0,929 & 1,537 & 0,915 & 1,878 & 1,095 \\
\hline 60 & 1,0 & 63,26 & 68,07 & 0,929 & 2,614 & 1,396 & 1,711 & 0,934 \\
\hline 80 & 0,0 & 82,05 & 97,50 & 0,842 & $\approx 1,180^{*}$ & $\approx 0,239^{*}$ & $\approx 1,119^{*}$ & $\approx 0,117^{*}$ \\
\hline 80 & 0,5 & 71,07 & 93,85 & 0,757 & 1,789 & 1,187 & 1,131 & 0,398 \\
\hline 80 & 1,0 & 68,97 & 80,28 & 0,859 & 1,864 & 1,145 & 1,638 & 0,762 \\
\hline
\end{tabular}

Nota: ${ }^{*}$ Valores obtidos por extrapolações dos diagramas tensão vs. deformação.

Na Tabela 7.2, apresentam-se também os valores dos índices de ductilidade para os diversos concretos, calculados a partir das curvas tensão vs. deformação dos corpos-de-prova cilíndricos e dos prismas de concreto simples. Observa-se que, na maioria dos casos, os prismas apresentaram índices de ductilidade superior aos cilíndricos, concordando com Chin et alii (1997). Em adição, considerando os valores dos índices de ductilidade obtidos com os diagramas tensão vs. deformação dos prismas, observa-se que taxas de adições de fibras da ordem de $0,5 \%$ são capazes garantir aos concretos com $f_{c j}=60 \mathrm{MPa}$ e $f_{c j}=80 \mathrm{MPa}$ índices de ductilidade próximos aos do concreto com $f_{c j}=40 \mathrm{MPa}$. 


\subsection{PILARES SUBMETIDOS À COMPRESSÃO CENTRADA}

Com o objetivo de torna a leitura deste capítulo mais dinâmica, optou-se por apresentar os gráficos relacionados aos ensaios de cada pilar no Apêndice A, no final da tese. Assim, apresentar-se-ão neste item apenas diagramas e dados resumidos de relevância para as discussões.

\subsubsection{Comportamento global dos pilares}

Com o procedimento de ensaio utilizado, foi possível obter o comportamento pós-pico de todos os pilares. A taxa de deformação sugerida pelo RILEM TC 148-SSC (2000), de 0,005mm/m.s, foi utilizada e mostrou-se adequada. Depois de atingida $70 \%$ da força máxima no trecho descendente do diagrama força vs. deslocamento, a taxa de deformação foi incrementada para $0,01 \mathrm{~mm} / \mathrm{m} . \mathrm{s}$, sendo mantida até o final do ensaio. Obteve-se uniformidade nas forças máximas resistidas entre os pilares gêmeos (ver Apêndice A). Contudo, observou-se certa discrepância entre os diagramas força vs. deslocamento desses pilares.

Com a reutilização das fôrmas (nove vezes) para a moldagem dos pilares, observou-se que essas se danificaram gradativamente com as concretagens. Esse fato gerou pequenos defeitos de geometria e esquadrejamento nos últimos modelos concretados. Desse modo, mesmo com a regularização, com enxofre, das superfícies das extremidades dos pilares, observaram-se, durante os ensaios, flexões indesejadas que podem ser comprovadas nas leituras dos LVDT dispostos nas faces desses elementos (ver Apêndice A).

Os colares metálicos apresentaram excelente desempenho. Em nenhum ensaio foi detectado escorregamento destes, nem tampouco fissuras e ruptura das extremidades dos pilares. Na Figura 7.9 apresentam-se detalhes das extremidades dos pilares após ensaio. 

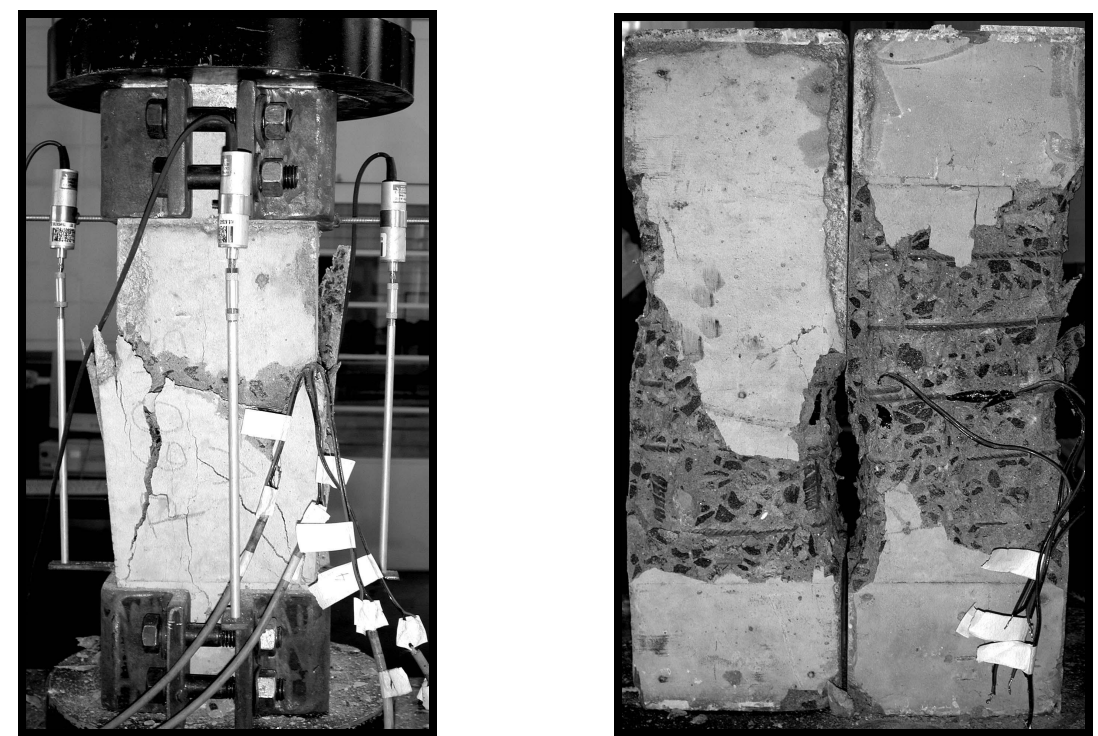

Figura 7.9 - Detalhes das extremidades dos pilares durante e após ensaio

A metodologia de disposição da instrumentação mostrou-se adequada. Nenhum extensômetro danificou-se durante a montagem das armaduras e nem durante as concretagens dos pilares. As leituras desses instrumentos só foram perdidas quando as deformações nas armaduras atingiam valores superiores a $10 \%$, ou quando fissuras no concreto rompiam os fios que os conectavam ao sistema de aquisição de dados.

Na Figura 7.10 apresentam-se detalhes dos pilares após ensaio. Nos pilares sem adição de fibras e com espaçamento de $15 \mathrm{~cm}$ entre estribos, observaram-se desprendimentos de grandes massas de concretos, tanto nos pilares com concretos de alta resistência como nos de resistência usual. Esse comportamento, também foi verificado por Câmara et alii (2003), para pilares com concretos de resistência entre 20MPa e 40MPa, e por Lima (1997), para pilares com concretos com resistência de $80 \mathrm{MPa}$.

Nos pilares sem adição de fibras e com espaçamento entre estribos de $5 \mathrm{~cm}$, observou-se o completo descolamento do cobrimento, logo após ser atingida a força máxima resistida por esses elementos. Entretanto, não foi observado desprendimento de grandes massas de concreto da região do núcleo dos pilares. Ao término dos ensaios, esses pilares apresentavam toda a região do núcleo de concreto íntegra. 
Finalmente, durante os ensaios dos pilares com adições de fibras, não foi observado desprendimento do cobrimento, nem tampouco de grandes massas de concreto do núcleo, mesmo para aqueles com espaçamentos entre estribos de $15 \mathrm{~cm}$. Apesar do elevado grau de fissuração, estes pilares permaneceram íntegros após o termino dos ensaios (ver Figura 7.10).
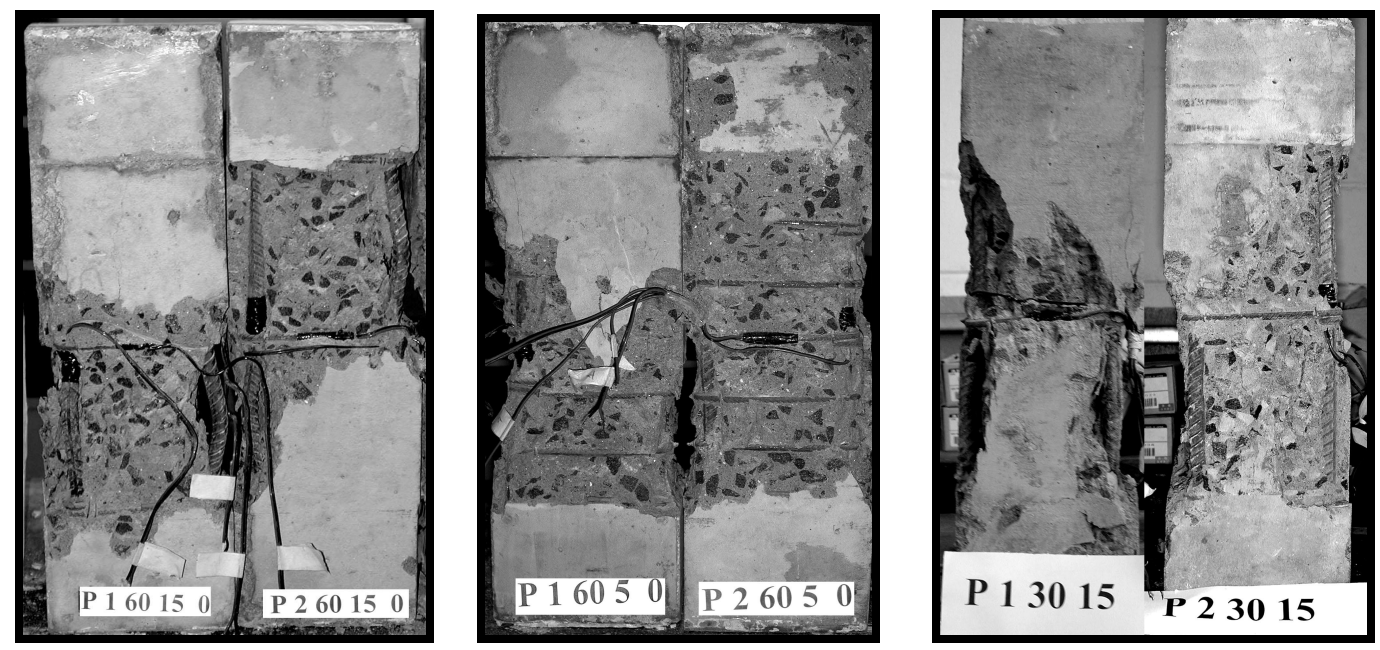

Sem fibra

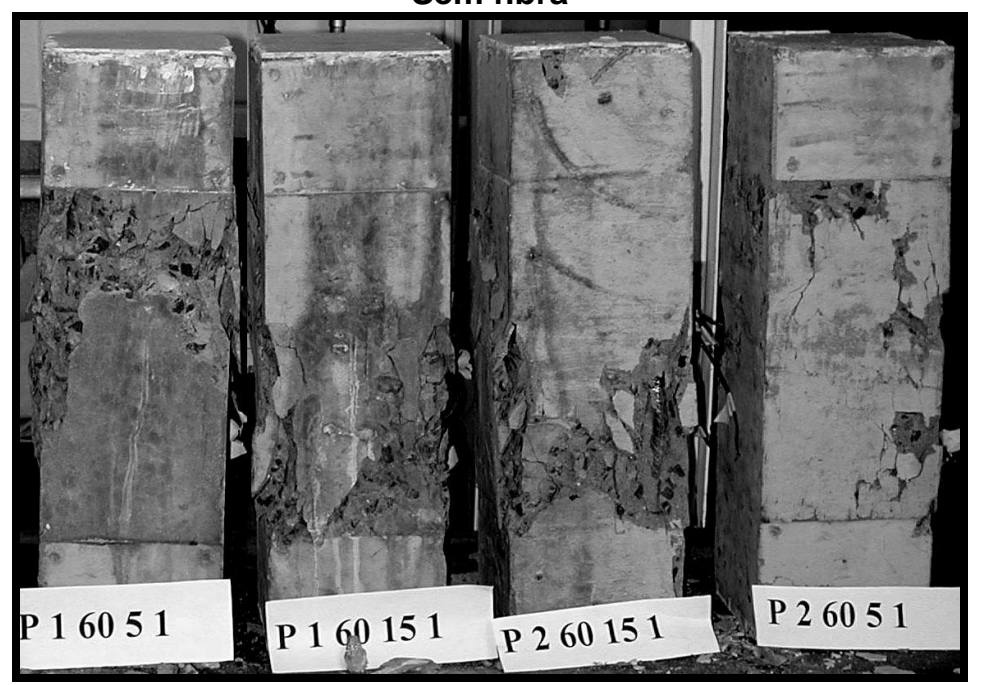

Com fibra

Figura 7.10 - Detalhes do descolamento dos cobrimentos nos pilares com e sem adição de fibras de aço

Em todos os casos, observou-se que as rupturas dos pilares se deram fora das regiões das extremidades. Apenas nos pilares sem adições de fibras foi possível detectar planos de cisalhamento de ruptura definidos. Os pilares com concretos de resistência média de $40 \mathrm{MPa}$ apresentaram plano de cisalhamento 
com inclinação média $(\alpha)$ de $56,75^{\circ}$ e desvio padrão de $\pm 2,44^{\circ}$ (ver Figura 7.11). Câmara et alii (2003) ensaiaram 18 pilares com resistência do concreto entre 20MPa e 40MPa; seções transversais retangulares com relações de $b / h$ igual a 1 , 1,5 e 2; e armaduras transversais dimensionadas segundo o Projeto de Revisão da NBR6118 (2001). Os autores em questão verificaram planos de cisalhamento com inclinações entre $49,8^{\circ}$ e $70,7^{\circ}$, com média de $59,2^{\circ}$ e desvio padrão de $\pm 4,3^{\circ}$. Observa-se que esses valores são compatíveis com os obtidos no presente estudo.

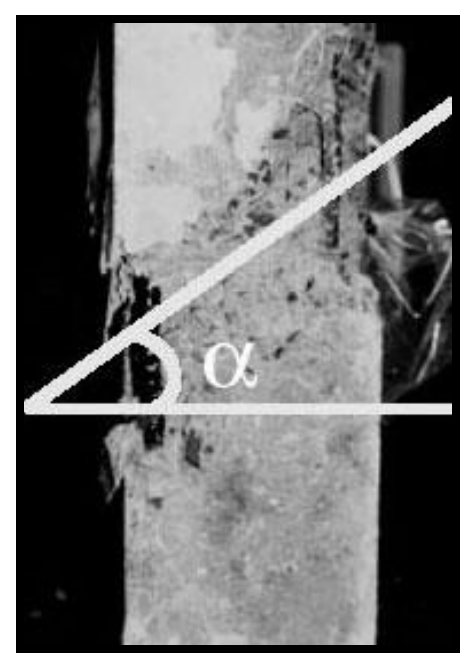

Figura 7.11 - Plano de cisalhamento de ruptura dos pilares

Os pilares com concreto de resistência média à compressão de 60MPa e espaçamento entre os estribos de $15 \mathrm{~cm}$ e $5 \mathrm{~cm}$ apresentaram ângulos de cisalhamento médios de $57,25^{\circ}$ e $53,13^{\circ}$, respectivamente e desvios padrão de $\pm 1,81^{\circ}$ e $\pm 1,20^{\circ}$, respectivamente. Já os pilares com concreto de resistência média à compressão de $80 \mathrm{MPa}$ e espaçamento entre os estribos de $15 \mathrm{~cm}$ e $5 \mathrm{~cm}$ apresentaram ângulos de cisalhamento médios de $59,05^{\circ}$ e $49,5^{\circ}$, respectivamente, e desvios padrão de $\pm 2,76^{\circ}$ e $\pm 2,2^{\circ}$, respectivamente.

Verificou-se que o ângulo de inclinação do plano de ruptura diminuiu com o aumento da taxa de armadura transversal. Essa observação também foi constatada por Cusson et alii (1996), que afirmam que o aumento das taxas de armaduras transversais e longitudinais diminui o valor do ângulo $\alpha$, e sugerem que 
$\alpha$ é função da tensão efetiva de confinamento e para pilares de $C A R$ pode ser expresso pela Eq.(7.1):

$$
\alpha=25+48 \cdot\left(\frac{f_{l e}}{f_{c}}\right)^{0,7} \geq 45^{\circ}
$$

na qual, $f_{l e}$ é a tensão efetiva de confinamento definida no Capítulo 2 e $f_{c}$ é a resistência do concreto à compressão simples na estrutura. Utilizando a Eq.(7.1) obtém-se que os valores dos ângulos $\alpha$, para os pilares com concreto com resistência média à compressão de $60 \mathrm{MPa}$ e espaçamento entre estribos de $15 \mathrm{~cm}$ e $5 \mathrm{~cm}$ são $63,9^{\circ}$ e $62,3^{\circ}$, respectivamente e para os pilares com $80 \mathrm{MPa}$ e espaçamento entre estribos de $15 \mathrm{~cm}$ e $5 \mathrm{~cm}$ são $64,1^{\circ}$ e $62,8^{\circ}$, respectivamente. Esses valores diferem dos resultados experimentais dos pilares com espaçamento entre os estribos de $15 \mathrm{~cm}$ e $5 \mathrm{~cm}$ de aproximadamente $10 \%$ e $22 \%$, respectivamente. Verifica-se, assim, que, com o aumento da taxa de armadura transversal, os valores do ângulo $\alpha$ calculados com a Eq.(7.1) se distanciam dos valores experimentais.

As flambagens das barras da armadura longitudinais sempre ocorreram depois de ter sido atingida a força máxima dos pilares, e se mostraram mais críticas nos pilares com espaçamento entre estribos de $15 \mathrm{~cm}$. Nos pilares com adição de fibras, constatou-se que, como não houve perda de massa de concreto, e, deste modo, as barras de aço permaneciam encapsuladas por um período mais longo, as flambagens destas foram retardadas.

\subsubsection{Forças últimas dos pilares e variação da tensão no concreto}

De acordo com Cusson e Paultre (1992) e como já discutido (Capítulo 2), a presença de elevadas taxas de armadura transversais nos pilares de concreto armado gera planos de falha ao longo de todo o perímetro delimitado pelos estribos. Esses planos causam o descolamento prematuro do cobrimento de concreto dos pilares, e, assim, a seção transversal resistente dos pilares é reduzida para apenas a área delimitada pelos estribos. Diversos pesquisadores (Cusson e Paultre, 1992; Foster et alii, 1998; Lima, 1997; Queiroga, 1999; Paiva, 1997; 
Fernandes, 1997 e etc), ainda afirmam, que mesmos em pilares com baixo e médio índice de confinamento a seção resistente do pilar no ponto $A$ (ver Figura 2.1) é reduzida para apenas a área delimitada pelos estribos.

Cusson e Paultre (op. cit) avaliaram a seção transversal efetivamente resistente por meio do cálculo da força teórica máxima, utilizando a Teoria da Resistência dos Materiais. Desse modo, pode-se expressar a força normal máxima teórica resistida por estes elementos por meio da Eq.(7.2):

$$
F_{\text {teo }}=f_{c} \cdot A_{c}+\sigma_{s} \cdot A_{s}
$$

na qual $A_{c}$ é a área de concreto da seção transversal do pilar; $\sigma_{s}$ é a tensão na armadura longitudinal; $A_{s}$ é a área da seção transversal da amadura longitudinal; e, por fim, $f_{c}$ é a resistência do concreto na estrutura dada pela Eq.(7.3):

$$
f_{c}=k \cdot f_{c j}
$$

na qual $f_{c j}$ é a resistência à compressão média do concreto obtida por meio de ensaio em corpos-de-prova cilíndricos $15 \mathrm{~cm}$ x $30 \mathrm{~cm}$ e $k$ é um coeficiente dado pela Eq.(7.4):

$$
k=k_{1} \cdot k_{2} \cdot k_{3}
$$

na qual, por sua vez, $k_{1}$ é um coeficiente que leva em conta o acréscimo de resistência do concreto após 28 dias, $k_{2}$ é um coeficiente que leva em consideração a super-estimativa da resistência do concreto nas estruturas quando avaliadas por meio de corpos-de-prova e $k_{3}$ considera a diminuição da resistência do concreto para ações de longa duração. Segundo Fusco (1989), o acréscimo de resistência no concreto após 28 dias e o efeito deletério causado por ações de longa duração são da ordem de $+20 \%$ e $-25 \%$, respectivamente. Deste modo, para projetos, os valores de $k_{1}$ e $k_{3}$ devem ser tomados iguais a 1,2 e 0,75 , respectivamente.

Para o presente trabalho, especificamente, como a resistência do concreto foi avaliada no dia do ensaio e a força foi aplicada de modo quase estático em um curto intervalo de tempo, os valores de $k_{1}$ e $k_{3}$ podem ser tomados iguais à unidade.

Fusco (1989) sugere o valor de 0,95 para $k_{2}$, para resistências à compressão avaliadas por meio de corpos-de-prova cilíndricos $15 \mathrm{~cm} \times 30 \mathrm{~cm}$. Contudo, não faz 
nenhuma ressalva quanto à variação desse coeficiente em relação a resistência à compressão do concreto.

Segundo ACI (1989), o valor de $k$ é igual a 0,85 para resistências à compressão avaliadas por meio de corpos-de-prova cilíndricos $15 \mathrm{~cm} \times 30 \mathrm{~cm}$ e independem da resistência do concreto. Adotando-se que $k_{1}$ e $k_{3}$ são iguais a 1,2 e 0,75, respectivamente, e utilizando a equação Eq.(7.4), obtém-se que o valor de $k_{2}$ utilizado pelo ACI (1989) é 0,95, valor este igual ao sugerido por Fusco (1989).

Ao contrário de outros códigos normativos, a norma norueguesa NBR (1989) especifica que o valor de $k$ é função da resistência do concreto. Segundo a norma em questão, $k$ varia de 0,84 , para concretos com resistência à compressão de 20MPa, a 0,65, para concretos com resistência à compressão de 100MPa. Esses valores são válidos apenas para resistências à compressão avaliadas por meio de corpos-de-prova cilíndricos $15 \mathrm{~cm} \quad x \quad 30 \mathrm{~cm}$. Adotando-se novamente que os coeficientes $k_{1}$ e $k_{3}$ são iguais a 1,2 e 0,75 , respectivamente, e utilizando a equação Eq.(7.4) calcularam-se os valores de $k_{2}$ segundo a NBR (op. cit.). Na Figura 7.12 são apresentados os valores de $k_{2}$, segundo a NBR (1989), e a equação logarítmica que correlaciona esse coeficiente com a resistência do concreto e que foi obtida por meio de análise de regressão.

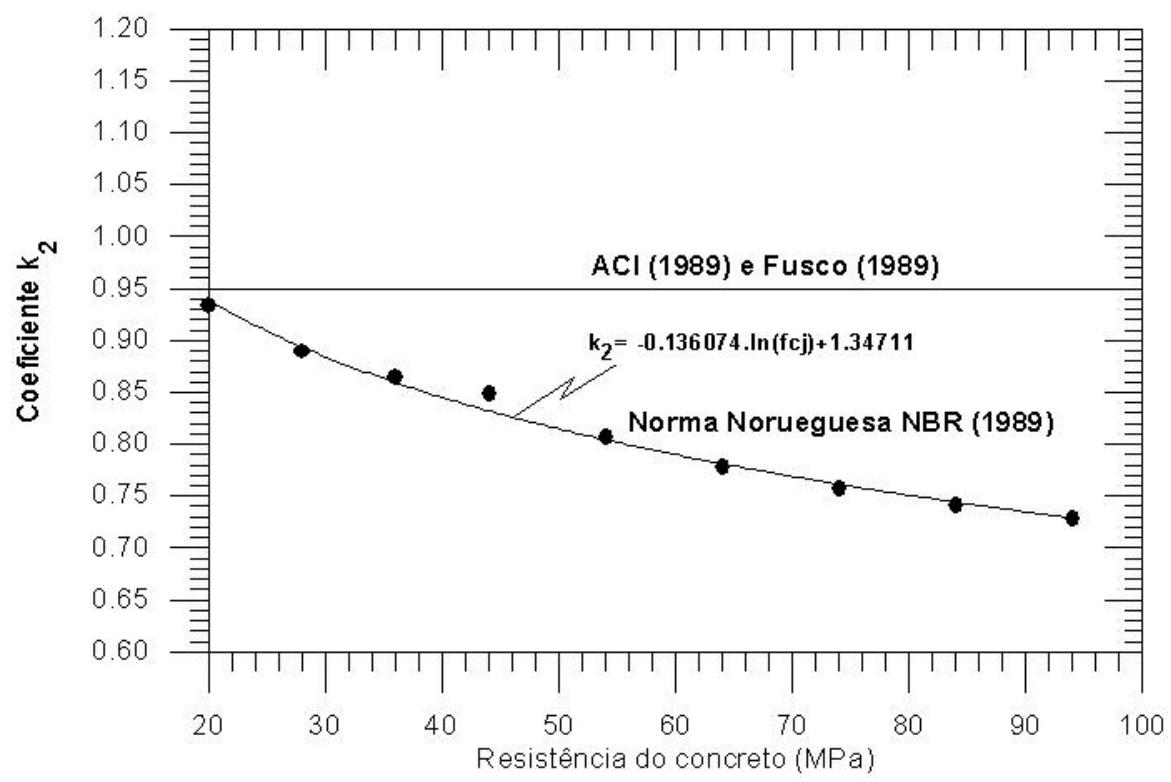

Figura 7.12 - Variação do coeficiente $k_{2}$ com a resistência do concreto de acordo com o ACI (1989), NBR (1989) e Fusco (1989) 
Procurando verificar a real resistência dos concretos nos pilares estudados, ensaiaram-se prismas de concreto simples com as mesmas características geométricas dos pilares e moldados sob as mesmas metodologias e procedimentos. Os valores das resistências obtidas foram apresentadas na Tabela 7.2. Observa-se que, realmente, a relação entre as resistências do concreto, medidas nos elementos estruturais e por meio de corpos-de-prova cilíndricos, varia com a resistência do concreto. Entretanto, observa-se que, além da geometria do elemento estrutural, a presença de armaduras também influencia na resistência do concreto, pois prejudica a vibração e gera descontinuidades na massa do concreto, as quais o torna mais poroso e menos resistente (Leonhardt,1977a).

Com base no exposto, utilizaram-se para o cálculo das forças últimas teóricas dos pilares a Eq.(7.2) e as resistências obtidas por meio dos prismas de concreto. Conseqüentemente, o valor de $k$ foi tomado igual à unidade. Calcularam-se duas forças teóricas para cada pilar: uma considerando a área do concreto, $A_{c}$, como sendo toda a área da seção transversal menos a área da armadura longitudinal; e outra considerando a área do concreto, $A_{c}=A_{c c}$, onde $A_{c c}$ é a área do núcleo de concreto do pilar e pode ser expressa pela Eq.(7.4):

$$
A_{c c}=c_{x} \cdot c_{y}-A_{s}
$$

na qual $c_{x}$ e $c_{y}$ são as dimensões do estribo mais externo, mensuradas de eixo a eixo de cada ramo, nas direções $x$ e $y$, respectivamente.

Os pilares foram divididos em duas categorias: quanto ao espaçamento entre estribos e quanto à presença de fibras metálicas adicionadas ao concreto. Nas Tabela 7.3 e Tabela 7.4 são apresentadas as forças últimas teóricas e experimentais, dos pilares ensaiados com espaçamento entre estribos de $15 \mathrm{~cm}$ e $5 \mathrm{~cm}$, respectivamente.

Analisando os resultados apresentados na Tabela 7.3, verifica-se que, para os pilares com concretos de alta resistência, espaçamento entre estribos de $15 \mathrm{~cm}$ e sem adição de fibras, a força teórica calculada, considerado toda a seção transversal do pilar como resistente, apresentou valores bem mais realistas que os 
da força teórica calculada considerando apenas o núcleo. Observa-se, que a diferença média entre as forças experimentais e as teóricas calculadas, considerando toda a seção transversal, é de $10 \%$, enquanto a diferença em relação à força teórica considerando apenas o núcleo dos pilares é de $20 \%$.

Tabela 7.3- Forcas últimas dos pilares com espaçamento entre estribos de $15 \mathrm{~cm}$

\begin{tabular}{|c|c|c|c|c|c|c|c|c|c|c|}
\hline Pilar & $\begin{array}{c}V_{f} \\
(\%)\end{array}$ & $\begin{array}{c}f_{c} \\
(M P a)\end{array}$ & $\begin{array}{l}\rho_{w} \\
(\%)\end{array}$ & $\begin{array}{c}\mathcal{E}_{S} \\
(\% \circ)\end{array}$ & $\begin{array}{c}\sigma_{s} \\
(M P a)\end{array}$ & $\begin{array}{l}F_{\text {exp }} \\
(k N)\end{array}$ & $\begin{array}{c}F_{t e o} \\
(k N)\end{array}$ & $\frac{F_{\text {teo }}}{F_{\text {exp }}}$ & $\begin{array}{c}F_{\text {teo-nu }} \\
(k N)\end{array}$ & $\frac{F_{\text {teo-nu }}}{F_{\text {exp }}}$ \\
\hline P14015 & 0,0 & 40,57 & 0,32 & 2,49 & 493,19 & 983,3 & 1135,1 & 1,15 & 843,0 & 0,86 \\
\hline$P 24015$ & 0,0 & 40,57 & 0,32 & 2,73 & 539,66 & 1015,7 & 1157,9 & 1,14 & 865,8 & 0,85 \\
\hline \multicolumn{7}{|c|}{ Valores médios } & \multicolumn{3}{|c|}{1,15} & 0,85 \\
\hline$P 160150$ & 0,0 & 61,85 & 0,32 & 2,55 & 503,47 & 1479,7 & 1608,5 & 1,09 & 1163,2 & 0,79 \\
\hline P260150 & 0,0 & 61,85 & 0,32 & 2,48 & 491,21 & 1438,3 & 1602,4 & 1,11 & 1157,2 & 0,80 \\
\hline P180150 & 0,0 & 82,05 & 0,32 & 2,57 & 508,61 & 1881,5 & 2055,6 & 1,09 & 1464,9 & 0,78 \\
\hline P280150 & 0,0 & 82,05 & 0,32 & 3,32 & 597,75 & 1923,8 & 2099,3 & 1,09 & 1508,6 & 0,78 \\
\hline \multicolumn{7}{|c|}{ Valores médios } & \multicolumn{3}{|c|}{1,10} & 0,79 \\
\hline P1601505 & 0,5 & 64,68 & 0,32 & 2,41 & 475,98 & 1628,7 & 1657,3 & 1,02 & 1191,7 & 0,73 \\
\hline$P 2601505$ & 0,5 & 64,68 & 0,32 & 2,80 & 553,70 & 1661,2 & 1695,4 & 1,02 & 1229,8 & 0,74 \\
\hline$P 160151$ & 1,0 & 63,26 & 0,32 & 2,90 & 574,26 & 1741,1 & 1674,3 & 0,96 & 1218,9 & 0,70 \\
\hline$P 260151$ & 1,0 & 63,26 & 0,32 & 2,58 & 509,40 & 1640,5 & 1642,4 & 1,00 & 1187,0 & 0,72 \\
\hline P1801505 & 0,5 & 71,07 & 0,32 & 2,70 & 534,12 & 1793,2 & 1826,4 & 1,02 & 1314,9 & 0,73 \\
\hline$P 2801505$ & 0,5 & 71,07 & 0,32 & 2,54 & 503,27 & 1724,2 & 1811,3 & 1,05 & 1299,7 & 0,75 \\
\hline P180151 & 1,0 & 68,97 & 0,32 & 2,97 & 586,52 & 1828,0 & 1805,9 & 0,99 & 1309,5 & 0,72 \\
\hline P280151 & 1,0 & 68,97 & 0,32 & 5,43 & 597,75 & 1748,3 & 1811,5 & 1,04 & 1315,0 & 0,75 \\
\hline \multicolumn{8}{|c|}{ Valores médios } & 1,01 & & 0,73 \\
\hline
\end{tabular}

Tabela 7.4- Forcas últimas dos pilares com espaçamento entre estribos de $5 \mathrm{~cm}$

\begin{tabular}{|c|c|c|c|c|c|c|c|c|c|c|}
\hline Pilar & $\begin{array}{c}V_{f} \\
(\%)\end{array}$ & $\begin{array}{c}f_{c} \\
(M P a)\end{array}$ & $\begin{array}{l}\rho_{w} \\
(\%)\end{array}$ & $\begin{array}{c}\mathcal{E}_{s} \\
(\% \circ)\end{array}$ & $\begin{array}{c}\sigma_{s} \\
(M p a)\end{array}$ & $\begin{array}{l}F_{\text {exp }} \\
(k N)\end{array}$ & $\begin{array}{l}F_{\text {teo }} \\
(k N)\end{array}$ & $\frac{F_{\text {teo }}}{F_{\text {exp }}}$ & $\begin{array}{c}F_{\text {teo-nu }} \\
(k N)\end{array}$ & $\frac{F_{\text {teo-nu }}}{F_{\text {exp }}}$ \\
\hline$P 16050$ & 0,0 & 61,85 & 0,96 & 2,83 & 559,43 & 1557,1 & 1635,9 & 1,05 & 1190,7 & 0,76 \\
\hline$P 26050$ & 0,0 & 61,85 & 0,96 & 4,25 & 597,53 & 1525,0 & 1654,6 & 1,09 & 1209,4 & 0,79 \\
\hline P18050 & 0,0 & 82,05 & 0,96 & 3,15 & 597,53 & 1853,1 & 2099,2 & 1,13 & 1508,6 & 0,81 \\
\hline$P 28050$ & 0,0 & 82,05 & 0,96 & 3,46 & 597,53 & 1890,8 & 2099,2 & 1,11 & 1508,6 & 0,80 \\
\hline \multicolumn{8}{|c|}{ Valores médios } & 1,09 & & 0,79 \\
\hline$P 160505$ & 0,5 & 64,68 & 0,96 & 2,62 & 517,51 & 1587,5 & 1677,6 & 1,06 & 1212,1 & 0,76 \\
\hline$P 260505$ & 0,5 & 64,68 & 0,96 & 2,79 & 551,52 & 1779,1 & 1694,3 & 0,95 & 1228,8 & 0,69 \\
\hline$P 16051$ & 1,0 & 63,26 & 0,96 & 2,79 & 552,31 & 1677,7 & 1663,5 & 0,99 & 1208,1 & 0,72 \\
\hline$P 26051$ & 1,0 & 63,26 & 0,96 & 3,96 & 597,53 & 1759,6 & 1685,7 & 0,96 & 1230,3 & 0,70 \\
\hline P180505 & 0,5 & 71,07 & 0,96 & 3,62 & 597,53 & 2018,5 & 1857,6 & 0,92 & 1346,0 & 0,67 \\
\hline$P 280505$ & 0,5 & 71,07 & 0,96 & 2,78 & 549,74 & 1906,2 & 1834,1 & 0,96 & 1322,5 & 0,69 \\
\hline$P 18051$ & 1,0 & 68,97 & 0,96 & 3,66 & 597,53 & 1993,4 & 1811,3 & 0,91 & 1314,9 & 0,66 \\
\hline$P 28051$ & 1,0 & 68,97 & 0,96 & 3,68 & 597,53 & 1909,4 & 1811,3 & 0,95 & 1314,9 & 0,69 \\
\hline \multicolumn{8}{|c|}{ Valores médios } & 0,96 & & 0,70 \\
\hline
\end{tabular}

Para os pilares com concretos de alta resistência, espaçamento entre estribos de $15 \mathrm{~cm}$ e com adição de fibras, a diferença média entre as forças 
experimentais e as teóricas calculadas considerando toda a seção transversal é de apenas $1 \%$, contra $27 \%$ considerando-se apenas o núcleo dos pilares. Esses resultados eram esperados, pois pequenas taxas de armadura transversal, como as observadas nestes casos, não são capazes de gerar os planos de falha ao longo do perímetro dos estribos. Assim, pode-se afirmar que para esses pilares a seção resistente corresponde a toda a seção transversal do pilar.

Analisando os resultados dos pilares com concretos de alta resistência, espaçamento entre estribos de $5 \mathrm{~cm}$ e sem adição de fibras (Tabela 7.4), observa-se que, ao contrário do esperado, os valores da força teórica calculada considerado toda a seção transversal também, correspondem a valores bem mais realistas (diferença de 9\%) que os da força teórica considerando o núcleo (diferença de $21 \%$ ). Isso comprova, que para esses pilares, toda a seção transversal resiste a esforços normais. É possível que para espaçamento entre estribos inferiores a $5 \mathrm{~cm}$, o cobrimento de concreto dos pilares não façam parte da seção resistente, como discutido no Capítulo 2.

Nos pilares com espaçamento entre estribos de $5 \mathrm{~cm}$ e com adição de fibras fica evidenciado que a seção resistente é toda a seção transversal e que a adição de fibras de aço tornou o trabalho núcleo-cobrimento mais integrado e uniforme. A diferença entre os valores das forças experimentais e teóricas considerando a seção transversal integralmente foi de apenas $4 \%$, contra $30 \%$ para a força teórica considerando o núcleo.

Como os resultados obtidos acima se apresentaram discordantes com as conclusões obtidas por outros pesquisadores, analisaram-se 28 pilares ensaiados por outros pesquisadores. Esses pilares eram de concretos de alta resistência e sem adição de fibras. Para tanto, utilizaram-se os coeficientes $k_{2}$ sugeridos pela norma norueguesa NBR (1989). Na Tabela 7.5 apresentam-se os valores das forças últimas experimentais e teóricas para os pilares ensaiados por Cusson e Paultre (1992), Lima (1997) e Queiroga (1999). Constata-se novamente que a seção transversal resistente do pilar corresponde a toda a seção transversal. A diferença média total entre as forças experimentais e as teóricas calculadas considerando-se toda a seção transversal foi de apenas 5\%, contra $26 \%$ das calculadas 
considerando apenas o núcleo. Esses valores confirmam os resultados obtidos no presente trabalho.

Tabela 7.5- Forcas últimas para os pilares de Lima (1997) e Queiroga (1999)

\begin{tabular}{|c|c|c|c|c|c|c|c|c|c|c|c|}
\hline & Pilar & $\begin{array}{l}f_{c j 10 \times 20} \\
(M P a)\end{array}$ & $\begin{array}{c}k_{2} \\
15 \times 30\end{array}$ & $\begin{array}{c}k_{2} \\
10 \times 20\end{array}$ & $\begin{array}{c}\sigma_{s} \\
(M P a)\end{array}$ & $A_{s t}$ & $\begin{array}{l}F_{\text {exp }} \\
(k N)\end{array}$ & $\begin{array}{l}F_{\text {teo }} \\
(k N)\end{array}$ & $\begin{array}{c}F_{\text {teo-nu }} \\
(k N)\end{array}$ & $\frac{F_{\text {teo }}}{F_{\text {exp }}}$ & $\frac{F_{\text {teo-nu }}}{F_{\text {exp }}}$ \\
\hline \multirow{9}{*}{ 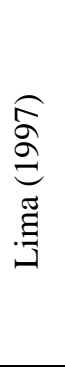 } & $P 1 / 1$ & 83,8 & 0,768 & 0,732 & 430,5 & $6,3 \mathrm{c} / 5$ & 2630 & 2828 & 1920 & 1,08 & 0,73 \\
\hline & $P 1 / 2$ & 83,8 & 0,768 & 0,732 & 461,7 & $6,3 \mathrm{c} / 5$ & 2701 & 2860 & 1951 & 1,06 & 0,72 \\
\hline & $P 1 / 3$ & 83,8 & 0,768 & 0,732 & 461,7 & $6,3 c / 5$ & 2834 & 2860 & 1951 & 1,01 & 0,69 \\
\hline & $P 1 r / 2$ & 85,1 & 0,766 & 0,730 & 512,6 & $6,3 \mathrm{c} / 5$ & 3063 & 2942 & 2022 & 0,96 & 0,66 \\
\hline & $P 1 r / 3$ & 85,1 & 0,766 & 0,730 & 461,7 & $6,3 \mathrm{c} / 5$ & 2820 & 2890 & 1970 & 1,03 & 0,70 \\
\hline & $P 2 / 2$ & 87,4 & 0,763 & 0,726 & 481,8 & $6,3 \mathrm{c} / 10$ & 2950 & 2963 & 2023 & 1,00 & 0,69 \\
\hline & $P 3 / 1$ & 94,9 & 0,752 & 0,716 & 451,0 & $6,3 \mathrm{c} / 5$ & 3415 & 3446 & 2299 & 1,01 & 0,67 \\
\hline & $P 3 / 2$ & 94,9 & 0,752 & 0,716 & 543,3 & $6,3 \mathrm{c} / 5$ & 3750 & 3540 & 2393 & 0,94 & 0,64 \\
\hline & $P 3 / 3$ & 94,9 & 0,752 & 0,716 & 420,3 & $6,3 \mathrm{c} / 5$ & 3230 & 3415 & 2268 & 1,06 & 0,70 \\
\hline \multicolumn{10}{|c|}{ Valores médios } & 1,02 & 0,67 \\
\hline \multirow{7}{*}{ 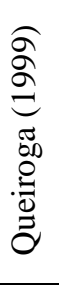 } & $P 2$ & 64,35 & 0,780 & 0,743 & 502,1 & $6,3 \mathrm{c} / 15$ & 2292 & 2367 & 1658 & 1,03 & 0,72 \\
\hline & $P 3$ & 53,40 & 0,806 & 0,767 & 502,1 & $6,3 \mathrm{c} / 10$ & 1835 & 2099 & 1493 & 1,14 & 0,81 \\
\hline & P4 & 53,40 & 0,806 & 0,767 & 502,1 & $6,3 \mathrm{c} / 10$ & 1864 & 2099 & 1493 & 1,13 & 0,80 \\
\hline & $P 5$ & 55,90 & 0,800 & 0,762 & 502,1 & $6,3 \mathrm{c} / 5$ & 2158 & 2163 & 1532 & 1,00 & 0,71 \\
\hline & P6 & 55,90 & 0,800 & 0,762 & 502,1 & $6,3 \mathrm{c} / 5$ & 2312 & 2163 & 1532 & 0,94 & 0,66 \\
\hline & $P 11$ & 65,47 & 0,778 & 0,741 & 502,1 & $6,3 \mathrm{c} / 5$ & 2288 & 2637 & 1818 & 1,15 & 0,79 \\
\hline & $P 12$ & 65,47 & 0,778 & 0,741 & 502,1 & $6,3 \mathrm{c} / 5$ & 2467 & 2637 & 1818 & 1,07 & 0,74 \\
\hline \multicolumn{10}{|c|}{ Valores médios } & 1,07 & 0,75 \\
\hline \multirow{13}{*}{ 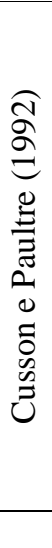 } & $1 A$ & 95,40 & 0,727 & - & 406 & - & 3757 & 4239 & 3046 & 1,13 & 0,81 \\
\hline & $1 B$ & 95,40 & 0,727 & - & 450 & - & 4139 & 4292 & 3099 & 1,04 & 0,75 \\
\hline & $1 C$ & 95,40 & 0,727 & - & 450 & - & 4195 & 4292 & 3099 & 1,02 & 0,74 \\
\hline & $1 D$ & 100,40 & 0,720 & - & 450 & - & 4461 & 4451 & 3207 & 1,00 & 0,72 \\
\hline & $2 A$ & 100,40 & 0,720 & - & 406 & - & 4170 & 4397 & 3154 & 1,05 & 0,76 \\
\hline & $2 B$ & 96,40 & 0,725 & - & 450 & - & 3848 & 4324 & 3121 & 1,12 & 0,81 \\
\hline & $2 C$ & 96,40 & 0,725 & - & 450 & - & 3985 & 4324 & 3121 & 1,09 & 0,78 \\
\hline & $2 D$ & 96,40 & 0,725 & - & 450 & - & 4095 & 4324 & 3121 & 1,06 & 0,76 \\
\hline & $3 A$ & 98,10 & 0,723 & - & 406 & - & 3884 & 4324 & 3104 & 1,11 & 0,80 \\
\hline & $3 B$ & 98,10 & 0,723 & - & 450 & - & 3870 & 4378 & 3158 & 1,13 & 0,82 \\
\hline & $3 C$ & 98,10 & 0,723 & - & 450 & - & 3959 & 4378 & 3158 & 1,11 & 0,80 \\
\hline & $3 D$ & 98,10 & 0,723 & - & 450 & - & 4121 & 4378 & 3158 & 1,06 & 0,77 \\
\hline & \multicolumn{9}{|c|}{ Valores médios } & 1,08 & 0,78 \\
\hline
\end{tabular}

Com o intuito de verificar a influência da taxa de adição de fibra (fator $X_{1}$ ), da resistência do concreto (fator $X_{2}$ ) e da taxa de armadura transversal (fator $X_{3}$ ), foi realizada uma análise de variância sobre os valores de $k_{2}$ obtidos experimentalmente. Assim, para calcular os valores experimentais de $k_{2}$, adotaram-se os seguintes procedimentos: a força última resistida apenas pelo concreto é dada como sendo a força última experimental resistida pelos pilares, menos a parcela resistida pela armadura longitudinal; a tensão última resistida 
pelo concreto é calculada dividindo-se a força última resistida por este material pela a área total da seção transversal dos pilares, menos a área da armadura longitudinal; e $k_{2}$ é calculado dividindo-se o valor obtido para tensão no concreto nos pilares pela resistência à compressão do concreto obtida por meio de corposde-prova cilíndricos $15 \mathrm{~cm}$ x $30 \mathrm{~cm}$.

Os valores médios experimentais de $k_{2}$ obtidos para os pilares com concretos de resistências 40MPa, 60MPa e 80MPa sem adição de fibras foram 0,75, 0,84 e 0,75, respectivamente. A NBR (1989) sugere os valores de 0,84, 0,78 e 0,72 , respectivamente, para esses pilares. Observa-se que as diferenças entre os valores experimentais e teóricos de $k_{2}$ para as respectivas resistências dos concretos são de 13\%, 7\%, 4\%. Na Tabela 7.6 são apresentados os valores de $k_{2}$, obtidos em cada ensaio de pilares com concreto de alta resistência. Observa-se que os valores de $k_{2}$ para os pilares com concretos de alta resistência variaram entre 0,98 e 0,70 .

Tabela 7.6- Valores experimentais de $k_{2}$ para os pilares ensaiados

\begin{tabular}{ccccc}
\hline Taxa de & \multicolumn{4}{c}{ Resistência do concreto $f_{c}(M P a)\left(X_{2}\right)$} \\
\cline { 2 - 5 } adição de & \multicolumn{4}{c}{80} \\
fibra $V_{f}(\%)$ & \multicolumn{4}{c}{ Espaçamento entre estribos $(\mathrm{cm})\left(X_{3}\right)$} \\
\cline { 2 - 5 }$\left(X_{1}\right)$ & 5 & 15 & 5 & 15 \\
\hline 0 & 0,871 & 0,838 & 0,727 & 0,760 \\
0 & 0,837 & 0,801 & 0,744 & 0,760 \\
0,5 & 0,864 & 0,901 & 0,835 & 0,738 \\
& 0,980 & 0,904 & 0,781 & 0,708 \\
1,0 & 0,939 & 0,969 & 0,962 & 0,872 \\
& 0,979 & 0,927 & 0,915 & 0,823 \\
\hline
\end{tabular}

Para realizar a análise de variância, os graus de significância do efeito de cada fator foram testados para graus de confiabilidade de $95 \%$ e $99 \%$, usando-se o $F$ teste (Montgomery, 1984). Na Tabela 7.7, apresentam-se os resultados da análise de variância realizada. Verifica-se que a taxa de adição de fibras e a resistência do concreto influenciam os valores do coeficiente $k_{2}$ para um grau de confiabilidade de $99 \%$ e a taxa de armadura transversal para um grau de confiabilidade de $95 \%$. Entretanto, os acoplamentos entre esses fatores não mostraram influência significativa sobre os valores de $k_{2}$, considerando-se também um grau de confiabilidade de $99 \%$. Constata-se ainda, que o fator de maior 
relevância é a resistência do concreto, seguido pela taxa de adição de fibras e pela taxa de armadura transversal.

Tabela 7.7 - Análise de variância para os valores experimentais de $k_{2}$

\begin{tabular}{lccccc}
\hline Variável & $\begin{array}{c}\text { Soma dos } \\
\text { quadrados }\end{array}$ & $\begin{array}{c}\text { Graus de } \\
\text { liberdade }\end{array}$ & $\begin{array}{c}\text { Média dos } \\
\text { quadrados }\end{array}$ & $\begin{array}{c}\text { Fator } \\
\left(F_{o}\right)\end{array}$ & $\begin{array}{c}\text { Mínimo fator de significância } \\
\text { requerido }\left(F_{0.05, n, 23}\right) \text { e }\left(F_{0.01, n, 23}\right)\end{array}$ \\
\hline $\begin{array}{c}\text { Fatores } \\
\text { principais }\end{array}$ & & & & & \\
$X_{1}$ & 0,07054 & 2 & 0,0353 & 30,159 & $3,42-5,66$ \\
$X_{2}$ & 0,05851 & 1 & 0,0585 & 50,028 & $4,28-7,88$ \\
$X_{3}$ & 0,00781 & 1 & 0,0078 & 6,680 & $4,28-7,88$ \\
Interações & & & & & \\
$X_{1} \times X_{2}$ & 0,00772 & 2 & 0,0039 & 3,302 & $3,42-5,66$ \\
$X_{1} \times X_{3}$ & 0,00290 & 2 & 0,0015 & 1,240 & $3,42-5,66$ \\
$X_{2} \times X_{3}$ & 0,00125 & 1 & 0,0012 & 1,066 & $4,28-7,88$ \\
$X_{1} \times X_{2} \times X_{3}$ & 0,00584 & 2 & 0,0029 & 2,496 & $3,42-5,66$ \\
Erro & 0,01400 & 12 & 0,0012 & - & - \\
Total & 0,16861 & 23 & - & - & - \\
\hline
\end{tabular}

Com base no exposto, nota-se que se fazem necessários maiores estudos experimentais para a determinação de uma correlação exata entre as reais resistências do concreto no elemento estrutural e as obtida por meio de corpos-deprova cilíndricos, considerando a variação da resistência à compressão do concreto, a taxa de adição de fibras e a taxa volumétrica de armadura. Ainda, verifica-se que os valores de $k_{2}$ sugeridos pela norma norueguesa NBR (1989) apresentaram bons resultados para concretos sem adição de fibras.

\subsubsection{Deformações na armadura transversal}

Para avaliar as deformações na armadura transversal correspondentes às forças máximas dos pilares foram utilizadas as médias das deformações das leituras dos dois extensômetros dispostos em dois ramos dos estribos centrais de cada pilar (ver Figura 6.14). As deformações nos estribos dos pilares de referência (P14015 e P24015) foram 0,702\%o e 1,338\%o, respectivamente. Esses valores são da ordem de apenas $31 \%$ da deformação de escoamento do aço $\left(\varepsilon_{y}=3,266 \%\right.$ ). Na Tabela 7.8, apresentam-se as deformações dos estribos $\left(\varepsilon_{t c c}\right)$ no instante em que foi atingida a força máxima resistida pelos pilares e, no apêndice $A$, as curva força vs. deformação dos estribos. Analisando os valores das deformações apresentadas 
na Tabela 7.8, nota-se que, em nenhum caso, a armadura transversal atingiu o escoamento no instante em que foi atingida a força última. Os valores médios das deformações são da ordem de $31 \%$ da deformação de escoamento do aço, para os pilares com espaçamento entre estribos de $15 \mathrm{~cm}$, e da ordem de $48 \%$, para os pilares com espaçamento entre estribos de $5 \mathrm{~cm}$. Constata-se, assim, que o valor médio das deformações dos pilares de referência é exatamente igual ao obtido para os pilares com concreto de alta resistência e mesma taxa de armadura transversal.

Tabela 7.8- Valores das deformações dos estribos correspondente a força máxima do $\underline{\text { pilar }\left(\varepsilon_{t c c}\right)(\% o)}$

\begin{tabular}{ccccc}
\hline Taxa de & \multicolumn{4}{c}{ Resistência do concreto $f_{c}(M P a)\left(X_{2}\right)$} \\
\cline { 2 - 5 } adição de & \multicolumn{4}{c}{80} \\
fibra $V_{f}(\%)$ & \multicolumn{4}{c}{80} \\
\cline { 2 - 5 }$\left(X_{1}\right)$ & 5 & Espaçamento entre estribos $s(\mathrm{~cm})\left(X_{3}\right)$ \\
\hline 0 & 0,752 & 1,062 & 5 & 15 \\
\hline 0 & 1,838 & 1,599 & 1,950 & 0,656 \\
& 1,097 & 0,471 & 2,154 & 0,665 \\
& 0,798 & 0,946 & 1,304 & 0,934 \\
& 1,151 & 1,088 & 2,155 & 1,418 \\
1,0 & 3,156 & 1,191 & 1,046 & 1,120 \\
& & & 1,483 & 1,121 \\
\hline
\end{tabular}

Procurando avaliar a influência da taxa de adição de fibra (fator $X_{1}$ ), da resistência do concreto (fator $X_{2}$ ) e da taxa de armadura transversal (fator $X_{3}$ ), foi realizada, novamente, uma análise de variância sobre os dados apresentados na Tabela 7.8. Os graus de significância do efeito de cada fator foram testados para graus de confiabilidade de $95 \%$ e $99 \%$, usando-se o $F$ teste. Na Tabela 7.9, apresentam-se os resultados da análise de variância realizada, através da qual contata-se que, tanto a taxa de adição de fibra, quanto a resistência do concreto, não influenciam a deformação da armadura transversal no instante em que é atingida a força máxima dos pilares, considerando um grau de confiabilidade de 99\%. Ainda, verifica-se que a taxa de armadura transversal interfere nos valores dessas deformações, para um grau de confiabilidade de 95\%. Não é verificada influência de nenhum acoplamento entre os fatores, para um grau de confiabilidade de $99 \%$.

Uma vez que a deformação na armadura transversal correspondente ao instante da força máxima resistida pelos pilares é função apenas da taxa de 
armadura transversal, pressupõe-se que a metodologia de Cusson e Paultre (1995), para o cálculo desta deformação, possa também ser aplicada aos pilares com adição de fibras metálicas. Assim, realizaram-se os cálculos das deformações das armaduras transversais de todos os pilares ensaiados, segundo os procedimentos de Cusson e Paultre (1995) - ver Capítulo 2. Na Tabela 7.10, apresentam-se os valores teóricos e experimentais para $\varepsilon_{t c c}$. Observa-se que as diferenças entre os valores obtidos com o modelo em questão e os experimentais variaram de $1 \%$ a 171\%, com média de 28\%. Baseando-se nesses valores, observa-se que o procedimento de Cusson e Paultre (1995), para o calculo da deformação da armadura transversal, não é capaz de fornecer valores precisos, necessitando modificações.

Tabela 7.9 - Análise de variância para os valores das deformações dos estribos

\begin{tabular}{cccccc}
\hline Variável & $\begin{array}{c}\text { Somados } \\
\text { quadrados }\end{array}$ & $\begin{array}{c}\text { Graus de } \\
\text { liberdade }\end{array}$ & $\begin{array}{c}\text { Média dos } \\
\text { quadrados }\end{array}$ & $\begin{array}{c}\text { Fator } \\
\left(F_{o}\right)\end{array}$ & $\begin{array}{c}\text { Mínimo fator de significância } \\
\text { requerido }\left(F_{0.05, n, 23}\right) \text { e }\left(F_{0.01, n, 23}\right)\end{array}$ \\
\hline $\begin{array}{c}\text { Fatores } \\
\text { principais }\end{array}$ & & & & & \\
$X_{1}$ & 0,32752 & 2 & 0,1638 & 0,561 & $3,42-5,66$ \\
$X_{2}$ & 0,03060 & 1 & 0,0306 & 0,105 & $4,28-7,88$ \\
$X_{3}$ & 1,82215 & 1 & 1,8222 & 6,243 & $4,28-7,88$ \\
Interações & & & & & \\
$X_{1} \times X_{2}$ & 1,16604 & 2 & 0,5830 & 1,998 & $3,42-5,66$ \\
$X_{1} \times X_{3}$ & 0,08172 & 2 & 0,0409 & 0,140 & $3,42-5,66$ \\
$X_{2} \times X_{3}$ & 0,12658 & 1 & 0,1265 & 0,434 & $4,28-7,88$ \\
$X_{1} \times X_{2} \times X_{3}$ & 1,31948 & 2 & 0,6597 & 2,261 & $3,42-5,66$ \\
Erro & 3,50227 & 12 & 0,2919 & - & - \\
Total & 8,37638 & 23 & - & - & - \\
\hline
\end{tabular}

Nas Figura 7.13 e Figura 7.14, apresentam-se os diagramas deformação média da armadura transversal vs. deformação axial dos pilares com resistência média do concreto à compressão de $60 \mathrm{MPa}$ e $80 \mathrm{MPa}$, respectivamente. Verifica-se que em 4 pilares apenas as armaduras transversais não atingiram o escoamento: P2501505, P160505, P180151 e P180505. Contudo, em todas as réplicas desses pilares as armaduras transversais atingiram o escoamento. Observa-se também, que, aparentemente, esse fato ocorreu de modo aleatório, pois todos os 4 modelos apresentavam características diferenciadas, considerando-se as variáveis estudadas (resistência à compressão do concreto, taxa de adição de fibra e taxa de armadura transversal). Esse fato pode ter ocorrido devido a alguma falha de fixação dos 
extensômetros elétricos, e, deste modo, a partir de elevadas deformações, a compatibilidade de deslocamentos, entre a armadura e esses instrumentos, ficou comprometida, gerando, assim, erros de leitura.

Tabela 7.10 - Comparação entre os valores teóricos e experimentais de $\left(\mathcal{E}_{t c c}\right)$

\begin{tabular}{|c|c|c|c|c|c|c|c|}
\hline Pilar & $\begin{array}{c}f_{t c c} \\
(M P a)\end{array}$ & $\begin{array}{c}f_{l e} \\
(M P a)\end{array}$ & $\begin{array}{c}\mathcal{E}_{c c} \\
(\% \circ)\end{array}$ & $\begin{array}{c}f_{c c} \\
(M P a)\end{array}$ & $\begin{array}{c}\mathcal{E}_{\text {tcc-teo }} \\
(\% o)\end{array}$ & $\begin{array}{c}\mathcal{E}_{t c c-\exp } \\
(\% o)\end{array}$ & $\frac{\mathcal{\varepsilon}_{t c c-t e o}}{\mathcal{E}_{t c c-\exp }}$ \\
\hline$P 160150$ & 263,74 & 0,101 & 2,516 & 64,64 & 1,256 & 1,06 & 1,18 \\
\hline$P 260150$ & 263,74 & 0,101 & 2,516 & 64,64 & 1,256 & 1,59 & 0,79 \\
\hline P16050 & 292,64 & 1,295 & 2,851 & 64,79 & 1,394 & 0,75 & 1,86 \\
\hline$P 26050$ & 292,64 & 1,295 & 2,851 & 64,79 & 1,394 & 1,83 & 0,76 \\
\hline P1601505 & 267,27 & 0,102 & 2,550 & 67,29 & 1,273 & 0,47 & 2,71 \\
\hline$P 2601505$ & 267,27 & 0,102 & 2,550 & 67,29 & 1,273 & 0,94 & 1,35 \\
\hline$P 160505$ & 294,55 & 1,308 & 2,867 & 67,43 & 1,403 & 1,09 & 1,29 \\
\hline$P 260505$ & 294,55 & 1,308 & 2,867 & 67,43 & 1,403 & 0,79 & 1,78 \\
\hline P160151 & 265,29 & 0,102 & 2,531 & 65,81 & 1,263 & 1,08 & 1,17 \\
\hline$P 260151$ & 265,29 & 0,102 & 2,531 & 65,81 & 1,263 & 1,19 & 1,06 \\
\hline P16051 & 293,40 & 1,299 & 2,857 & 65,94 & 1,397 & 1,15 & 1,21 \\
\hline$P 26051$ & 293,40 & 1,299 & 2,857 & 65,94 & 1,397 & 3,15 & 0,44 \\
\hline P180150 & 302,70 & 0,116 & 2,887 & 93,76 & 1,441 & 0,65 & 2,22 \\
\hline$P 280150$ & 302,70 & 0,116 & 2,887 & 93,76 & 1,441 & 0,66 & 2,18 \\
\hline P18050 & 319,22 & 1,419 & 3,092 & 93,87 & 1,520 & 1,95 & 0,78 \\
\hline$P 28050$ & 319,22 & 1,419 & 3,092 & 93,87 & 1,520 & 2,15 & 0,71 \\
\hline P1801505 & 298,06 & 0,114 & 2,843 & 90,29 & 1,419 & 0,93 & 1,53 \\
\hline$P 2801505$ & 298,06 & 0,114 & 2,843 & 90,29 & 1,419 & 1,41 & 1,01 \\
\hline P180505 & 315,36 & 1,397 & 3,175 & 90,41 & 1,502 & 1,30 & 1,16 \\
\hline$P 280505$ & 315,36 & 1,397 & 3,175 & 90,41 & 1,502 & 2,15 & 0,70 \\
\hline P180151 & 280,80 & 0,107 & 2,678 & 77,41 & 1,337 & 1,12 & 1,19 \\
\hline$P 280151$ & 280,80 & 0,107 & 2,678 & 77,41 & 1,337 & 1,12 & 1,19 \\
\hline P18051 & 302,65 & 1,343 & 2,939 & 77,53 & 1,441 & 1,04 & 1,39 \\
\hline$P 28051$ & 302,65 & 1,343 & 2,939 & 77,53 & 1,441 & 1,48 & 0,97 \\
\hline \multicolumn{7}{|c|}{ Valores médios } & 1,28 \\
\hline
\end{tabular}

Como foi discutido no item 3.3, Capitulo 3 desta tese, a adição de fibras aumenta o coeficiente de Poisson do compósito. Entretanto, comparando-se os trechos iniciais dos diagramas até as deformações axiais dos pilares de aproximadamente 3,5\%o, observa-se que, para pilares com a mesma resistência média do concreto e mesma taxa de armadura transversal, os diagramas desses elementos praticamente coincidem, não sendo, assim, influenciado pela taxa de adição de fibras.

Finalmente, observa-se que as armaduras transversais apenas atingiram o escoamento para deformação axial média da ordem de $6 \%$. Nota-se, ainda, que 
esse valor é aproximadamente o dobro da deformação axial correspondente a força máxima resistida pelos pilares.

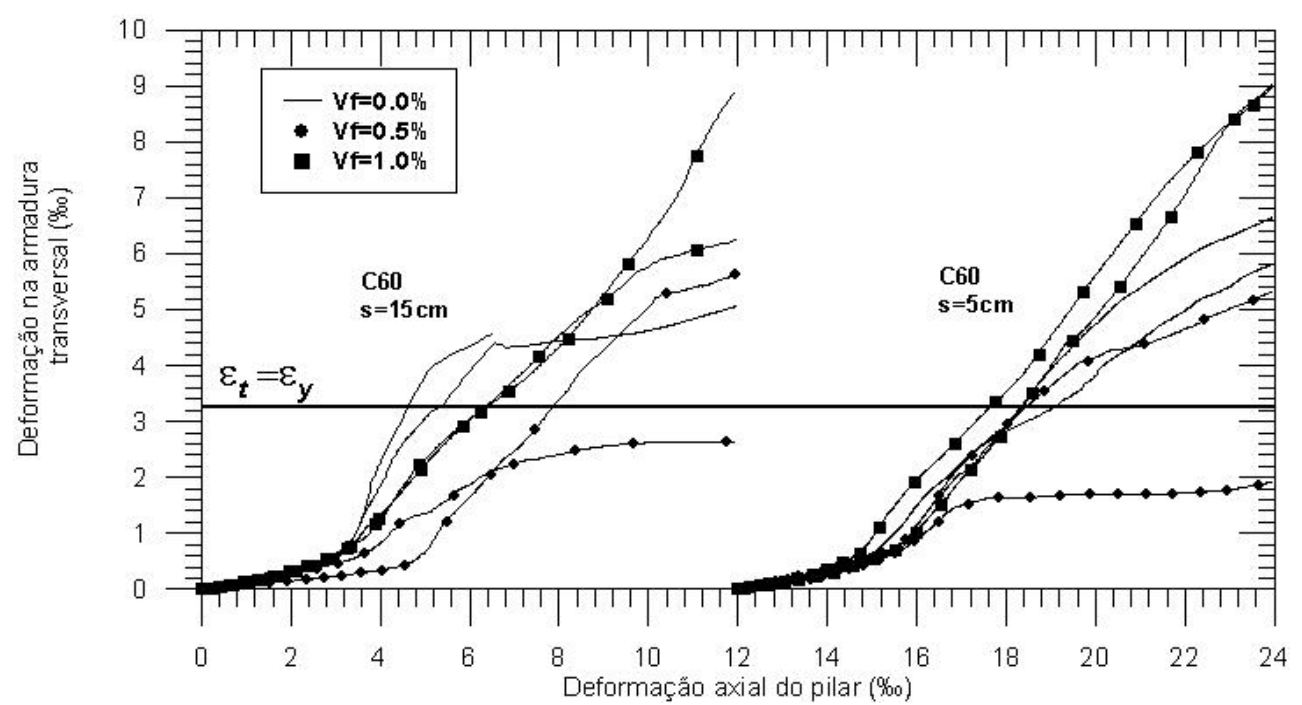

Figura 7.13 - Diagramas deformação na armadura transversal vs. deformação dos pilares com concretos com resistência de 60MPa

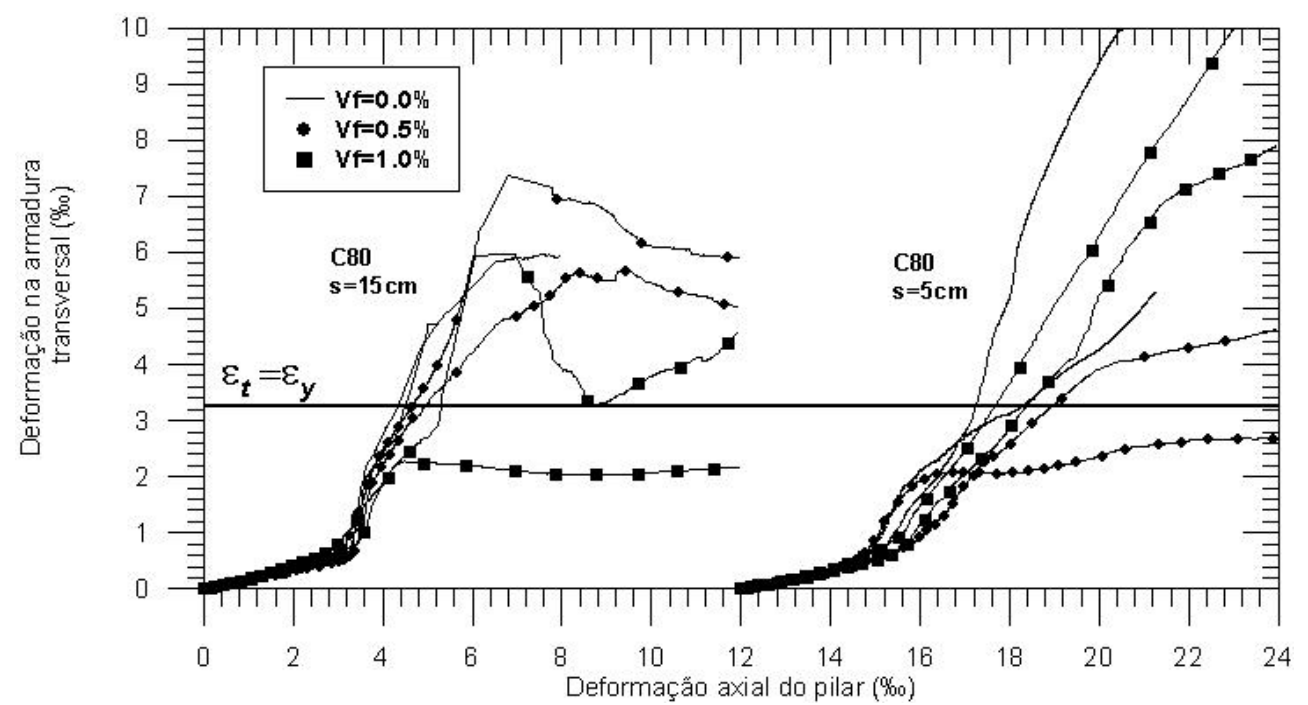

Figura 7.14 - Diagramas deformação na armadura transversal vs. deformação dos pilares com concretos com resistência de $80 \mathrm{MPa}$

\subsubsection{Avaliação do modelo de Cusson e Paultre (1995)}

Com o objetivo de avaliar a precisão do modelo de Cusson e Paultre (1995) em predizer o comportamento dos pilares com $C A R$, realizou-se um estudo onde os resultados experimentais foram comparados com os fornecidos pelo 
modelo em questão. Foram selecionadas cinco variáveis de análise: a deformação dos pilares correspondente a força máxima resistida pelos pilares $\left(\varepsilon_{c c}\right)$, a tensão no concreto correspondente à força máxima, calculada considerando apenas o núcleo delimitado pelos estribos $\left(f_{c c}\right)$, a deformação da armadura transversal correspondente a força máxima $\left(\varepsilon_{t c c}\right)$, e os índices de ductilidade $\left(\varepsilon_{0,5 f c c} / \mathcal{E}_{c c}\right) \mathrm{e}$ $\left(I D_{\text {pós }}\right)$.

A resistência do concreto utilizada foi calculada considerando $k=0,95$ (ACI, 1989) e as resistências médias obtidas nos corpos-de-prova cilíndricos, uma vez que, Cusson e Paultre (1995) utilizaram esse coeficiente e corpo-de-prova para formular seu modelo. Ainda, foram utilizados os valores das características físicas e mecânicas dos aços apresentadas na Tabela 6.3. Na Tabela 7.11 apresentam-se os valores das cinco variáveis obtidas com o modelo e experimentalmente, e um comparativo entre estes, e, na Figura 7.15, as curvas teóricas e experimentais tensão no concreto vs. deformação dos pilares.

Analisando os resultados obtidos, observa-se que a variável melhor modelada foi a tensão no concreto $\left(f_{c c}\right)$, com divergência dos valores experimentais de aproximadamente 15\%. A máxima divergência foi observada para a variável $\left(\varepsilon_{0,5 f c c} / \mathcal{E}_{c c}\right)$, que foi de aproximadamente $48 \%$. Kappos e Konstantinidis (1999) avaliaram o modelo em questão utilizando três das cinco variáveis estudadas $\left(\varepsilon_{c c}, f_{c c}, \mathrm{e}^{\varepsilon_{0,5 f c c}} / \varepsilon_{c c}\right)$ e obtiveram discrepâncias de 37,2\%, 13,5\% e 55,1\%, respectivamente. Como já apresentado no capítulo dois, Quintana (2001) observou que os valores da deformação da armadura transversal correspondente a força máxima $\left(\varepsilon_{t c c}\right)$, calculados com o modelo em questão, podem diferir expressivamente dos experimentais. Essas observações encontram-se em concordância as observadas nesta tese.

Comparando-se as tensões experimentais no concreto $\left(f_{c c}\right)$ dos pilares com espaçamento entre estribos de $15 \mathrm{~cm}$ e $5 \mathrm{~cm}$, constata-se que a elevação da taxa de armadura transversal não foi suficiente para gerar confinamento capaz de aumentar a tensão no concreto. A diferença média entre a tensão nos pilares com 
espaçamento de $15 \mathrm{~cm}$ e $5 \mathrm{~cm}$ foi de apenas $0,5 \%$, valor este considerado não significativo.

Finalmente, analisando visualmente as curvas apresentadas, observa-se discrepância considerável entre os valores teórico-experimentais das deformações $\left(\varepsilon_{c c}\right)$ e de todo o caminho pós-pico.

Tabela 7.11- Variáveis de avaliação do modelo de Cusson e Paultre (1995)

\begin{tabular}{|c|c|c|c|c|c|c|c|c|c|c|c|}
\hline \multirow[b]{2}{*}{ Pilar } & \multirow[b]{2}{*}{$\begin{array}{c}f_{c j} \\
(M P a)\end{array}$} & \multicolumn{5}{|c|}{ Cusson e Paultre (1995) } & \multicolumn{5}{|c|}{ Experimental } \\
\hline & & $\begin{array}{c}\mathcal{E}_{c c} \\
(\% o)\end{array}$ & $\begin{array}{c}f_{c c} \\
(M P a)\end{array}$ & $\begin{array}{c}\mathcal{E}_{t c c} \\
(\% o)\end{array}$ & $\frac{\varepsilon_{0,5 f c c}}{\varepsilon_{c c}}$ & $I D_{\text {pós }}$ & $\begin{array}{c}\mathcal{E}_{c c} \\
(\% o)\end{array}$ & $\begin{array}{c}f_{c c} \\
(M P a)\end{array}$ & $\begin{array}{c}\varepsilon_{t c c} \\
(\% o)\end{array}$ & $\frac{\varepsilon_{0,5 f c c}}{\varepsilon_{c c}}$ & $I D_{\text {pós }}$ \\
\hline P14015 & 43,03 & 2,23 & 42,03 & 1,11 & 3,67 & 1,39 & 3,04 & 46,30 & 0,34 & 2,17 & 1,22 \\
\hline$P 24015$ & 43,03 & 2,23 & 42,03 & 1,11 & 3,67 & 1,39 & 4,10 & 48,45 & 0,73 & 1,89 & 0,96 \\
\hline$P 160150$ & 66,85 & 2,51 & 64,66 & 1,26 & 2,61 & 1,24 & 3,52 & 82,34 & 1,06 & 1,95 & 1,05 \\
\hline$P 260150$ & 66,85 & 2,51 & 64,66 & 1,26 & 2,61 & 1,24 & 3,38 & 78,77 & 0,84 & 1,83 & 0,92 \\
\hline$P 16050$ & 66,85 & 2,85 & 64,79 & 1,39 & 5,39 & 1,57 & 3,60 & 85,58 & 0,73 & 3,30 & 1,41 \\
\hline$P 26050$ & 66,85 & 2,85 & 64,79 & 1,39 & 5,39 & 1,57 & 4,45 & 82,29 & 1,83 & 2,31 & 1,33 \\
\hline P180150 & 97,50 & 2,89 & 93,77 & 1,44 & 1,97 & 1,06 & 3,24 & 108,97 & 1,97 & 1,67 & 0,87 \\
\hline$P 280150$ & 97,50 & 2,89 & 93,77 & 1,44 & 1,97 & 1,06 & 3,31 & 108,87 & 1,90 & 1,61 & 0,70 \\
\hline P18050 & 97,50 & 3,09 & 93,88 & 1,52 & 3,72 & 1,43 & 4,45 & 104,18 & 2,06 & 3,30 & 1,39 \\
\hline \multirow[t]{2}{*}{$P 28050$} & 97,50 & 3,09 & 93,88 & 1,52 & 3,72 & 1,43 & 4,12 & 106,72 & 2,15 & 4,03 & 1,31 \\
\hline & & \multicolumn{10}{|c|}{ Comparação entre os valores experimentais e teóricos acima (\%) } \\
\hline \multicolumn{2}{|c|}{ Pilar } & \multicolumn{2}{|r|}{$\varepsilon_{c c}$} & \multicolumn{2}{|r|}{$f_{c c}$} & \multicolumn{2}{|r|}{$\varepsilon_{t c c}$} & \multicolumn{2}{|c|}{$\frac{\varepsilon_{0,5 f c c}}{\varepsilon_{c c}}$} & \multicolumn{2}{|c|}{$I D_{\text {pós }}$} \\
\hline \multicolumn{2}{|c|}{$P 14015$} & \multicolumn{2}{|r|}{$-26,64$} & \multicolumn{2}{|r|}{$-9,22$} & \multicolumn{2}{|c|}{226,47} & \multicolumn{2}{|c|}{$-69,12$} & \multicolumn{2}{|c|}{$-13,93$} \\
\hline \multicolumn{2}{|c|}{$P 24015$} & \multicolumn{2}{|r|}{$-45,61$} & \multicolumn{2}{|r|}{$-13,25$} & & 2,05 & -94 & 18 & -44 & \\
\hline P16 & 150 & & $-28,69$ & & $-21,47$ & & 8,87 & -33 &, 85 & -18 & \\
\hline$P 26$ & 150 & & $-25,74$ & & $-17,91$ & & 0,00 & -42 & 62 & -34 & \\
\hline PlC & 950 & & $-20,83$ & & $-24,29$ & & 0,41 & -63 & ,33 & -11 & \\
\hline$P 26$ & 950 & & $-35,96$ & & $-21,27$ & & 24,04 & -13 & 3,33 & -18 & \\
\hline P18 & 150 & & $-10,80$ & & $-13,95$ & & 26,90 & -17 & ,96 & -21 & \\
\hline$P 28$ & 150 & & $-12,69$ & & $-13,87$ & & 24,21 & & 36 & -51 & \\
\hline$P 18$ & 950 & & $-30,56$ & & $-9,89$ & & 26,21 & -12 &, 73 & -2 , & \\
\hline$P 28$ & 950 & & $-25,00$ & & $-12,03$ & & 29,30 & 7 & 69 & -9 , & \\
\hline Média \pm & ,Padrão & & $26,3 \pm 9,73$ & & $5,7 \pm 4,94$ & 30 , & $71 \pm 81,0$ & $-48,2$ & $\pm 42,5$ & $-22,63$ & 15,1 \\
\hline
\end{tabular}

As obtenções de $\varepsilon_{c c}$ e do caminho pós-pico estão sujeitas a algumas ambigüidades, entre as quais destacam-se as que se referem ao comprimento de avaliação das deformações, à geometria do pilar e à localização do plano de ruptura (Kappos e Konstantinidis, 1999). Observa-se que esses dois primeiros fatores, utilizados no presente trabalho, diferem dos utilizados por Cusson e Paultre (1995) para formulação do modelo. Ainda, foi utilizada, no modelo de Cusson e Paultre (1995), a equação Eq.(4.8) sugerida pelo FIB (1999) para o 
cálculo da deformação $\varepsilon_{c o}$. Observou-se, que os valores obtidos por meio dessa equação foram inferiores aos experimentais, diferindo de aproximadamente de $15 \%$ para o concreto $\operatorname{com} f_{c j}=40 \mathrm{MPa}$, de $23 \%$ para o concreto $\operatorname{com} f_{c j}=60 \mathrm{MPa}$ e de $27 \%$ para o concreto $\operatorname{com} f_{c j}=80 \mathrm{MPa}$. Esse fato pode ter prejudicado ainda mais a modelagem do caminho pós-pico e de $\varepsilon_{c c}$ dos pilares ensaiados.

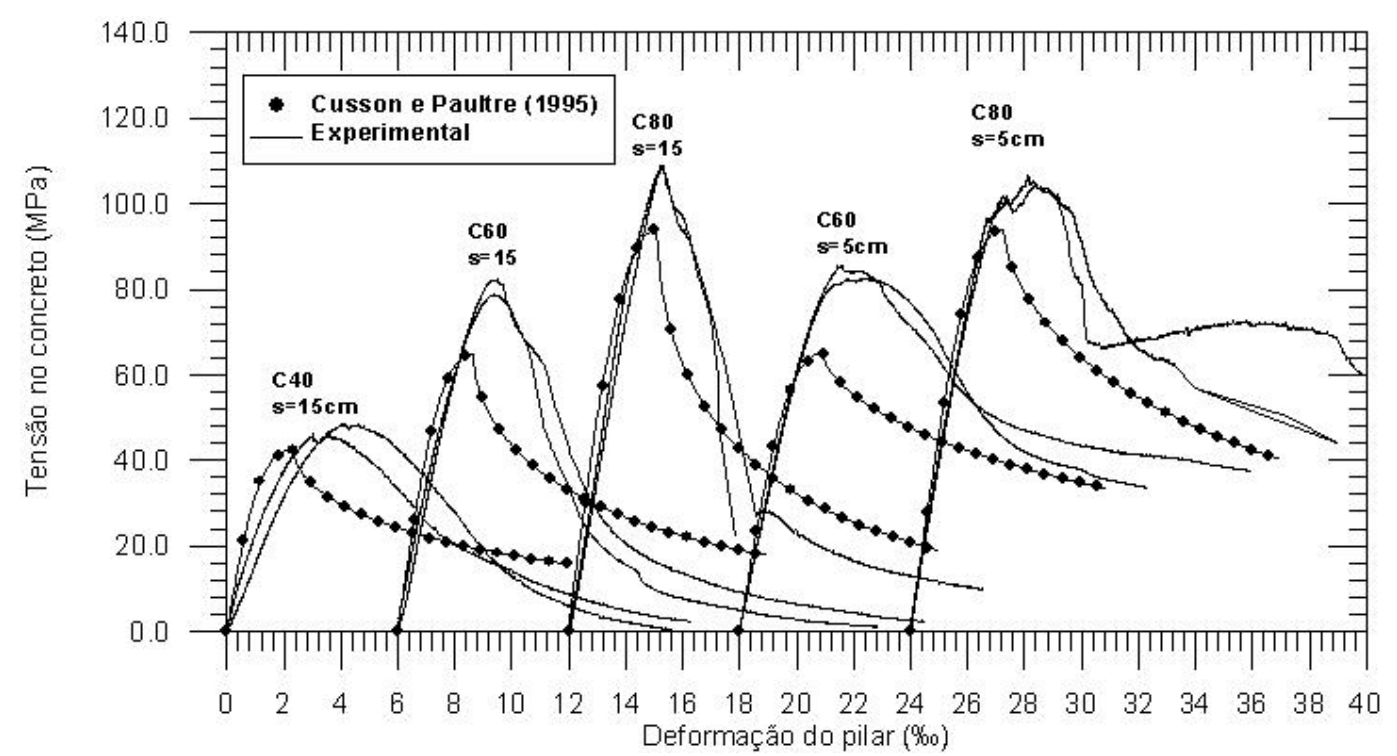

Figura 7.15 - Diagramas tensão no concreto vs. deformação dos pilares sem adição de fibra

\subsubsection{Avaliação da ductilidade dos pilares}

Para avaliação dos índices de ductilidade dos pilares, foram utilizados os diagramas paramétricos tensão no concreto vs. deformação do pilar. Desse modo, não se consideraram os efeitos favoráveis das armaduras longitudinais. Na Figura 7.16 e na Figura 7.17 apresentam-se as curvas paramétricas tensão concreto vs. deformação do pilar com resistência à compressão média do concreto de $60 \mathrm{MPa} \mathrm{e}$ $80 \mathrm{MPa}$, respectivamente. Ainda, apresenta-se a curva dos pilares com concreto de resistência usual. Para obtenção das curvas em questão, utilizou-se análise de regressão polinomial não linear sobre os diagramas dos dois pilares gêmeos, para cada combinação entre as variáveis estudadas. Em todos os casos, encontraram-se coeficientes de correlação, $r^{2}$, superiores a $94 \%$. 
Analisado-se os diagramas em questão, verifica-se que teores de fibras da ordem de $0,5 \%$, aparentemente são capazes de proverem aos pilares com concretos de alta resistência a mesma ductilidade dos pilares com concretos de 40MPa. Ainda, constata-se que espaçamentos entre estribos de $5 \mathrm{~cm}$ foram capazes de elevar de modo considerável a ductilidade dos pilares. A ductilidade dos pilares com espaçamento entre estribos de $5 \mathrm{~cm}$ foi muito superior à dos pilares de referencia.

Nas Tabela 7.12 e Tabela 7.13 são apresentados os valores dos índices de ductilidade $I D_{\text {pos }}$ e $\varepsilon_{0.5 f c c / \varepsilon c c}$, respectivamente, para os pilares com concretos de alta resistência ensaiados.

Os pilares com concreto de resistência média à compressão de $40 \mathrm{MPa}$ apresentaram índices de ductilidade médios, $I D_{p o s}$ e $\varepsilon_{0.5 f c c} d \mathcal{E}_{c c}$, iguais a 1,10 e 2,04, respectivamente. Esses valores diferem de $10 \%$ dos valores obtidos por Câmara et alii (2003), apresentados no item 5.2 do Capítulo 5 desta tese. Ainda, observa-se que os valores coincidem com os sugeridos como ideais no Capítulo 5 (ID pos $\mathrm{e}$ $\mathcal{E}_{0.5 f c d} \mathcal{E}_{c c}$, iguais a 1,008 e 1,972 , respectivamente).

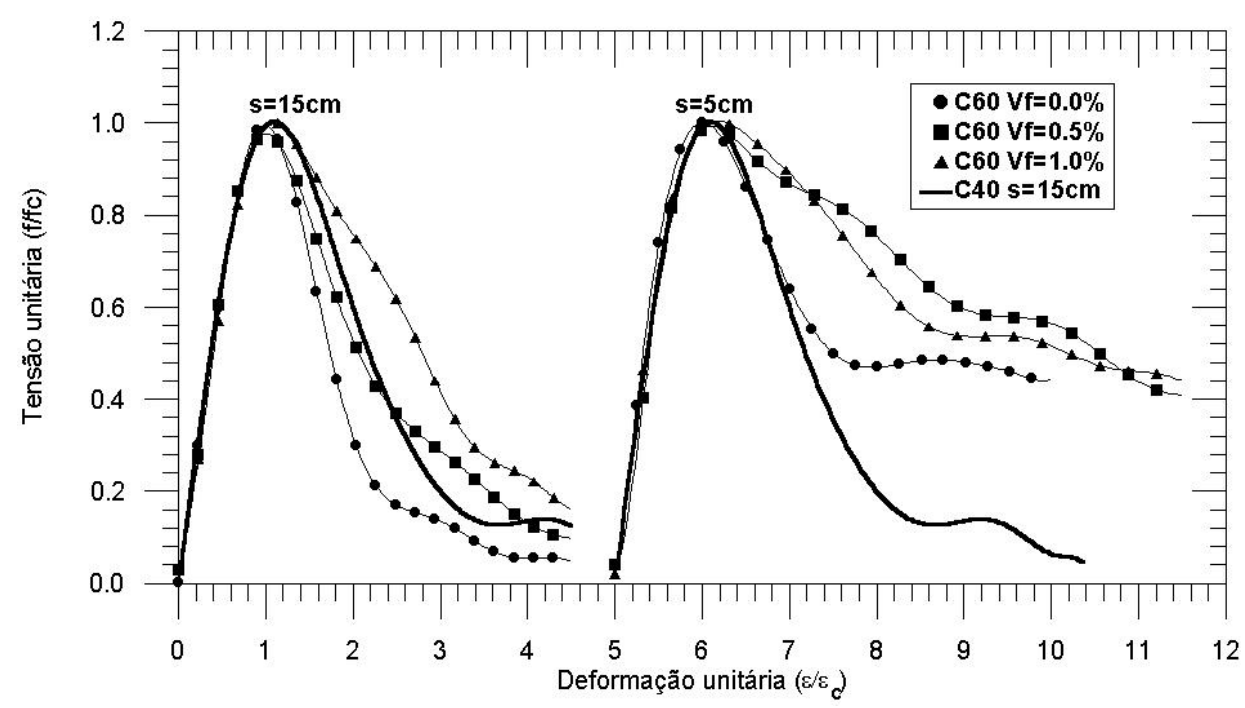

Figura 7.16 - Diagramas paramétricas tensão no cocreto vs. deformação dos pilares com concretos com resistência média de 60MPa 


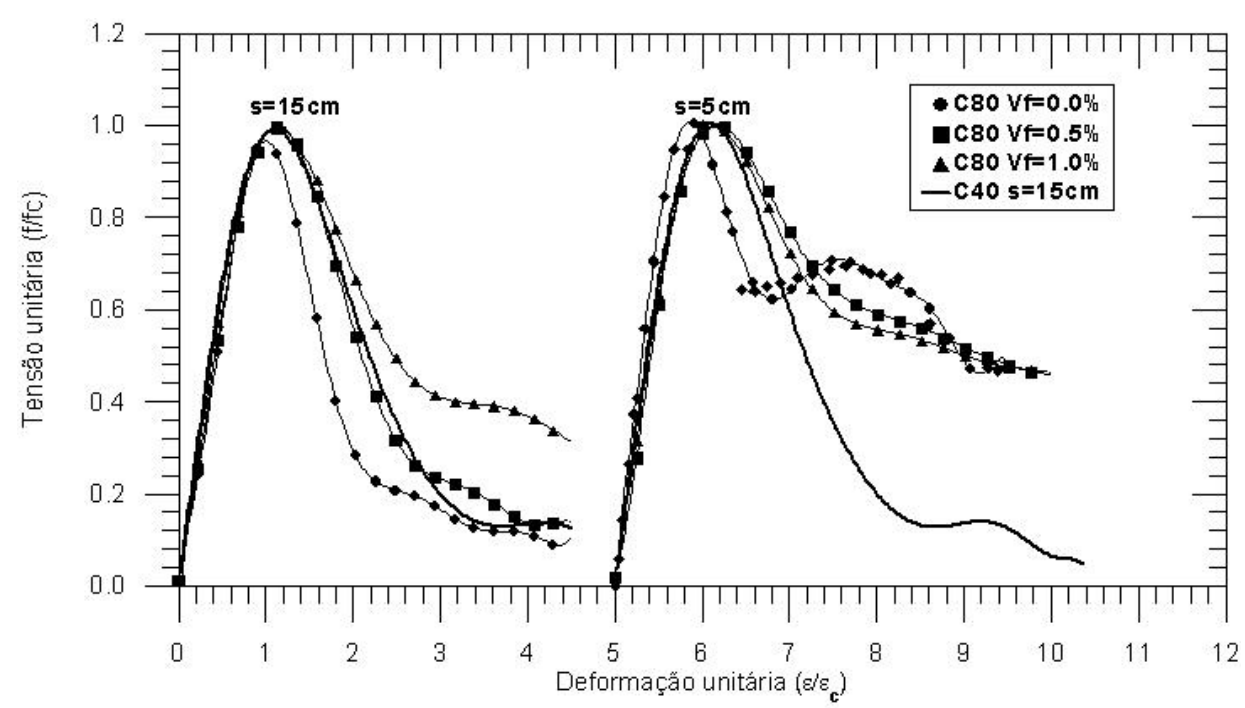

Figura 7.17 - Diagramas paramétricas tensão no cocreto vs. deformação dos pilares com concretos com resistência média de 80MPa

Tabela 7.12- Valores dos índices de ductilidade IDpos para os pilares

\begin{tabular}{ccccc}
\hline Taxa de & \multicolumn{4}{c}{ Resistência do concreto $f_{c}(\mathrm{MPa})\left(X_{2}\right)$} \\
\cline { 2 - 5 } adição de & \multicolumn{4}{c}{80} \\
\cline { 2 - 5 } fibra $V_{f}(\%)$ & \multicolumn{4}{c}{ Espaçamento entre estribos $s(\mathrm{~cm})\left(X_{3}\right)$} \\
\cline { 2 - 5 }$\left(X_{1}\right)$ & 5 & 15 & 5 & 15 \\
\hline \multirow{2}{*}{0} & 1,411 & 1,051 & 1,390 & 0,872 \\
& 1,339 & 0,927 & 1,313 & 0,704 \\
0,5 & 1,777 & 1,125 & 1,600 & 1,019 \\
& 1,449 & 1,330 & 1,340 & 1,031 \\
1,0 & 1,871 & 1,304 & 1,451 & 1,455 \\
& 1,688 & 1,446 & 1,383 & 1,057 \\
\hline
\end{tabular}

Tabela 7.13- Valores dos índices de ductilidade $\boldsymbol{\varepsilon}_{0.5 f c d} / \boldsymbol{\varepsilon}_{c c}$ para os pilares

\begin{tabular}{ccccc}
\hline Taxa de & \multicolumn{4}{c}{ Resistência do concreto $f_{c}(M P a)\left(X_{2}\right)$} \\
\cline { 2 - 5 } adição de & \multicolumn{4}{c}{80} \\
fibra $V_{f}(\%)$ & \multicolumn{4}{c}{80} \\
\cline { 2 - 5 }$\left(X_{1}\right)$ & 5 & Espaçamento entre estribos $s(\mathrm{~cm})\left(X_{3}\right)$ \\
\hline \multirow{2}{*}{0} & 3,309 & 15 & 5 & 15 \\
& 2,316 & 1,953 & 3,307 & 1,678 \\
0,5 & 5,774 & 1,837 & 4,033 & 1,611 \\
& 2,676 & 2,423 & 4,560 & 1,801 \\
1,0 & 5,434 & 2,659 & 2,448 & 1,905 \\
& 4,069 & 2,968 & 3,988 & 3.307 \\
& & & 3,905 & 1.930 \\
\hline
\end{tabular}

Os pilares com concreto de altas resistências apresentaram índices de ductilidade, $I D_{p o s}$ e $\varepsilon_{0.5 f c c} \mathcal{E}_{c c}$, variando entre 0,704 a 1,871 e 1,611 a 5,434 , respectivamente. Observa-se que é possível melhorar o comportamento pós-pico dos pilares por meio de adição de fibras e maiores taxas de armadura transversal, 
de modo que, esses elementos atinjam a ductilidade mínima dos pilares de referência.

Para verificar a influência da taxa de adição de fibra (fator $X_{1}$ ), da resistência do concreto (fato $X_{2}$ ) e do espaçamento entre estribos (fator $X_{3}$ ) foi realizada uma análise de variância sobre os dados das Tabela 7.12 e Tabela 7.13. Os graus de significância do efeito de cada fator foram testados para graus de confiabilidade de $95 \%$ e $99 \%$, usando-se o $F$ teste. Na Tabela 7.14 e na Tabela 7.15, apresentam-se os resultados da análise de variância realizada.

Tabela 7.14 - Análise de variância para os valores de $I_{\text {Pós }}$

\begin{tabular}{cccccc}
\hline Variável & $\begin{array}{c}\text { Somados } \\
\text { quadrados }\end{array}$ & $\begin{array}{c}\text { Graus de } \\
\text { liberdade }\end{array}$ & $\begin{array}{c}\text { Média dos } \\
\text { quadrados }\end{array}$ & $\begin{array}{c}\text { Fator } \\
\left(F_{o}\right)\end{array}$ & $\begin{array}{c}\text { Mínimo fator de significância } \\
\text { requerido }\left(F_{0.05, n, 23}\right) e\left(F_{0.01, n, 23}\right)\end{array}$ \\
\hline $\begin{array}{c}\text { Fatores } \\
\text { principais }\end{array}$ & & & & \\
$X_{1}$ & 0,447877 & 2 & 0,2239 & 10,997 & $3,42-5,66$ \\
$X_{2}$ & 0,184275 & 1 & 0,1843 & 9,049 & $4,28-7,88$ \\
$\quad X_{3}$ & 0,916895 & 1 & 0,9169 & 45,024 & $4,28-7,88$ \\
Interações & & & & & \\
$X_{1} \times X_{2}$ & 0,016531 & 2 & 0,0083 & 0,406 & $3,42-5,66$ \\
$X_{1} \times X_{3}$ & 0,038640 & 2 & 0,0193 & 0,949 & $3,42-5,66$ \\
$X_{2} \times X_{3}$ & 0,000007 & 1 & 0,0000 & 0,000 & $4,28-7,88$ \\
$X_{1} \times X_{2} \times X_{3}$ & 0,047162 & 2 & 0,0236 & 1,158 & $3,42-5,66$ \\
Erro & 0,244374 & 12 & 0,0204 & & \\
Total & 1,895762 & 23 & & & \\
\hline
\end{tabular}

Tabela 7.15 - Análise de variância para os valores de $\boldsymbol{\varepsilon}_{0.5 f c c} \mathcal{\varepsilon}_{c c}$

\begin{tabular}{cccccc}
\hline Variável & $\begin{array}{c}\text { Somados } \\
\text { quadrados }\end{array}$ & $\begin{array}{c}\text { Graus de } \\
\text { liberdade }\end{array}$ & $\begin{array}{c}\text { Médiados } \\
\text { quadrados }\end{array}$ & $\begin{array}{c}\text { Fator } \\
\left(F_{o}\right)\end{array}$ & $\begin{array}{c}\text { Mínimo fator de significância } \\
\text { requerido }\left(F_{0.05, n, 23}\right) e\left(F_{0.01, n, 23}\right)\end{array}$ \\
\hline $\begin{array}{c}\text { Fatores } \\
\text { principais }\end{array}$ & & & & \\
$X_{1}$ & 4,24580 & 2 & 2,1229 & 2,594 & $3,42-5,66$ \\
$X_{2}$ & 0,36064 & 1 & 0,3606 & 0,441 & $4,28-7,88$ \\
$\quad X_{3}$ & 16,25260 & 1 & 16,2526 & 19,857 & $4,28-7,88$ \\
Interações & & & & & \\
$X_{1} \times X_{2}$ & 0,90462 & 2 & 0,4523 & 0,553 & $3,42-5,66$ \\
$X_{1} \times X_{3}$ & 0,13117 & 2 & 0,0656 & 0,080 & $3,42-5,66$ \\
$X_{2} \times X_{3}$ & 0,00299 & 1 & 0,0030 & 0,004 & $4,28-7,88$ \\
$X_{1} \times X_{2} \times X_{3}$ & 0,86313 & 2 & 0,4316 & 0,527 & $3,42-5,66$ \\
Erro & 9,82161 & 12 & 0,8185 & & \\
Total & 32,58259 & 23 & & & \\
\hline
\end{tabular}

Analisando os resultados obtidos com o índice de ductilidade $I D_{\text {pós }}$, verifica-se que os três fatores estudados influenciam a ductilidade dos pilares para graus de confiabilidade de $99 \%$. Ainda, que o fator mais influente é a taxa de 
armadura transversal, seguido pela resistência do concreto e pela taxa de adição de fibras. A taxa de adição de fibras tem praticamente a mesma influência da resistência do concreto, isto significa, que a perda de ductilidade com o aumento da resistência do concreto pode ser compensada com adição de fibras metálicas. Constata-se ainda que o aumento da taxa de armadura transversal é mais eficiente que a adição de fibras metálicas, considerando a ductilidade de pilares submetidos à compressão centrada. Não se constatou influencia significativa dos acoplamentos dos fatores analisados para graus de confiabilidade de 99\%. Este fato implica que a superposição de efeitos é válida para a avaliação do ganho de ductilidade dos pilares, quando do aumento da taxa de armadura transversal e da taxa de adição de fibras.

Avaliando os resultados obtidos com o índice de ductilidade, $\varepsilon_{0.5 f c d} \varepsilon_{c c}$, observa-se que apenas a taxa de armadura transversal tem influência na ductilidade dos pilares, para graus de confiabilidade de 99\%. Tanto a resistência do concreto e a taxa de adição de fibras, quanto os acoplamentos entres os fatores, não apresentaram significância, para graus de confiabilidade de 99\%. Esses resultados são contraditórios, uma vez que é possível observar visualmente o ganho de ductilidade dos pilares com a adição de fibras (Figura 7.16 e Figura 7.17). Também é notório que a resistência do concreto tem influência significativa no comportamento pós-pico desses elementos estruturais. A justificativa para esses resultados é que esse índice de ductilidade avalia o comportamento pós-pico dos diagramas por meio de apenas um ponto da curva, e assim fica sujeito a resultados conflitantes, como discutido no item 4.2 do Capítulo 4 dessa teses.

Com o objetivo de estabelecer uma equação para obtenção das taxas ideais de adição de fibra e de armadura transversal, realizou-se uma regressão polinomial linear, com os valores dos índices de ductilidade apresentados na Tabela 7.12. Obteve-se uma equação polinomial com coeficiente de correlação, $r^{2}$, de $95 \%$. Assim, com base nesta análise pode-se escrever que o índice de ductilidade póspico dos pilares submetidos à compressão centrada pode ser expresso pela Eq. (7.6): 


$$
I D_{\text {pós }}=1,371+0,582 \cdot \rho_{w}+0,414 \cdot R-7,838 \cdot 10^{-3} \cdot f_{c j}
$$

na qual, $\rho_{w}$ é a taxa de armadura transversal dada pela Eq.(5.1), $R$ é o índice de reforço da adição de fibras metálicas e $f_{c j}$ é a resistência do concreto obtida por meio de corpos-de-prova cilíndricos $15 \mathrm{~cm} \times 30 \mathrm{~cm}$.

Para se obterem taxas ideais de fibras e de armadura transversal, pode-se considerar que o índice de ductilidade mínimo aceitável é aquele apresentado pelos pilares com resistência à compressão do concreto de $40 \mathrm{MPa}\left(I D_{\text {pós }}=1,1\right)$. Deste modo, substituindo o valor desse índice de ductilidade na Eq. (7.6), obtémse a Eq.(7.7):

$$
0,271+0,582 \cdot \rho_{w}+0,414 \cdot R-7,838 \cdot 10^{-3} \cdot f_{c j}=0
$$

a partir da qual, substituindo-se a resistência do concreto, pode-se calcular o índice de reforço da adição de fibras ou a taxa de armadura transversal mínimas, ambos necessários para se obter a ductilidade mínima aceitável para os pilares de CAR. Assim, para resistências médias de $60 \mathrm{MPa}$ e $80 \mathrm{MPa}$ os valores ideais de $R$ são aproximadamente 0,48 e 0,86 , respectivamente.

\subsection{MODIFICAÇÃO DO MODELO DE CUSSON E PAULTRE (1995)}

Baseado no apresentado nos itens anteriores desse capítulo, a resistência do concreto nas estruturas de concreto armado deve ser calculada a partir da Eq. (7.8):

$$
f_{c}=k \cdot f_{c j}
$$

na qual $f_{c j}$ é a resistência à compressão média do concreto obtida por meio de ensaio em corpos-de-prova cilíndricos $15 \mathrm{~cm} \times 30 \mathrm{~cm}$ e $k$ é um coeficiente dado pela Eq.(7.9):

$$
k=k_{1} \cdot k_{2} \cdot k_{3}
$$

na qual $k_{1}$ é um coeficiente que leva em conta o acréscimo de resistência do concreto após 28 dias, $k_{2}$ é um coeficiente que leva em consideração a estimativa da resistência do concreto nas estruturas, quando avaliadas por meio de corpos-deprova, e $k_{3}$ considera a diminuição da resistência do concreto para ações de longa 
duração. Na falta de dados experimentais, pode-se adotar $k_{1}=1,2, k_{3}=0,75$, como sugerido por Fusco (1989). Observou-se que maiores estudos sobre o valor exato do coeficiente $k_{2}$ para estruturas de concreto armado se fazem necessários. Contudo, na falta de valores mais precisos, pode-se tomar $k_{2}$ como sendo os valores especificados pela norma norueguesa NBR (1989), que são calculados pela Eq.(7.10):

$$
k_{2}=-0.136 \cdot \ln \left(f_{c j}\right)+1.347
$$

Para realizar as modificações das equações do modelo de Cusson e Paultre (1995) os valores de $k_{2}$ foram calculados com a equação Eq.(7.10).

Para o trecho ascendente do diagrama tensão vs. deformação do concreto confinado e/ou com adição de fibra, continua-se sugerindo a utilização da equação proposta por Popovics (1973) e que pode ser escrita pela Eq.(7.11):

$$
\frac{\sigma_{c}}{f_{c c f}}=\frac{\beta \cdot\left(\frac{\varepsilon_{c}}{\varepsilon_{c c f}}\right)}{(\beta-1)+\left(\frac{\varepsilon_{c}}{\varepsilon_{c c f}}\right)^{\beta}}
$$

na qual, $\varepsilon_{c}$ é a deformação em um ponto qualquer do diagrama, $\varepsilon_{c c f}$ é a deformação correspondente à tensão máxima do concreto confinado e/ou adição de fibra, e, finalmente, $\beta$ é um coeficiente expresso pela Eq.(7.12):

$$
\beta=\frac{E_{c}}{E_{c}-\left(f_{c c f} / \varepsilon_{c c f}\right)}
$$

Para o trecho descendente do diagrama tensão vs. deformação do concreto confinado e/ou com adição de fibra, sugere-se, também, a equação proposta por Fafitis e Shah (1985), cuja formulação matemática é escrita por meio da Eq.(7.13):

$$
\frac{\sigma_{c}}{f_{c c f}}=\exp \left(k_{11} \cdot\left(\varepsilon_{c}-\varepsilon_{c c f}\right)^{k_{22}}\right)
$$

na qual $k_{22}$ é um coeficiente que foi obtido por análise de regressão e é responsável pela curvatura da curva, e $k_{11}$ é o coeficiente responsável pela inclinação da curva, tendo sido ajustado por meio do ponto $\left(\varepsilon_{0,5 c c f}, 0,5 f_{c c f}\right)$. Para o 
cálculo de $k_{22}$, utilizaram-se os pilares ensaiados por Cusson e Paultre (1993), os ensaiados no presente trabalho e o modelo proposto para CRFA apresenta no Capítulo 4. Observou-se a não existência de acoplamentos entre a taxa de adição de fibra e a taxa de armadura transversal, deste modo, os cálculos das parcelas de $k_{22}$ foram realizados separadamente para cada variável. Nas Figura 7.18 e Figura 7.19, apresentam-se as variações de $k_{22}$ em relação ao índice de reforço da adição de fibras e a pressão efetiva de confinamento, respectivamente. Superpondo os efeitos das duas parcelas apresentadas nessas figuras, obtém-se que o coeficiente $k_{22}$ pode ser expresso pela Eq.(7.14):

$$
k_{22}=1,344-8,864 \cdot\left(\frac{f_{l e}}{f_{c}}\right)+41,455 \cdot\left(\frac{f_{l e}}{f_{c}}\right)^{2}+0,525 \cdot R^{0,789}
$$

na qual $f_{l e}$ é a pressão efetiva de confinamento, e $R$ é o índice de reforço da adição de fibras de aço.

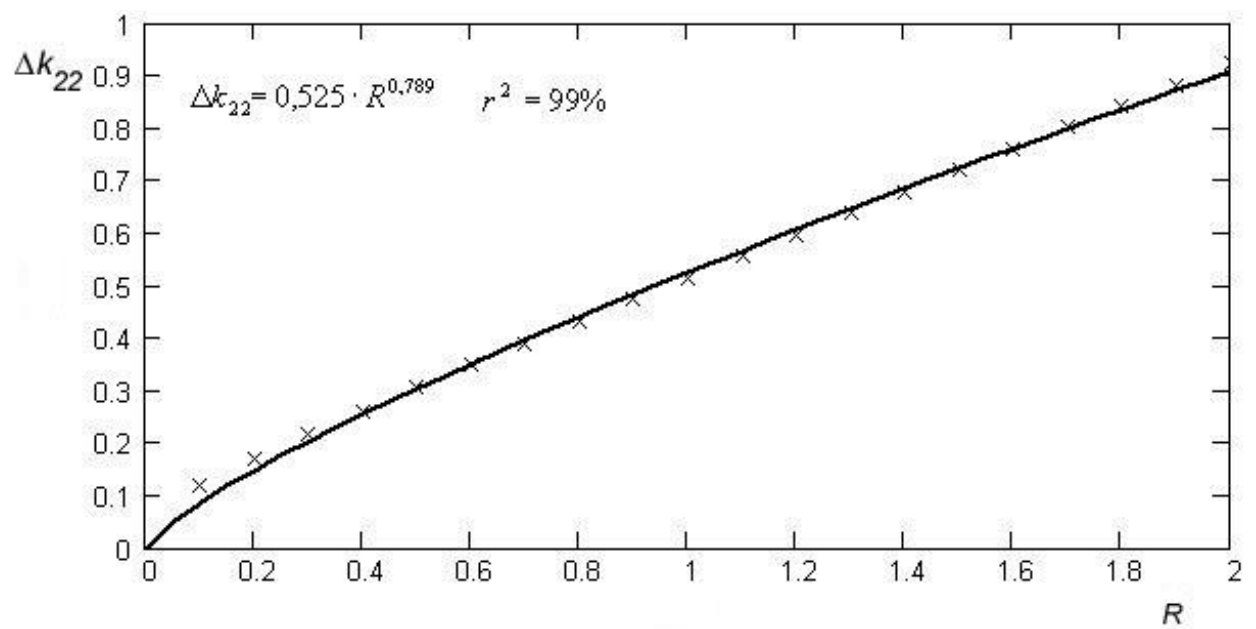

Figura 7.18 - Variação de $k_{22}$ em relação ao índice de reforça da adição de fibra de aço

O coeficiente $k_{11}$ pode é expresso pela equação Eq. (7.15)

$$
k_{11}=\frac{\ln (0,5)}{\left(\varepsilon_{0,5 c c f}-\varepsilon_{c c f}\right)^{k_{22}}}
$$

na qual $\varepsilon_{0,5 c c f}$ é a deformação no ramo descendente do diagrama tensão vs. deformação correspondente a $50 \%$ da tensão máxima. 


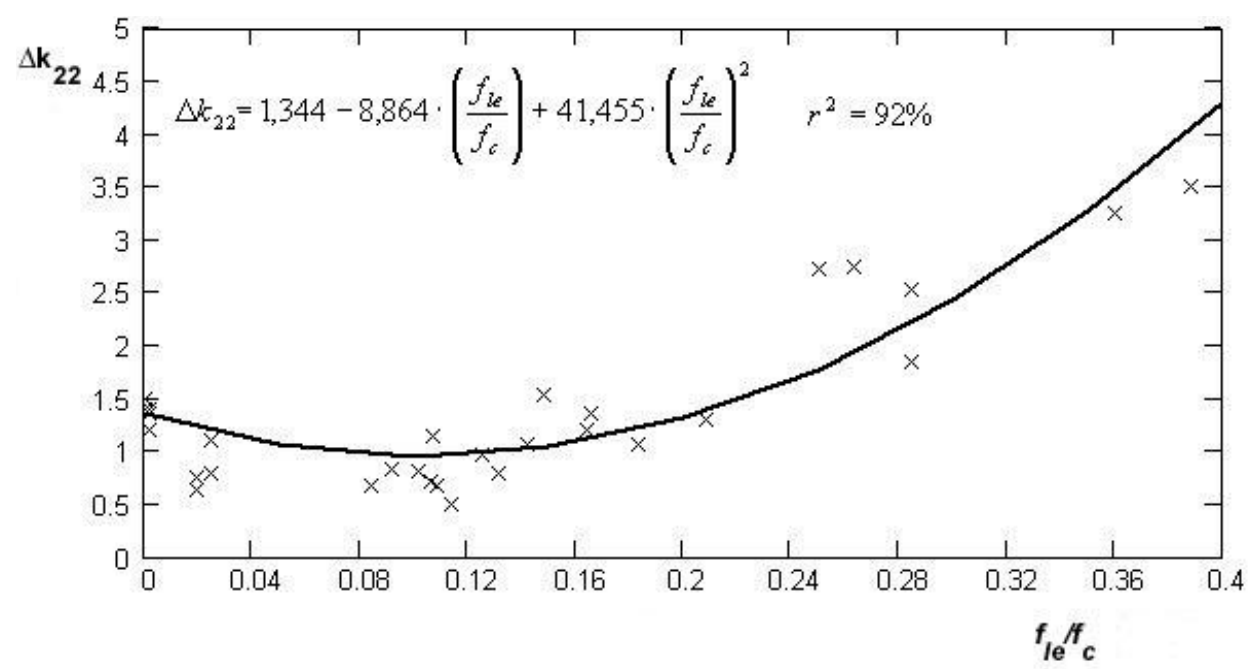

Figura 7.19 - Variação de $k_{22}$ em relação a pressão efetica de confinamento

Durante os estudos paramétricos observou-se que a adição de fibras não altera a resistência à compressão do concreto, o que foi confirmado em seguida pelo programa experimental. Deste modo, o ganho de resistência do concreto confinado e/ou com adição de fibras é função apenas da relação entre a pressão efetiva de confinamento e a resistência do concreto na estrutura. Assim, para o cálculo do ganho de resistência do concreto, utilizaram-se os resultados experimentais dos ensaios dos pilares de Cusson e Paultre (1993), de Nagashima et alli (1992) e do presente trabalho. Na Figura 7.20, mostra-se a variação do ganho de resistência em função do índice de confinamento, e cuja função matemática é expressa na Eq.(7.16):

$$
\frac{f_{c c f}}{f_{c}}=1,0+2,203 \cdot\left(\frac{f_{l e}}{f_{c}}\right)^{0,863}
$$

na qual $f_{l e} / f_{c}$ é o índice de confinamento do concreto. 


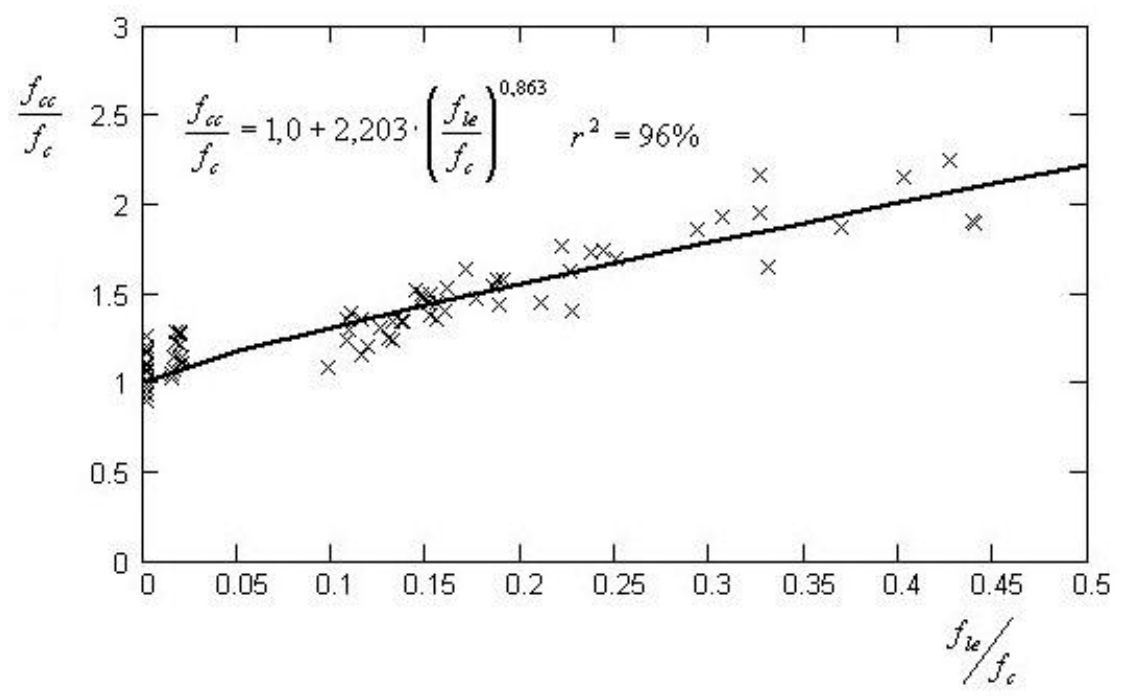

Figura 7.20 - Variação do ganho de resistência em relação ao índice de confinamento

Observou-se que a deformação correspondente a tensão máxima do concreto é muito pouco influenciada pela taxa de adição de fibras, levando alguns autores a desprezar essa influência. Além disso, analizando os resultados dos pilares ensaiados a compressão centrada, observa-se que não existe interação entre a taxa de adição de fibra e a taxa de armadura transversal. Apesar do exposto, considerou-se a pequena variação da deformação correspondente à tensão máxima em relação ao índice de reforço da adição de fibras, de modo que o modelo de Cusson e Paultre (1995) ficasse concordante com o modelo proposto nesse trabalho para o CRFA. Deste modo, a variação da deformação correspondente à tensão máxima pode ser escrita pela Eq.(7.17):

$$
\varepsilon_{c c f}-\varepsilon_{c o}=0,266 \cdot\left(\frac{f_{l e}}{f_{c}}\right)^{1,7}+3,2 \cdot 10^{-4} \cdot R
$$

na qual a parcela referente ao índice de confinamento foi calculada considerando apenas os pilares de Cusson e Paultre (1995) e de Nagashima et alli (1992). Não se utilizaram os pilares do presente trabalho, uma vez que a variação da deformação de pico foi praticamente nula. A parcela referente ao índice de reforço foi obtida a partir do modelo proposto para o CRFA.

Para a obtenção de uma equação que correlacione a variação da deformação no trecho descendente do diagrama correspondente a $50 \%$ da tensão 
máxima, novamente foram realizadas análises de regressão apenas considerando o índice de reforço e, em seguida, considerando apenas o índice de confinamento. Para tanto, para a parcela referente ao índice de confinamento, utilizaram-se, novamente, apenas os pilares de Cusson e Paultre (1995) e de Nagashima et alli (1992) e para a segunda parcela os prismas e pilares do presente trabalho. Na Figura 7.21, apresenta-se o diagrama do ganho da deformação $\varepsilon_{0,5 f c c f}$ em relação ao índice de reforço, e cuja equação pode ser escrita matematicamente pela Eq.(7.18):

$$
\varepsilon_{0,5 c c f}-\varepsilon_{0,5 f c}=0,175 \cdot\left(\frac{f_{l e}}{f_{c}}\right)^{1,1}+0,134 \cdot\left(\frac{R}{f_{c}}\right)^{0,701}
$$

obserava-se que para essa equação, $f_{l e}$ deve ser calculado considerando a tensão na armadura transversal $f_{t c c}$ igual a tensão de escoamento do aço.

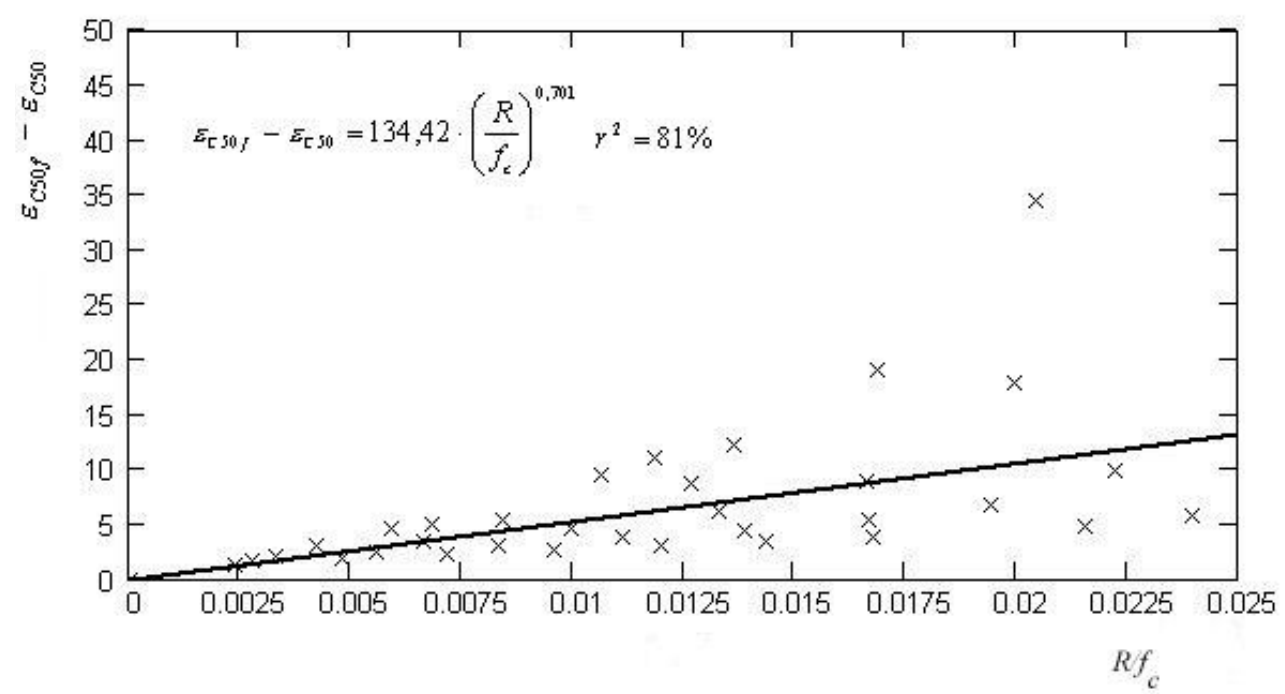

Figura 7.21 - Variação do ganho de deformação $\boldsymbol{\varepsilon}_{c 0,5 f c f}$ em relação ao índice de reforço

$\mathrm{Na}$ falta de resultados experimentais, as deformações correspondentes à tensão máxima e a $50 \%$ da tensão máxima podem ser calculadas pelas expressões sugeridas pelo FIB (1999), e que são expressas pelas Eq.(7.19) e Eq.(7.20), respectivamente. 


$$
\begin{gathered}
\varepsilon_{c o}=-0,0017-0,0010\left(\frac{f_{c}}{f_{c m o}}\right) \\
\frac{\varepsilon_{0,5 f c}}{\varepsilon_{c o}}=\frac{1}{2} \cdot\left(\frac{1}{2} \cdot \frac{E_{c}}{E_{c o}}+1\right)+\sqrt{\frac{1}{4} \cdot\left(\frac{1}{2} \cdot \frac{E_{c}}{E_{c o}}+1\right)^{2}-\frac{1}{2}}
\end{gathered}
$$

nas quais

$$
\begin{aligned}
E_{c o} & =\frac{f_{c}}{\varepsilon_{c o}} \quad(M P a) \\
E_{c o} & =\frac{f_{c}}{\varepsilon_{c o}} \quad(M P a) \\
E_{c} & =\alpha_{e} \cdot \alpha_{\beta} \cdot\left[f_{c} / f_{c m o}\right]^{1 / 3} \quad(M P a)
\end{aligned}
$$

na qual, por sua vez $f_{c m o}$ é igual a 70MPa, $\alpha_{e}$ é igual a $21500 \mathrm{MPa}$ e $\alpha_{\beta}$ é um coeficiente que depende do tipo de agregado graúdo que constitui o concreto para o agregado basáltico, $\alpha_{\beta}$ é igual a 1,2.

\subsubsection{Avaliação da deformação na armadura transversal}

Com o objetivo de melhorar a discussão acerca das deformação na armadura transversal, a Figura 2.1, apresentada no Capítulo 2 desta tese, é novamente mostrada na Figura 7.22.

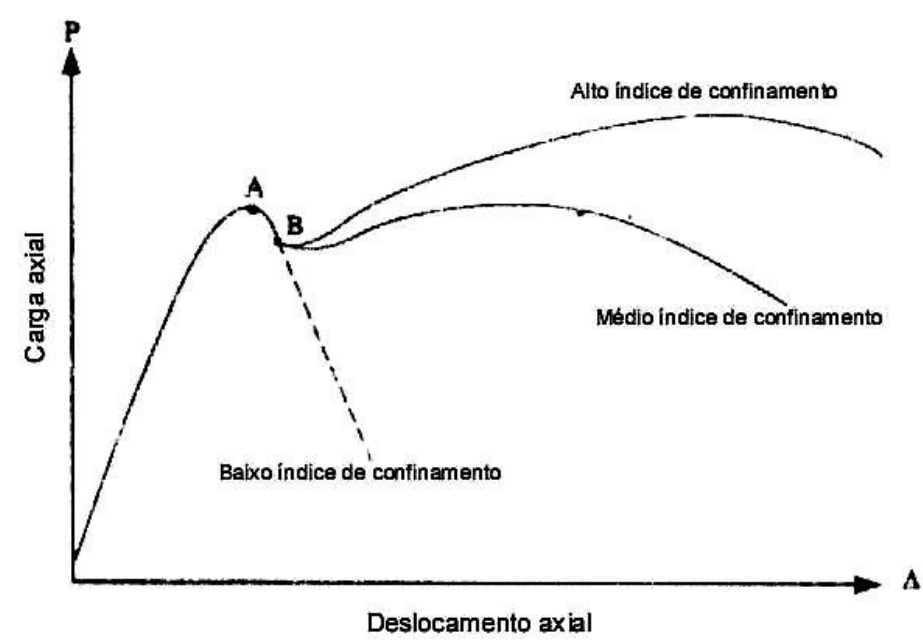

Figura 7.22 - Comportamento esquemático dos pilares de concreto de alta resistência sob compressão centrada (ACI-441, 1997). 
Analisando os diagramas apresentados na Figura 7.22, observa-se que, de acordo com o índice de confinamento, é possível obterem-se três tipos de diagramas carga vs. deslocamento para os pilares com concretos de alta resistência. Ao se comparar esses diagramas com os dos pilares ensaiados no presente trabalho, constata-se que os pilares, aqui ensaiados, apresentavam baixo índice de confinamento. Desse modo, após o pico de força (ponto $A$ ) observou-se ganho de ductilidade, com a elevação da taxa de armadura transversal, contundo, não foi verificado ganho de capacidade de carga, nem tampouco um segundo pico de força. Já os pilares ensaiados por Cusson e Paultre (1993), apresentavam índices de ductilidade variando entre médio e alto, sendo constatado, na grande maioria dos pilares, um segundo pico de força após o ponto A.

Cusson e Paultre (1995), durante a formulação de seu modelo para o concreto confinado, utilizaram as deformações na armadura transversal correspondente aos segundo pico de força, a fim de formular a metodologia para o cálculo dessas deformações. Devido à inexistência desse segundo pico, utilizaramse os valores do primeiro pico para comparar os resultados dos ensaios dos pilares da presente tese com o modelo em questão no item 7.2.3 desse capítulo. Devido ao exposto, observa-se que Cusson e Paultre obtiveram melhor correlação entre os valores experimentais e teóricos.

Objetivando-se apresentar uma equação que modelasse o comportamento das deformações na armadura transversal correspondente ao ponto A do diagrama força vs. deslocamento axial dos pilares, realizou-se uma análise de regressão nãolinear com os dados dos pilares do presente trabalho e dos pilares de Cusson e Paultre (1993). A equação obtida apresentou coeficiente de correlação, $r^{2}$, de $59,9 \%$ e o comportamento desta deformação em relação ao índice de confinamento é mostrado na Figura 7.23 e expresso matematicamente pela equação Eq.(7.24)

$$
\frac{\varepsilon_{t c}}{\varepsilon_{t y}}=0,369-1,131 \cdot\left(\frac{f_{l e}}{f_{c}}\right)^{1,445}
$$




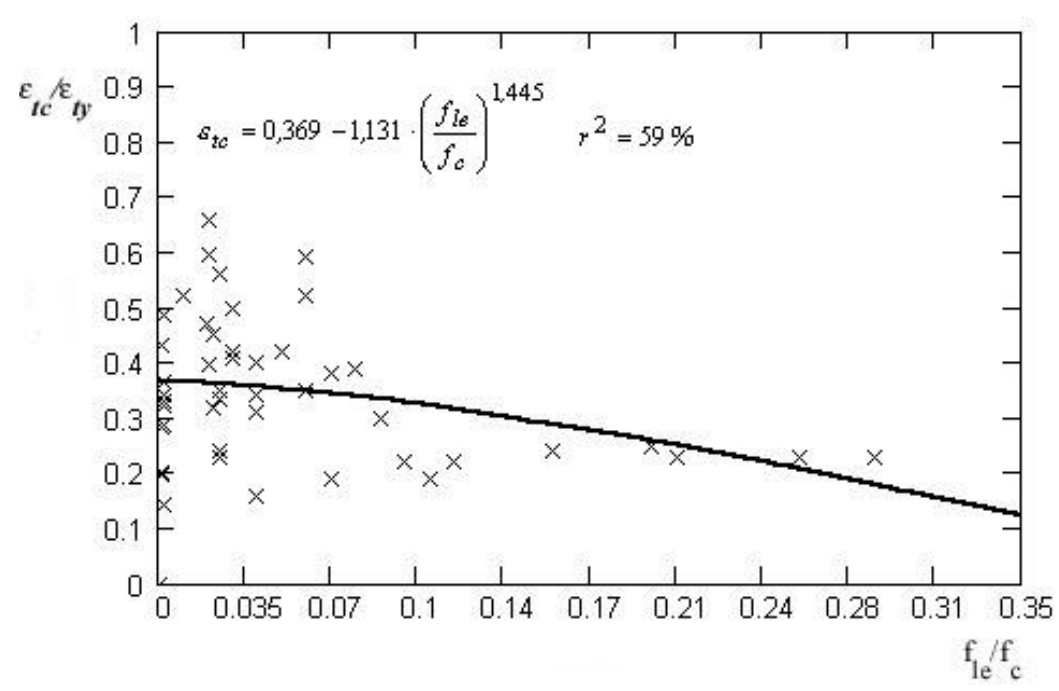

Figura 7.23 - Variação da deformação na armadura transversal em relação ao índice de confinamento, para o ponto A no diagrama força $v$ s. deslocamento axial dos pilares

Para o cálculo da deformação na armadura transversal correspondente ao segundo pico de força, sugere-se o procedimento de Cusson e Paultre (1995) sem nenhuma alteração. Deste modo, com base nesse procedimento, a deformação na armadura de confinamento, pode ser expressa pela Eq.(7.25):

$$
\varepsilon_{t c c}=v \cdot \varepsilon_{c c}-\left(\frac{f_{l e}-v \cdot f_{l e}}{E_{s e c c}}\right)
$$

na qual $v$ é o coeficiente de Poisson do concreto confinado, no ponto correspondente à máxima tensão e que pode ser tomado como 0,$5 ; E_{\text {secc }}$ é o módulo de elasticidade secante no segundo ponto de máxima tensão do concreto confinado; e $f_{l e}$ é a pressão efetiva de confinamento, dada pela Eq.(7.26):

$$
f_{l e}=K_{e} \cdot f_{l}
$$

na qual

$$
\begin{aligned}
& K_{e}=\frac{\left(1-\frac{\sum_{i} w_{i}^{2}}{6 \cdot c_{x} \cdot c_{y}}\right) \cdot\left(1-\frac{\left(s-\phi_{t}\right)}{2 \cdot c_{x}}\right) \cdot\left(1-\frac{\left(s-\phi_{t}\right)}{2 \cdot c_{y}}\right)}{1-\rho_{l}} \\
& f_{l}=\frac{f_{t c c}}{s} \cdot\left(\frac{A_{s t x}+A_{s t y}}{c_{x}+c_{y}}\right)
\end{aligned}
$$


nas quais $f_{t c c}$ é a tensão na armadura transversal de confinamento; $s$ é a distância de centro a centro entre estribos; $A_{s t x}$ e $A_{s t y}$ são as áreas da seção transversal das armaduras de confinamento, paralelas aos eixos $x$ e $y$, respectivamente; $c_{x}$ e $c_{y}$ são as larguras do núcleo do pilar, nas direções $x$ e $y$, respectivamente; $w_{i}$ são os espaços entre as armaduras longitudinais; $\phi_{t}$ é o diâmetro dos estribos; e $\rho_{l}$ é a taxa de armadura longitudinal, em relação ao núcleo do pilar.

Novamente, para o cálculo de $\varepsilon_{t c c}$ segue-se o procedimento iterativo apresentado no Capítulo 2. Assim, pode-se inicialmente supor a tensão $f_{\text {tcc }}$ como sendo a tensão de escoamento da armadura transversal. Em seguida trabalha-se com as equações Eq.(7.25) a Eq.(7.28). Verifica-se se a deformação $\varepsilon_{t c c}$, calculada pela equação Eq.(7.25) é compatível com a tensão inicialmente adotada para $f_{t c c}$ através da curva tensão deformação do aço utilizado. Caso não exista compatibilidade entre os dois valores, refaz-se o procedimento com um novo valor para $f_{t c c}$.

\subsubsection{Procedimento para modelagem do pilares}

Para modelagem do diagrama força vs. deformação dos pilares com concretos de alta resistência, por meio do modelo modificado de Cusson e Paultre (1995), apresentado acima, os pilares devem ser analisados seguindo os seguintes procedimentos:

1 - considera-se a seção transversal resistente do pilar como sendo a seção íntegra, ignorando-se o efeito do confinamento;

2 - considera-se a seção transversal resistente do pilar como sendo apenas a seção do núcleo do pilar delimitada pelos ramos mais externos dos estribos, e a pressão lateral de confinamento deve ser calculada considerando a deformação da armadura transversal dada pela Eq.(7.25); e

3 - o diagrama resultante será formado pelas linhas externas dos dois diagramas obtidos nos procedimentos 1 e 2 . 
Para um melhor entendimento do procedimento descrito, apresenta-se na Figura 7.24 a modelagem do pilar 5D de Cusson e Paultre (1993). Observa-se que o modelo modificado conseguiu predizer com elevada precisão o comportamento deste pilar.
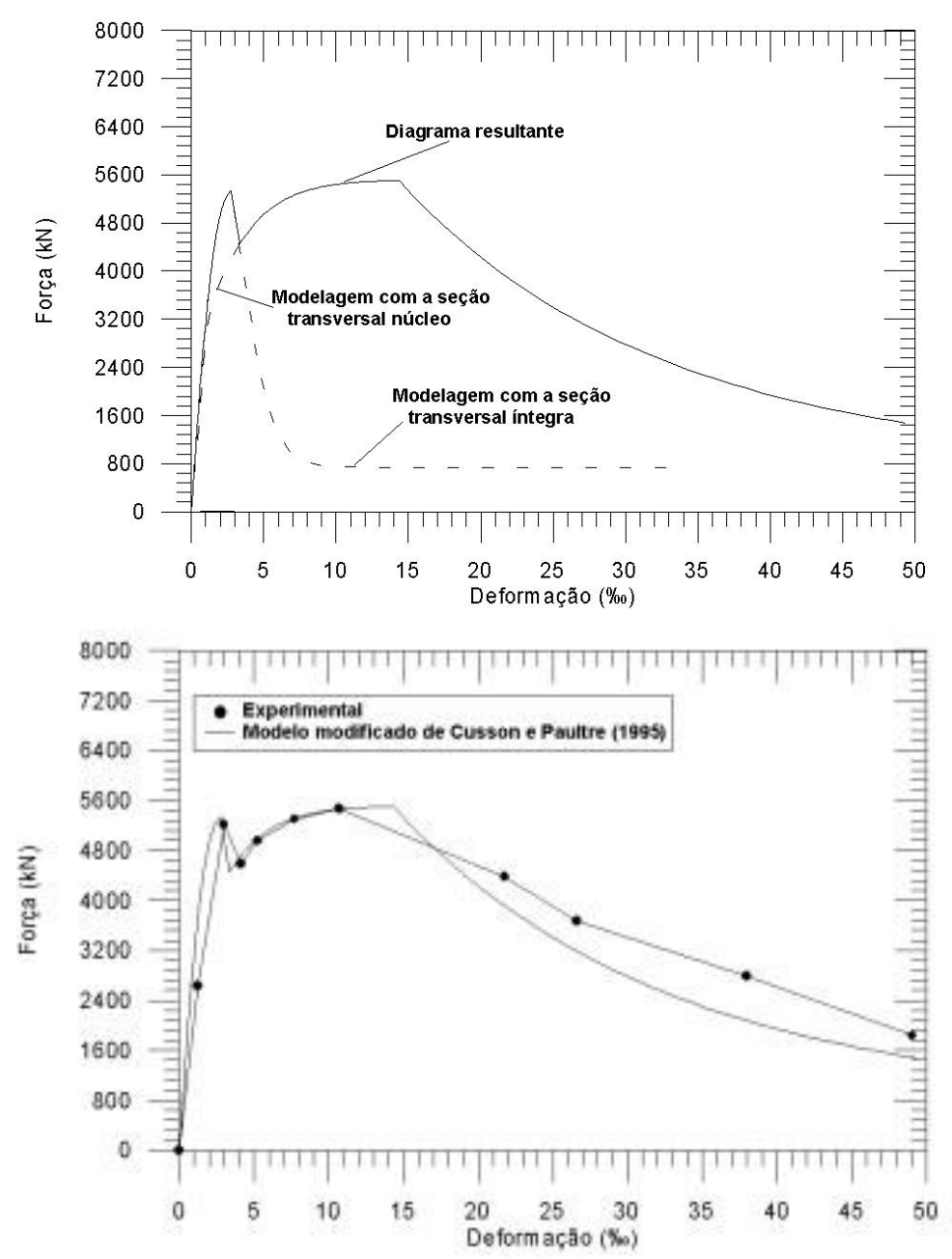

Figura 7.24 - Procedimento de modelagem por meio do modelo modificado de Cusson e Paultre (1995)

Com o objetivo de avaliar as modificações sugeridas para o modelo de Cusson e Paultre (1995), confrontou-se os diagramas força vs. deformação experimentais dos pilares ensaiados à compressão centrada da presente tese com os fornecidos pelo modelo em questão. Nas Figura 7.25 e Figura 7.26, apresentam-se as curvas teóricas e experimentais força vs. deformação dos pilares, nas quais observa-se que o modelo em questão, com as modificações sugeridas, 
conseguiu representar de modo bastante satisfatório o comportamento desses pilares. Ainda, comparando-se os diagramas apresentados nas Figura 7.25 e Figura 7.26 com os diagramas mostrados na Figura 7.15, constata-se que o modelo com as modificações apresentou resultados mais condizentes.

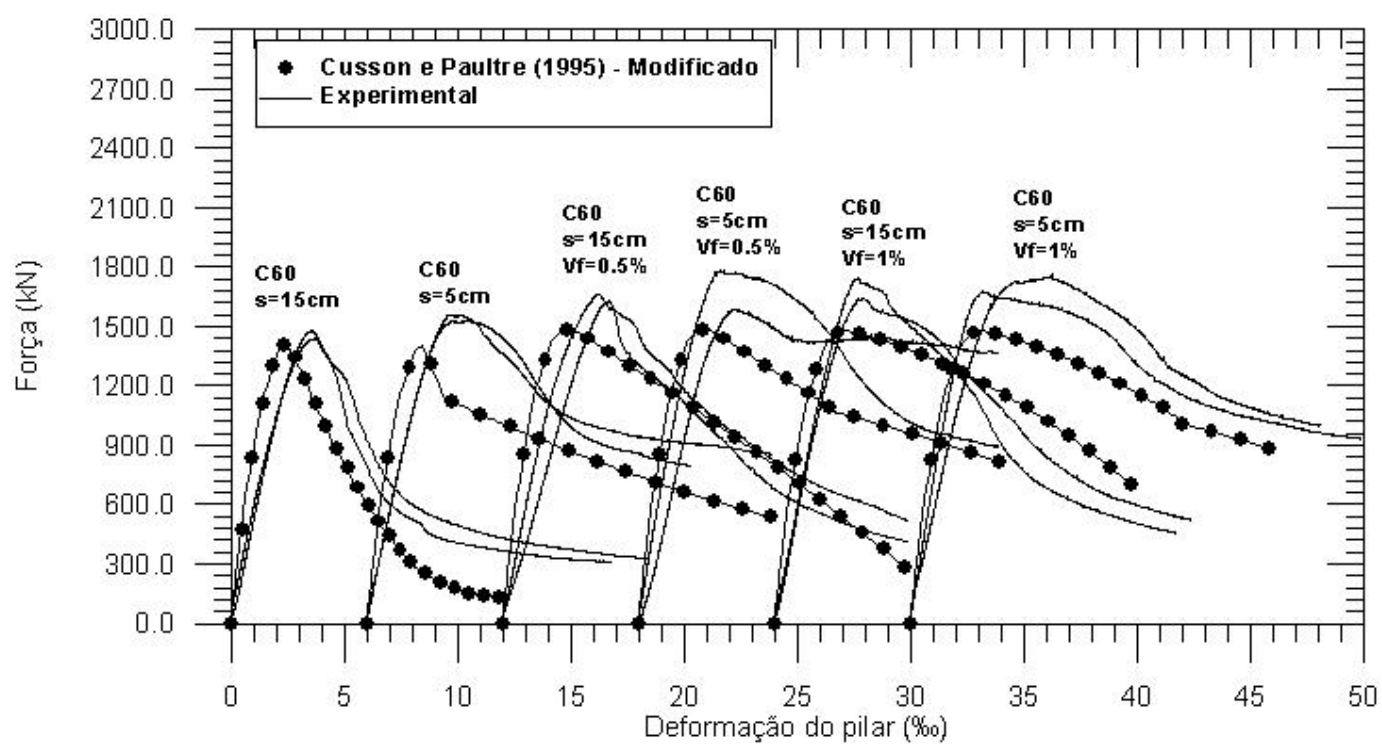

Figura 7.25 - Modelagem dos pilares ensaiados na presente tese com 60MPa, por meio do modelo modificado de Cusson e Paultre (1995)

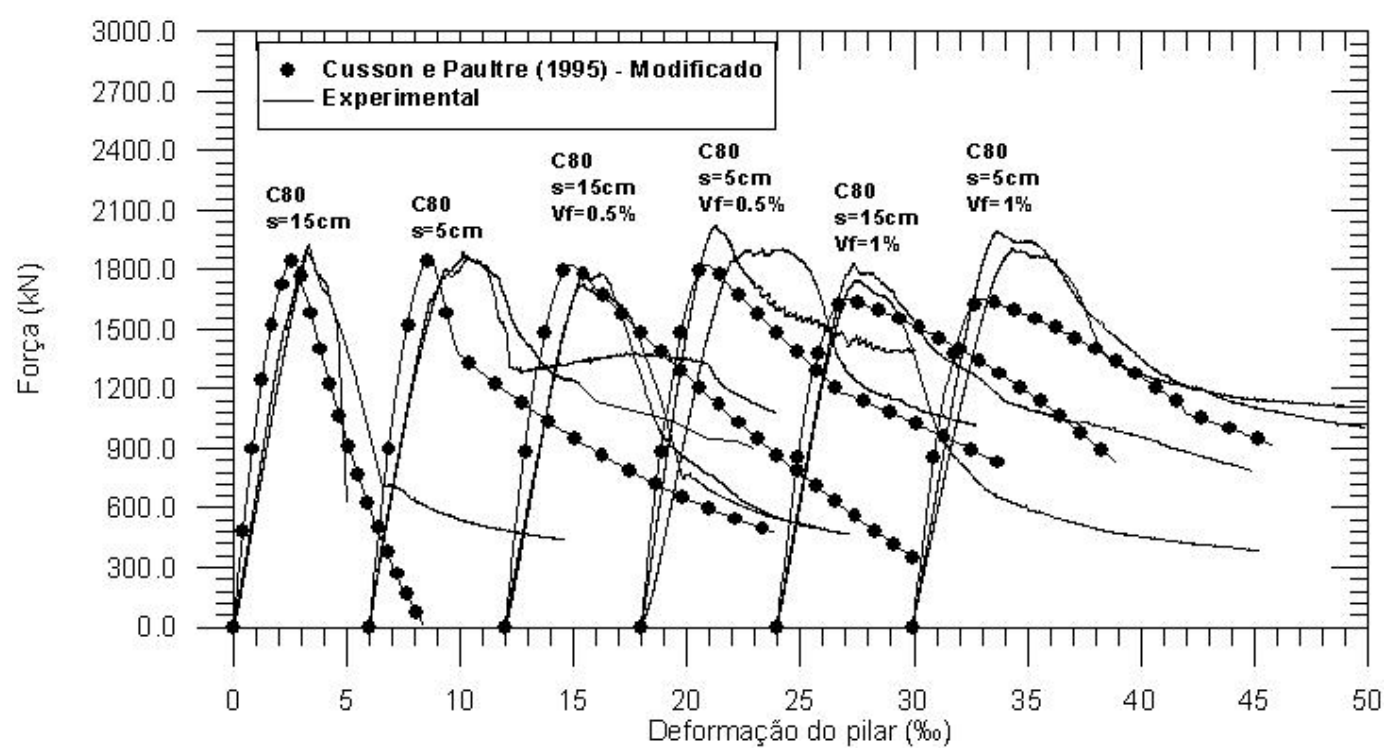

Figura 7.26 - Modelagem dos pilares ensaiados na presente tese com 60MPa, por meio do modelo modificado de Cusson e Paultre (1995) 


\subsection{CONCLUSÕES PARCIAIS}

Foi observado que os diagramas obtidos por meio de corpos-de-prova cilíndricos e os prismas de concreto simples apresentaram-se divergentes, tanto no que diz respeito à tensão máxima, quanto à forma do diagrama tensão vs. deformação. Ainda, os prismas de concreto apresentaram maior ductilidade que os corpos-de-prova cilíndricos.

Observou-se que o coeficiente $k_{2}$ é realmente influenciado pela resistência do concreto, pelas taxas de armadura presente no elemento estrutural e pela taxa de adição de fibras. Verificou-se que apenas os valores de $k_{2}$ sugeridos pela norma norueguesa NBR (1989) aproximaram-se dos valores experimentais. Ainda, constatou-se que se fazem necessários mais estudos experimentais sobre os valores do coeficiente $k_{2}$, quando da variação das taxas de armaduras, da resistência do concreto e da taxa de adição de fibras metálicas.

Mostrou-se que, mesmo para espaçamentos entre estribos de $5 \mathrm{~cm}$, a seção resistente dos pilares de alta resistência corresponde a toda a seção transversal desses elementos. Essa observação foi comprovada para resistência do concreto entre 50MPa e 100MPa. Observou-se também que a adição de fibras melhora o trabalho conjunto entre o cobrimento e núcleo dos pilares, evitando o desprendimento de massas de concreto do núcleo e do próprio cobrimento, mesmo para elevadas deformações impostas aos pilares.

Verificou-se que, mesmo elevando o coeficiente de Poisson do concreto, a taxa de adição de fibras não aumenta os valores das deformações nas armaduras transversais correspondente à força axial máxima. Ainda, observou-se que os valores experimentais das deformações das armaduras transversais, no instante que é atingida a força máxima, e os valores teóricos calculados com o modelo de Cusson e Paultre (1995) variaram de $2 \%$ a $136 \%$, com média de $34 \%$.

Para avaliação do modelo de Cusson e Paultre (1995), em predizer o comportamento dos pilares com $C A R$, foram utilizados 5 variáveis. Apenas para a variável tensão no concreto, considerando apenas o núcleo do pilar $\left(f_{c c}\right)$, a diferença entre os valores experimentais e teóricos foi inferior a 10\%. Para todas 
as outras variáveis, a diferença foi aproximadamente igual ou superior a $20 \%$. Finalmente, observou-se que o modelo conseguiu representar as curvas experimentais apenas de forma razoável.

A avaliação da ductilidade dos pilares mostrou que é possível melhorar o comportamento pós-pico dos pilares por meio de adição de fibras metálicas. Ainda, observou-se que o índice de ductilidade, $\varepsilon_{0.5 f c d} \mathcal{E}_{c c}$, não foi capaz de fornecer resultados condizentes com o problema em questão.

Finalmente, constatou-se que taxas de fibra da ordem de 0,5\% foram capazes de garantir aos pilares com concretos $\operatorname{com} f_{c j}=60 \mathrm{MPa}$ a mesma ductilidade dos pilares de referência e, deste modo, essa taxa será utilizada na segunda fase do programa experimental. 


\subsection{CONSIDERAÇÕES INICIAIS}

Neste capítulo são apresentados e discutidos os resultados experimentais dos 15 pilares ensaiados à flexo-compressão. Optou-se, novamente, por apresentar a maioria dos gráficos relacionados aos ensaios no Apêndice B, no final desta tese. Apesar dos concretos da fase um e dois apresentarem os mesmos traços, decidiuse apresentar os resultados das duas fases separadamente. Desse modo, são apresentadas e discutidas, neste capítulo, as propriedades à compressão e à tração dos concretos utilizados apenas na segunda fase do programa experimental.

\subsection{CARACTERÍSTICAS DO CONCRETO}

\subsubsection{Comportamento à compressão}

$\mathrm{Na}$ Tabela 8.1 são apresentadas as características dos concretos utilizados na moldagem dos pilares. Observa-se que o concreto com $f_{c j}=40 \mathrm{MPa}$ apresentou resistência à compressão cerca de $10 \%$ inferior ao da primeira fase do programa experimental; contudo, a trabalhabilidade foi igual. Quanto aos concretos com resistência média a compressão de $60 \mathrm{MPa}$, foi apenas observada uma pequena diferença na resistência à compressão do concreto com $0,5 \%$ de adição de fibras, $10 \%$ menor ao da primeira fase. Os abatimentos no tronco de cone desses concretos foram praticamente os mesmos aos obtidos na primeira fase do programa experimental. A temperatura ambiente, durante as concretagens, variou entre $25^{\circ} \mathrm{C}$ e $30^{\circ} \mathrm{C}$, e a umidade relativa do ar entre $53 \%$ e $67 \%$. Apesar da elevada temperatura e baixa umidade durante a concretagem dos pilares com concreto com $f_{c j}=60 \mathrm{MPa}$ e sem adição de fibras, não foi constatada perda de trabalhabilidade, nem tampouco de resistência à compressão. 
Tabela 8.1- Características dos concretos utilizados na moldagem dos pilares

\begin{tabular}{ccccccccc}
\hline Concreto & $V_{f}$ & Slump & $T$ & $U$ & $\gamma_{c}$ & $f_{c j 3}$ & $f_{c j 7}$ & $f_{\text {cjensaio }}$ \\
$f_{c j}$ & $(\%)$ & $(\mathrm{mm})$ & $\left({ }^{\circ} \mathrm{C}\right)$ & $(\%)$ & $\left(\mathrm{kg} / \mathrm{m}^{3}\right)$ & $(\mathrm{MPa})$ & $(\mathrm{MPa})$ & $(\mathrm{MPa})$ \\
\hline 40 & 0,0 & 195 & 25,0 & 66 & 2350 & 20,01 & 36,25 & 39,21 \\
60 & 0,0 & 145 & 30,5 & 53 & 2501 & 46,50 & 57,91 & 66,38 \\
60 & 0,5 & 95 & 26,5 & 67 & 2506 & 49,11 & 53,58 & 62,48 \\
\hline
\end{tabular}

Por causa dos problemas ocorridos no cronograma de ensaios da fase um, decidiu-se alterar o cronograma da fase dois. Desse modo, os pilares com concretos com $f_{c j}=40 \mathrm{MPa}$ foram ensaiados aos 14 dias e aqueles com $f_{c j}=60 \mathrm{MPa}$ aos 23dias.

Nove corpos-de-prova cilíndricos foram moldados durante as concretagens e foram submetidos às mesmas condições de cura dos pilares. Seguindo o mesmo procedimento da fase um, três corpos-de-prova foram ensaiados aos três dias, três aos sete dias e três nos dias dos ensaios dos pilares. Novamente, apenas os corposde-prova dos dias dos ensaios dos pilares foram ensaiados em equipamento com controle de deslocamento. Estes tiveram suas deformações avaliadas por meio de três $L V D T$, com precisão de $0,001 \mathrm{~mm}$, dispostos de forma triangular em pontos equiidistantes, tendo como comprimento de avaliação todos os $30 \mathrm{~cm}$ da altura dos corpos-de-prova. A metodologia de ensaio utilizada foi similar à da primeira fase. Não foram moldados prismas de concreto para ensaio à compressão nesta fase.

Da Figura 8.1 à Figura 8.3 apresentam-se os diagramas tensão vs. deformação dos concretos obtidos com os corpos-de-prova cilíndricos. Novamente, calcularam-se curvas ótimas utilizando regressão polinomial nãolinear com os dados dos três corpos-de-prova cilíndricos. Todas as curvas obtidas apresentaram coeficientes de correlação, $r^{2}$, superior a 96\%. Em seguida, utilizando-se os polinômios obtidos, foram calculados os índices de ductilidade para os diversos concretos. Na Tabela 8.2 mostram-se as características do comportamento pós-pico dos diagramas tensão vs. deformação dos concretos. 


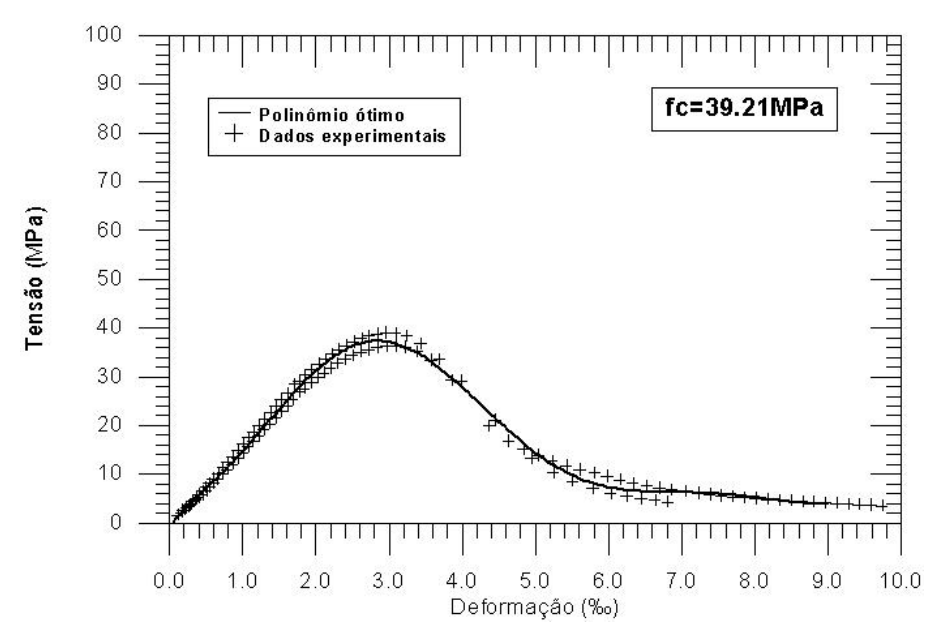

Figura 8.1 - Diagramas tensão vs. deformação do concreto com resistência $40 \mathrm{MPa}$

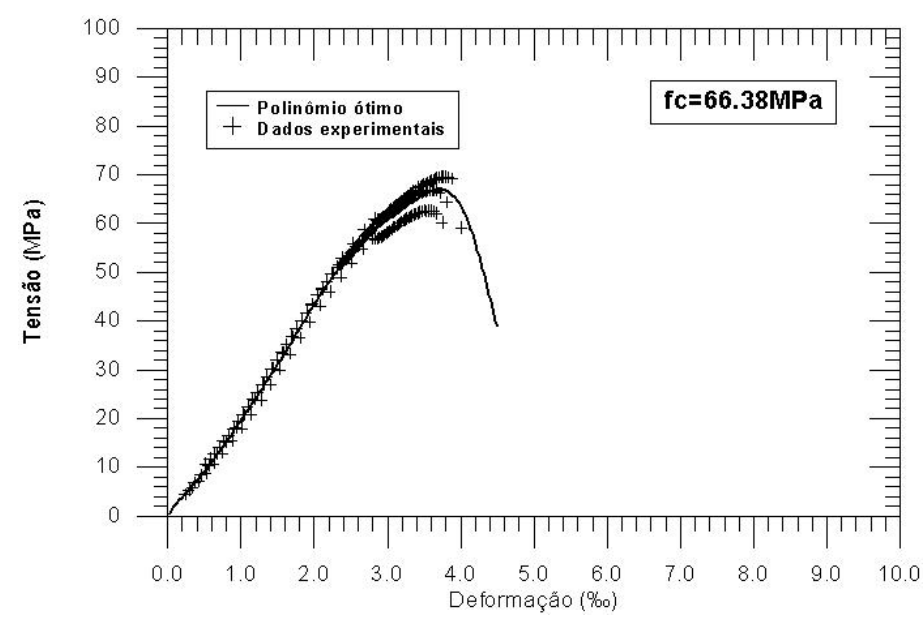

Figura 8.2 - Diagramas tensão vs. deformação do concreto com resistência 60MPa e $V_{f}=0,0 \%$

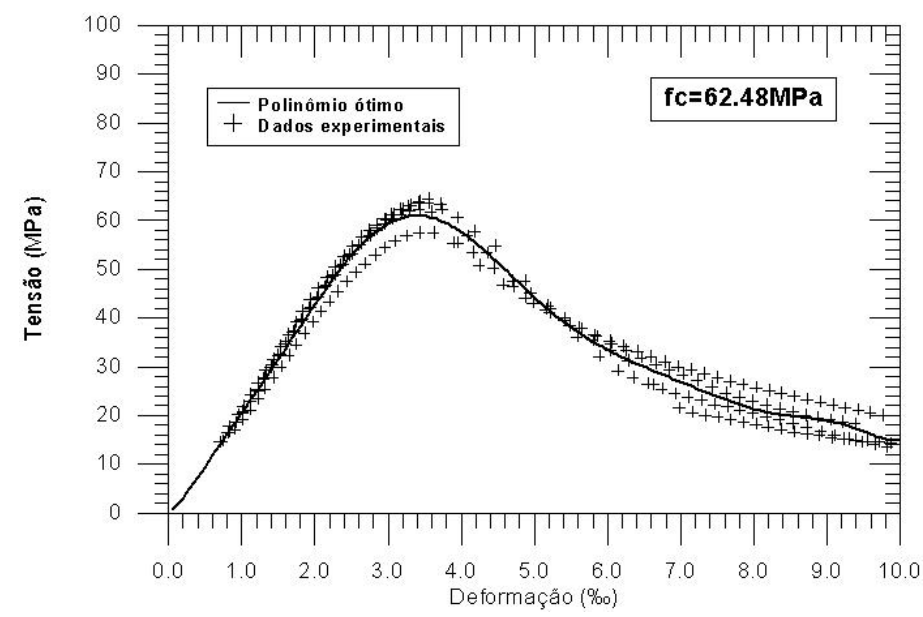

Figura 8.3 - Diagramas tensão vs. deformação do concreto com resistência 60MPa e $V_{f}=0,5 \%$ 
Tabela 8.2- Características das curvas tensão vs. deformação dos concretos

\begin{tabular}{ccccccc}
\hline $\begin{array}{c}\text { Concreto } \\
f_{c j}\end{array}$ & $V_{f}$ & $f_{c j}$ & $\mathcal{E}_{c o}$ & $\mathcal{E}_{0.5 f c}$ & $\mathcal{E}_{0.5 f c} / \mathcal{E}_{c o}$ & $I D_{\text {pós }}$ \\
\hline 40 & 0,0 & $(\mathrm{MPa})$ & $(\% \circ)$ & $(\% \circ)$ & & \\
\hline 60 & 0,0 & 39,2 & 2,84 & 4,66 & 1,638 & 0,804 \\
60 & 0,5 & 66,4 & 3,71 & 5,06 & $\approx 1,363^{*}$ & $\approx 0,353^{*}$ \\
\hline
\end{tabular}

Nota: "Valor obtido por extrapolação do diagrama tensão vs. deformação

Analisando os valores dos índices de ductilidade obtidos, constata-se que $0,5 \%$ de fibra foi capaz de prover ao concreto com resistência média à compressão de 60MPa índices pouco maiores que os com resistência de 40MPa. Observa-se ainda que os índices de ductilidade coincidem com os obtidos na primeira fase do programa experimental.

Analisando os diversos diagramas tensão vs. deformação dos concretos, tanto da fase um do programa experimental como da fase dois, por meio do modelo proposto no item 4.3 (capítulo 4), observou-se que a equação proposta pelo FIB (1999) para o cálculo da deformação correspondente à máxima tensão do concreto sempre forneceu valores bem inferiores aos obtidos experimentalmente. E, conseqüentemente, a equação Eq.(4.21) que se baseou nesta equação proposta pelo FIB (1999), seguiu a mesma tendência de valores. Esse fato pode ser explicado, uma vez que a medição dessa variável é intrinsecamente relacionada à metodologia de ensaio e de medição dos deslocamentos utilizada. Como foram utilizados capeamentos de enxofre e comprimento de medição das deformações de prato a prato da prensa, os valores obtidos para as deformações são superiores aos que seriam obtidos caso essas deformações fossem avaliadas por meio de clipgages. Esses últimos instrumentos, usualmente utilizam como comprimento de avaliação os $10 \mathrm{~cm}$ centrais dos corpos-de-prova e deste modo não sofre influência do capeamento. Assim, para a avaliação do modelo proposto, decidiu-se utilizar os valores experimentais das deformações correspondentes à tensão máxima.

Na Tabela 8.3 apresentam-se os valores dos índices de ductilidade obtidos com o modelo e nas Figura 8.4 a Figura 8.6 apresentam-se os diagramas teóricos e experimentais. Observa-se que as diferenças médias dos índices de ductilidade, $I D_{\text {pos }}$ e $\varepsilon_{0.5 f_{c}} / \mathcal{E}_{c}$, teóricos e experimentais foram de $3 \%$ e $15 \%$, respectivamente. 
Constatando-se que o modelo conseguiu de forma satisfatória modelar os comportamentos dos diversos concretos.

Tabela 8.3- Índices de ductilidade obtidos com o modelo proposto

\begin{tabular}{ccccccccc}
\hline Concreto & $f_{c}$ & $\varepsilon_{c o}$ & $\varepsilon_{0.5 f d} / \mathcal{E}_{c o}$ & $\varepsilon_{0.5 f d} / \mathcal{E}_{c o}$ & $(2) /(1)$ & $I D_{p o s}$ & $I D_{p o s}$ & $(3) /(4)$ \\
$f_{c j}$ & $(\mathrm{MPa})$ & $(\% \circ)$ & Exp. $(1)$ & Teo. $(2)$ & & Exp. $(3)$ & Teo. $(4)$ & \\
\hline 40 & 39,2 & 2,84 & 1,638 & 1,492 & 0,91 & 0,804 & 0,726 & 0,90 \\
60 & 66,4 & 3,71 & $\approx 1,363^{*}$ & 1,326 & 0,97 & $\approx 0,353^{*}$ & 0,495 & 1,40 \\
60 & 62,5 & 3,41 & 1,853 & 2,245 & 1,21 & 1,063 & 1.218 & 1,15 \\
\hline \multicolumn{7}{c}{ Valores médios } & \multicolumn{7}{c}{1,03} & & & 1,15 \\
\hline
\end{tabular}

Nota: *Valor obtido por extrapolação do diagrama tensão vs. deformação

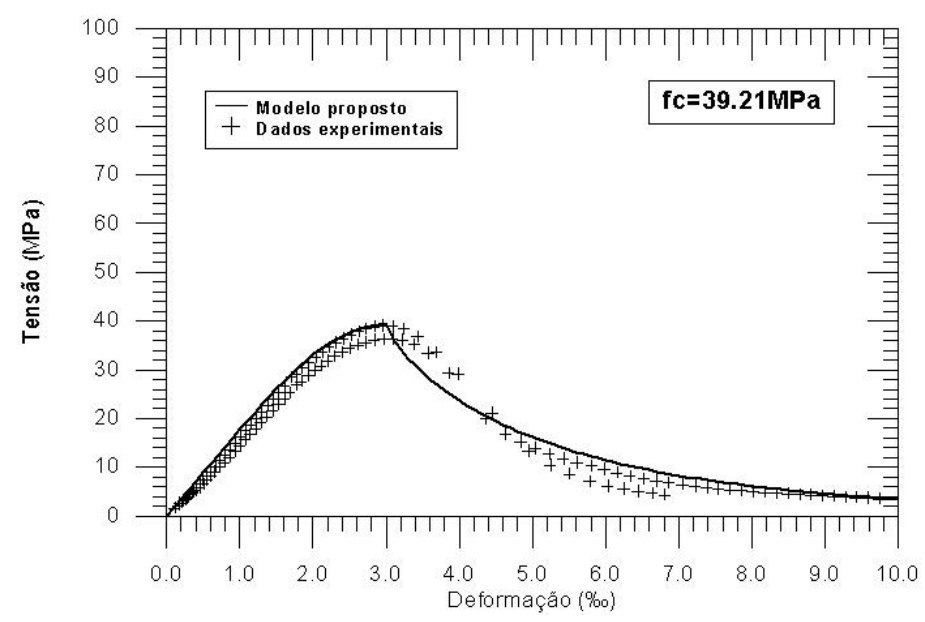

Figura 8.4 - Comparação entre os diagramas tensão vs. deformação do concreto com resistência 40MPa com o modelo proposto

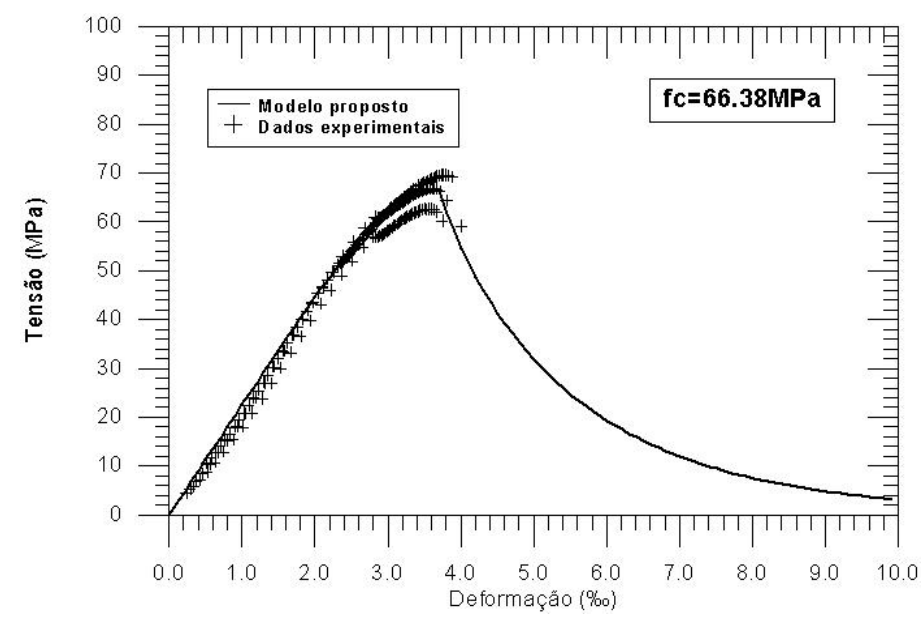

Figura 8.5 - Comparação entre os diagramas tensão vs. deformação do concreto com resistência 60MPa com o modelo proposto 


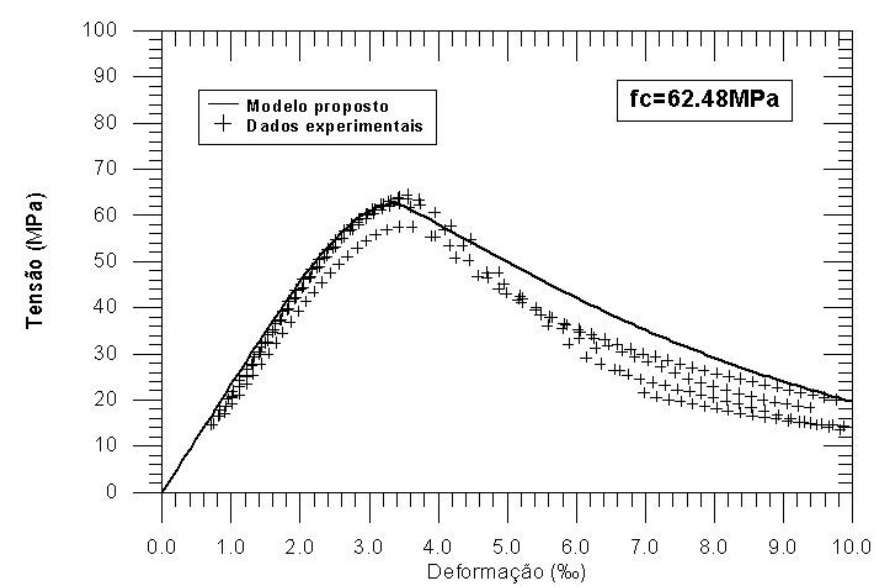

Figura 8.6 - Comparação entre os diagramas tensão vs. deformação do concreto com resistência 60MPa e $V_{f}=0,5 \%$ com o modelo proposto

\subsubsection{Comportamento à tração}

Durante cada concretagem foram moldados quatro prismas de concreto, com dimensões $15 \mathrm{~cm} x 15 \mathrm{~cm} x 50 \mathrm{~cm}$, para ensaio à flexão. Esses prismas foram submetidos às mesmas condições de cura dos pilares. Todos os quatro prismas foram ensaiados à flexão no dia do ensaio dos pilares. Para tanto, utilizou-se equipamento com controle de deslocamento e as deflexões centrais foram medidas por dois relógios comparadores, com precisão de $0,001 \mathrm{~mm}$. O ensaio consistiu da aplicação de quatro pontos de carga igualmente espaçados e seguiu os procedimentos sugeridos pela JSCE (1984). Na Figura 8.7 apresentam-se detalhes do ensaio à flexão do concreto e nas Figura 8.8 e Figura 8.9 os diagramas tensão de tração vs. deflexão central dos prismas dos diversos concretos. Observa-se que as resistências à tração dos concretos com resistência à compressão de 40MPa e $60 \mathrm{MPa}$ sem e com adição de fibras foram $3,7 \mathrm{MPa}, 4,6 \mathrm{MPa}$ e $5,6 \mathrm{MPa}$, respectivamente.

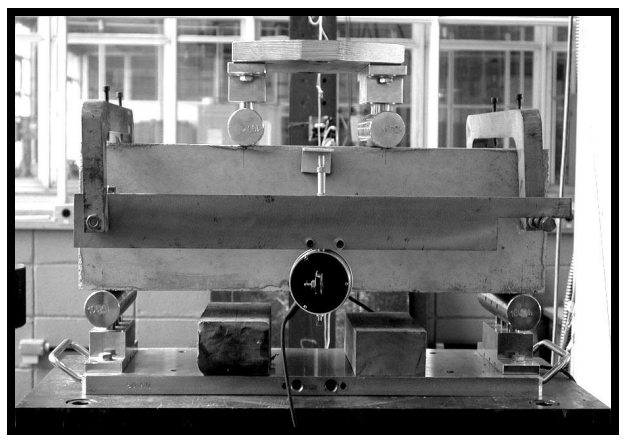

Figura 8.7 - Detalhes do ensaio à flexão do concreto 


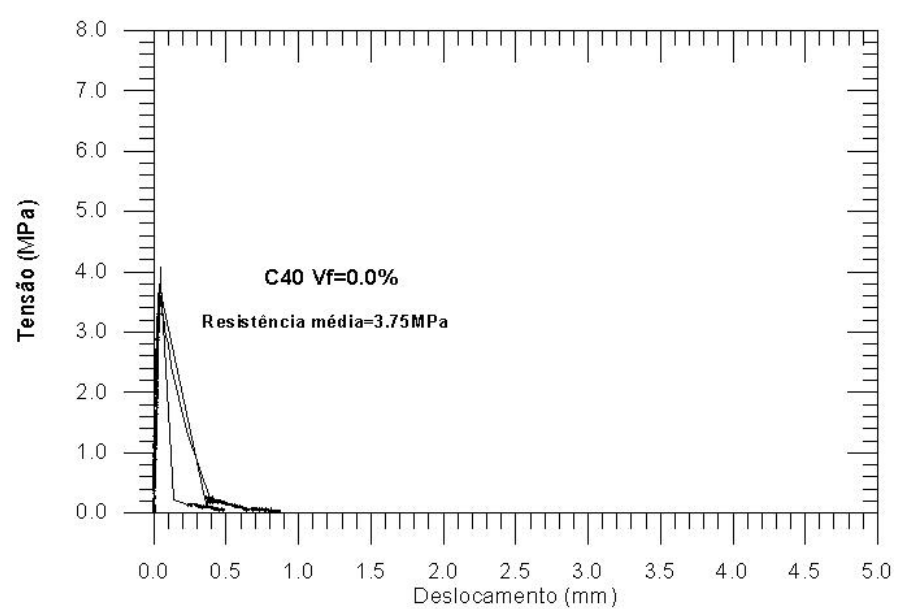

Figura 8.8 - Diagramas tensão de tração vs. deformação do concreto com resistência $40 M P a$

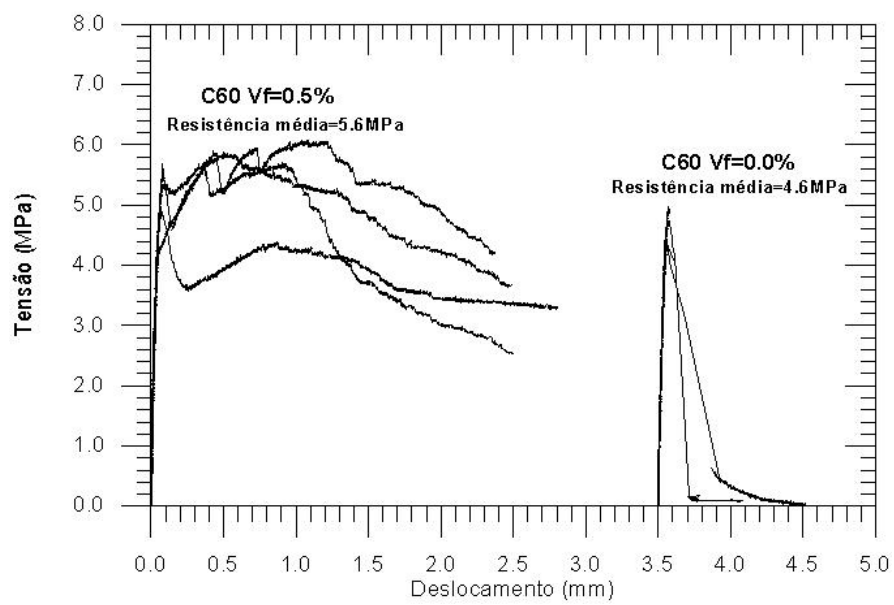

Figura 8.9 - Diagramas tensão de tração vs. deformação dos concreto com resistência $60 \mathrm{MPa}$ e, com e sem adição de fibras

Verifica-se que os concretos sem adição de fibras praticamente não possuem comportamento pós-pico. Para esses concretos, observou-se, durante o ensaio, o aparecimento de apenas uma fissura na face inferior do prisma, próximo ao instante em que se atingiu a força máxima. Essa fissura propagou-se de modo quase instantâneo até a face superior do prisma, tornando-o um mecanismo. Já para o concreto com adição de $0,5 \%$ de fibras, observa-se um comportamento quase elasto-plástico, com comportamento pós-pico quase horizontal, com grandes deslocamentos. Durante os ensaios, verificou-se o surgimento de duas ou mais fissuras no trecho central dos prismas, contudo, as fibras garantiram o controle das aberturas dessas fissuras. Finalmente, constatou-se um aumento da ordem de $20 \%$ na resistência à tração do concreto com resistência à compressão 
média de 60MPa, com adição de fibras, em relação ao concreto sem adição de fibras.

Inicialmente, foi planejada a utilização do modelo de Armelin e Banthia (1997) para modelar o comportamento à flexão dos CRFA. Contudo, os pesquisadores em questão não apresentam os valores das constantes $A, B$ e $C$ para a função $f_{\text {hook }}$ do modelo em questão (ver Capítulo 3). Desse modo, optou-se por utilizar o modelo de Balaguru e Shah (1992) para a resistência à tração do concreto. Em todas as modelagens dos pilares foi considerada a resistência à tração do concreto, tanto para os com, quanto para os sem adição de fibras de aço. Para os pilares sem adição de fibras, utilizou-se o modelo do FIB (1999) para modelar o comportamento à tração do concreto.

\subsection{PILARES SUBMETIDOS À COMPRESSÃO EXCÊNTRICA}

\subsubsection{Comportamento global dos pilares}

Os procedimentos de ensaios utilizados permitiram a obtenção de todo o caminho pós-pico de todos os pilares. A taxa de deslocamento sugerida pelo RILEM TC 148-SSC (2000), mostrou-se novamente adequada para os ensaios dos pilares à flexo-compressão. Todos os ensaios foram finalizados quando era atingido o deslocamento lateral máximo de aproximadamente $100 \mathrm{~mm}$. Antes do início dos ensaios, as excentricidades de força foram medidas, obtendo-se valores de $10,4 \mathrm{~mm} \pm 1 \mathrm{~mm}, 20,0 \mathrm{~mm} \pm 1 \mathrm{~mm}$ e $30,5 \mathrm{~mm} \pm 1 \mathrm{~mm}$.

As leituras dos deslocamentos mostraram-se bastante uniformes (ver Apêndice B e Figura 6.18). Os deslocamentos medidos pelos dois LVDT posicionados na vertical (4 e 5) praticamente foram os mesmos, não sendo observadas flexões no plano perpendicular ao da rotulação. Constatou-se ainda que, com exceção dos pilares com $f_{c j}=40 \mathrm{MPa}$, os deslocamentos medidos pelos LVDT (1 e 3) posicionados na horizontal foram praticamente iguais, o que mostra uniformidade na distribuição do momento aplicado.

Novamente, a reutilização (cinco vezes) das formas não se mostrou uma metodologia adequada. Verificou-se que essas se danificaram e durante a última 
concretagem (pilares de referência com concreto com $f_{c j}=40 \mathrm{MPa}$ ), um dos sarrafos de pinos rompeu, e assim, imperfeições geométricas nos pilares foram geradas. Por esse motivo, os pilares de referência apresentaram seção transversal com dimensões variando entre $14,5 \mathrm{~cm}$ e $16 \mathrm{~cm}$.

Problemas na vibração do concreto foram observados no pilar P360505. Este apresentou vazios na região a meia altura em três faces do pilar. Por serem vazios de dimensões consideráveis, realizou-se um reparo, utilizando resina epoxídica, cuja resistência à compressão máxima era de $60 \mathrm{MPa}$, atingida aos três dias.

A instrumentação utilizada mostrou-se adequada. Em alguns pilares, alguns extensômetros dispostos tanto na armadura longitudinal como na transversal, danificaram-se durante a concretagem. Assim, observa-se, no Apêndice B, que em alguns diagramas não foram apresentadas as leituras de alguns extensômetros. Como era esperado, o sinal do extensômetro disposto no concreto foi perdido instantes antes de ser atingida a força máxima. Esse fato ocorreu, em alguns casos, por destacamento desse instrumento e, em outros, por desprendimento do cobrimento de concreto a que ele estava fixado. Mesmo se sabendo que o sinal desse extensômetro seria perdido para valores de força próximos ao da máxima, decidiu-se por utilizá-lo na posição em questão, apenas com o objetivo de se ter controle maior do instante em que se atingia a força máxima resistente pelos pilares.

Os colares metálicos, dispostos nas extremidades dos pilares, apresentaram desempenho excepcional. Além de fixarem os pilares às rótulas, garantiram a integridade das extremidades dos pilares, não sendo observada nenhuma fissura no concreto nessas regiões.

Todos os pilares, com exceção dos de referência, apresentaram ruptura no ponto médio ao longo de suas alturas. A ruptura dos três pilares de referência ocorreu a aproximadamente $40 \mathrm{~cm}$ da extremidade superior, onde a seção transversal dos pilares apresentava dimensões $h=14,7 \mathrm{~cm}$ e $b=14,9 \mathrm{~cm}$. Na Figura 8.10 são mostrados detalhes do modo de colapso dos pilares ensaiados à flexocompressão. 

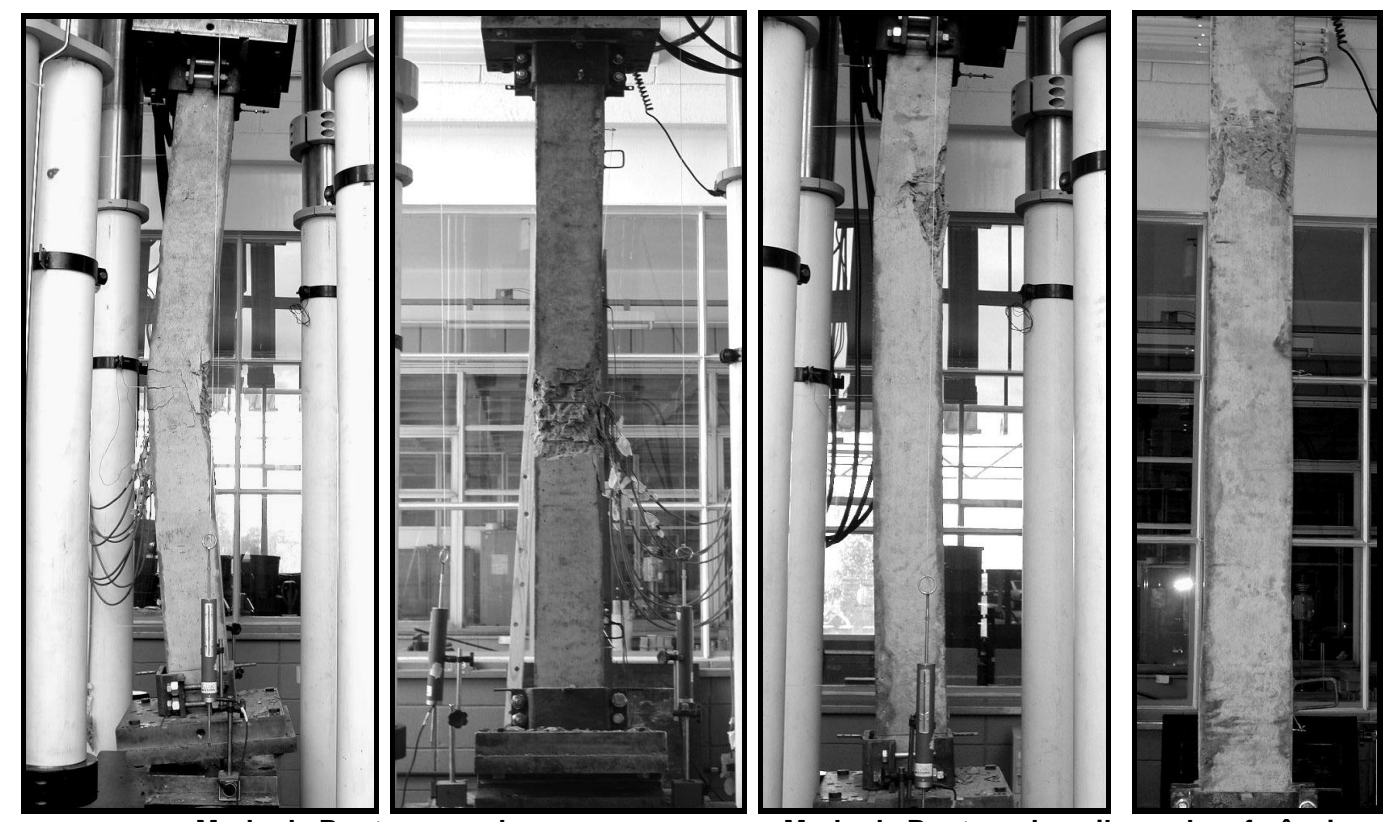

Modo de Ruptura usual

Modo de Ruptura dos pilares de referência

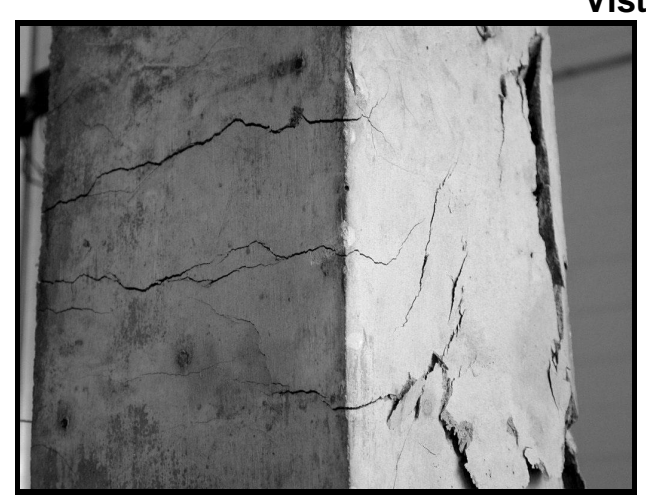

Detalhes do lado tracionado e comprimido do pilar

Figura 8.10 - Detalhes do modo de colapso dos pilares submetidos à compressão excêntrica

Observou-se que a região mais comprimida da seção transversal dos pilares ensaiados à flexo-compressão comportou-se de modo semelhante ao verificado para os pilares submetidos à compressão centrada. Grandes massas de concreto desprenderam-se dessa região nos pilares sem adição de fibras e com espaçamento de entre estribos de $15 \mathrm{~cm}$. Nos pilares sem adição de fibras e com espaçamento entre estribos de $5 \mathrm{~cm}$, observou-se o descolamento do cobrimento, logo após ser atingida a força máxima, e a formação de um núcleo resistente delimitado pelos estribos. Toda a região nuclear desses pilares permaneceu íntegra ao término dos ensaios. Finalmente, não foi observado desprendimento do cobrimento, nem tampouco de grandes massas de concreto durante o ensaio dos 
pilares com adição de fibras. Apesar do elevado grau de fissuração, toda a seção transversal destes pilares permaneceu íntegra após o termino dos ensaios, mesmo para aqueles com espaçamentos entre estribos de $15 \mathrm{~cm}$. Na Figura 8.11, apresentam-se detalhes das regiões de ruptura dos pilares com e sem adição de fibras.
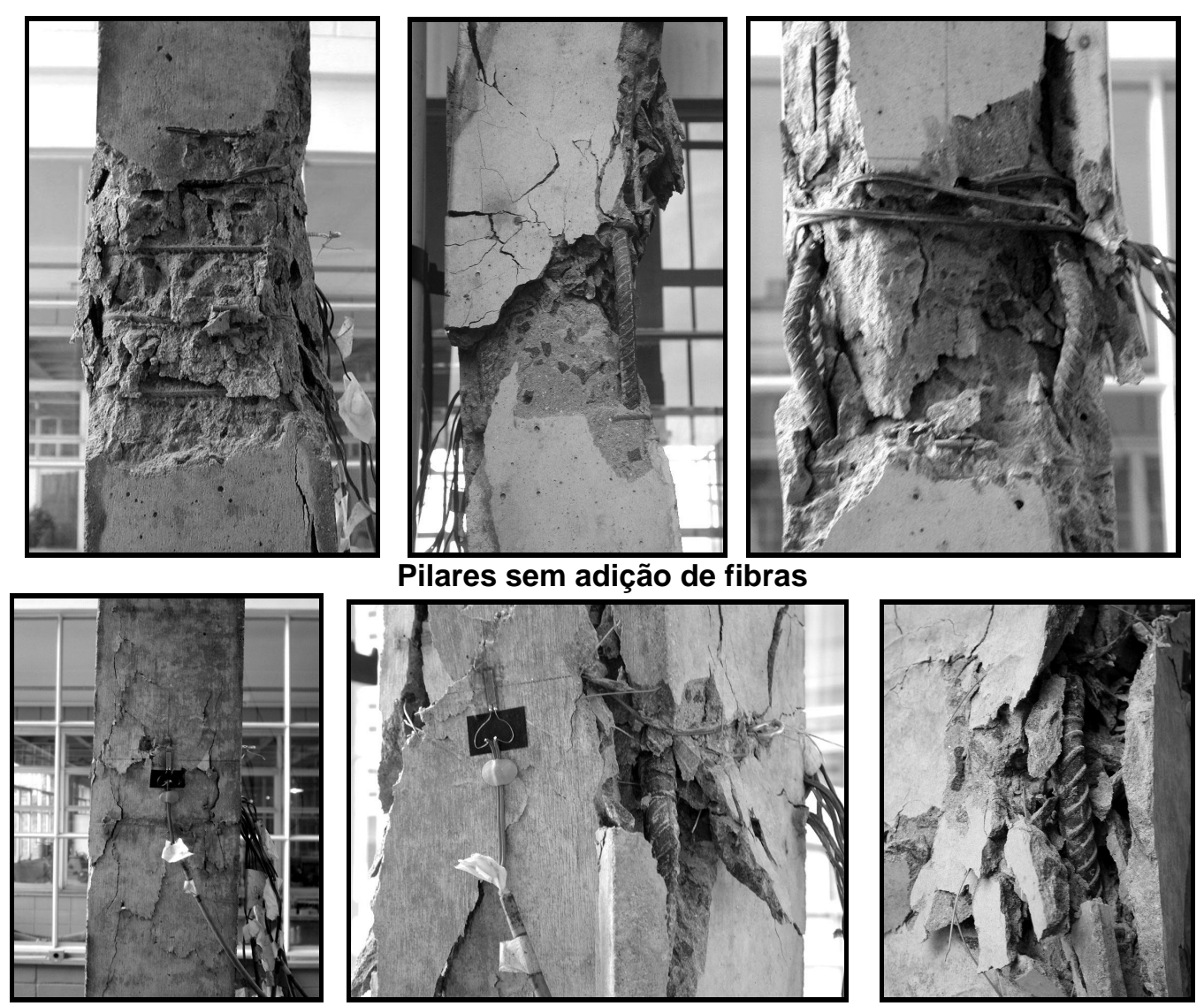

Pilares com adição de fibras

Figura 8.11 - Detalhes do descolamento dos cobrimentos nos pilares com e sem adição de fibras de aço e submetidos à compressão excêntrica

Em todos os pilares o modo de colapso foi caracterizado por flexocompressão. Nos pilares com excentricidades de força de $1 \mathrm{~cm}$ e $2 \mathrm{~cm}$, a ruptura se iniciou com o esmagamento do concreto na face mais comprimida, seguido pelo surgimento de fissuras de tração na face menos comprimida e a formação de uma rótula plástica. Verificou-se, durante os ensaios desses pilares, que toda a seção transversal permanecia comprimida até ser atingida a força máxima. A partir desse instante, observou-se uma inversão do sinal das tensões na região menos 
comprimida da seção transversal, isto é, a região que antes se apresentava sob tensões de compressão, subitamente passou a ser submetida a tensões de tração. Maiores detalhes do esmagamento do concreto e do aparecimento de fissuras de tração podem ser observados na Figura 8.10.

Nos pilares com excentricidade de força de $3 \mathrm{~cm}$, observou-se que a seção transversal se apresentava, desde o início do ensaio, parcialmente submetida a tensões de compressão e tração. Esse comportamento já era esperado, uma vez que a força resultante, nesses pilares, encontrava-se fora do núcleo central. Entretanto, observou-se que, até $75 \%$ da força máxima, as tensões de tração apresentavam intensidades inferiores à resistência à tração do concreto. A partir deste ponto, observou-se o surgimento de fissuras de tração na face tracionada do pilar.

$\mathrm{O}$ comportamento à flambagem das barras da armadura longitudinal foi semelhante ao observado nos pilares ensaiados à compressão centrada. Observouse, em todos os pilares ensaiados à compressão excêntrica, que apenas as barras da armadura longitudinal disposta na face mais comprimida flambaram. A flambagem dessas barras sempre ocorreu depois de ter sido atingida a força máxima dos pilares e de modo bem mais abrupto que nos pilares ensaiados à compressão centrada. Novamente, o comportamento mais crítico foi observado nos pilares com espaçamento entre estribos de $15 \mathrm{~cm}$ e, nos pilares com adição de fibras, constatou-se que a flambagem ocorreu mais tardiamente. Detalhes da flambagem das barras da armadura longitudinal podem ser observados na Figura 8.11 .

\subsubsection{Avaliação do sistema de apoio}

O pré-requisito primordial, para que o ensaio de flexo-compressão forneça bons resultados, consiste na capacidade do sistema de apoio em transferir integralmente o momento externo ao pilar. Isto significa que esses aparelhos devem possuir rigidez à rotação nula. Assim, a eficiência dos aparelhos de apoios pode ser avaliada por meio do cálculo dos momentos externos e internos. Desse modo, para o sistema ser eficiente, o momento externo aplicado deve ser igual ao 
momento interno resistido pelo pilar. Esse equilíbrio pode ser expresso matematicamente pela Eq.(8.1):

$$
M_{S}(x)=M_{R}(x)
$$

na qual $M_{S}(x)$ e $M_{R}(x)$ são os momentos solicitante e resistente em uma dada seção transversal do pilar, respectivamente.

O momento externo aplicado pode ser calculado como sendo o produto da força resultante aplicada pela soma da excentricidade imposta com o deslocamento lateral de segunda ordem do pilar. Assim, tem-se:

$$
M_{S}(x)=F \cdot\left(e+e_{2}(x)\right)
$$

na qual $F$ é a resultante da força externa aplicada, $e$ é a excentricidade da força resultante e $e_{2}(x)$ é a função da deflexão lateral do pilar. Os deslocamentos de segunda ordem do pilar podem ser aproximados por uma função senoidal, expressa pela Eq.(8.3):

$$
e_{2}(x)=a \cdot \operatorname{sen}\left(\frac{\pi \cdot x}{L}\right)
$$

na qual $a$ é a deflexão máxima localizada no ponto médio ao longo da altura do pilar; $L$ é o comprimento de flambagem do pilar, medido do centro de rotação do apoio superior ao centro de rotação do apoio inferior; e $x$ é a posição de uma seção transversal genérica ao longo da altura do pilar, medido a partir do centro de rotação do apoio inferior.

O momento resistente da seção transversal é dado pelo produto da curvatura da seção transversal pelo índice de rigidez do pilar, podendo ser escrito pela Eq.(8.4):

$$
M_{R}(x)=-E_{c} \cdot I \cdot \frac{\partial^{2} e_{2}(x)}{\partial x^{2}}=-E_{c} \cdot I \cdot \frac{\varepsilon_{1}(x)-\varepsilon_{2}(x)}{h}
$$

na qual $E_{c}$ é o módulo de elasticidade do concreto, $I$ é o momento de inércia da seção transversal, $\varepsilon_{l}(x)$ é a deformação na face menos comprimida da seção transversal, $\varepsilon_{2}(x)$ é a deformação na face mais comprimida da seção transversal, e $h$ é a profundidade da seção transversal, medida de face a face do pilar. Calculando-se a derivada segunda da equação Eq.(8.3) e substituindo o resultado na Eq.(8.4), obtém-se: 


$$
M_{R}(x)=E_{c} \cdot I \cdot a \cdot \frac{\pi^{2}}{L^{2}} \cdot \operatorname{sen}\left(\frac{\pi \cdot x}{L}\right)=-E_{c} \cdot I \cdot \frac{\varepsilon_{1}(x)-\varepsilon_{2}(x)}{h}
$$

Analisando a equação Eq.(8.5) observa-se que os máximos momentos, solicitante e resistente, atuantes ocorrem na seção a meia altura do pilar, isto é, $x=L / 2$. Assim, substituindo esse valor nas equações Eq.(8.2) e Eq.(8.5), tem-se que:

$$
\begin{aligned}
& M_{R-\max }=E_{c} \cdot I \cdot a \cdot \frac{\pi^{2}}{L^{2}}=-E_{c} \cdot I \cdot \frac{\varepsilon_{1}(L / 2)-\varepsilon_{2}(L / 2)}{h} \\
& M_{S-\max }=F \cdot\left(e+e_{2}(L / 2)\right)=F \cdot(e+a)
\end{aligned}
$$

Adotando que as hipóteses de Kirchoff (seções planas permanecem planas e perpendiculares à linha neutra) são validas para os pilares analisados até a força máxima; considerando os diagramas de deformações das armaduras dos pilares com concretos com resistência média à compressão de 60MPa (Apêndice B); e extrapolando os valores destas deformações para as faces do pilar, constata-se que as deformações no concreto não ultrapassaram o valor de $3 \%$, até a força correspondente a $95 \%$ da força máxima. Para valores de deformação até 3\%o, observa-se que os módulos de elasticidade do concreto com $f_{c j}=60 \mathrm{MPa}$, com e sem fibras, são praticamente constantes (ver Figura 8.5 e Figura 8.6) e iguais a aproximadamente $21 \mathrm{GPa}$ e $20 \mathrm{GPa}$, respectivamente. Verifica-se, ainda, que a taxa de armadura transversal não interfere no comportamento do trecho ascendente do diagrama força vs. deslocamento transversal dos pilares.

Finalmente, observa-se que, para os pilares submetidos a forças com excentricidades de $1 \mathrm{~cm}$ e $2 \mathrm{~cm}$, todas as seções transversais permanecem integralmente comprimidas até a força máxima. Desse modo, o momento de inércia pode ser calculado considerando-se toda a seção transversal do pilar. Assim, realizando-se a homogeneização da seção transversal, obtém-se que o momento de inércia desses pilares é aproximadamente $5,492 \cdot 10^{-5} \mathrm{~m}^{4}$.

Procurando avaliar a eficiência dos aparelhos de apoio utilizados, foram calculados os momentos solicitantes e resistentes de oito pilares ensaiados: P160150, P260150, P16050, P26050, P1601505, P2601505, P160505 e P260505. Para tanto, foram utilizados a equação Eq.(8.6) e os diagramas força vs. deslocamento transversal e força vs. deformação na armadura longitudinal desses 
pilares ensaiados. Nas Figura 8.12 e Figura 8.13, apresentam-se as curvas força vs. momentos fletores interno e externo dos pilares em questão.

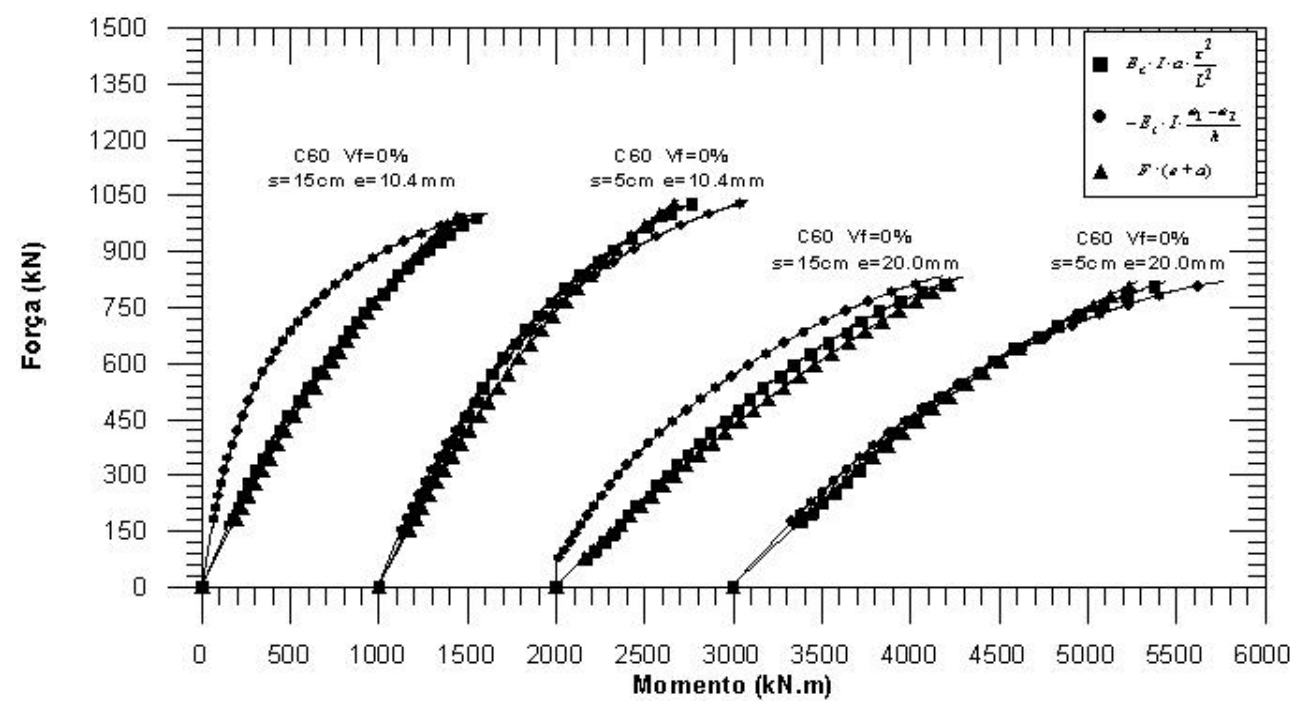

Figura 8.12 - Diagramas forçca vs. momentos fletores dos pilares com concretos com $f_{c j}=60$ e $\mathrm{Vf}=0,0 \%$, e submetidos a excentricidades de $1 \mathrm{~cm}$ e $2 \mathrm{~cm}$.

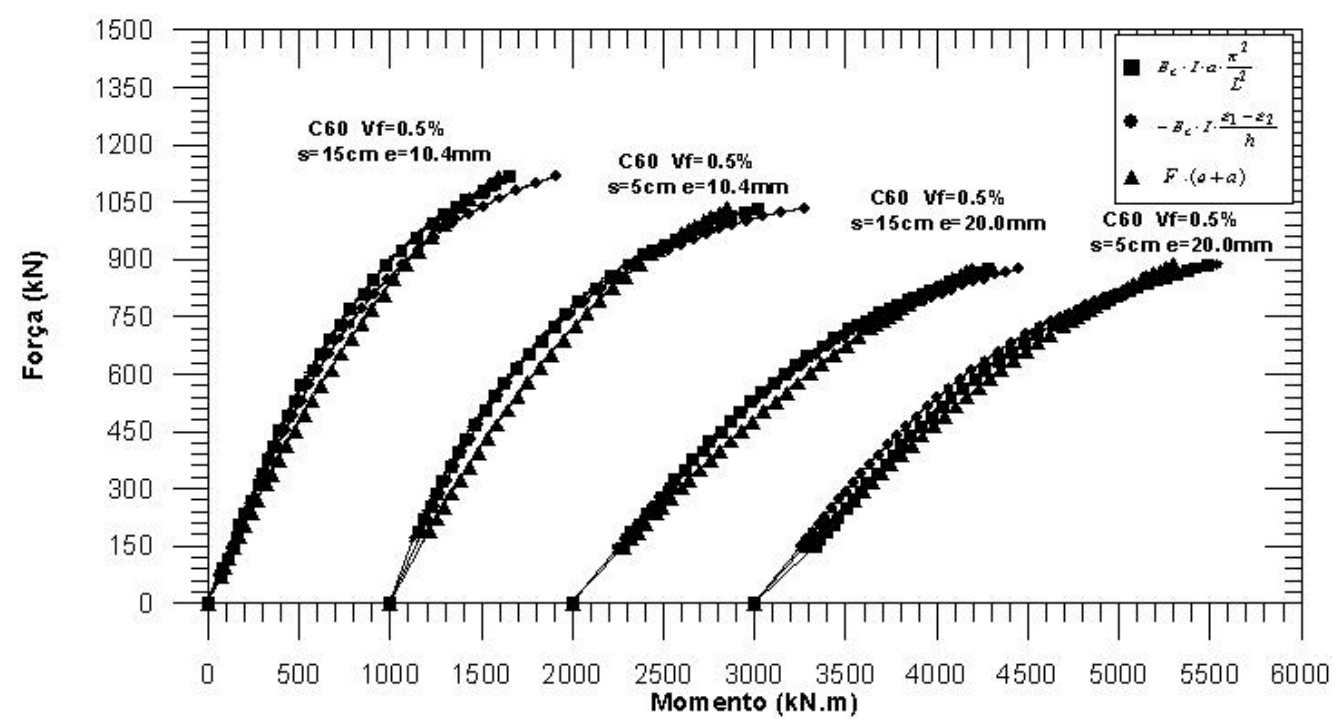

Figura 8.13 - Diagramas forçca vs. momentos fletores dos pilares com concretos com $f_{c j}=60$ e $V f=0,5 \%$, e submetidos a excentricidades de $1 \mathrm{~cm}$ e $2 \mathrm{~cm}$

Verifica-se que os diagramas dos momentos solicitantes e resistentes dos pilares apresentaram-se praticamente coincidentes. Em apenas dois pilares (P160150 e P260150), observou-se que o diagrama do momento resistente calculado por meio das deformações nas armaduras distanciou-se do diagrama do momento solicitante, como também do diagrama do momento resistente calculado por meio da deflexão lateral do pilar. Apesar de ser observada elevada 
discrepância entre esses diagramas para a força de aproximadamente $500 \mathrm{kN}$, os diagramas tendem ao mesmo momento fletor quando é atingida a força máxima.

Como conclusão, pode-se afirmar que o sistema de apoio apresentou elevada eficiência, conseguindo transferir para o pilar de modo integral o momento solicitante.

\subsubsection{Armadura longitudinal}

Analisando os diagramas força vs. deformação na armadura longitudinal, apresentados no Apêndice B, observa-se que, no trecho ascendente dos diagramas dos pilares ensaiados com excentricidade de força de $1 \mathrm{~cm}$, todas as barras da armadura longitudinal encontravam-se comprimidas. Contudo, atingida a força máxima, o sinal das deformações das barras menos comprimidas se inverte e, a partir desse ponto, observam-se deformações de tração. A máxima deformação de compressão das barras da face menos comprimida dos pilares ensaiados com $1 \mathrm{~cm}$ de excentricidade de força foi em média de $0,7 \%$, e, após a força máxima, essas barras atingiram o escoamento por tração em todos os pilares. Já para as barras junto à face menos comprimida desses pilares, verificou-se que em todos os ensaios estas atingiram o escoamento sob tensões de compressão. O mesmo comportamento dos pilares ensaiados com $1 \mathrm{~cm}$ de excentricidade foi observado para os pilares ensaiados com $2 \mathrm{~cm}$. A máxima deformação de compressão das barras da face menos comprimida desses pilares foi em média de 0,35\%o, e, após a força máxima, estas também atingiram o escoamento por tração. Novamente, todas as barras junto à face menos comprimida atingiram o escoamento sob tensões de compressão.

A inversão do sinal nas barras dispostas próximas à face menos comprimida dos pilares, que foram ensaiados com excentricidade de força de $1 \mathrm{~cm}$ e $2 \mathrm{~cm}$, pode ser explicada pelo fato de que, nas proximidades da força máxima, os deslocamentos laterais elevam-se rapidamente. Esse rápido aumento nos deslocamentos laterais é causado pelo esmagamento do concreto e a formação de uma rótula plástica a meia altura do pilar. Como consequiência, observa-se que o momento de segunda ordem também é rapidamente incrementado, fazendo com 
que o efeito de flexão se sobreponha ao de compressão, resultando no aparecimento abrupto de tensões de tração nos pilares. Lee e Son (2000) também observaram esse comportamento tanto para pilares curtos (índice de esbeltez igual a 19), como para pilares esbeltos (índices de esbeltez igual a 61).

Finalmente, nos pilares ensaiados com $3 \mathrm{~cm}$ de excentricidade de força, nota-se que, por causa do elevado efeito da flexão, as barras dispostas próximas à face menos comprimida já se encontravam tracionadas desde o início do ensaio e atingiram o escoamento logo após a força máxima. Constata-se, também que, antes de ser atingida a força máxima, as barras junto à face menos comprimida desses pilares já se encontram escoando sob tensões de compressão.

\subsubsection{Deformações na armadura transversal}

Os diagramas força vs. deformação na armadura transversal dos pilares são apresentados no Apêndice B. As análises das deformações dessas armadura foi realizada conjuntamente com os diagramas força vs. deformação na armadura longitudinal e separadamente para cada ramo do estribo, seguindo a disposição dos extensômetros apresentada na Figura 8.14.

Observa-se, de modo geral, em todos os trechos ascendentes dos diagramas, que as deformações transversais do concreto são pequenas e não são capazes de conduzir os estribos ao escoamento. Para esse trecho dos diagramas, observa-se que, na grande maioria dos pilares, as deformações no ramo $S G 2$ dos estribos são de compressão, porém, seus valores são desprezíveis. Os ramos $S G 1$ e SG3 apresentavam-se tracionados, contudo, os valores das deformações não ultrapassam cerca de $20 \%$ da deformação de escoamento do aço. O ramo $S G 4$ dos estribos é o que se apresenta mais deformado, atingindo, em alguns pilares, valor de cerca de $80 \%$ da deformação de escoamento do aço. 


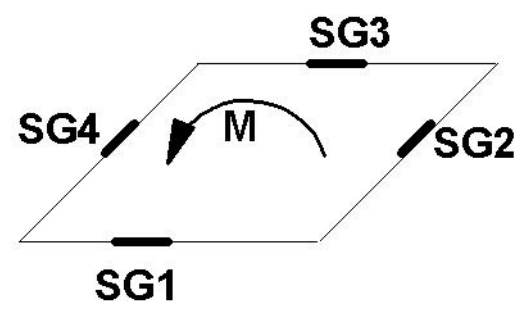

Figura 8.14 - Disposição dos extensômetros na armadura transversal

Como comentado no item 8.3.1, observa-se, nos diagramas das armaduras longitudinais (ver Apêncide B), que nos pilares ensaiados com excentricidades de $1 \mathrm{~cm}$ e $2 \mathrm{~cm}$, toda a seção transversal permanecia comprimida até ser atingida a força máxima. Nesse instante, observou-se a inversão do sinal das deformações nas duas barras da armadura longitudinal localizadas junto à face menos comprimida dos pilares. Isso significa que a linha neutra, que antes se encontrava fora da seção transversal, passou para dentro da seção, gerando regiões no concreto submetidas a tensões de tração. Esse fato foi evidenciado, durante os ensaios, com o surgimento de fissuras de tração no concreto na face menos comprimida dos pilares em questão. A partir deste instante observou-se que esses pilares comportaram-se de modo semelhante aos ensaiados com excentricidade de $3 \mathrm{~cm}$. Com a elevação dos deslocamentos axiais impostos aos pilares, após ser atingida a força máxima, verificou-se o gradativo e completo esmagamento do concreto na face mais comprimida e, na face menos comprimida do pilar, o progressivo aumento das aberturas de fissuras de tração. Observou-se ainda que, em alguns pilares, fissuras de tração surgiram exatamente na seção transversal que continha o estribo instrumentado, ou nas proximidades dessa seção. Em outros pilares, verificou-se o aparecimento de fissuras alguns centímetros acima e abaixo dessa seção transversal, formando um pequeno bloco de concreto não fissurado, contendo o estribo instrumentado. Analisando esses dois casos ocorridos, constata-se que, no primeiro, a presença de grandes vazios na seção transversal, provocados pelas fissuras, impede que as deformações transversais do concreto, oriundas da face mais comprimida do pilar, sejam capazes de provocar grandes deformações nos ramos $S G 2, S G 1$ e $S G 3$ dos estribos. Já no segundo caso, o bloco de concreto não fissurado garante que a expansão lateral do concreto, da face mais 
comprimida do pilar, solicite os estribos de forma um pouco mais uniforme e, assim, os ramos $S G 1, S G 2$ e $S G 3$ sejam mais solicitados.

Com base no exposto, observa-se que em apenas alguns pilares o ramo $S G 2$ dos estribos atingiu o escoamento, para intensidades de forças da ordem de $20 \%$ da força máxima no trecho descendente do diagrama força vs. deformação. Apesar disso, observou-se que as barras da armadura longitudinal, localizadas na face menos comprimida desses pilares, encontravam-se tracionadas.

Em virtude do elevado grau de esmagamento do concreto, após ser atingida a força máxima, verifica-se que a deformação no ramo $S G 4$ dos estribos rapidamente atingia o valor correspondente à deformação de escoamento do aço, e que apenas no pilar P1601505 esse ramo do estribo não atingiu o escoamento.

Em $60 \%$ dos pilares ensaiados, observou-se o escoamento dos ramos dos estribos paralelo ao plano de flexão, $S G 1$ e $S G 3$, no trecho descendente do diagrama força vs. deformação, para intensidades de forças da ordem de $60 \%$ da força máxima.

A análise da influência da taxa de armadura transversal, taxa de adição de fibras e a excentricidade da força aplicada nas deformações na armadura transversal dos pilares ensaiados à flexo-compressão foi realizada para três intensidades de força: 1- a força correspondente a $95 \%$ da força máxima no trecho ascendente do diagrama força vs. deslocamento; 2- a força máxima; e 3- a força correspondente a $85 \%$ da força máxima no trecho descendente do diagrama força vs. deslocamento. Para a avaliação das deformações nos ramos dos estribos paralelos ao plano de flexão, foi utilizada a média dos extensômetros $S G 1$ e $S G 3$. Todas as deformações foram parametrizadas por meio da leitura do extensômetro SG4 do pilar P160150.

Na Tabela 8.4, apresentam-se as deformações na armadura transversal para a intensidade de força correspondente a $95 \%$ da força máxima no trecho ascendente do diagrama força vs. deslocamento dos pilares. Verifica-se que nenhum ramo do estribo central atingiu a deformação de escoamento do aço $\left(\varepsilon_{y}=3,26 \%\right.$ o $)$ para esta intensidade de força. As maiores deformações são 
observadas no ramo do estribo paralelo à face mais comprimida do pilar $(S G 4)$, que na média atingiam cerca de $26 \%$ da deformação de escoamento do aço. No ramo paralelo à face menos comprimida do pilar as deformações eram praticamente nulas, e na maioria dos casos observa-se uma pequena deformação de compressão. Já nos ramos paralelos ao plano de flexão, as deformações do aço não ultrapassavam $10 \%$ da deformação de escoamento.

Tabela 8.4- Deformação na armadura transversal para 95\% da força máxima no trecho ascendente

\begin{tabular}{|c|c|c|c|c|c|c|}
\hline \multirow[b]{2}{*}{ Pilar } & \multicolumn{3}{|c|}{$\varepsilon_{t}(\% \circ)$} & \multirow{2}{*}{$\frac{S G_{4}}{S G_{4}^{*}}$} & \multirow{2}{*}{$\frac{S G_{2}}{S G_{4}^{*}}$} & \multirow{2}{*}{$\frac{S G_{1}+S G_{3}}{2 \cdot S G_{4}^{*}}$} \\
\hline & $S G_{4}$ & $S G_{2}$ & $\frac{S G_{1}+S G_{3}}{2}$ & & & \\
\hline$P 160150$ & $0,5625^{*}$ & - & 0,2383 & 1,00 & - & 0,42 \\
\hline P1601505 & 0,6828 & - & 0,2991 & 1,21 & - & 0,53 \\
\hline$P 16050$ & 0,5816 & 0,0709 & 0,3123 & 1,03 & 0,13 & 0,56 \\
\hline$P 160505$ & 0,8660 & 0,0381 & 0,3350 & 1,54 & 0,07 & 0,60 \\
\hline \multicolumn{4}{|c|}{ Valores médios } & 1,20 & 0,08 & 0,45 \\
\hline$P 260150$ & 0,6405 & $-0,0295$ & 0,1752 & 1,14 & $-0,05$ & 0,31 \\
\hline$P 2601505$ & 0,8410 & $-0,0242$ & 0,2521 & 1,50 & $-0,04$ & 0,45 \\
\hline P26050 & 0,6414 & $-0,0262$ & 0,2247 & 1,14 & $-0,05$ & 0,40 \\
\hline$P 260505$ & 0,7993 & $-0,0209$ & 0,2535 & 1,42 & $-0,04$ & 0,45 \\
\hline \multicolumn{4}{|c|}{ Valores médios } & 1,23 & $-0,04$ & 0,31 \\
\hline P360150 & 0,6904 & $-0,0161$ & 0,0927 & 1,23 & $-0,03$ & 0,16 \\
\hline P3601505 & 1,8030 & 0,0482 & 0,2423 & 3,21 & 0,09 & 0,43 \\
\hline P36050 & 0,6356 & $-0,0442$ & 0,1327 & 1,13 & $-0,08$ & 0,24 \\
\hline P360505 & 1,8487 & $-0,1585$ & 0,2953 & 3,29 & $-0,28$ & 0,52 \\
\hline \multicolumn{4}{|c|}{ Valores médios } & 2,21 & $-0,04$ & 0,16 \\
\hline
\end{tabular}

Avaliando detalhadamente o efeito das variáveis estudadas nas deformações dos estribos, observa-se que a taxa de armadura transversal não alterou as deformações nos ramos $S G 4$ e $S G 2$ dos estribos. Em adição, observa-se um pequeno aumento nas deformações nos ramos $S G 1$ e $S G 3$, quando da elevação da taxa de armadura transversal.

Não se observou influência da taxa de adição de fibras nas deformações do ramo $S G 2$ dos estribos. Já para os ramos $S G 1, S G 3$ e $S G 4$, verifica-se um pequeno aumento nas deformações quando ocorre a elevação da taxa de adição de fibras e a resultante da força de compressão permanece dentro do núcleo central. Entretanto, quando a resultante da força de compressão encontrou-se fora desta região $(e=3 \mathrm{~cm})$, observa-se que a elevação da taxa de adição de fibras aumentou em 2,75 
vezes a deformação no ramo $S G 4$ e em 2,4 vezes a deformação nos ramos $S G 1$ e $S G 3$ dos estribos.

Com a elevação da excentricidade da força resultante, as deformações no ramo $S G 2$ dos estribos continuaram muito próximas de zero, aparentemente não sendo influenciadas por essa variável. Porém, observou-se uma pequena elevação da deformação no ramo SG4. Entretanto, quando a excentricidade da força ultrapassa o limite do núcleo central, observa-se um aumento acentuado nas deformações nesse ramo dos estribos. Em contrapartida, é verificado um decréscimo quase que linear nas deformações dos ramos SG1 e SG3 dos estribos com a elevação da excentricidade.

$\mathrm{Na}$ Tabela 8.5, apresentam-se os valores as deformações na armadura transversal para a intensidade de força correspondente à força máxima resistida pelos pilares. Observa-se que também para esta intensidade de força, nenhum ramo dos estribos atingiu a deformação de escoamento. As deformações nos ramos $S G 1, S G 2$ e $S G 3$ dos estribos permaneceram praticamente inalteradas. Entretanto, as deformações no ramo $S G 4$ elevaram-se, em média, $45 \%$.

Tabela 8.5-Deformação na armadura transversal para força máxima

\begin{tabular}{|c|c|c|c|c|c|c|}
\hline \multirow[b]{2}{*}{ Pilar } & \multicolumn{3}{|c|}{$\varepsilon_{t}(\% o)$} & \multirow{2}{*}{$\frac{S G_{4}}{S G_{4}^{*}}$} & \multirow{2}{*}{$\frac{S G_{2}}{S G_{4}^{*}}$} & \multirow{2}{*}{$\frac{S G_{1}+S G_{3}}{2 \cdot S G_{4}^{*}}$} \\
\hline & $S G_{4}$ & $S G_{2}$ & $\frac{S G_{1}+S G_{3}}{2}$ & & & \\
\hline$P 160150$ & $0,8003^{*}$ & - & 0,2640 & 1,00 & - & 0,33 \\
\hline P1601505 & 1,0713 & - & 0,3620 & 1,34 & - & 0,45 \\
\hline P16050 & 0,9362 & 0,0186 & 0,3891 & 1,17 & 0,02 & 0,49 \\
\hline$P 160505$ & 1,4691 & $-0,0409$ & 0,4370 & 1,84 & $-0,05$ & 0,55 \\
\hline \multicolumn{4}{|c|}{ Valores médios } & 1,34 & $-0,01$ & 0,45 \\
\hline$P 260150$ & 0,9136 & $-0,0452$ & 0,1819 & 1,14 & $-0,06$ & 0,23 \\
\hline$P 2601505$ & 1,1129 & $-0,0414$ & 0,2800 & 1,39 & $-0,05$ & 0,35 \\
\hline$P 26050$ & 1,1339 & $-0,0472$ & 0,2340 & 1,42 & $-0,06$ & 0,29 \\
\hline P260505 & 1,3573 & $-0,0566$ & 0,2895 & 1,70 & $-0,07$ & 0,36 \\
\hline \multicolumn{4}{|c|}{ Valores médios } & 1,41 & $-0,06$ & 0,31 \\
\hline P360150 & 0,8797 & $-0,0052$ & 0,0761 & 1,10 & $-0,01$ & 0,10 \\
\hline P3601505 & 2,2199 & 0,0689 & 0,1789 & 2,77 & 0,09 & 0,22 \\
\hline P36050 & 0,8982 & $-0,0371$ & 0,1334 & 1,12 & $-0,05$ & 0,17 \\
\hline P360505 & 2,5608 & $-0,1792$ & 0,3906 & 3,20 & $-0,22$ & 0,49 \\
\hline \multicolumn{4}{|c|}{ Valores médios } & 2,05 & $-0,05$ & 0,24 \\
\hline
\end{tabular}


Para esta intensidade de força, observou-se, novamente, que a taxa de armadura transversal não influenciou nas deformações do ramo $S G 2$ dos estribos, como também, ocorreu pequeno aumento nas deformações nos ramos SG1 e SG3 quando da elevação desta. Ao contrário do observado na Tabela 8.4, verifica-se aqui um pequeno aumento nas deformações no ramo $S G 4$ quando da elevação da taxa de armadura transversal. Os modos de influência da adição de fibras metálicas e da excentricidade da força não se alteraram com o aumento da intensidade de força.

Na Tabela 8.6, apresentam-se as deformações na armadura transversal para a intensidade de força correspondente a $85 \%$ da força máxima no trecho descendente do diagrama força vs. deslocamento dos pilares. Verifica-se que, na média, as deformações do ramo $S G 4$ dos estribos correspondem a valores superiores ou muito próximos da deformação de escoamento. As deformações no ramo $S G 2$ continuam praticamente nulas, porém, é observado que a maioria dos pilares já apresentavam tensões de tração nesse ramo para este ponto do ensaio. Também é observado um expressivo aumento nas deformações dos ramos $S G 1$ e $S G 3$, contudo, não ultrapassavam o valor de $50 \%$ da deformação de escoamento do aço. Os modos de influência das variáveis estudadas praticamente se mantiveram também para este ponto de análise.

\subsubsection{Avaliação da capacidade resistente dos pilares}

Na Figura 8.15 apresentam-se os diagramas paramétricos força vs. excentricidade relativa da força atuante nos pilares ensaiados. Os pontos dos diagramas relativos à excentricidade nula foram obtidos a partir dos resultados dos ensaios dos pilares da primeira fase do programa experimental. Analisando os diagramas, observa-se que o comportamento da variação da capacidade de força resistente dos pilares em relação à excentricidade relativa é praticamente linear. Todas as séries de pilares apresentaram o mesmo comportamento, não sendo observada interferência da taxa de armadura transversal, nem tampouco da taxa de adição de fibra. Por meio de análise de regressão, obteve-se uma equação 
polinomial de grau um, com 99\% de correlação, considerando todas as séries de pilares. Excentricidades relativas de $10 \%$ e $20 \%$ implicaram em redução da força resistente de aproximadamente $27 \%$ e $53 \%$, respectivamente.

Tabela 8.6- Deformação na armadura transversal para $85 \%$ da força máxima no trecho descendente

\begin{tabular}{|c|c|c|c|c|c|c|}
\hline \multirow[b]{2}{*}{ Pilar } & \multicolumn{3}{|c|}{$\mathcal{E}_{t}(\% \circ)$} & \multirow{2}{*}{$\frac{S G_{4}}{S G_{4}^{*}}$} & \multirow{2}{*}{$\frac{S G_{2}}{S G_{4}^{*}}$} & \multirow{2}{*}{$\frac{S G_{1}+S G_{3}}{2 \cdot S G_{4}^{*}}$} \\
\hline & $S G_{4}$ & $S G_{2}$ & $\frac{S G_{1}+S G_{3}}{2}$ & & & \\
\hline$P 160150$ & $2,9520 *$ & - & 1,0400 & 1,00 & - & 0,45 \\
\hline P1601505 & 2,0480 & - & 1,0398 & 0,69 & - & 0,45 \\
\hline P16050 & 3,1330 & 0,0176 & 1,3384 & 1,06 & 0,01 & 0,58 \\
\hline$P 160505$ & 2,9351 & 0,0657 & 1,2421 & 0,99 & 0,02 & 0,54 \\
\hline \multicolumn{4}{|c|}{ Valores médios } & 0,94 & 0,01 & 0,51 \\
\hline$P 260150$ & 3,7612 & 0,0543 & 1,5973 & 1,27 & 0,02 & 0,70 \\
\hline$P 2601505$ & 5,2716 & $-0,0595$ & 1,0329 & 1,79 & $-0,02$ & 0,45 \\
\hline$P 26050$ & 3,7732 & $-0,0048$ & 0,2008 & 1,28 & 0,00 & 0,09 \\
\hline$P 260505$ & 2,7937 & $-0,0918$ & 1,0646 & 0,95 & $-0,03$ & 0,46 \\
\hline \multicolumn{4}{|c|}{ Valores médios } & 1,32 & $-0,01$ & 0,42 \\
\hline$P 360150$ & 2,3431 & 0,0904 & 0,3317 & 0,79 & 0,03 & 0,14 \\
\hline P3601505 & 6,3121 & 0,5765 & 1,4173 & 2,14 & 0,20 & 0,62 \\
\hline P36050 & 2,7496 & 0,27618 & 0,6538 & 0,93 & 0,09 & 0,28 \\
\hline$P 360505$ & 3,5657 & $-0,0399$ & 0,5963 & 1,21 & $-0,01$ & 0,26 \\
\hline \multicolumn{4}{|c|}{ Valores médios } & 1,27 & 0,08 & 0,33 \\
\hline
\end{tabular}

Objetivando-se verificar o comportamento da variação da capacidade de força resistente dos pilares, com concretos de resistência à compressão de $20 \mathrm{MPa}$ e 40MPa, em relação à excentricidade relativa, calcularam-se as perdas de força resistente de pilares com as mesmas características físicas e geométricas dos ensaiados experimentalmente, com o auxílio do programa ANAPROT. Para tanto, foi considerado o diagrama tensão vs. deformação do concreto, sugerido pelo FIB (1999), e os diagramas experimentais dos aços apresentadas no Capítulo 6, item 6.2.3. Na Figura 8.16 são apresentados os diagramas paramétricos força vs. excentricidade relativa, para os pilares com concretos com resistência de $20 \mathrm{MPa}$ e 40MPa. Verifica-se que o comportamento da perda de capacidade de força resistente dos pilares com concretos de resistência usual é similar ao comportamento dos pilares de alta resistência ensaiados experimentalmente. Entretanto, observa-se que essa perda de capacidade é um pouco menos acentuada para os pilares de resistência usual. Excentricidades relativas de $10 \%$ e $20 \%$ implicaram em redução da força resistente de aproximadamente $21 \%$ e $41 \%$, 
respectivamente. Não foram utilizados os pilares de referência para a análise acima, uma vez que o modo de colapso destes foi diferenciado por causa de imperfeições geométricas.

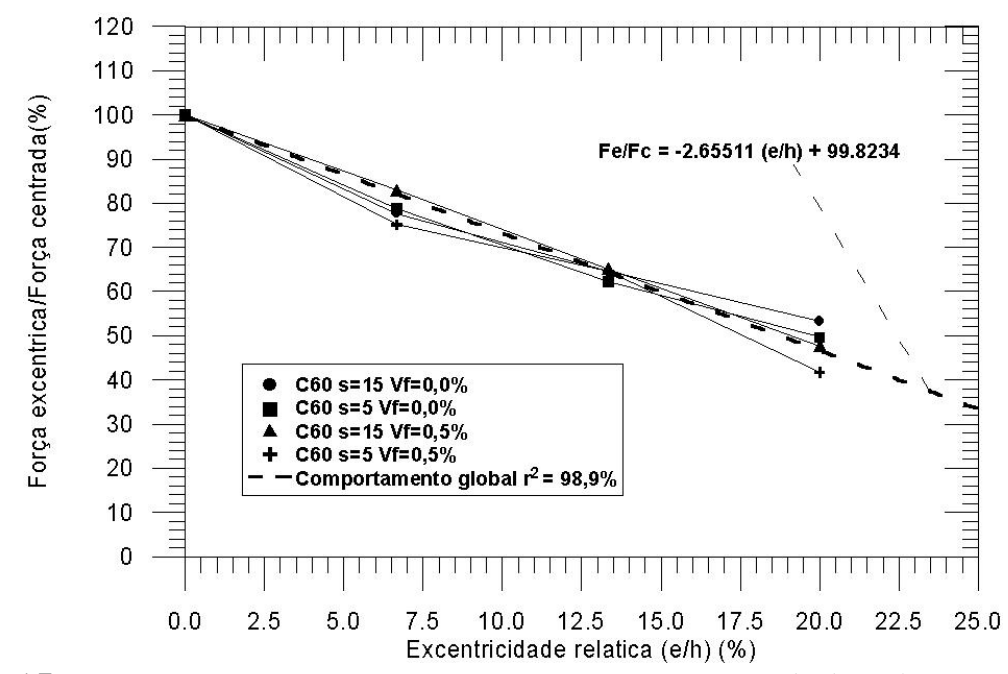

Figura 8.15 - Diagramas força paramétrica vs. excentricidade relativa dos pilares submetidos à flexo-compressão

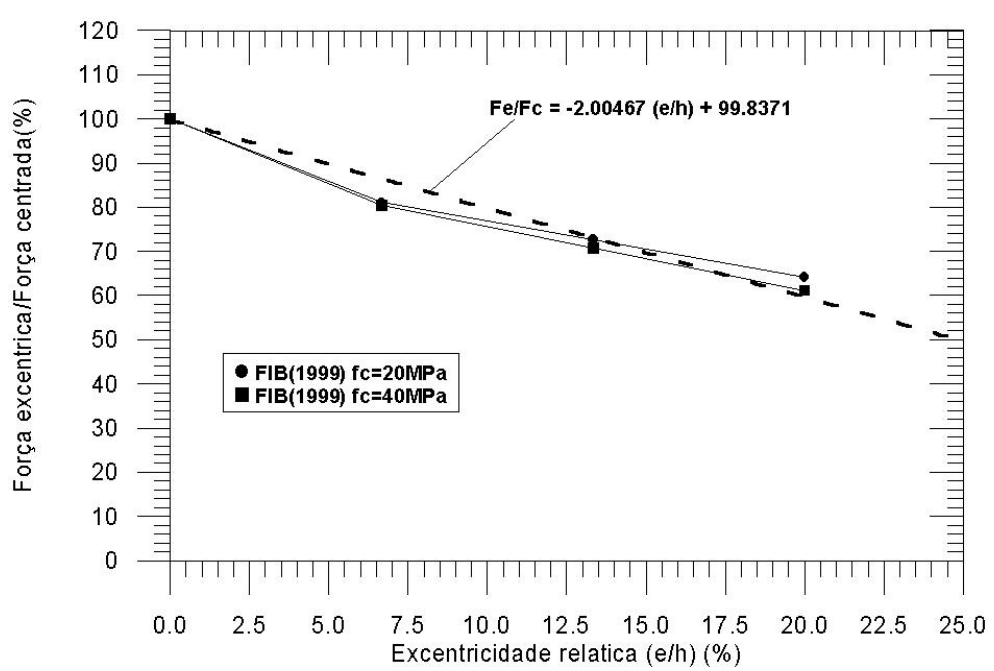

Figura 8.16 - Diagramas força paramétrica vs. excentricidade relativa para pilares com concretos de 20MPa e 40MPa segundo o FIB (1999)

Para avaliar a força e o momento fletor máximos resistentes dos pilares ensaiados à flexo-compressão, foi utilizado o programa ANAPROT, bem como utilizaram-se as propriedades mecânicas dos aços, obtidas experimentalmente, e apresentadas no Capítulo 6, item 6.2.3. Os diagramas dos concretos foram 
modelados pelos modelos do FIB (1999), pelo modelo proposto para o CRFA no Capítulo 4 e pelo modelo de Cusson e Paultre (1995).

Para o modelo do FIB (op. cit.) e o modelo para o CRFA foi adotado o coeficiente $k_{2}$ calculado segundo a norma norueguesa NBR (1989) e considerando as resistências à compressão do concreto apresentadas na Tabela 8.1. Para o modelo de Cusson e Paultre (1995) também utilizaram-se as resistências à compressão do concreto apresentadas na Tabela 8.1, contudo, o coeficiente $k_{2}$ foi tomado como aquele sugerido pelo ACI (1989). Além disso, para o modelo de Cusson e Paultre (1995) considerou-se apenas a área de concreto do núcleo $A_{c c}$.

Os pilares foram discretizados por meio de 20 elementos finitos de viga (ver Capítulo 4). Na modelagem dos pilares de referência, consideraram-se as imperfeições de geometria das seções transversais ao longo de toda a altura, avaliadas experimentalmente a cada $10 \mathrm{~cm}$.

Na Tabela 8.7, na Tabela 8.8 e na Tabela 8.9, apresentam-se as forças e momentos fletore máximos teóricos e experimentais segundo os modelos do FIB (1999), modelo para o CRFA e Cusson e Paultre (1995), respectivamente.

Tabela 8.7 - Capacidade resistente dos pilares ensaiados à flexo-compressão segundo FIB(1999)

\begin{tabular}{|c|c|c|c|c|c|c|c|}
\hline Pilar & $\begin{array}{c}a_{\exp } \\
(\mathrm{mm})\end{array}$ & $\begin{array}{c}M_{\exp } \\
(k N . c m)\end{array}$ & $\begin{array}{c}M_{t e o} \\
(k N . c m)\end{array}$ & $\frac{M_{\text {teo }}}{M_{\exp }}$ & $\begin{array}{l}F_{\text {exp }} \\
(k N)\end{array}$ & $\begin{array}{l}F_{\text {teo }} \\
(k N)\end{array}$ & $\frac{F_{\text {teo }}}{F_{\text {exp }}}$ \\
\hline$P 140$ & 7,936 & 1508 & 1487 & 0,99 & 823 & 810 & 0,98 \\
\hline$P 240$ & 10,453 & 1988 & 2064 & 1,04 & 653 & 722 & 1,11 \\
\hline P340 & 12,156 & 2134 & 2462 & 1,15 & 500 & 629 & 1,26 \\
\hline \multicolumn{4}{|c|}{ Valores médios } & 1,06 & & & 1,12 \\
\hline$P 160150$ & 6,725 & 1803 & 1855 & 1,03 & 1053 & 1031 & 0,98 \\
\hline$P 260150$ & 9,560 & 2586 & 2555 & 0,99 & 875 & 838 & 0,96 \\
\hline P360150 & 13,222 & 3159 & 2959 & 0,94 & 722 & 656 & 0,91 \\
\hline$P 16050$ & 8,494 & 2054 & 1855 & 0,90 & 1087 & 1031 & 0,95 \\
\hline$P 26050$ & 10,763 & 2644 & 2555 & 0,97 & 859 & 838 & 0,98 \\
\hline P36050 & 11,863 & 2901 & 2959 & 1,02 & 685 & 656 & 0,96 \\
\hline P1601505 & 7,170 & 2076 & 1788 & 0,86 & 1182 & 980 & 0,83 \\
\hline$P 2601505$ & 9,750 & 2760 & 2455 & 0,89 & 928 & 799 & 0,86 \\
\hline P3601505 & 11,881 & 2880 & 2817 & 0,98 & 679 & 643 & 0,95 \\
\hline P160505 & 8,510 & 2060 & 1788 & 0,87 & 1089 & 980 & 0,90 \\
\hline$P 260505$ & 10,264 & 2835 & 2455 & 0,87 & 937 & 799 & 0,85 \\
\hline P360505 & 10,883 & 2505 & 2817 & 1,12 & 605 & 643 & 1,06 \\
\hline \multicolumn{4}{|c|}{ Valores médios } & 0,95 & & & 0,93 \\
\hline
\end{tabular}


Tabela 8.8 - Capacidade resistente dos pilares ensaiados à flexo-compressão segundo o modelo para CRFA

\begin{tabular}{|c|c|c|c|c|c|c|c|}
\hline Pilar & $\begin{array}{c}a_{\exp } \\
(m m)\end{array}$ & $\begin{array}{c}M_{\exp } \\
(k N . c m)\end{array}$ & $\begin{array}{c}M_{t e o} \\
(k N . c m)\end{array}$ & $\frac{M_{\text {teo }}}{M_{\text {exp }}}$ & $\begin{array}{l}F_{\text {exp }} \\
(k N)\end{array}$ & $\begin{array}{l}F_{\text {teo }} \\
(k N)\end{array}$ & $\frac{F_{\text {teo }}}{F_{\text {exp }}}$ \\
\hline P140 & 7,936 & 1508 & 1160 & 0,77 & 823 & 768 & 0,93 \\
\hline$P 240$ & 10,453 & 1988 & 1724 & 0,87 & 653 & 670 & 1,03 \\
\hline P340 & 12,156 & 2134 & 2053 & 0,96 & 500 & 578 & 1,15 \\
\hline \multicolumn{4}{|c|}{ Valores médios } & 0,87 & & & 1,04 \\
\hline$P 160150$ & 6,725 & 1803 & 1742 & 0,97 & 1053 & 984 & 0,93 \\
\hline$P 260150$ & 9,560 & 2586 & 2426 & 0,94 & 875 & 797 & 0,91 \\
\hline P360150 & 13,222 & 3159 & 2809 & 0,89 & 722 & 622 & 0,86 \\
\hline$P 16050$ & 8,494 & 2054 & 1742 & 0,85 & 1087 & 984 & 0,91 \\
\hline$P 26050$ & 10,763 & 2644 & 2426 & 0,92 & 859 & 797 & 0,93 \\
\hline P36050 & 11,863 & 2901 & 2809 & 0,97 & 685 & 622 & 0,91 \\
\hline P1601505 & 7,170 & 2076 & 1814 & 0,87 & 1182 & 996 & 0,84 \\
\hline$P 2601505$ & 9,750 & 2760 & 2512 & 0,91 & 928 & 817 & 0,88 \\
\hline P3601505 & 11,881 & 2880 & 2914 & 1,01 & 679 & 665 & 0,98 \\
\hline P160505 & 8,510 & 2060 & 1814 & 0,88 & 1089 & 996 & 0,91 \\
\hline$P 260505$ & 10,264 & 2835 & 2512 & 0,89 & 937 & 817 & 0,87 \\
\hline$P 360505$ & 10,883 & 2505 & 2914 & 1,16 & 605 & 665 & 1,10 \\
\hline \multicolumn{4}{|c|}{ Valores médios } & 0,94 & & & 0,92 \\
\hline
\end{tabular}

Tabela 8.9 - Capacidade resistente dos pilares ensaiados à flexo-compressão segundo Cusson e Paultre(1995)

\begin{tabular}{|c|c|c|c|c|c|c|c|}
\hline Pilar & $\begin{array}{c}a_{\exp } \\
(m m)\end{array}$ & $\begin{array}{c}M_{\text {exp }} \\
(k N . c m)\end{array}$ & $\begin{array}{c}M_{t e o} \\
(k N . c m)\end{array}$ & $\frac{M_{\text {teo }}}{M_{\text {exp }}}$ & $\begin{array}{l}F_{\text {exp }} \\
(k N)\end{array}$ & $\begin{array}{l}F_{\text {teo }} \\
(k N)\end{array}$ & $\frac{F_{t e o}}{F_{\text {exp }}}$ \\
\hline$P 140$ & 7,936 & 1508 & 1124 & 0,75 & 822 & 542 & 0,66 \\
\hline$P 240$ & 10,453 & 1988 & 1566 & 0,79 & 653 & 475 & 0,73 \\
\hline P340 & 12,156 & 2134 & 1840 & 0,86 & 500 & 414 & 0,83 \\
\hline \multicolumn{4}{|c|}{ Valores médios } & 0,80 & & & 0,74 \\
\hline$P 160150$ & 6,725 & 1803 & 1542 & 0,86 & 1053 & 865 & 0,82 \\
\hline$P 260150$ & 9,560 & 2586 & 2116 & 0,82 & 875 & 690 & 0,79 \\
\hline P360150 & 13,222 & 3159 & 2458 & 0,78 & 722 & 542 & 0,75 \\
\hline$P 16050$ & 8,494 & 2054 & 1682 & 0,82 & 1087 & 854 & 0,79 \\
\hline$P 26050$ & 10,763 & 2644 & 2209 & 0,84 & 859 & 691 & 0,80 \\
\hline P36050 & 11,863 & 2901 & 2514 & 0,87 & 685 & 570 & 0,83 \\
\hline P1601505 & 7,170 & 2076 & 1502 & 0,72 & 1182 & 821 & 0,69 \\
\hline$P 2601505$ & 9,750 & 2760 & 2037 & 0,74 & 928 & 660 & 0,71 \\
\hline P3601505 & 11,881 & 2880 & 2343 & 0,81 & 679 & 533 & 0,78 \\
\hline P160505 & 8,510 & 2060 & 1615 & 0,78 & 1089 & 819 & 0,75 \\
\hline$P 260505$ & 10,264 & 2835 & 2108 & 0,74 & 937 & 670 & 0,72 \\
\hline P360505 & 10,883 & 2505 & 2403 & 0,96 & 605 & 558 & 0,92 \\
\hline \multicolumn{4}{|c|}{ Valores médios } & 0,81 & & & 0,78 \\
\hline
\end{tabular}

Analisando os resultados experimentais apresentados, observa-se que tanto a adição de fibras metálicas como o aumento da taxa de armadura transversal não melhoraram a capacidade resistente dos pilares. Verifica-se que, tanto as forças, quanto os momentos máximos resistentes praticamente mantiveram os mesmos valores entre as séries dos pilares com concretos de alta resistência. 
Analisando os dados apresentados na Tabela 8.7, observa-se que o modelo do FIB (op. cit.) conseguiu predizer tanto os momentos fletores máximos quanto as forças máximas dos pilares com boa precisão. Verifica-se que foi possível predizer os momentos e forças máximas resistentes dos pilares de referência, apesar das imperfeições geométricas. As diferenças médias entre os momentos e forças máximas teóricas e experimentais para esses pilares foram de apenas $6 \% \mathrm{e}$ $12 \%$, respectivamente. Boa concordância também foi observada entre pilares com CAR, sendo a diferença média entre os valores teóricos e experimentais dos momento e forças máximas da ordem de $5 \%$ e $7 \%$, respectivamente.

O modelo proposto para o CRFA também apresentou bom desempenho (ver Tabela 8.8), tanto em predizer os momentos e forças máximas dos pilares com concretos de resistência usuais, como os de alta resistência. Para os pilares com $C R U$, as diferenças médias entre os momentos e forças máximas teóricas e experimentais foram de $13 \%$ e $4 \%$, respectivamente. Para os pilares com CAR, a diferença entre os momentos fletores máximos teóricos e experimentais foi de $6 \%$ e entre as forças máximas foi de $8 \%$.

Finalmente, observa-se que o modelo de Cusson e Paultre (1995) foi o modelo que apresentou piores resultados. Esse fato é explicado, uma vez que, na modelagem foi utilizada apenas a seção transversal do núcleo do pilar. Deste modo, como para os pilares analisados o confinamento não alterou a capacidade de carga dos pilares e para a força e momento máximos a seção transversal trabalha integralmente, o modelo mostra-se a favor da segurança. Para os pilares de $C A R$, observam-se diferenças médias entre os valores experimentais e teóricos dos momentos e forças máximas de $19 \%$ e $22 \%$, respectivamente.

Nas Figura 8.17 a Figura 8.28, apresentam-se os diagramas momento vs. curvatura experimentais e teóricos, segundo os modelos do FIB (1999), o proposto para CRFA neste trabalho e o de Cusson e Paultre (1995). 


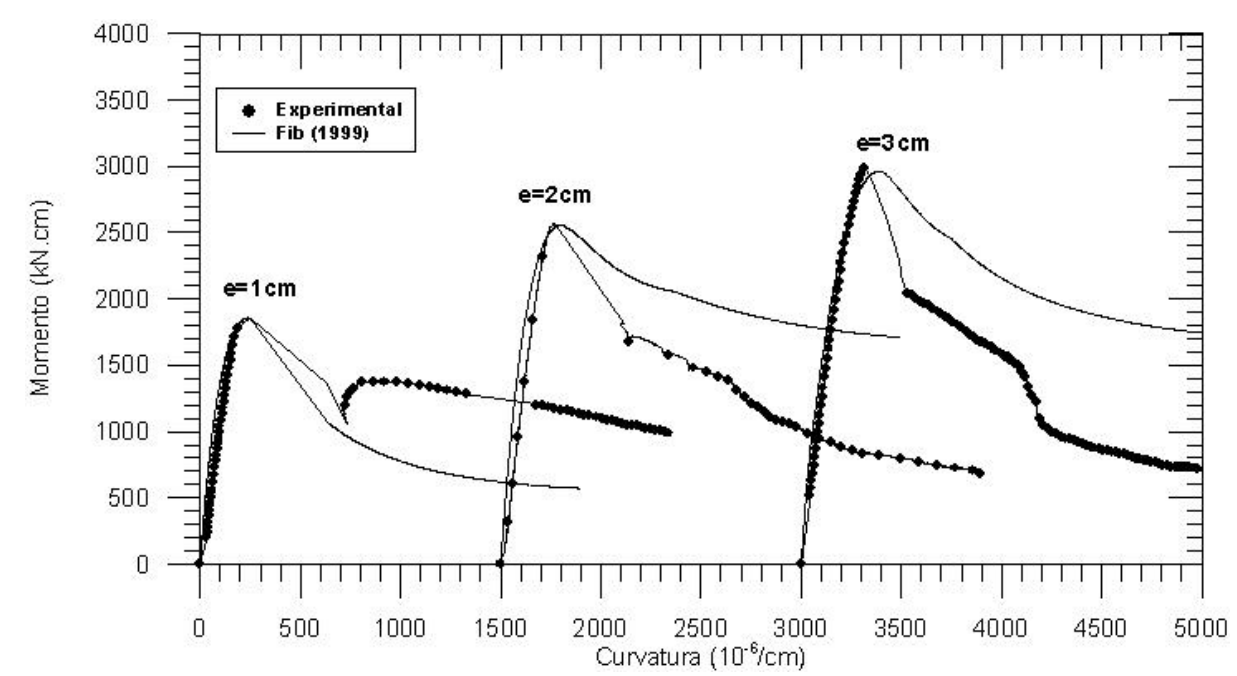

Figura 8.17 - Diagramas momento vs. curvatura dos pilares com $f_{c j}=60, s=15 \mathrm{~cm} e$ $V_{f}=0 \%$, e modelados pelo FIB (1999)

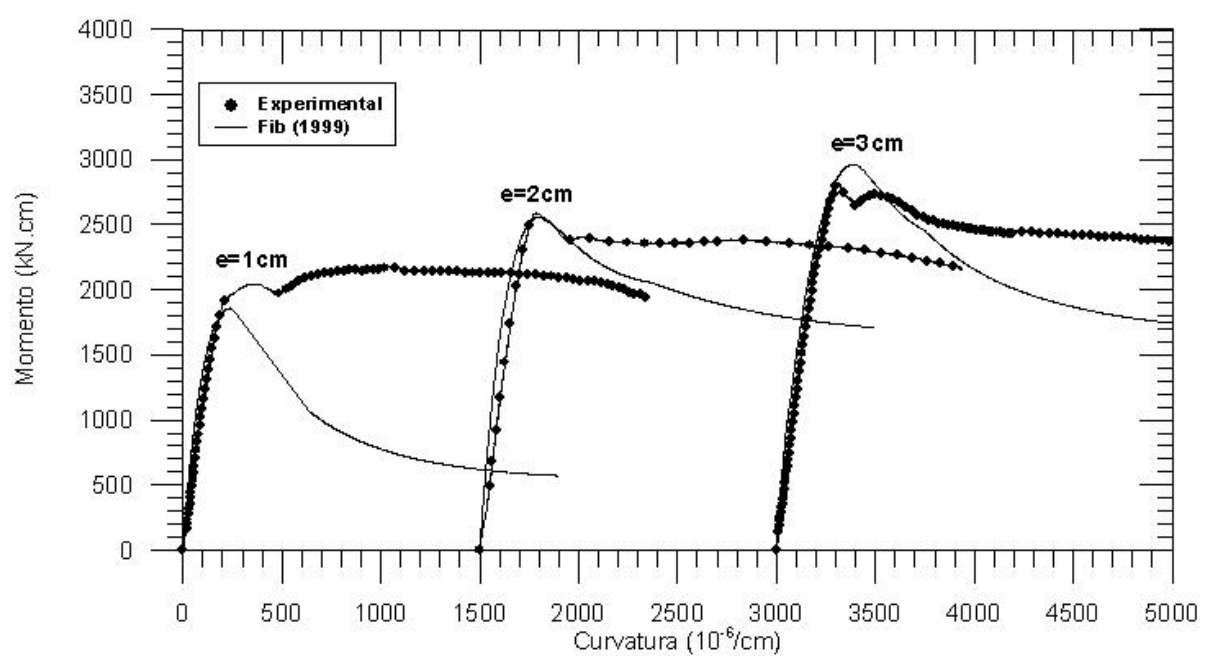

Figura 8.18 - Diagramas momento vs. curvatura dos pilares com $f_{c j}=60, s=5 \mathrm{~cm} e$ $V_{f}=0 \%$, e modelados pelo FIB (1999)

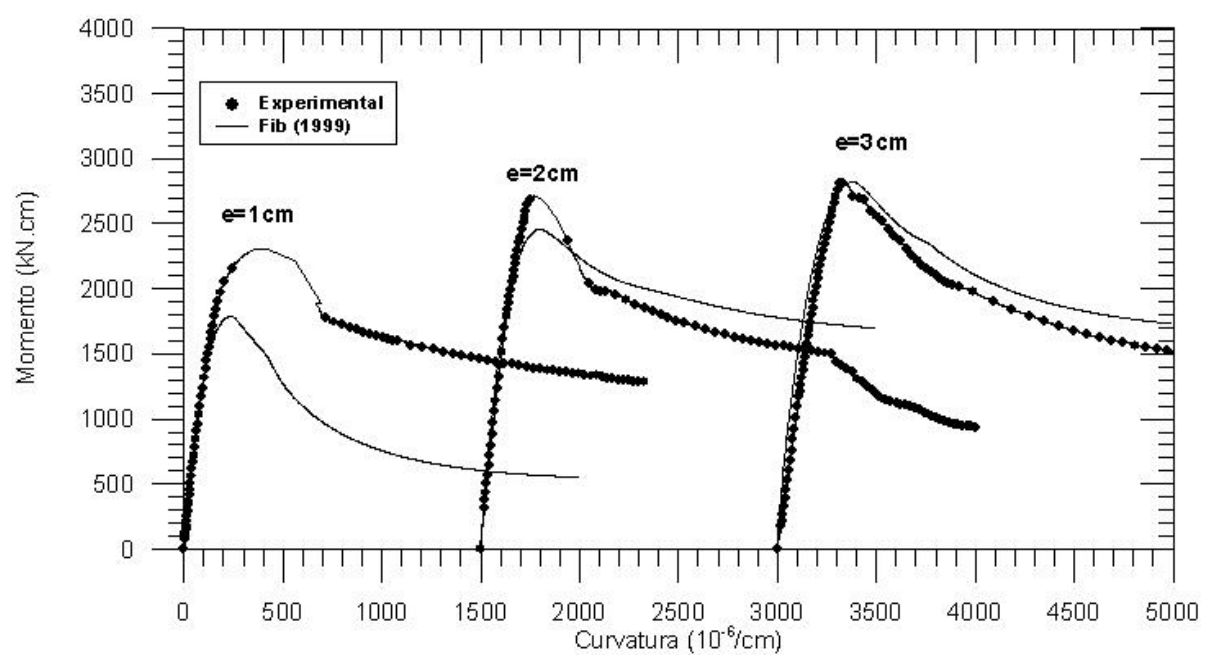

Figura 8.19 - Diagramas momento vs. curvatura dos pilares com $f_{c j}=60, s=15 \mathrm{~cm}$ e $V_{f}=0,5 \%$, e modelados pelo FIB (1999) 


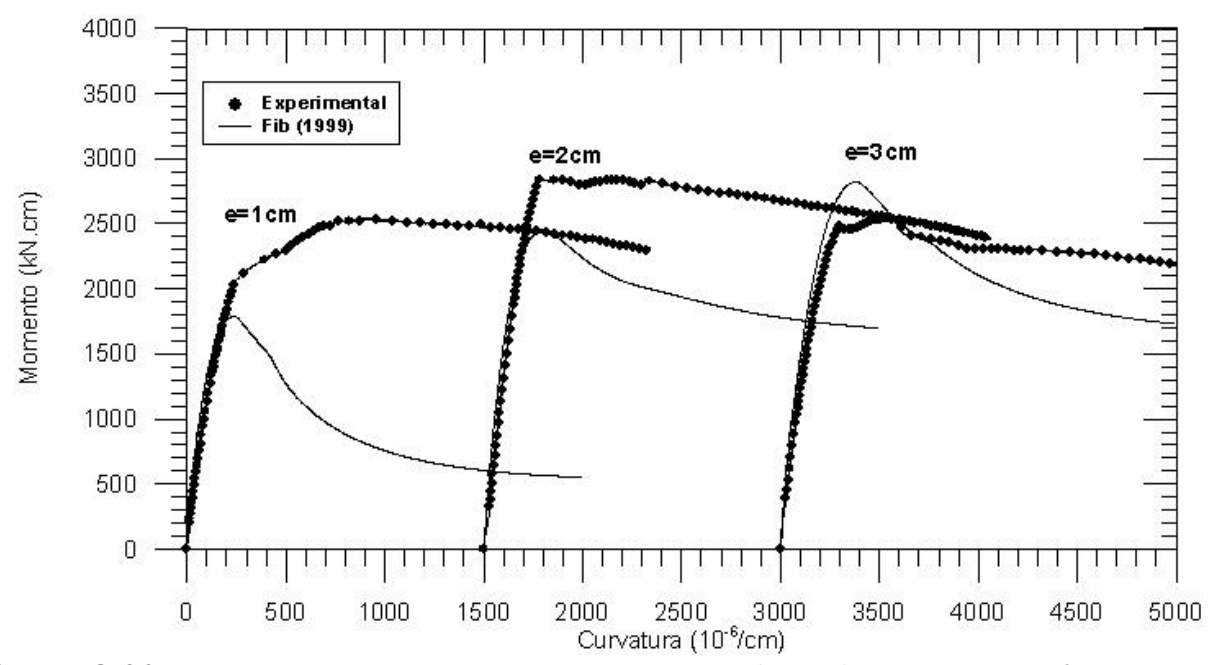

Figura 8.20 - Diagramas momento vs. curvatura dos pilares com $f_{c j}=60, s=5 \mathrm{~cm}$ e $V_{f}=0,5 \%$, e modelados pelo FIB (1999)

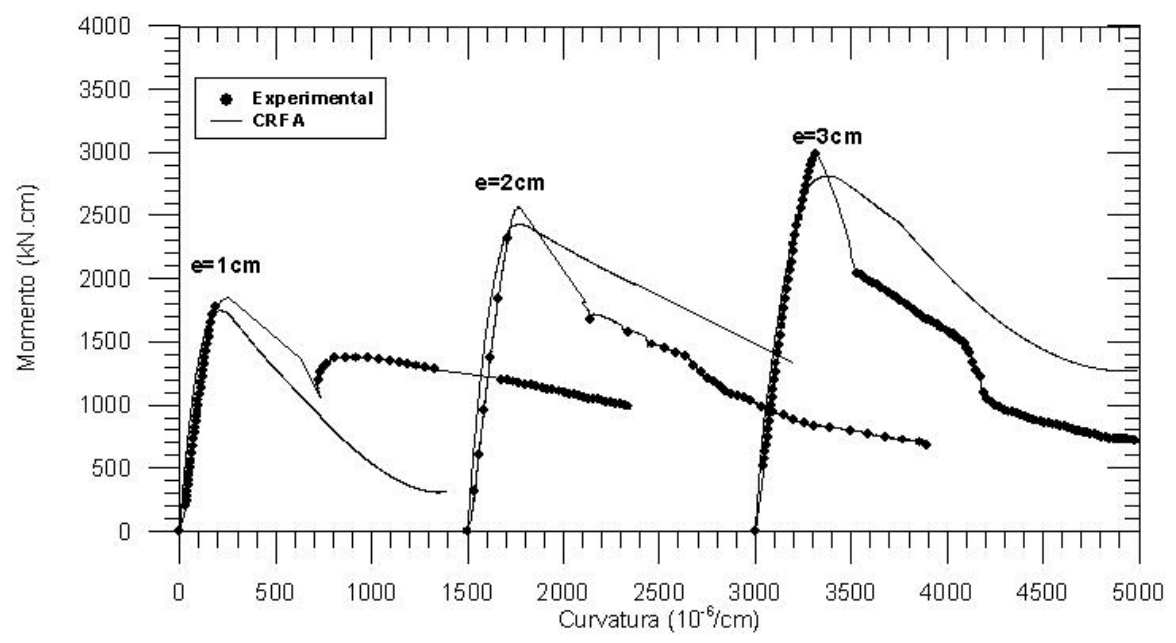

Figura 8.21 - Diagramas momento vs. curvatura dos pilares com $f_{c j}=60, s=15 \mathrm{~cm}$ e $V_{f}=0 \%$, e modelados pelo modelo proposto para o $C R F A$

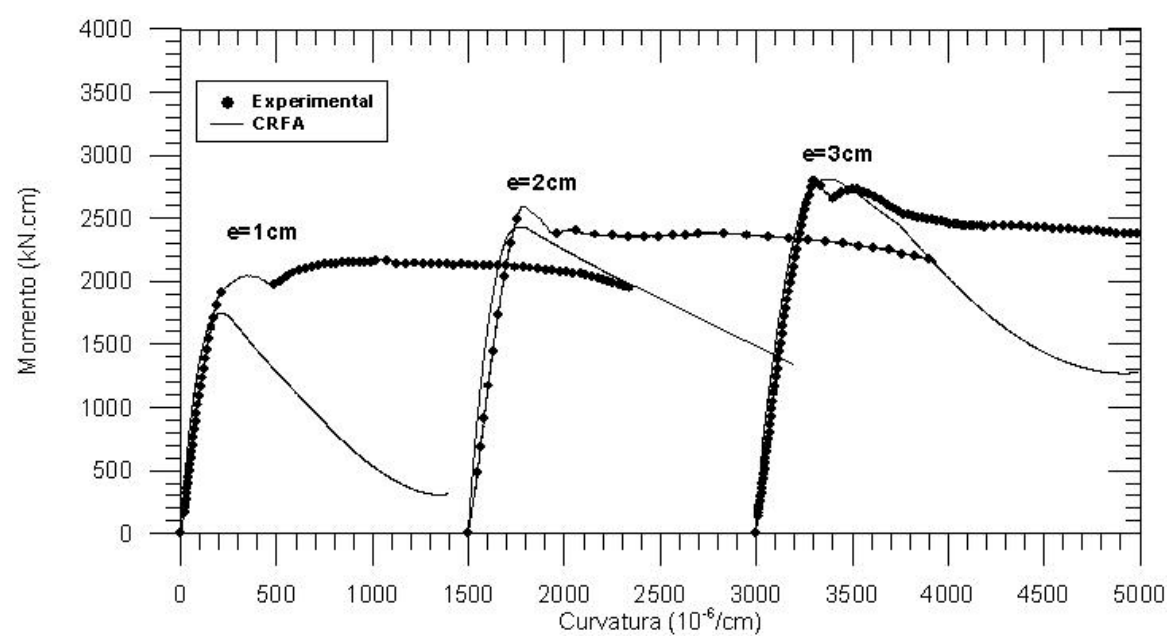

Figura 8.22 - Diagramas momento vs. curvatura dos pilares com $f_{c j}=60, s=5 \mathrm{~cm} e$ $V_{f}=0 \%$, e modelados pelo modelo proposto para o CRFA 


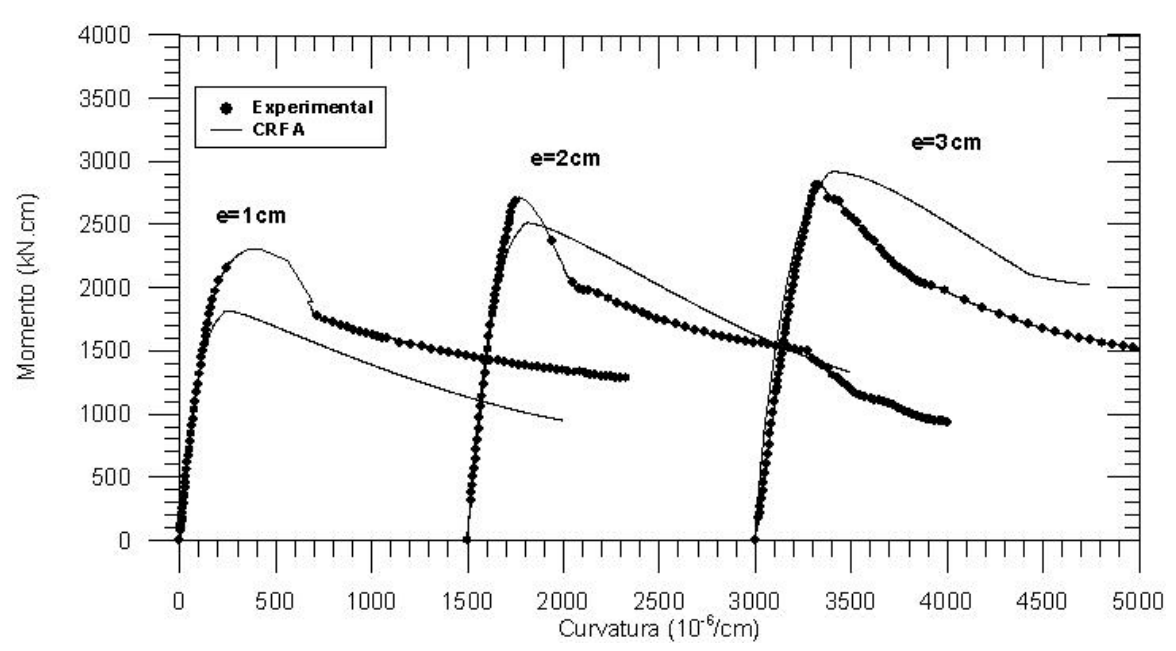

Figura 8.23 - Diagramas momento vs. curvatura dos pilares com $f_{c j}=60, \mathrm{~s}=15 \mathrm{~cm}$ e $V_{f}=0,5 \%$, e modelados pelo modelo proposto para o CRFA

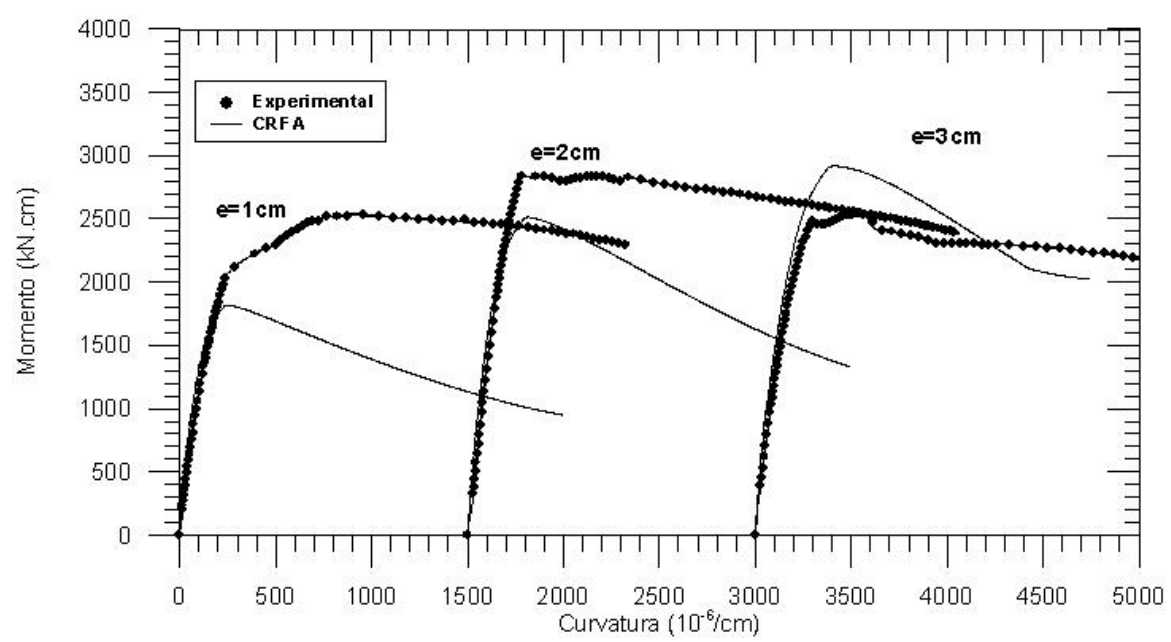

Figura 8.24 - Diagramas momento vs. curvatura dos pilares com $f_{c j}=60, s=5 \mathrm{~cm}$ e $V_{f}=0,5 \%$, e modelados pelo modelo proposto para o CRFA

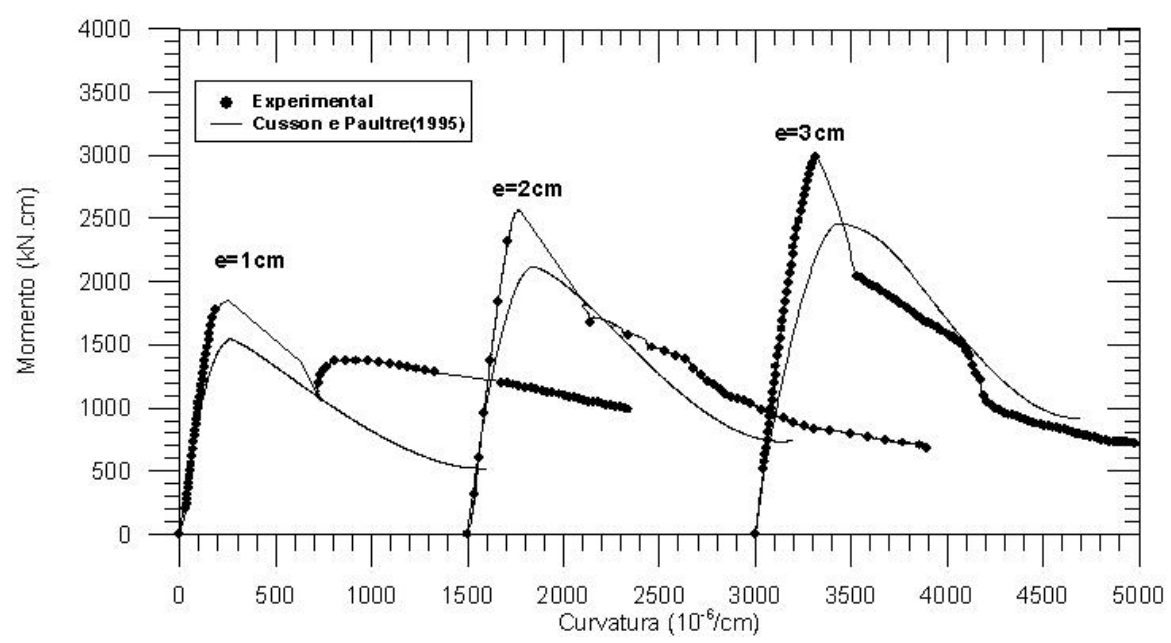

Figura 8.25 - Diagramas momento vs. curvatura dos pilares com $f_{c j}=60, s=15 \mathrm{~cm}$ e $V_{f}=0 \%$, e modelados pelo modelo de Cusson e Paultre (1995) 


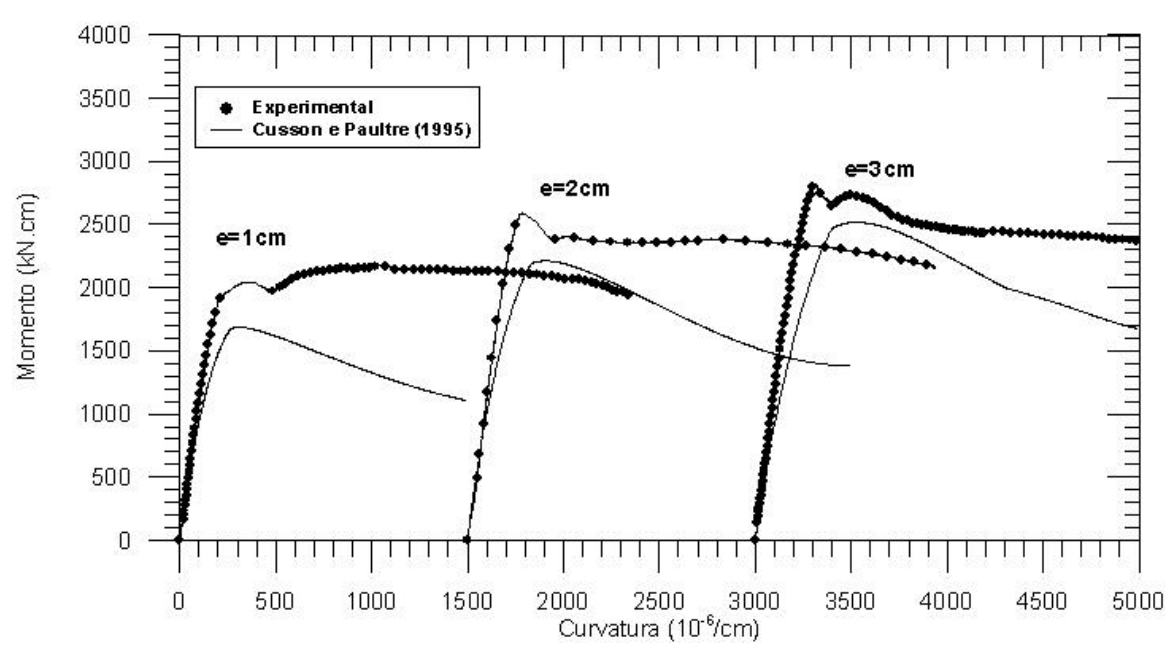

Figura 8.26 - Diagramas momento vs.curvatura dos pilares com $f_{c j}=60, s=5 \mathrm{~cm} e$ $V_{f}=0 \%$, e modelados pelo modelo de Cusson e Paultre (1995)

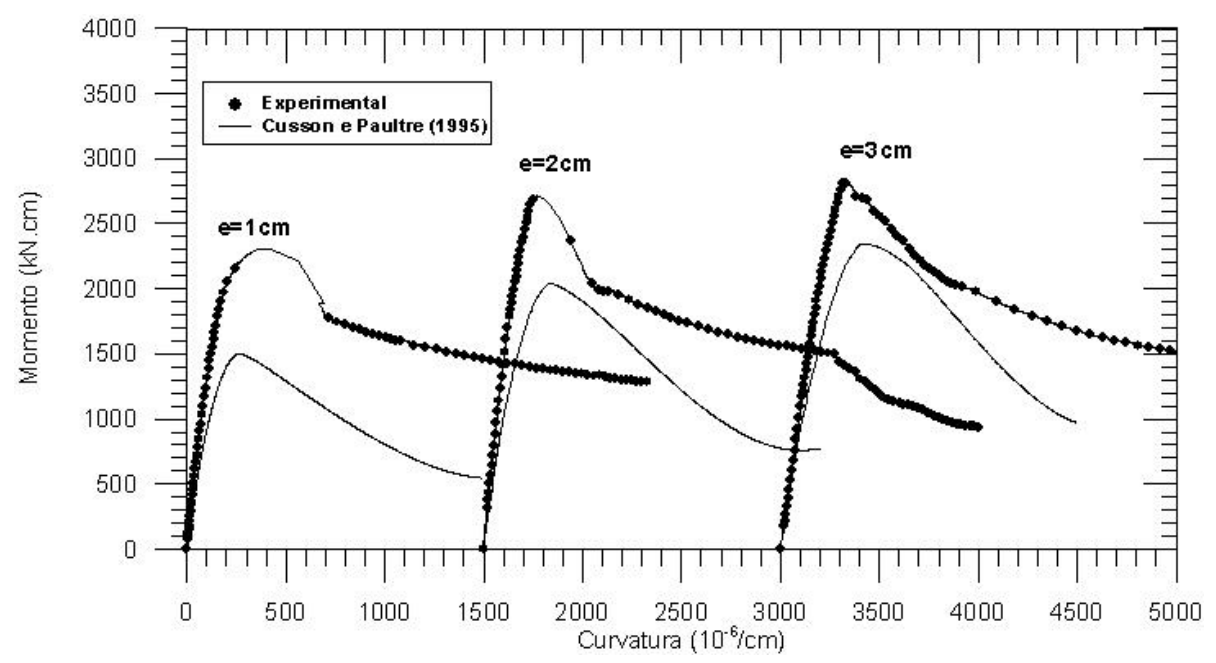

Figura 8.27 - Diagramas momento vs.curvatura dos pilares com $f_{c j}=60, \mathrm{~s}=15 \mathrm{~cm}$ e $V_{f}=0,5 \%$, e modelados pelo modelo de Cusson e Paultre (1995)

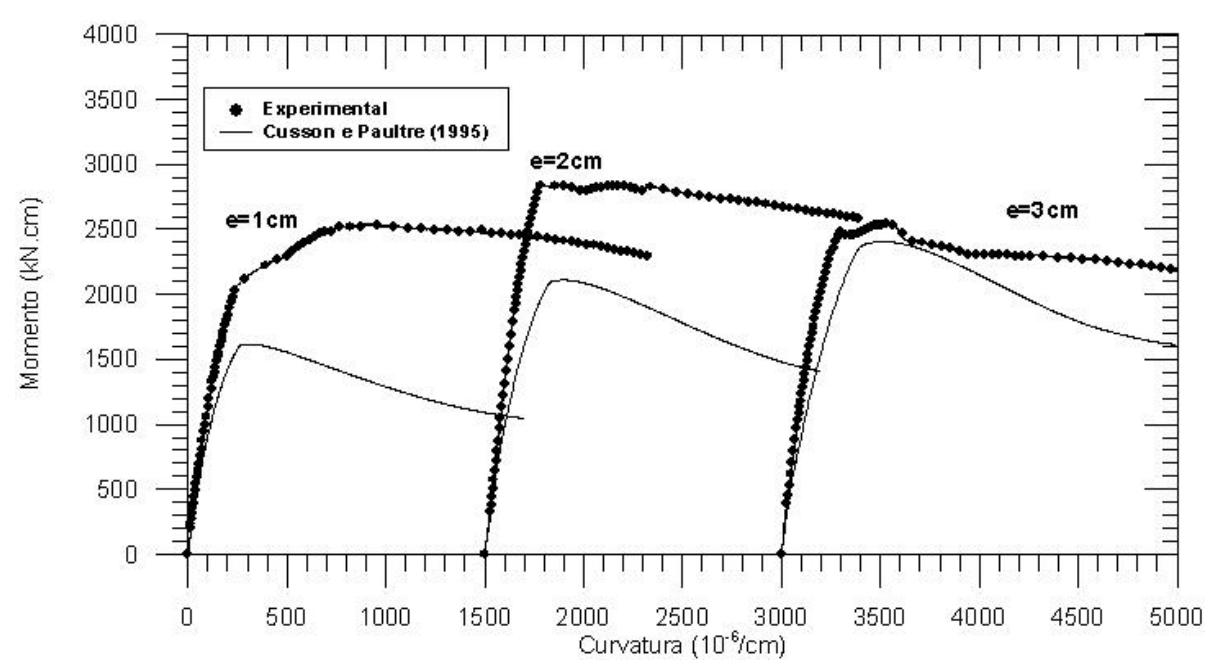

Figura 8.28 - Diagramas momento vs. curvatura dos pilares com $f_{c j}=60, s=5 \mathrm{~cm}$ e $V_{f}=0,5 \%$, e modelados pelo modelo de Cusson e Paultre (1995) 
Analisando os diagramas apresentados, observa-se que todos os modelos teóricos conseguiram predizer os trechos ascendentes dos diagramas momento vs. curvatura com boa precisão. Entretanto, observa-se que todos os modelos não conseguiram modelar o comportamento descendente dos diagramas de modo satisfatório, verificando-se grandes discrepâncias para alguns pilares.

Na modelagem dos trechos descendentes dos diagramas, constata-se que o modelo do FIB (1999) apresentou melhores resultados para os pilares com espaçamento entre estribos de $15 \mathrm{~cm}$ e sem adição de fibras. Isto pode ser explicado, uma vez que, esse modelo não leva em consideração nem a taxa de adição de fibras nem o confinamento por meio da armadura transversal.

O modelo proposto para o CRFA também apresentou melhores resultados para os pilares com espaçamentos entre estribos de $15 \mathrm{~cm}$. Observa-se ainda, que esse modelo também apresentou bons resultados na modelarem dos pilares com $s=15 \mathrm{~cm}$ e $V_{f}=0,5 \%$. Esse modelo, por não considerar o confinamento por meio da armadura transversal, apresentou resultados não satisfatórios para os pilares com $s=5 \mathrm{~cm}$.

O modelo de Cusson e Paultre (1995) apresentou grandes discrepâncias para quase todos os pilares. Observa-se ainda, que mesmo no trecho ascendente dos diagramas observam-se divergências. Essas diferenças foram intensificadas pela consideração da seção transversal resistente como sendo apenas a região do núcleo do pilar.

\subsubsection{Avaliação da ductilidade dos pilares}

Para a avaliação da variação da ductilidade dos pilares submetidos à compressão excêntrica foram utilizados além dos pilares ensaiados na segunda fase do programa experimental, os pilares da primeira fase. Contudo, observa-se que os pilares da primeira fase apresentavam $50 \mathrm{~cm}$ de altura e os da segunda $170 \mathrm{~cm}$. Essa diferença de altura gera diagramas força vs. deslocamento diferentes para os dois pilares. Desse modo, para comparar os diagramas dos pilares em 
questão, são necessárias algumas modificações nos diagramas força vs. deslocamento dos pilares de $50 \mathrm{~cm}$, para levar em consideração o efeito escala.

Considerando pilares com as mesmas características físicas e mesma seção transversal, porém com alturas diferentes, observa-se que durante todo o trecho ascendente do diagrama força vs. deslocamento, o gradiente de tensão ao longo de toda a altura dos pilares é praticamente nulo. Com isso, independente da altura dos pilares, as deformações são iguais e constantes em todas as seções transversais e em todos os pilares, para uma dada força de compressão. Este fato faz com que a variação do trecho ascendente dos diagrama força vs. deslocamento entre pilares com altura diferentes seja proporcional a esta dimensão. Assim, tomando-se dois pilares, um com $50 \mathrm{~cm}$ de altura e outro com $100 \mathrm{~cm}$, o deslocamento do primeiro pilar será a metade do deslocamento do segundo pilar, para uma mesma força no trecho ascendente do diagrama força vs. deslocamento.

No instante em que é atingida a força máxima no diagrama força vs. deslocamento, observa-se a formação de um plano de cisalhamento em uma região qualquer ao longo da altura do pilar. Esse plano de cisalhamento sempre é perpendicular à menor dimensão do pilar e é função da resistência do concreto e das taxas de armadura transversal e longitudinal e da geometria do pilar (Câmara et alii, 2003 e Cusson et alii, 1996). A partir do instante em que é atingida a força máxima, a capacidade resistente do pilar é reduzida e, com isto, ocorre um alívio nas tensões em todas as outras seções transversais que estejam fora da região de formação do plano cisalhante. Assim, independente da altura do pilar, a partir deste ponto, todo o incremento de deslocamento concentra-se praticamente na região de formação do plano de cisalhamento (Van Mier e Vonk, 1991). Essa concentração de deformação faz com que pilares de maior altura apresentem menores índices de ductilidade, quando esses índices são avaliados por meio dos diagramas tensão vs. deformação, e as deformação são avaliadas considerando-se toda a altura dos pilares. Esse fenômeno pode ser evidenciado na Figura 8.29, na qual são comparados os diagramas força vs. deformação de pilares com alturas diferentes e mesmas características físicas e seções transversais. 

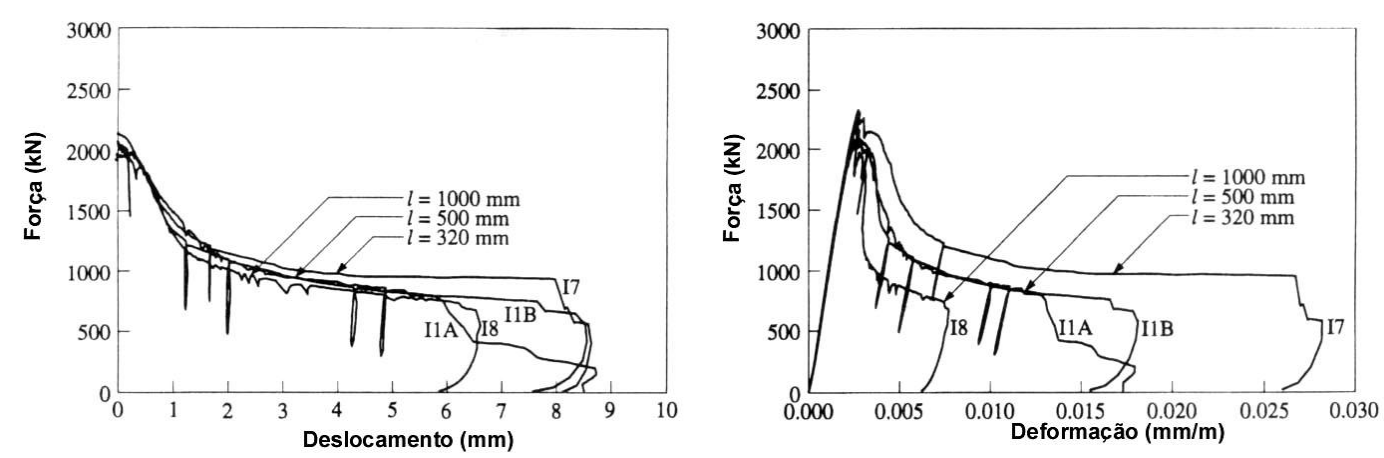

Figura 8.29 - Diagramas força vs. deformação de pilares com alturas diferente (Cusson et alii, 1996)

Com base no exposto, para transformar os diagramas força vs. deslocamento dos pilares de $50 \mathrm{~cm}$ de altura, para diagramas aproximados de pilares de $170 \mathrm{~cm}$ de altura, pode-se utilizar o seguinte procedimento: trecho ascendente - multiplica-se os deslocamentos dos pilares de $50 \mathrm{~cm}$ por 5 ; trecho descendente - o incremento de deslocamento é igual ao deslocamento do pilar de $50 \mathrm{~cm}$ menos o deslocamento elástico do pilar, não considerando a região de formação do plano de cisalhamento. Para o cálculo dos diagramas dos pilares com adição de fibras de aço, considerou-se que as fibras não alteram a inclinação do plano de cisalhamento.

Da Figura 8.30 a Figura 8.33 apresentam-se os diagramas força vs. deslocamento dos pilares ensaiados com excentricidades de força de $0 \mathrm{~cm}, 1 \mathrm{~cm}$, $2 \mathrm{~cm}$ e $3 \mathrm{~cm}$; e nas Tabela 8.10 e Tabela 8.11 apresentam-se os índices de ductilidade $I D_{\text {pós e }} \mathcal{E}_{0.5 f c c} / \mathcal{E}_{c c}$, respectivamente, calculados a partir desses diagramas. 


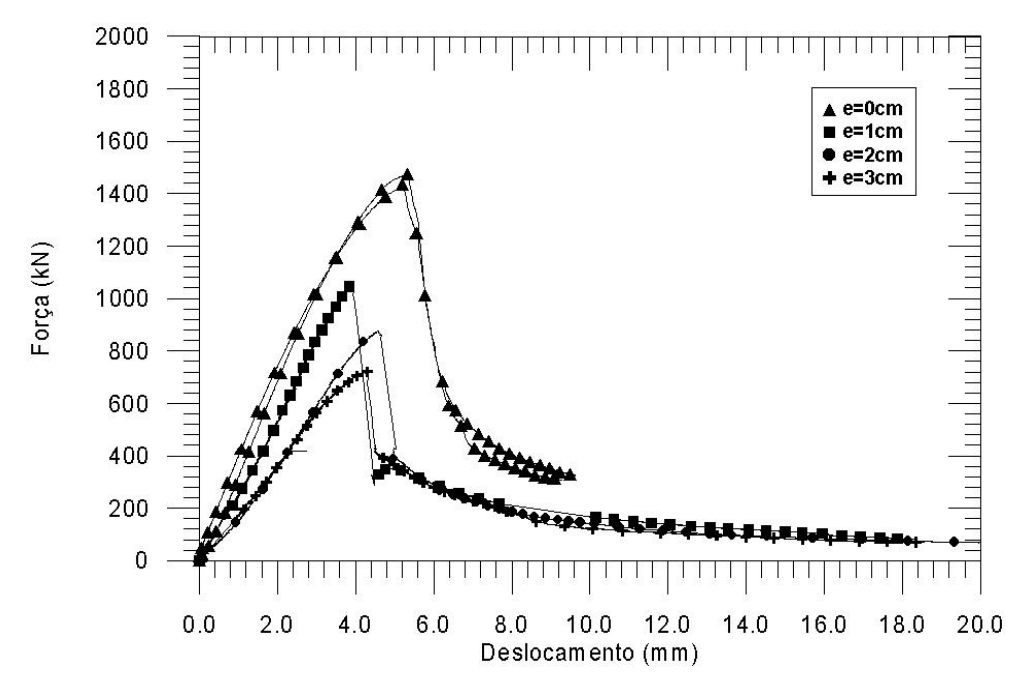

Figura 8.30 - Diagramas força vs. deslocamento longitudinal dos pilares com concretos $f_{c j}=60, V_{f}=0,0 \%$, e $s=15 \mathrm{~cm}$

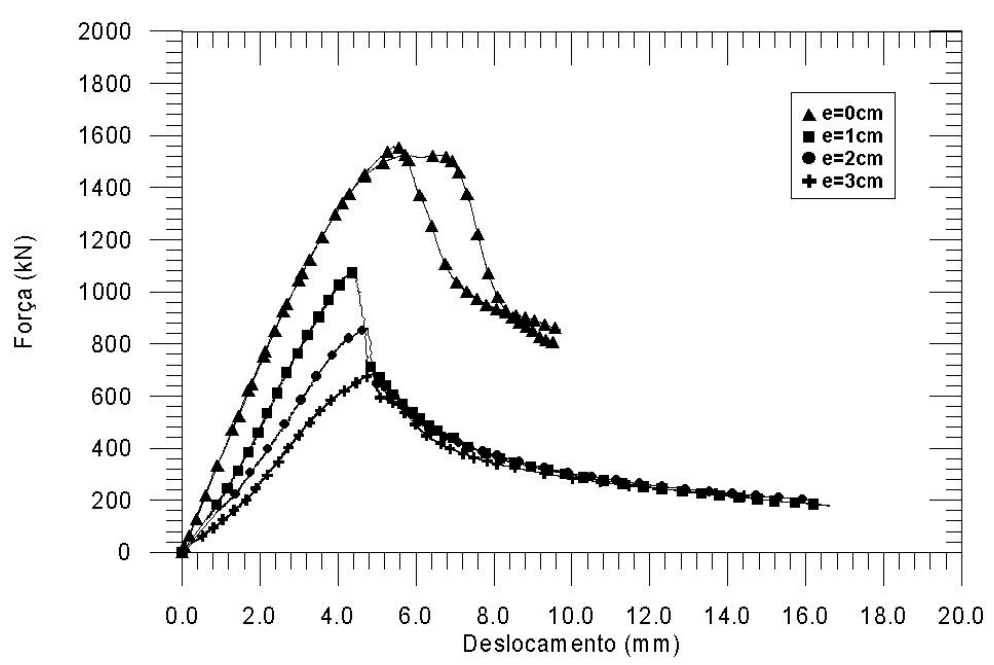

Figura 8.31 - Diagramas força vs. deslocamento longitudinal dos pilares com concretos $f_{c j}=60, V_{f}=0,0 \%$, e $s=5 \mathrm{~cm}$

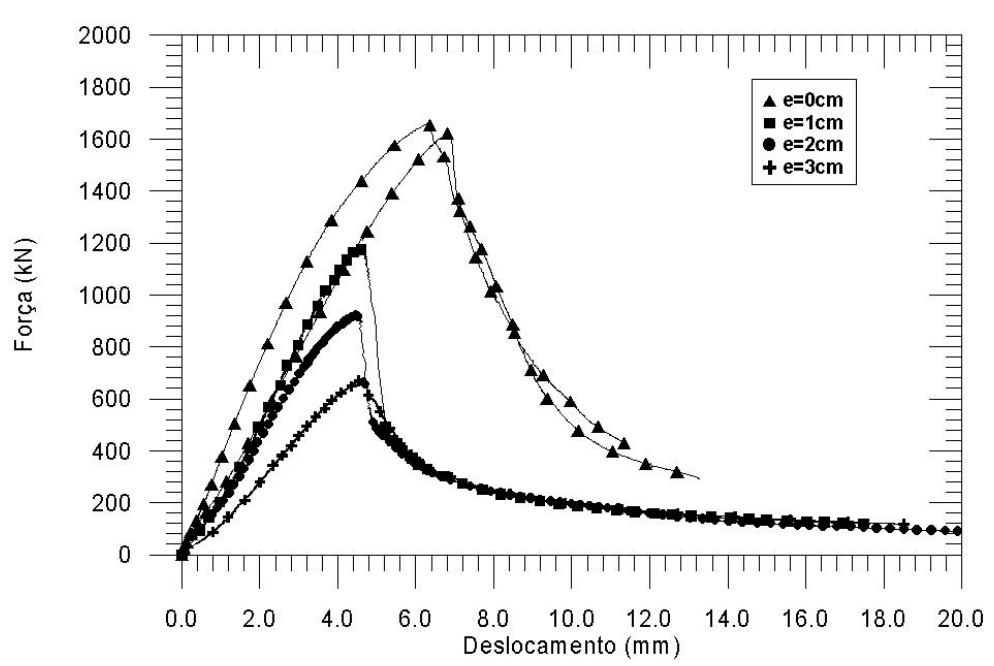

Figura 8.32 - Diagramas força vs. deslocamento longitudinal dos pilares com concretos $f_{c j}=60, V_{f}=0,5 \%$, e $s=15 \mathrm{~cm}$ 


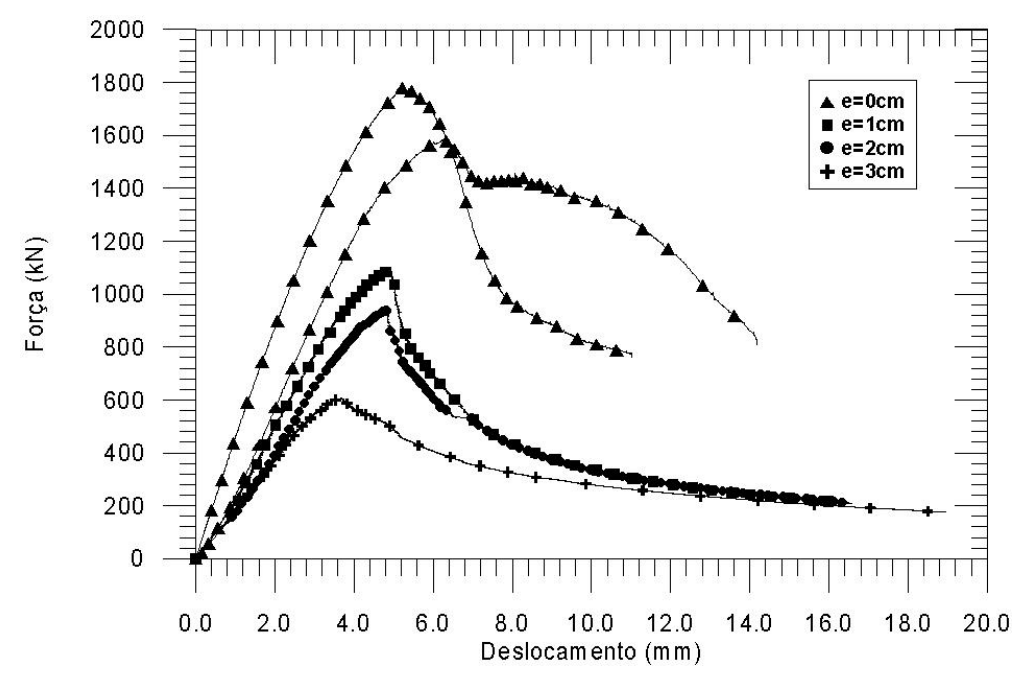

Figura 8.33 - Diagramas força vs. deslocamento longitudinal dos pilares com concretos $f_{c j}=60, V_{f}=0,5 \%$, e $s=5 \mathrm{~cm}$

Tabela 8.10- Valores dos índices de ductilidade $I D_{\text {pos }}$ para os pilares

\begin{tabular}{ccccccccc}
\hline Taxa de & \multicolumn{7}{c}{ Espaçamento entre estribos $s(\mathrm{~cm})\left(X_{2}\right)$} \\
\cline { 2 - 9 } adição de & \multicolumn{7}{c}{15} \\
fibra $V_{f}$ & \multicolumn{7}{c}{5} \\
\cline { 2 - 9 }$(\%)\left(X_{1}\right)$ & 0 & 1 & 2 & 3 & 0 & 1 & 2 & 3 \\
\hline 0 & 0,696 & 0,712 & 0,844 & 0,953 & 0,435 & 0,497 & 0,448 & 0,544 \\
0,5 & 0,804 & 0,772 & 0,862 & 1,233 & 0,504 & 0,524 & 0,565 & 0,745 \\
\hline
\end{tabular}

Tabela 8.11- Valores dos índices de ductilidade $\boldsymbol{\varepsilon}_{0.5 f c d} \boldsymbol{\varepsilon}_{c c}$ para os pilares

\begin{tabular}{ccccccccc}
\hline Taxa de & \multicolumn{7}{c}{ Espaçamento entre estribos $(\mathrm{cm})\left(X_{2}\right)$} \\
\cline { 2 - 9 } adiça o de & \multicolumn{7}{c}{15} \\
fibra $V_{f}$ & \multicolumn{7}{c}{ Excentricidade $(\mathrm{cm})\left(X_{3}\right)$} \\
$(\%)\left(X_{1}\right)$ & 0 & 1 & 2 & 3 & 0 & 1 & 2 & 3 \\
\hline 0 & 1,679 & 1,315 & 1,485 & 1,630 & 1,168 & 1,102 & 1,09 & 1,173 \\
0,5 & 2,002 & 1,420 & 1,564 & 2,379 & 1,317 & 1,124 & 1,152 & 1,341 \\
\hline
\end{tabular}

Os pilares com concreto com resistência à compressão de $40 \mathrm{MPa}$ e ensaiados com excentricidades de força de $1 \mathrm{~cm}, 2 \mathrm{~cm}$ e $3 \mathrm{~cm}$, apresentaram índices de ductilidade médios, $I D_{p o s}$ e $\varepsilon_{0.5 f c c} \mathcal{E}_{c c}$, iguais a $0,43,0,62$ e 0,77 ; e, $1,14,1,24$ e 1,54 , respectivamente. 
Analisando os diagramas apresentados e os dados mostrados nas Tabela 8.10 e Tabela 8.11, observa-se que realmente é possível melhorar o comportamento pós-pico dos pilares por meio de adição de fibras e maiores taxas de armadura transversal, de modo que esses elementos atinjam a ductilidade mínima dos pilares de referência.

Para verificar a influência da taxa de adição de fibra (fator $X_{1}$ ), do espaçamento entre estribos (fato $X_{2}$ ) e da excentricidade de força (fator $X_{3}$ ), foi realizada uma análise de variância sobre os dados. Os graus de significância do efeito de cada fator foram testados para graus de confiabilidade de $95 \%$ e $99 \%$, usando-se o $F$ teste. Na Tabela 8.12 e na Tabela 8.13, apresentam-se os resultados da análise de variância realizada.

Analisando os resultados obtidos com o índice de ductilidade $I D_{\text {pós }}$, verifica-se que os três fatores estudados influenciam a ductilidade dos pilares para graus de confiabilidade de $99 \%$. Ainda, que o fator mais influente é a taxa de armadura transversal, seguido pela excentricidade da força e pela taxa de adição de fibras. Esses dois últimos fatores têm praticamente a mesma influência. Constata-se ainda, que, também para os pilares submetidos a flexo-compressão, o aumento da taxa de armadura transversal é mais eficiente que a adição de fibras metálicas. Seguindo o mesmo comportamento encontrado para os pilares submetidos à compressão centrada, não se constatou influencia significativa do acoplamento entre a taxa de adição de fibras e a taxa de armadura transversal para graus de confiabilidade de 99\%. Entretanto, observa-se que os acoplamentos entre a excentricidade e a taxa de adição de fibras e entre a excentricidade e a taxa de armadura transversal são significantes para graus de confiabilidade de $95 \%$ e $99 \%$, respectivamente.

Avaliando os resultados obtidos com o índice de ductilidade, $\varepsilon_{0.5 f c d} \varepsilon_{c c}$, observa-se que todos os três fatores estudados influenciam a ductilidade dos pilares para graus de confiabilidade de $99 \%$. O fator mais importante é a taxa de armadura transversal, seguido pela taxa de adição de fibras e pela excentricidade da força. Observa-se, ainda, que por este índice nenhum acoplamento é significante para graus de confiabilidade de $99 \%$. 
Tabela 8.12 - Análise de variância para os valores de $I D_{\text {pos }}$

\begin{tabular}{lccccc}
\hline Variável & $\begin{array}{c}\text { Soma dos } \\
\text { quadrados }\end{array}$ & $\begin{array}{c}\text { Graus de } \\
\text { liberdade }\end{array}$ & $\begin{array}{c}\text { Média dos } \\
\text { quadrados }\end{array}$ & $\begin{array}{c}\text { Fator } \\
\left(F_{0}\right)\end{array}$ & $\begin{array}{c}\text { Mínimo fator de significância } \\
\text { requerido }\left(F_{0.05, n, 15}\right) \text { e }\left(F_{0.01, n, 15}\right)\end{array}$ \\
\hline $\begin{array}{c}\text { Fatores } \\
\text { principais }\end{array}$ & & & & & \\
$X_{1}$ & 0,048400 & 1 & 0,0484 & 32,310 & $4,54-8,68$ \\
$X_{2}$ & 0,427062 & 1 & 0,4271 & 285,088 & $4,54-8,68$ \\
$X_{3}$ & 0,169643 & 3 & 0,0565 & 37,749 & $3,29-5,42$ \\
Interações & & & & & \\
$X_{1} \times X_{2}$ & 0,000169 & 1 & 0,0002 & 0,113 & $4,54-8,68$ \\
$X_{1} \times X_{3}$ & 0,023721 & 3 & 0,0079 & 5,278 & $3,29-5,42$ \\
$X_{2} \times X_{3}$ & 0,026425 & 3 & 0,0088 & 5,88 & $3,29-5,42$ \\
Erro & 0,004494 & 3 & 0,0015 & - & - \\
Total & 0,699914 & 15 & - & - & - \\
\hline
\end{tabular}

Tabela 8.13 - Análise de variância para os valores de $\boldsymbol{\varepsilon}_{0.5 f c c} / \boldsymbol{\varepsilon}_{c c}$

\begin{tabular}{lccccc}
\hline Variável & $\begin{array}{c}\text { Soma dos } \\
\text { quadrados }\end{array}$ & $\begin{array}{c}\text { Graus de } \\
\text { liberdade }\end{array}$ & $\begin{array}{c}\text { Média dos } \\
\text { quadrados }\end{array}$ & $\begin{array}{c}\text { Fator } \\
\left(F_{o}\right)\end{array}$ & $\begin{array}{c}\text { Mínimo fator de significância } \\
\text { requerido }\left(F_{0.05, n, 23}\right) \text { e }\left(F_{0.01, n, 23}\right)\end{array}$ \\
\hline $\begin{array}{c}\text { Fatores } \\
\text { principais }\end{array}$ & & & & & \\
$X_{1}$ & 0,171603 & 1 & 0,1716 & 10,711 & $4,54-8,68$ \\
$X_{2}$ & 1,003503 & 1 & 1,0035 & 62,635 & $4,54-8,68$ \\
$X_{3}$ & 0,400729 & 3 & 0,1336 & 8,337 & $3,29-5,42$ \\
Interações & & & & & \\
$X_{1} \times X_{2}$ & 0,045689 & 1 & 0,0456 & 2,852 & $4,54-8,68$ \\
$X_{1} \times X_{3}$ & 0,103318 & 3 & 0,0344 & 2,150 & $3,29-5,42$ \\
$X_{2} \times X_{3}$ & 0,140440 & 3 & 0,0468 & 2,922 & $3,29-5,42$ \\
Erro & 0,048065 & 3 & 0,0160 & - & - \\
Total & 1,913346 & 15 & - & - & - \\
\hline
\end{tabular}

\subsection{EFEITO DA FLEXÃO NO CONFINAMENTO DO CONCRETO}

Com base no estudo experimental de pilares submetidos à flexocompressão, aqui realizado, pode-se afirmar que alguns ramos dos estribos que compõe a armadura transversal não atingem a deformação de escoamento do aço, mesmo em pilares submetidos à pequenas excentricidade de força. Deste modo, é possível assumir que o ramo do estribo paralelo à face mais comprimida do pilar sempre atinge o escoamento, e que a deformação no ramo do estribo paralelo à face menos comprimida é nula. Já os ramos paralelos ao plano de flexão, na maioria dos casos, as deformações atingem ou são próximas da deformação de escoamento do aço. Com base nessas hipóteses, a distribuição de força na 
armadura transversal do pilar pode ser representada esquematicamente na Figura 8.34 .

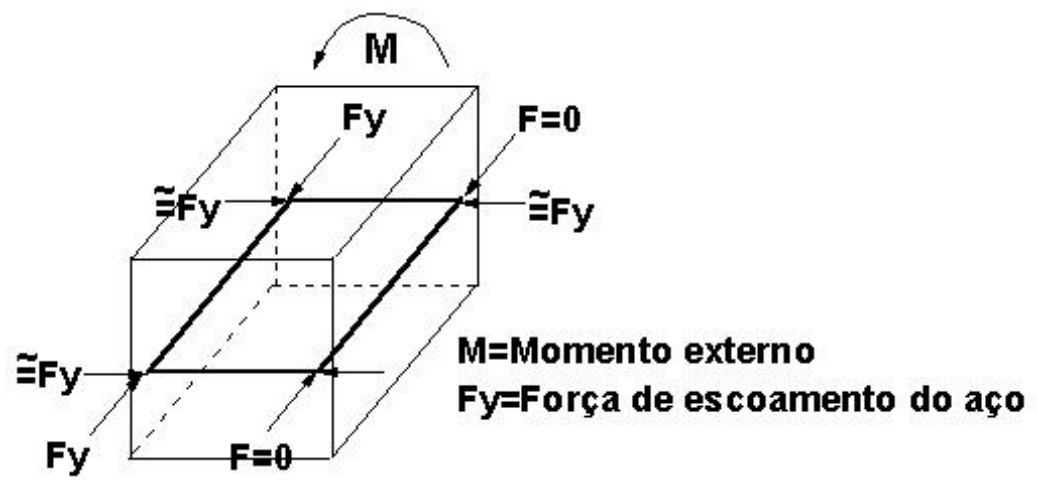

Figura 8.34 - Hipótese da distribuição de forças na armadura transversal

Com o objetivo de verificar qual é a forma da distribuição das tensões de confinamento no concreto para a distribuição de força na armadura transversal apresentada na Figura 8.34, realizou-se uma análise elástico-linear, por meio do Método dos Elementos Finitos. Para tanto, consideraram-se dois blocos de concreto entre dois estribos consecutivos, com as dimensões do núcleo central dos pilares estudados, isto é, $12,37 \mathrm{~cm} \times 12,37 \mathrm{~cm} \times 15 \mathrm{~cm}$ e $12,37 \mathrm{~cm} \times 12,37 \mathrm{~cm} \times 5 \mathrm{~cm}$. O módulo de elasticidade do concreto foi tomado como sendo $20 \mathrm{GPa}$ e o coeficiente de Poisson 0,4. Apenas as forças na armadura transversal foram consideradas na modelagem. Foram utilizados elementos finitos tetraédricos com 13 nós e 3 graus de liberdade por nó. Na Figura 8.35, apresentam-se o elemento finito e as discretizações utilizadas. 

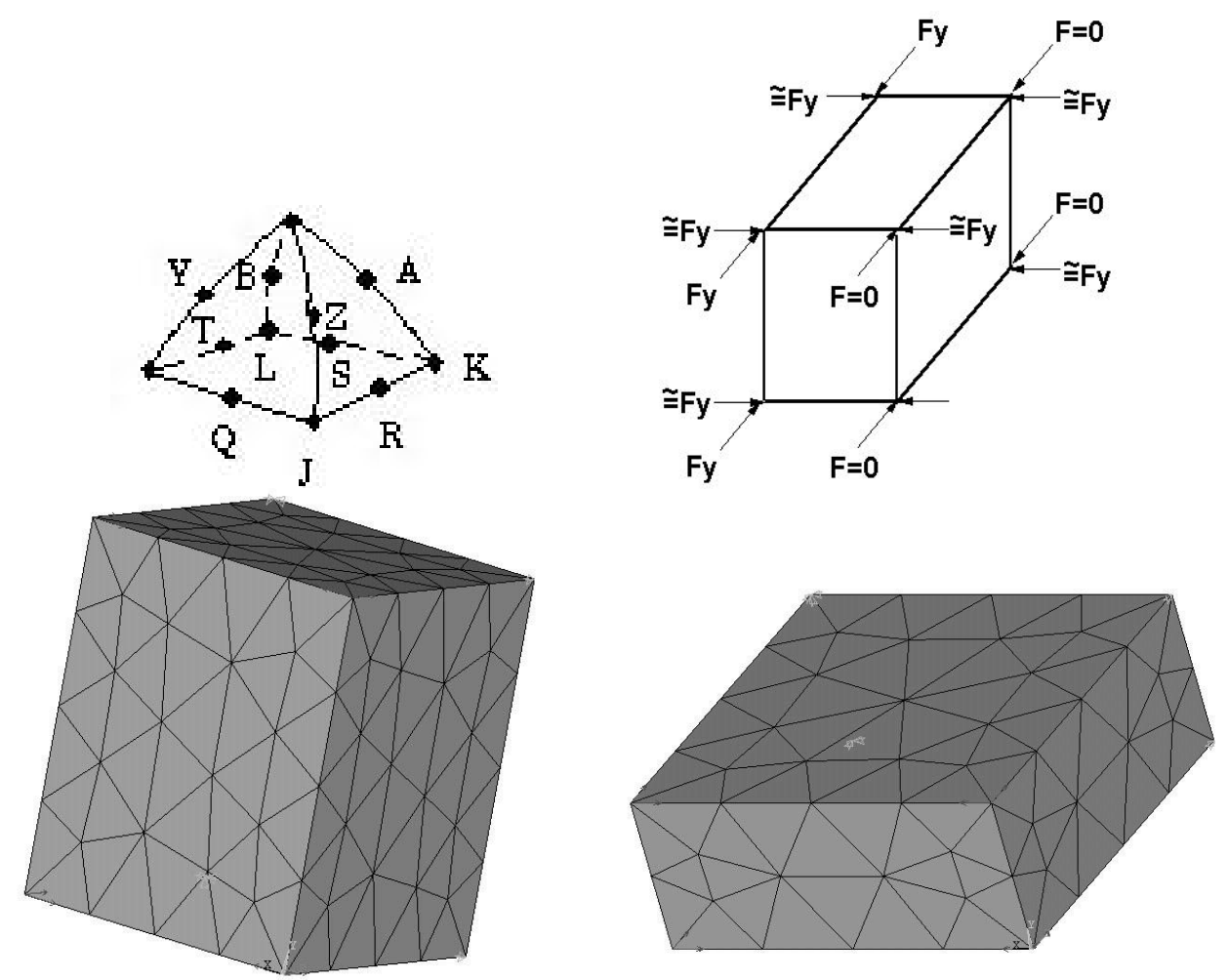

Figura 8.35 - Elemento finito e discretização utilizados no estudo da distribuição das tensões de confinamento nos pilares ensaiados a flexo-compressão

Na Figura 8.36 e na Figura 8.37, apresentam-se as distribuições das tensões de confinamento nas direções $x, y$ e $z$, para os pilares com espaçamento entre estribos de $15 \mathrm{~cm}$ e $5 \mathrm{~cm}$, respectivamente.

Analisando esses diagramas, observa-se que, na face menos comprimida, as tensões de confinamento são de tração e, na face mais comprimida as tensões se distribuem de forma mais uniforme e semelhantemente à distribuição observada nos pilares submetidos à compressão centrada. Já na face paralela ao plano de flexão, observa-se que as tensões de confinamento têm maiores intensidades nas proximidades da face mais comprimida do pilar. Esse comportamento faz com que a área da seção transversal de concreto efetivamente confinada, que se localiza na região média entre dois estribos consecutivos, seja reduzida praticamente pela metade, quando comparada com a situação em que todos os ramos dos estribos são solicitados uniformemente (ver Figura 8.38). Apesar disto, observa-se que a 
área efetivamente confinada localizada na região comprimida da seção transversal praticamente não é alterada.

Com base na Figura 8.38 e assumindo que a variação das pressões laterais ao longo da seção transversal pode ser considerada linear (Saatacioglu et alii, 1995), pode-se assumir que a pressão lateral de confinamento na região comprimida da seção transversal do pilar fica praticamente inalterada (ver Figura 8.38).

Dois outros fatos que merecem ser mencionados é que, primeiramente taxas maiores de armadura transversal impedem o desprendimento de grandes massas de concreto do núcleo do pilar, o que retarda a formação da rótula plástica. Esse efeito se torna ainda mais interessante nos pilares submetidos à flexocompressão, uma vez que o desprendimento de massas de concreto é muito mais crítico. O segundo ponto positivo dessa armadura adicional é que ela também retarda a flambagem das barras da armadura longitudinal nos pilares submetidos à flexo-compressão. Observa-se nesses pilares que as deformações nas barras comprimidas da armadura longitudinal atingem a deformação de escoamento do aço bem antes de ser atingida a força máxima. Esse fato faz com que essas barras fiquem sujeitas à flambem de modo bem mais prematuro.

Com base no estudo apresentado acima, utilizou-se o modelo modificado de Cusson e Paultre (1995) para modelar os pilares ensaiados à compressão excêntrica, sendo utilizado os procedimentos de modelagem sugeridos. Da Figura 8.39 e Figura 8.42, apresentam-se os diagramas os pilares ensaiados à compressão excêntrica experimentais e teóricos. Observa-se que o modelo modificado apresentou desempenho bastante satisfatório. 

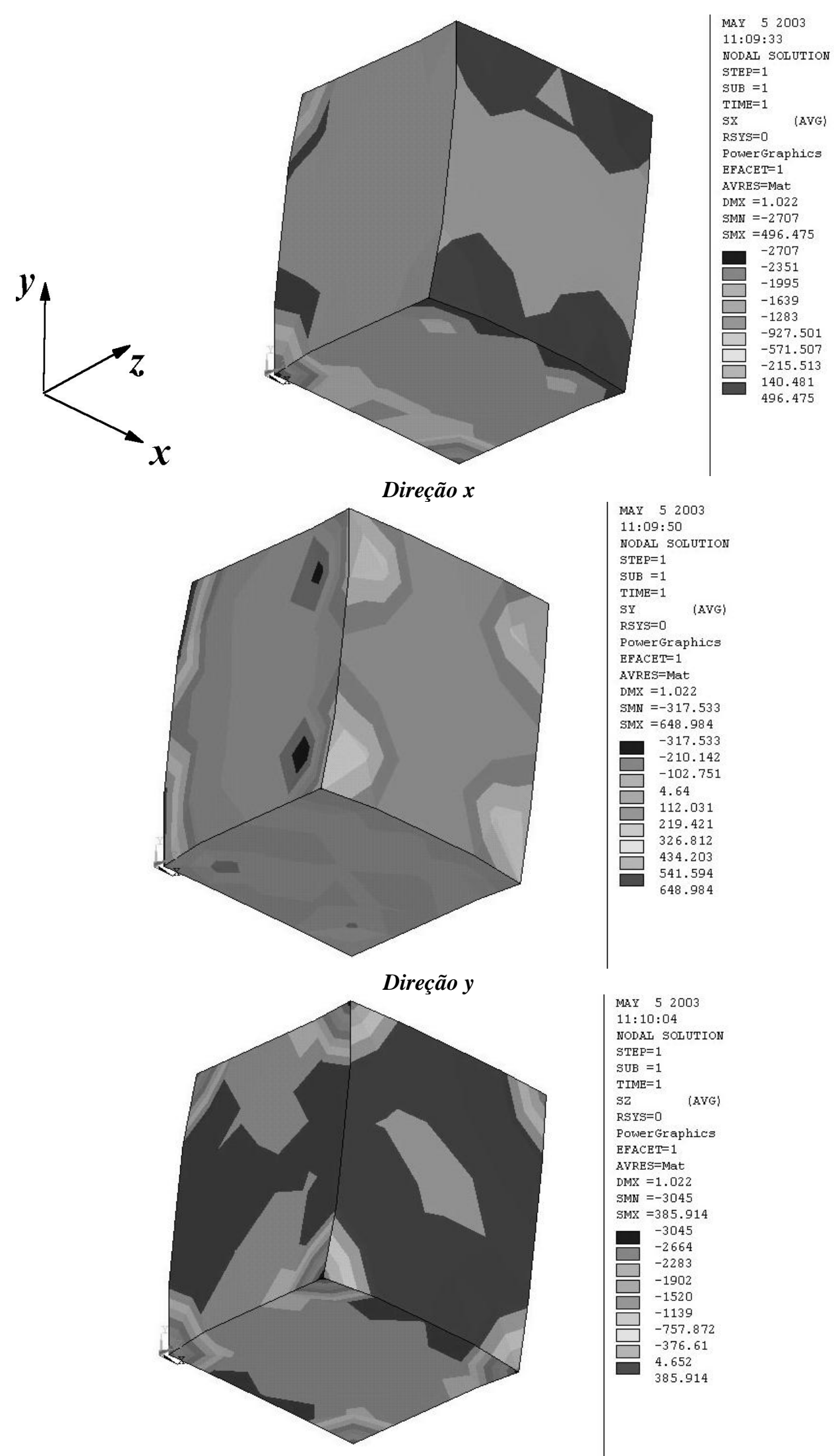

MAY 52003

$11: 10: 04$

NODAL SOLUTION

STEP $=1$
SUB $=1$

TIME $=1$

$\mathrm{SZ}$

RSYS=0

(AVG)

PowerGraphics

EFACET $=1$

AVRES $=$ Mat

$\begin{aligned} \text { DMX } & =1.022 \\ \text { SMN } & =-3045\end{aligned}$

SMX $=385.91$

-3045
-2664

-2664
-2283
-1902

-1520
-1139

-1139
-757.872
-376.61

4.652
385.91

Direção $z$

Figura 8.36 - Distribuições das tensões nas direções $x$, y e $z$, na face menos comprimida dos pilares com espaçamento entre estribos de $15 \mathrm{~cm}$ 

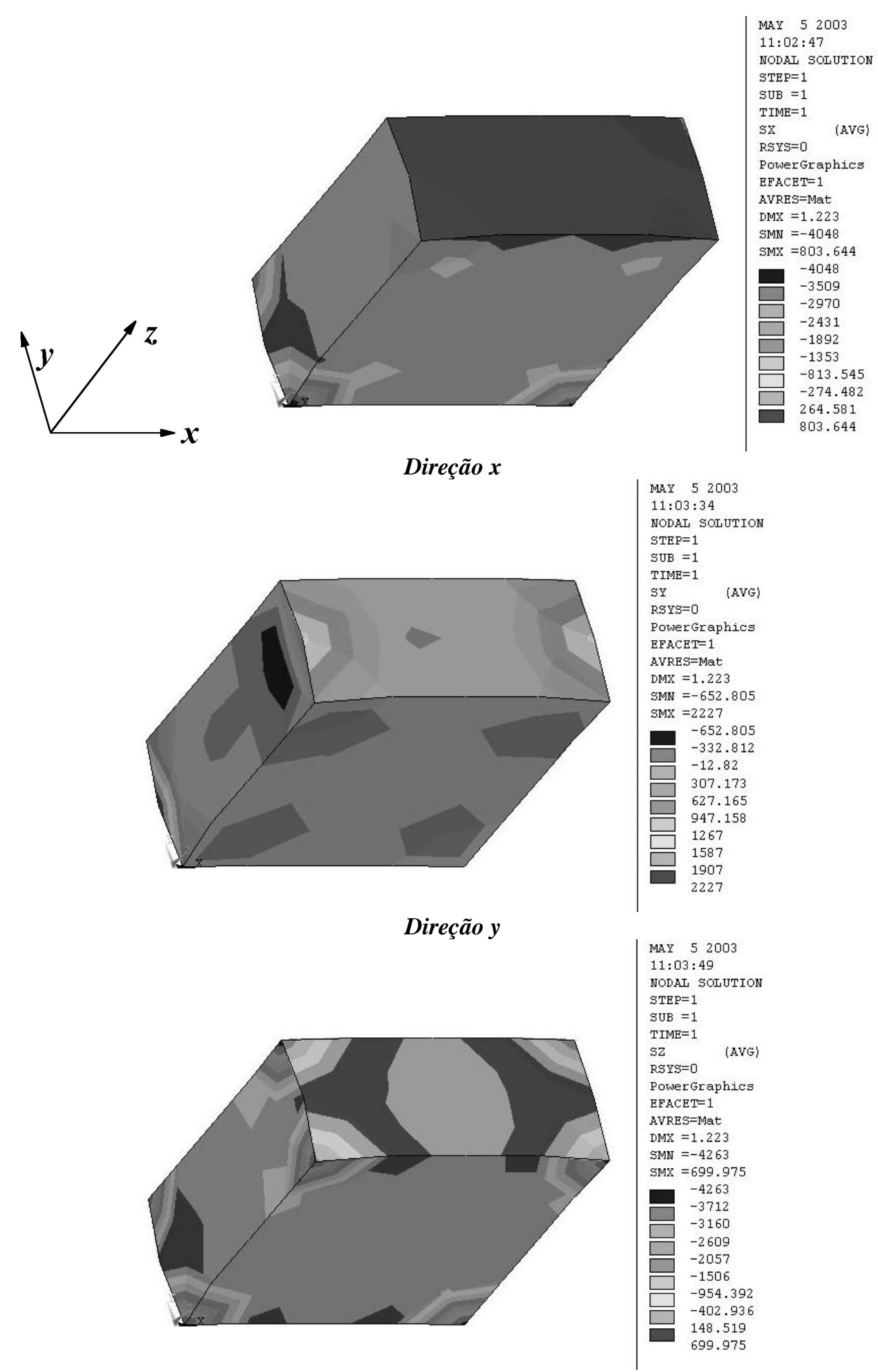

Direção $z$

Figura 8.37 - Distribuições das tensões nas direções $x$, y e $z$, na face menos comprimida dos pilares com espaçamento entre estribos de $5 \mathrm{~cm}$ 

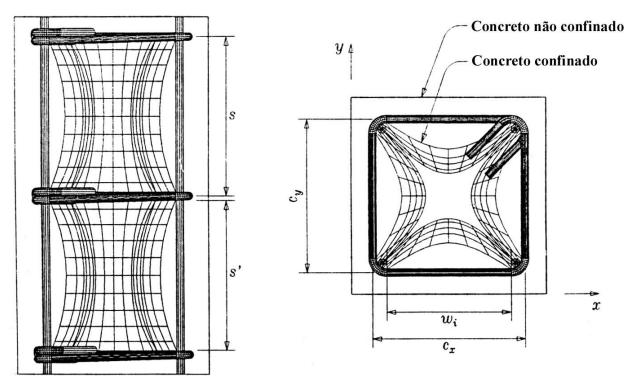

Compressão centrada

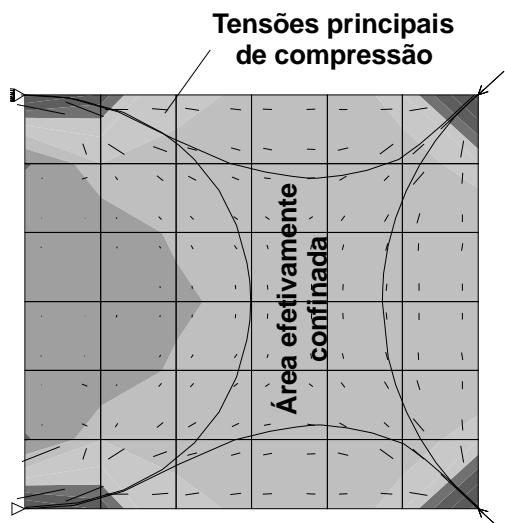

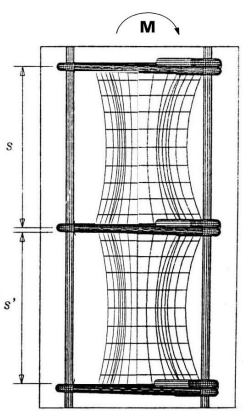

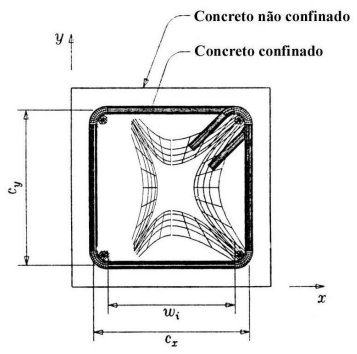

Compressão excêntrica

\section{Compressão excêntrica}

Figura 8.38 - Distribuição da pressão lateral promovida pela armadura de confinamento para pilares submetidos à compressão excêntrica e centrada (parte dessa figura foi adaptada de Cusson e Paultre, 1995)

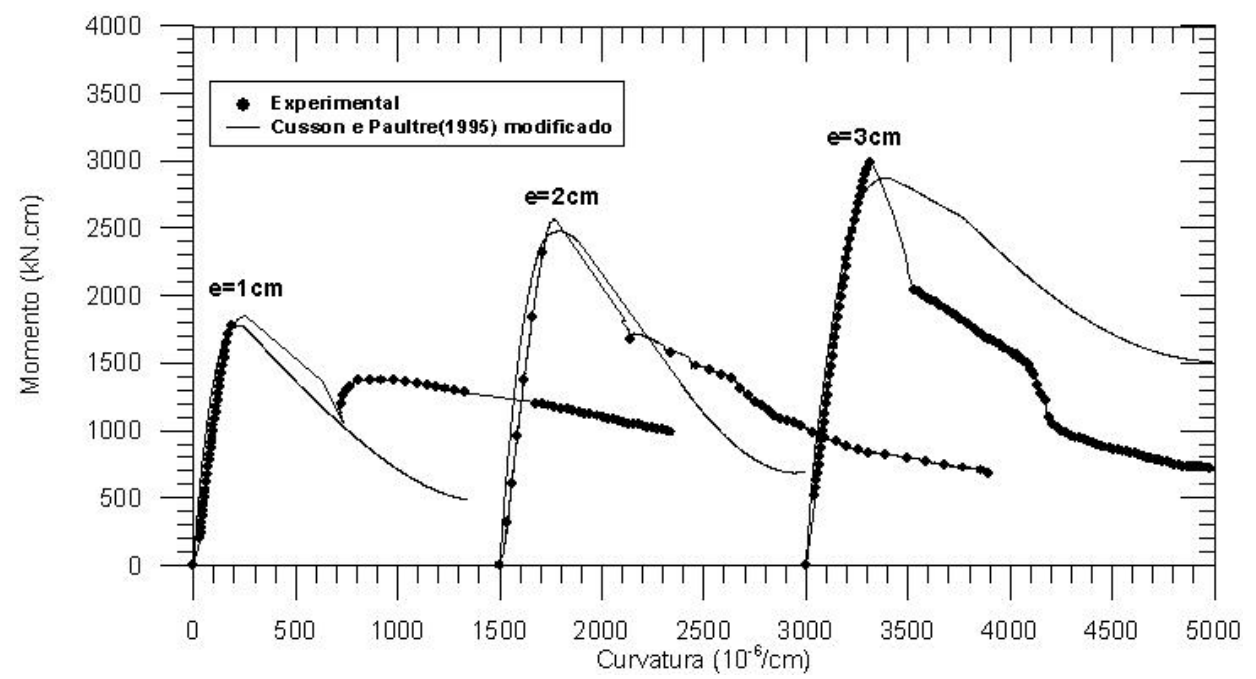

Figura 8.39 - Diagramas momento vs. curvatura dos pilares com $f_{c j}=60, \mathrm{~s}=15 \mathrm{~cm}$ e $V_{f}=0 \%$, e modelados pelo modelo modificado de Cusson e Paultre (1995) 


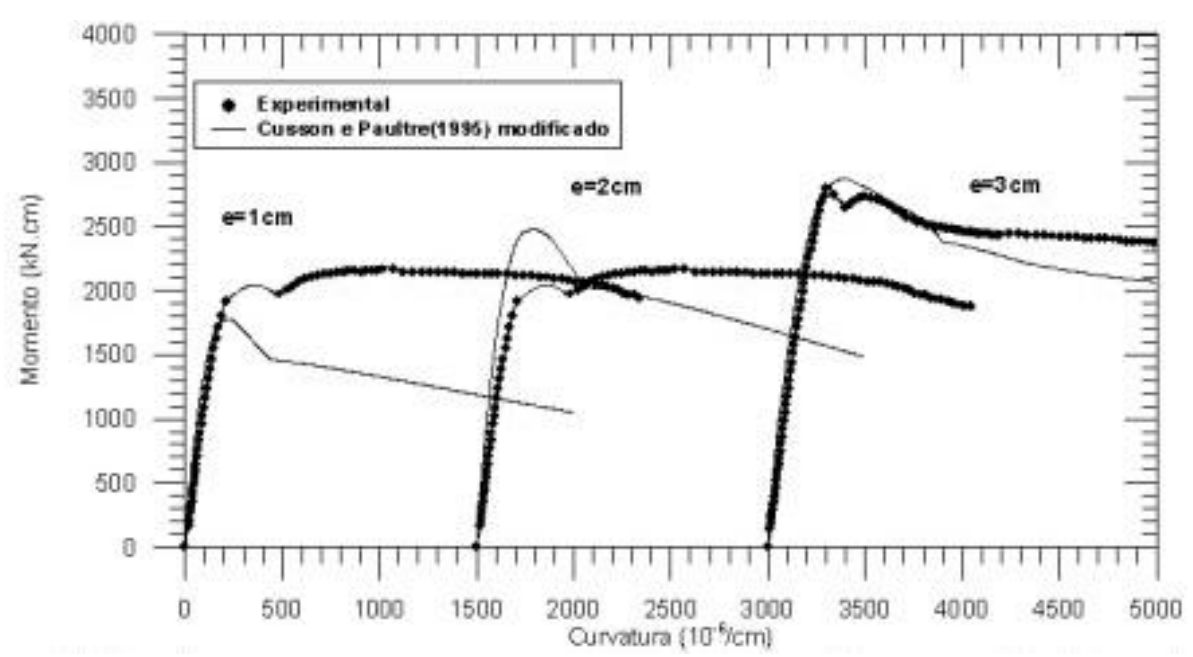

Figura 8.40 - Diagramas momento vs. curvatura dos pilares com $f_{c j}=60, s=5 \mathrm{~cm}$ e $V_{f}=0 \%$, e modelados pelo modelo modificado de Cusson e Paultre (1995)

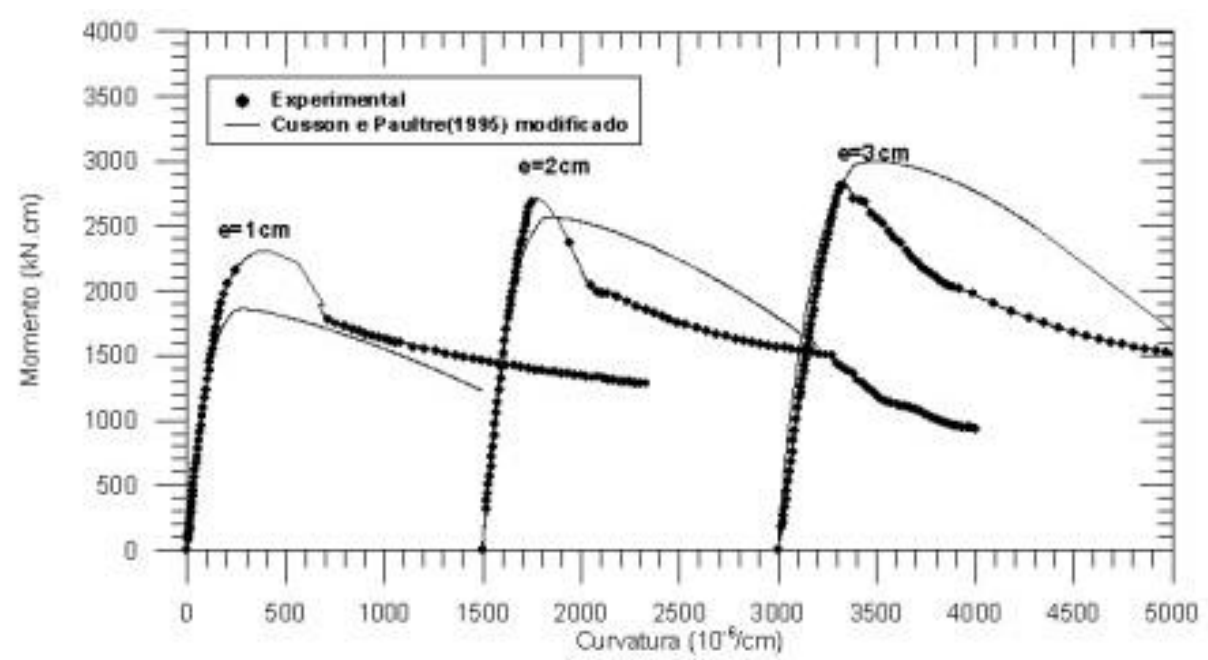

Figura 8.41 - Diagramas momento vs. curvatura dos pilares com $f_{c j}=60, s=15 \mathrm{~cm}$ e $V_{f}=0,5 \%$, e modelados pelo modelo modificado de Cusson e Paultre (1995)

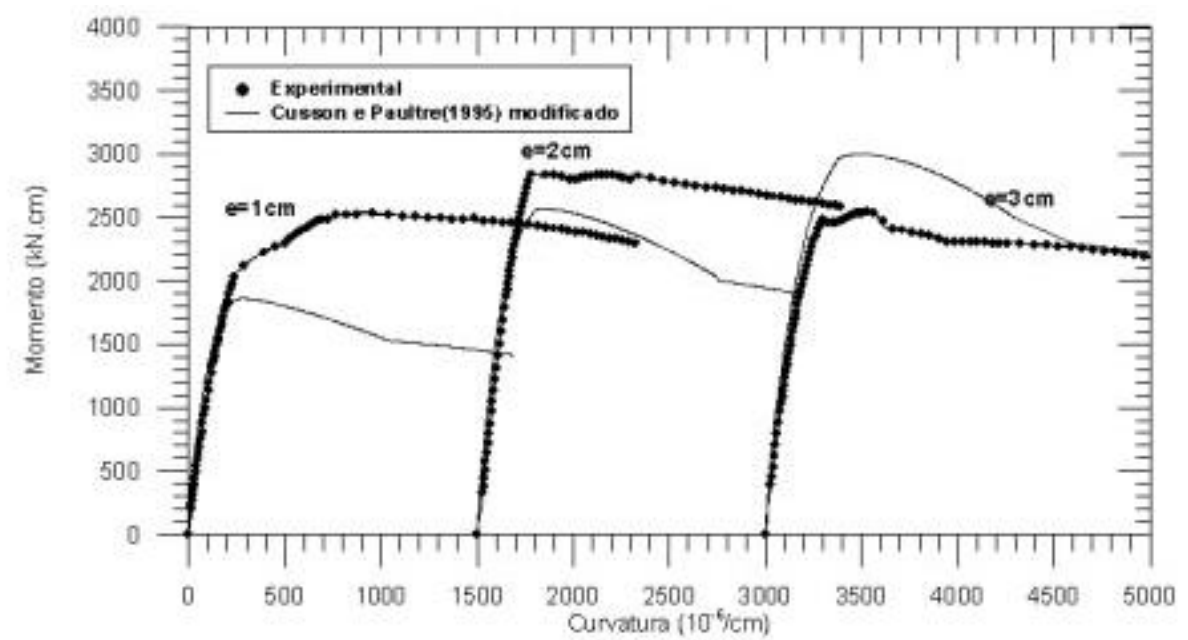

Figura 8.42 - Diagramas momento vs .curvatura dos pilares com $f_{c j}=60, s=5 \mathrm{~cm}$ e $V_{f}=0,5 \%$, e modelados pelo modelo modificado de Cusson e Paultre (1995) 


\subsection{CONCLUSÕES PARCIAIS}

A metodologia utilizada para realização dos ensaios submetidos à flexocompressão apresentou excelentes resultados. O sistema de apoio em faca permitiu a transferência de modo integral do momento aplicado à estrutura.

A flambagem das barras longitudinais nos pilares submetidos à flexocompressão ocorre de modo mais abrupto que nos pilares submetidos à compressão centrada.

Mesmo nos pilares com excentricidades de força que permaneciam dentro do núcleo central, observou-se inversão de sinal das deformações na face menos comprimida dos pilares, com a formação da rótula plástica.

Quanto à armadura transversal, verificou-se que apenas o ramo do estribo paralelo à face mais comprimida do pilar sempre atingiu o escoamento. A deformação do ramo paralelo à face menos comprimida aparentemente é função das posições das fissuras de tração. Nos pilares em que esse ramo atingiu o escoamento, a intensidade de força correspondente no trecho descendente do diagrama força vs. deformação da armadura transversal foi em média de $20 \%$ da força máxima resistida pelos pilares e as barras da armadura longitudinal, localizadas na face menos comprimida, encontram-se tracionadas. Finalmente, em $60 \%$ dos pilares ensaiados, observou-se o escoamento dos ramos dos estribos paralelo ao plano de flexão, para intensidades de força da ordem de $60 \%$ da força máxima no trecho descendente do diagrama força vs. deformação da armadura transversal.

Constatou-se que a redução da força resistente é uma função linear da excentricidade, e que excentricidades relativas de $10 \%$ e $20 \%$ implicaram em redução desta de aproximadamente $27 \%$ e $53 \%$, respectivamente. Os modelos do FIB (1999) e o proposto nesse trabalho para o CRFA conseguiram de modo bastante satisfatório predizer, tanto o momento fletor máximo, quanto a força máxima resistida pelos pilares. O modelo de Cusson e Paultre (1995) apresentou as maiores discrepâncias entre os valores teóricos e experimentais, uma vez que, se considerou na modelagem apenas á área da seção transversal do núcleo. Esses 
modelos também conseguiram modelar os trechos ascendentes dos diagramas momento vs. curvatura dos pilares com grande exatidão. Entretanto, não se observou de modo geral boa concordância para o trecho descendente dos diagramas.

Observou-se que os índices de ductilidade são influenciados, tanto pela geometria dos pilares, quanto pelo comprimento de avaliação das deformações. Pilares de maior altura apresentam menor índices de ductilidade.

Em conclusão, verificou-se que a excentricidade de força e seus acoplamentos com a taxa de armadura transversal e a taxa de adição de fibras influência na ductilidade dos pilares. $\mathrm{O}$ aumento da excentricidade de força tornou o comportamento pós-pico dos pilares mais dúctil. 


\section{CONCLUSÃO}

Esta tese investigou o comportamento pós-pico de pilares moldados com concreto armado de alta resistência com e sem adição de fibras e submetidos à flexo-compressão. Para tanto, realizou-se inicialmente um estudo paramétrico para verificar os principais fatores de influência nesse comportamento pós-pico e o modo de influência de cada fator. Em seguida, executou-se um extenso estudo experimental, no qual foram ensaiados 39 pilares de concreto armado e 12 pilares de concreto simples, divididos em duas fases. Na primeira fase, investigou-se o comportamento dos pilares com CAR submetidos à compressão centrada, avaliando-se a influência de três fatores: a taxa de adição de fibras de aço, a taxa de armadura transversal e a resistência do concreto. Na segunda fase, o comportamento dos pilares submetidos à flexo-compressão foi estudado, sendo também investigada a influência de três fatores: a excentricidade da força aplicada, a taxa de adição de fibras metálicas e a taxa de armadura transversal.

Com base nos estudos descritos, podem-se tecer as seguintes conclusões:

\section{1) Estudo paramétrico}

a) A partir do estudo paramétrico verificou-se que os fatores: resistência do concreto à compressão simples; taxa de armadura longitudinal; taxa de armadura transversal; geometria da seção transversal; índice de reforço da adição de fibras; e a excentricidade da força aplicada, influenciam no comportamento pós-pico dos pilares de concreto de alta resistência.

b) Os resultados desse estudo mostraram ainda que os índices de ductilidade variam linearmente com esses fatores e que apenas o 
acoplamento entre as resistências dos concretos e os índices de reforço da adição de fibras têm influência significativa.

c) Observou-se que os diagramas momento fletor reduzido vs. força normal reduzida são influenciados pelo confinamento da seção transversal. Esse fato dificulta a geração de ábacos de dimensionamento para esses elementos.

d) Observou-se, na Literatura atual, uma quantidade incipiente de trabalhos experimentais sobre pilares com CAR submetidos à flexocompressão. Ainda assim, observa-se que, nos poucos trabalhos existentes, os pesquisadores não apresentaram diagramas com o comportamento pós-pico desses elementos.

\section{2) Fase 1 do programa experimental}

a) Os diagramas tensão vs. deformação do concreto simples são altamente influenciados pela geometria dos corpos-de-prova, como também da geometria da estrutura de concreto. Ainda, verificou-se que não só a forma do diagrama, mas também a resistência do concreto é influenciada pela geometria dos corpos-de-prova e da estrutura.

b) $\mathrm{O}$ coeficiente $k_{2}$ é realmente influenciado pela resistência do concreto, pelas taxas de armadura presente no elemento estrutural e pela taxa de adição de fibras. A norma norueguesa NBR (1989) foi o código de dimensionamento para estruturas de concreto armado que aposentou valores mais realistas para $k_{2}$.

c) Fazem-se necessários mais estudos sobre os reais valores do coeficiente $k_{2}$, uma vez que não foi encontrado nenhuma investigação sobre o efeito das taxas de armadura do elemento estrutural e da taxa de adição de fibra nos valores desse coeficiente.

d) Mostrou-se que para o primeiro pico de carga dos pilares com CAR confinado, toda a seção transversal trabalha integralmente, mesmo para espaçamentos entre estribos de $5 \mathrm{~cm}$. Além disso, que a adição de fibras 
metálicas melhora o trabalho conjunto entre o cobrimento e núcleo dos pilares.

e) Verificou-se que, mesmo elevando o coeficiente de Poisson do compósito CRFA, a taxa de adição de fibras não aumenta os valores das deformações nas armaduras transversais correspondente à força axial máxima. Também foi verificado que para pilares com baixo índice de confinamento a armadura transversal só atinge o escoamento para deformações axiais médias da ordem de $6 \%$.

f) O modelo de Cusson e Paultre (1995) permitiu modelar os pilares aqui ensaiados apenas de modo razoável. Esse fato é explicável, uma vez que, para pilares com baixos índices de reforço, não é observado o segundo pico de força e que para o primeiro pico de força, toda a seção transversal resiste a esforços. Essa discrepância foi observada devido ao fato que se utilizou apenas a seção transversal do núcleo nas modelagens.

g) A avaliação da ductilidade dos pilares mostrou que é possível melhorar o comportamento pós-pico dos pilares por meio de adição de fibras metálicas. Índices de reforço da ordem de 0,48 são capazes de garantir aos pilares com concretos com $f_{c j}=60 \mathrm{MPa}$ a mesma ductilidade dos pilares $\operatorname{com} f_{c j}=40 \mathrm{MPa}$, e índices de reforço da ordem de 0,86 aos pilares $\operatorname{com} f_{c j}=80 \mathrm{MPa}$.

h)Com base nos estudos realizados nessa tese, foi possível modificar o modelo de Cusson e Paultre (1995), de modo que fosse possível a este modelo a consideração da adição de fibras metálicas com ganchos nas extremidades. Ainda, alterou-se o equacionamento do coeficiente $k_{22}$ de modo a garantir uma melhor modelagem para pilares com baixa taxa de armadura transversal.

i) Observou-se que o modelo modificado de Cusson e Paultre (1995), conjuntamente com os procedimentos sugeridos para a modelagem de 
pilares, conseguiu predizer de modo bastante satisfatório o comportamento dos pilares de CAR aqui ensaiados experimentalmente.

j) Baseando-se nos resultados experimentais, sugeriu-se uma equação que garante a ductilidade mínima dos pilares de CAR.

\section{3) Fase 2 do programa experimental}

a) A metodologia empregada nos ensaios de pilares submetidos à compressão excêntrica apresentou resultados excepcionais. Observou-se que as condições de contorno (sistema de apoio em faca) garantiram a transferência integral do momento aplicado à estrutura, por excentricidade de força.

b) A flambagem das barras comprimidas da armadura longitudinal dos pilares submetidos à flexo-compressão ocorre de modo mais abrupto que nos pilares submetidos à compressão centrada. Observa-se ainda que a degradação da massa de concreto comprimida nesses pilares também ocorre de modo mais crítico.

c) Mesmo nos pilares com excentricidades de força que permaneciam dentro do núcleo central, observou-se inversão de sinal das deformações na fase menos comprimida dos pilares com a formação da rótula plástica. Fenômeno esse, observado também por outros pesquisadores.

d) Observou-se, nos ensaios, que apenas o ramo do estribo paralelo à fase mais comprimida do pilar sempre atingiu o escoamento e que a deformação do ramo paralelo à fase menos comprimida aparentemente é função das posições das fissuras de tração. Em $60 \%$ dos pilares ensaiados, observou-se o escoamento dos ramos dos estribos paralelo ao plano de flexão.

e) Como não foi constado o aumento da capacidade resistente dos pilares em relação à elevação da taxa de armadura transversal nos pilares ensaiados, os modelos do FIB (1999) e o proposto nesse trabalho para o 
CRFA conseguiram de modo bastante satisfatório predizer tanto o momento fletor máximo, quanto a força máxima resistente dos pilares. Novamente, observou-se que a não consideração de toda seção transversal interferiu nos resultados fornecidos pelo modelo de Cusson e Paultre (1995).

f) Observou-se que os índices de ductilidade são influenciados pelo comprimento de avaliação das deformações.

g) Verificou-se que a excentricidade de força e seus acoplamentos com a taxa de armadura transversal e a taxa de adição de fibras influenciam na ductilidade dos pilares. $\mathrm{O}$ aumento da excentricidade de força tornou o comportamento pós-pico mais dúctil.

h) O estudo do efeito da flexão no confinamento do concreto mostrou que, é possível utilizar o modificar o modelo de Cusson e Paultre (1995) para modelar os pilares aqui ensaiados. Constatou-se ainda, que esse procedimento conseguiu predizer de modo bem satisfatório os diagramas momento vs. curvatura dos pilares.

Finalmente, avaliando-se os parágrafos anteriores, constatam-se que os objetivos propostos foram atingidos e que esta tese gerou contribuições relevantes e inéditas, dentre as quais, destacam-se:

- Proposição de um modelo matemático que analisa o comportamento à compressão do concreto confinado e com e sem adição de fibras metálicas;

- Proposição de uma metodologia adequada para a realização de ensaios de pilares submetidos à flexo-compressão; proposição de equações para o cálculo das taxas de armadura transversal e de adição de fibras metálicas ideais para os pilares com concretos de alta resistência, para garantir um índice de ductilidade aceitável;

- Geração de dados experimentais sobre pilares com concretos de alta resistência confinados e com adição de fibras metálicas submetidos a compressão excêntrica; e, 
- Avaliação do comportamento pós-pico de pilares com CAR confinados e/ou adição de fibras metálicas submetidos à flexo-compressão.

Para continuidade da pesquisa sugerem-se os seguintes estudos:

1) Avaliar o comportamento do coeficiente $k_{2}$ em relação à taxa de armadura e de adição de fibras metálicas;

2) Avaliar outras configurações de armadura transversal em pilares submetidos à compressão excêntrica;

3) Estudar o comportamento dos pilares com CAR submetidos à compressão excêntrica, com pequenas excentricidades ( $e / h$ variando entre $0 \%$ e $7 \%$ ).

4) Verificar a redução da área efetiva de confinamento em pilares submetidos à flexo-compressão oblíqua; e, por fim,

5) Estudar outros tipos e geometrias de fibras metálicas, estabelecendo as equações do diagrama tensão vs. deformação para essas fibras. 


\section{REFERÊNCIAS BIBLIOGRÁFICAS}

ACI-ASCE, Joint Committee 441. State-of-the-Art Report on High-Strength Concrete columns. ACI - Structural Journal, v. 94, No. 3, 1997, pp.323-335.

AHMAD, S. H. e SHAH, S. P. Stress-strain curves of concrete confined by spiral reinforcement. ACI Journal, v.79 n.6, 1982, pp.484-490.

AHMAD, S. H. e SHAH, S. P. Structural properties of high strength concrete and its implications for pre-cast prestressed concrete. PCI Journal, v.30, No. 6, 1985, pp.2-117.

AÏTICIN, P. C. Concreto de alto desempenho. Editado por Pini Ltda, São Paulo, 2000, p.667.

AMERICAN CONCRETE INSTITUTE, ACI Comittee 363. State-of-the-Art Report on High-Strength Concrete. In: ACI Manual of Concrete Practice, Detroit, part 1,1991, p.48.

AMERICAN CONCRETE INSTITUTE, ACI Comittee 544. State-of-the-Art Report on fiber reinforced Concrete. In: ACI special publication SP-81, 1984, pp.411-431.

AMERICAN CONCRETE INSTITUTE. Committe 318 (ACI 318R-89). Building code requirements for reinforced concrete. American Concrete Institute, Detroit - USA, 1989, p.353.

AMERICAN CONCRETE INSTITUTE. Committe 544 (ACI 544.3R-93). Manual of concrete practice: part 5. ACI, Guide for specifying proportioning, mixing, placing and finishing steel fiber reinforced concrete. Detroit - USA, 1993, p.19.

AMERICAN CONCRETE INSTITUTE. Committe 544 (ACI 544.3R-98). Design considerations for steel fiber reinforced concrete. ACI Structural Journal, Detroit - USA, 1988, p.18. 
AMERICAN CONCRETE INSTITUTE. Committe 544 (ACI544.2R-89). Measurement of properties of fiber reinforced concrete. Detroit - USA, 1989, p. 22.

AMERICAN SOCIETY FOR TESTING AND MATERIAL. ASTM C1018. Standard test method for flexure toughness and first crack strength of fiber reinforced concrete. Book of ASTM Standards. Philadelphia - USA, 1994.

ARMELIN, H. S. Contribuição ao estudo do concreto projetado por via seca com fibras de aço destinado ao revestimento de túneis NATM. Dissertação de Mestrado - Escola Politécnica, Universidade de São Paulo. São Paulo, 1992, p.145.

ARMELIN, H. S. e BANTHIA, N. Predicting the flexural post-cracking performance of steel fiber reinforced concrete from the pullout of single fibers. ACI journal, v. 94, No. 1, 1997, pp.18-31.

ASSOCIAÇÃO BRASILEIRA DE NORMAS TÉCNICAS. NBR 8953:1992Concreto para fins estruturais: classificação por grupos de resistência. Rio de Janeiro 1992.

ASSOCIAÇÃO BRASILEIRA DE NORMAS TÉCNICAS. Projeto de revisão da NBR 6118 - Projeto de estruturas de concreto. Rio de janeiro, 2001, p.232.

ATTARD, M. M. e FOSTER, S. L. Static ductility of high strength concrete columns under eccentric loading. International symposium on utilization of high-strength/high-performance concrete,4. Paris May 1996, pp.863-871.

ATTARD, M. M. e SETUNGE, S. Stress-strain relationship of confined and unconfined concrete. ACI journal, v. 93, No. 5, 1996, pp.432-442.

AZIZINAMINI, A. e KEBRAEL, M. Flexural capacity of high-strength concrete columns. $4^{\text {th }}$ International symposium on utilization of high-strength/highperformance concrete, Paris 1996, pp.873-881.

BALAGURU, P. N. e SHAH, S. P. Fiber reinforced cement composites. USA. McGraw-Hill, 1992, p.530.

BANTHIA, N. e DUBEY, A. Measurement of flexural toughness of fiberreinforced concrete using a novel technique - Part 1: Assessment and calibration. ACI Material Journal, v. 96 No. 6, 1999, pp.651-656. 
BANTHIA, N. e TROTTIER, J. F. Concrete reinforced with deformed fibers, Part I: Bond-Slip Mechanisms. ACI Material Journal, v. 91 No. 5, 1994, pp.435-446.

BANTHIA, N. e TROTTIER, J. F. Concrete reinforced with deformed fibers, Part II: Toughness characterization. ACI Material Journal, v. 92 No. 2, 1995, pp.146-154.

BANTHIA, N. e TROTTIER, J. F. Test methods for flexural toughness characterization of fiber reinforced concrete: Some concerns and a proposition. ACI Material Journal, v. 92 No. 1, 1995, pp.48-57.

BAYRAK, O. e SHEIK, S. A. Confinement reinforcement design considerations for ductile HSC columns. Journal of Structural Engineering, ASCE, v. 124, No. 9, 1998, pp.999-1010.

BENTUR, A. e MINDESS, S. Fiber reinforced cementious composites. UK., Barking, Elsevier, 1990, p.449.

BJERKELI, L.; TOMASZEWICZ, A. e JENSEN, J. J. Deformation propertied and ductility of high strength concrete. High performance concrete. ACI SP121-12, 1990, pp.215-238.

BOX, G. E. P.; HUNTER, W. G. e HUNTER, J. S. Statistics for experimenters: an introduction to design, data analysis, and model building. Edited by John Wiley \& sons. New York, 1993, p.653.

BUDWEG, F. M. G. e BOSCOV, P. Concreto reforçado por fibra de aço. $36^{\circ}$ Congresso Brasileiro do Concreto. Porto Alegre - RS, 1994, pp.253-266.

CÂMARA, E.; LIMA JÚNIOR, H. C.; WILLRICH, F. L.; FABRO, G. e GIONGO, J. S. Comportamento estrutural dos pilares dimensionados segundo o projeto de revisão da Norma NBR 6118 (2001). Revista Brasileira do Concreto - Instituto Brasileiro do Concreto, São Paulo, Brasil v. out/de, n. 31, p. 46-61, 2002.

CARBONARI, B. M. T. e CARBONARI, G. Concreto de alto desempenho do laboratório à obra. ENTAC 98 - Qualidade no processo construtivo. Florianópolis SC, abril, 1998. 
CARREIRA, D. J. e CHU, K. H. Stress-strain relationship for plain concrete in compression. ACI Journal, v. 82, No. 6, 1985, pp.797-804.

CECCATO, M. R. Estudo da trabalhabilidade do concreto reforçado com fibras de aço. Dissertação de Mestrado - Escola Politécnica, Universidade de São Paulo. São Paulo, 1998, p.98.

CEDERWALL, K.; ENGSTROM, B. e GRAUERS, M. High-strength concrete used in composite columns. High performance concrete. ACI SP-121-11, 1990, pp.195-207.

CHAN, W. W. L. The ultimate strength and deformation of plastic hinges in reinforced concrete framework. Magazine of concrete research, v. 21, No.7 Nov. 1955, pp.121-132.

CHEN, W.F. Plasticity in reinforced concrete. Edited by McGraw Hill, United Stated of American, 1982.

CHIN, M.S.; MANSUR, M.A. e WEE, T.H. Effect of shape, size and casting direction of specimens on stress-strain curves of high-strength concrete. ACI Material Journal, May-June, 1997. pp.209-219.

CLAESON, C. e GYLLTOFT, K. Slender concrete columns subject to sustained and short-term eccentric loading. ACI journal, v. 97, No. 1, 2000, pp.45-52.

COHN, M. Z. and RIZA, P. Flexural ductility of concrete structural concrete sections. PCI Journal, v. 36, No. 2, 1991, pp.72-87.

COMITÉ EURO-INTERNATIONAL DE BETON. CEB - Fip model code 1990 Final draft. Bulletin d'Information, Comité Euro-International de Beton, 1990.

CRAIG, R. J.; DUNYA, S.; RIAZ, J. e SHIRAZI, H. Torsional behavior of reinforced fibrous concrete beams. ACI special publication SP-81, 1984, pp.17-49.

CRAIG, R. J.; MAHADEV, S.; PATEL, C.C.; VITERI, M. e KERTESZ, C. Behavior of joints using reinforced fibrous concrete. ACI special publication SP-81, 1984, pp.125-167.

CRAIG, R. J.; McCONNELL, J. e GERMAM, G. Behavior of reinforced fibrous concrete columns. ACI special publication SP-81, 1984, pp.69-105. 
CUSSON, D. e PAUTRE, P. Behavior of high-strength concrete columns confined by retangular ties under concentric loading. Internal report of Department of Civil Engineering, University of Sherbrooke, SMS-92/2, 1992, p.47.

CUSSON, D. e PAUTRE, P. Confinement model for high-strength concrete tie columns. Internal report of Department of Civil Engineering, University of Sherbrooke, SMS-93/2, 1993, p.54

CUSSON, D. e PAUTRE, P. High-strength concrete columns confined by rectangular ties. Journal of structural engineering. ASCE. v. 120 No. 3, 1994, pp.783-804.

CUSSON, D. e PAUTRE, P. Stress-strain model for confined high-strength concrete. Journal of structural engineering. ASCE. v. 121 No. 3, 1995, pp.468-477.

CUSSON, D.; LARRARD, F.; BOULAY, C. e PAUTRE, P. Strain localization in confined high-strength concrete columns. Journal of structural engineering. ASCE. v. 122 No. 9, 1996, pp.1055-1061.

DAL MOLIN, D. C. C. Contribuição ao estudo das propriedades mecânicas dos concretos de alta resistência com e sem adição de microssílica. Tese de doutorado, Universidade de São Paulo, São Paulo, 1995, 260p.

DING, Y. e KUSTERLE, W. Compression stress-strain relationship of steel fiber-reinforced concrete at early age. Cement and concrete research, No. 30, 2000, pp.1573-1579.

DINIZ, S. M. C. e FRANGOPOL, D. M. Strength and ductility simulation of high-strength concrete columns. Journal of Structure Engineering, ASCE, vol. 123, No. 10, October, 1997, pp.1365-1374.

ESSAWY, A. S. e EL-HAWARY, M. Strength and ductility of spirally reinforced rectangular concrete columns. Construction and Building Materials, v. 12, No. 1, 1998, pp.31-37.

EZELDIN, A S. e BALAGURU, P. N. Normal and high-strength fiberreinforced concrete under compression. Journal of materials in civil engineering, v. 4, No. 4, 1992, pp.415-429. 
FAFITIS, A. e SHAH, S. P. Lateral reinforcement for high-strength concrete columns. ACI SP-87-12, 1985, pp.213-232.

FAFITIS, A. e SHAH, S. P. Predictions of ultimate behavior of confined columns subjected to large deformations. ACI Journal, v. 82-35, 1985, pp.423-433.

FANELLA, D. A. e NAAMAN, A. E. Stress-strain properties of fiber reinforced mortar in compression. ACI Journal, No. 82-41, 1985, pp.475-483.

FERNANDES, F. J. Pilares mistos: tubos de aço com seções quadradas e retangulares e núcleo de concreto de alta resistência. Dissertação de Mestrado - FEC, Universidade Estadual de Campinas. Campinas, 1997, p.110.

FERREIRA, O P. e GOMES, C. E. M. Influência do teor de fibras de aço e consumo de cimento em matrizes de concreto de cimento Portland com adições de látex SBR e da sílica ativa. IV Congresso de Engenharia Civil UFJF. Vol. 1, agosto 2000, pp.463-475.

FIB. Structural concrete - Textbook on behavior, design and performance. Updated knowledge of the CEB/FIP Model Code 1990. Comité EuroInternational du Beton, volume 1, 1999.

FIGUEREDO, A D. Parâmetros de controle e dosagem do concreto projetado com fibras de aço. Tese de doutorado - Escola Politécnica, Universidade de São Paulo. São Paulo, 1997, p.342.

FOSTER, S. J.; LIU, J. e SHEIKH, S. A. Cover spalling in HSC columns in concentric compression. Journal of structural engineering. ASCE. v. 124 No. 12, 1998, pp.1431-1437.

FURLAN JR., S. Vigas de concreto com taxas reduzidas de armadura de cisalhamento: influência do emprego de fibras curtas e de protensão. Tese de Doutorado. Escola de Engenharia de São Carlos, Universidade de São Paulo, São Carlos, 1995, p.373.

FUSCO, P.B. O cálculo de concreto armado no regime ruptura. Anais do simpósio EPUSP sobre estruturas de concreto, v. 1, 1989, pp.241-310. 
GANESAN N. e MURTHY, J. V. R. Strength and behavior of confined steel fiber reinforced concrete columns. ACI journal, v. 87, No. 3, 1990, pp.221227.

GE, H. e USAMI, T. Cyclic tests of concrete filled steel box columns. Journal of Structural Engineering, ASCE, v. 122, No. 10, 1996, pp.1169-1177.

GHOSH, S.K. e SAATCIOGLU, M. Ductility and Seismic Behavior. In: HighStrength Concrete, Published by McGraw and Edited by Ahmed and S. Shah. Chapter 8, 1994, pp.237-312.

GOMES, C. E. M. e FERREIRA, O. P. Influência do teor de fibra de aço e consumo de cimento em matrizes de concreto de cimento Portland com adições de SBR e da sílica ativa. IV Congresso de Engenharia Civil - UFJF, vol. 1, ago. 2000, pp. 463-475.

GUIMARÃES, A . E. P. Análise de pilares de concreto de alta resistência com adição de fibras metálicas submetidos à compressão centrada. Tese de Doutorado- Escola de Engenharia de São Carlos, Universidade de São Paulo, São Carlos, 1999, p.145.

Guimarães, A E. P.; GiOngo, J. S. e BitTenCOUt, T. N. Pilares em concretos de alta resistência: análise da ductilidade com adição de fibras. Jornadas Sudamericanas de Ingenieria Estruturas. Punta Del este - Uruguai, Nov. 2000, CD-ROM, pp.1-19.

HELENE, P. e TERZIAN, P. Manual de dosagem e controle do concreto. Editora PINI, São Paulo, 1995, p.349.

HOGNESTAD, E.; HANSON, N. W. e McHENRY, D. Concrete stress distribution in ultimate strength design. ACI Journal, v. 52, No. 4, 1955, pp.455-480.

HOGNESTAD, E.; HANSON, N.W. e MCHENRY, D. Concrete stress distribution in ultimate strength design. ACI Structural Journal, v. 52, No. 6, 1955, pp.455-479.

HOSHIKUMA, J.; KAWASHIMA, K. NAGAYA, K. e TAYLOR, A. W. Stressstrain model for confined reinforced concrete in bridge piers. Journal of structural engineering. ASCE. v. 123 No. 5, 1997, pp.624-633. 
HSU, C. T. T.; HE, R. J. L. e ELZEDIN, A S. Load-deflection behavior of steel fiber reinforced concrete beams. ACI Structural Journal, v. 89, No. 6, 1992, pp.650-657.

HSU, L. S. e HSU, C. T. T. Stress-strain behavior of steel fiber high-strength concrete under compression. ACI Structural Journal, v. 91, No. 4, 1994, pp.448-457.

HUGHES, B. P. e FATTUHI, N. I. Stress-strain curves for fiber reinforced concrete in compression. Cement and concrete research. No.7, 1977, pp.173184.

IBRAHIM, H. H. H. e MACGREGOR, J. G. Flexural behavior of laterally reinforced high-strength concrete sections. ACI Structural Journal, v. 93, No. 6, 1996, pp.674-684.

IBRAHIM, H. H. H. e MACGREGOR, J. G. Modification of ACI rectangular stress-block for high strength concrete. ACI Structural Journal, v. 94, No. 1, 1997, pp.40-48.

IBRAHIM, H. H. H. e MACGREGOR, J. G. Tests of eccentrically loaded highstrength concrete columns. ACI Structural Journal, v. 93, No. 5, 1996, pp.585-594.

JAPAN SOCIETY OF CIVIL ENGINEERS. Method of test for compressive strength and compressive toughness of steel fiber reinforced concrete. JSCE - SF5. Concrete Library of JSCE. Tokyo - Japan, 1984.

JOHNSTON, C. D. Fiber-reinforced concrete applications in Alberta. In: Second University-Industry Workshop on fiber reinforced concrete and other advanced material. Toronto, Canada, 1995, pp.87-100.

JOHNSTON, C. D. Steel fiber reinforced mortar and concrete: a review of mechanical properties. ACI special publication SP-44, 1974, pp.127-142.

KARSAN, I. D. e JIRSAN, J. O. Behavior of concrete under varying strain gradient. Journal of structural div. ASCE. v. 96 No. 8, 1970, pp.1675-1696.

KATZ, A. e BENTUR, A. High performance fibers in high strength cementitious matrices. High performance fiber reinforced cement composites. Edited by H. W. Reinhardt and A. E. Naaman, 1992, pp.273-274. 
KENT, D. C. e PARK, R. Flexural members with confined concrete. Journal of structural div. ASCE. v. 97 No. 7, 1971, pp.1969-1990.

KILPATRICK, A E e RANGAN B V. Tests on High Strength Concrete - Filled Steel Tubular Columns. ACI Structural Journal, Vol. 96, March/April 1999, pp.268-274.

KOSAKA. Y.; TANIGAWAT, Y. e HATANAKA, S. Lateral confining stress due to steel fibers in concrete under compression. The international journal of cement composites and lightweight concrete, v. 7, No. 2, 1985, pp.81-92.

KRÜGER, S. D. Uma metodologia para a análise de pórticos planos de concreto armado sujeitos a grandes deslocamentos. Dissertação de Mestrado. Departamento de Engenharia Civil PUC/Rio, Abril de 1989, p.180.

LAHLOU, K.; LACHEMI, M. e AÏTICIN, P. C. Confined high strength concrete under dynamic compressive load. Journal of Structural Engineering, ASCE, v. 125, No. 10, 1999, pp.1100-1108.

LEE, J. H. e SON, H. S. Failure and strength of high-strength concrete columns subjected to eccentric loads. ACI journal, v. 97, No. 1, 2000, pp.75-85.

LEONHARDT, F. Construções de concreto - Princípios básicos sobre a armação de estruturas de concreto armado. Editado por Interciência LTDA, v. 1, Rio de Janeiro, 1977a, p.305.

LEONHARDT, F. Construções de concreto - Princípios básicos sobre a armação de estruturas de concreto armado. Editado por Interciência LTDA, v. 3, Rio de Janeiro, 1977b, p.273.

LIMA JR., H. C. e GIONGO, J. S. Avaliação da ductilidade do concreto de alta resistência reforçado com fibras de aço. Anais do $43^{\circ}$ Congresso Brasileiro do Concreto, CD-ROOM I-025, 2001, p.16.

LIMA JUNIOR, H.C. e GIONGO, J. S. Fator de ductilidade para pilares de concreto de alta resistência. Revista Engenharia Estudo e Pesquisa. Editora Interciência. No. 2, v. 3, 2000, pp.65-74.

LIMA JUNIOR, H.C. e GIONGO, J. S. Modelo teórico para análise de pilares de concreto de alta resistência com confinamento lateral. Revista Engenharia Estudo e Pesquisa. Editora Interciência. No. 1, v. 3, 2000, pp.99-105. 
LIMA, F. B. Pilares de concreto de alto desempenho: fundamentos $e$ experimentação. Tese de Doutorado- Escola de Engenharia de São Carlos, Universidade de São Paulo, São Carlos, 1997, p.170.

LIMA, F. B.; GIONGO, J. S. e TAKEYA, T. Axially loaded HPC columns. [CDROM]. In: International Conference on High-performance concrete, and performance and quality of concrete structures, 2., Gramado, Brazil, June 1-4, 1999, p.18.

LIU, J.; FOSTER, S. J. e ATTARD, M. M. Strength of tied high-strength concrete columns loaded in concentric compression. ACI journal, v. 97, No. 1, 2000, pp.149-156.

LLOYD, N. A e RANGAN B V. Studies on high-Strength concrete columns under Eccentric Compression. ACI Structural Journal, Vol. 93, November/December 1996, pp.631-638.

MACGREGOR, J.G. Reinforced concrete, mechanics and design. Edited by Prentice Hall, United Stated of American, 1997, p.939.

MANDER, J. B.; PRIESTLEY, M. J. N. e PARK, R. Theoretical Stress-Strain Model for Confined Concrete. Journal of structural div. ASCE. v. 114 No. 8, 1988, pp.1804-1825.

MANGAT, P. S. e MOTAMEDI, M. A. Influence of steel fiber and stirrup reinforcement on the properties of concrete in compression members. The international journal of cement composites and lightweight concrete, v. 7, No. 3, 1985, pp.183-192.

MANGAT, P. S. e MOTAMEDI, M. A. Influence of steel fiber reinforcement on the fracture behavior of concrete in compression. The international journal of cement composites and lightweight concrete, v. 6, No. 4, 1984, pp.219232.

MARQUES, S. P. C. e MARQUES, D. C. S. C. Análise numérica não linear de pilares de concreto armado sob carga excêntrica. $42^{\circ}$ Congresso Brasileiro do Concreto. Salvador - BA, 1999, CD-ROM, pp.1-15.

MARTINEZ, S.; NILSON, A H. e SLATE, F. C. Spirally reinforced high strength concrete columns. ACI Journal, v.81 n.5, 1984, pp.431-442. 
MAU, S. T.; ELWI, A E. e ZHOU, S. Analytical study of spacing of lateral steel and column confinement. Journal of structural engineering. ASCE. v. 124 No. 3, 1998, pp.262-269.

MAU, S. T.; HOLLAND, J. e HONY, L. Small-columns compression tests on concrete confined by WWF. Journal of structural engineering. ASCE. v. 124 No. 3, 1998, pp.252-261.

MEHTA, P. K. e AITCIN, P-C. Microstructural basis of selection of materials and mix proportions for high - strength concrete. In: International symposium on utilization of high strength concrete, 2., 1990, Berkeley, California. Proceedings, Detroit: American Concrete Institute, 1990, pp.265 286.

MENDES, H. O. Ductilidade de elementos de concreto de alta resistência. Dissertação de Mestrado - Universidade Federal do Rio de Janeiro/COOPE. Rio de Janeiro, 1993, p.149.

MIRMIRAN, A. E SHAHAWY, M. Behavior of concrete columns confined by fiber composites. Journal of structural engineering. ASCE. v. 123 No. 5, 1997, pp.583-590.

MONTGOMERY, D. C. Design and analysis of experiments. Edited by John Wiley \& sons. New York, 1984, p.704.

MUGURUMA, H.; WATANABE, S.; KATSUTA, S. e TANAKA, S. A stressstrain model of confined concrete. JCA Cement and concrete, V. 34 Japan Cement ASSN. Tokyo, 1980, pp.429-432.

NAAMAM, A E.; HARAJLI, M. H. e WIGHT, J. K. Analysis of ductility in partially prestressed concrete flexural members. PCI Journal, v. 31, No. 3, 1986, pp.64-87.

NAGASHIMA, T.; SUGANO, S.; KIMURA, H. e ICHIKAWA, A. Monotonic axial compression test on ultra-high-strength concrete tied columns. Tenth World Conference on Earthquake Engineering, Rotterdam, 1992, pp.29832988. 
NATARAJA, M.C.; DHANG, N. e GUPTA, A. P. Stress-strain curves for steelfiber reinforced concrete under compression. Cement and concrete composites, No. 21, 1999, pp.383-390.

NATARAJA, M.C.; DHANG, N. e GUPTA, A. P. Toughness characterization of steel fiber-reinforced concrete by JSCE approach. Cement and concrete research, No. 30, 2000, pp.593-597.

NORGES BYGGSTANDARDISERINGSRAD-NBR. Prosjektering av betongkonstruksjoner beregning-og konstruksjonsregler (concrete structures design rules). NS 3473, Norges Standardiseringsforbund, Oslo, 1989, p.103.

NUNES, L. N. Estudo da influência da geometria da fibra de aço na tenacidade à flexão dos compósitos de matriz de concreto. Dissertação de Mestrado Escola Politécnica, Universidade de São Paulo. São Paulo, 1998, p.193.

OTTER, D.E. E NAAMAN, A.E. Strain rate effects the compressive properties of fibre reinforced concrete. International symposium on fibre reinforced concrete, India, 1987, pp.2225-2235.

PAIVA, N. M. B. Pilares de concreto de alta resistência com seção transversal solicitada à compressão simples. Dissertação de Mestrado. FEC Universidade Estadual de Campinas. Campinas 1997, p.102.

PARK, R. Design and behavior of RC columns incorporating high-strength material. Concrete International, v. 18, No. 2, 1998, pp.55-62.

PARK, R. e PAULAY, T. Reinforced concrete structures. Edited by John Wiley \& Sons, Canada, 1975, p.769.

PARK, R.; PRIESTLEY, M. J. N. e GILL, W. D. et al. Ductility of squareconfined concrete columns. Journal of structural div. ASCE. v. 108 No. 4, 1982, pp.929-623.

PERDÃO JR. P. Estudo comparativo entre pilares circulares de concreto de alta resistência com armadura de confinamento helicoidal e pilares circulares de seção mista: tubo metálico e núcleo de concreto de alta resistência. Dissertação de Mestrado - FEC, Universidade Estadual de Campinas. Campinas, 1994, p.119. 
PINTO JR. N. O. Tenacidade e resistência à tração na flexão de concreto de alto desempenho reforçados com fibras de aço de baixo e alto teor de carbono. $41^{\circ}$ Congresso Brasileiro do Concreto. Rio de Janeiro - RJ, 1998, CD-ROM, pp.1-16.

QUEIROGA, M. V. M. Análise experimental de pilares de concreto de alto desempenho submetidos à compressão simples. Dissertação de Mestrado Escola de Engenharia de São Carlos, Universidade de São Paulo, São Carlos, 1999, p. 162.

QUEIROGA, M. V. M.; GIONGO, J. S. e TAKEYA, T. Experimental analysis of high strength concrete columns (60MPa) under axial compression. In: Utilization of high strength / high performance concrete. Sandefjord, Norwegian Concrete Association, 1999. v.1, pp.556-565.

QUINTANA, C. B. Comportamento do concreto confinado. Dissertação de Mestrado. Universidade Federal do Rio de Janeiro - COPPE, Rio de Janeiro, 2001, p. 187.

RAMAKRISHNAM, V.; COYLE, W. V.; KULANDAISAMY, V. e SCHIRADER, E.K. Performance characteristics of fiber reinforced concrete with low fiber contents. ACI journal, v. 78, No. 5, 1981, pp.384394.

RAMOS, R. F. Análise experimental de pilares de concreto armado sob ação centrada com resistência do concreto de 25MPa. Dissertação de Mestrado. Escola de Engenharia de São Carlos, Universidade de São Paulo, São Carlos, 2001, p.247.

RANGAM, B. V. Studies on high performance high strength concrete (HPHSC) columns. High performance concrete. ACI SP-186-44, 1999, pp.745-764.

RAZVI, S. R. e SAATCIOGLU, M. Circular high-strength concrete columns under concentric compression. ACI Structural Journal, v. 96, No. 5, 1999-a, pp.817-825.

RAZVI, S. R. e SAATCIOGLU, M. Confinement Model for High-strength concrete. Journal of structural div. ASCE. v. 125 No. 3, 1999-b, pp.281-289. 
RAZVI, S. R. e SAATCIOGLU, M. Confinement of reinforced concrete columns with welded wire fabric. ACI Structural Journal, v. 86, No. 5, 1989, pp.615-623.

RICHART, F. E.; BRANDTZAEG, A e BROWN, R. L. A study of the failure of concrete under combined compressive stress. Bull. No. 185, engineering Experimental Station, University of Illinois, Urbana, Ill, 1928, p.105.

RILEM TC 148-SSC. Test method for measurement of the strain-softening behavior of concrete under uniaxial compression. Materials and Structures, v.33, July, 2000, pp.347-351.

ROMUALDI, J. P. e BASTON, G. B. Mechanics of crack arrest in concrete. ASCE, Journal Eng. Mech. Civ., 89, 1963, pp.147-168.

ROSTÁSY, F.S. e HARTWICH, K. Compressive strength and deformation of steel fiber reinforced concrete under high rate of strain. The International Journal of Cement Composites and Lightweight Concrete, v. 7, No. 1, 1985, pp.21-28.

SAATCIOGLU, M. e BAINJO, D. Circular high-strength concrete columns under simulated seismic loading. Journal of Structural Engineering, ASCE, v. 125 , No. 3, 1999, pp.272-280.

SAATCIOGLU, M. e RAZVI, S. High-strength concrete columns with square sections under concentric compression. Journal of Structure Engineering, ASCE, vol. 124, No. 12, December 1998, pp.1438-1447.

SAATCIOGLU, M. e RAZVI, S. R. Strength and ductility of confined concrete. Journal of structural div. ASCE. v. 118 No. 6, 1992, pp.1590-1607.

SAATCIOGLU, M.; SLAMAT, A H. e RAZVI, S. R. Confinement columns under eccentric loading. Journal of structural div. ASCE. v. 121 No. 11, 1995, pp.1547-1556.

SAMAAN, M.; MIRMIRAN, A. E SHAHAWY, M. Model of concrete confined by fiber composites. Journal of Structure Engineering, ASCE, vol. 124, No. 9, September 1998, pp.1025-1031. 
SARGIN, M.; GLOSH, S. K. e HANDA, V. K. Effects of lateral reinforcement upon the strength and deformation properties of concrete. Magazine of concrete research, v. 23, No. 75-76, 1971, pp.99-110.

SCOTT, B. D.; PARK, R. e PRIESTLEY, M. J. N. Stress-strain behavior of concrete confined by overlapping hoops at low and high strain rates. ACI journal, v. 79, No. 2, 1982, pp.13-27.

SCOTT, R. H.; HAMIL, S. J. e BAGLIM, P. S. Behavior of high strength concrete beam-column connection. High performance concrete. ACI SP186-41, 1999, pp.699-713.

SHEIKH, S. A and YEH C. C. Tied concrete columns under axial load and flexure. Journal of Structure Engineering, ASCE, vol. 116, No. 10, 1990, pp.2780-2800.

SHEIKH, S. A e YEH C. C. Flexural behavior of confined concrete columns. ACI journal, v. 83, No. 1, 1986, pp.389-404.

SHEIKH, S. A. A comparative study of confinement models. ACI Journal, vol.79, No. 2, 1982, pp.296-306.

SHEIKH, S. A. e UZUMERI, S. M. Analytical model for concrete confinement in tied columns. Journal of structural engineering ASCE., 1982, pp.27032772 .

SHEIKH, S. A. e UZUMERI, S. M. Strength and ductility of tied concrete columns. Journal of structural div. ASCE. v. 106 No. 5, 1980, pp.1079-1102.

SHEIKH, S. A.; SHAH, D. V. e KHOURY, S. S. Confinement of high-strength concrete columns. ACI Structural Journal, v. 91, No. 1, 1994. pp.100-111.

SOLIMAM, M. T. M. е YU, C. C. The flexural stress-strain relationship of concrete confined by rectangular transversal reinforcement. Magazine of Concrete Research, v. 19 No. 61, 1967, pp.223-238.

SOROUSHIAN, P. e LEE, C.D. A physical simulation of the fiber reinforced concrete behavior under compression. Proceedings of the International Symposium on fiber reinforced concrete. Madras - India, December, 1987, pp.1151 -1161. 
STURMAN, G. M.; SHAH, S. P. e WINTER, G. Effects of flexural strain gradients on microcraking and stress-strain behavior of concrete. ACI Journal, v. 62-50, 1965, pp.805-821.

TAERWE, L. R. Influence of steel fiber on strain-softening of high strength concrete. ACI Material Journal, v. 89, No. 1, 1992, pp.54-60.

TAKEUTI, A. R. Reforço de pilares de concreto armado por meio de encamisamento com concreto de alto desempenho. Dissertação de Mestrado. Departamento de Estruturas EESC/USP São Carlos, 1999, p.184.

TIMOSHENKO, S. P. e GOODIER, J. N. Theory of Elasticity. Editora McGRAW book Company, INC. , third edition, New York, 1970, p.568.

VAN MIER, J. G. M. e VONK, R. A. . Fracture of concrete under multiaxial stress - recent developments . Material and Structures, 24, 1991, pp.61-65.

VAN MIER, J. G. M. Fracture processes of concrete. CRC press, 1997, p.448.

VAN VLACK, L. H. Materials engineering. Edited by Addison Wesley Pub, 1982, p. 256.

VANDERLEI, R. D. Análise experimental de pilares de concreto armado de alto desempenho sob flexo-compressão reta. Dissertação de Mestrado. Escola de Engenharia de São Carlos, Universidade de São Paulo, São Carlos, 1999, p.142.

WEBB, J. High strength concrete: economics, design and ductility. Concrete International, v. 15, No. 1, 1993, pp.27-32.

WILLIAMSON, G. R. The effect of steel fibers on the compressive strength of concrete. ACI special publication SP-44, 1974, pp.195-207.

WILlRICH, F. L.; LIMA Jr., H. C. e DA SILVA, S. L. Concrete columns strengthened by concrete jacket. In: XXX Jornadas Sul-americana de Engenharia Estrutural, 2002, Brasília. Anais da XXX Jornadas Sul-americana de Engenharia Estrutural - CD-ROOM - TRB0040. 2002, pp.1-14.

XIAO, Y. e MARTIROSSYAN, A. Seismic performance of high strength concrete columns. Journal of structural engineering. ASCE. v. 124 No. 3, 1998, pp.241-251. 
XIE, J.; ElWI, A E. e MACGREGOR, J. G. Performance of high-strength concrete tied columns - A parametric study. ACI Structural Journal, v. 94, No. 2, 1997, pp.91-102.

ZOLLO, R. F. Fiber-reinforced concrete: an overview after 30 years of development. Cement and Concrete Composites, No. 19, 1997, pp.107-122. 


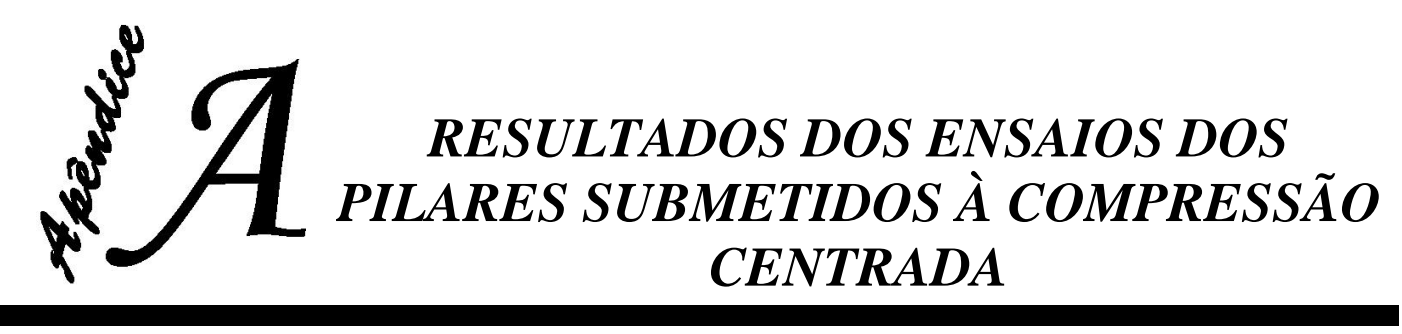

\section{A.1.Pilar P14015}

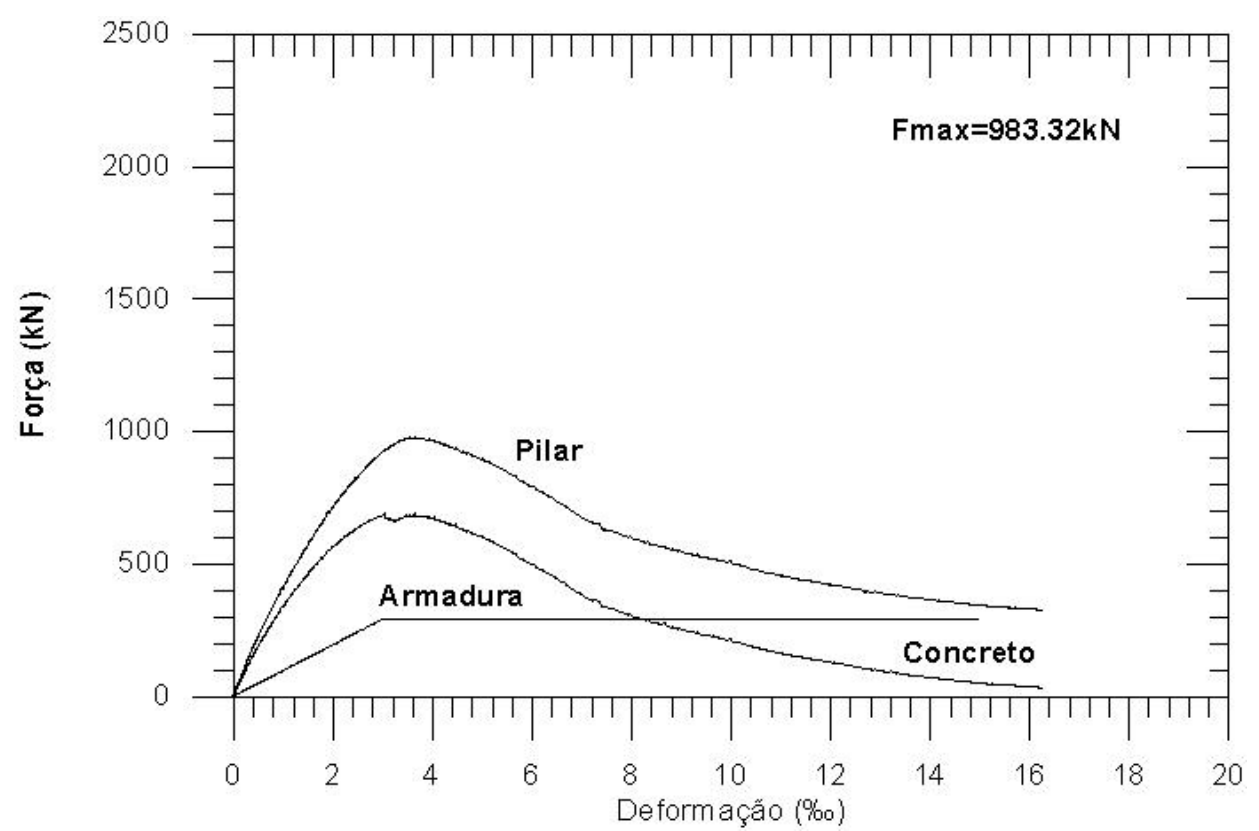

Figura A.1 - Diagramas forças parciais vs. deformação do pilar, do concreto $e$ da armadura longitudinal.

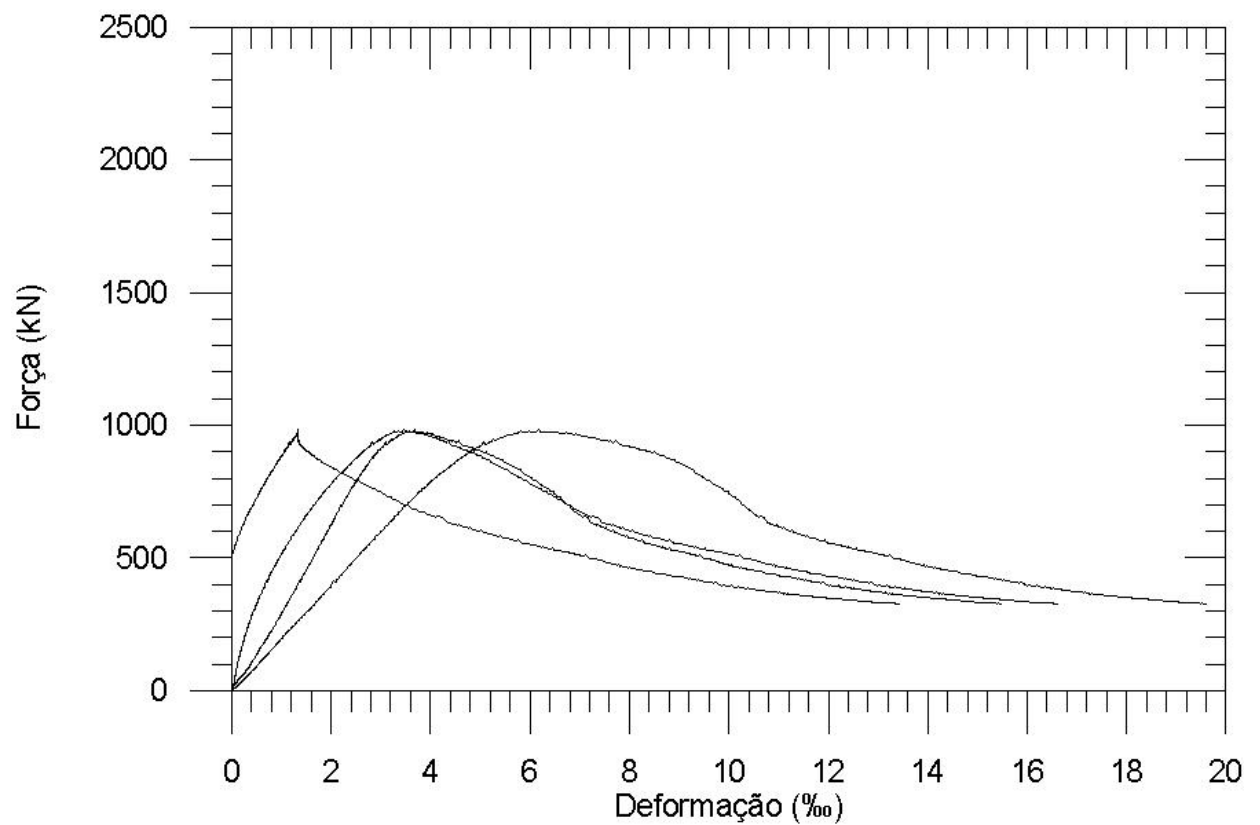

Figura A.2 - Diagramas força aplicada vs. deformação lida por cada LVDt. 


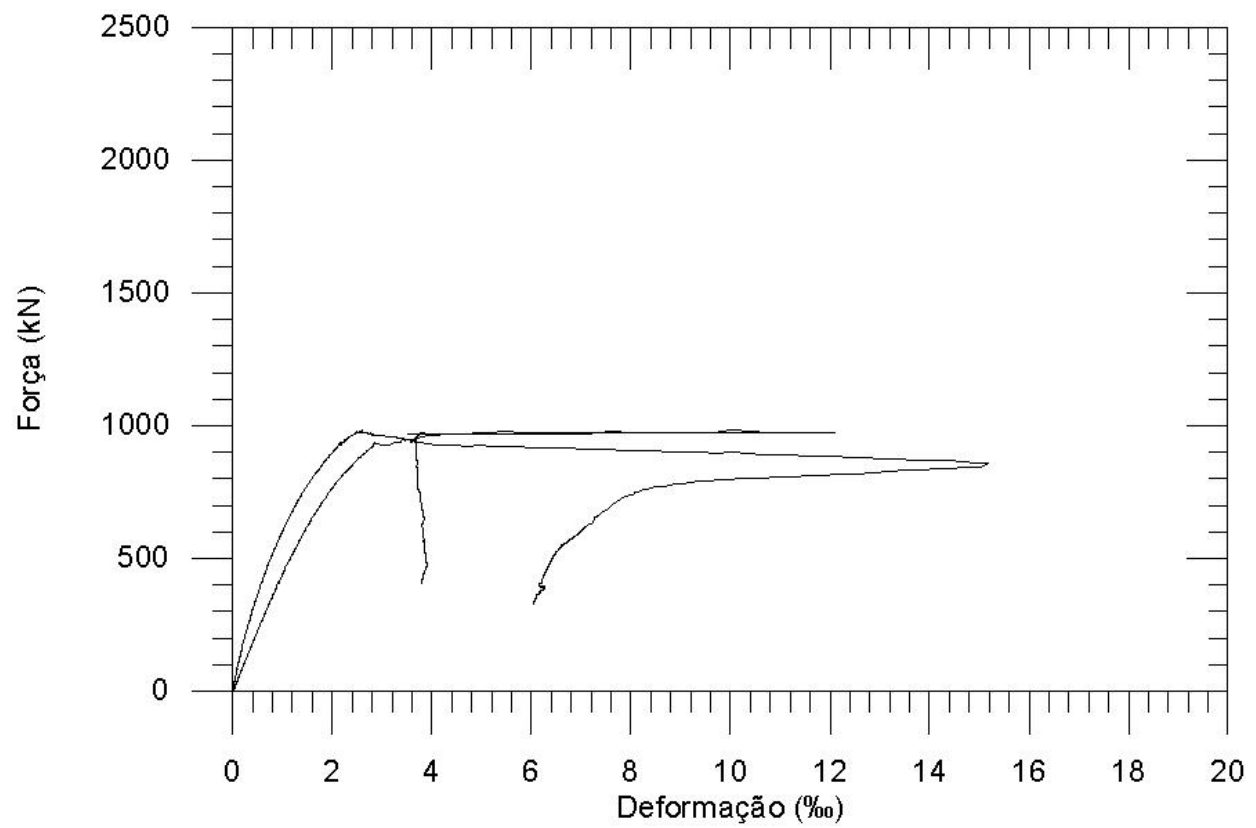

Figura A.3 - Diagramas força aplicada vs. deformação lida pelos extensômetros na armadura longitudinal.

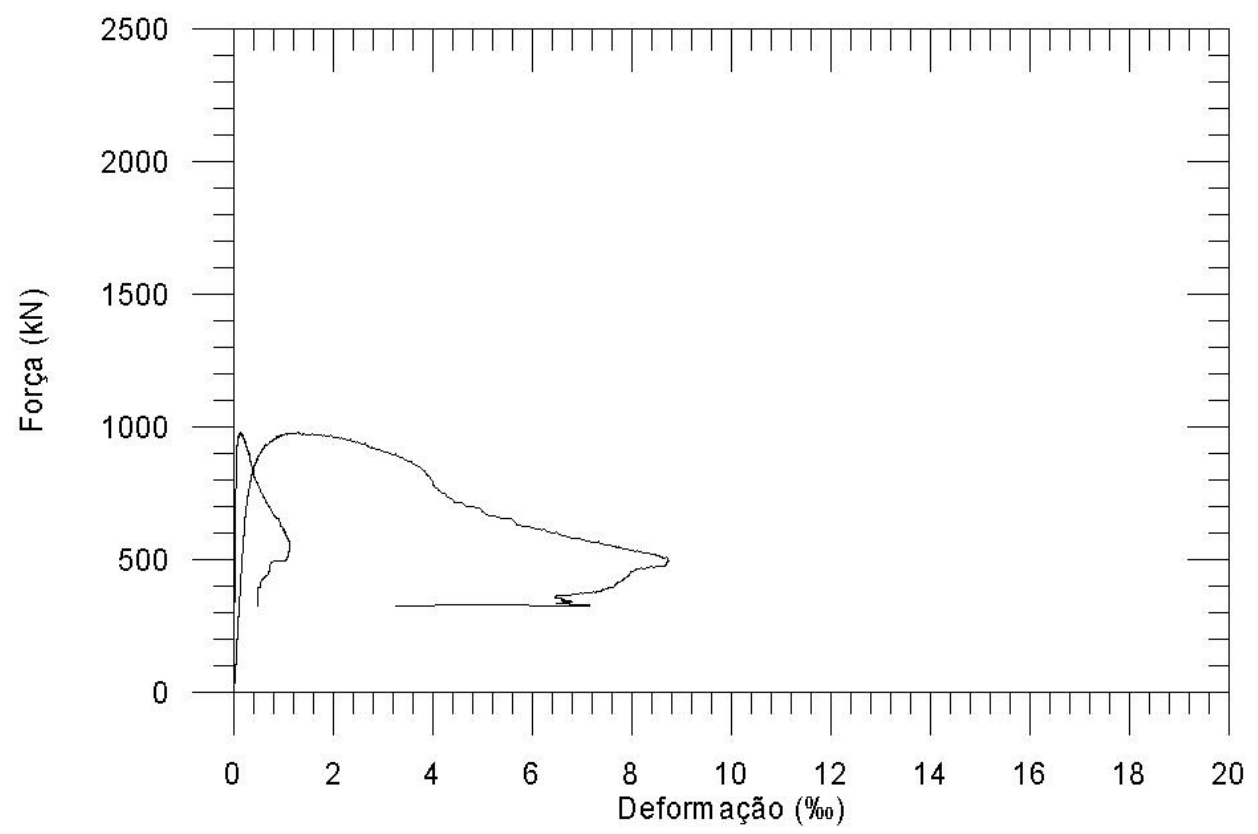

Figura A.4 - Diagramas força aplicada vs. deformação lida pelos extensômetros na armadura transversal. 


\section{A.2.Pilar P24015}

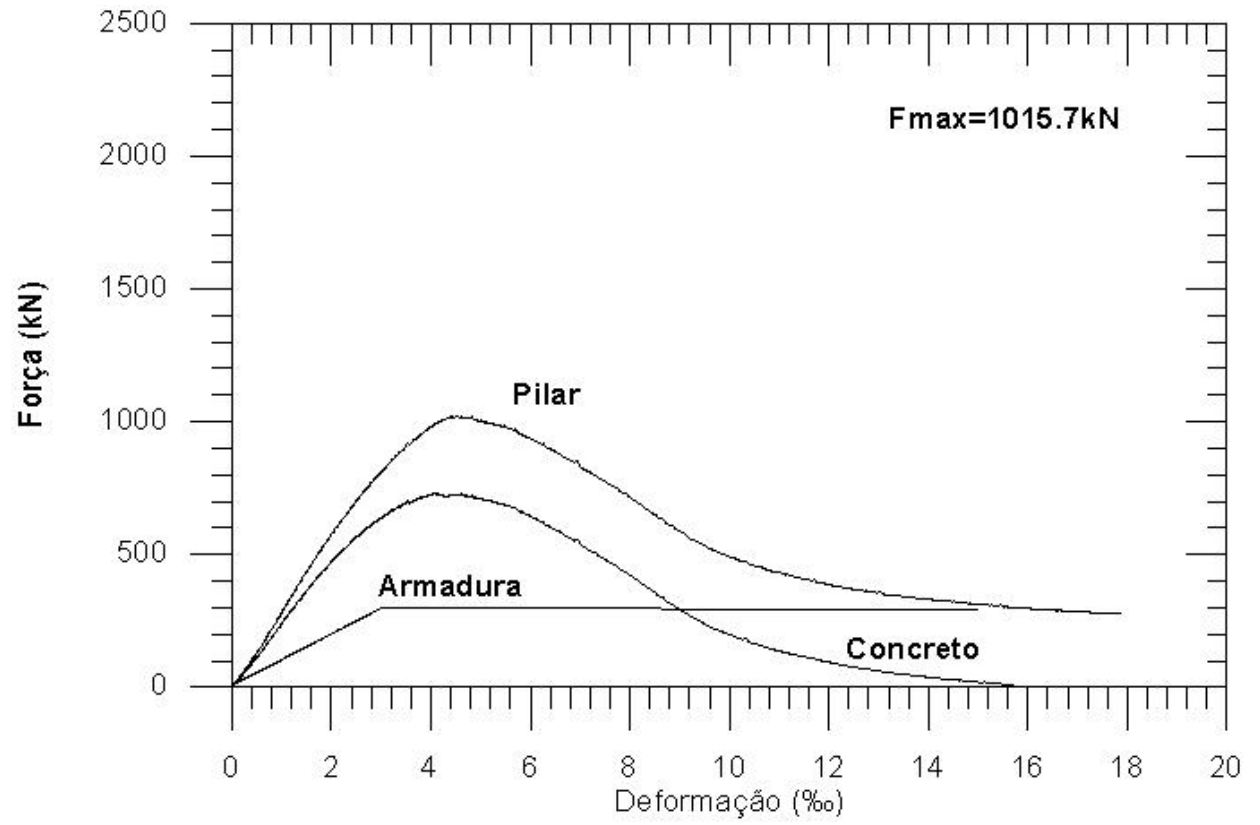

Figura A.5 - Diagramas forças parciais vs. deformação do pilar, do concreto e da armadura longitudinal.

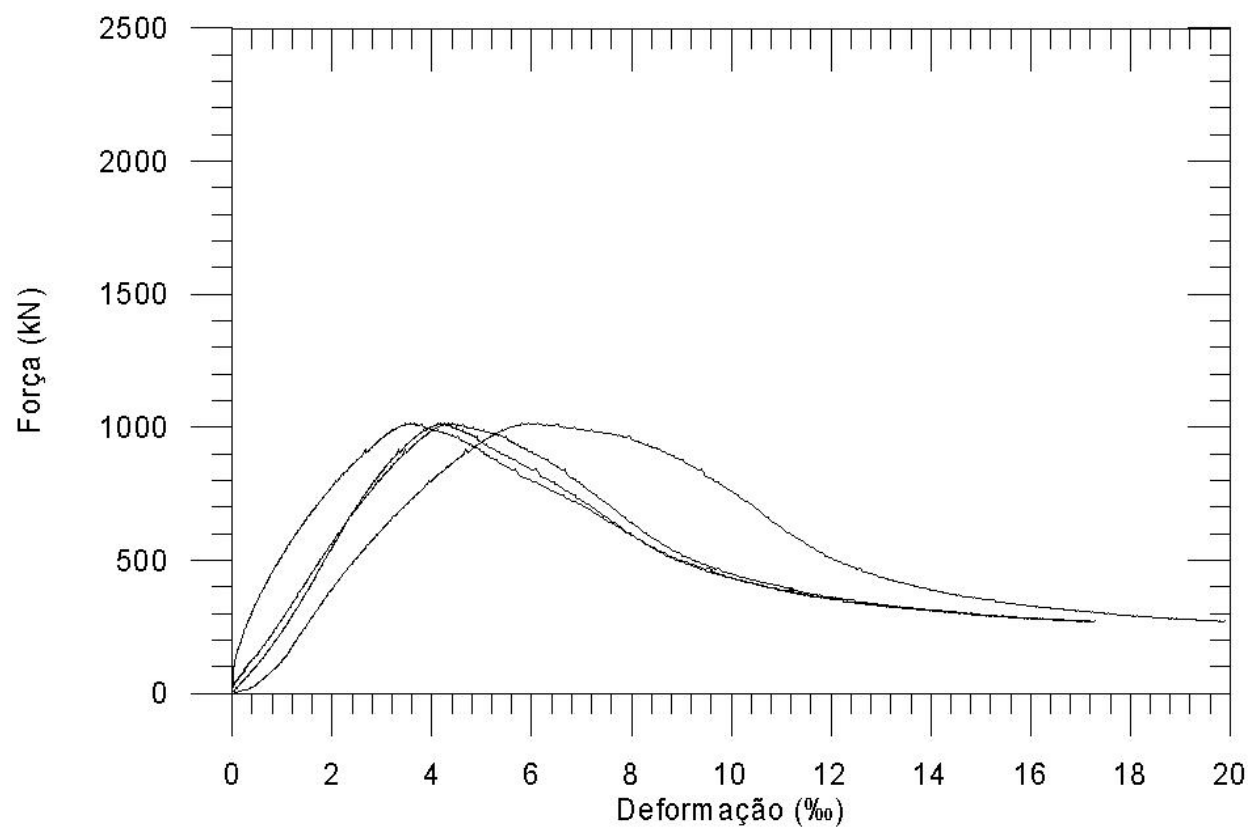

Figura A.6 - Diagramas força aplicada vs. deformação lida por cada LVDt. 


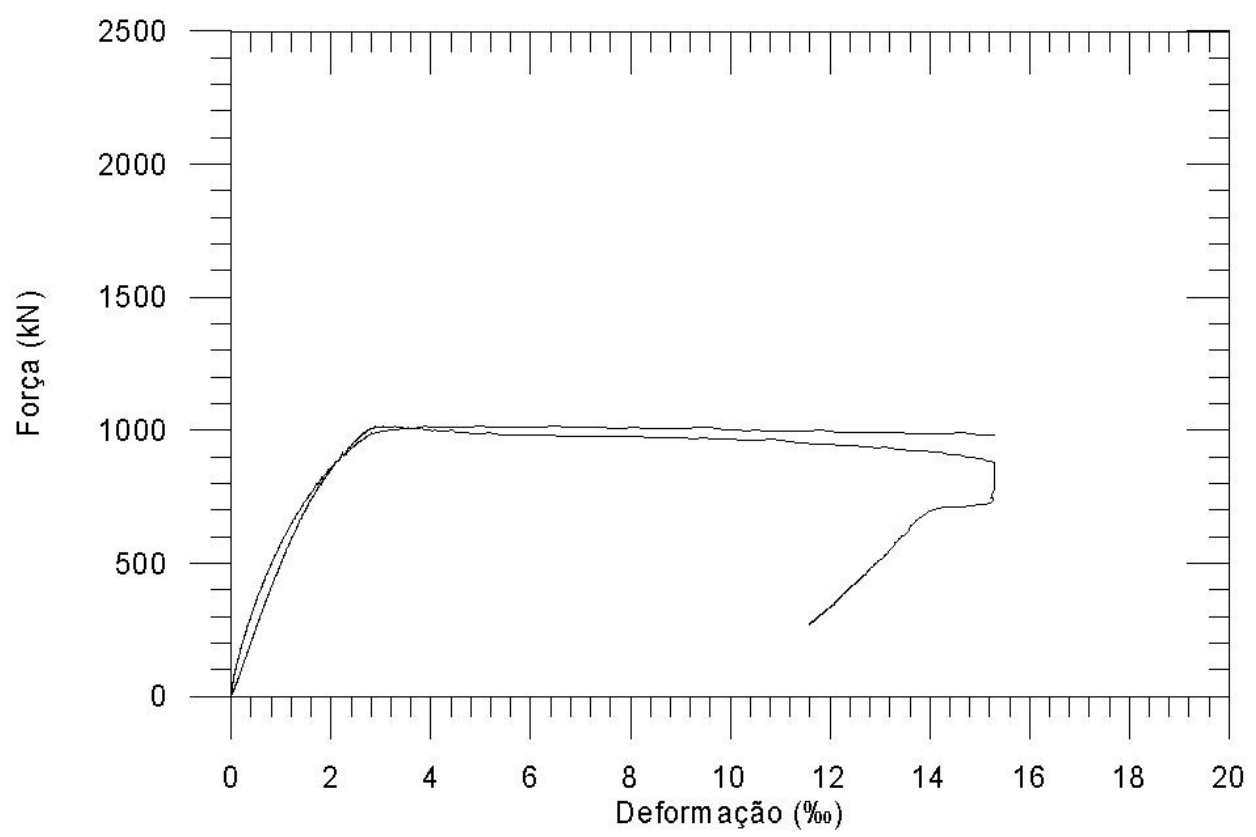

Figura A.7 - Diagramas força aplicada vs. deformação lida pelos extensômetros na armadura longitudinal.

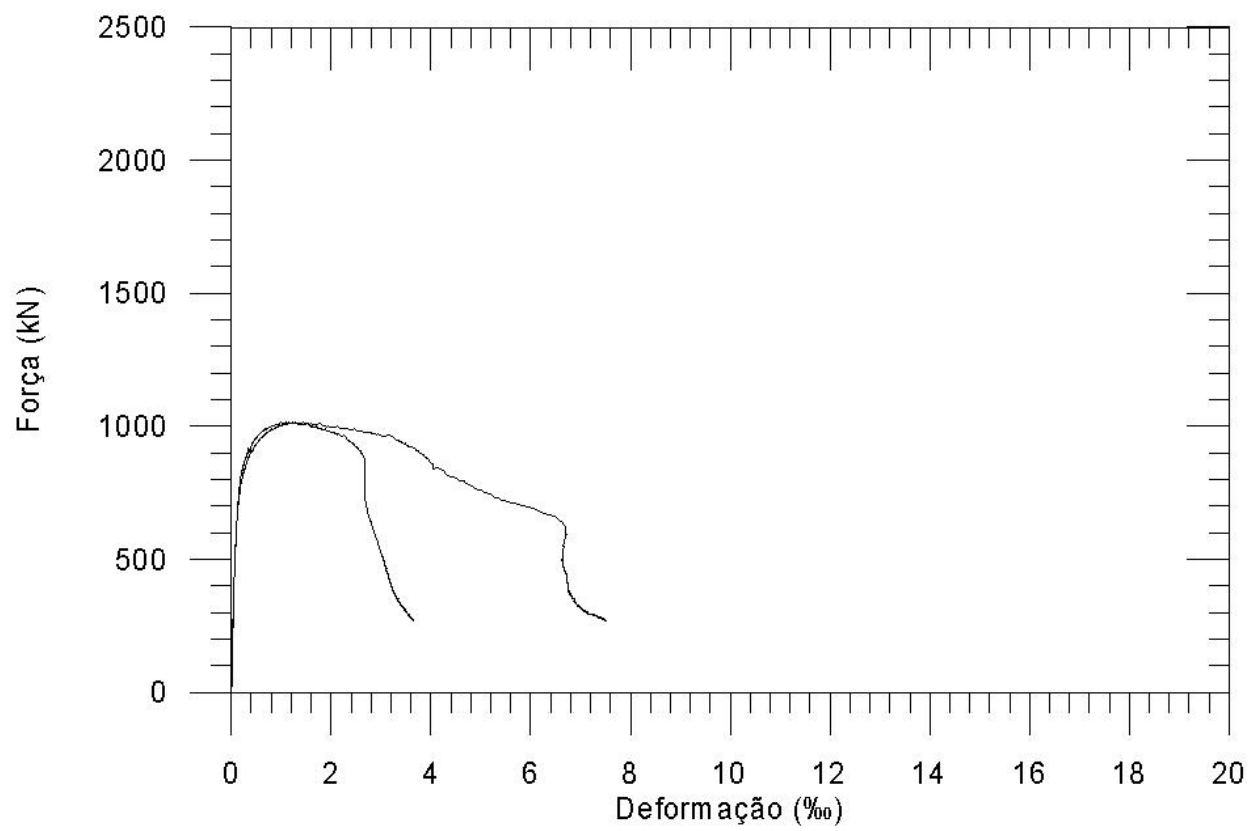

Figura A.8 - Diagramas força aplicada vs. deformação lida pelos extensômetros na armadura transversal. 


\section{A.3.Pilar P160150}

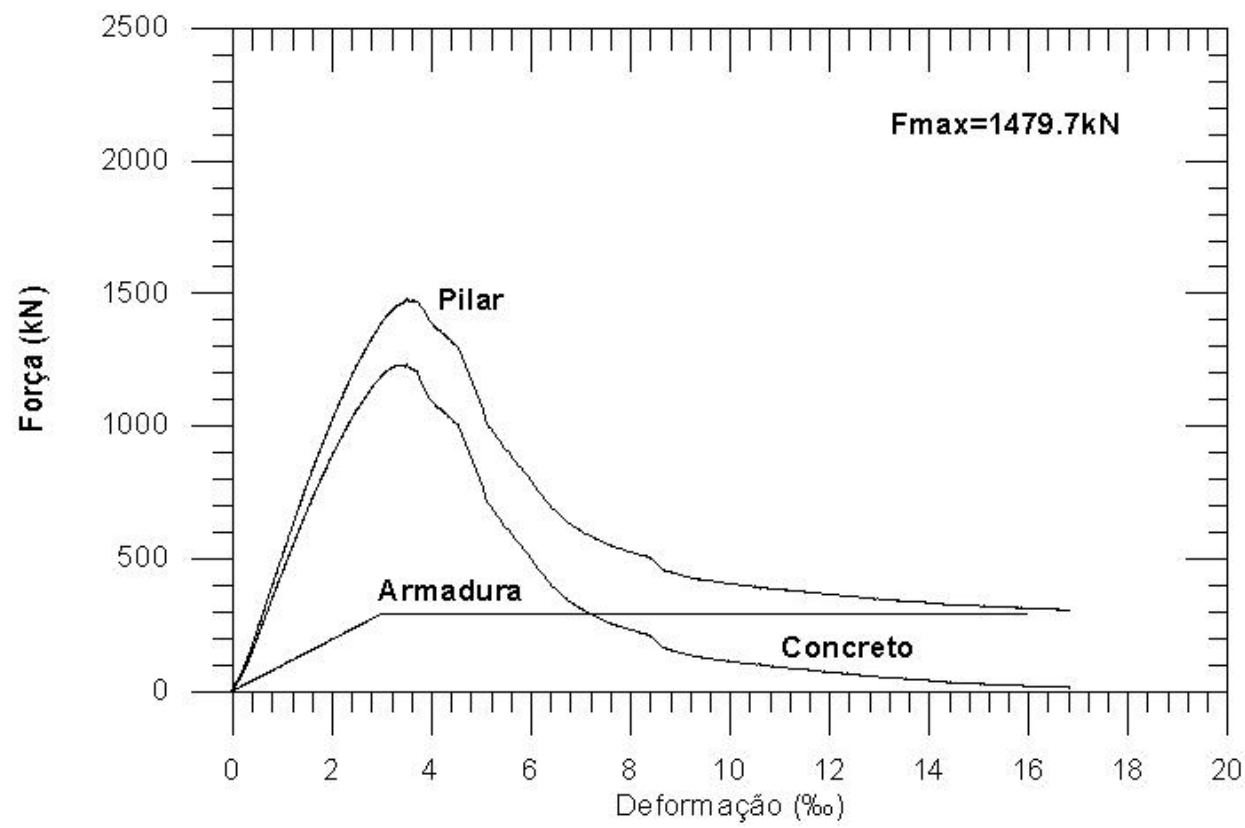

Figura A.9 - Diagramas forças parciais vs. deformação do pilar, do concreto e da armadura longitudinal.

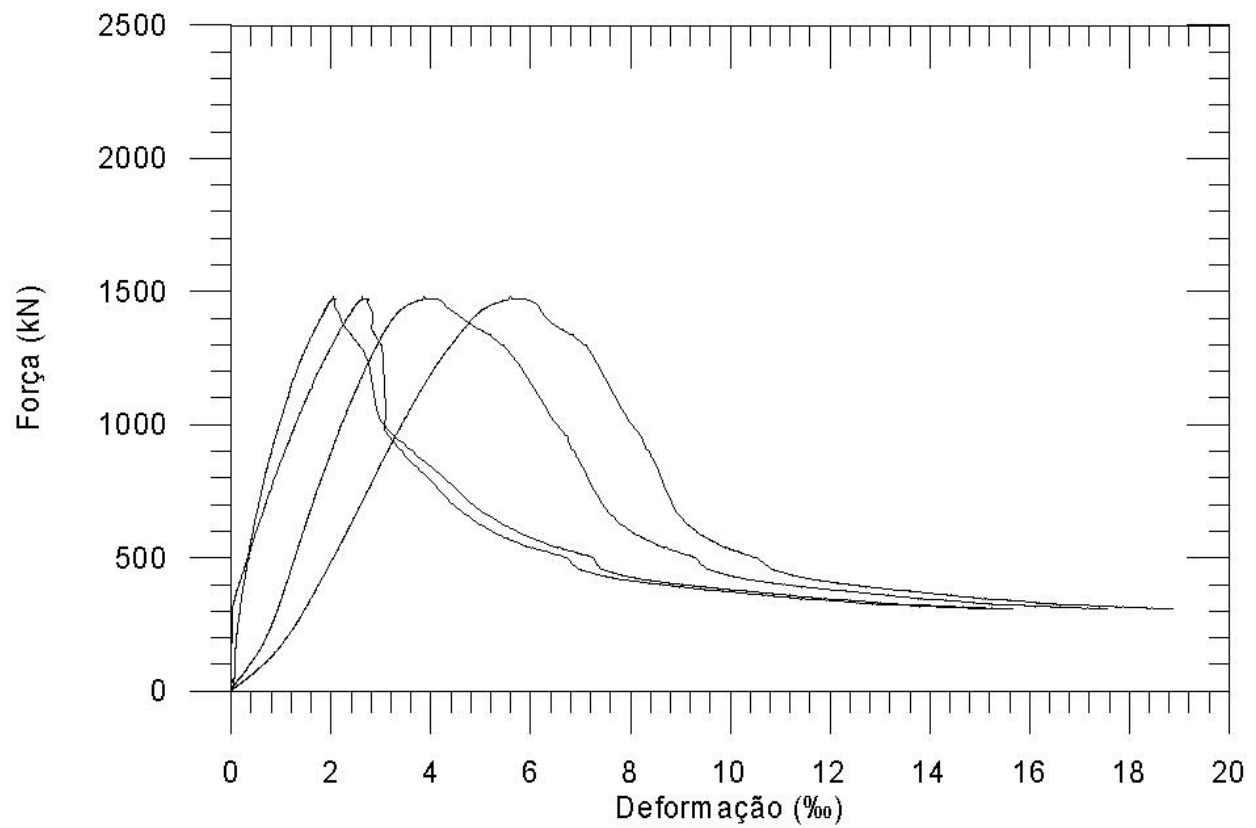

Figura A.10 - Diagramas força aplicada vs. deformação lida por cada LVDt. 


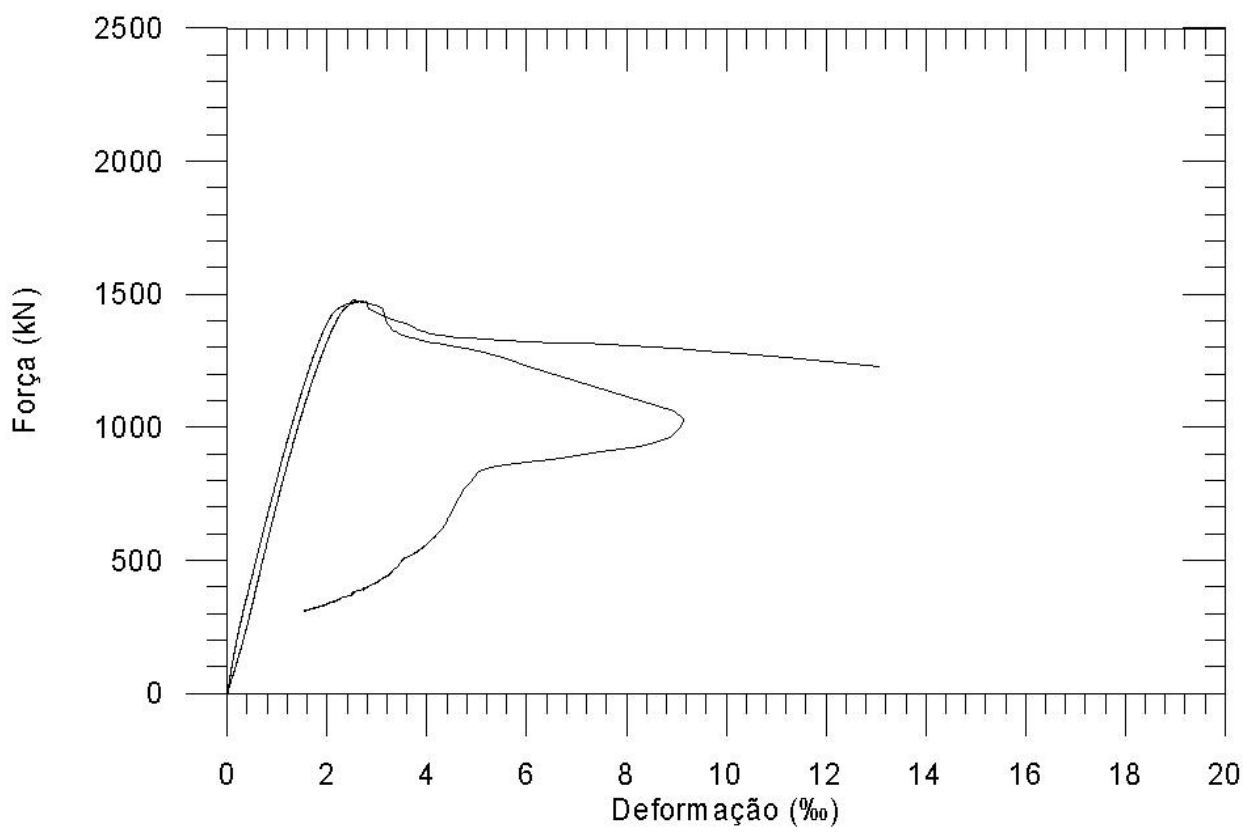

Figura A.11 - Diagramas força aplicada vs. deformação lida pelos extensômetros na armadura longitudinal.

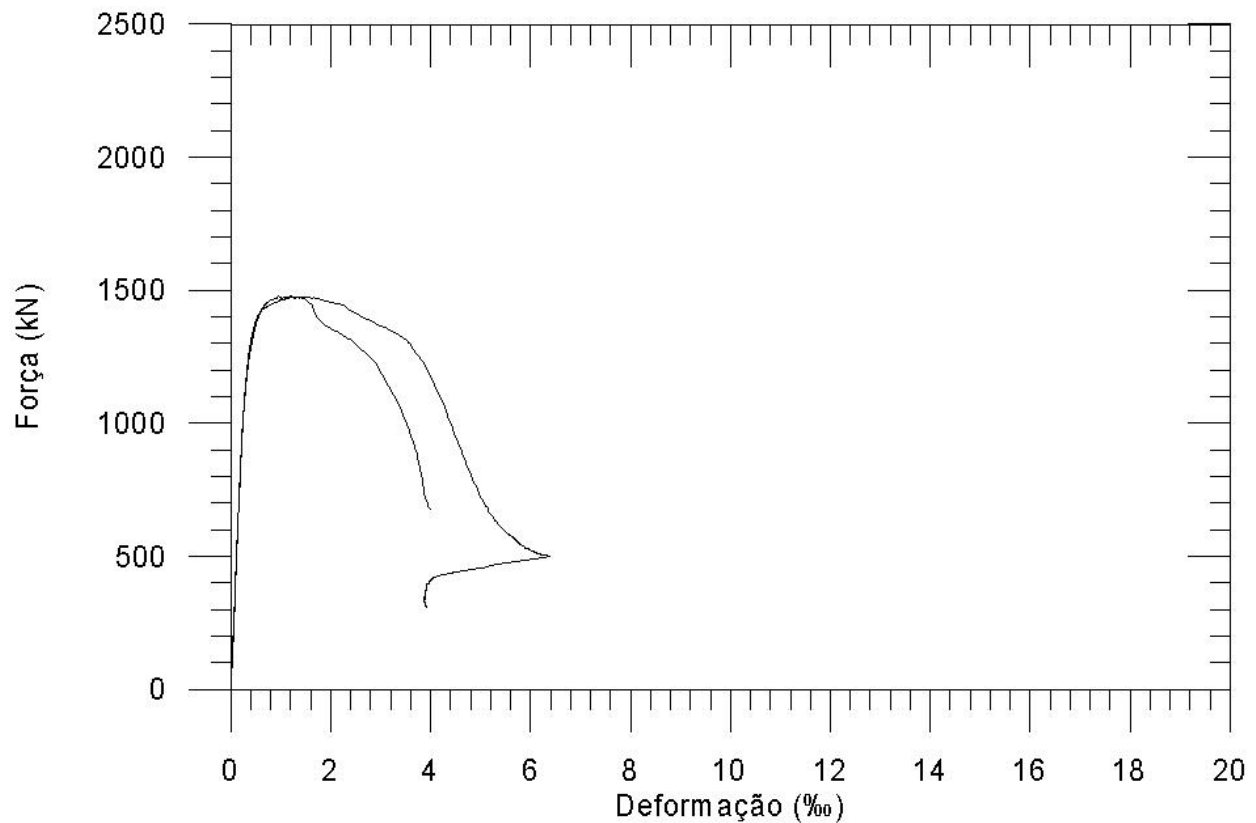

Figura A.12 - Diagramas força aplicada vs. deformação lida pelos extensômetros na armadura transversal. 


\section{A.4.Pilar P260150}

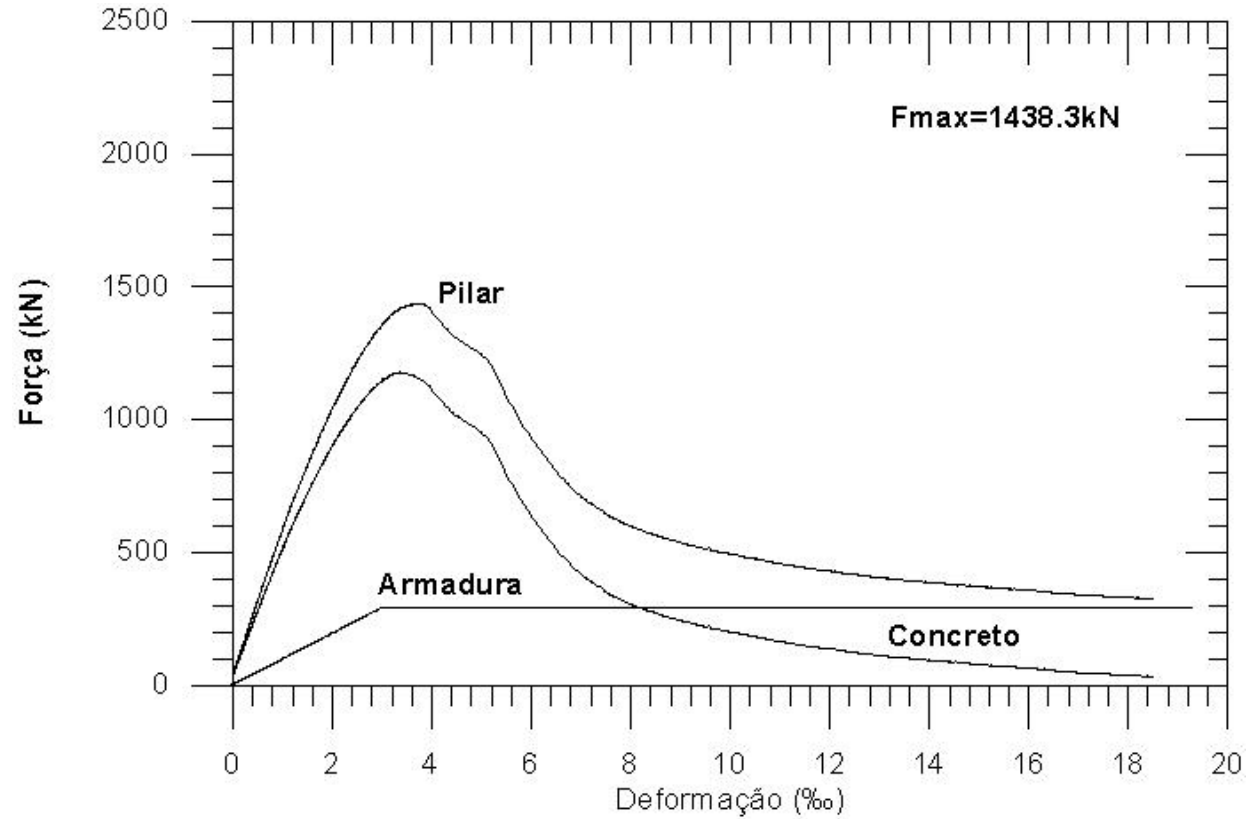

Figura A.13 - Diagramas forças parciais vs. deformação do pilar, do concreto e da armadura longitudinal.

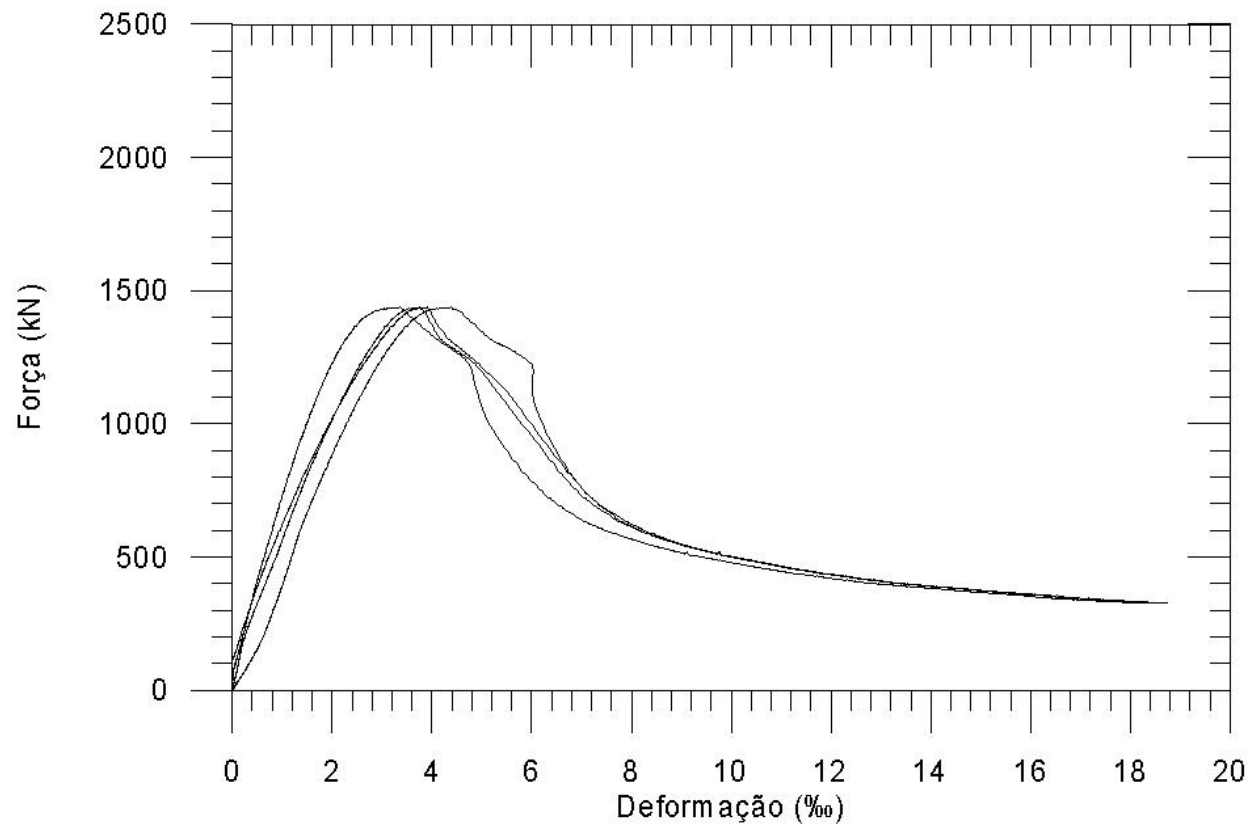

Figura A.14 - Diagramas força aplicada vs. deformação lida por cada LVDt. 


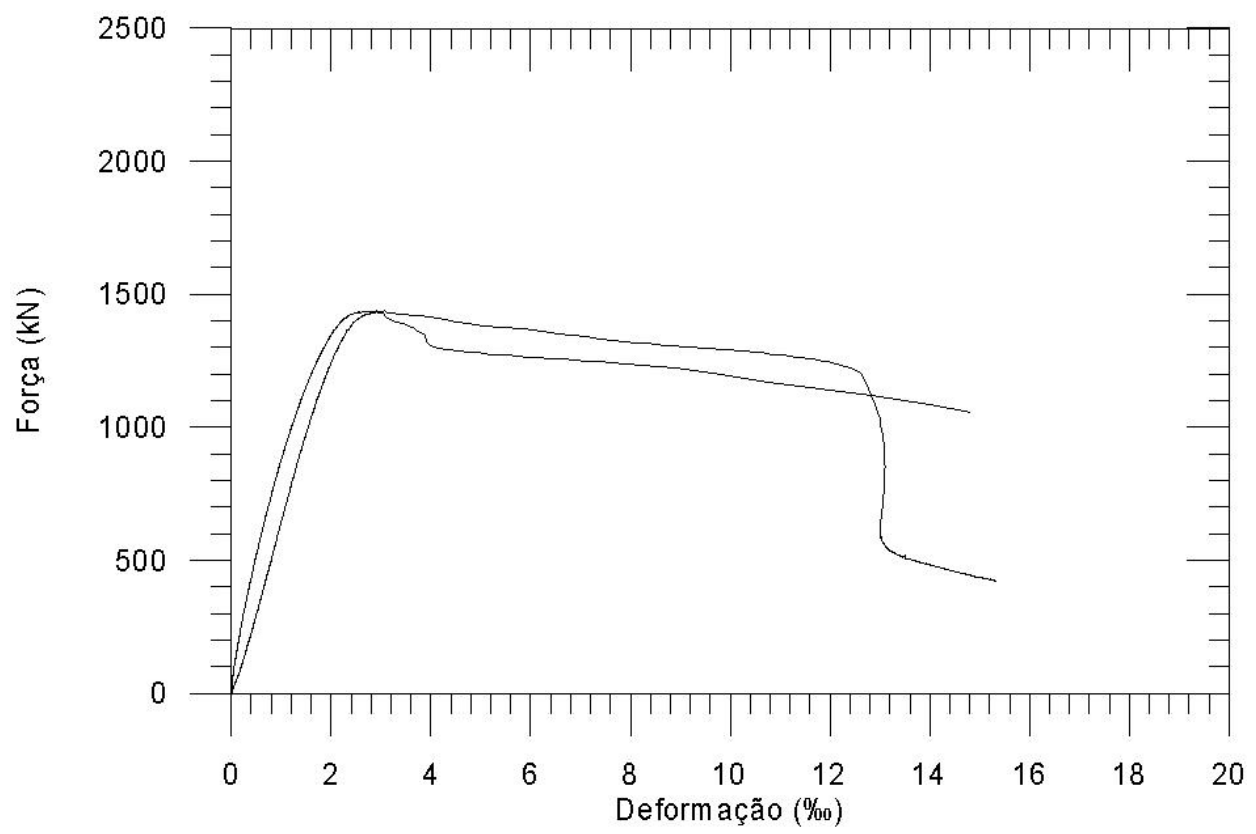

Figura A.15 - Diagramas força aplicada vs. deformação lida pelos extensômetros na armadura longitudinal.

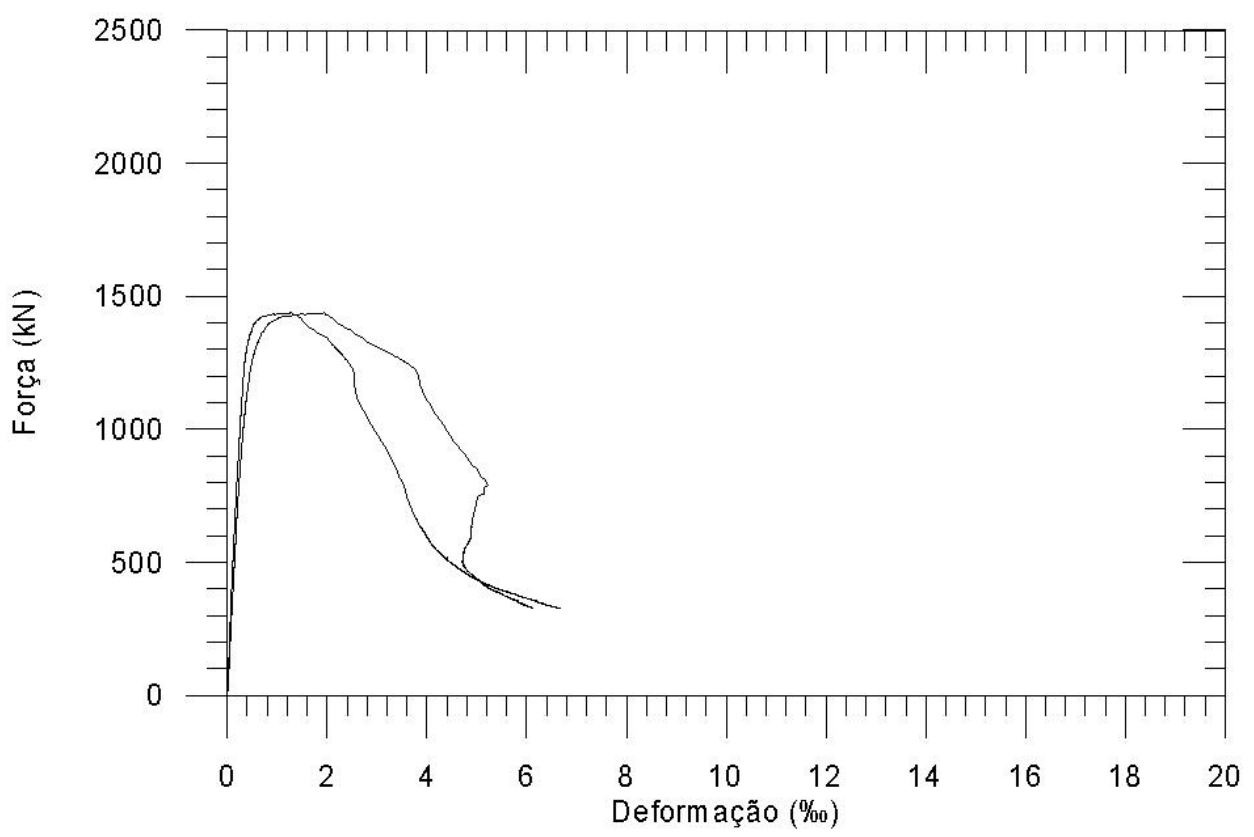

Figura A.16 - Diagramas força aplicada vs. deformação lida pelos extensômetros na armadura transversal. 


\section{A.5.Pilar P16050}

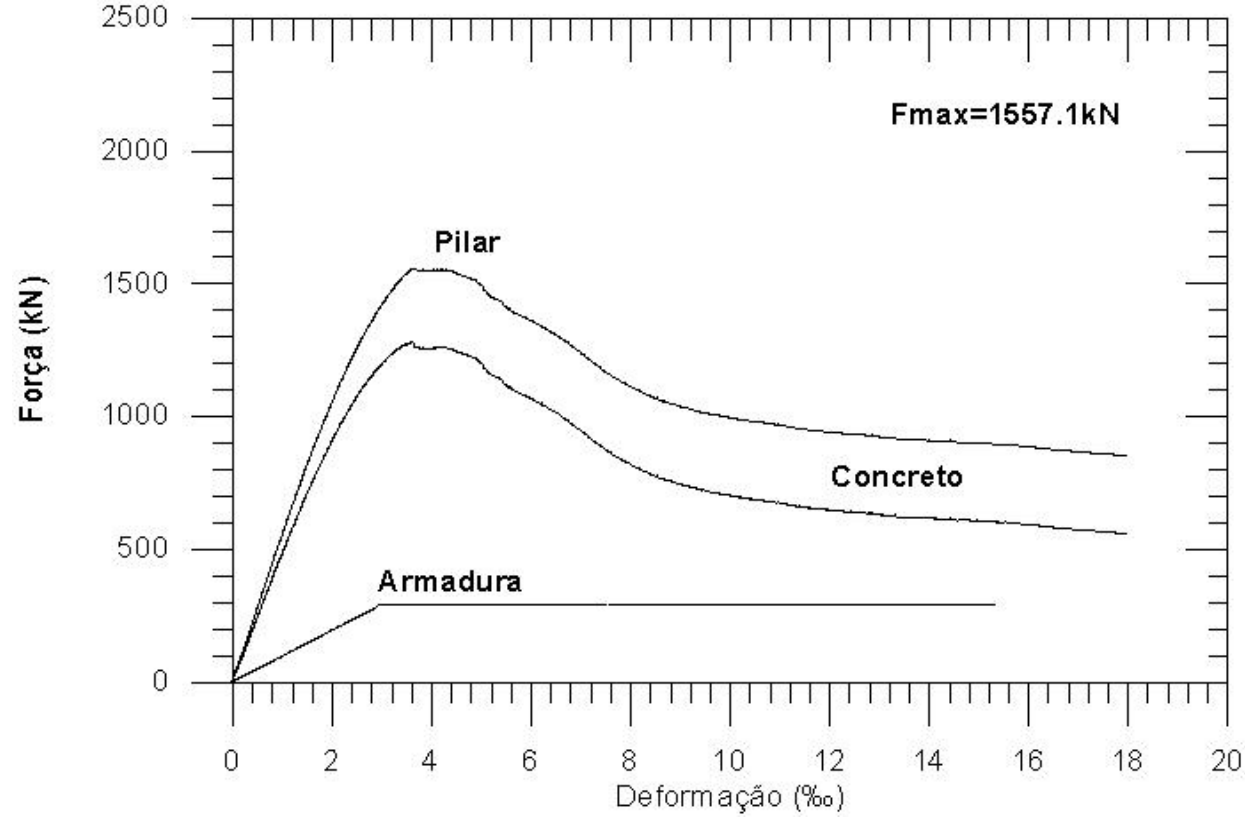

Figura A.17 - Diagramas forças parciais vs. deformação do pilar, do concreto e da armadura longitudinal.

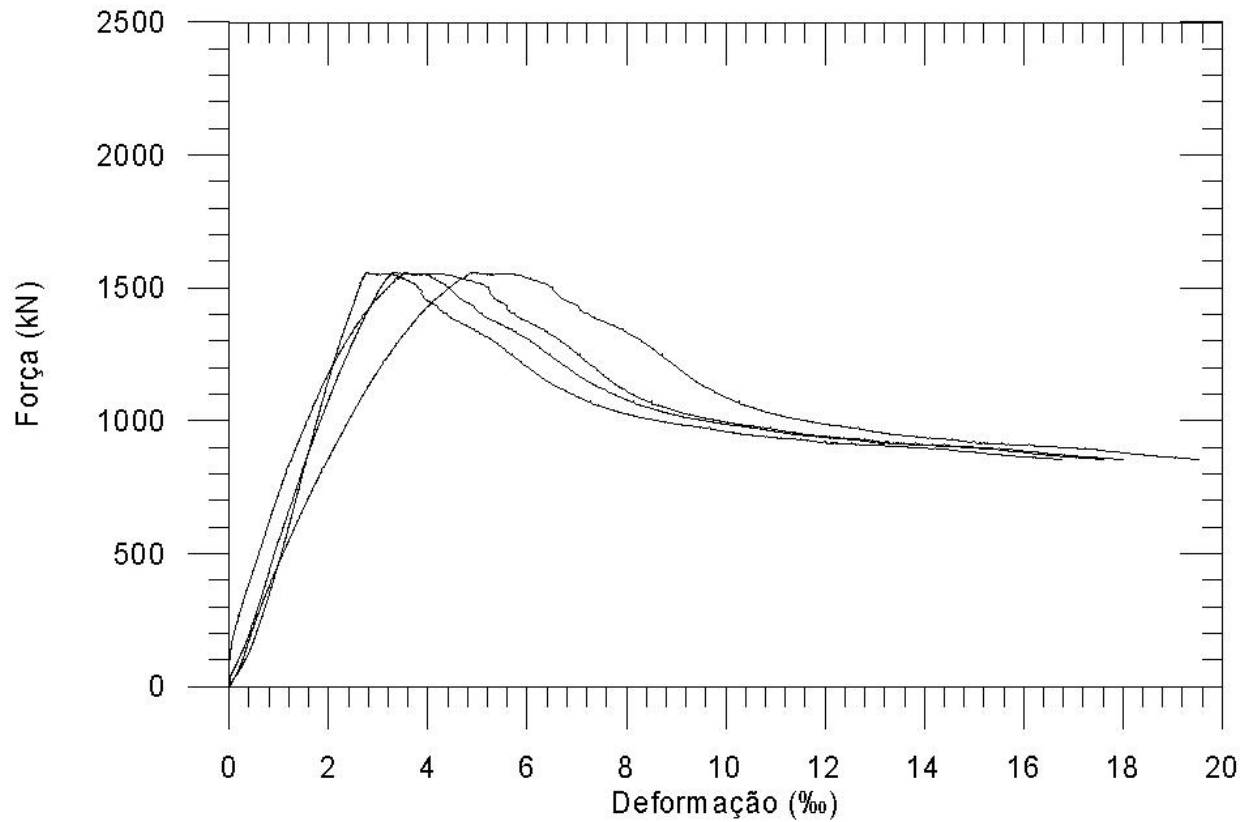

Figura A.18 - Diagramas força aplicada vs. deformação lida por cada LVDt. 


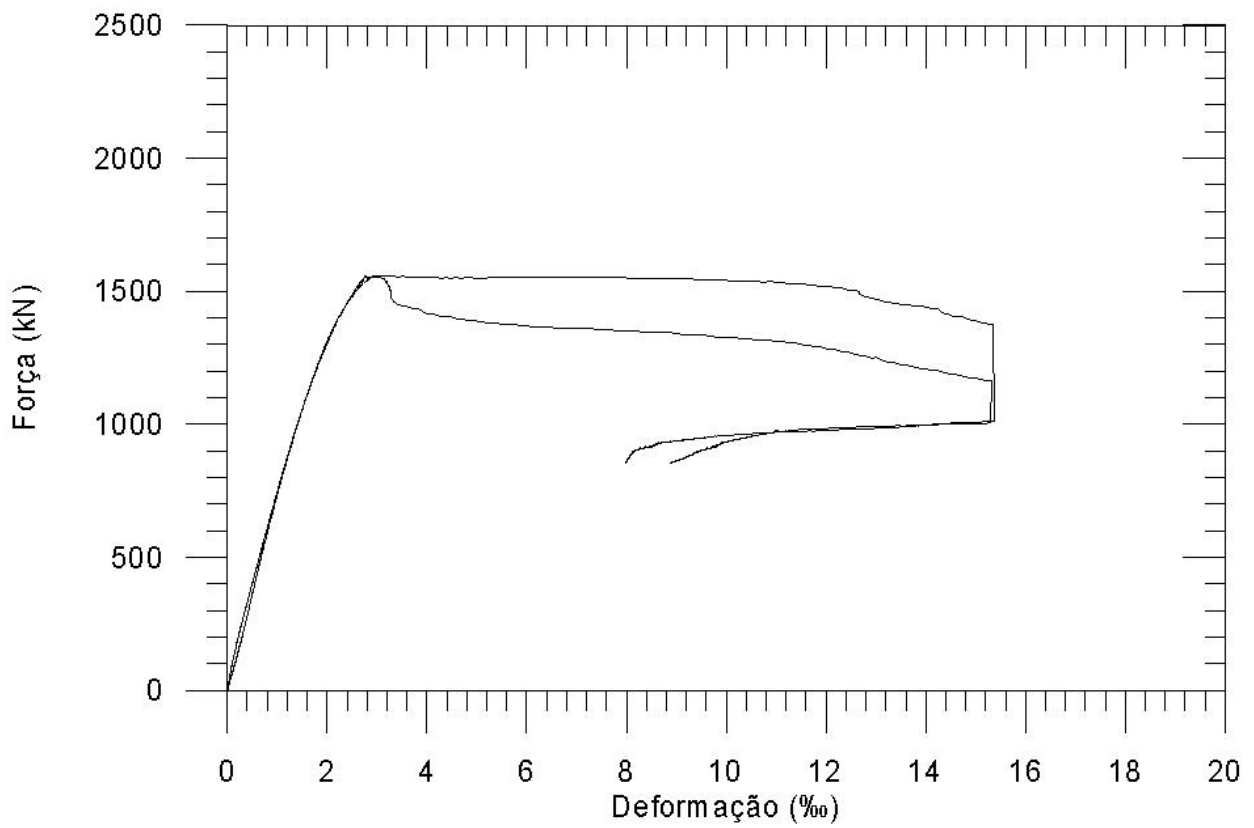

Figura A.19 - Diagramas força aplicada vs. deformação lida pelos extensômetros na armadura longitudinal.

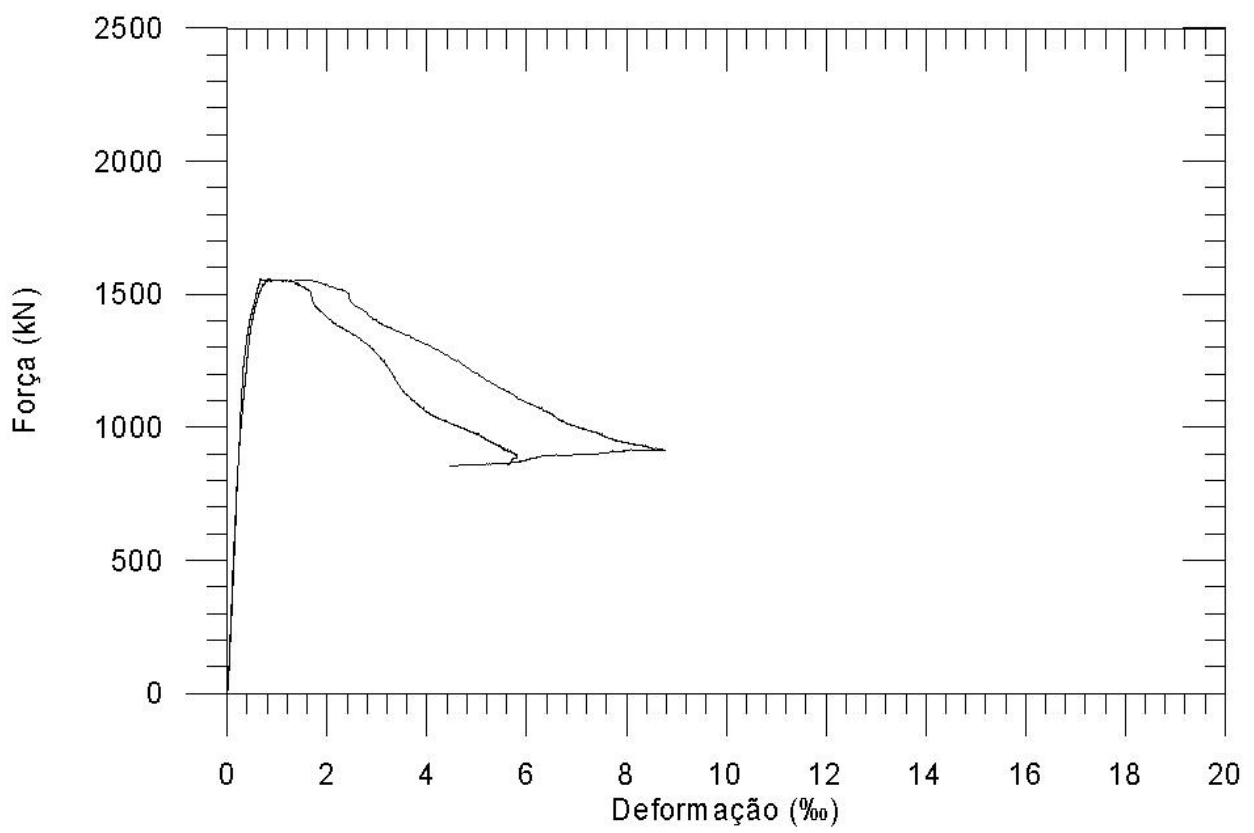

Figura A.20 - Diagramas força aplicada vs. deformação lida pelos extensômetros na armadura transversal. 


\section{A.6.Pilar P26050}

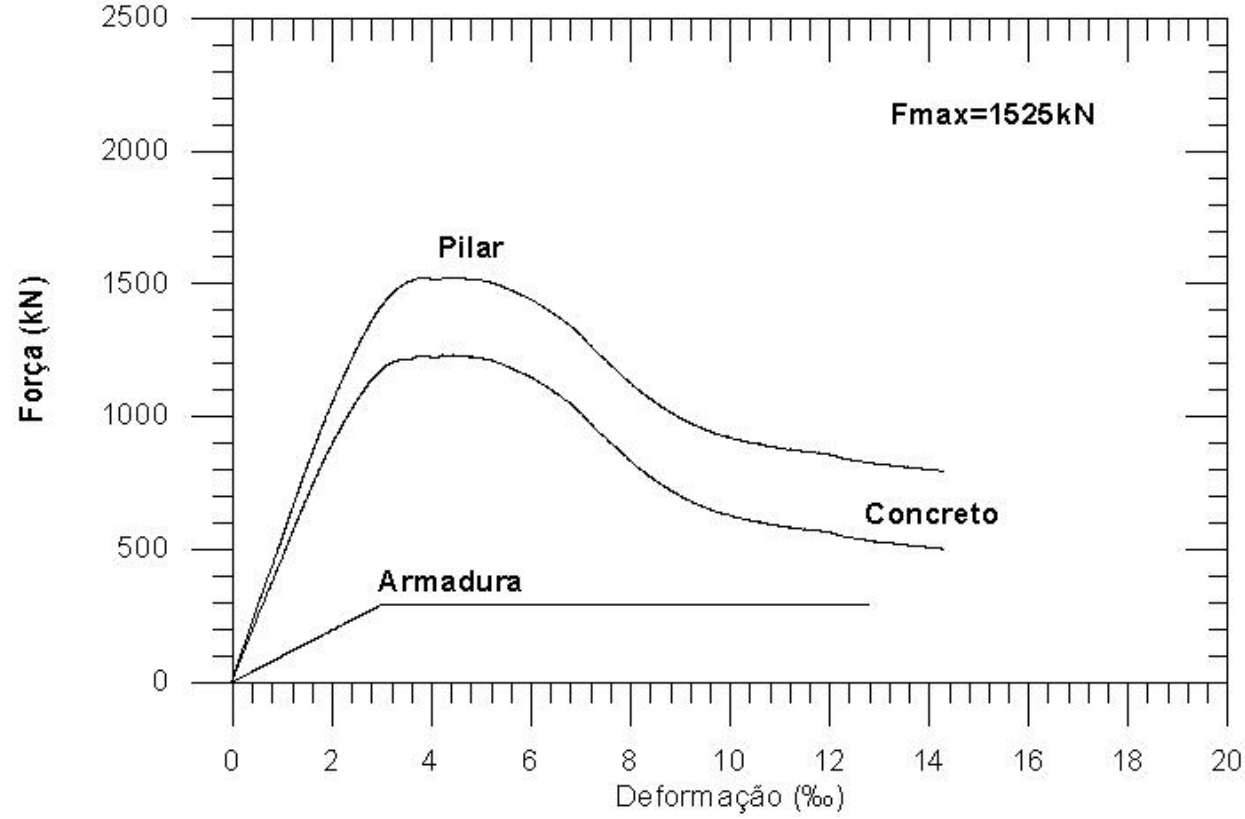

Figura A.21 - Diagramas forças parciais vs. deformação do pilar, do concreto e da armadura longitudinal.

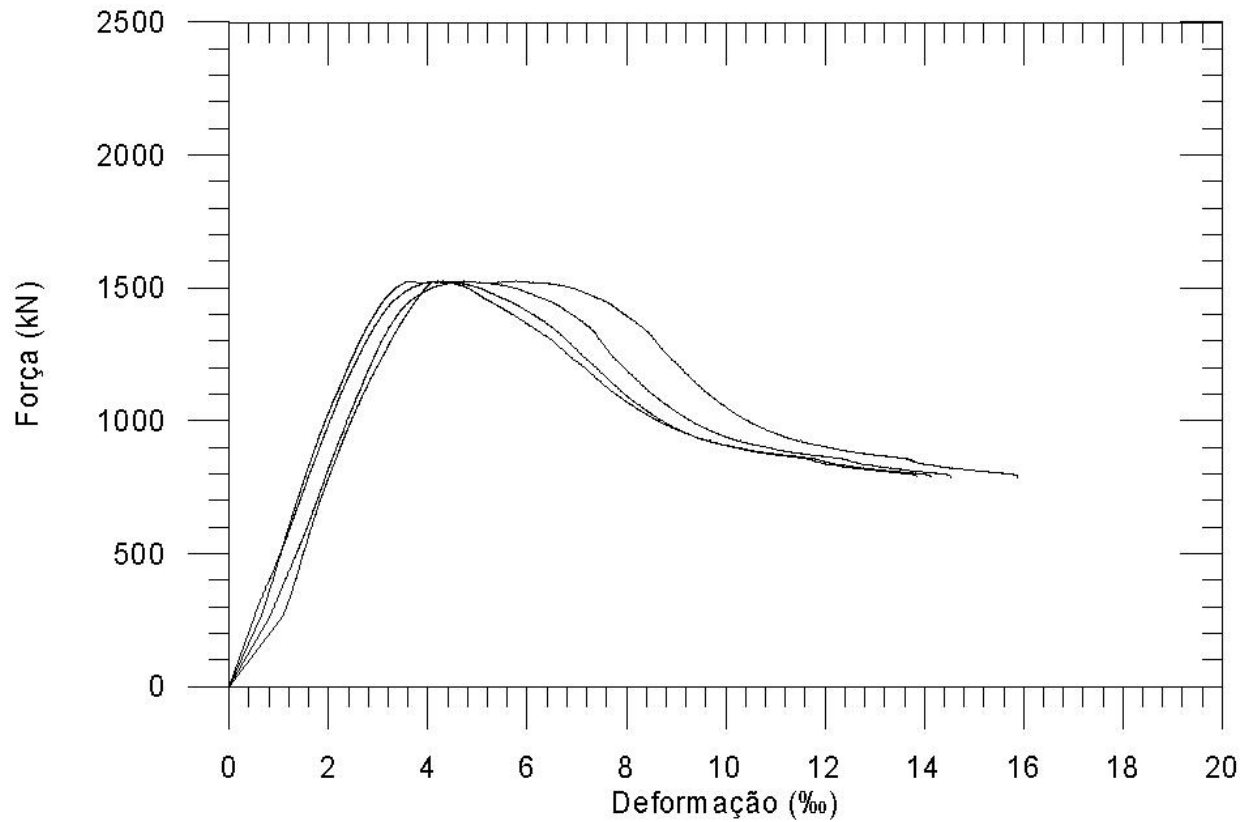

Figura A.22 - Diagramas força aplicada vs. deformação lida por cada LVDt. 


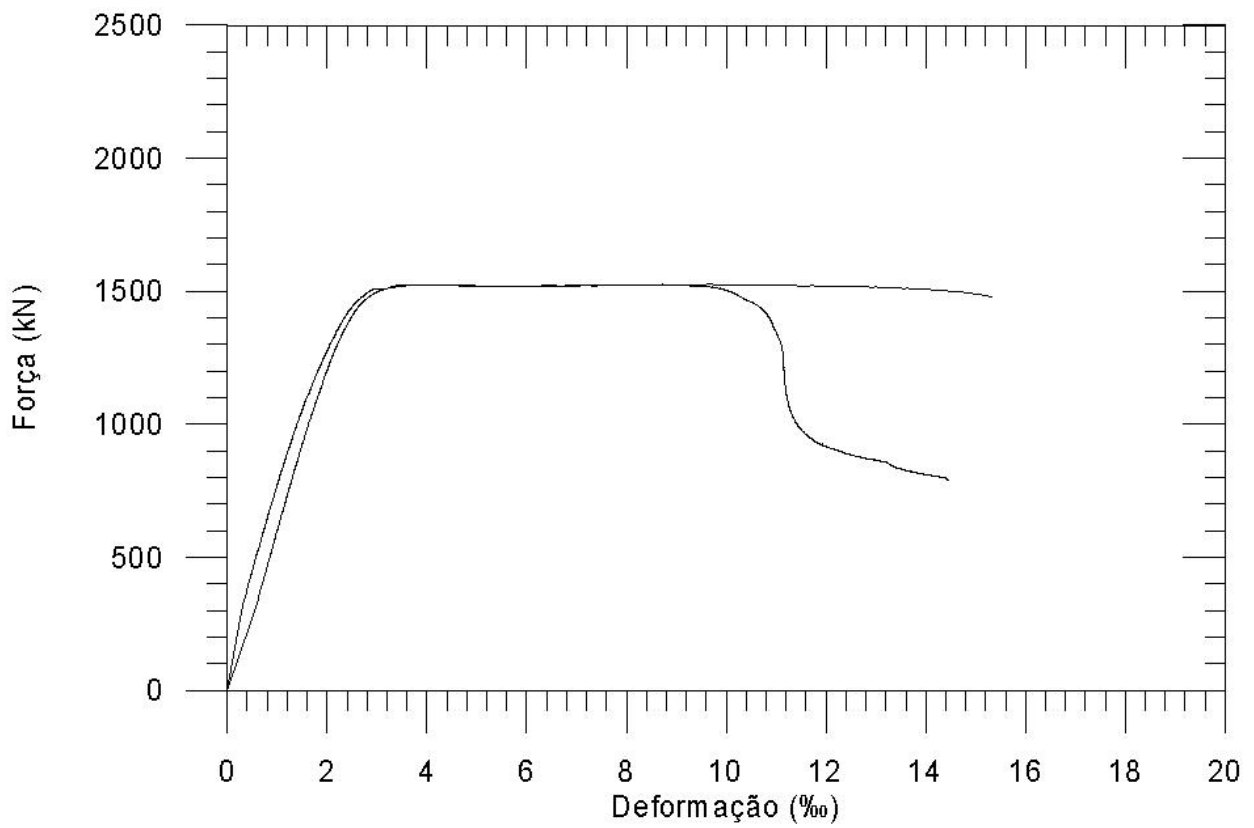

Figura A.23 - Diagramas força aplicada vs. deformação lida pelos extensômetros na armadura longitudinal.

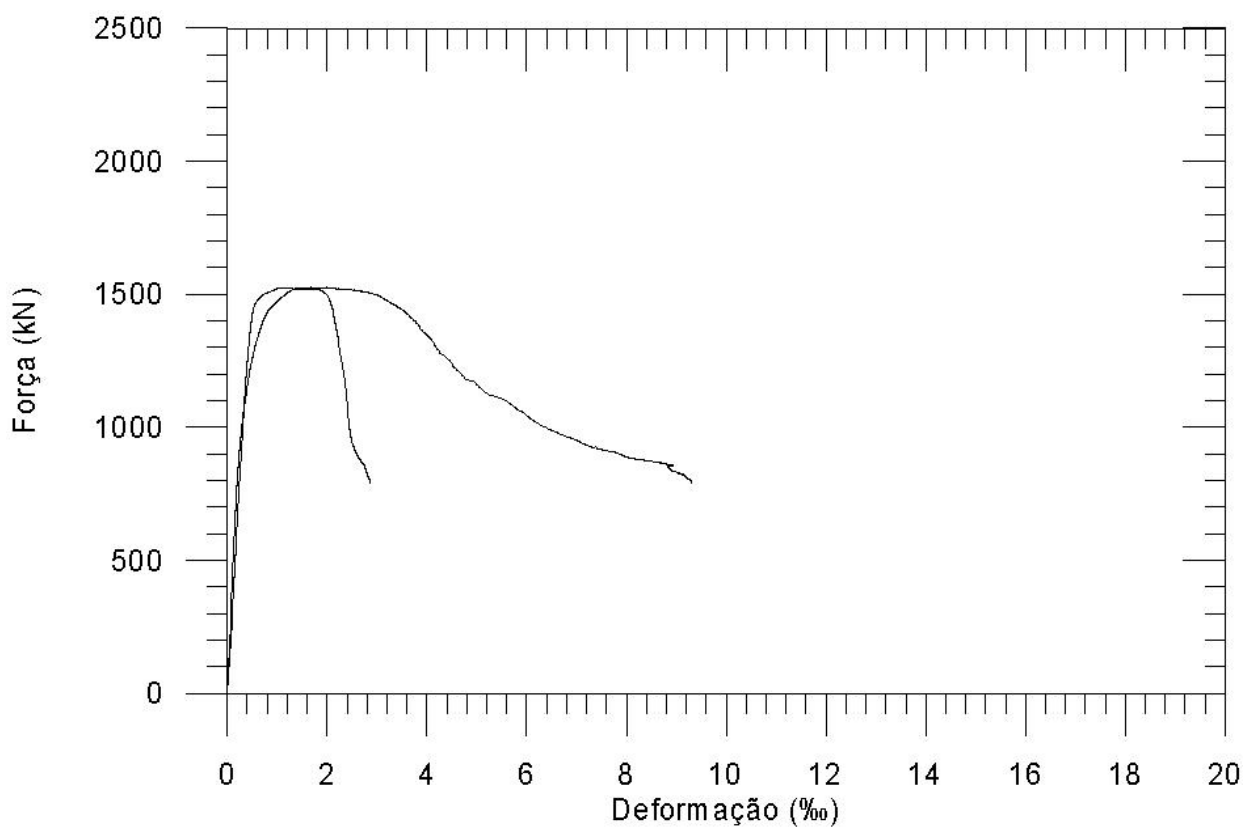

Figura A.24 - Diagramas força aplicada vs. deformação lida pelos extensômetros na armadura transversal. 


\section{A.7.Pilar P1601505}

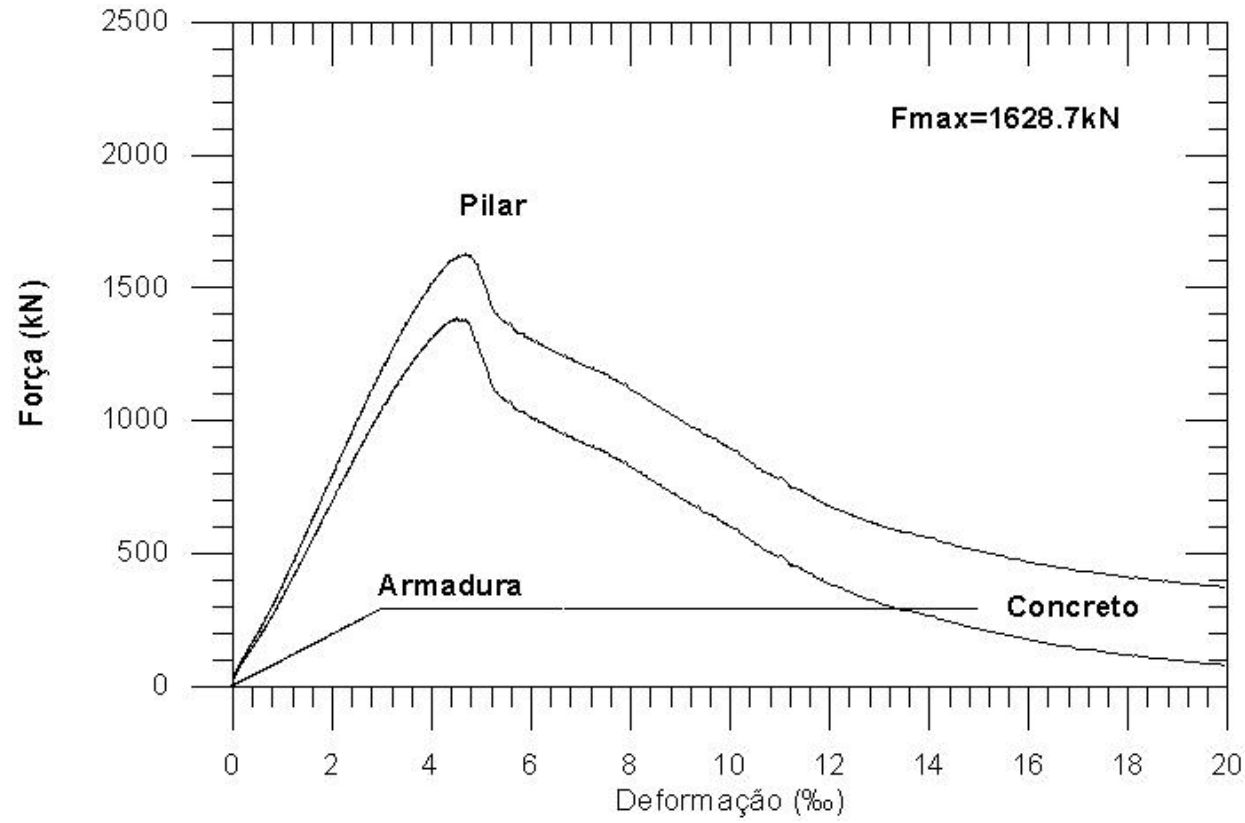

Figura A.25 - Diagramas forças parciais vs. deformação do pilar, do concreto e da armadura longitudinal.

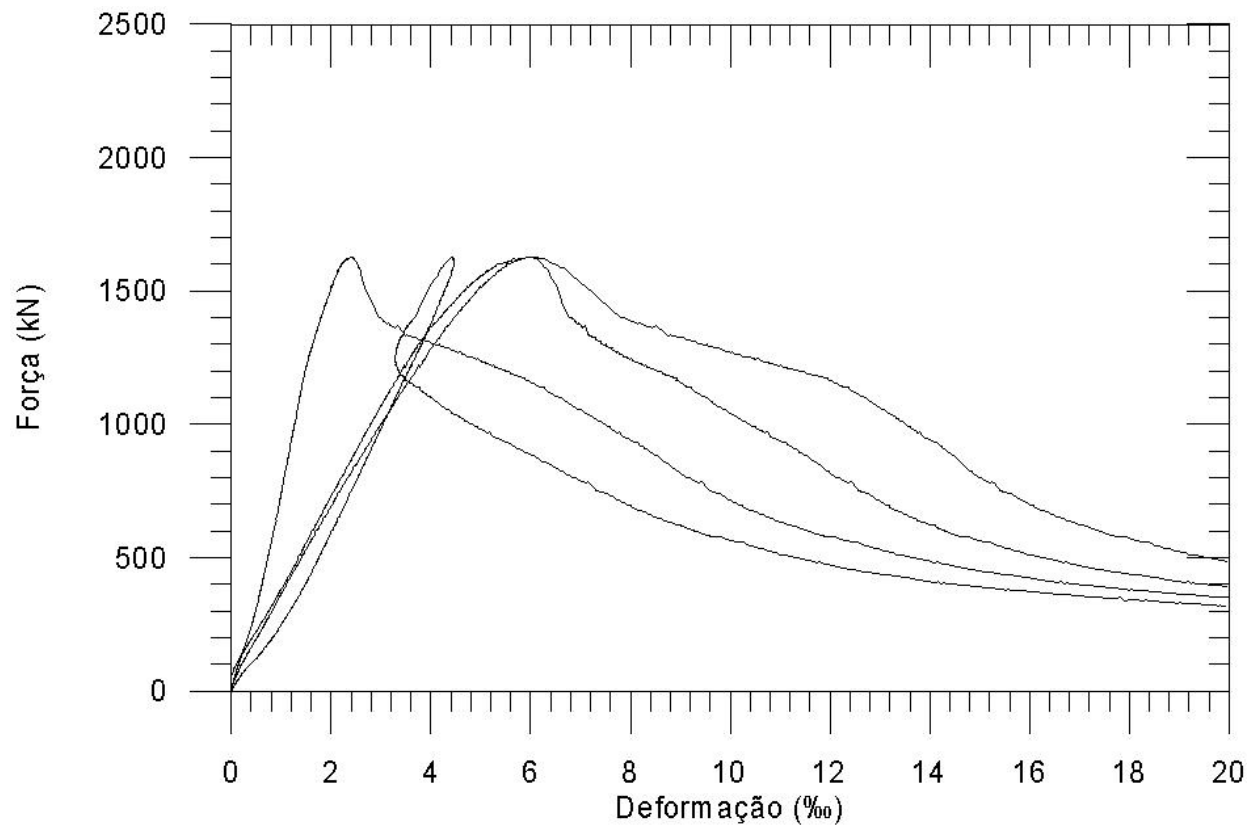

Figura A.26 - Diagramas força aplicada vs. deformação lida por cada LVDt. 


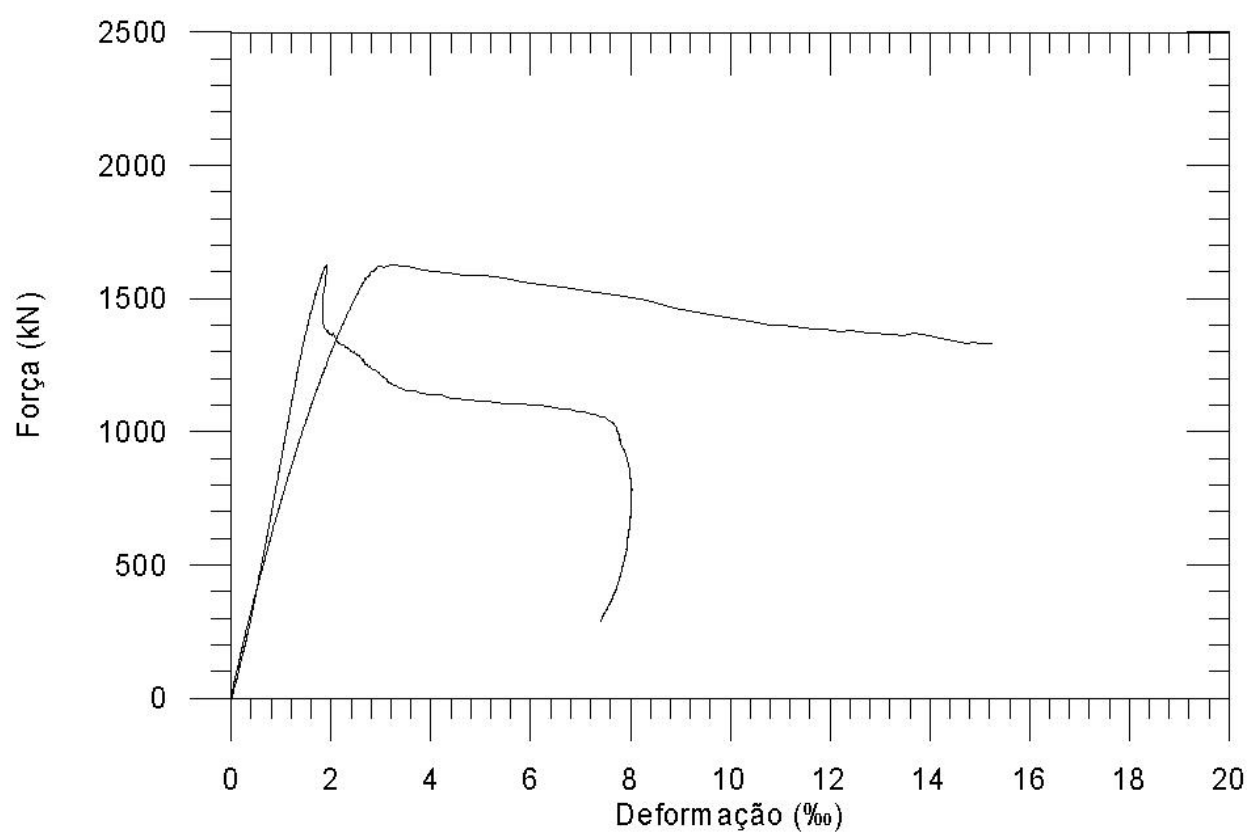

Figura A.27 - Diagramas força aplicada vs. deformação lida pelos extensômetros na armadura longitudinal.

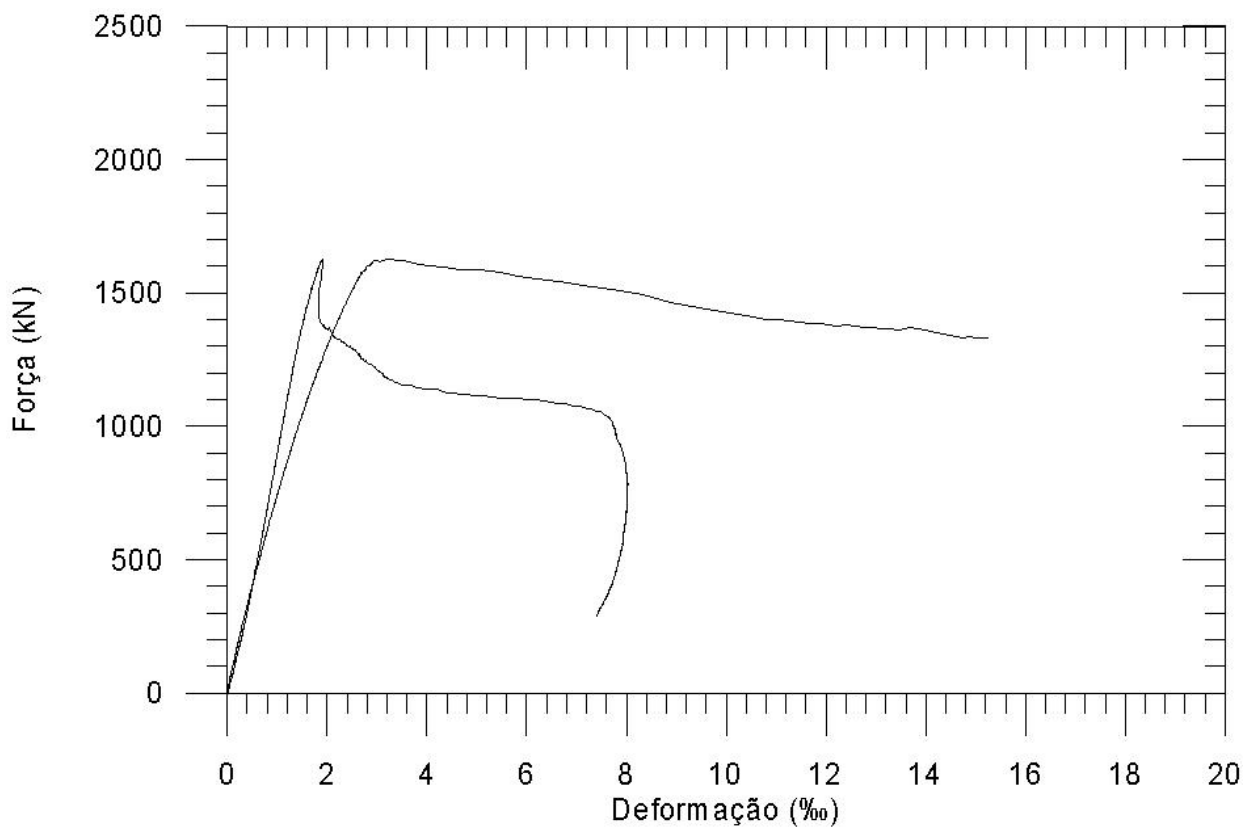

Figura A.28 - Diagramas força aplicada vs. deformação lida pelos extensômetros na armadura transversal. 


\section{A.8.Pilar P2601505}

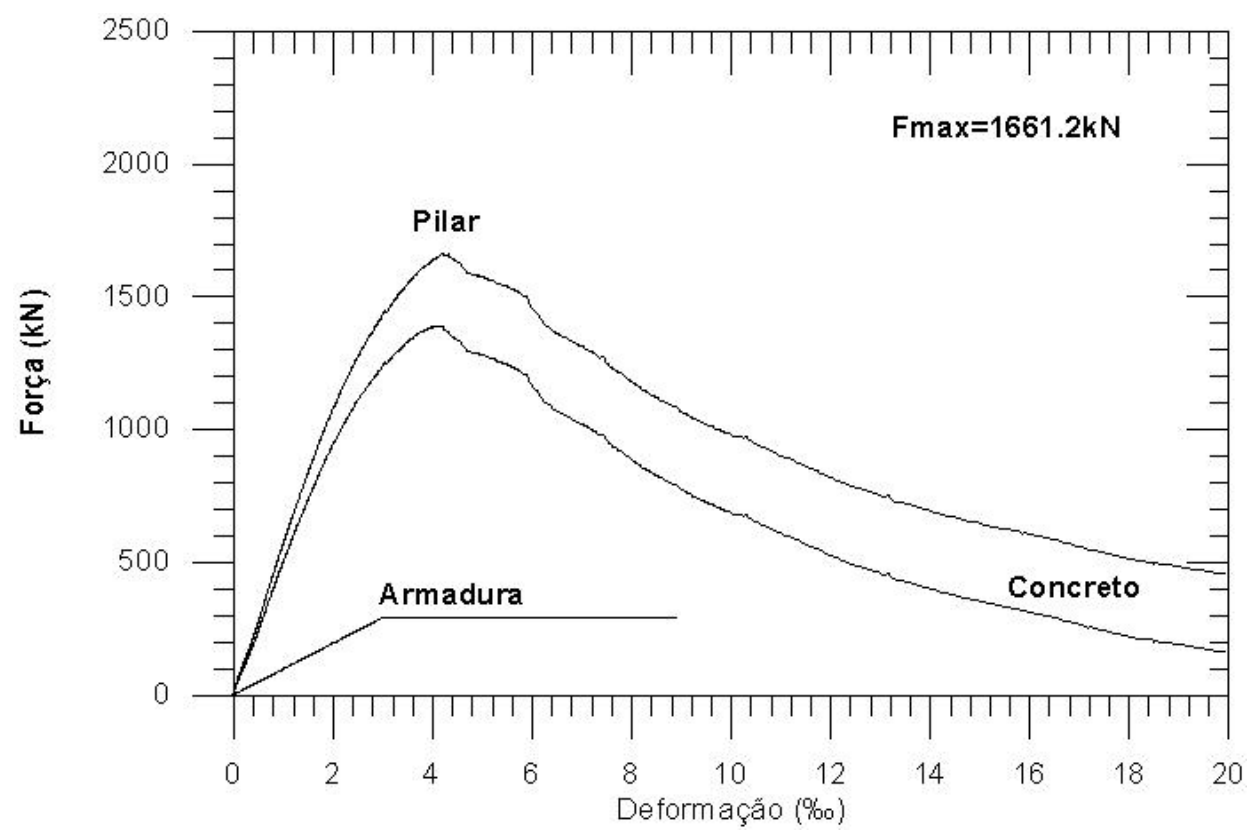

Figura A.29 - Diagramas forças parciais vs. deformação do pilar, do concreto e da armadura longitudinal.

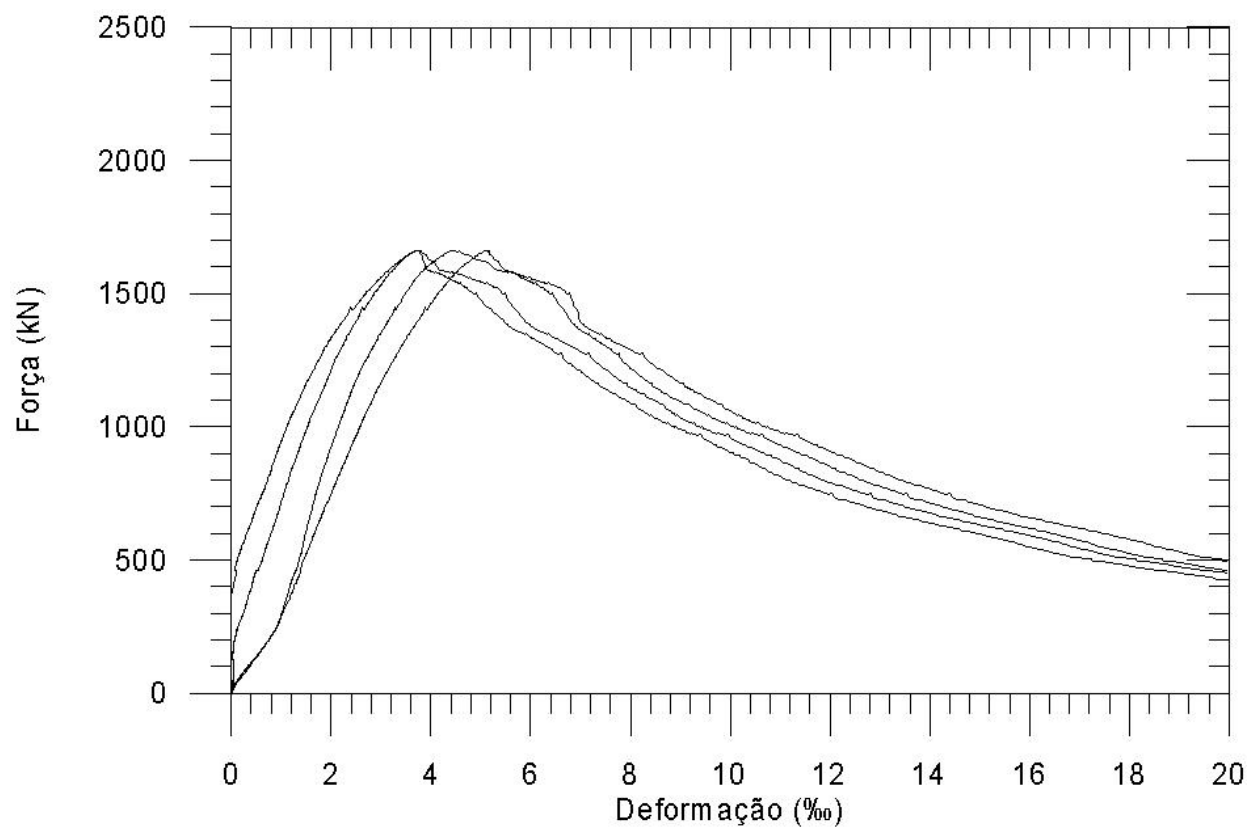

Figura A.30 - Diagramas força aplicada vs. deformação lida por cada LVDt. 


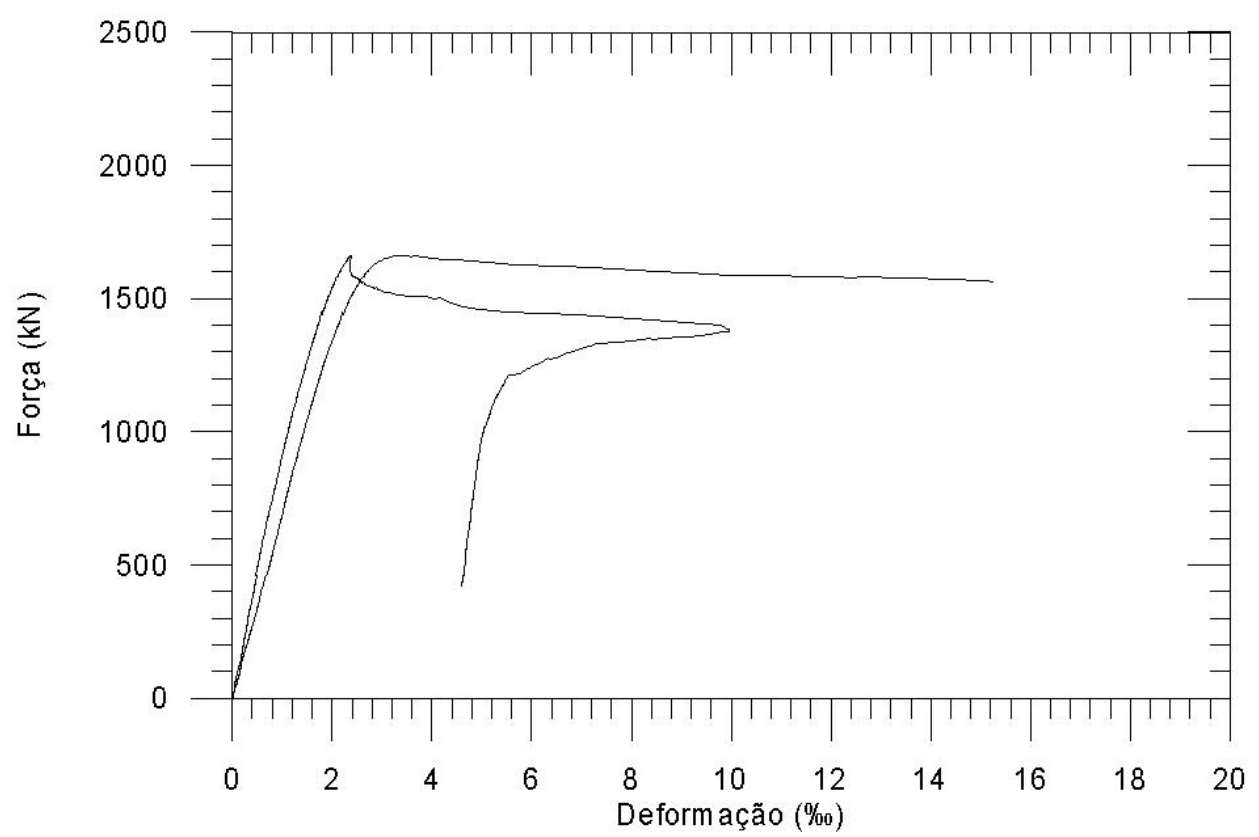

Figura A.31 - Diagramas força aplicada vs. deformação lida pelos extensômetros na armadura longitudinal.

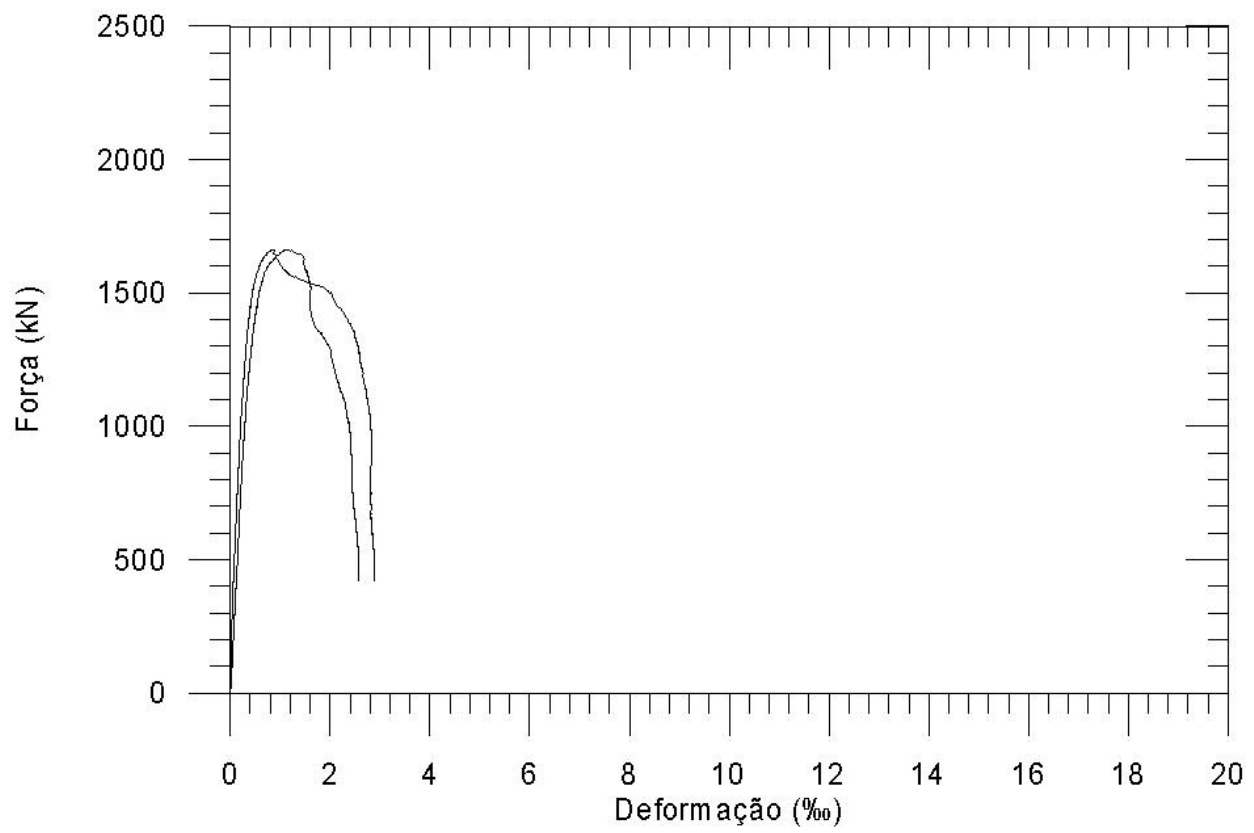

Figura A.32 - Diagramas força aplicada vs. deformação lida pelos extensômetros na armadura transversal. 


\section{A.9.Pilar P160505}

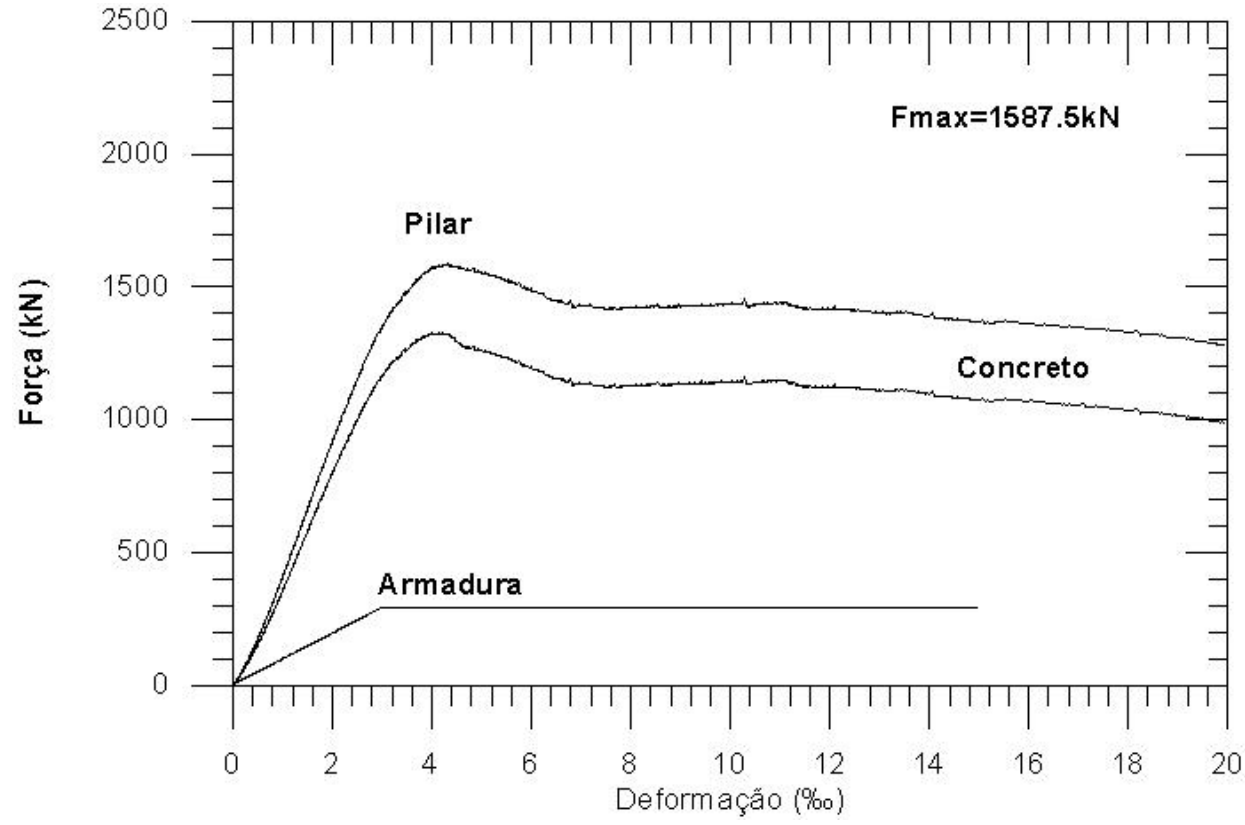

Figura A.33 - Diagramas forças parciais vs. deformação do pilar, do concreto e da armadura longitudinal.

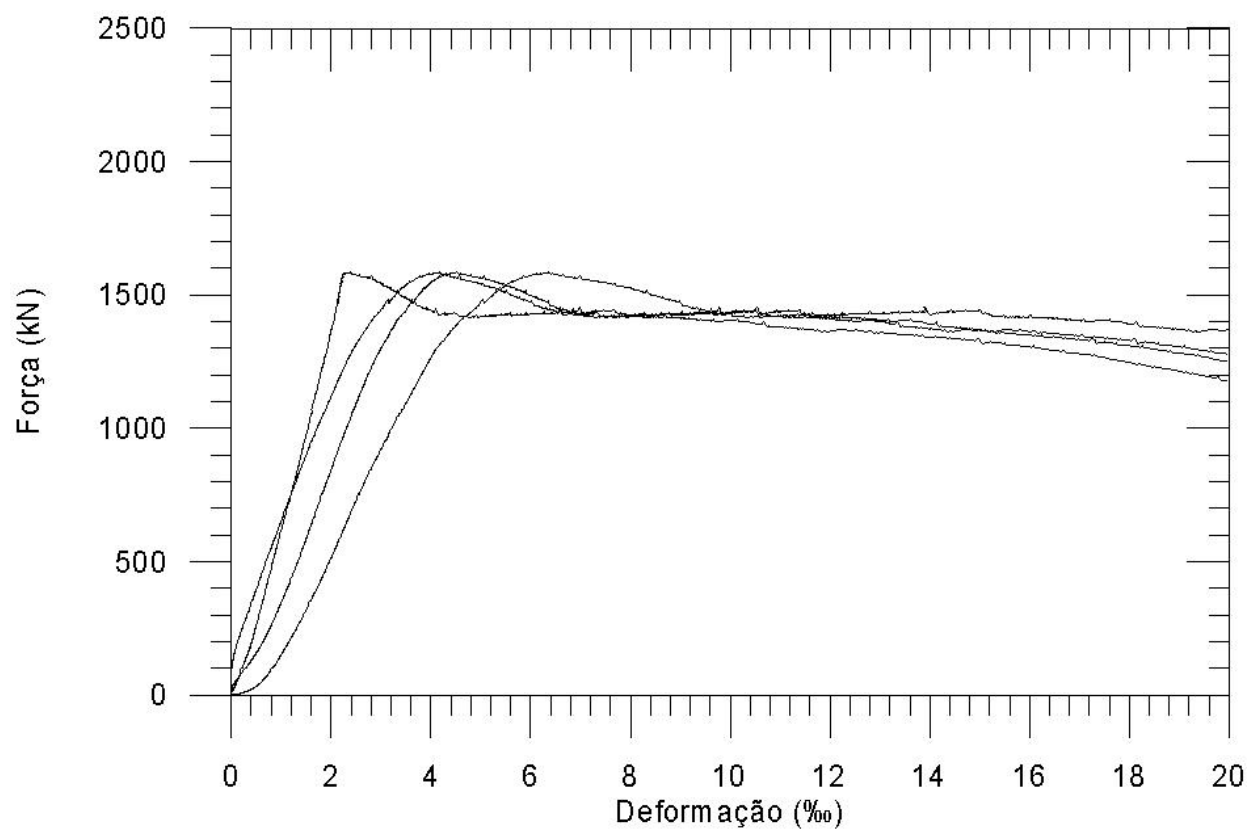

Figura A.34 - Diagramas força aplicada vs. deformação lida por cada LVDt. 


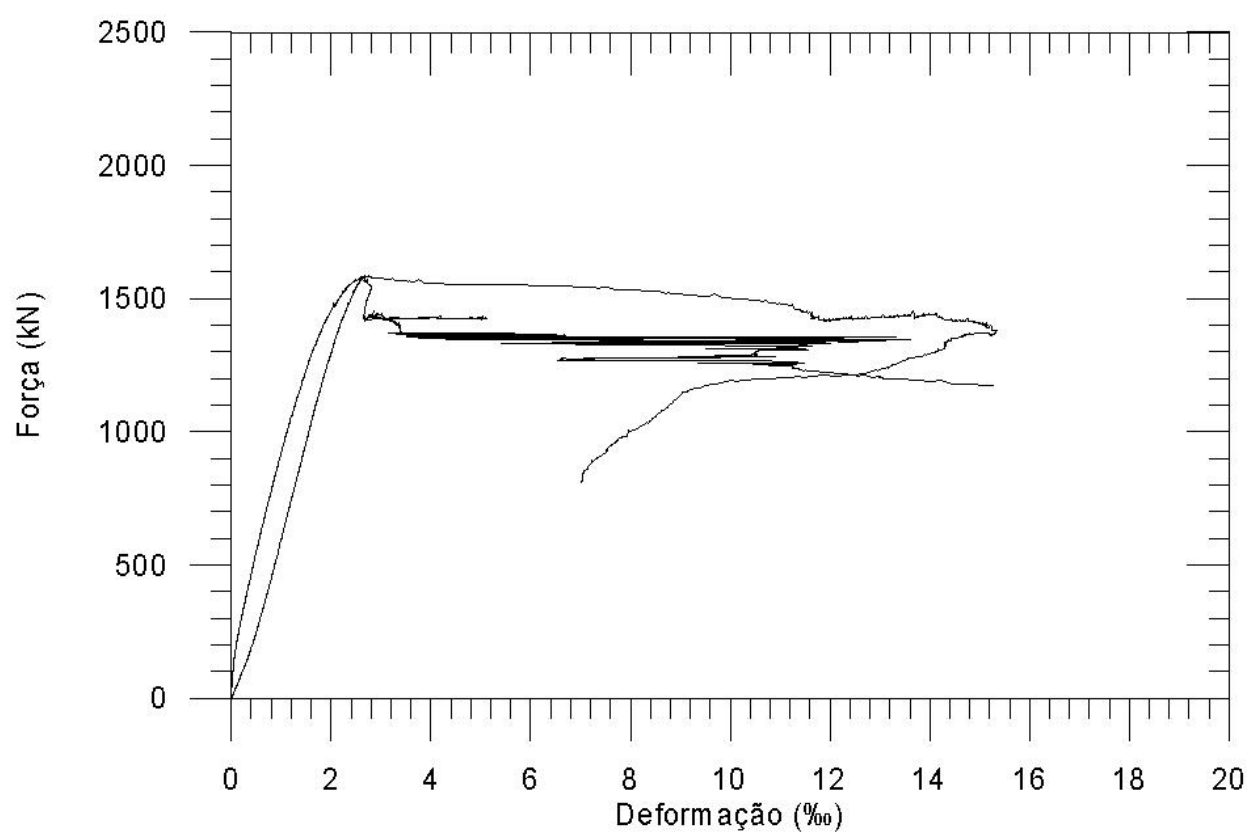

Figura A.35 - Diagramas força aplicada vs. deformação lida pelos extensômetros na armadura longitudinal.

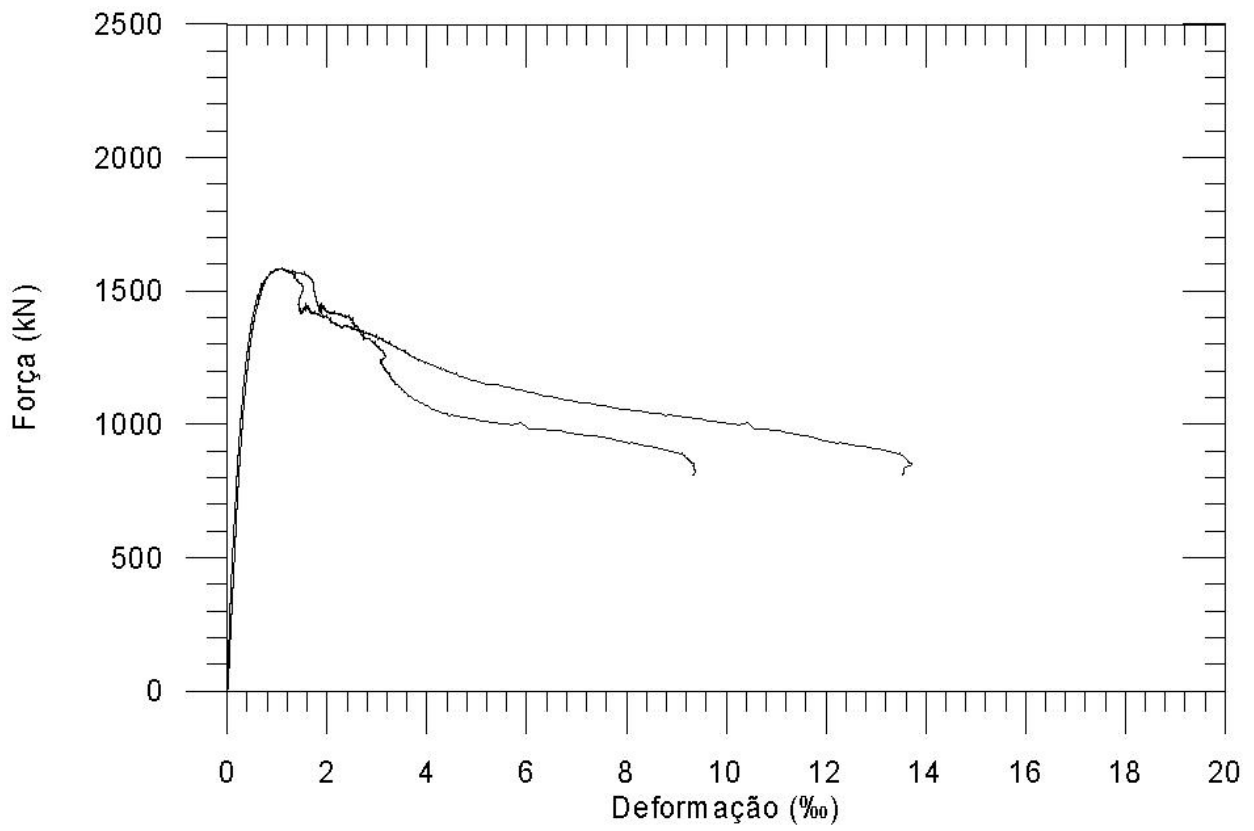

Figura A.36 - Diagramas força aplicada vs. deformação lida pelos extensômetros na armadura transversal. 


\section{A.10.Pilar P260505}

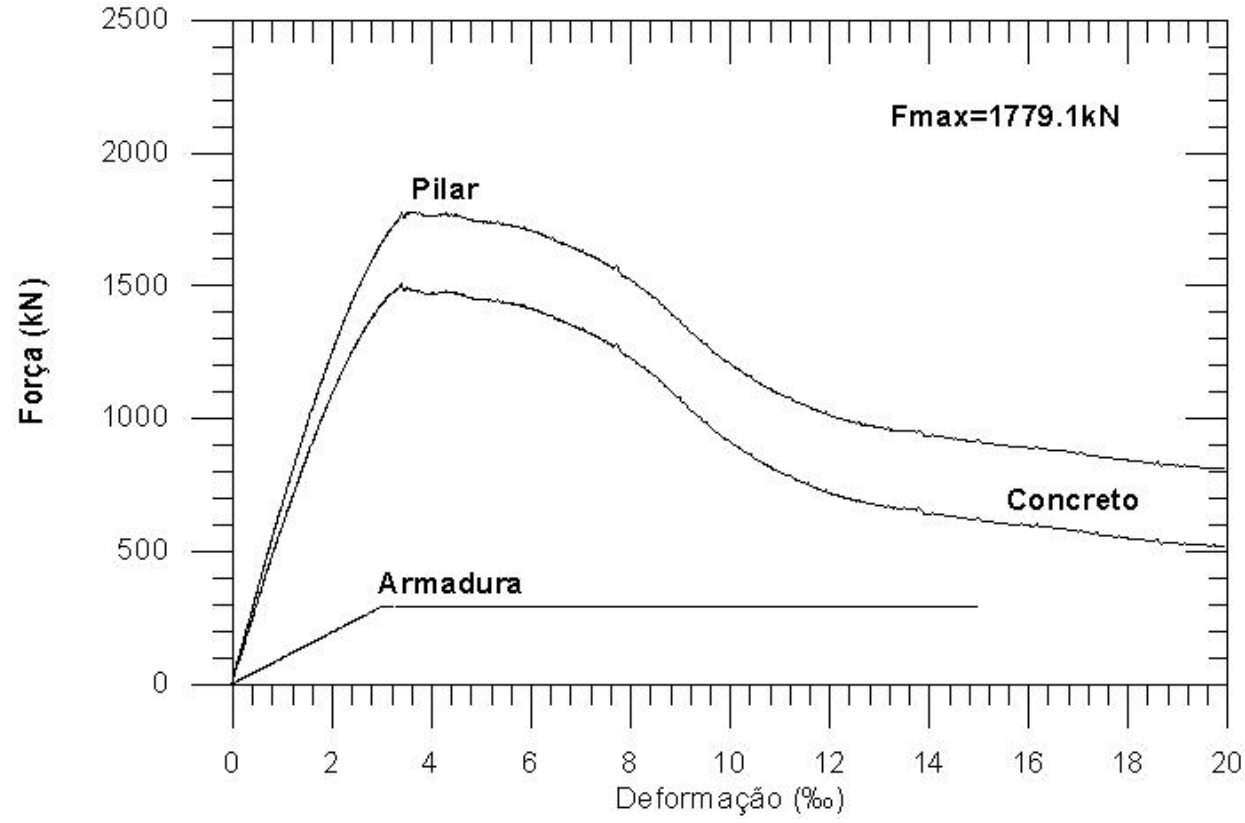

Figura A.37 - Diagramas forças parciais vs. deformação do pilar, do concreto e da armadura longitudinal.

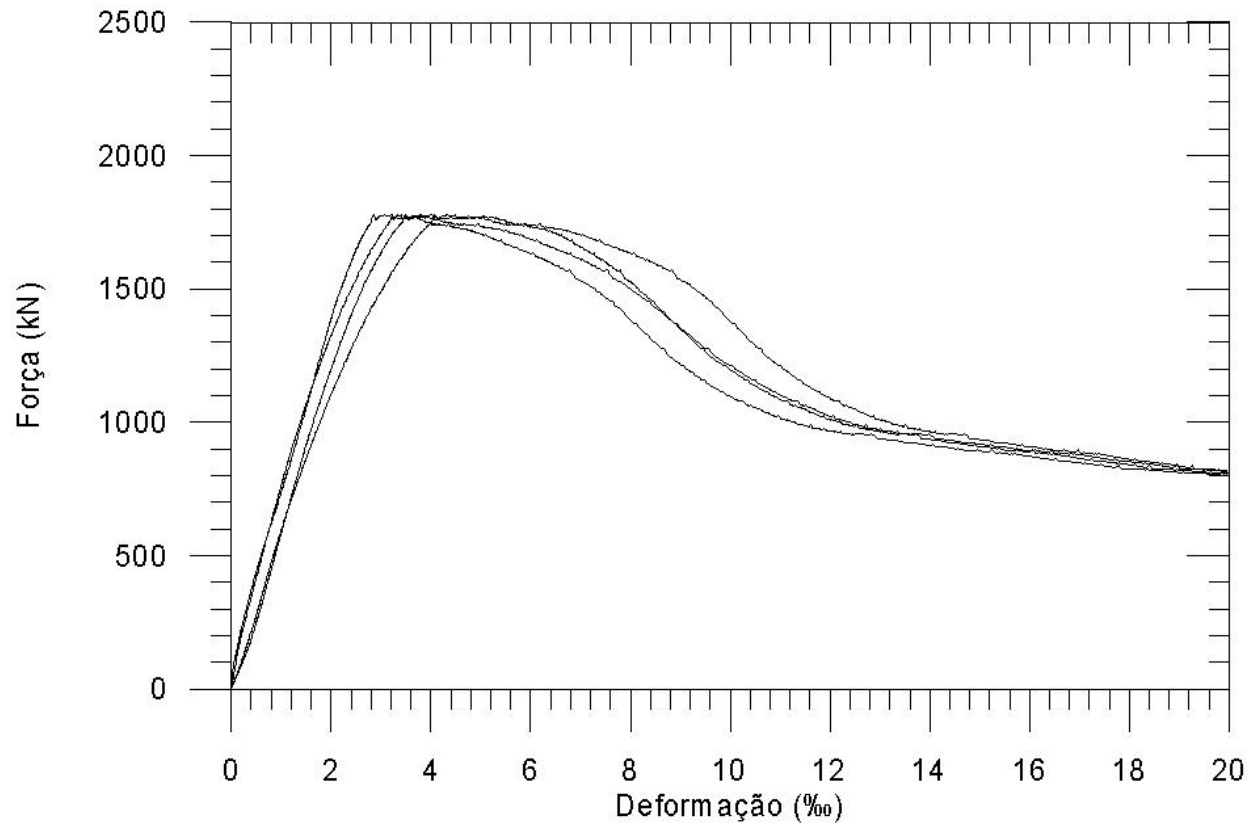

Figura A.38 - Diagramas força aplicada vs. deformação lida por cada LVDt. 


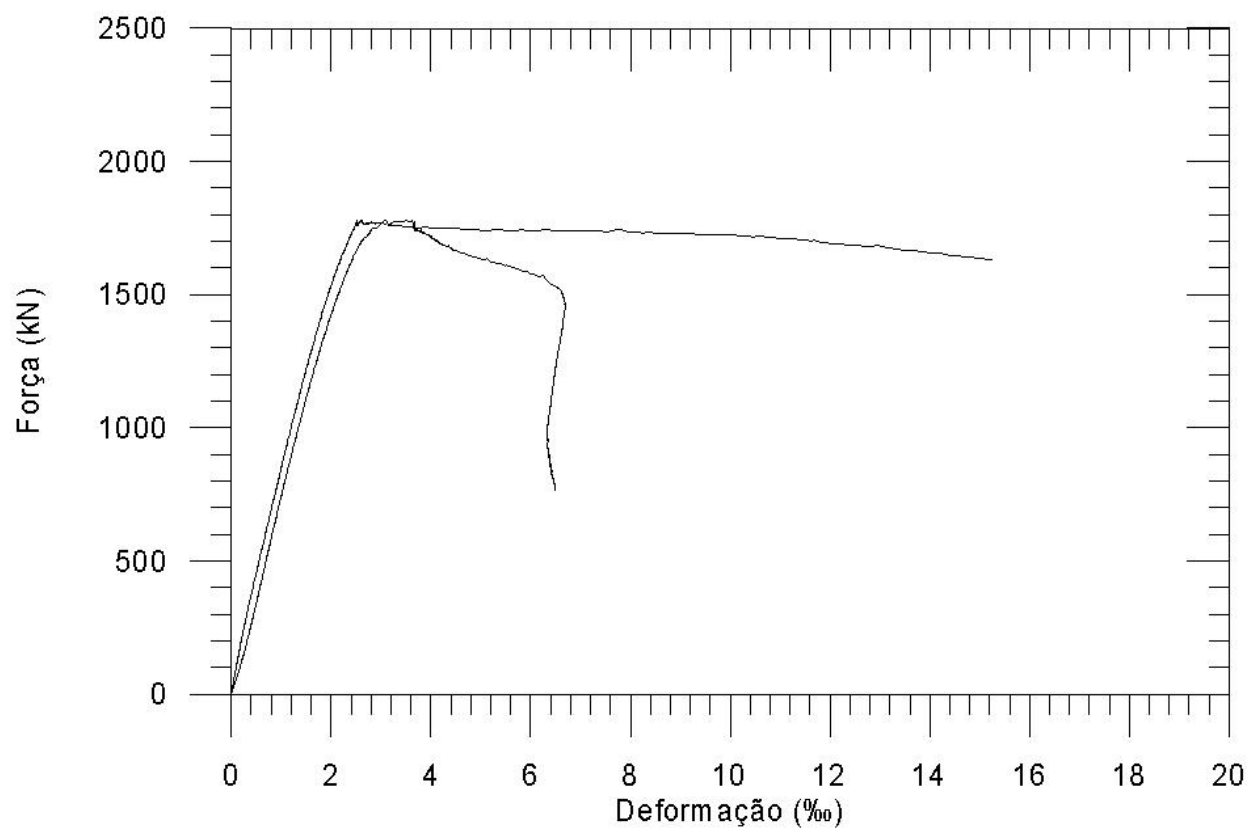

Figura A.39 - Diagramas força aplicada vs. deformação lida pelos extensômetros na armadura longitudinal.

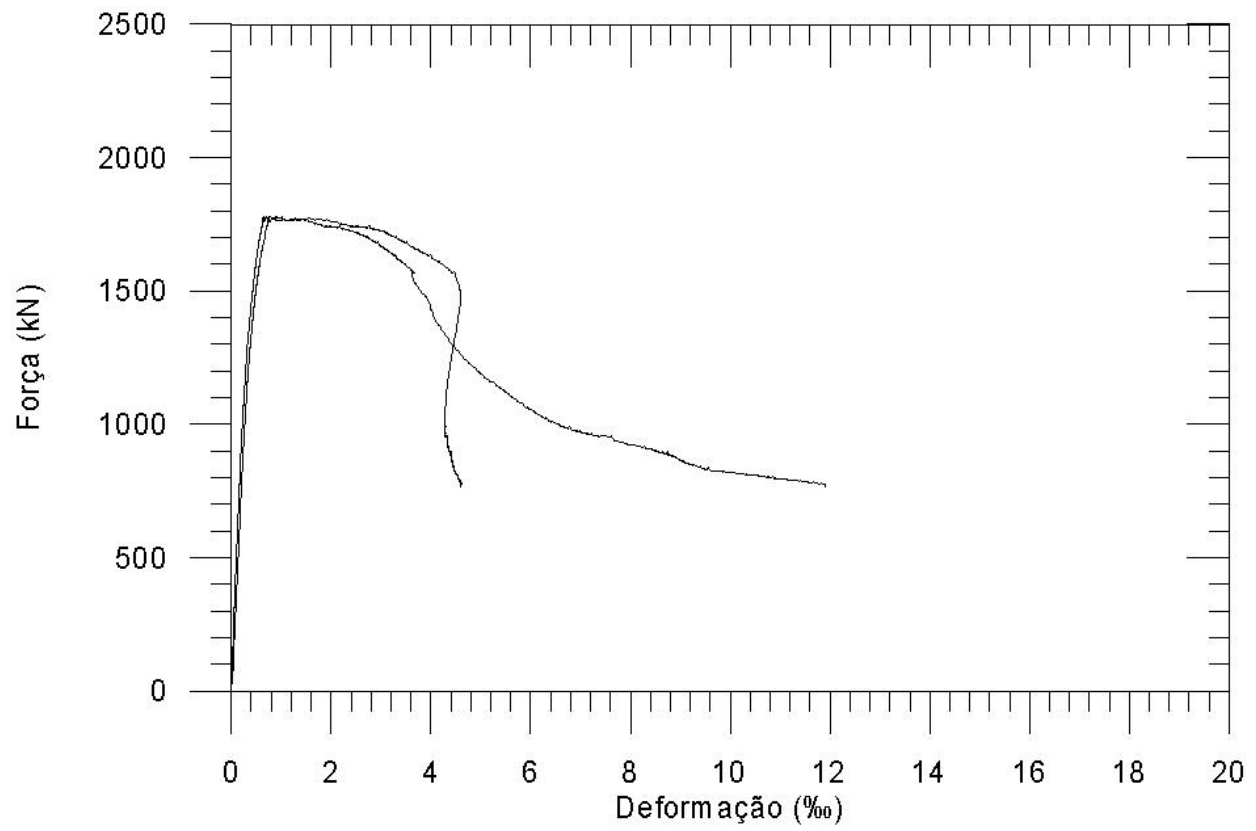

Figura A.40 - Diagramas força aplicada vs. deformação lida pelos extensômetros na armadura transversal. 


\section{A.11.Pilar P160151}

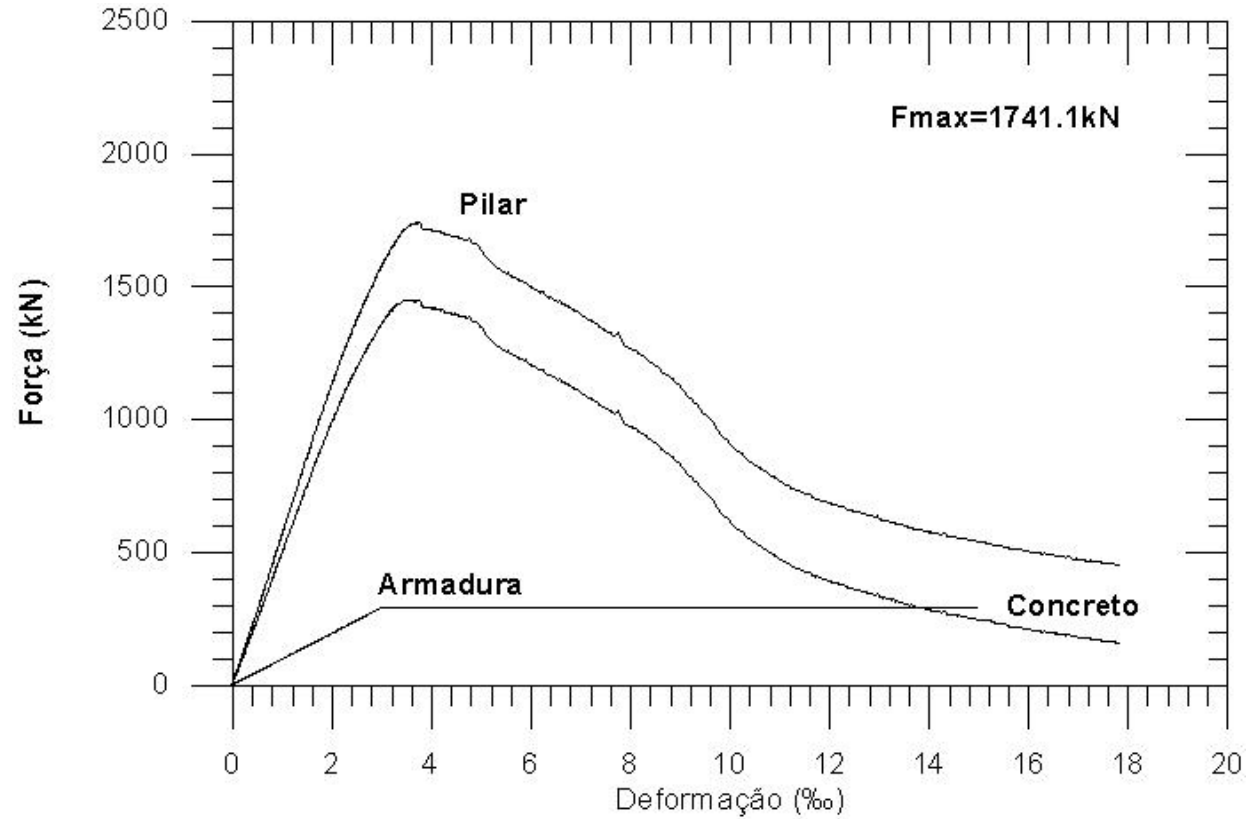

Figura A.41 - Diagramas forças parciais vs. deformação do pilar, do concreto e da armadura longitudinal.

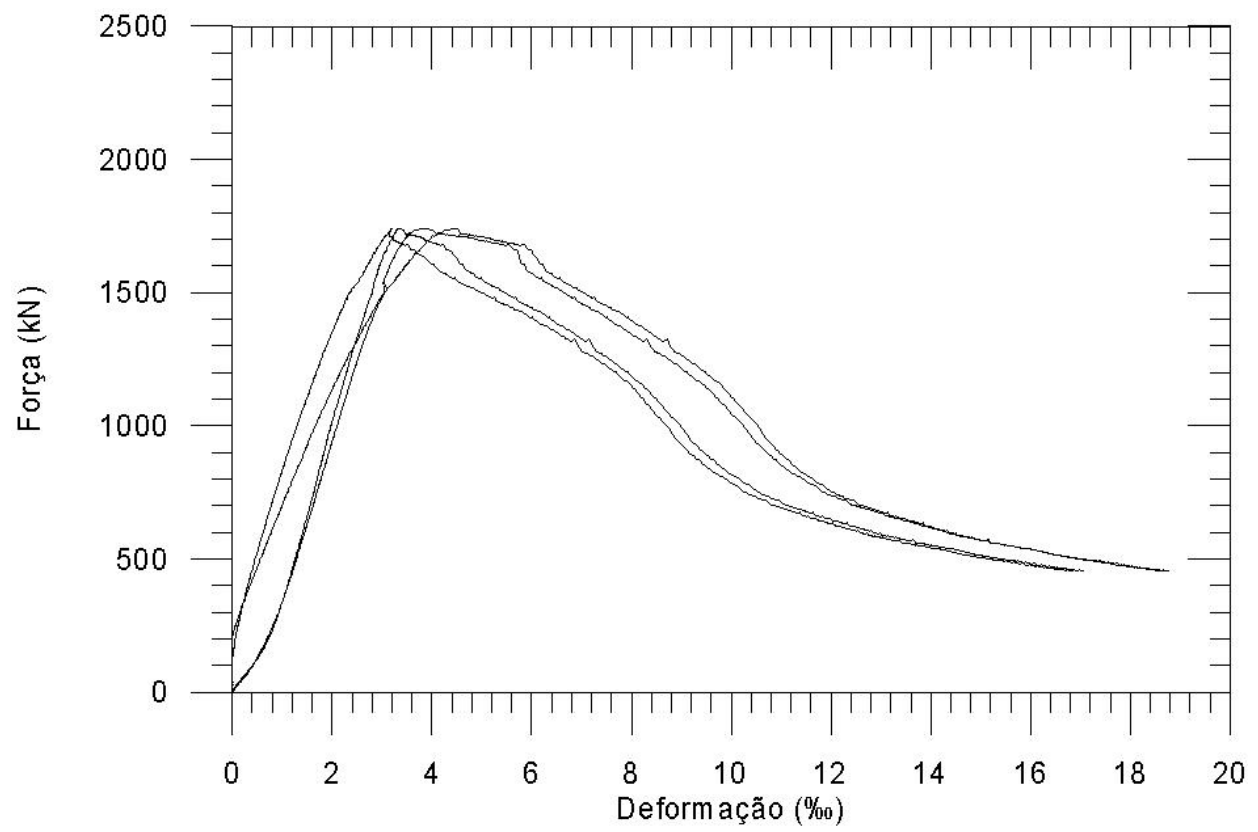

Figura A.42 - Diagramas força aplicada vs. deformação lida por cada LVDt. 


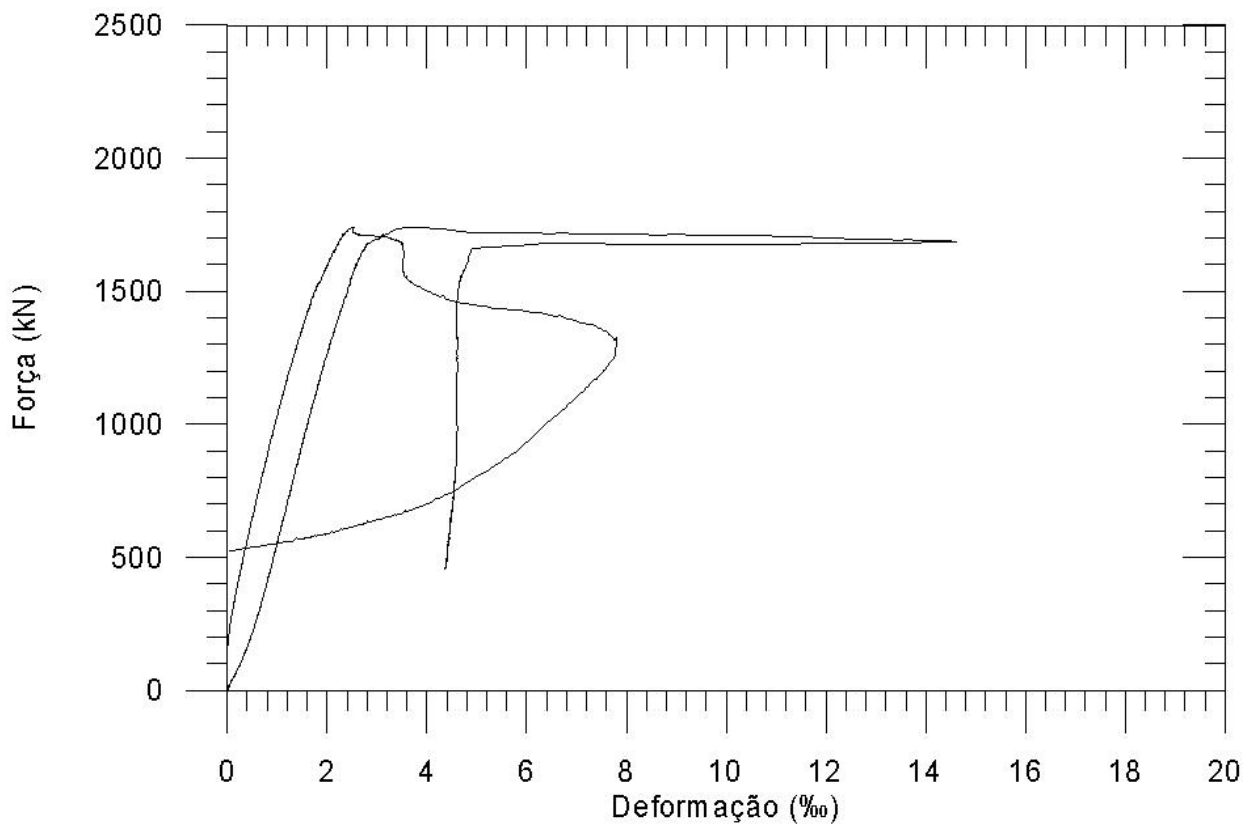

Figura A.43 - Diagramas força aplicada vs. deformação lida pelos extensômetros na armadura longitudinal.

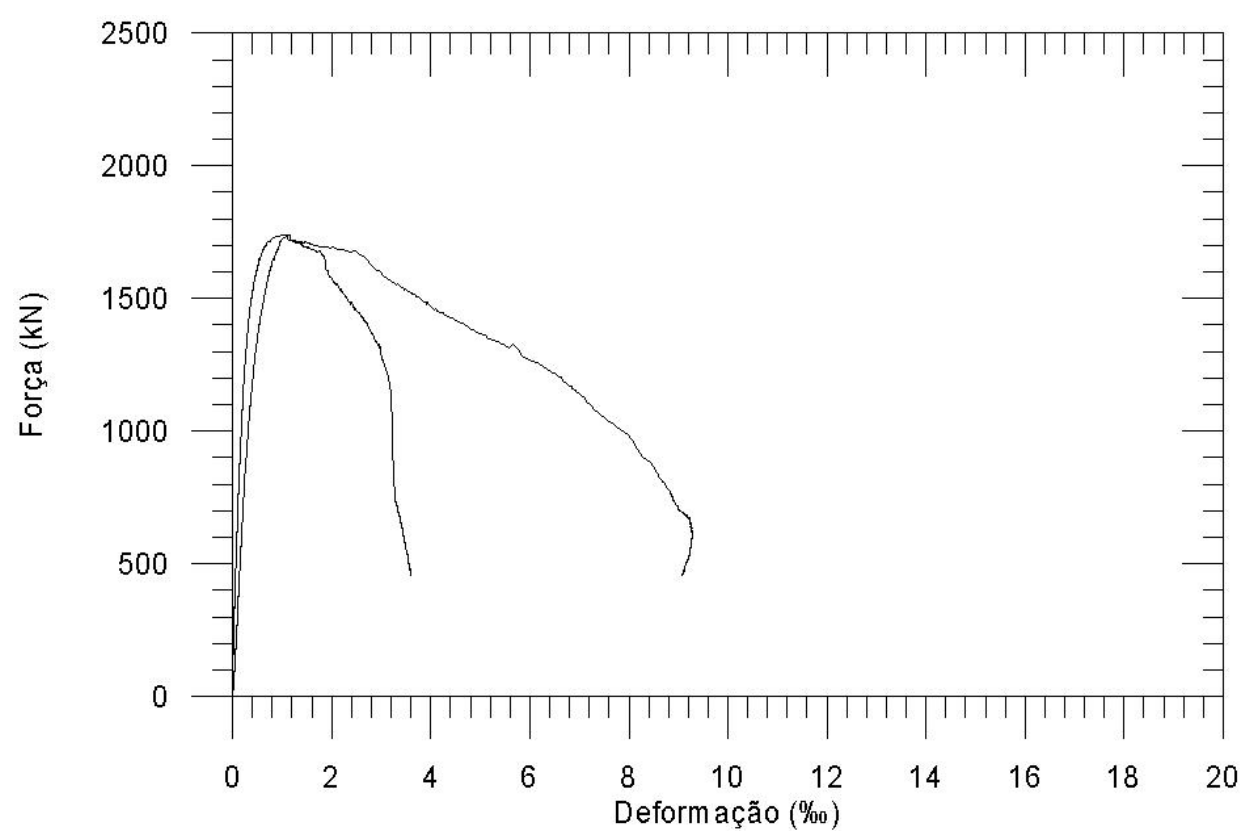

Figura A.44 - Diagramas força aplicada vs. deformação lida pelos extensômetros na armadura transversal. 


\section{A.12.Pilar P260151}

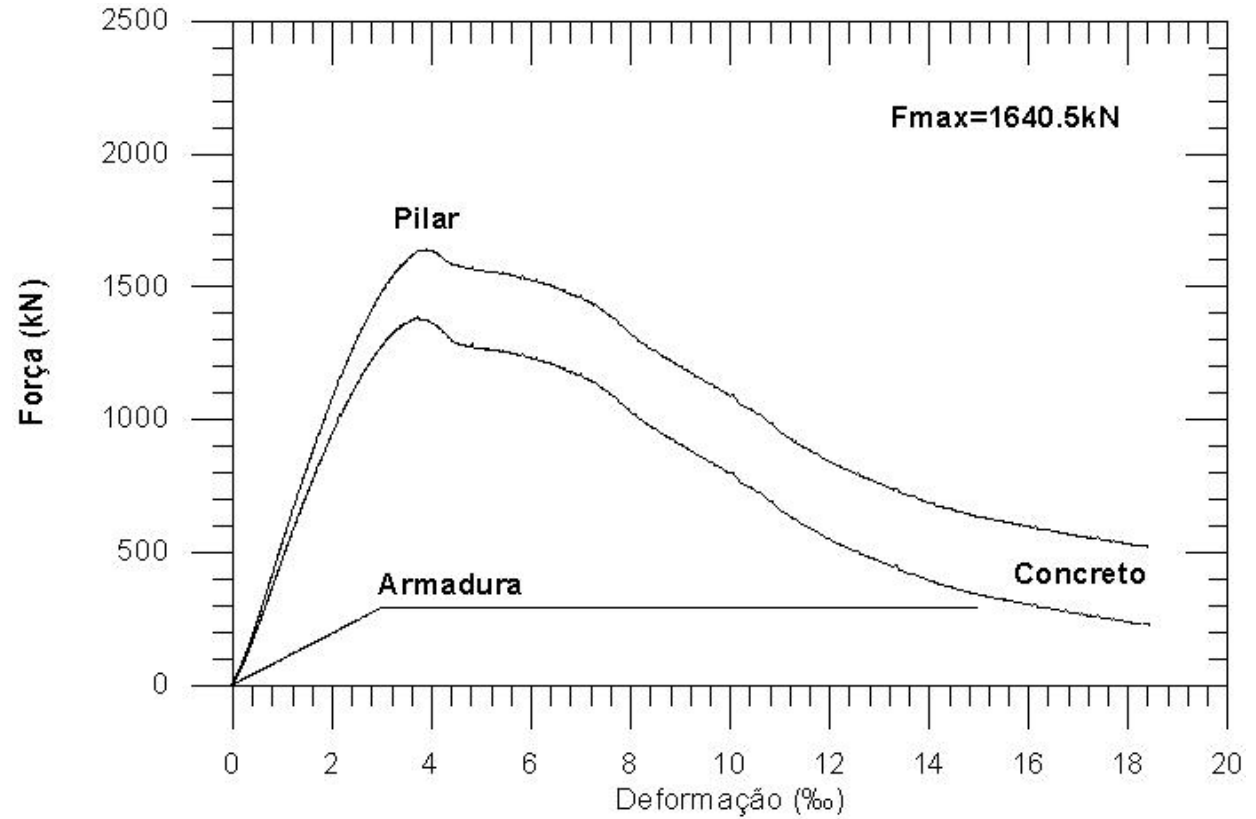

Figura A.45 - Diagramas forças parciais vs. deformação do pilar, do concreto e da armadura longitudinal.

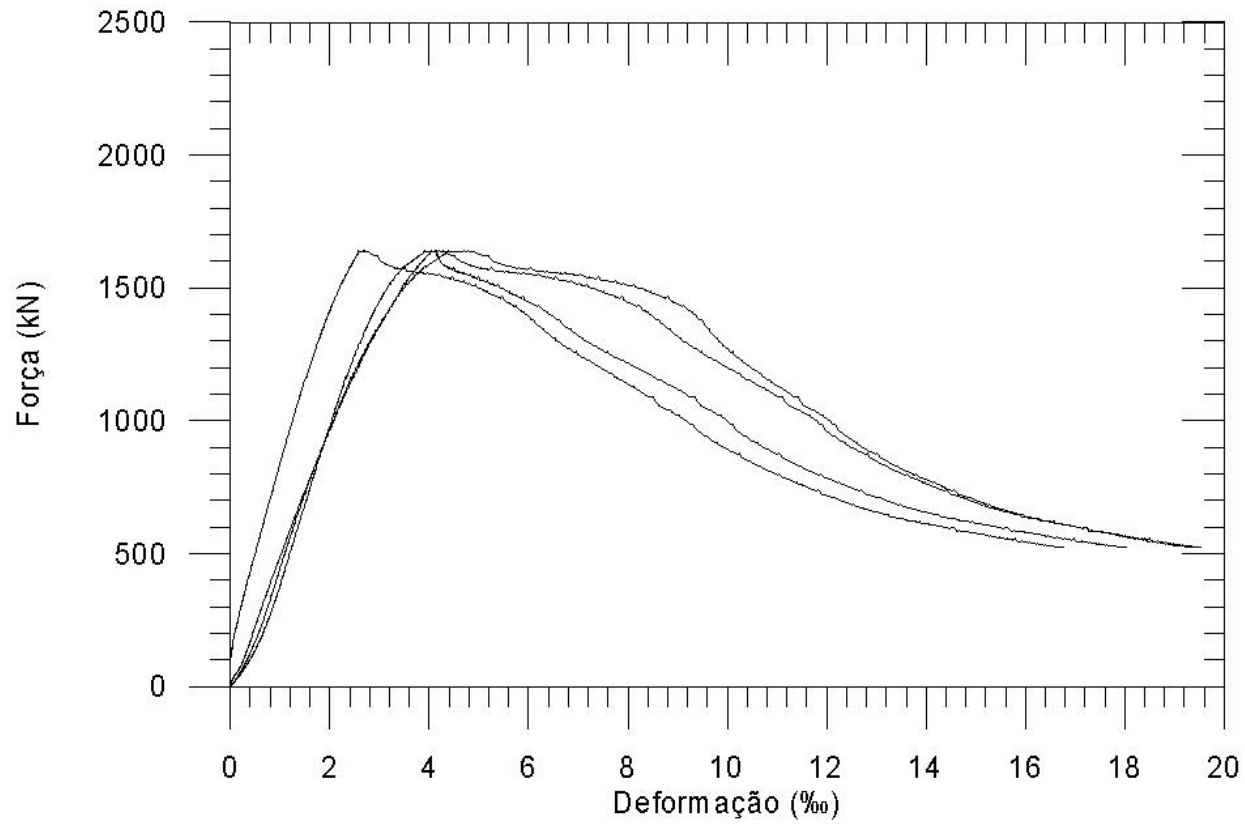

Figura A.46 - Diagramas força aplicada vs. deformação lida por cada LVDt. 


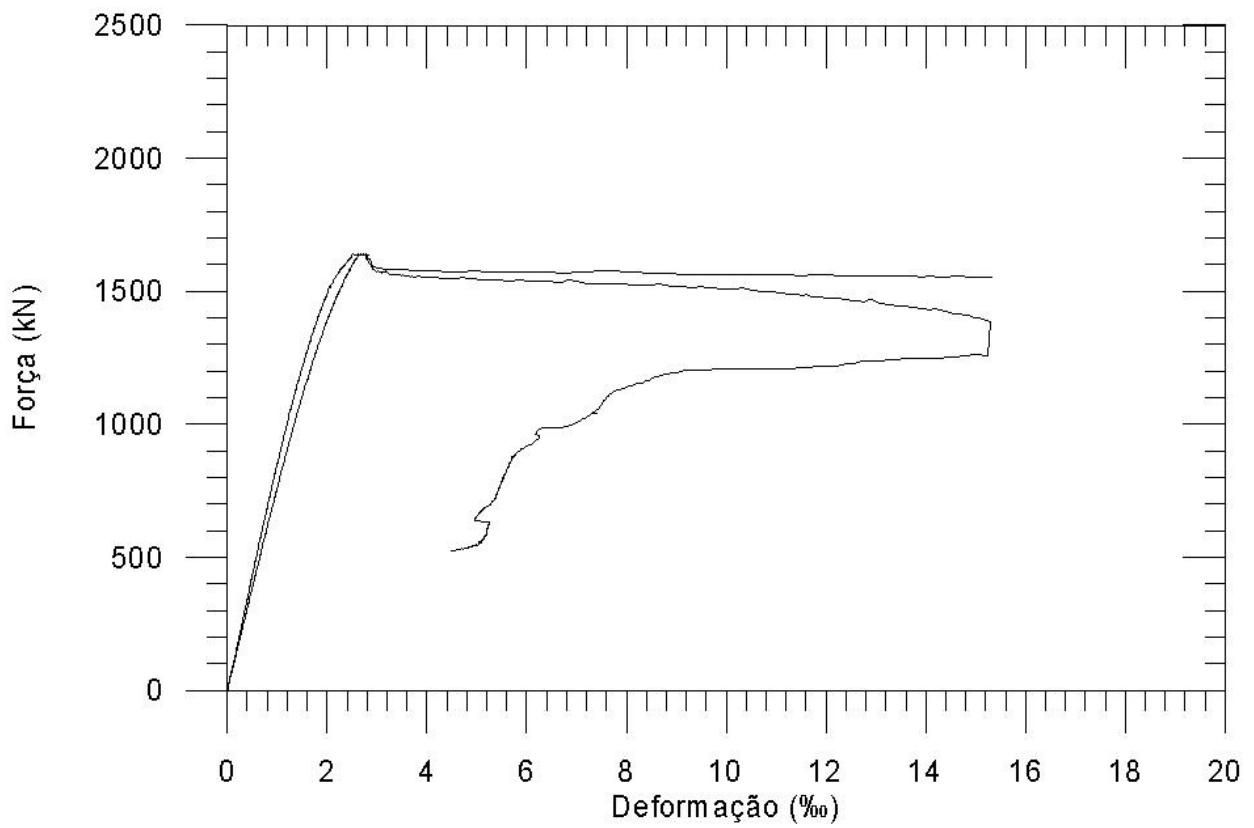

Figura A.47 - Diagramas força aplicada vs. deformação lida pelos extensômetros na armadura longitudinal.

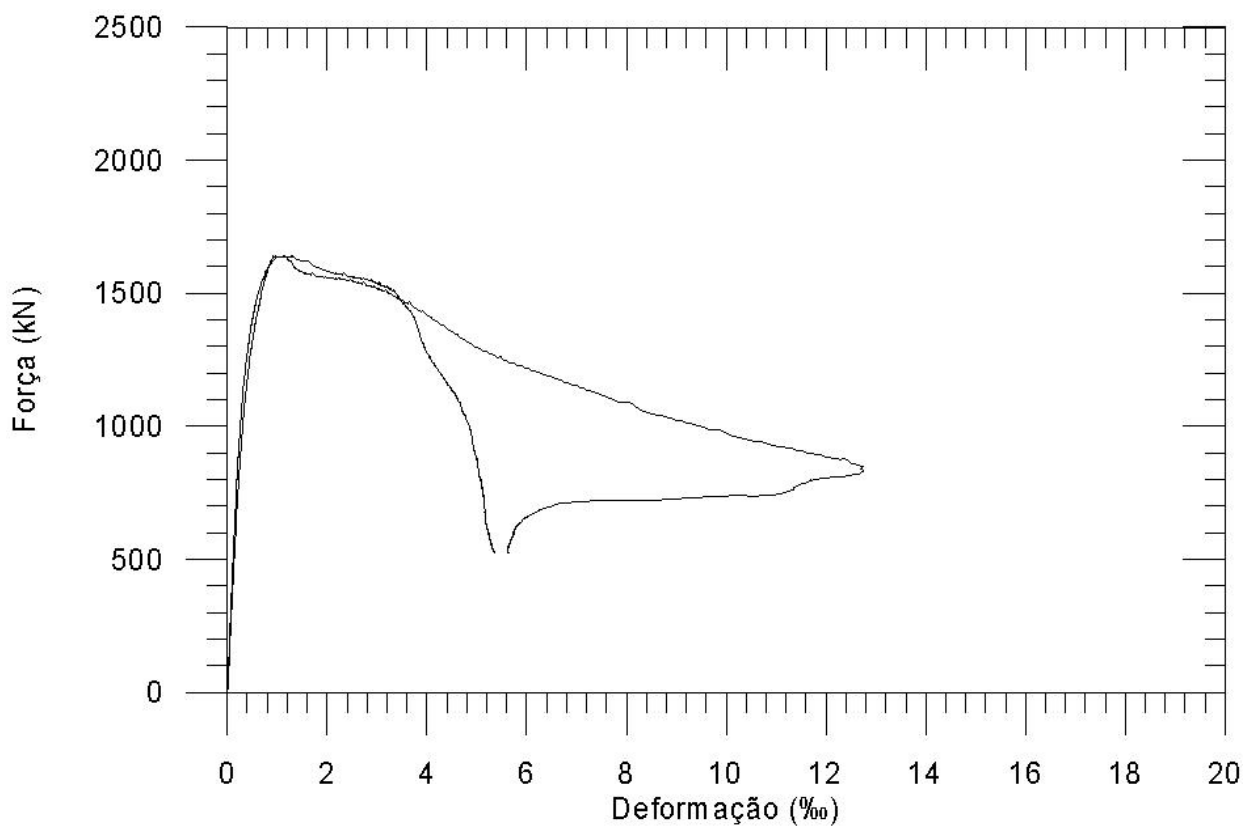

Figura A.48 - Diagramas força aplicada vs. deformação lida pelos extensômetros na armadura transversal. 


\section{A.13.Pilar P16051}

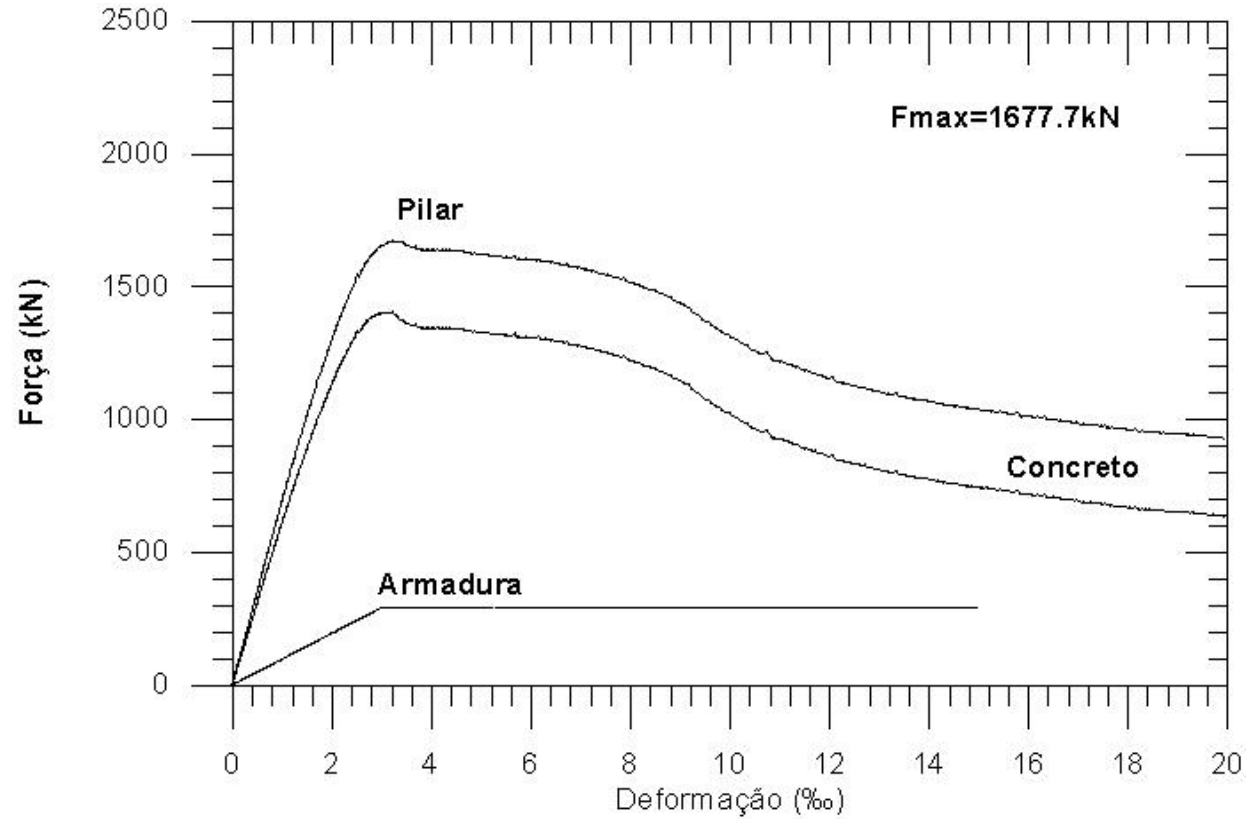

Figura A.49 - Diagramas forças parciais vs. deformação do pilar, do concreto e da armadura longitudinal.

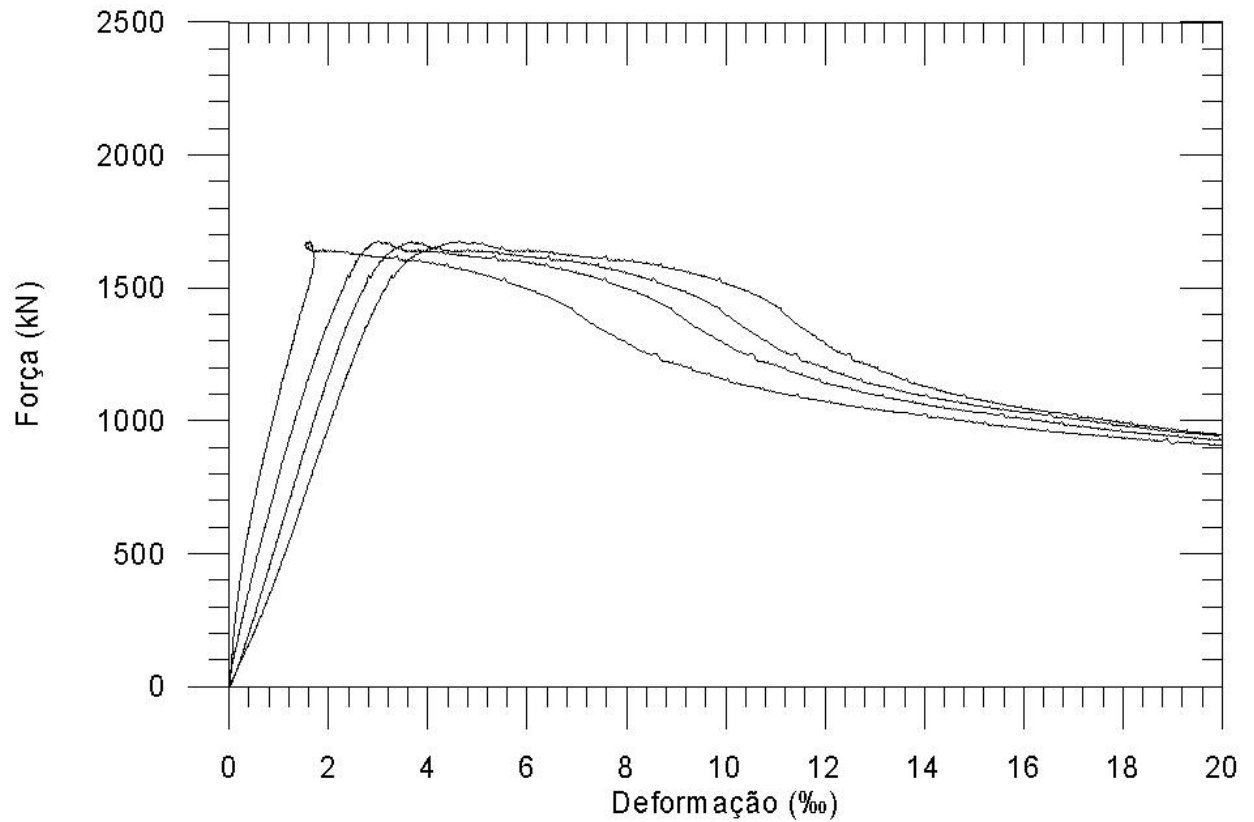

Figura A.50 - Diagramas força aplicada vs. deformação lida por cada LVDt. 


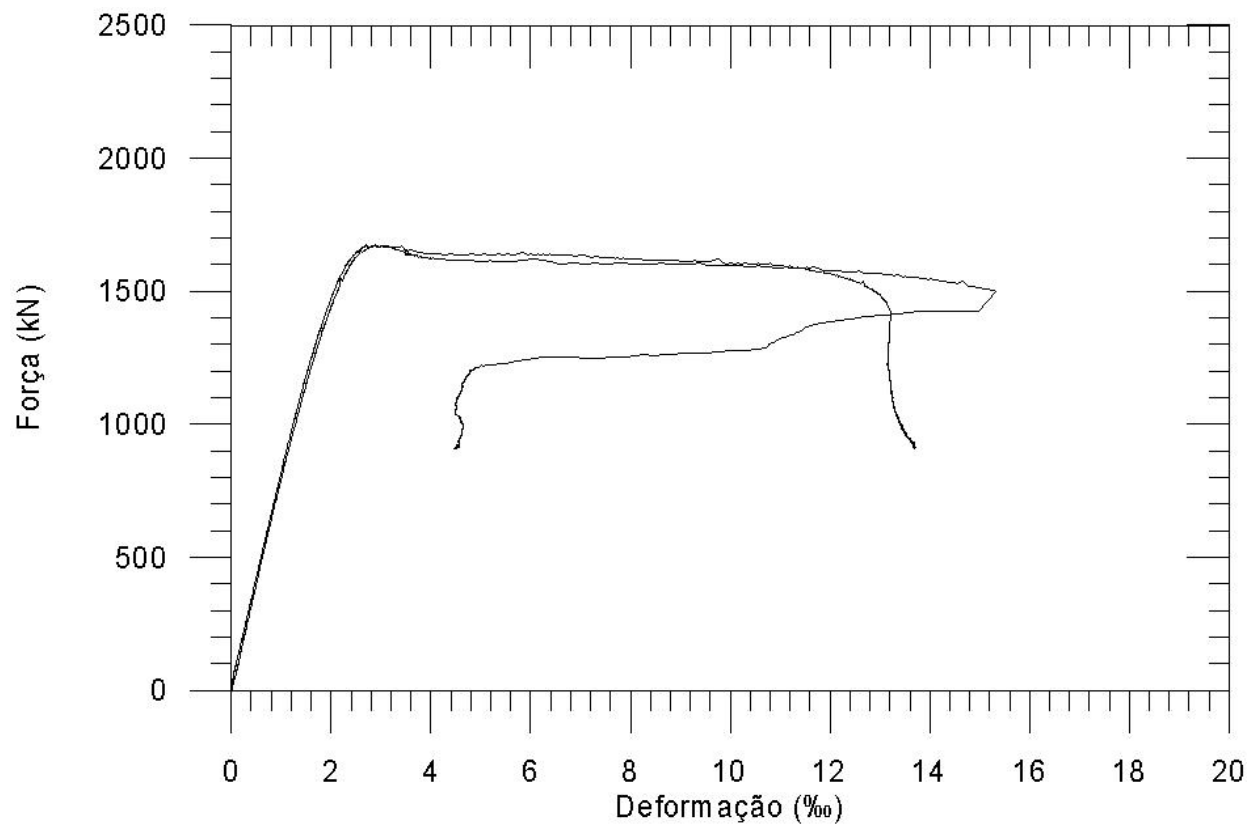

Figura A.51 - Diagramas força aplicada vs. deformação lida pelos extensômetros na armadura longitudinal.

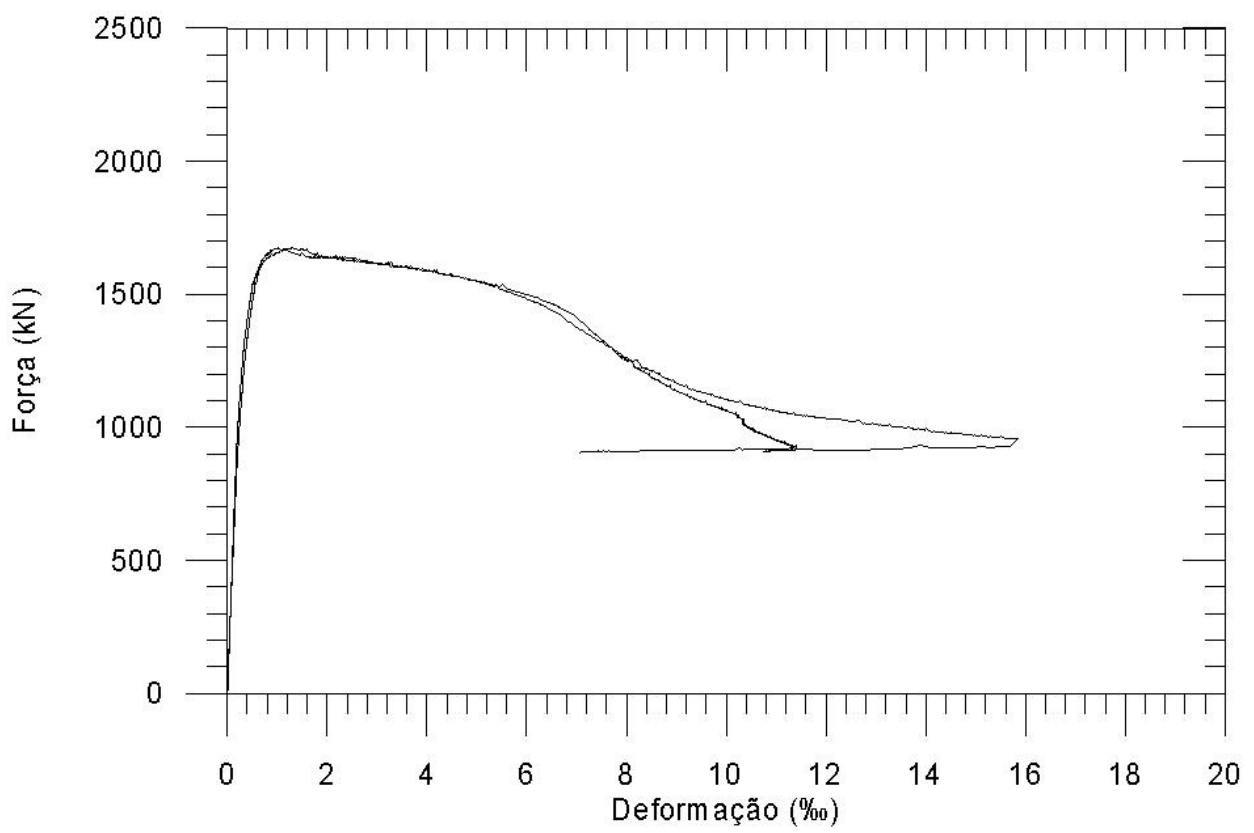

Figura A.52 - Diagramas força aplicada vs. deformação lida pelos extensômetros na armadura transversal. 


\section{A.14.Pilar P26051}

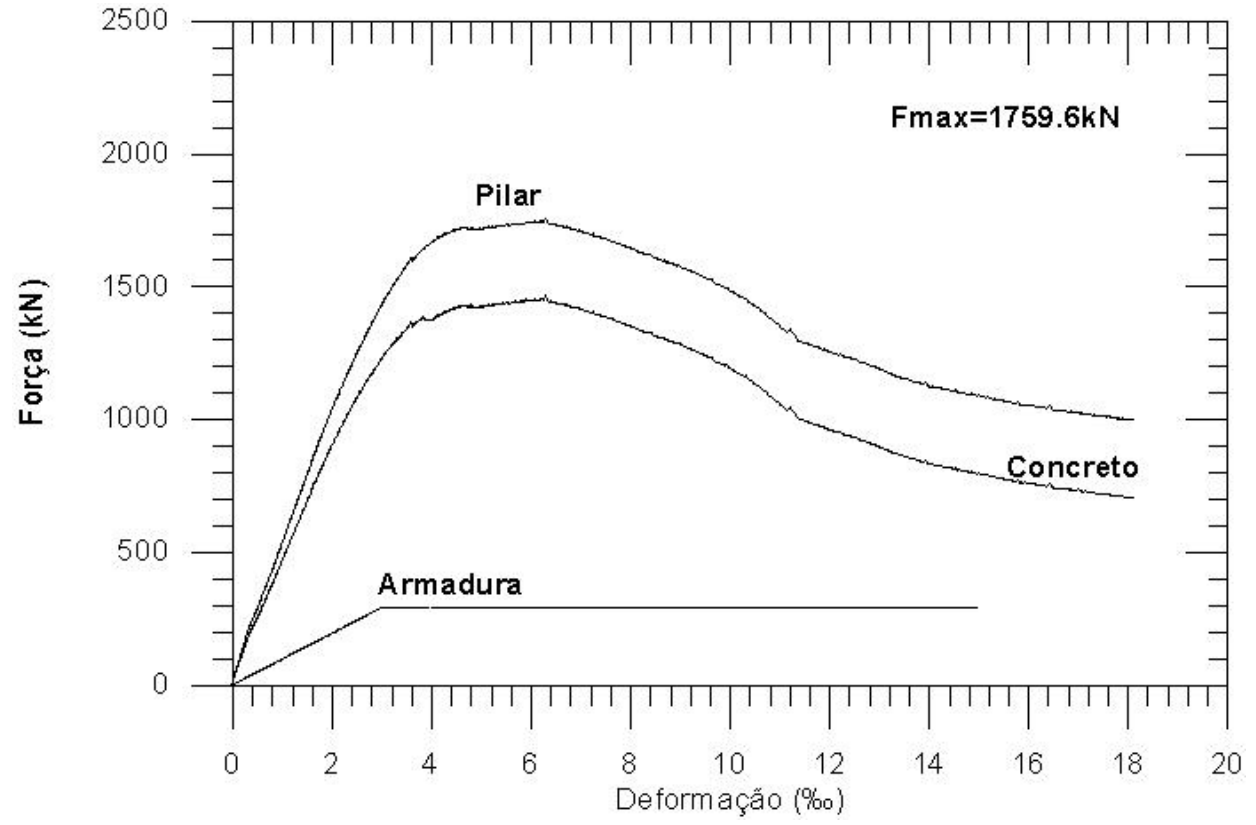

Figura A.53 - Diagramas forças parciais vs. deformação do pilar, do concreto e da armadura longitudinal.

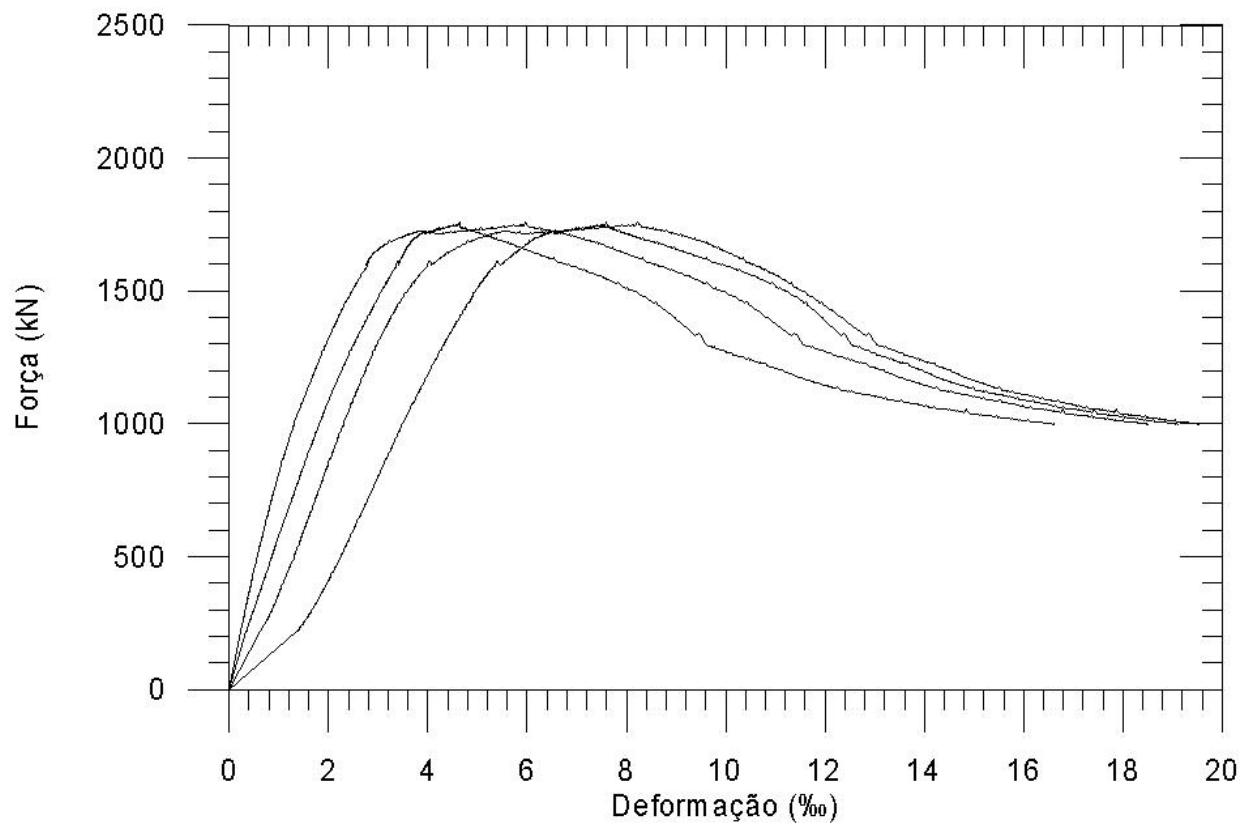

Figura A.54 - Diagramas força aplicada vs. deformação lida por cada LVDt. 


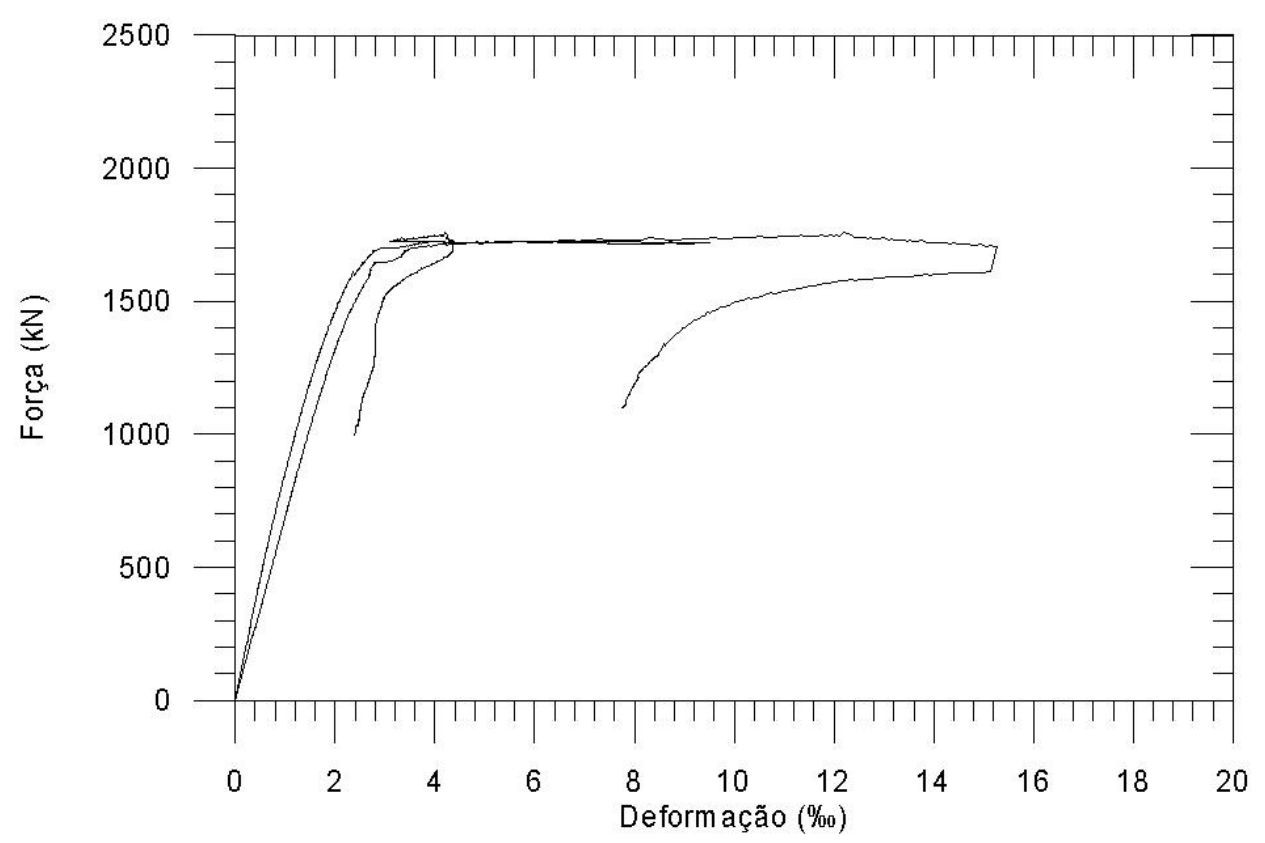

Figura A.55 - Diagramas força aplicada vs. deformação lida pelos extensômetros na armadura longitudinal.

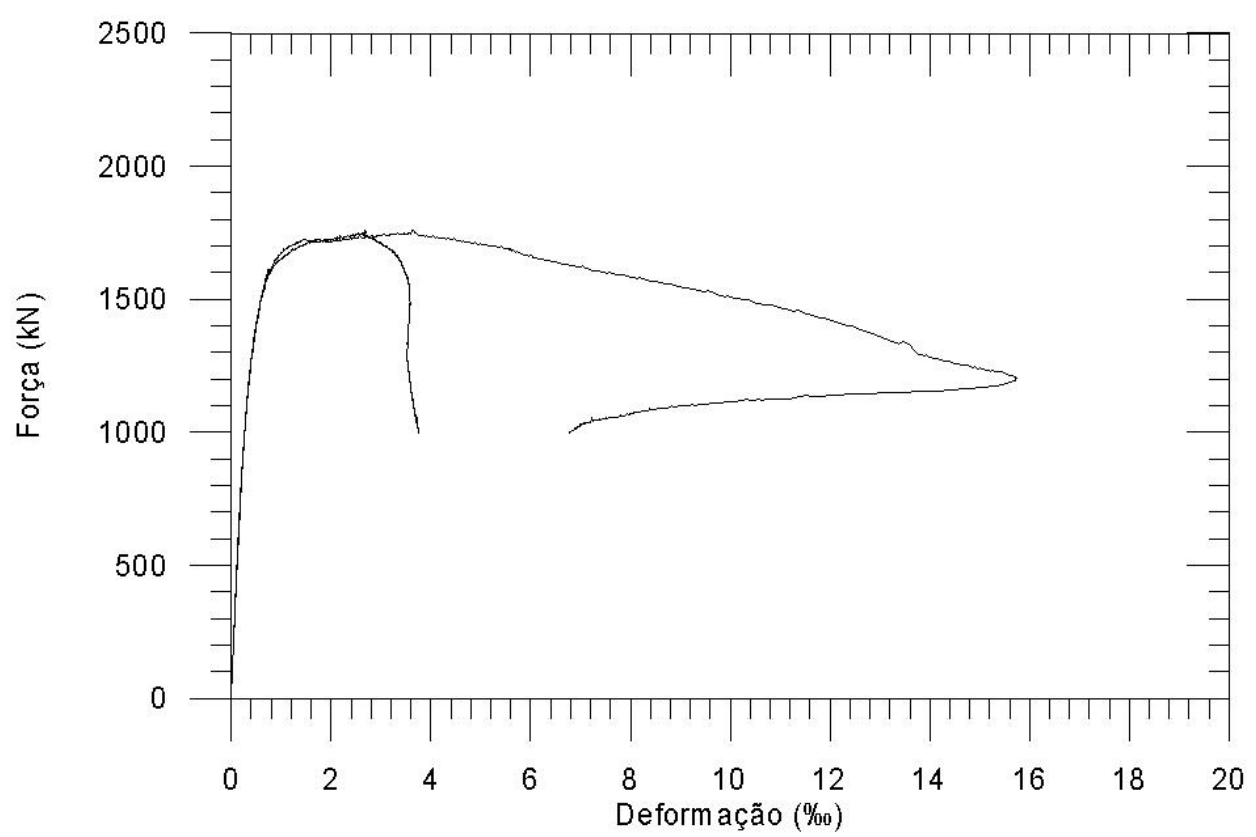

Figura A.56 - Diagramas força aplicada vs. deformação lida pelos extensômetros na armadura transversal. 


\section{A.15.Pilar P180150}

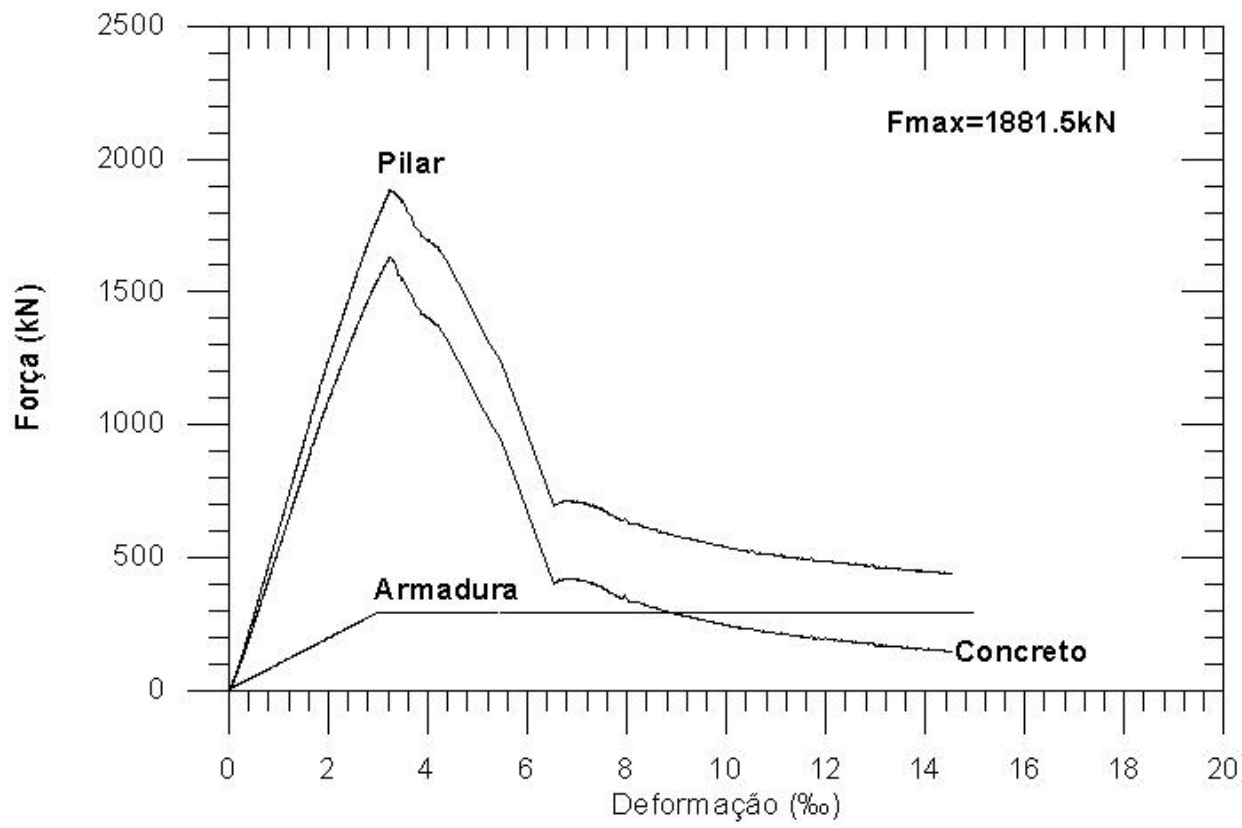

Figura A.57 - Diagramas forças parciais vs. deformação do pilar, do concreto e da armadura longitudinal.

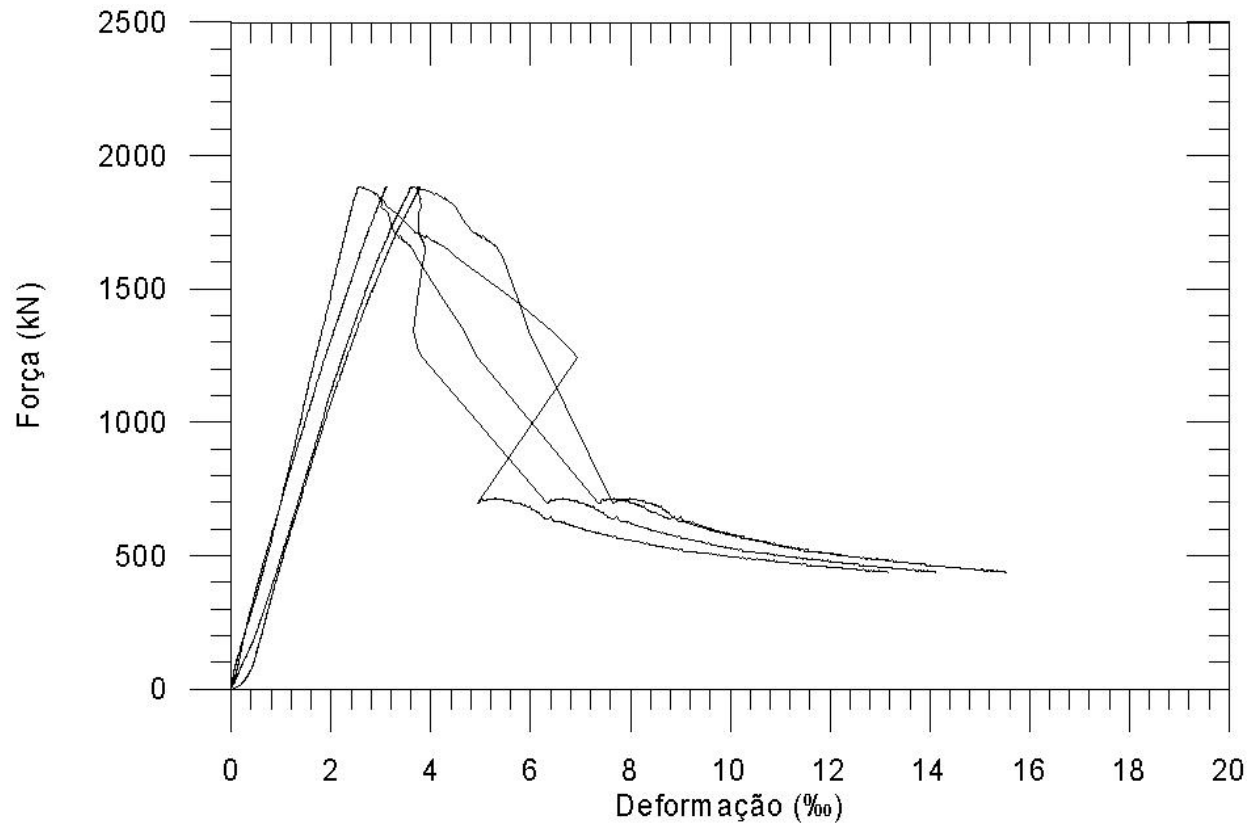

Figura A.58 - Diagramas força aplicada vs. deformação lida por cada LVDt. 


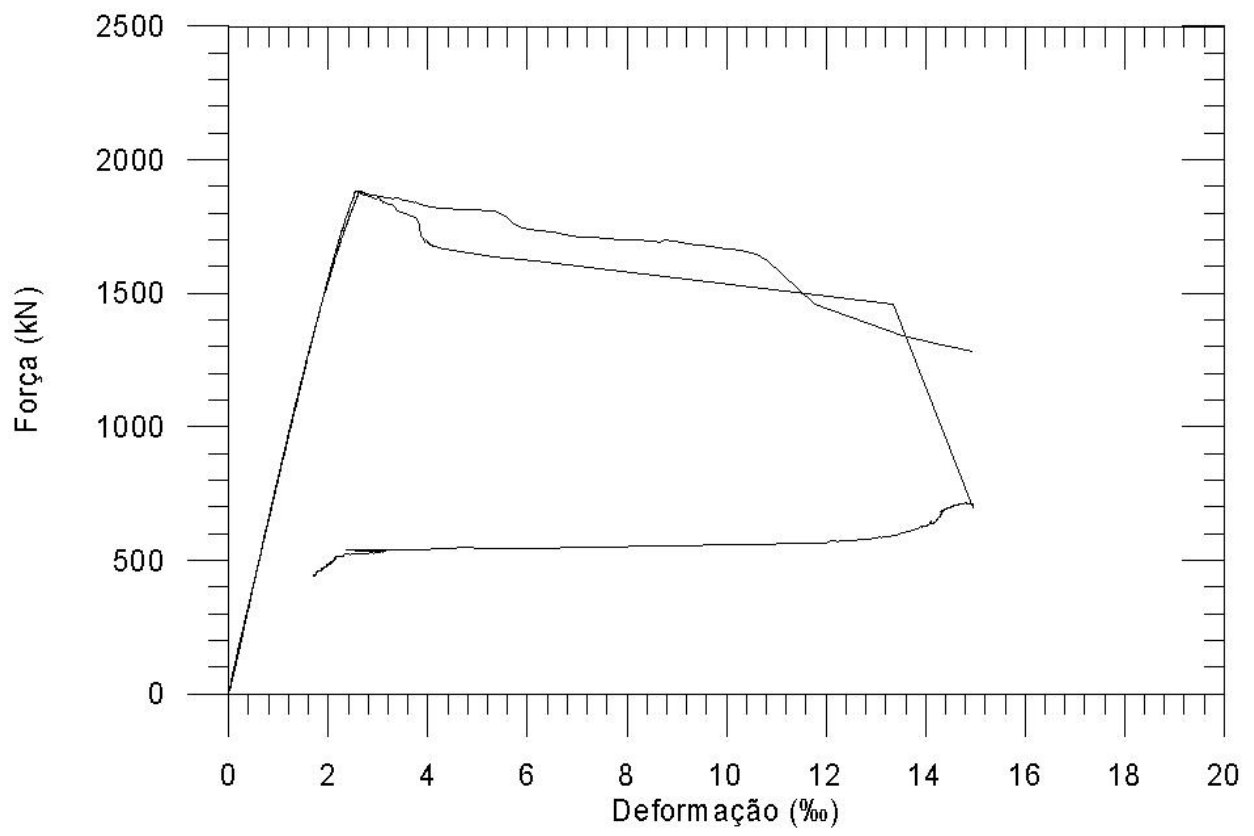

Figura A.59 - Diagramas força aplicada vs. deformação lida pelos extensômetros na armadura longitudinal.

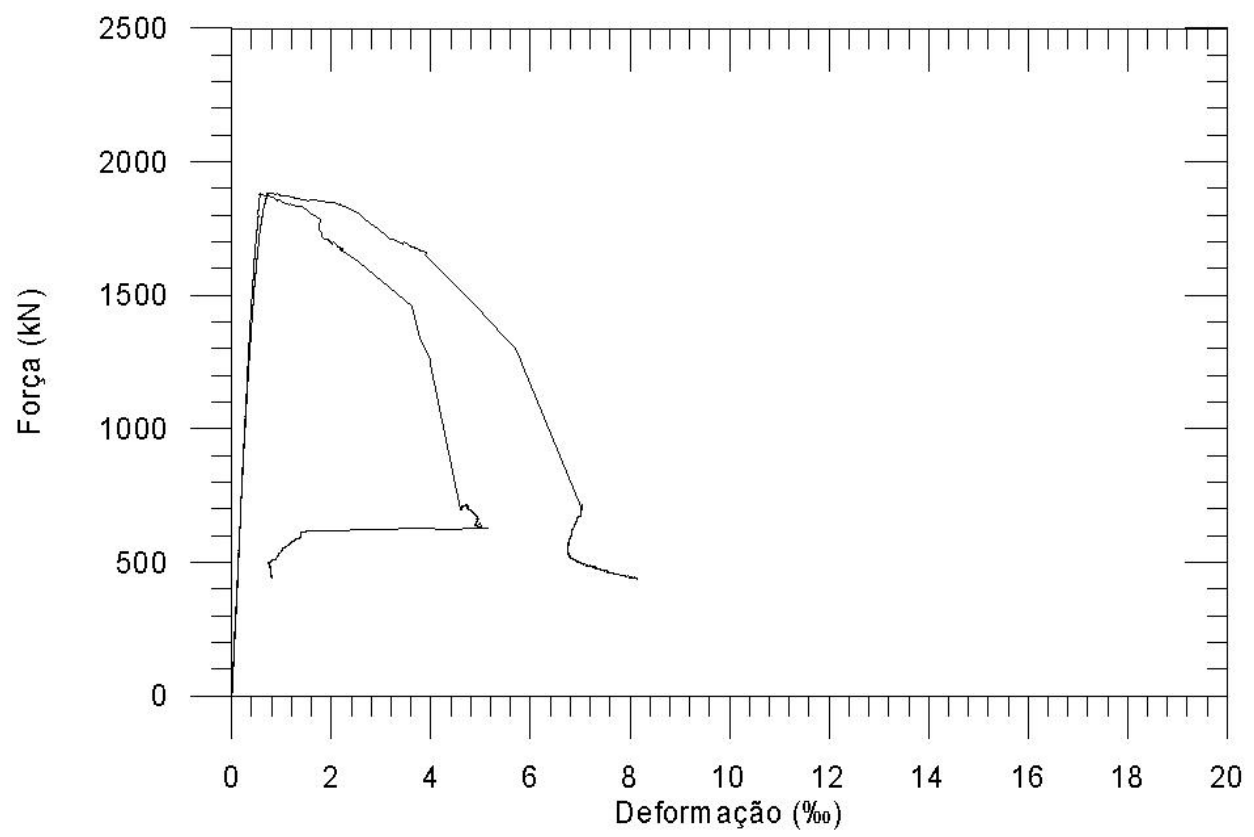

Figura A.60 - Diagramas força aplicada vs. deformação lida pelos extensômetros na armadura transversal. 


\section{A.16.Pilar P280150}

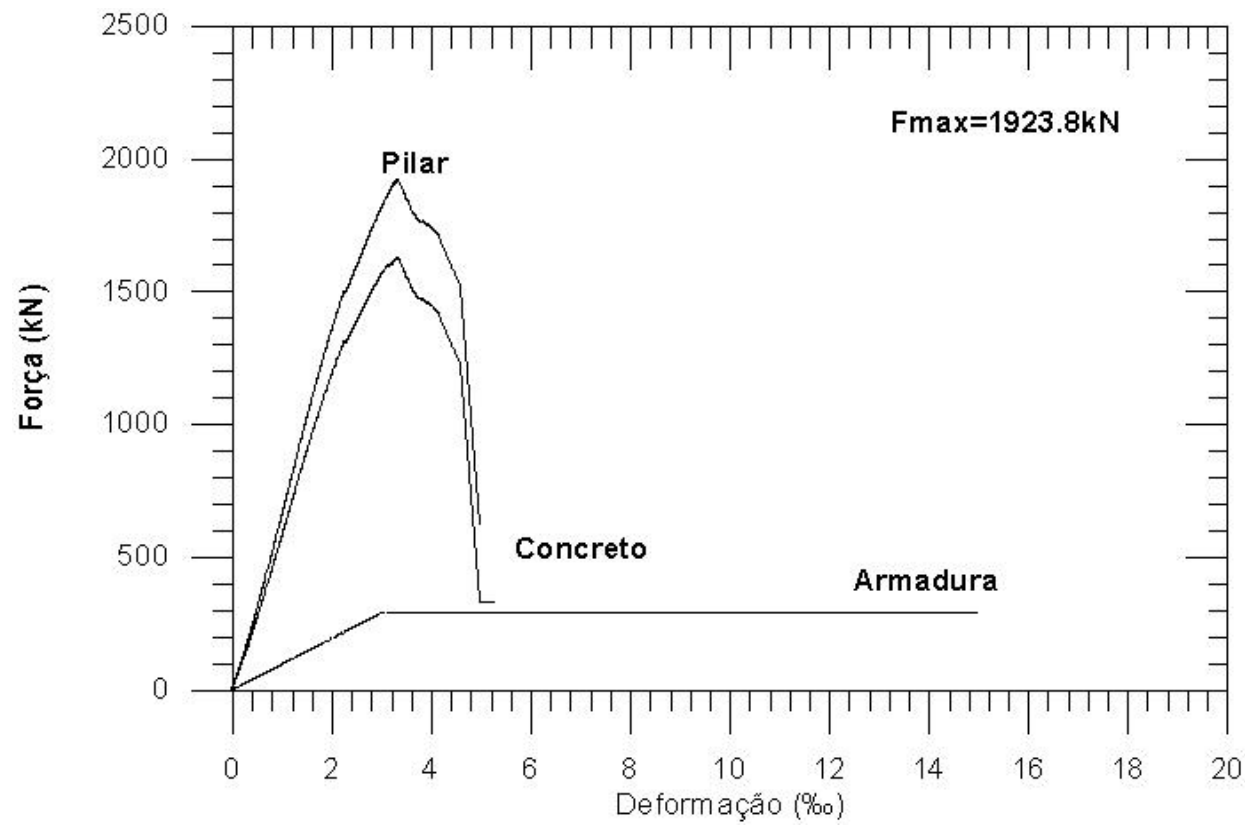

Figura A.61 - Diagramas forças parciais vs. deformação do pilar, do concreto e da armadura longitudinal.

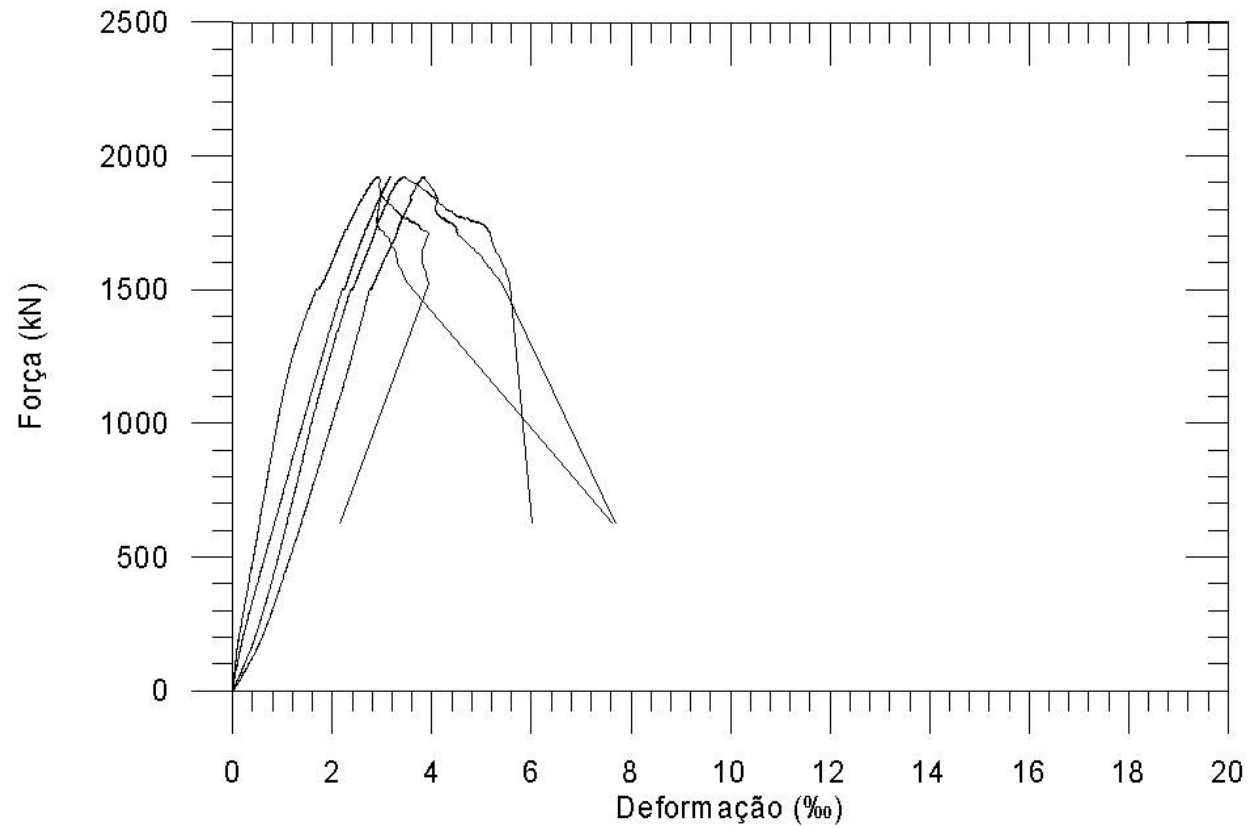

Figura A.62 - Diagramas força aplicada vs. deformação lida por cada LVDt. 


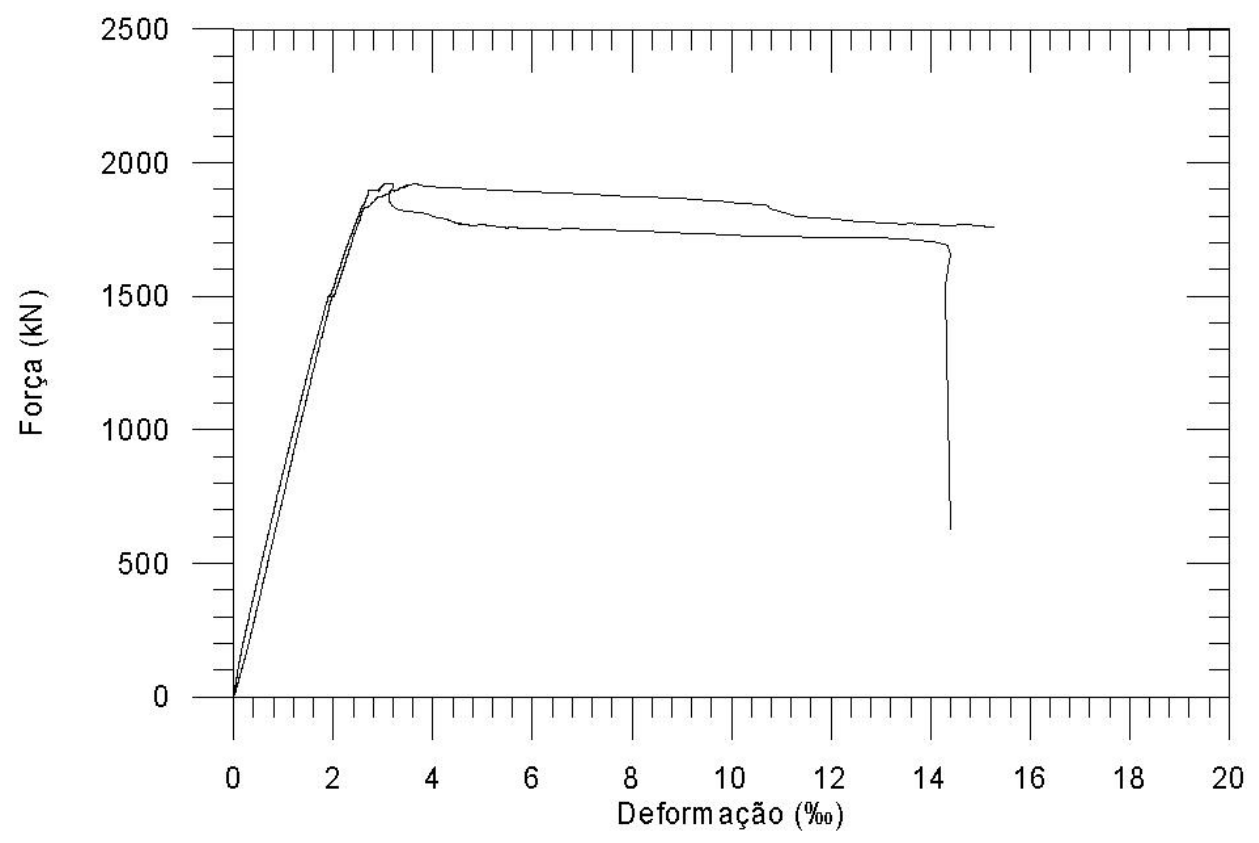

Figura A.63 - Diagramas força aplicada vs. deformação lida pelos extensômetros na armadura longitudinal.

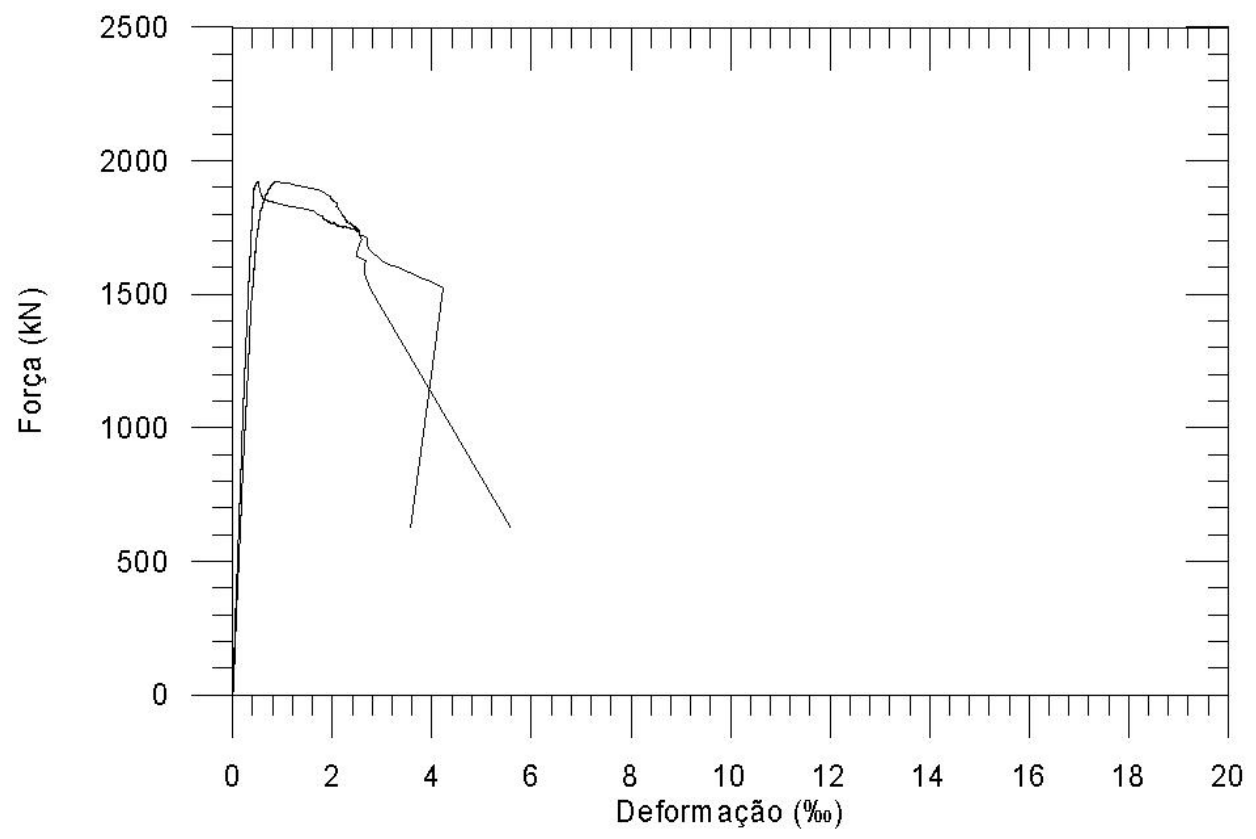

Figura A.64 - Diagramas força aplicada vs. deformação lida pelos extensômetros na armadura transversal. 


\section{A.17.Pilar P18050}

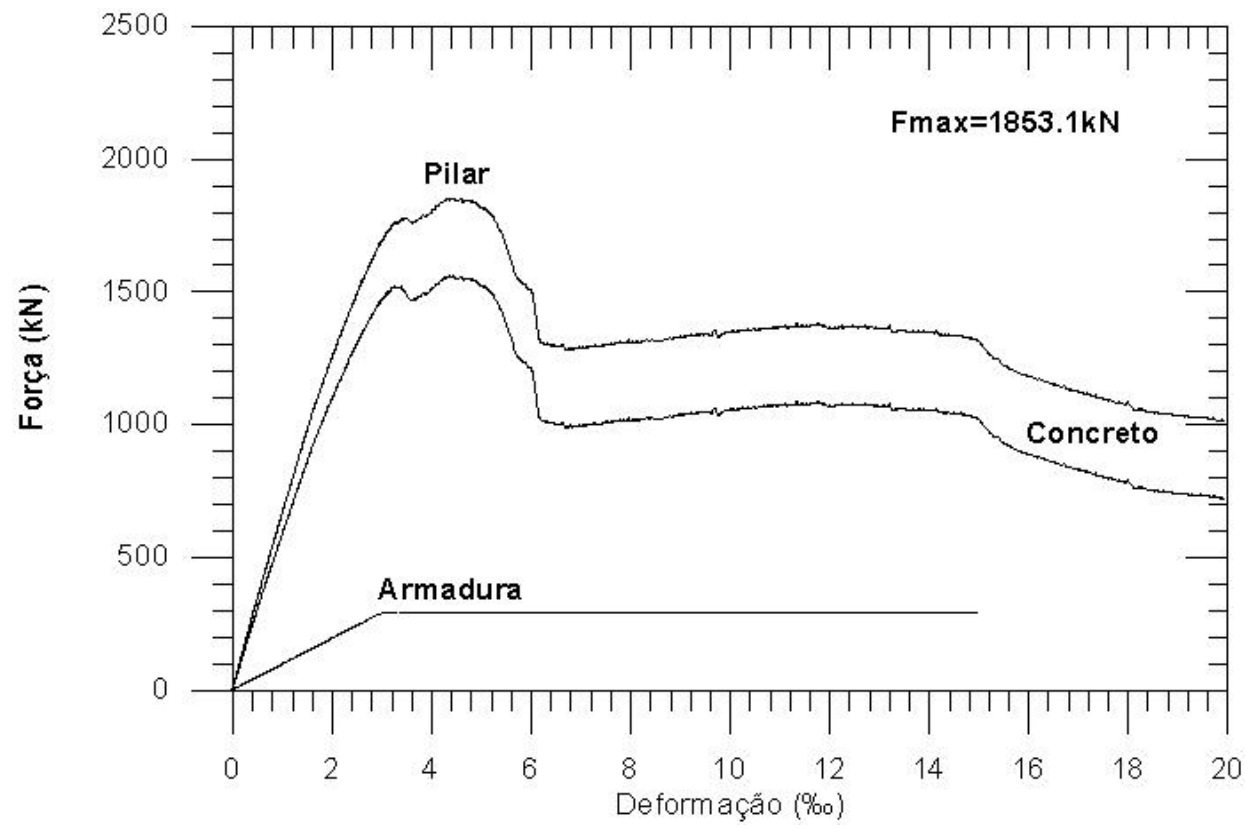

Figura A.65 - Diagramas forças parciais vs. deformação do pilar, do concreto e da armadura longitudinal.

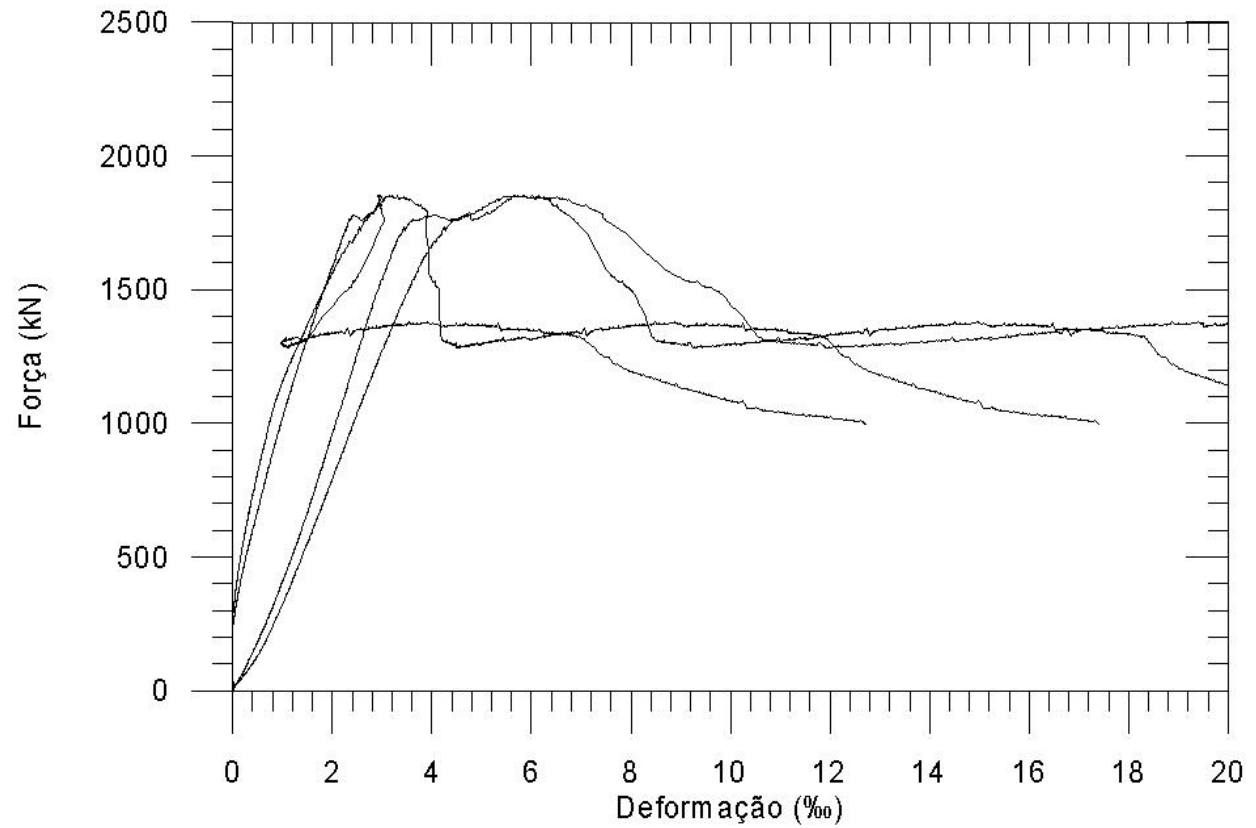

Figura A.66 - Diagramas força aplicada vs. deformação lida por cada LVDt. 


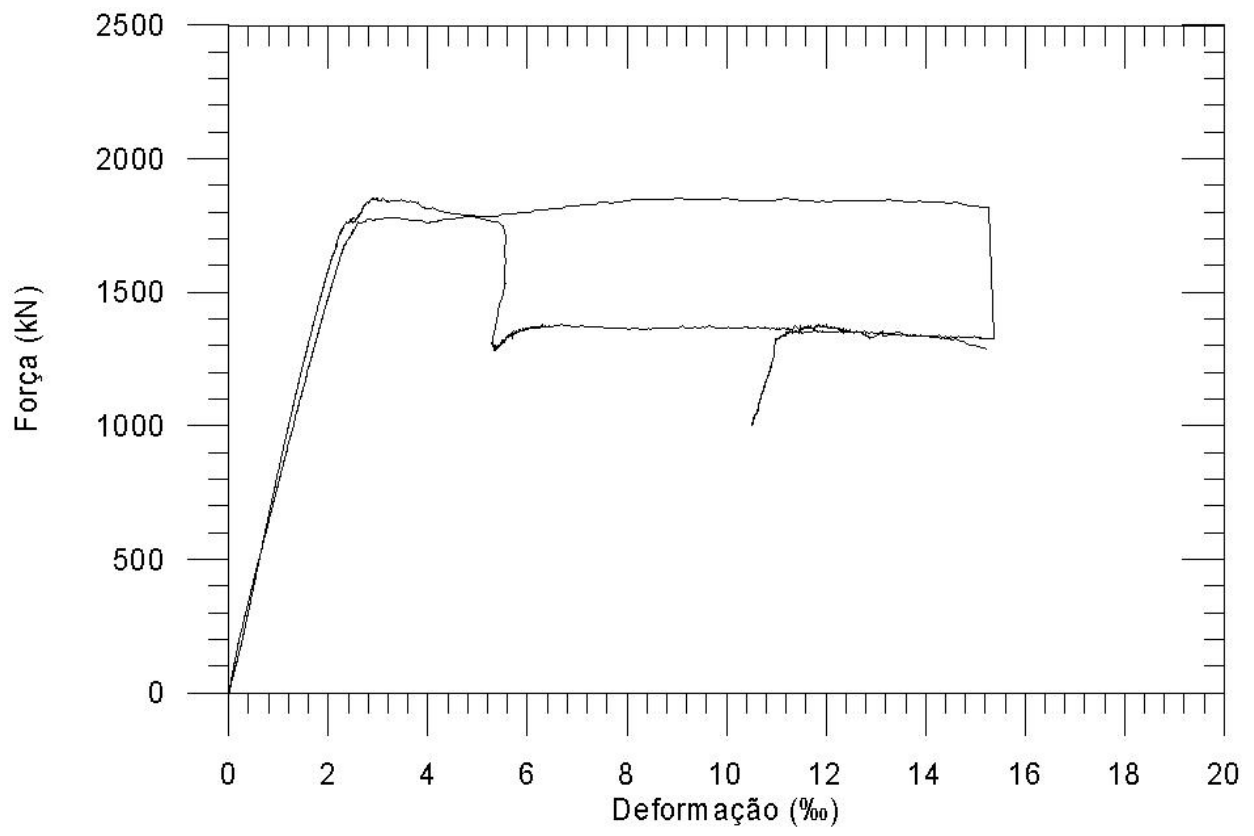

Figura A.67 - Diagramas força aplicada vs. deformação lida pelos extensômetros na armadura longitudinal.

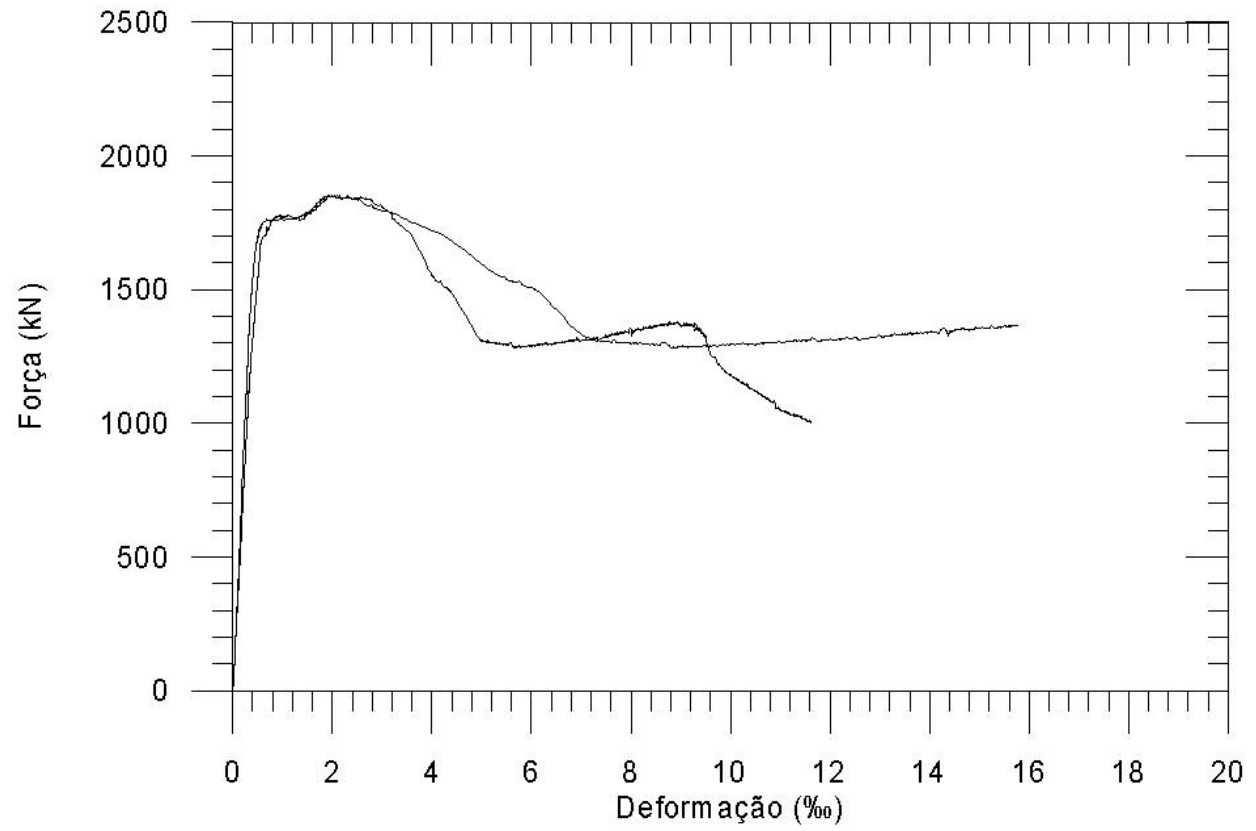

Figura A.68 - Diagramas força aplicada vs. deformação lida pelos extensômetros na armadura transversal. 


\section{A.18.Pilar P28050}

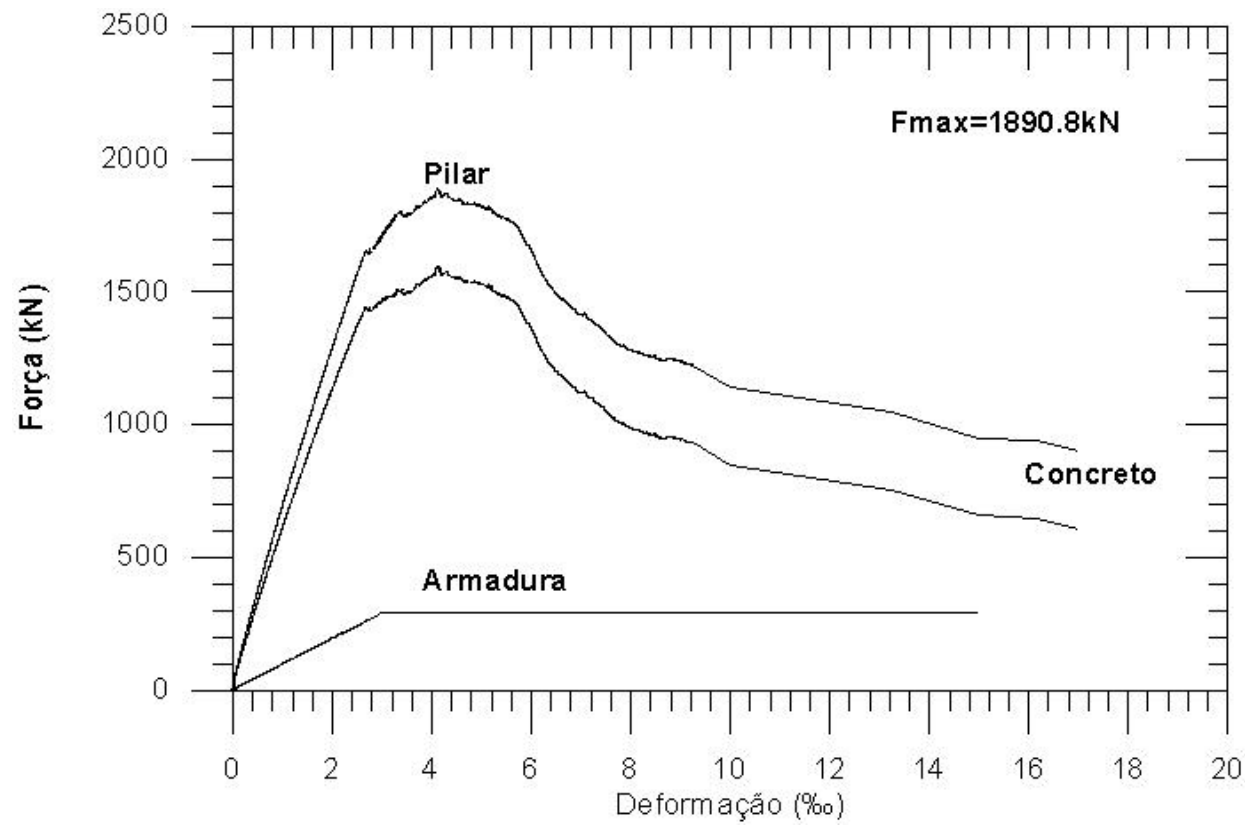

Figura A.69 - Diagramas forças parciais vs. deformação do pilar, do concreto e da armadura longitudinal.

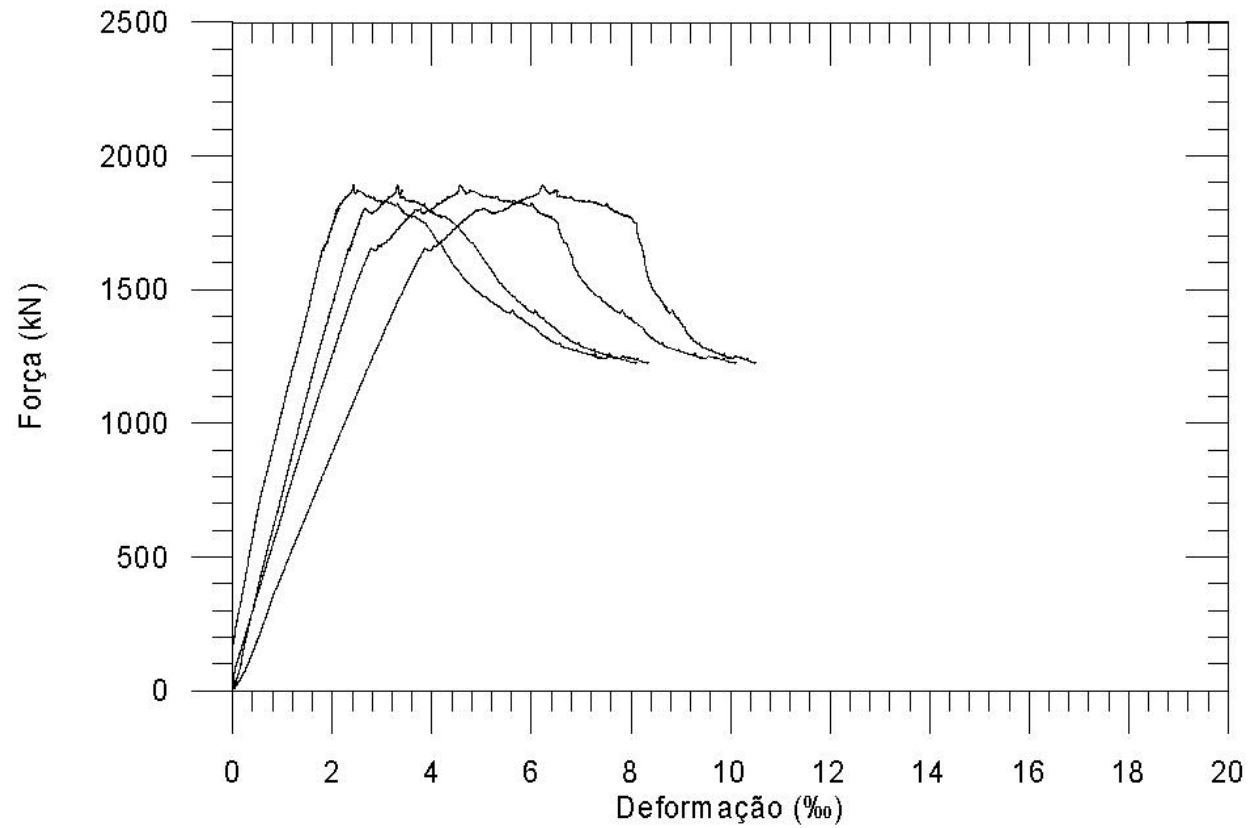

Figura A.70 - Diagramas força aplicada vs. deformação lida por cada LVDt. 


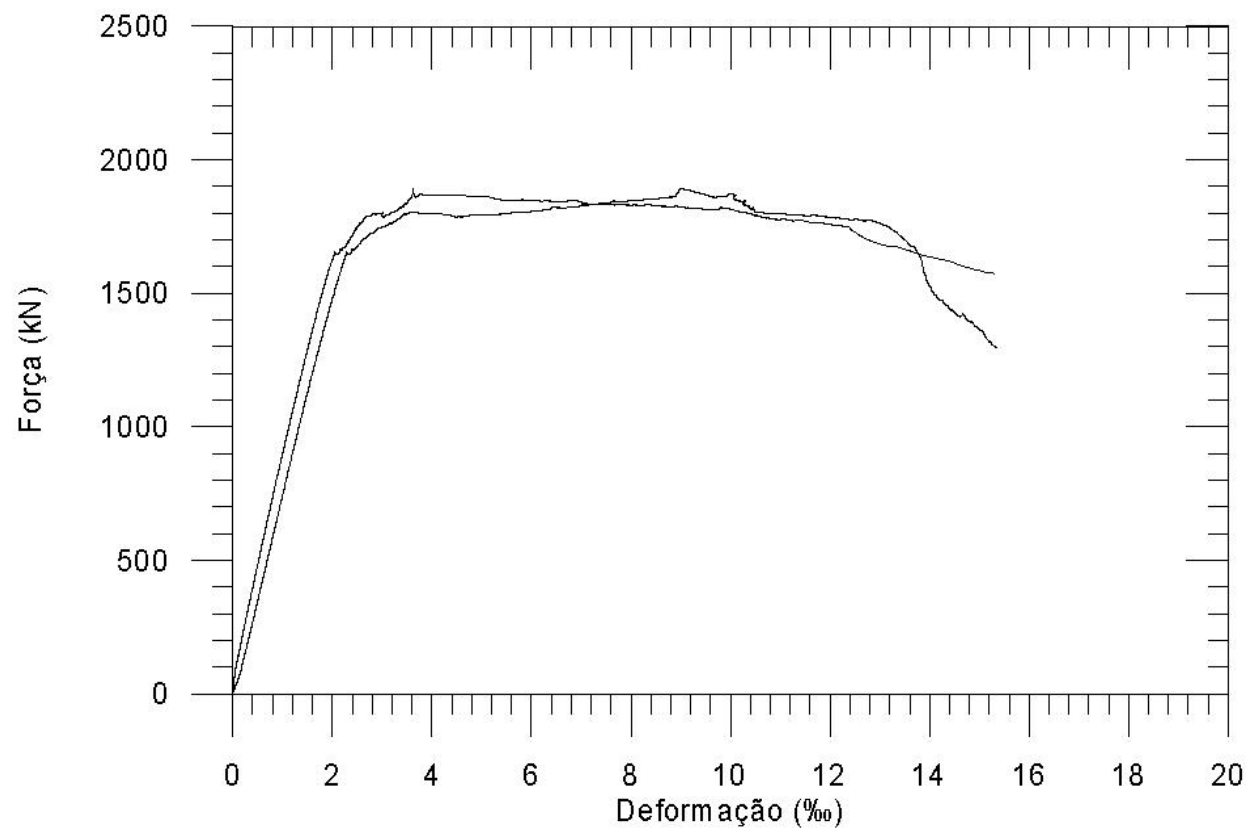

Figura A.71 - Diagramas força aplicada vs. deformação lida pelos extensômetros na armadura longitudinal.

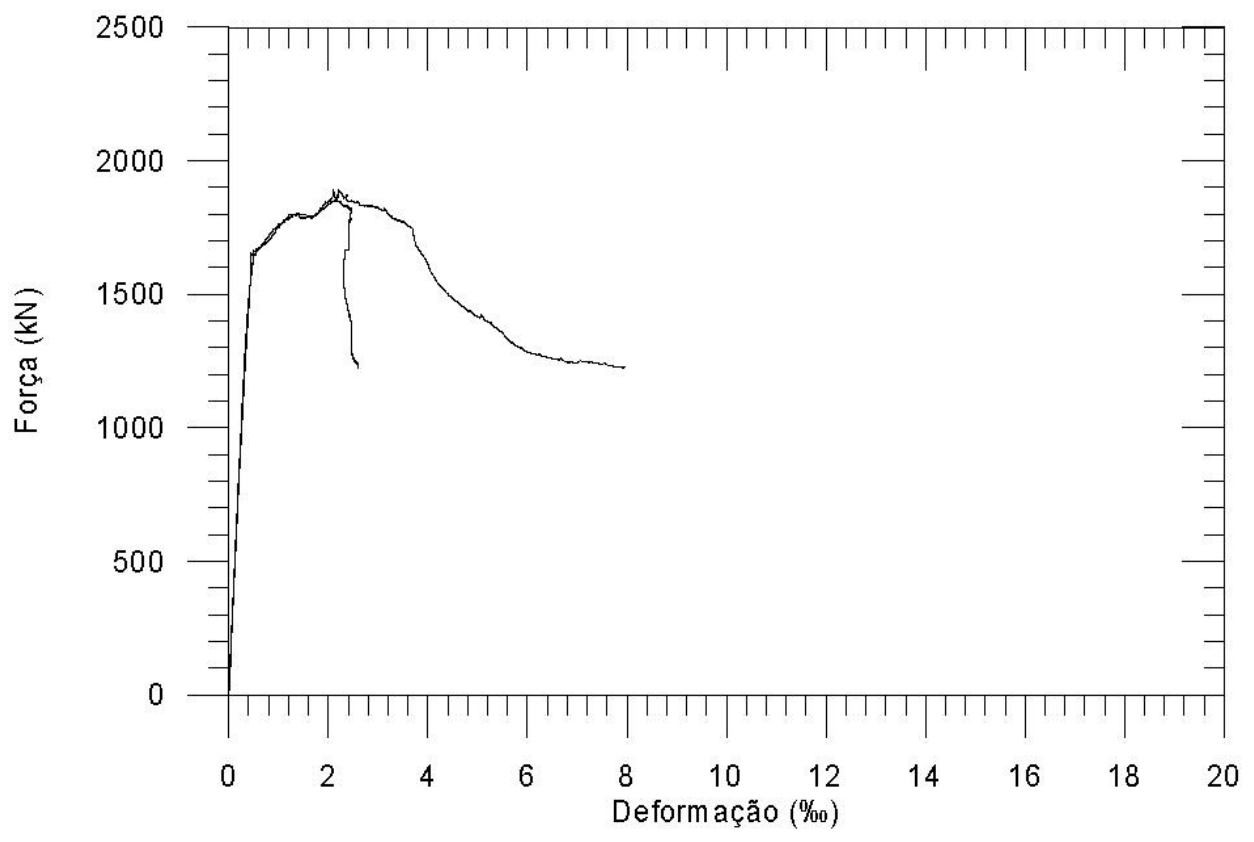

Figura A.72 - Diagramas força aplicada vs. deformação lida pelos extensômetros na armadura transversal. 


\section{A.19.Pilar P1801505}

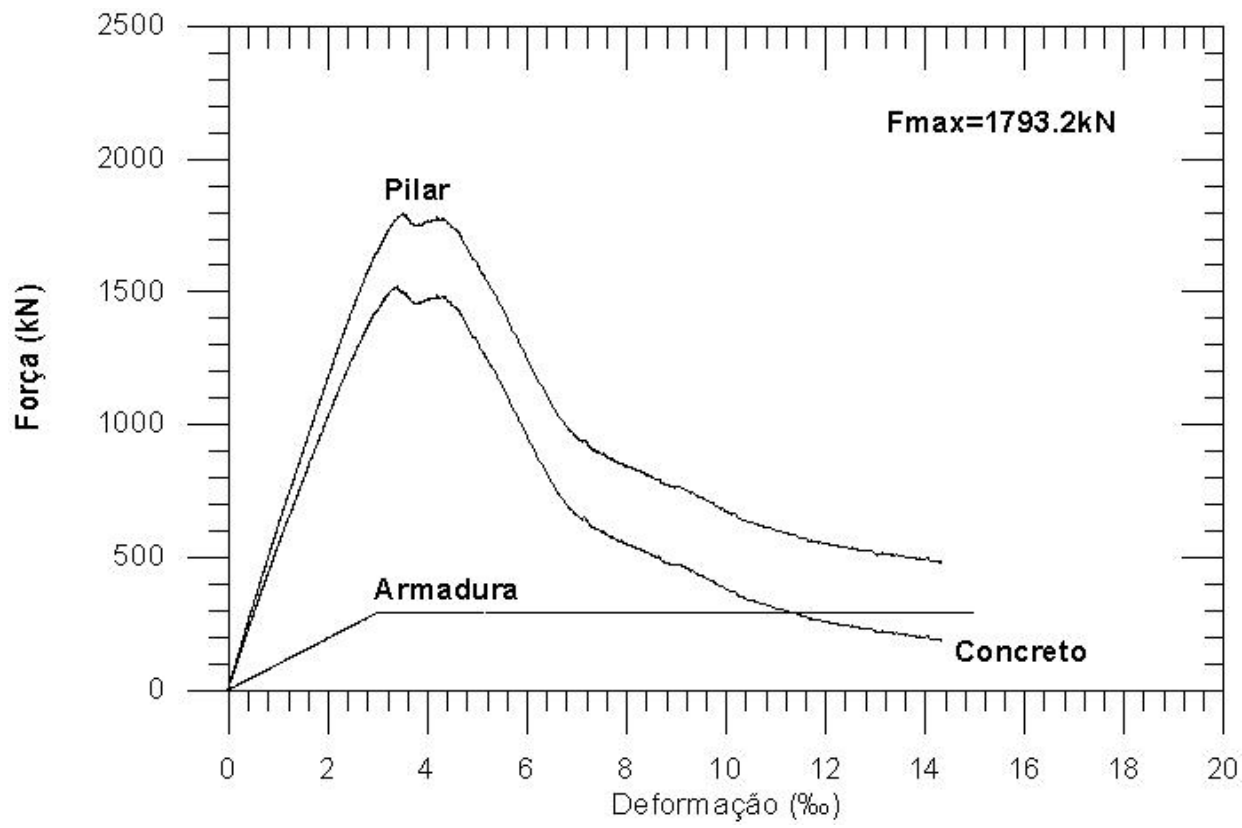

Figura A.73 - Diagramas forças parciais vs. deformação do pilar, do concreto e da armadura longitudinal.

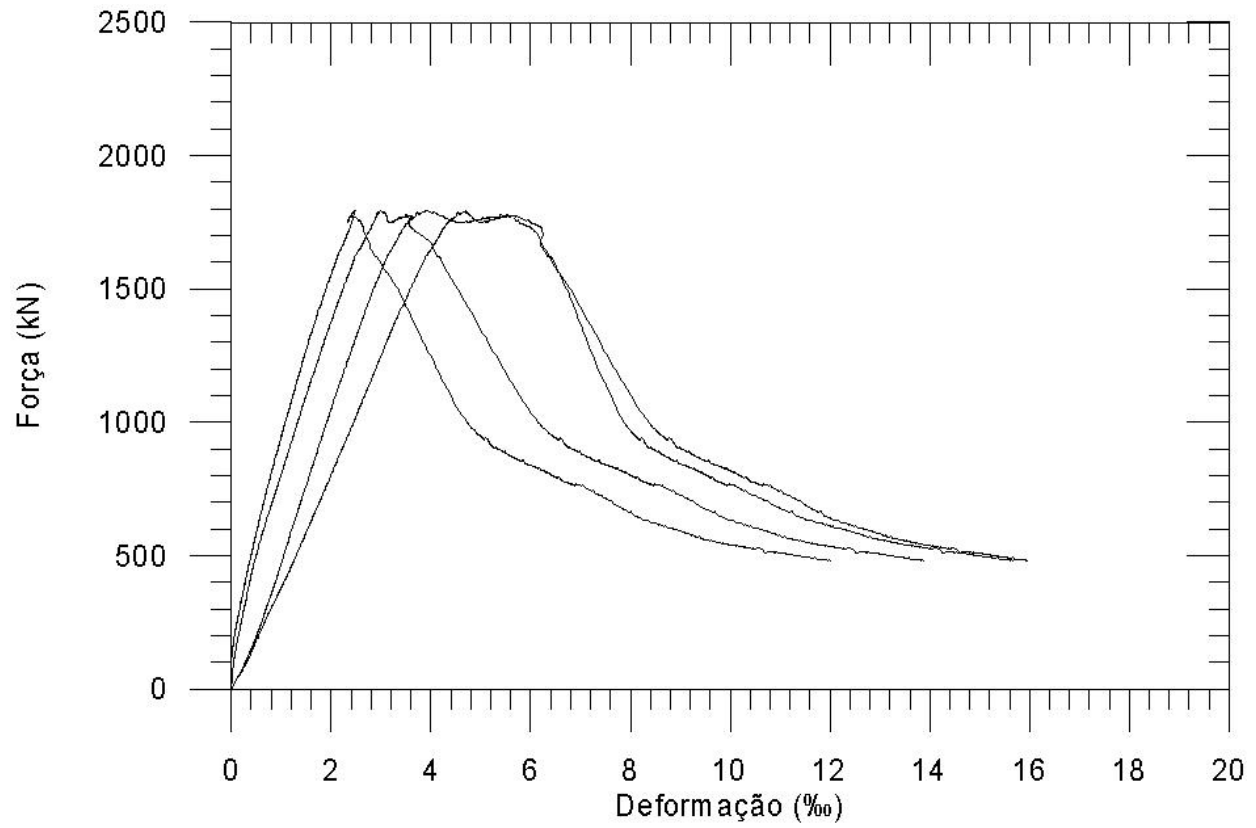

Figura A.74 - Diagramas força aplicada vs. deformação lida por cada LVDt. 


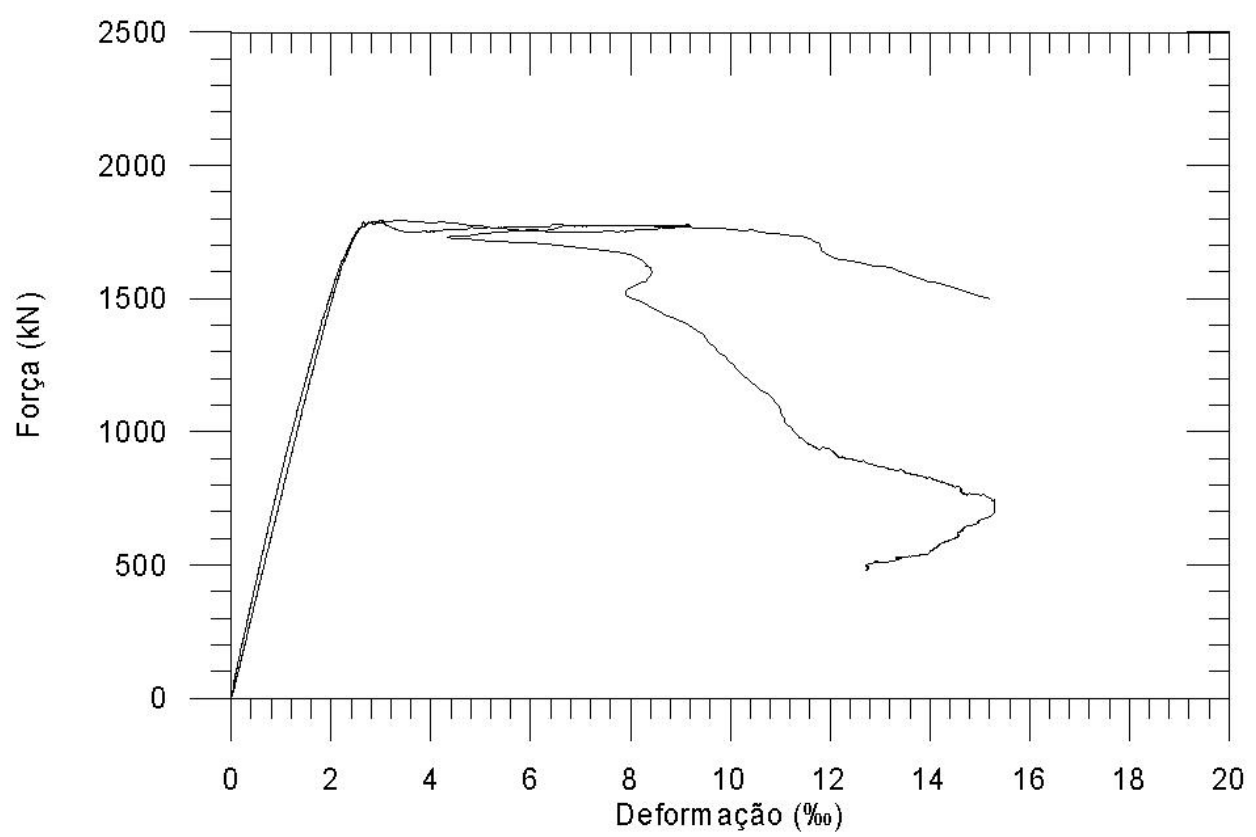

Figura A.75 - Diagramas força aplicada vs. deformação lida pelos extensômetros na armadura longitudinal.

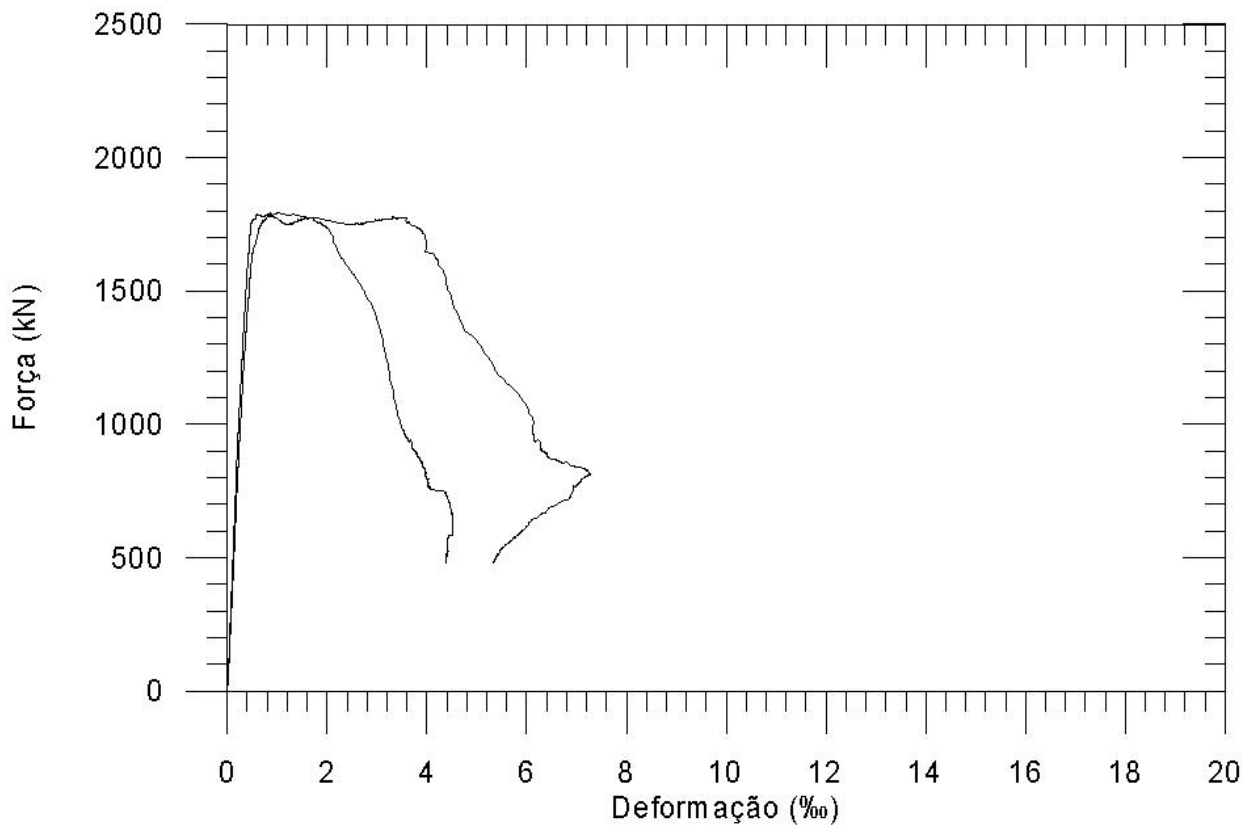

Figura A.76 - Diagramas força aplicada vs. deformação lida pelos extensômetros na armadura transversal. 


\section{A.20.Pilar P2801505}

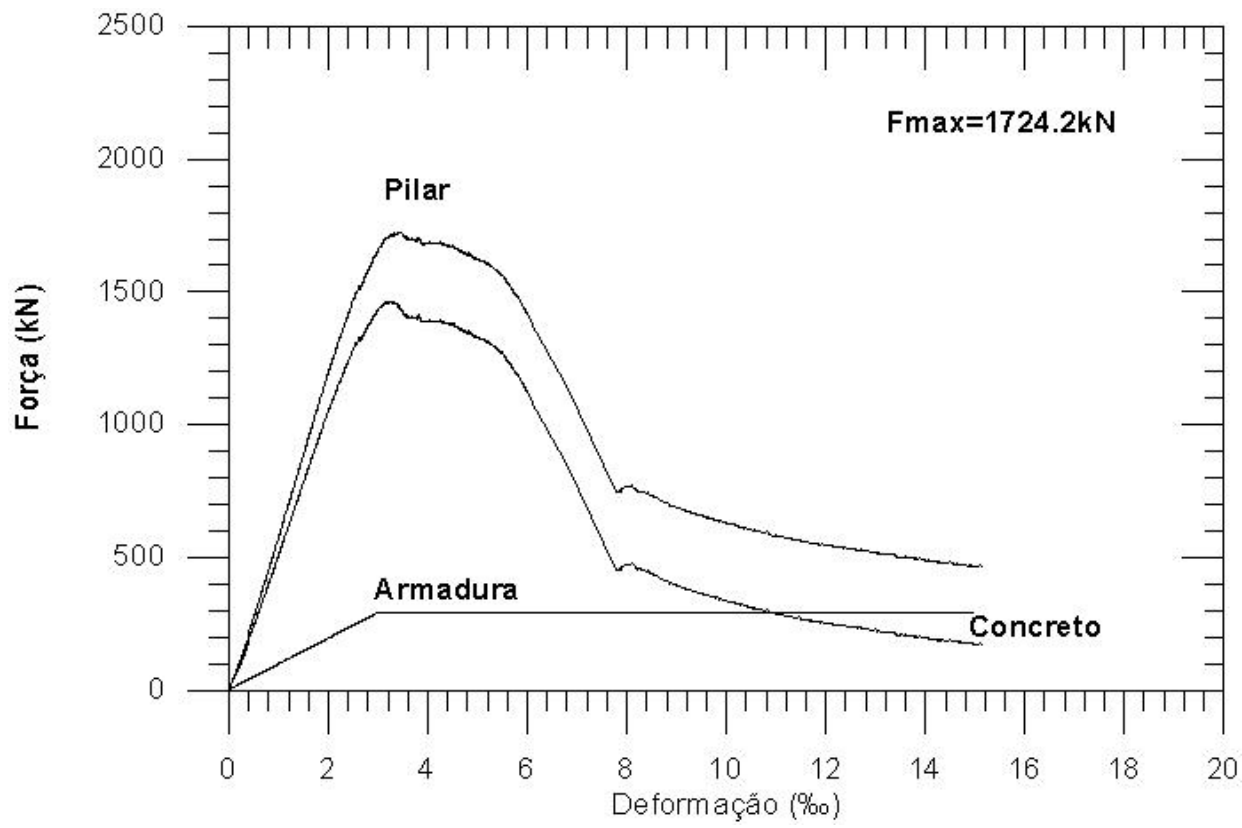

Figura A.77 - Diagramas forças parciais vs. deformação do pilar, do concreto e da armadura longitudinal.

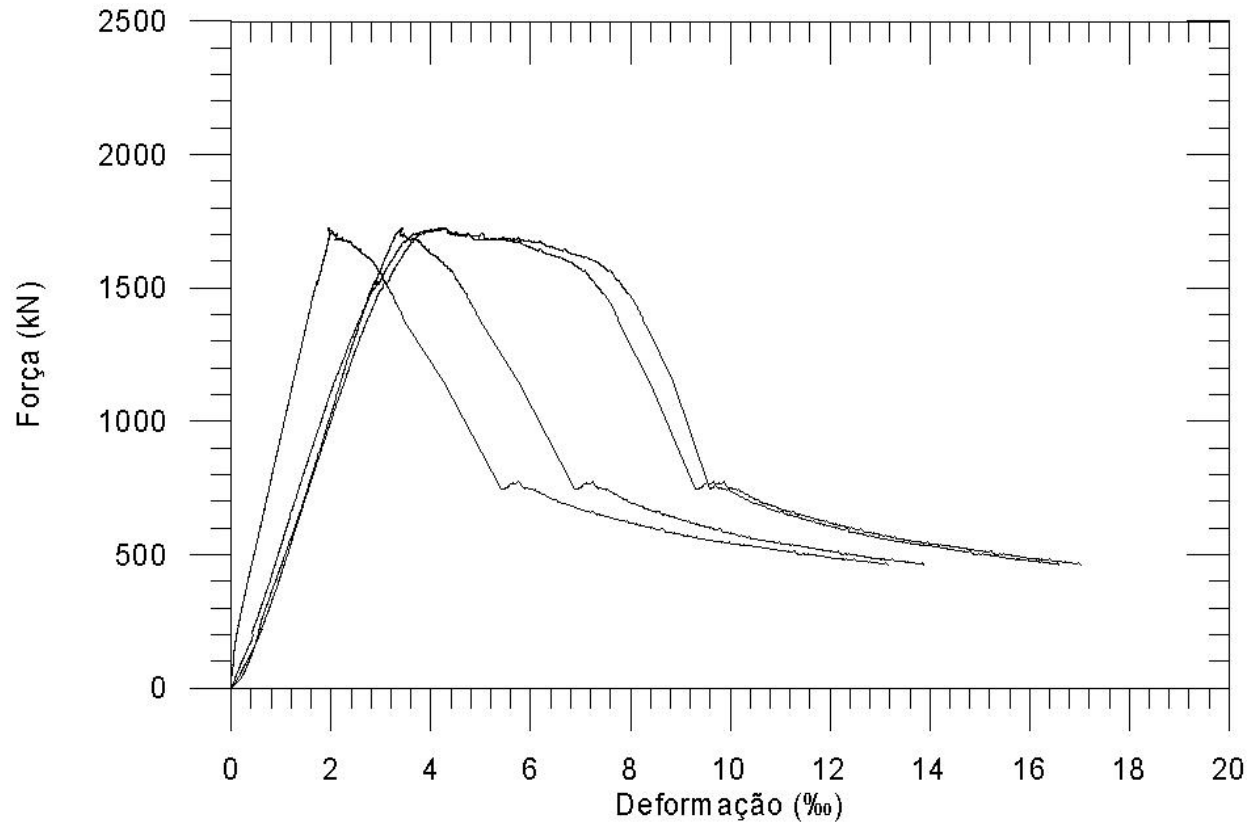

Figura A.78 - Diagramas força aplicada vs. deformação lida por cada LVDt. 


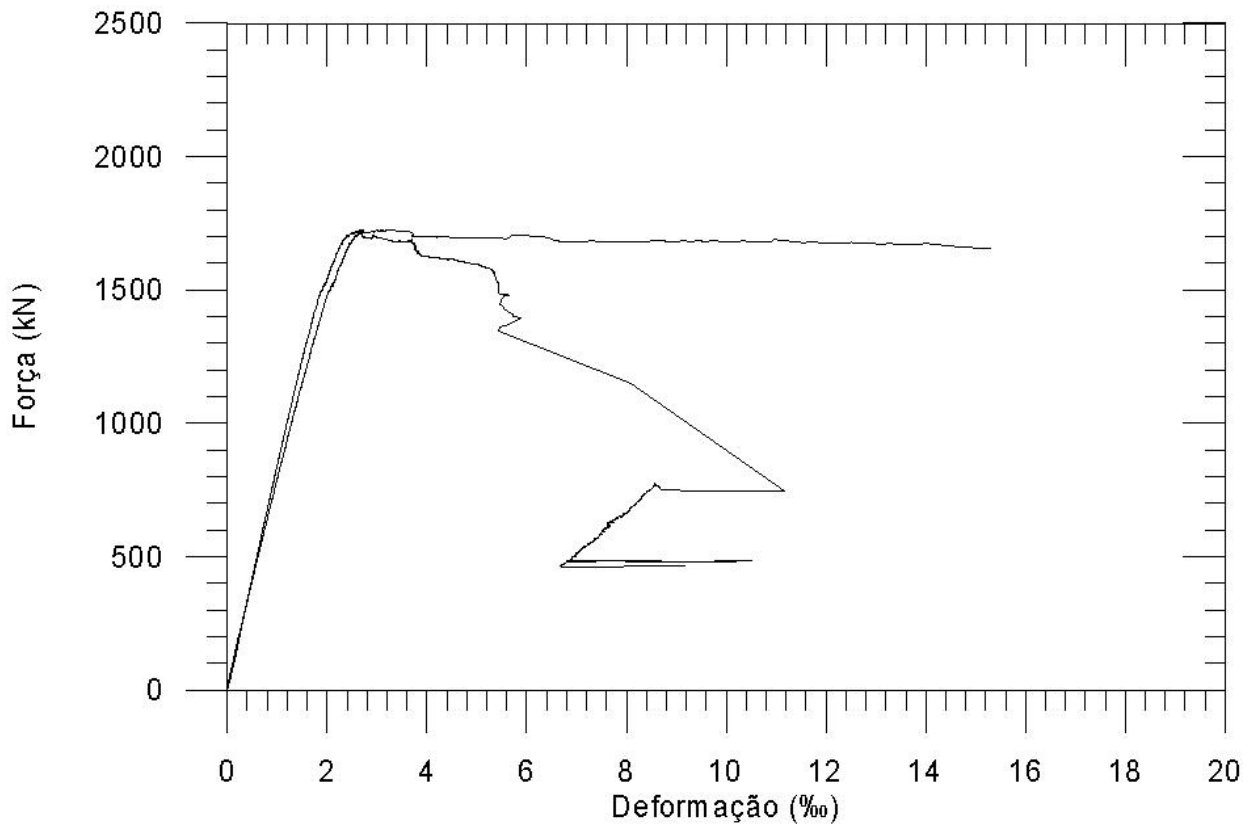

Figura A.79 - Diagramas força aplicada vs. deformação lida pelos extensômetros na armadura longitudinal.

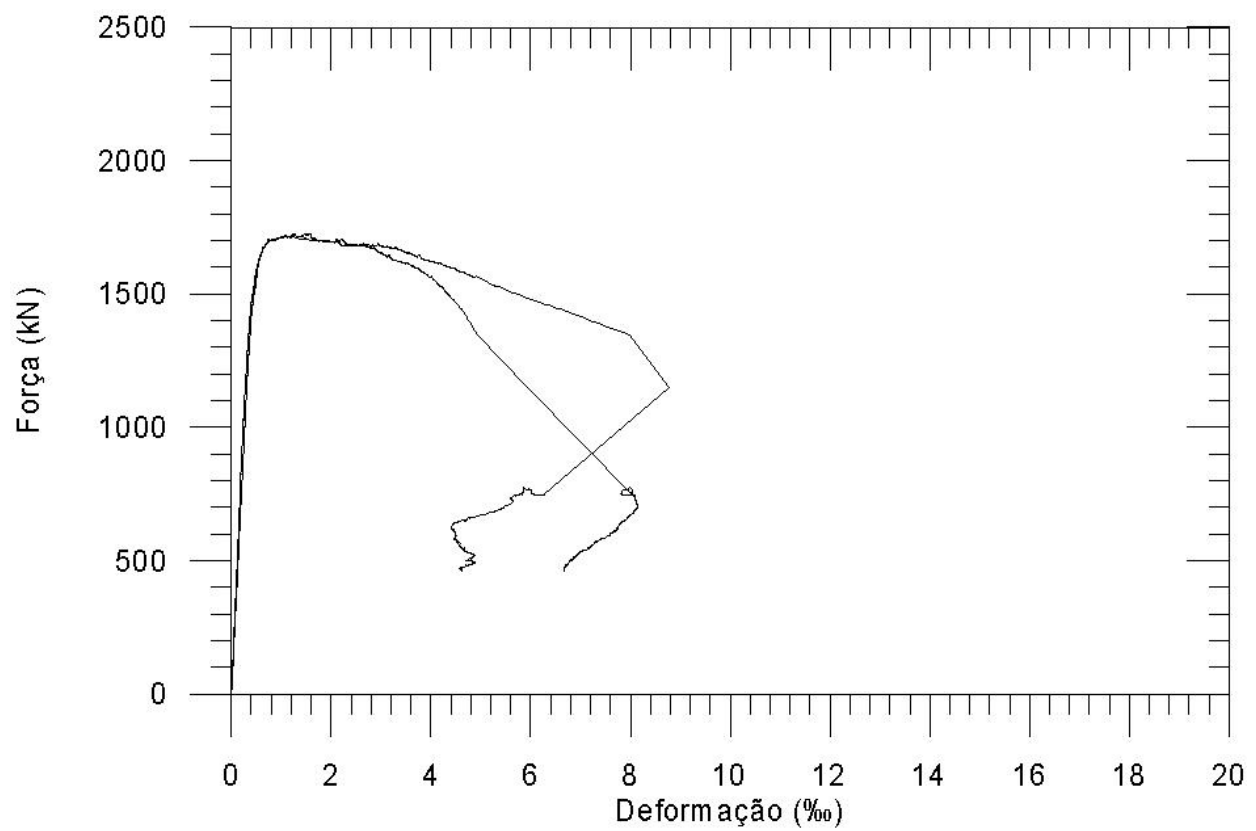

Figura A.80 - Diagramas força aplicada vs. deformação lida pelos extensômetros na armadura transversal. 


\section{A.21.Pilar P180505}

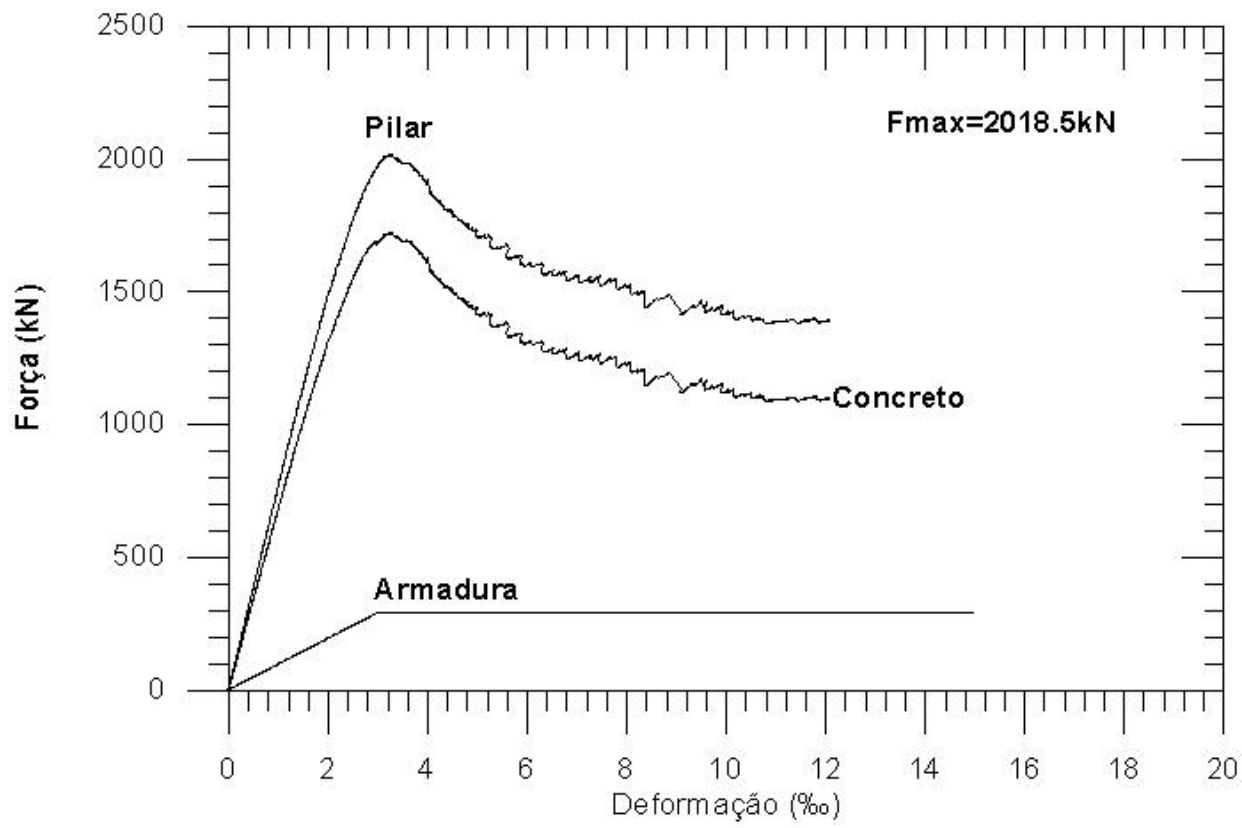

Figura A.81 - Diagramas forças parciais vs. deformação do pilar, do concreto e da armadura longitudinal.

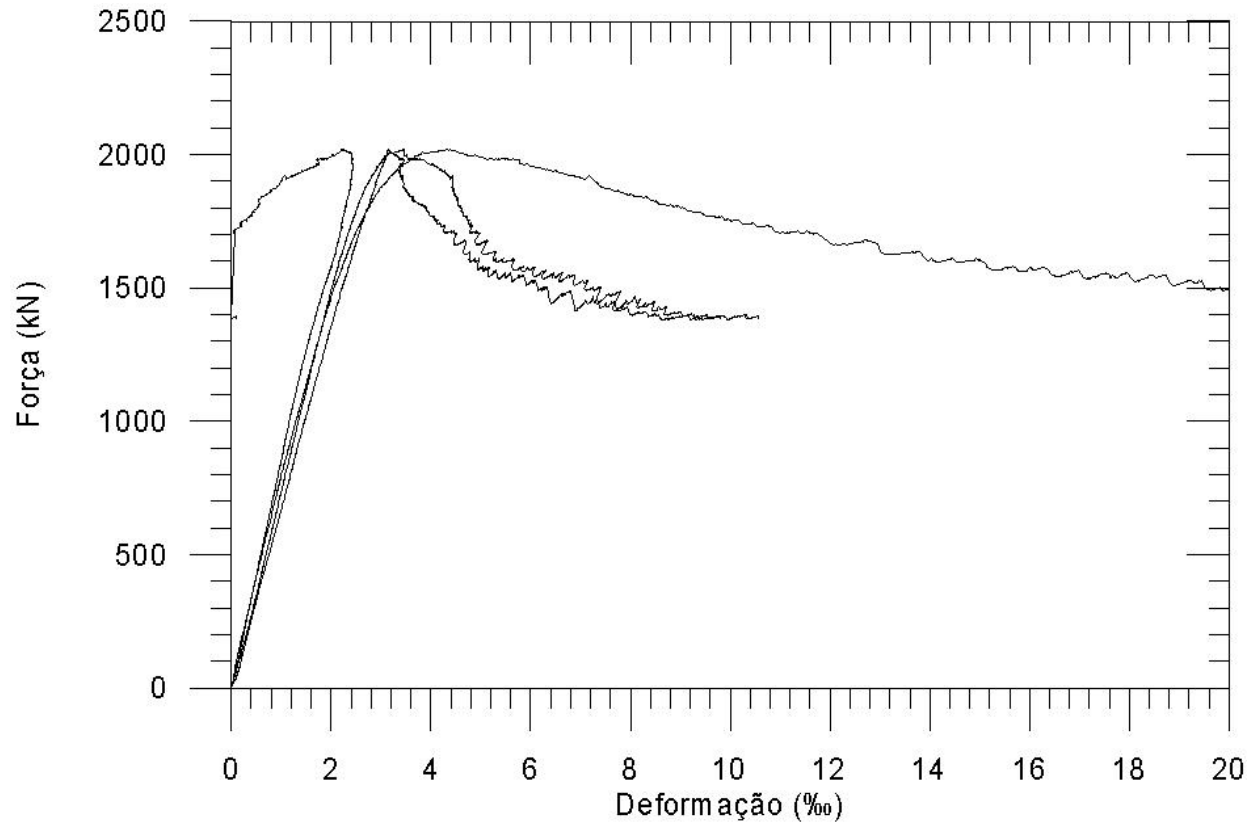

Figura A.82 - Diagramas força aplicada vs. deformação lida por cada LVDt. 


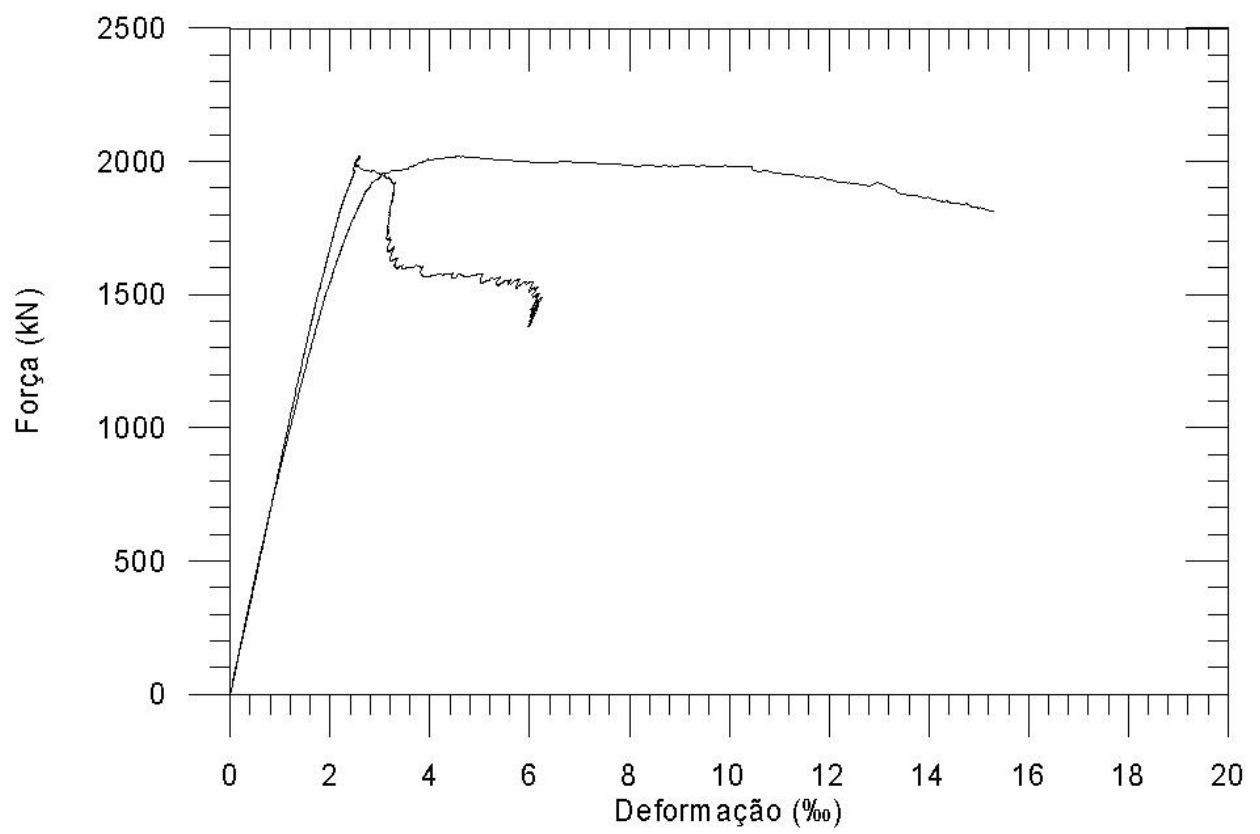

Figura A.83 - Diagramas força aplicada vs. deformação lida pelos extensômetros na armadura longitudinal.

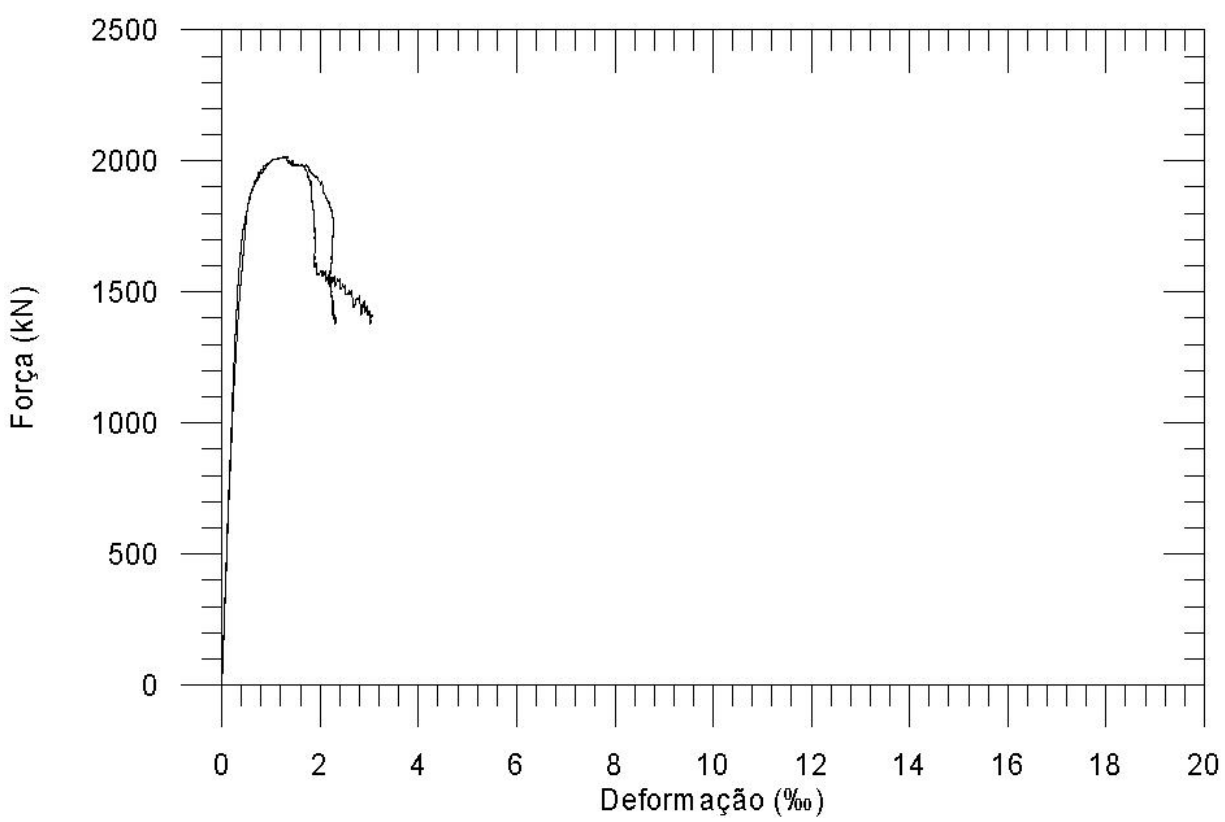

Figura A.84 - Diagramas força aplicada vs. deformação lida pelos extensômetros na armadura transversal. 


\section{A.22.Pilar P280505}

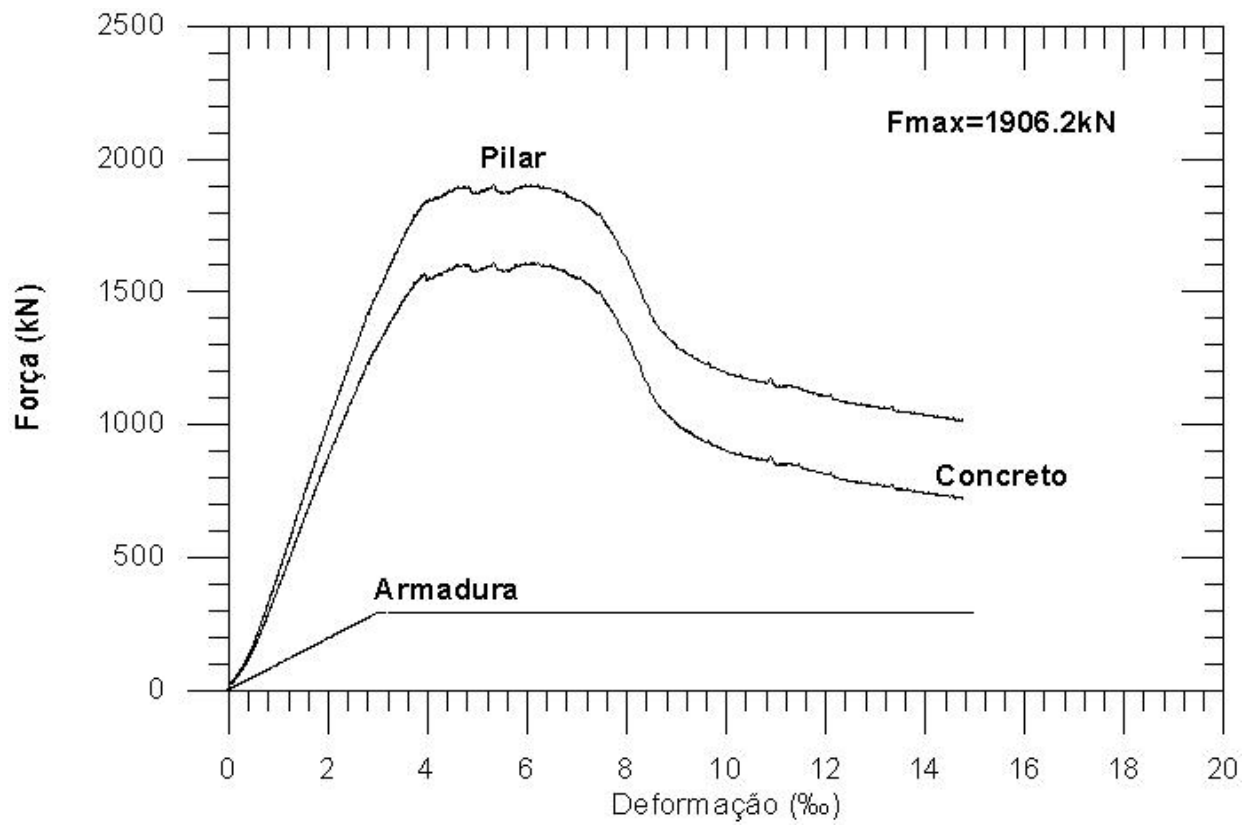

Figura A.85 - Diagramas forças parciais vs. deformação do pilar, do concreto e da armadura longitudinal.

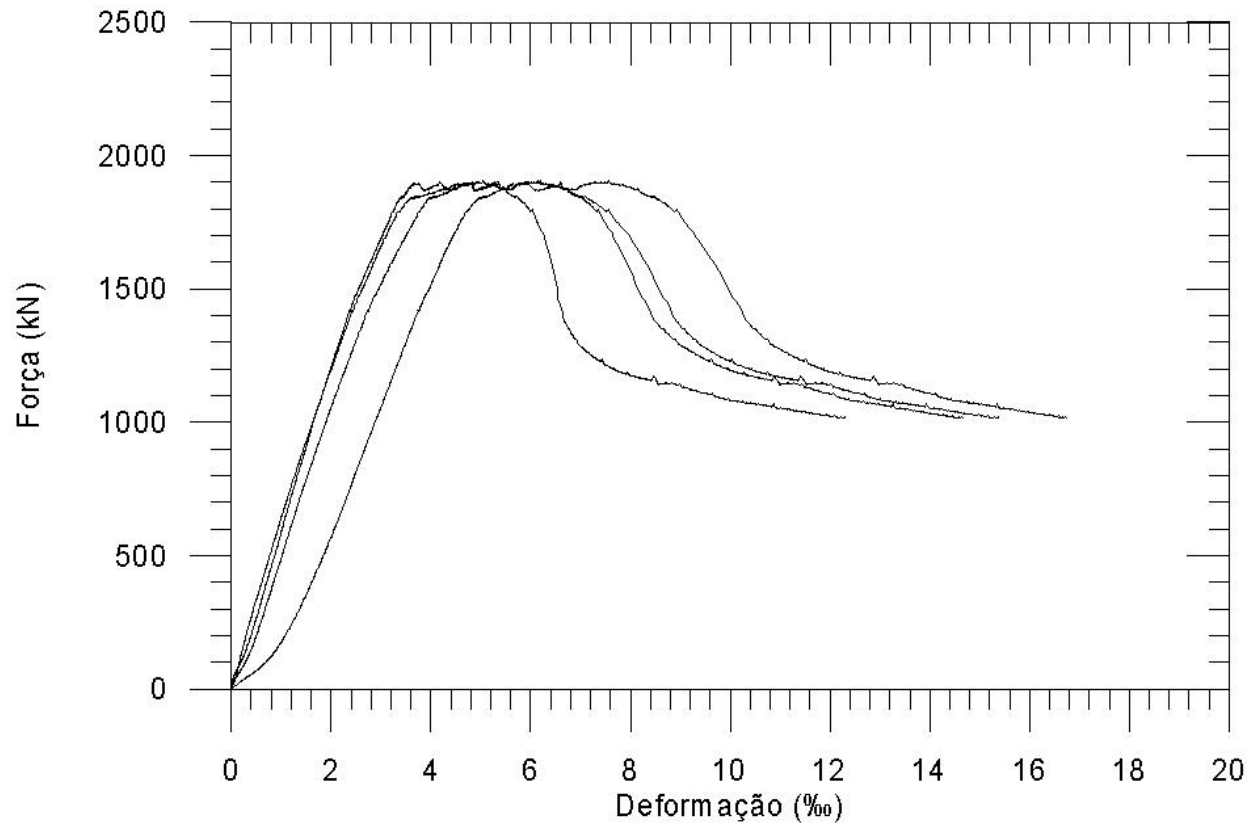

Figura A.86 - Diagramas força aplicada vs. deformação lida por cada LVDt. 


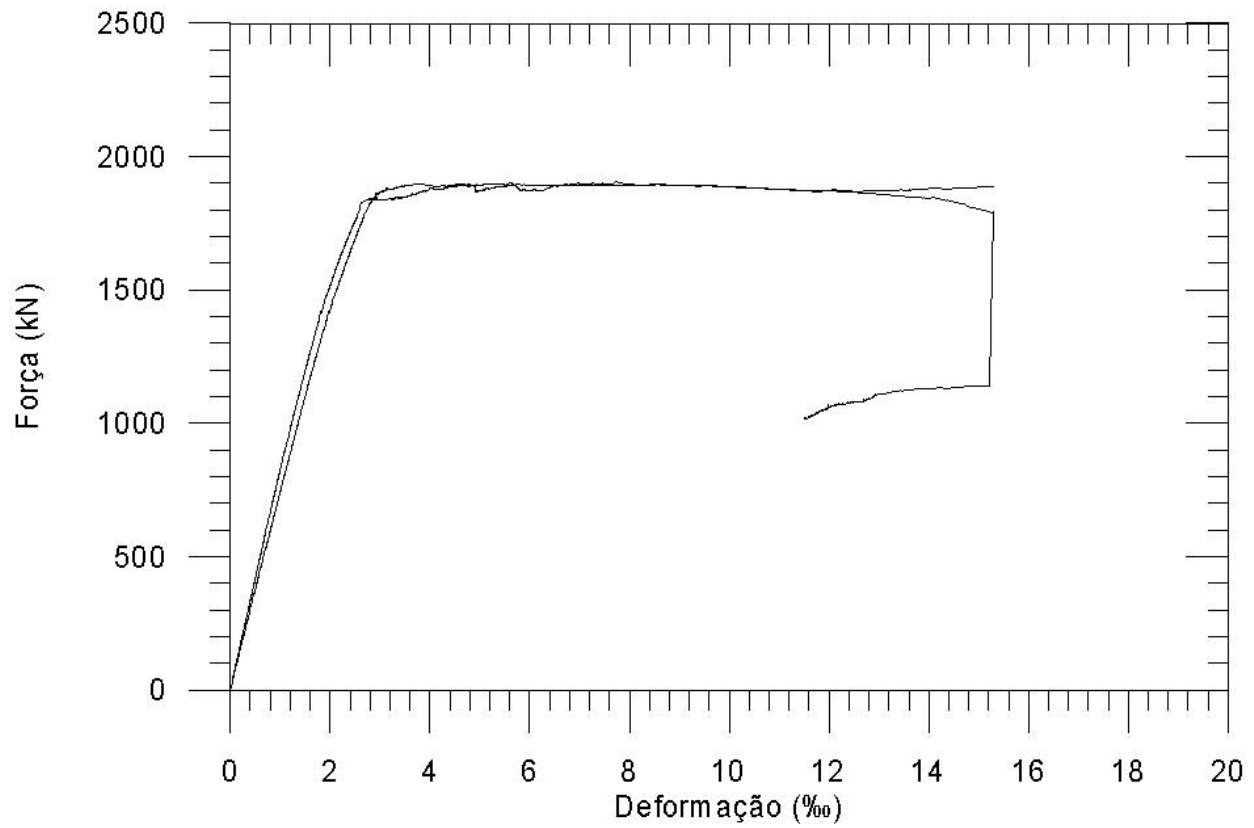

Figura A.87 - Diagramas força aplicada vs. deformação lida pelos extensômetros na armadura longitudinal.

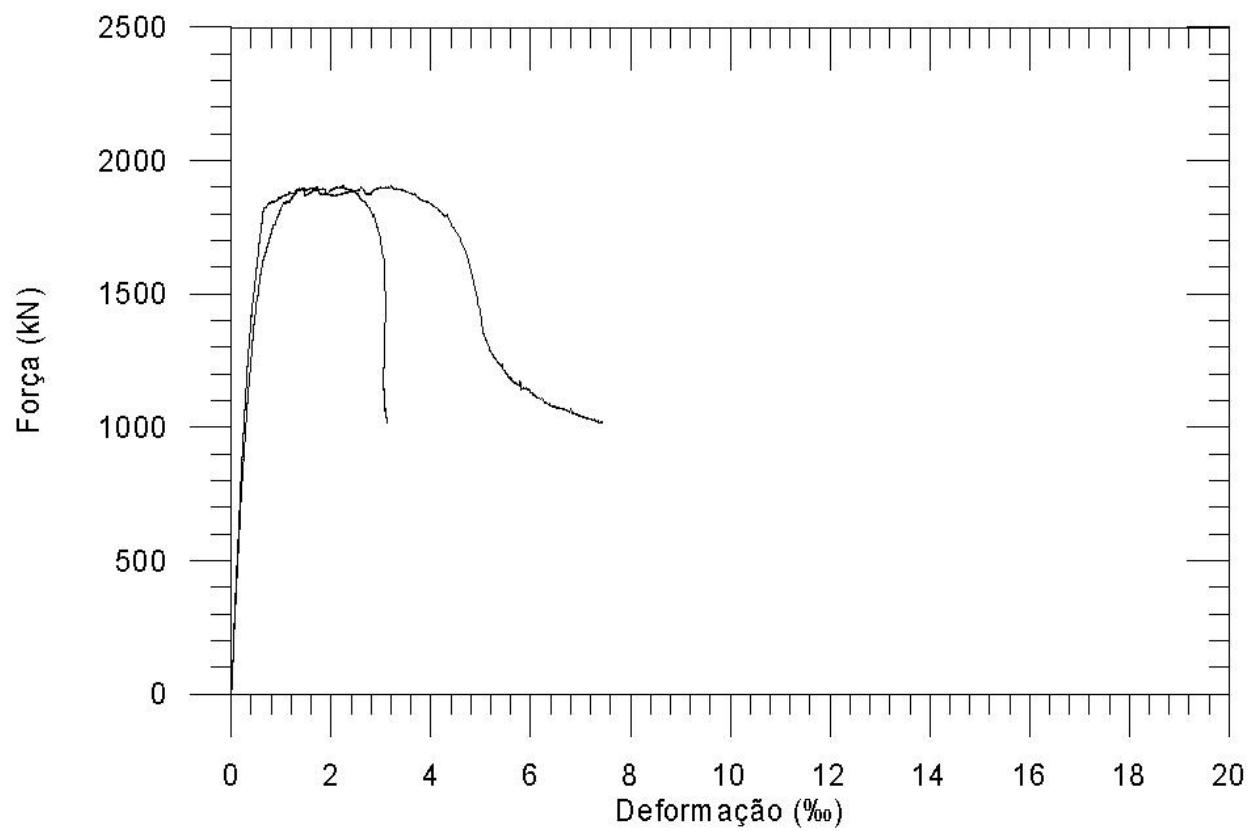

Figura A.88 - Diagramas força aplicada vs. deformação lida pelos extensômetros na armadura transversal. 


\section{A.23.Pilar P180151}

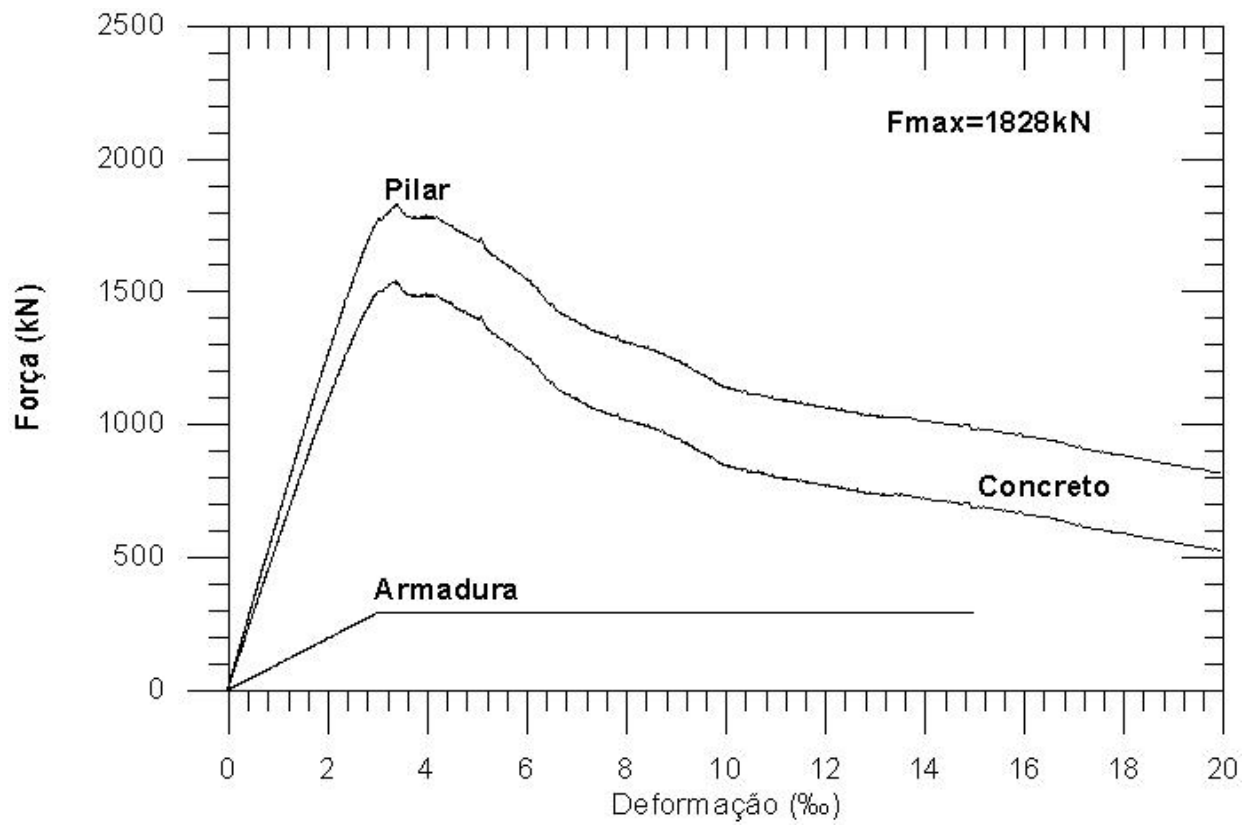

Figura A.89 - Diagramas forças parciais vs. deformação do pilar, do concreto e da armadura longitudinal.

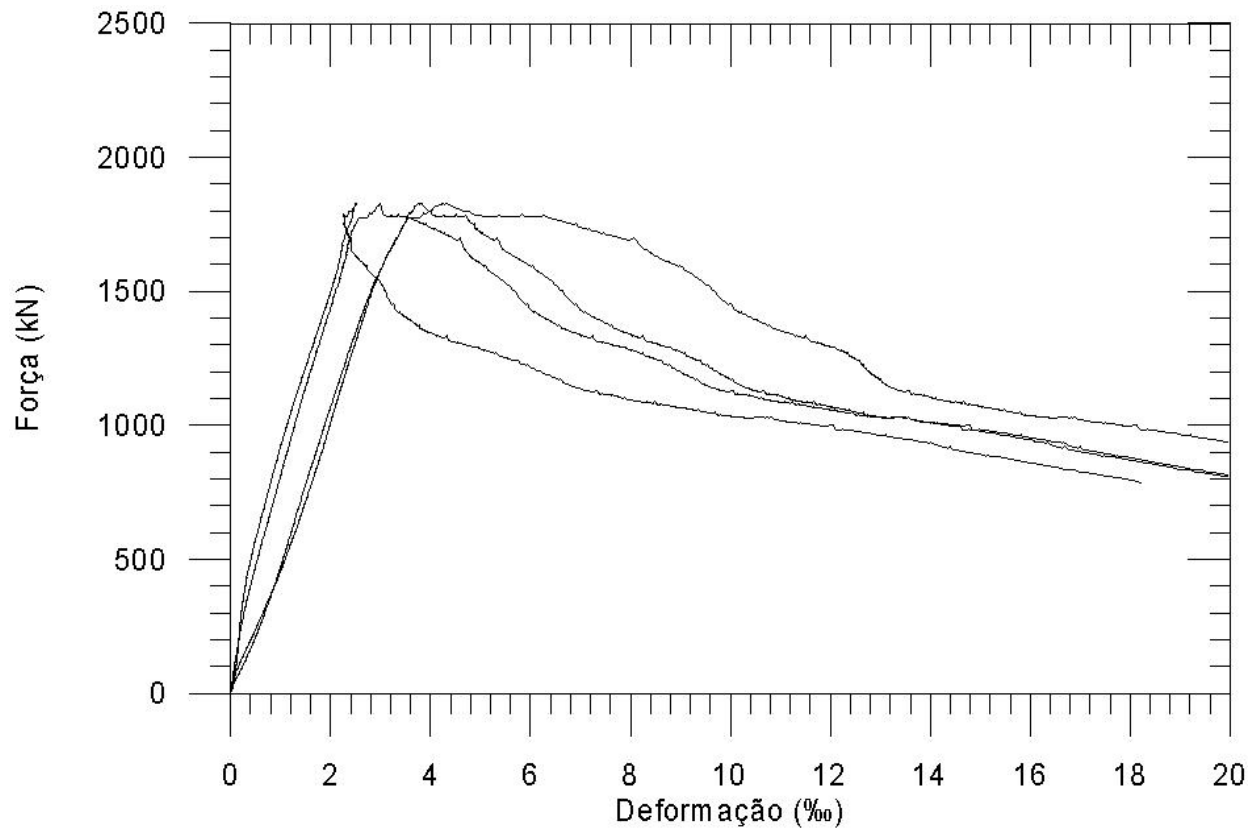

Figura A.90 - Diagramas força aplicada vs. deformação lida por cada LVDt. 


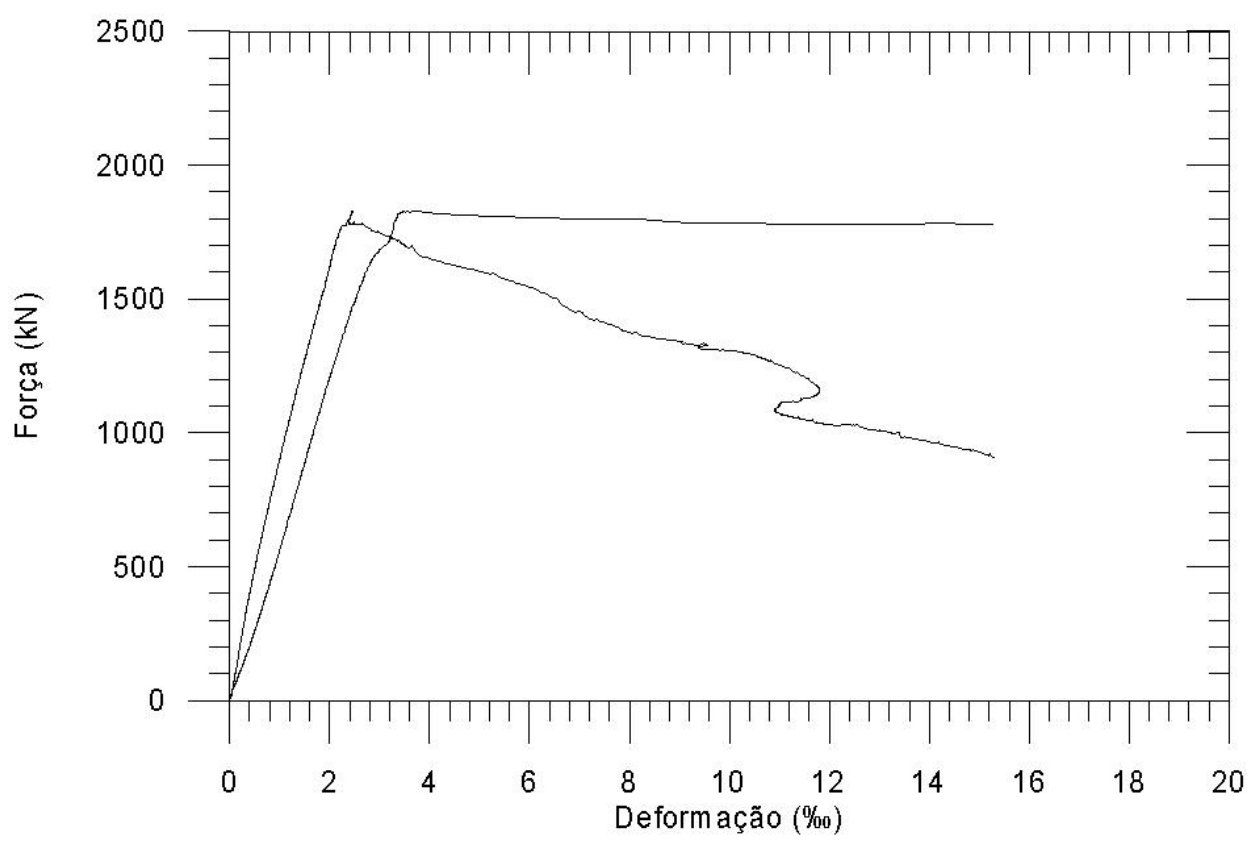

Figura A.91 - Diagramas força aplicada vs. deformação lida pelos extensômetros na armadura longitudinal.

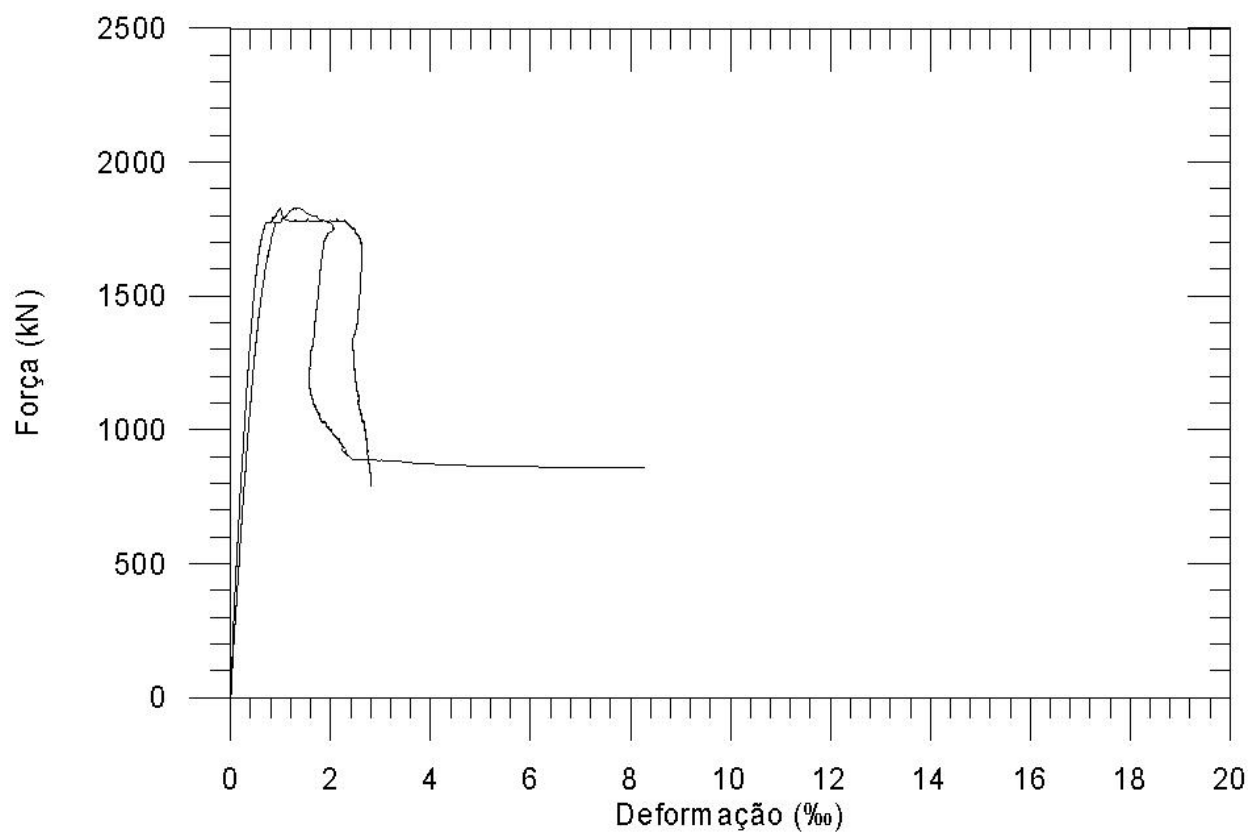

Figura A.92 - Diagramas força aplicada vs. deformação lida pelos extensômetros na armadura transversal. 


\section{A.24.Pilar P280151}

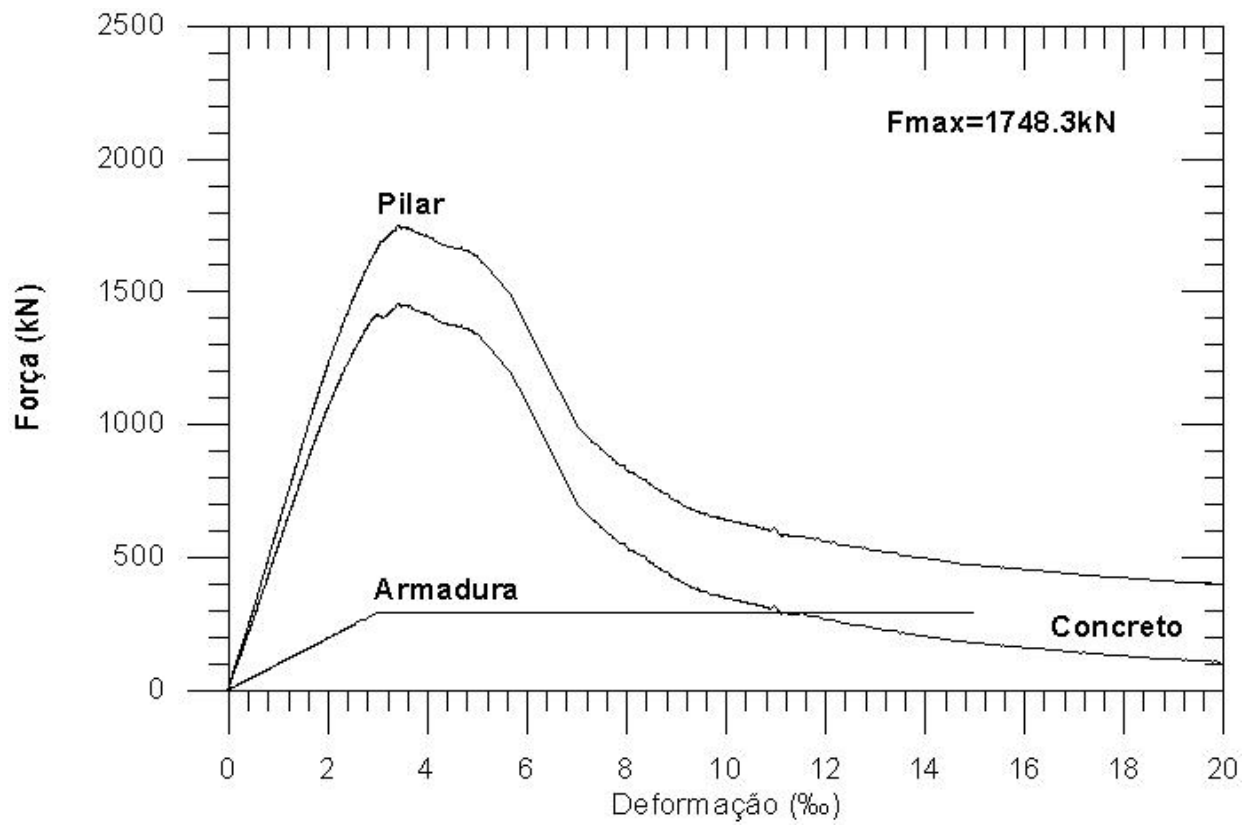

Figura A.93 - Diagramas forças parciais vs. deformação do pilar, do concreto e da armadura longitudinal.

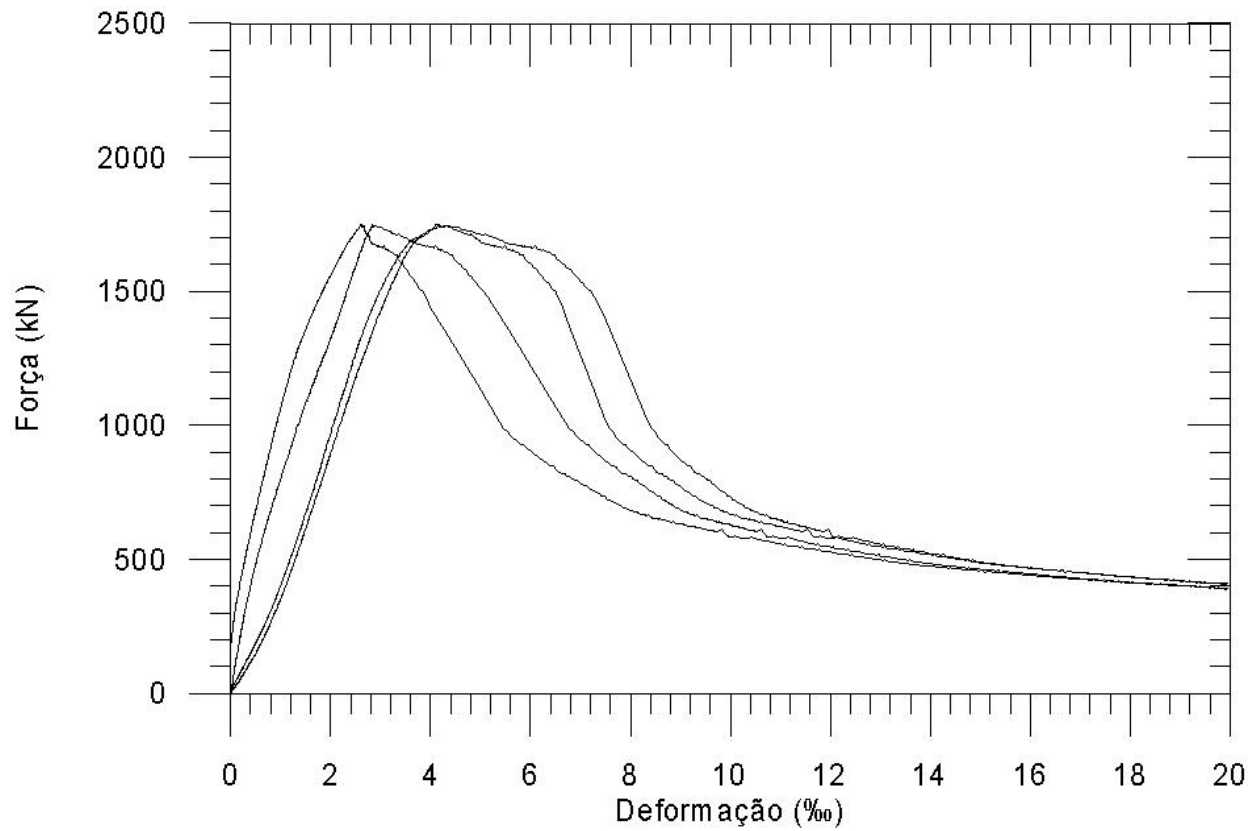

Figura A.94 - Diagramas força aplicada vs. deformação lida por cada LVDt. 


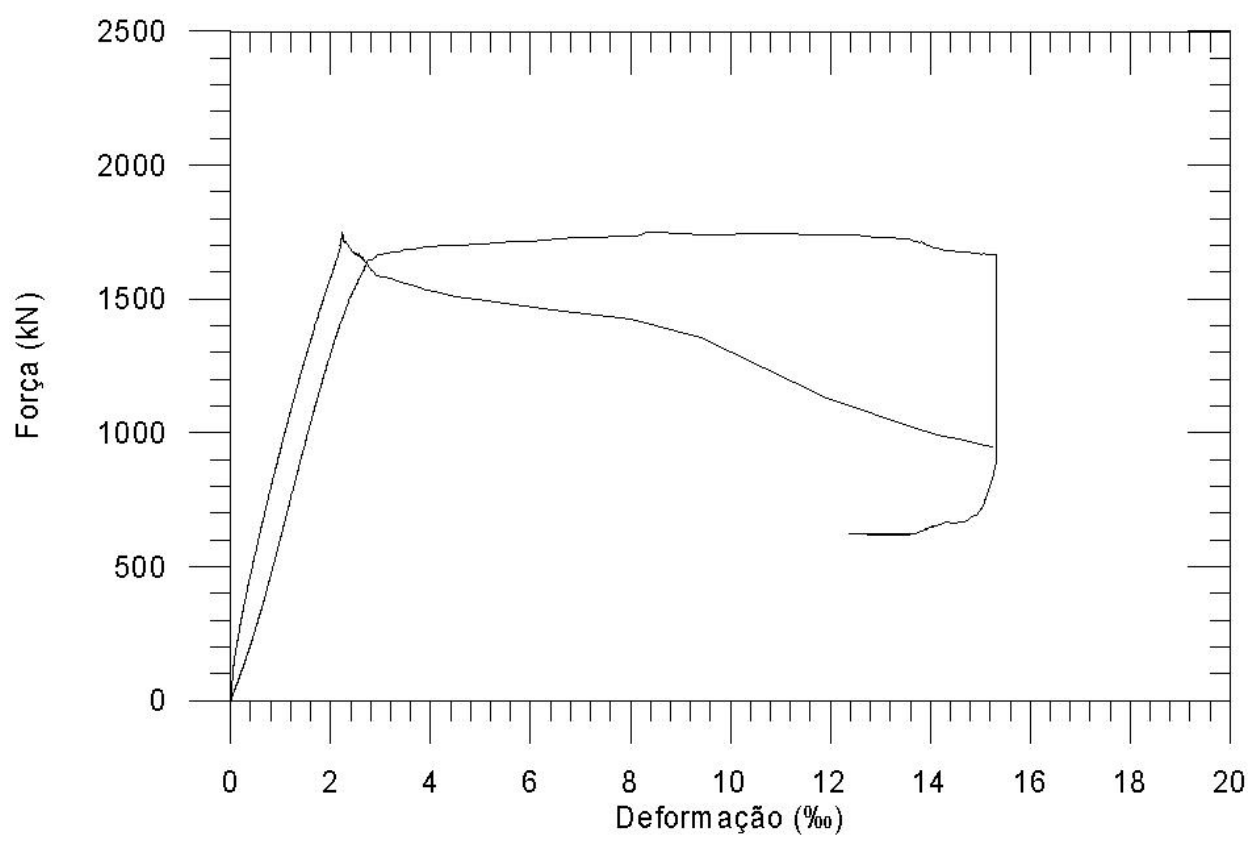

Figura A.95 - Diagramas força aplicada vs. deformação lida pelos extensômetros na armadura longitudinal.

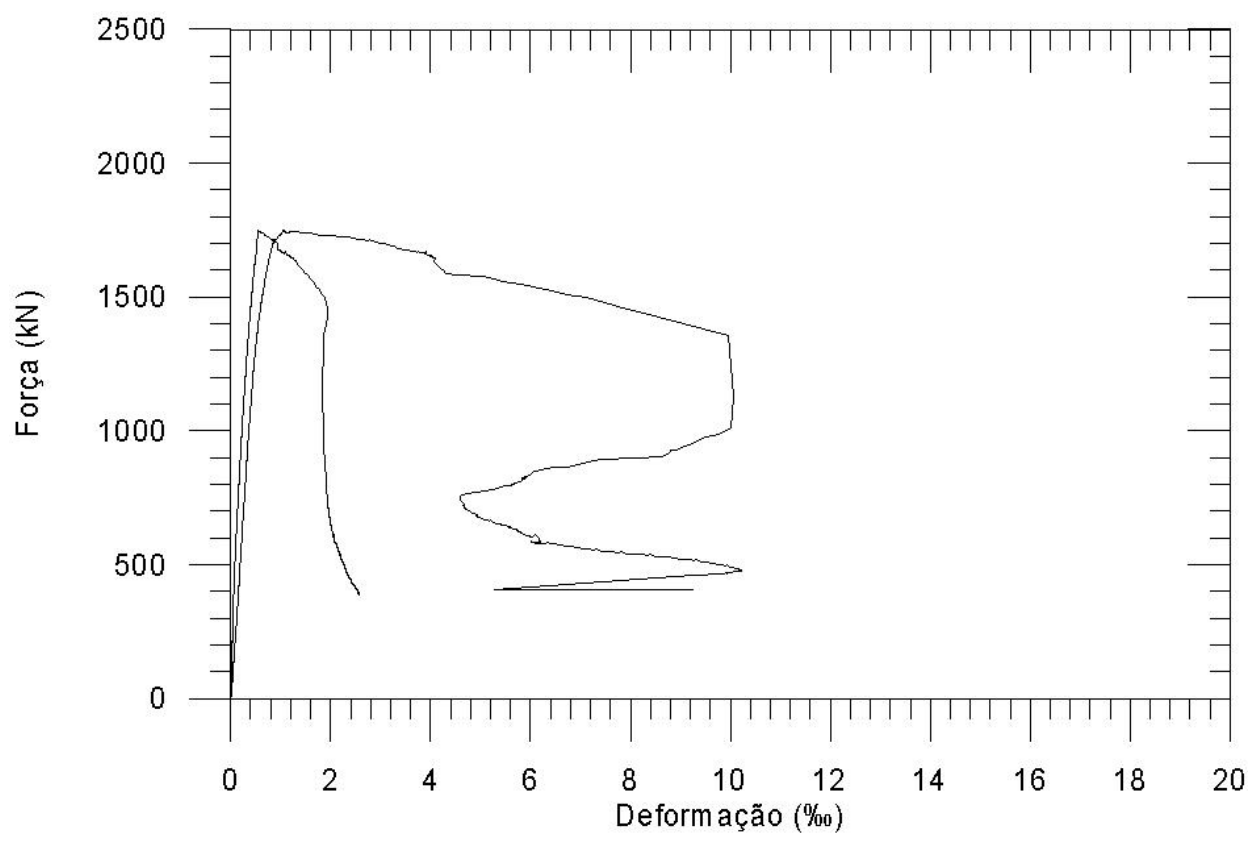

Figura A.96 - Diagramas força aplicada vs. deformação lida pelos extensômetros na armadura transversal. 


\section{A.25.Pilar P18051}

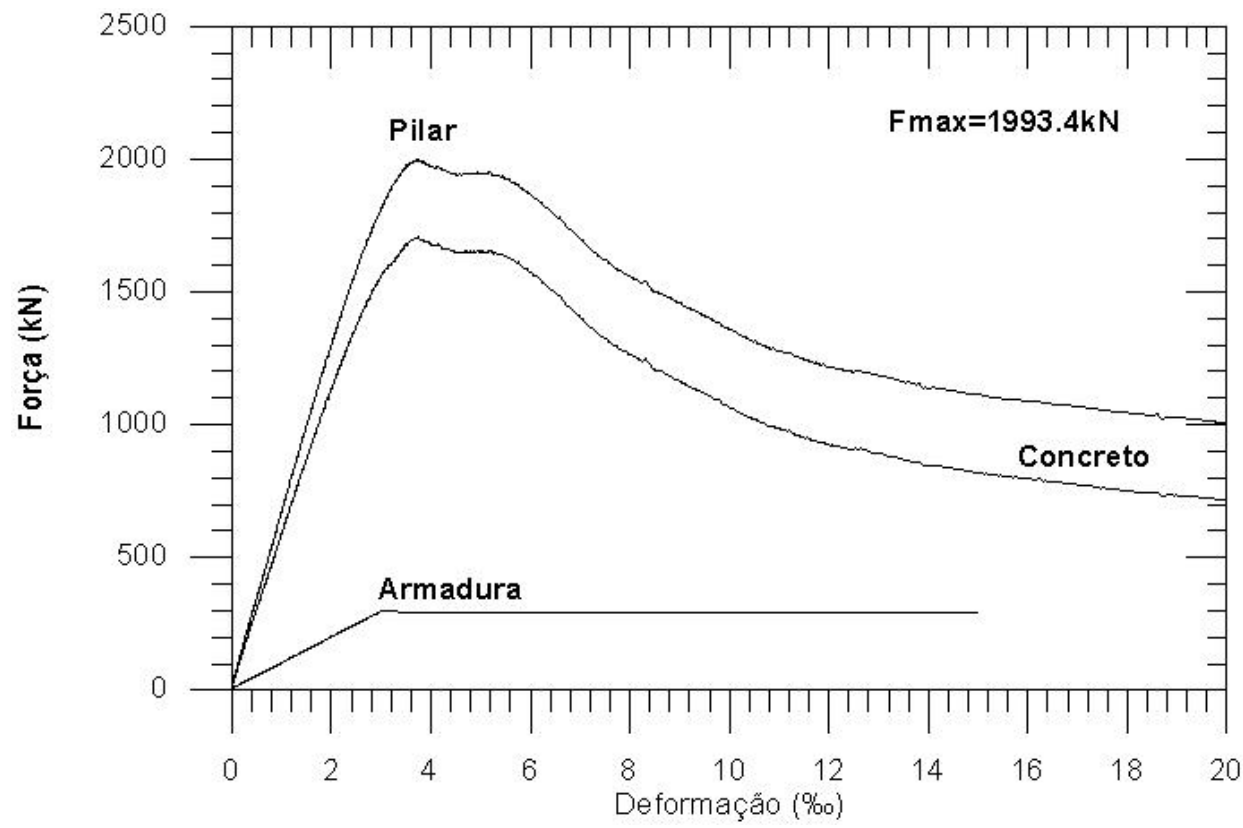

Figura A.97 - Diagramas forças parciais vs. deformação do pilar, do concreto e da armadura longitudinal.

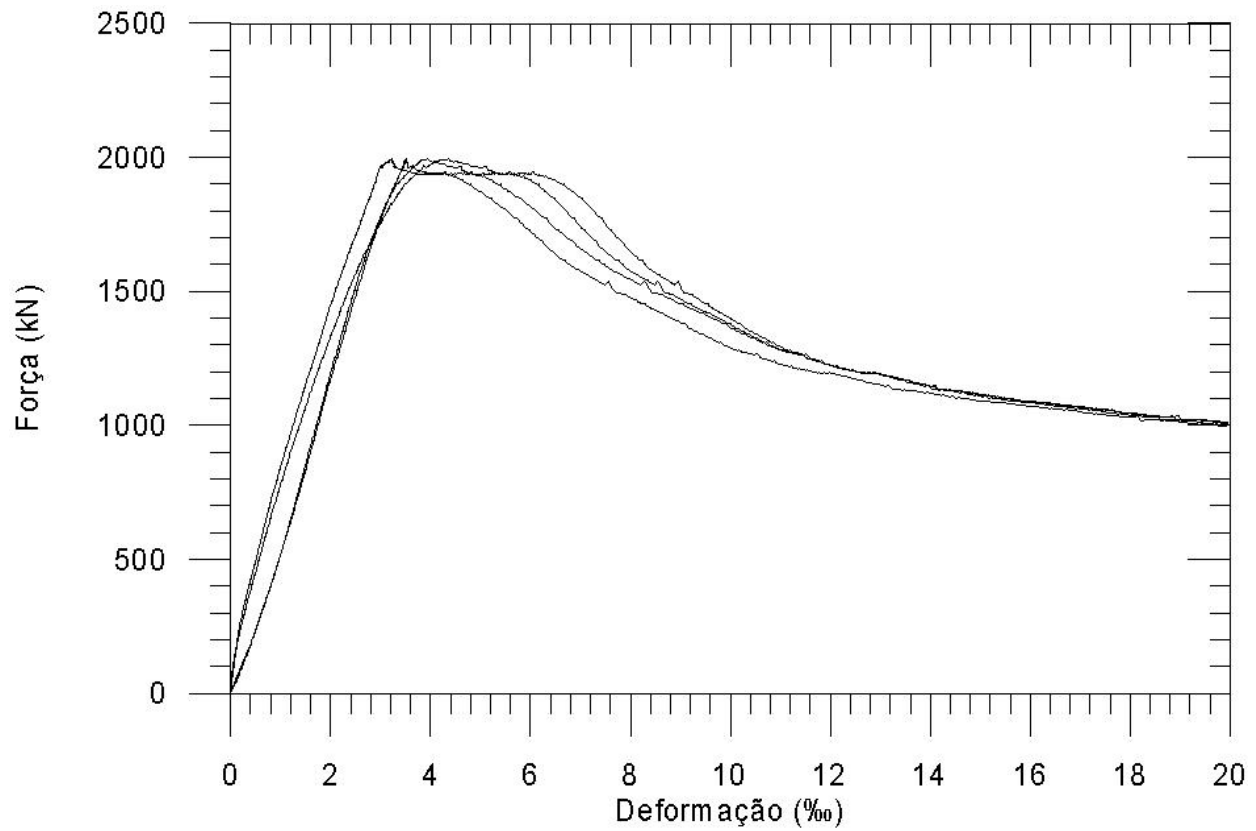

Figura A.98 - Diagramas força aplicada vs. deformação lida por cada LVDt. 


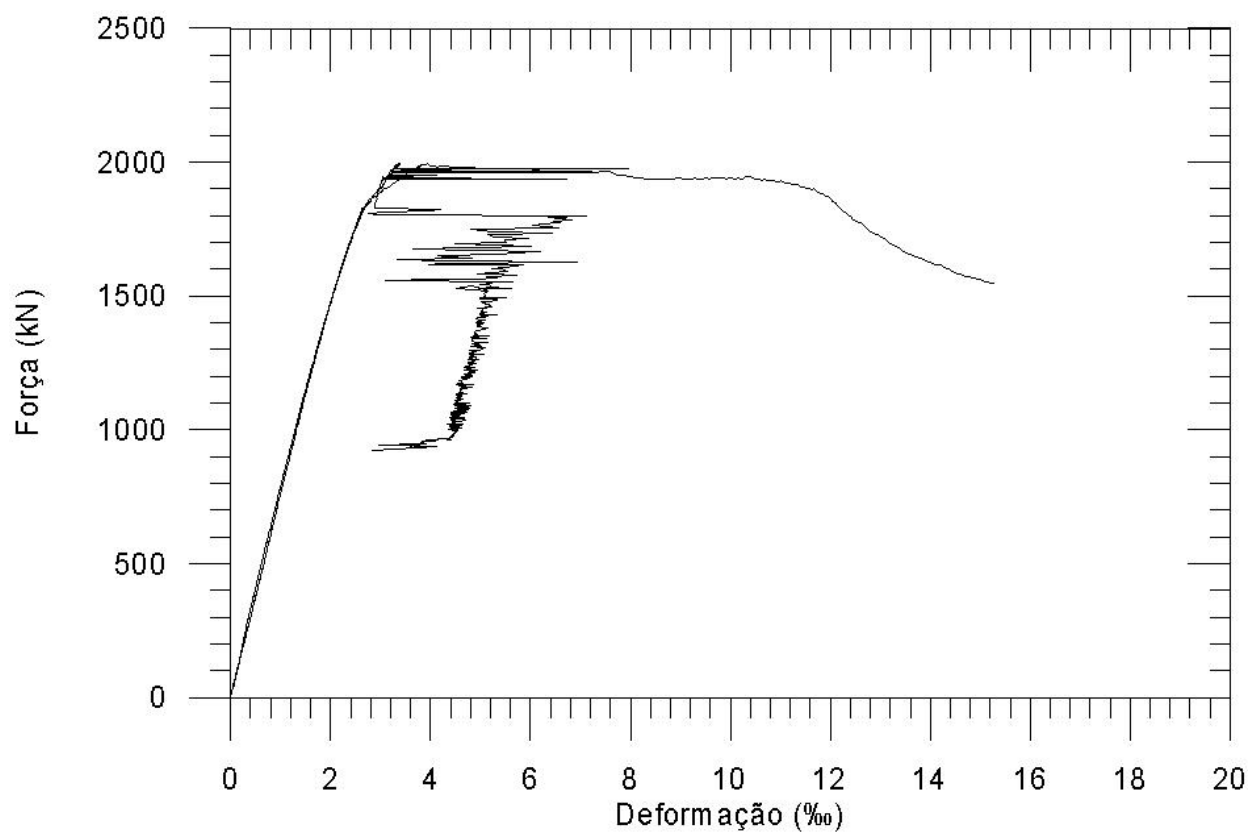

Figura A.99 - Diagramas força aplicada vs. deformação lida pelos extensômetros na armadura longitudinal.

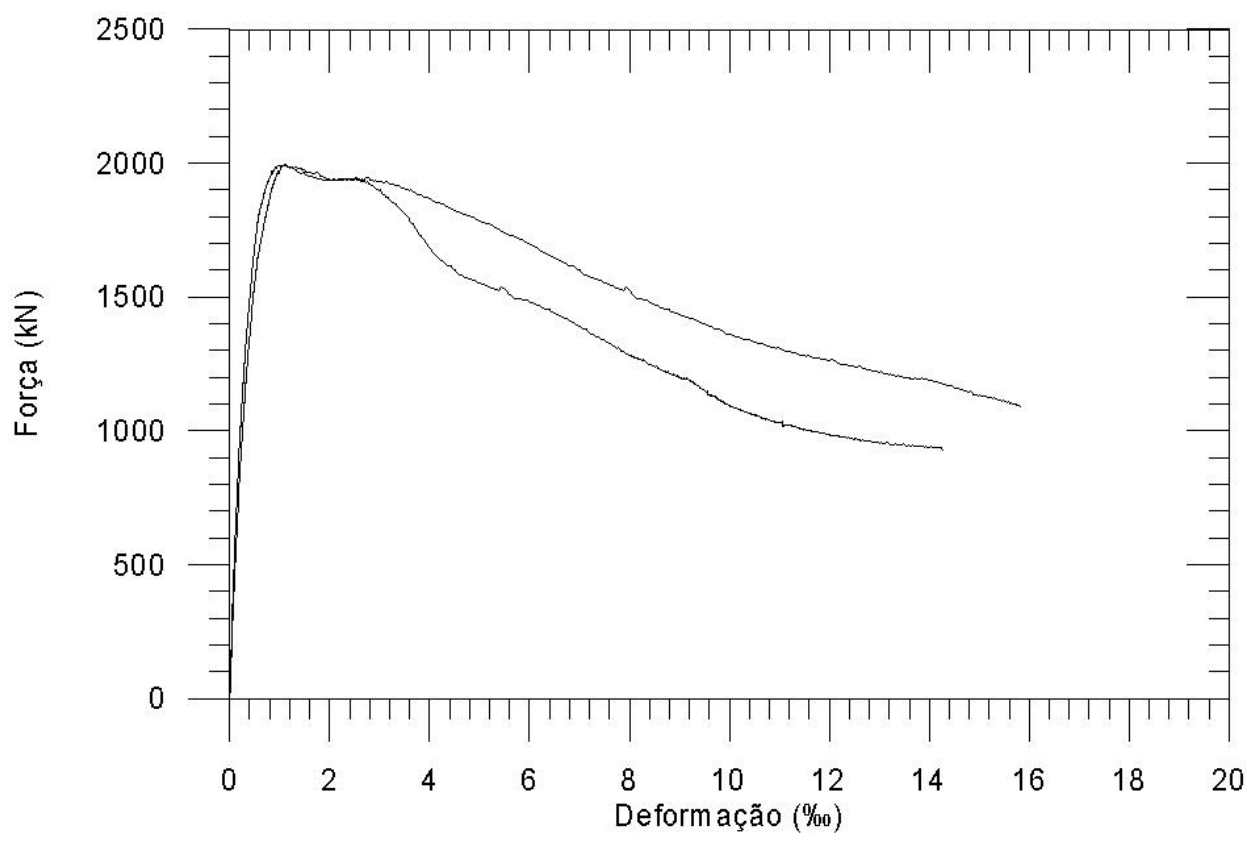

Figura A.100 - Diagramas força aplicada vs. deformação lida pelos extensômetros na armadura transversal. 


\section{A.26.Pilar P28051}

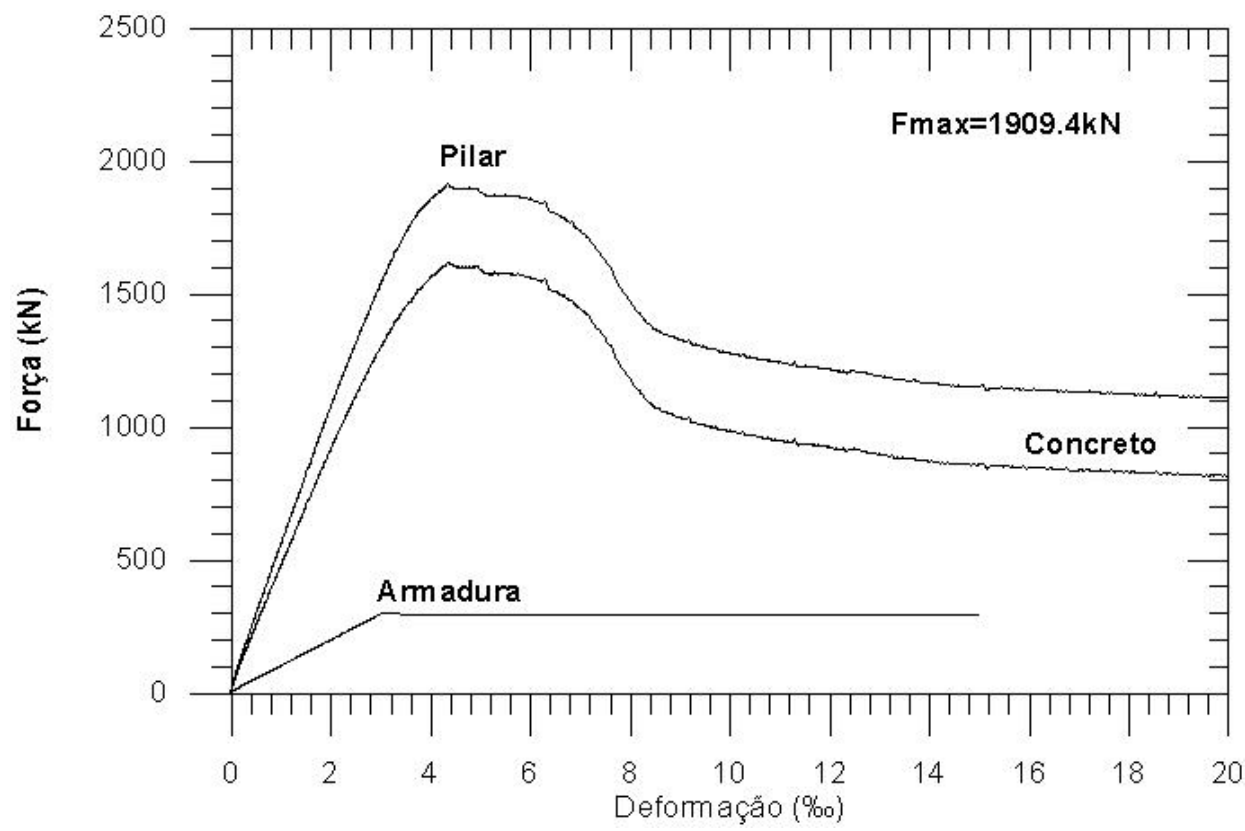

Figura A.101 - Diagramas forças parciais vs. deformação do pilar, do concreto e da armadura longitudinal.

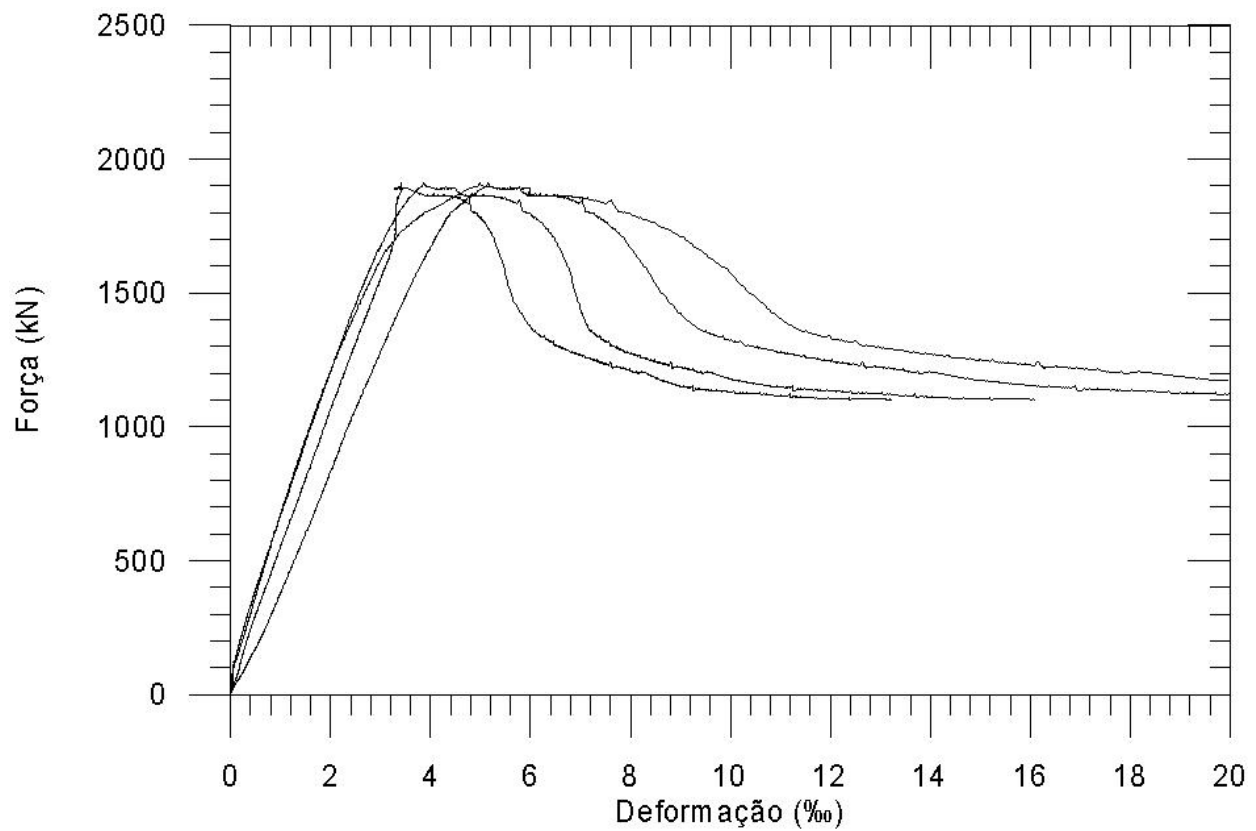

Figura A.102 - Diagramas força aplicada vs. deformação lida por cada LVDt. 


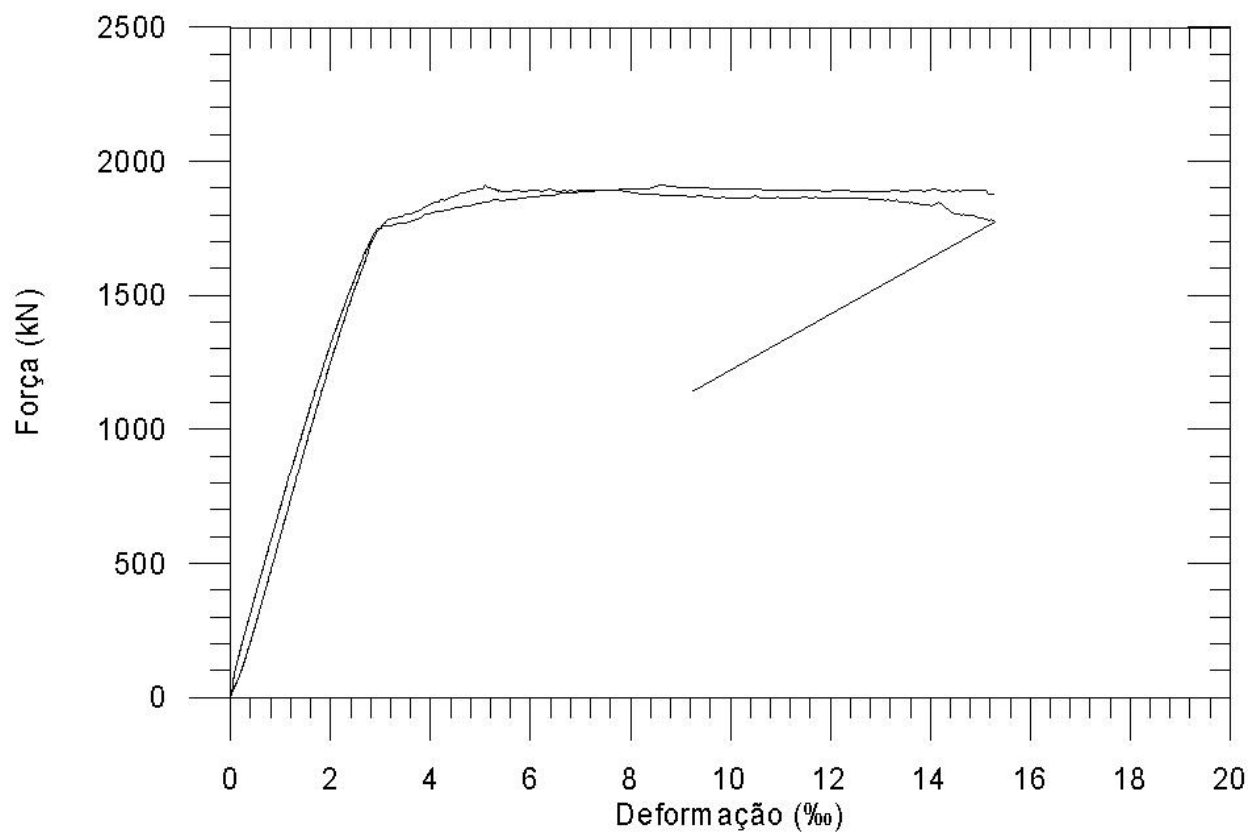

Figura A.103 - Diagramas força aplicada vs. deformação lida pelos extensômetros na armadura longitudinal.

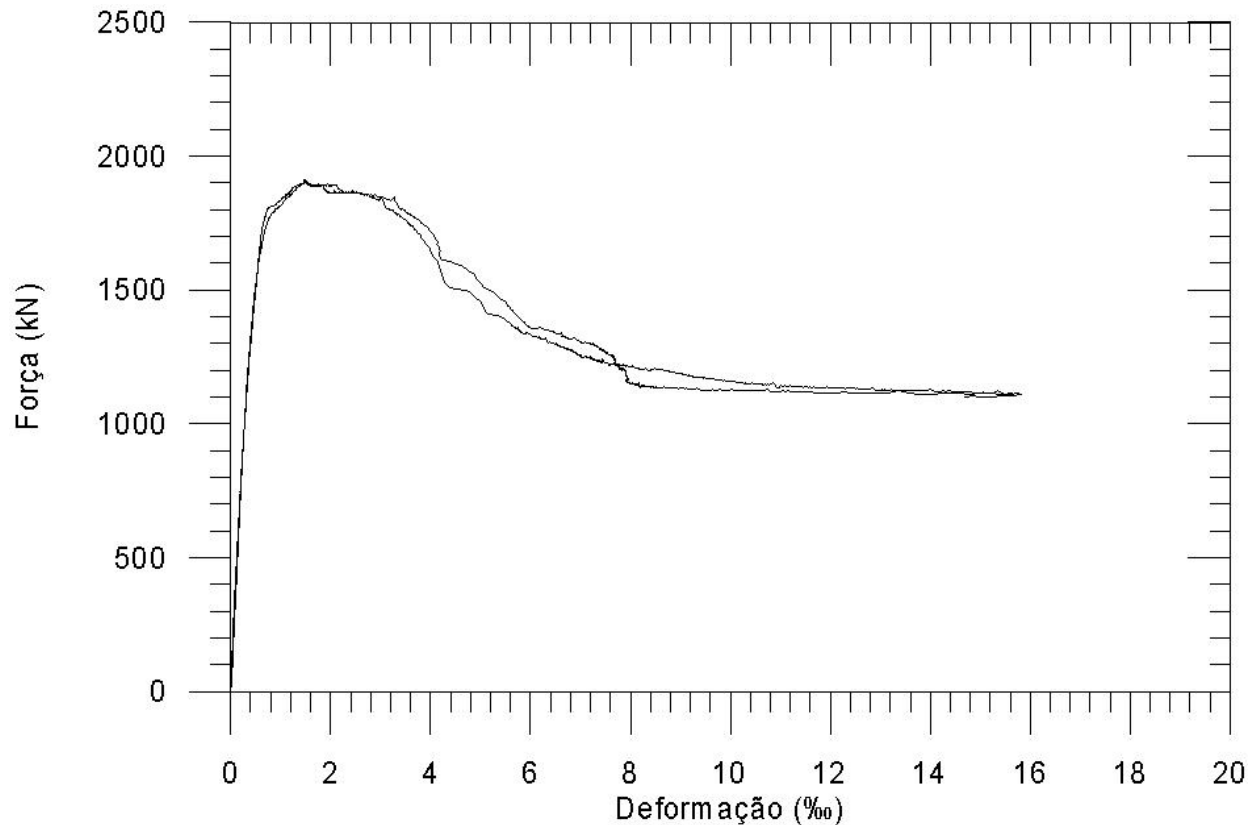

Figura A.104 - Diagramas força aplicada vs. deformação lida pelos extensômetros na armadura transversal. 


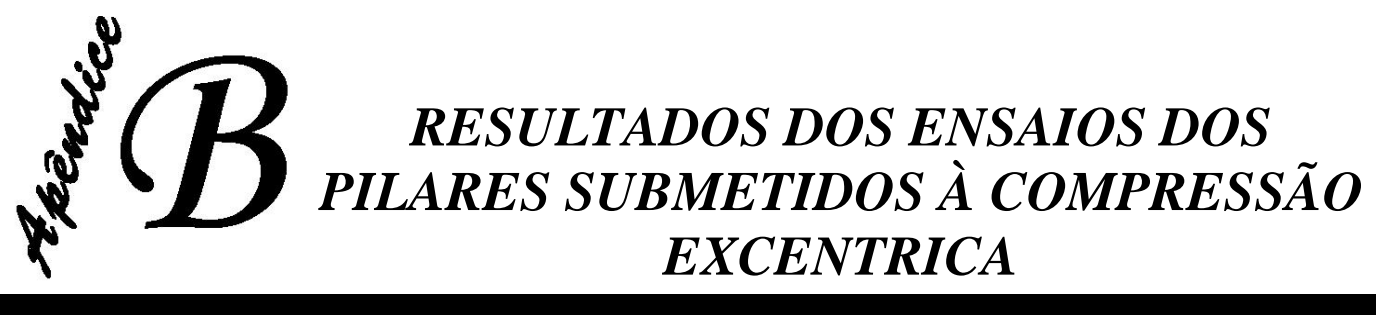

\section{B.1.Pilar P160150}

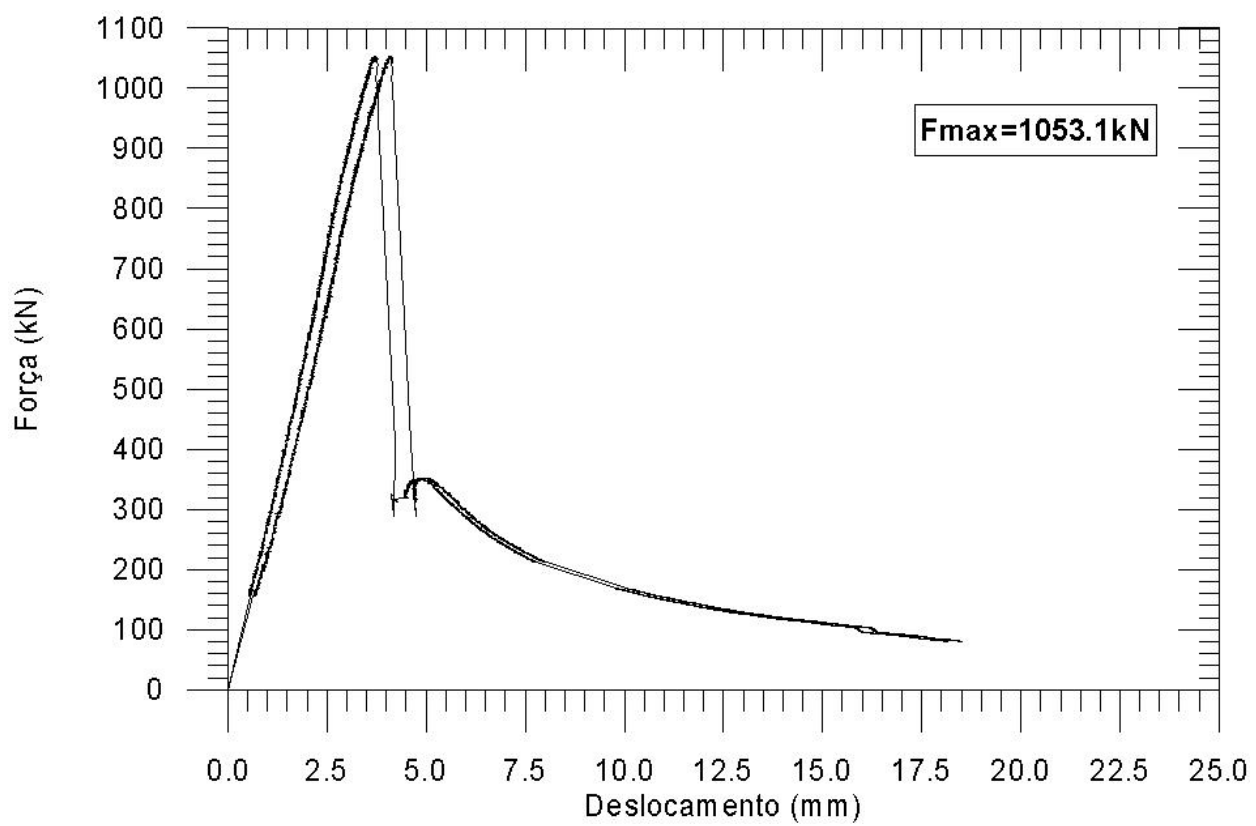

Figura B.1 - Diagramas forças vs. deslocamento vertical do pilar

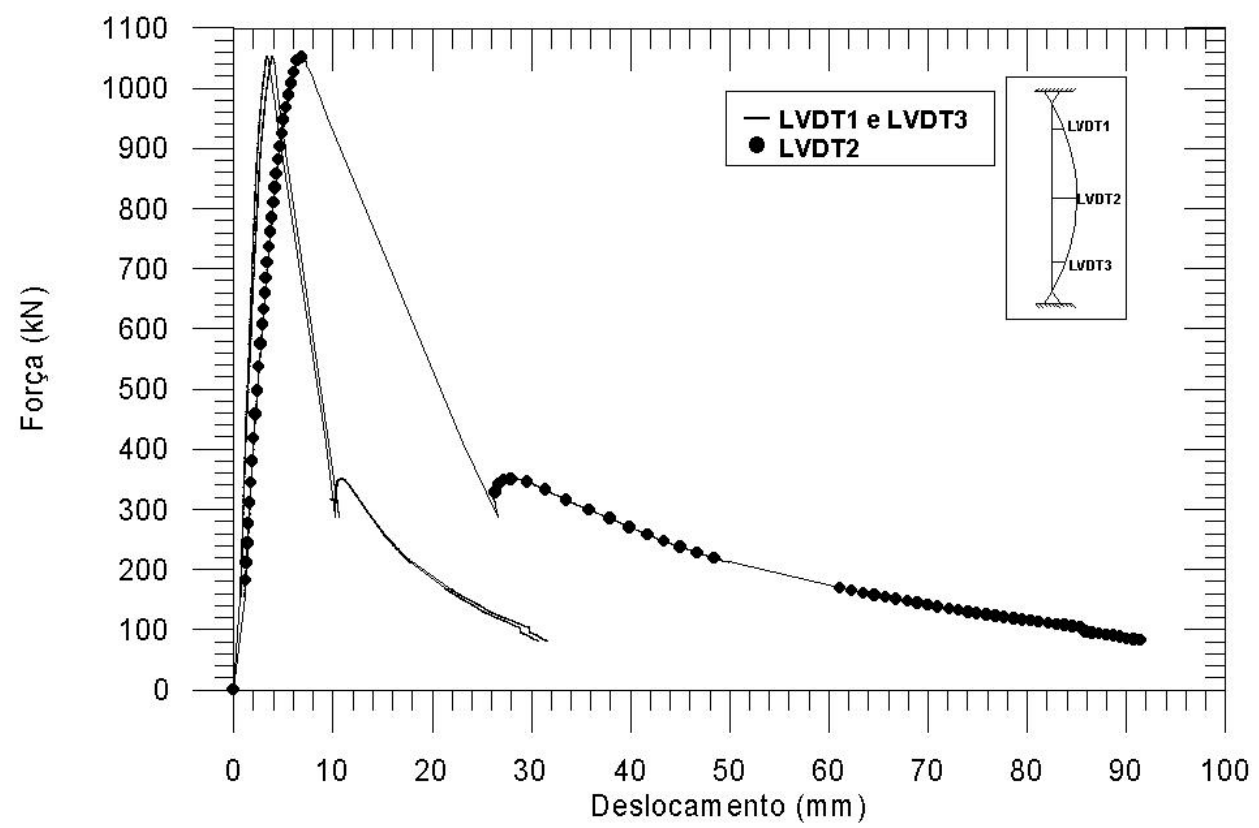

Figura B.2 - Diagramas força vs. deslocamento transversal do pilar 


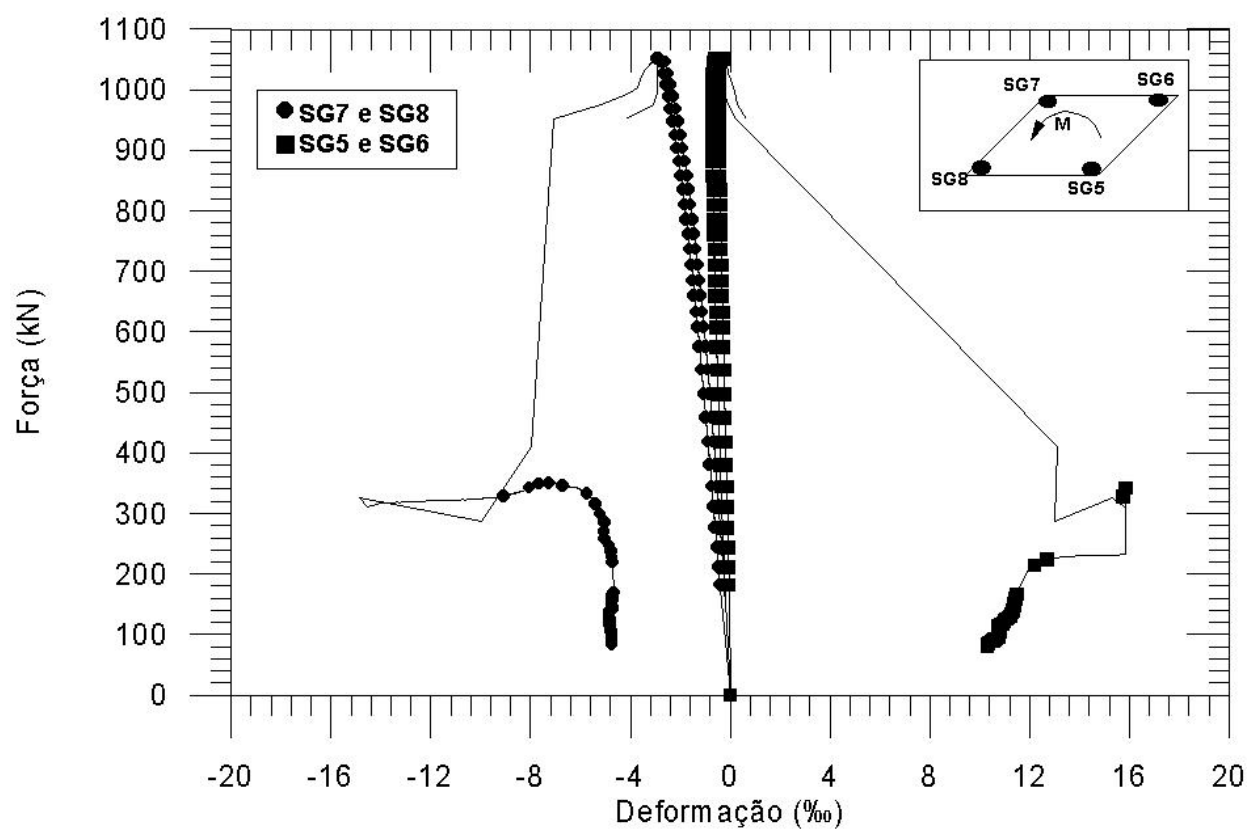

Figura B.3 - Diagramas força vs. deformação na armadura longitudinal

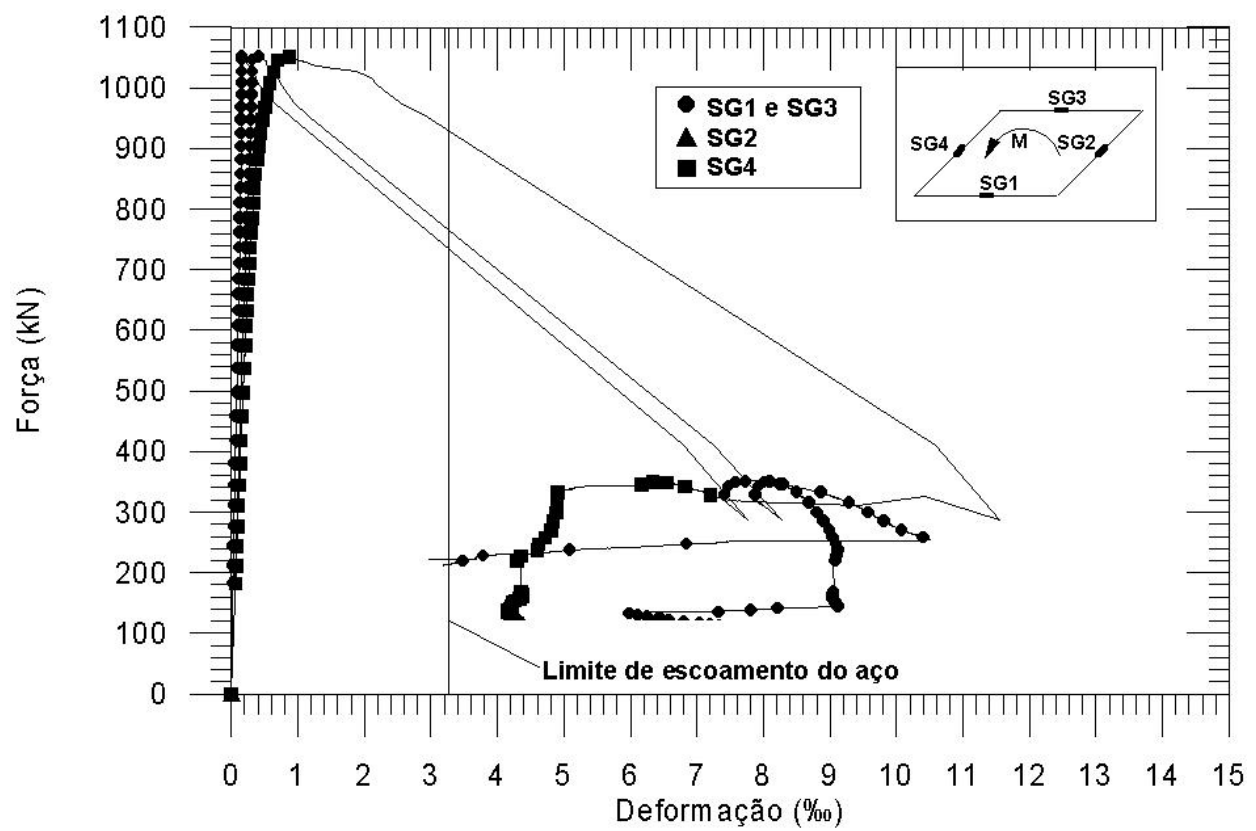

Figura B.4 - Diagramas força vs. deformação na armadura transversal. 


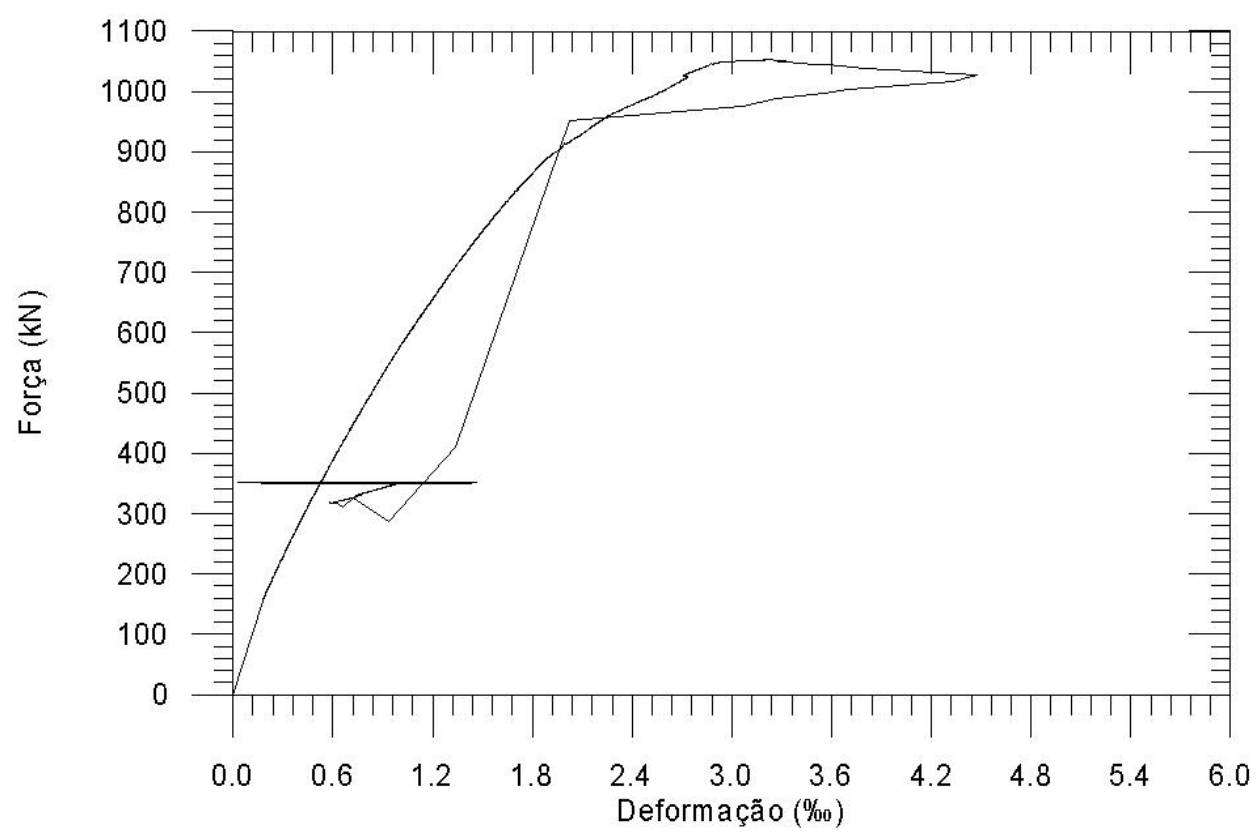

Figura B.5 - Diagramas força vs. deformação no concreto

\section{B.2.Pilar P260150}

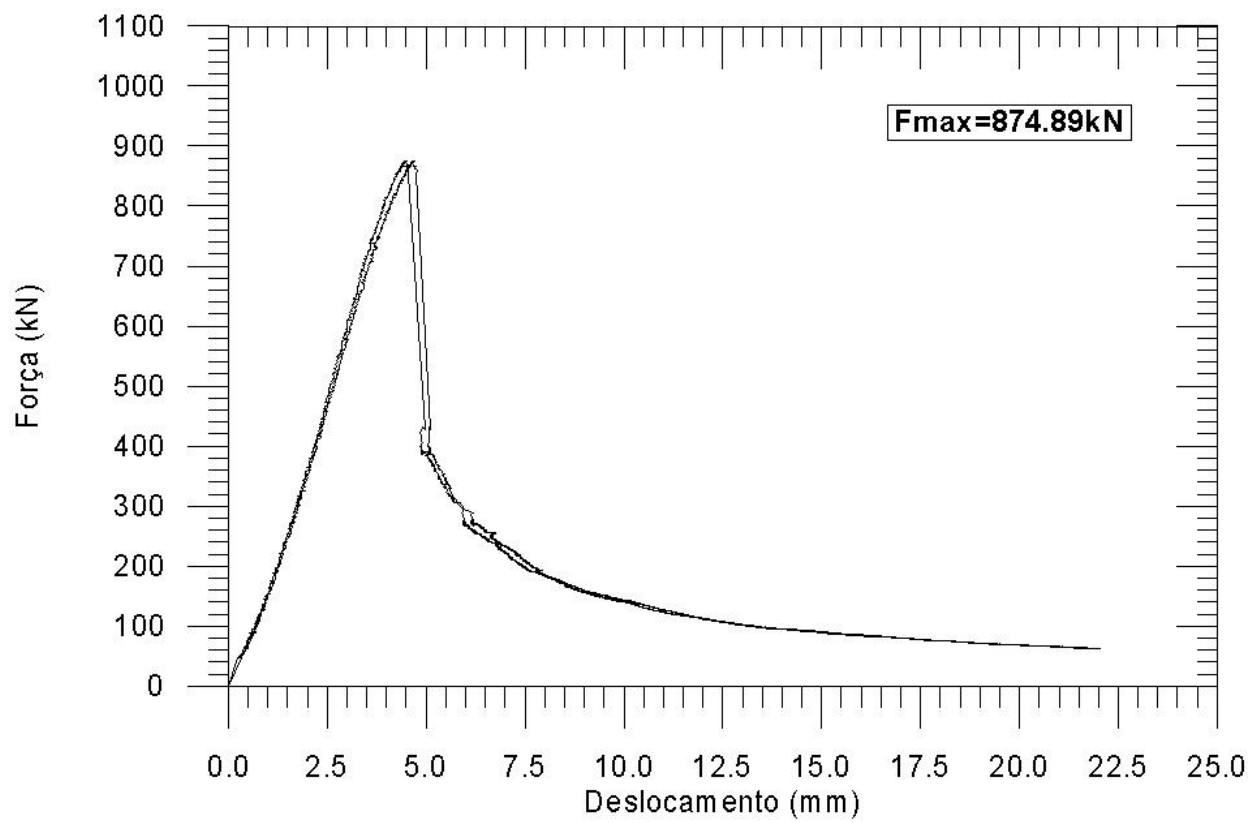

Figura B.6 - Diagramas forças vs. deslocamento vertical do pilar 


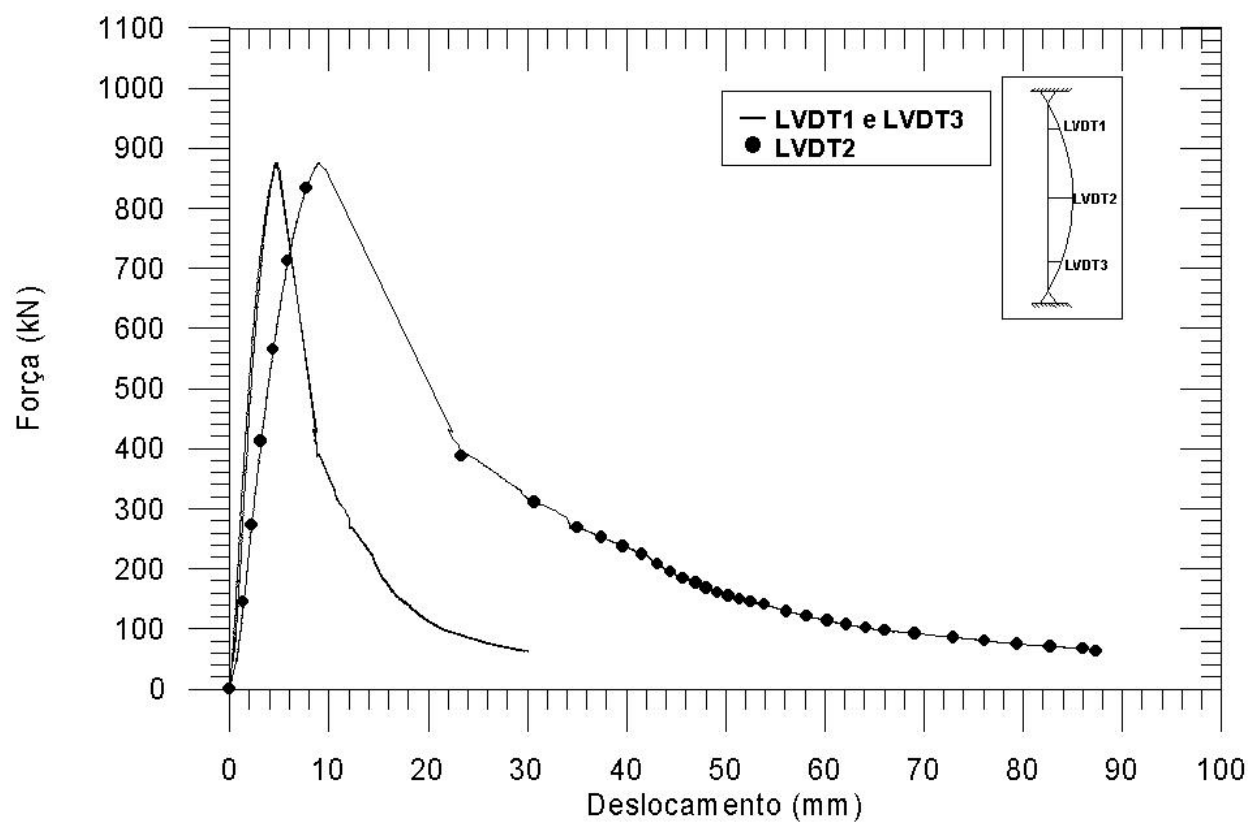

Figura B.7 - Diagramas força vs. deslocamento transversal do pilar

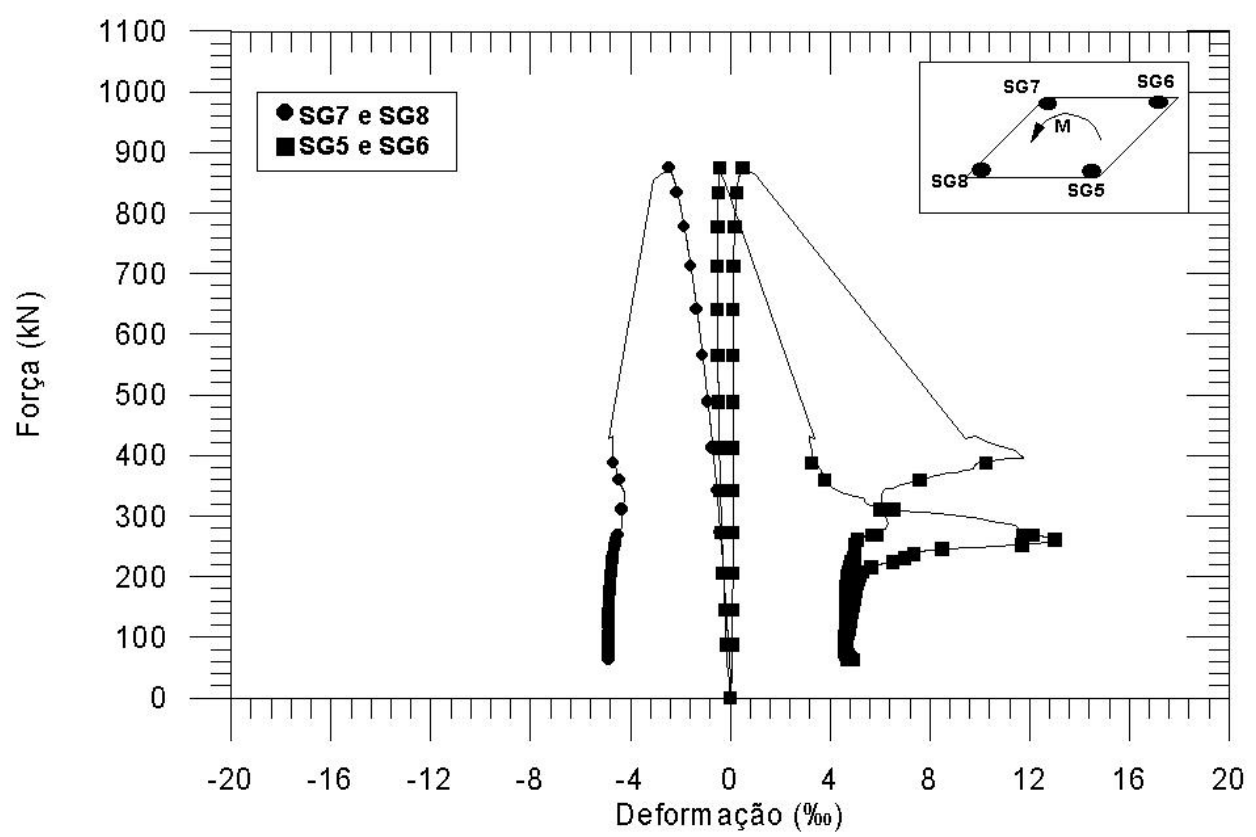

Figura B.8 - Diagramas força vs. deformação na armadura longitudinal 


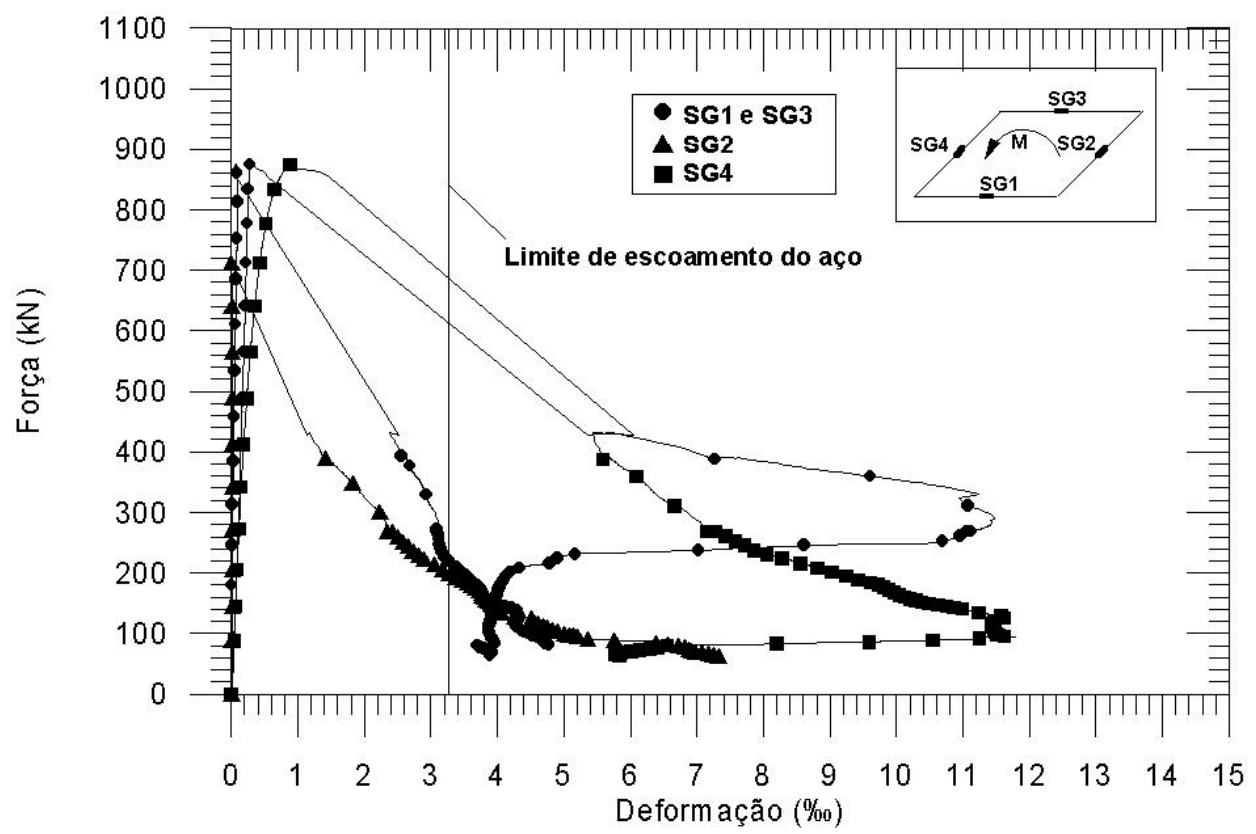

Figura B.9 - Diagramas força vs. deformação na armadura transversal.

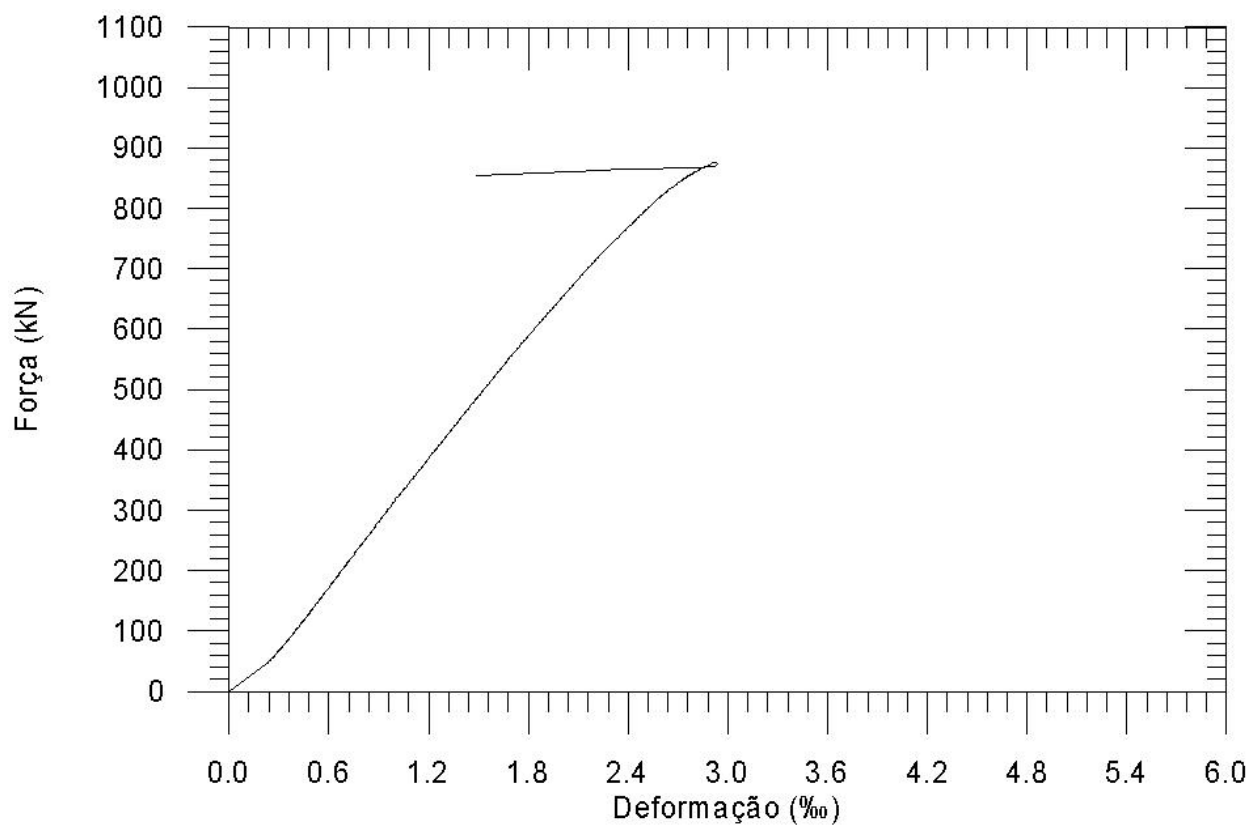

Figura B.10 - Diagramas força vs. deformação no concreto 


\section{B.3.Pilar P360150}

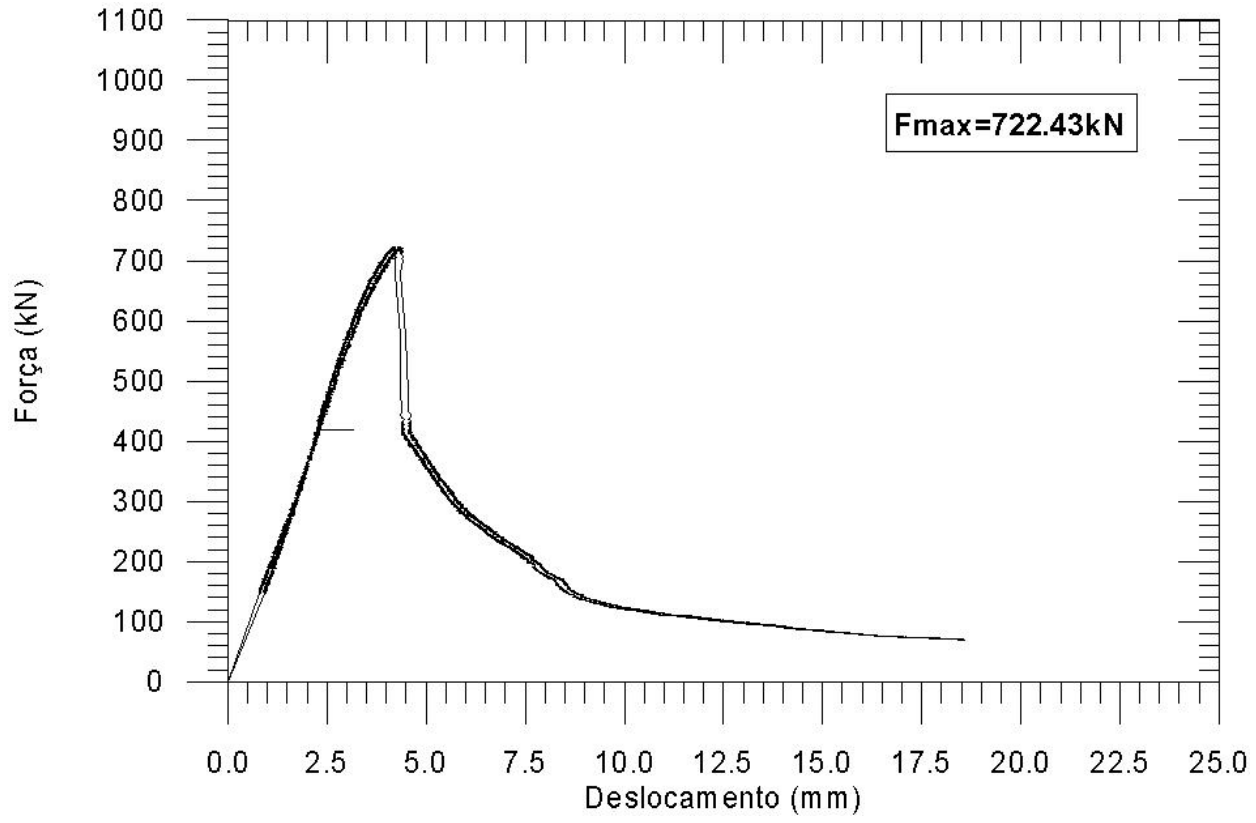

Figura B.11 - Diagramas forças vs. deslocamento vertical do pilar

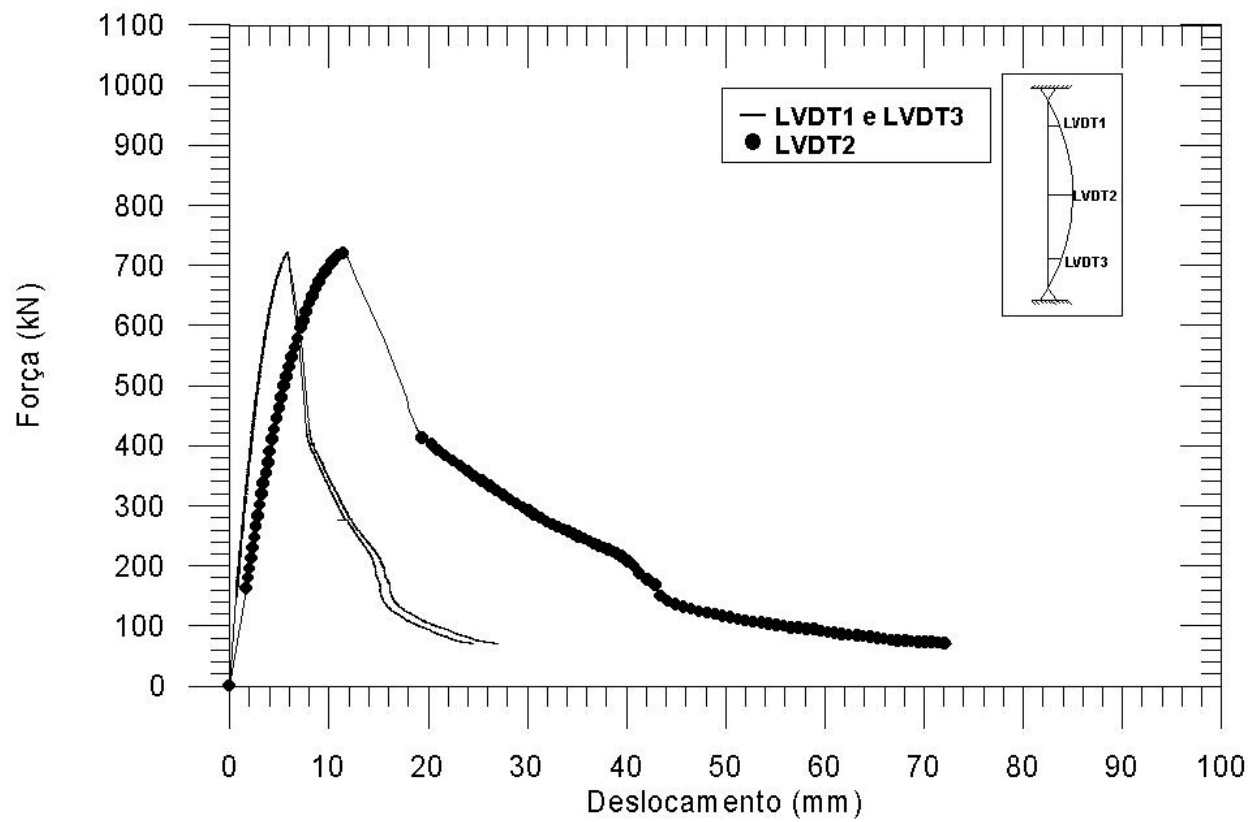

Figura B.12 - Diagramas força vs. deslocamento transversal do pilar 


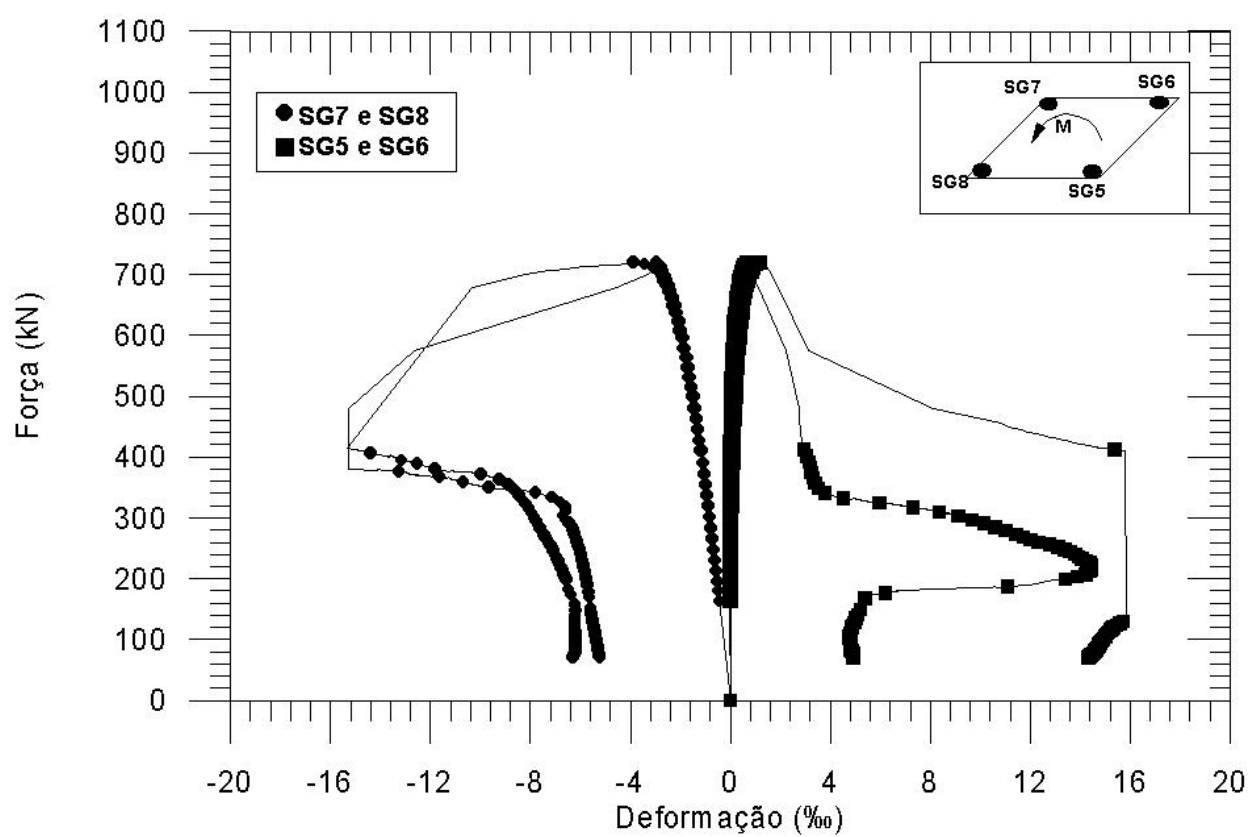

Figura B.13 - Diagramas força vs. deformação na armadura longitudinal

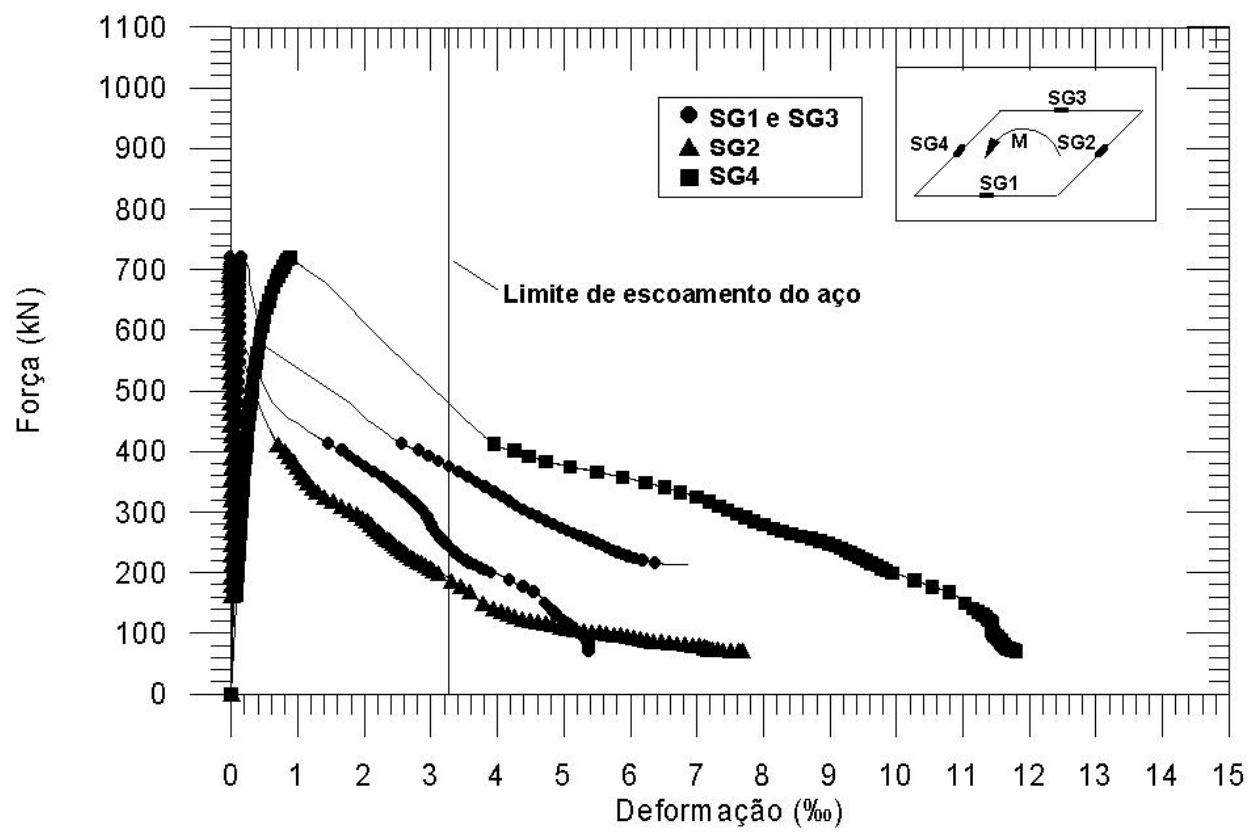

Figura B.14 - Diagramas força vs. deformação na armadura transversal. 


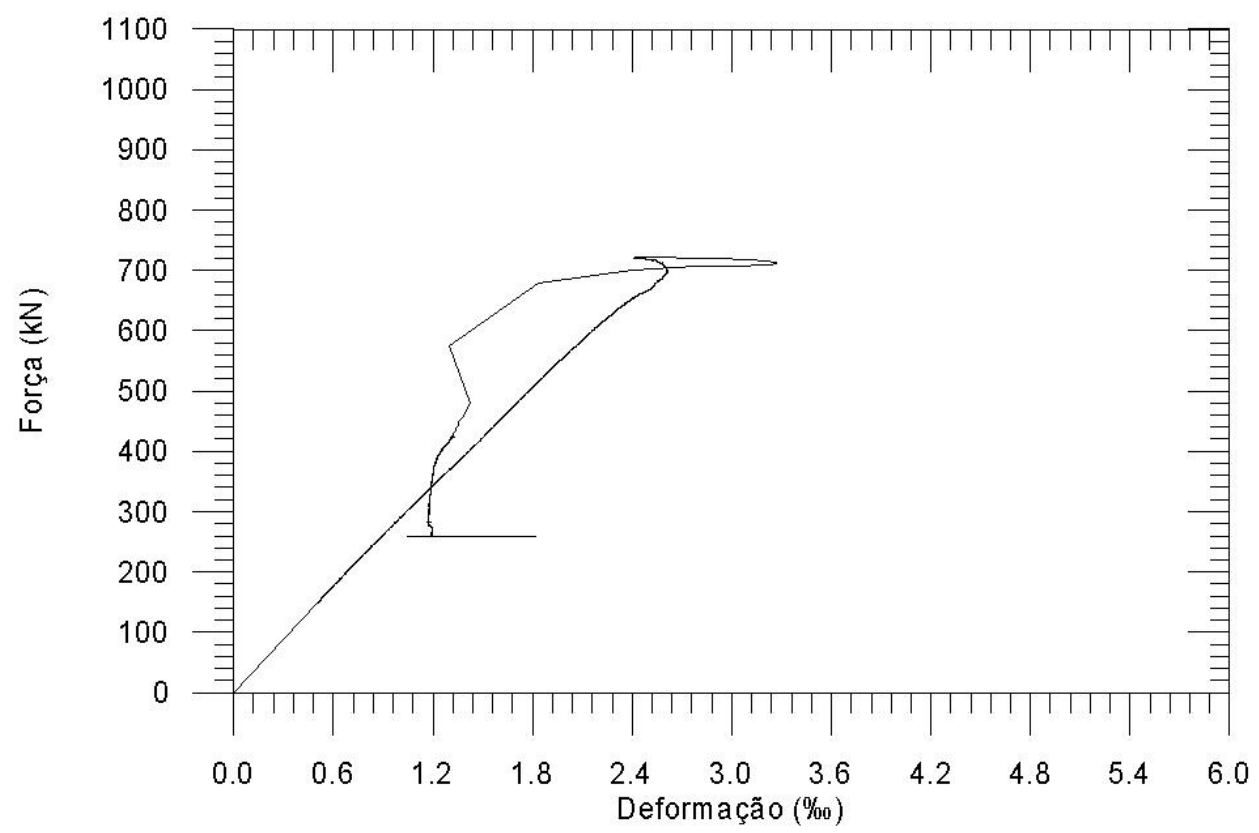

Figura B.15 - Diagramas força vs. deformação no concreto

\section{B.4.Pilar P16050}

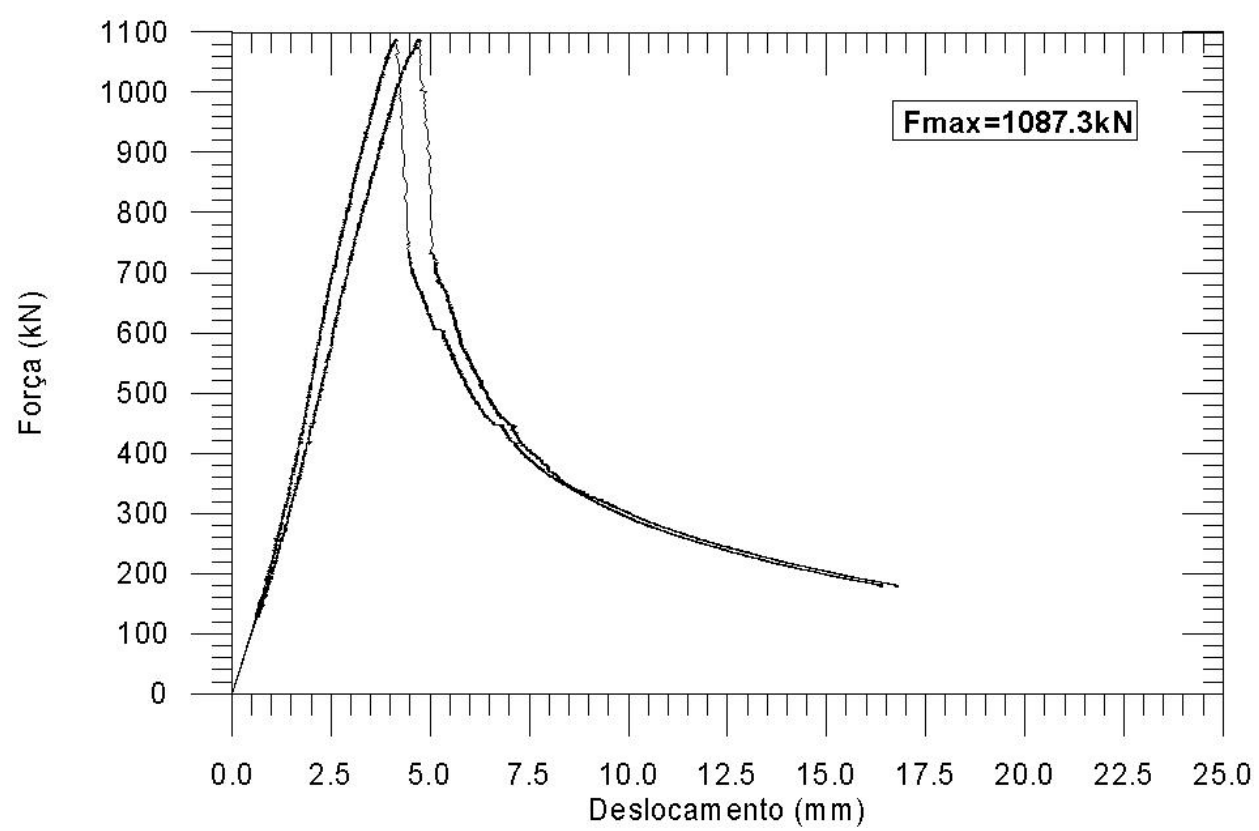

Figura B.16 - Diagramas forças vs. deslocamento vertical do pilar 


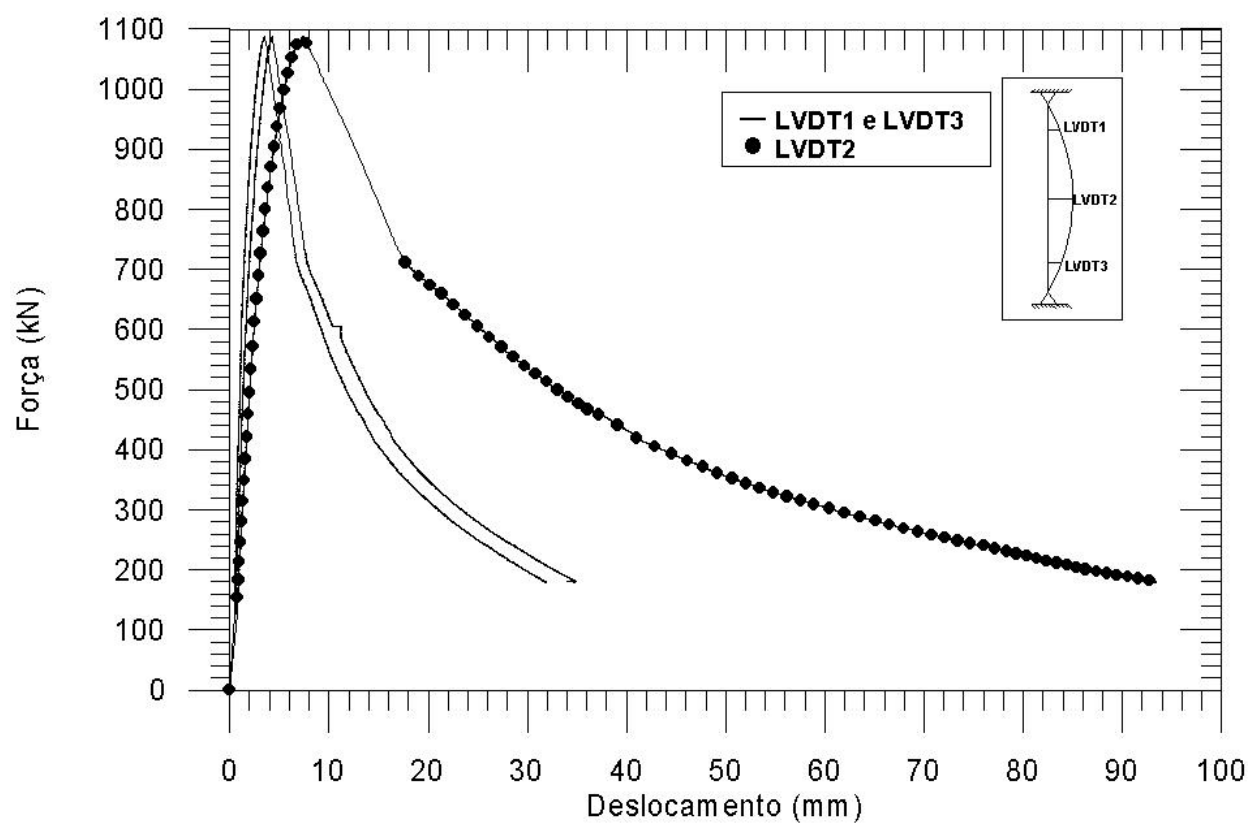

Figura B.17 - Diagramas força vs. deslocamento transversal do pilar

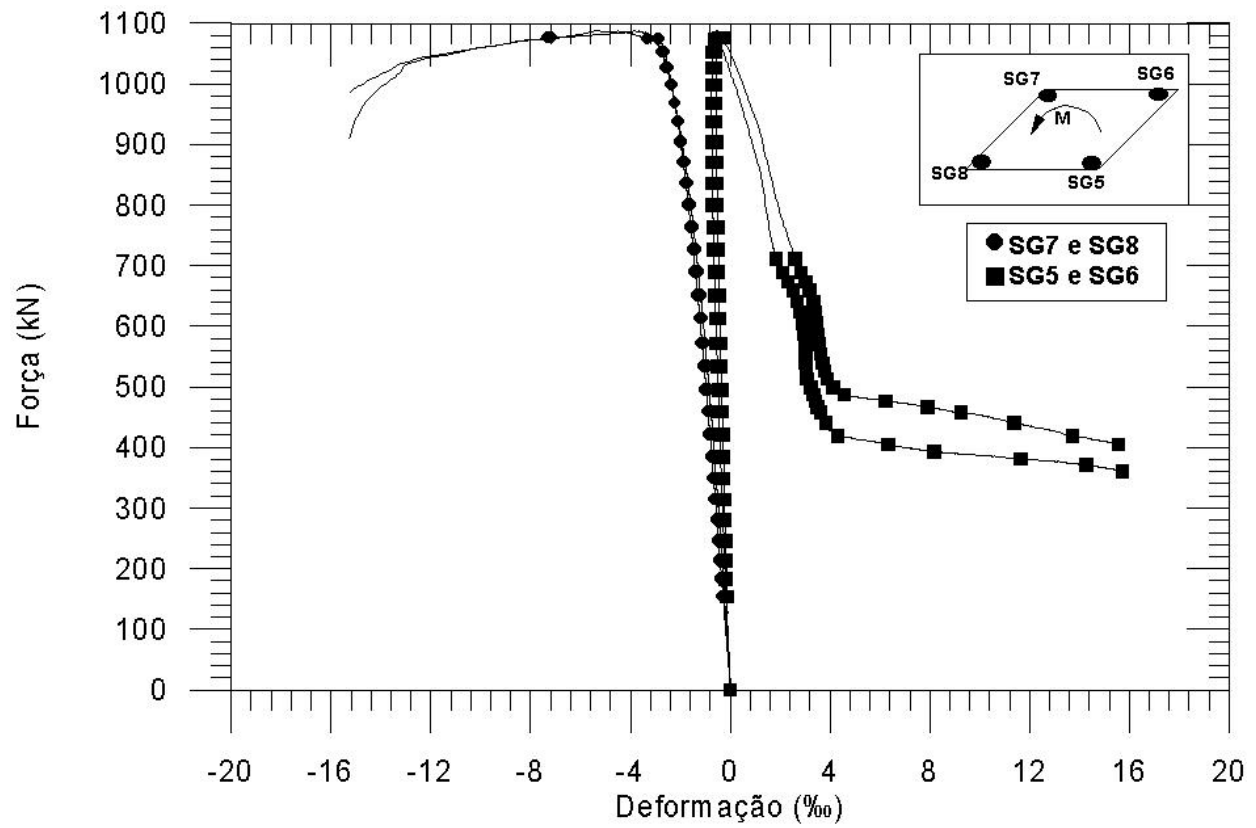

Figura B.18 - Diagramas força vs. deformação na armadura longitudinal 


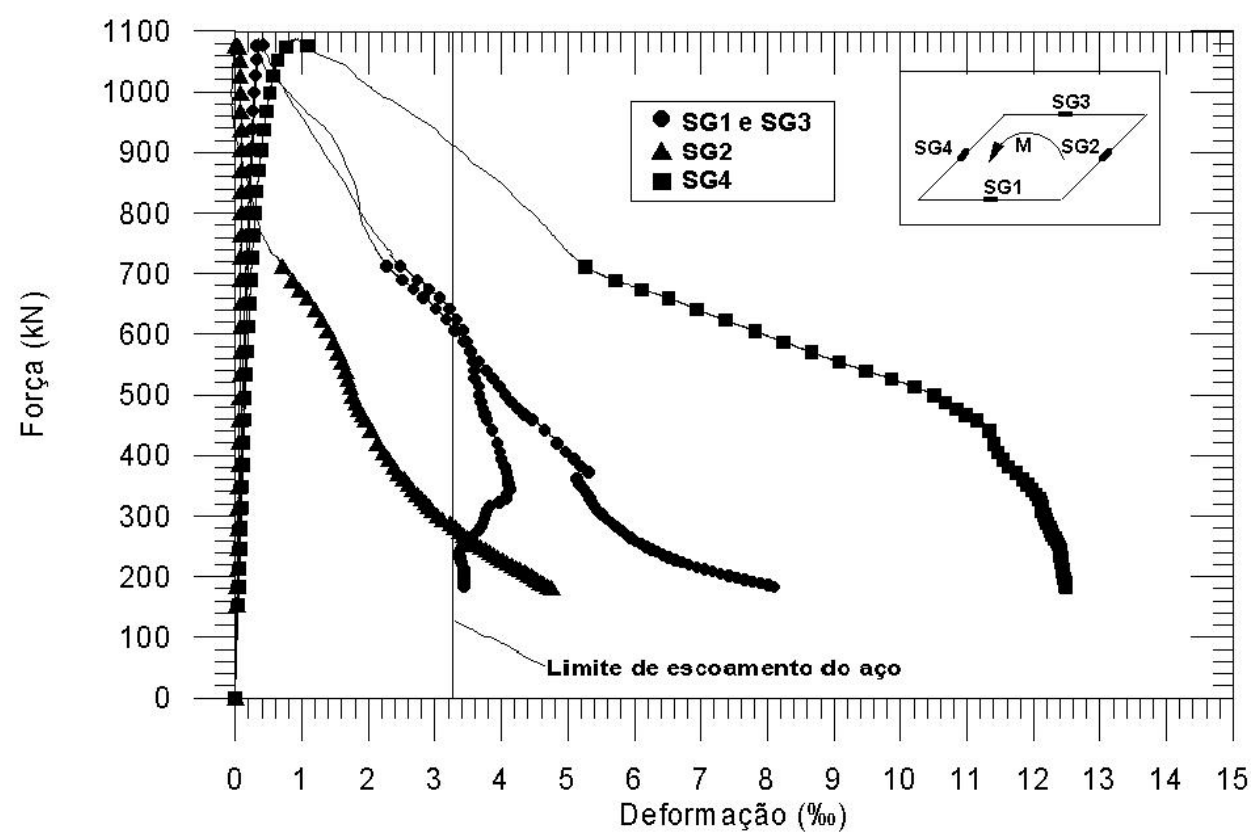

Figura B.19 - Diagramas força vs. deformação na armadura transversal.

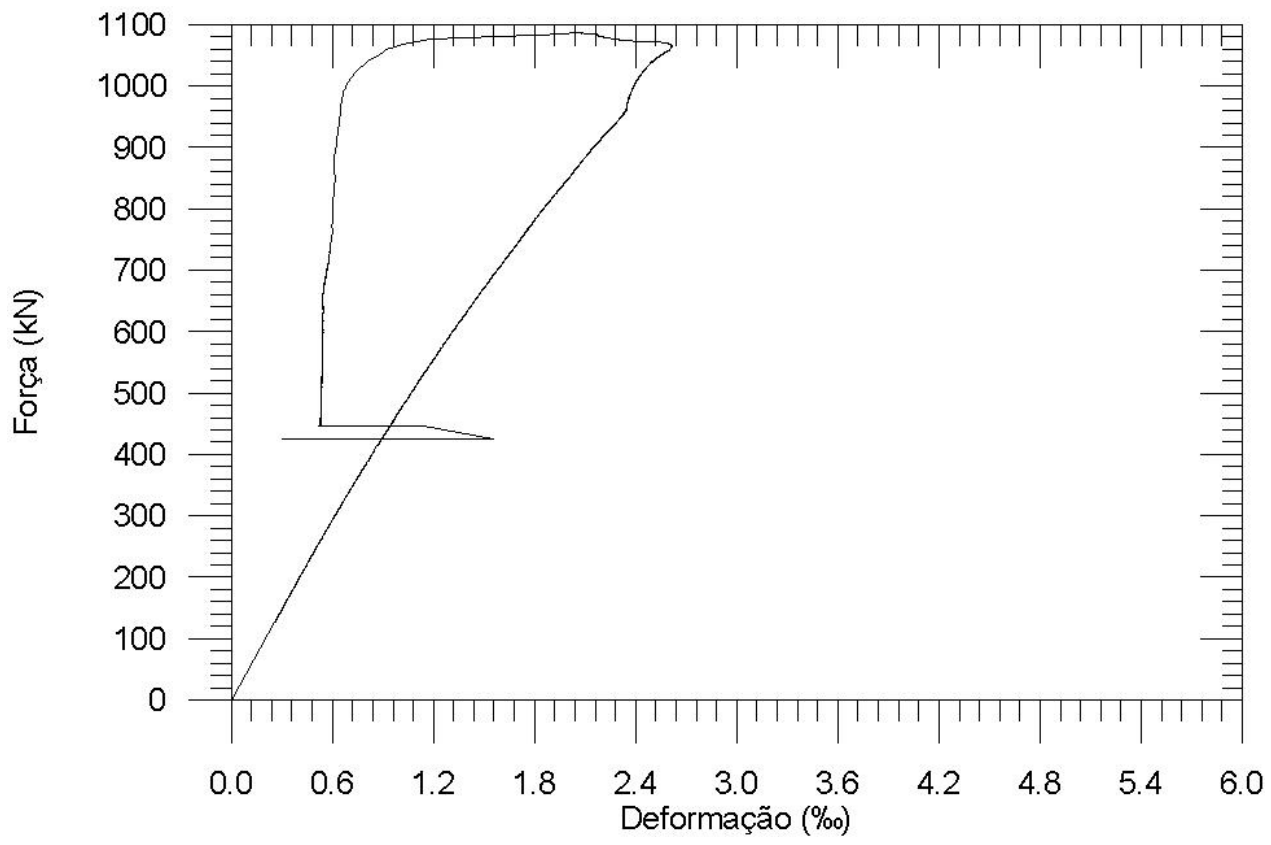

Figura B.20 - Diagramas força vs. deformação no concreto 


\section{B.5.Pilar P26050}

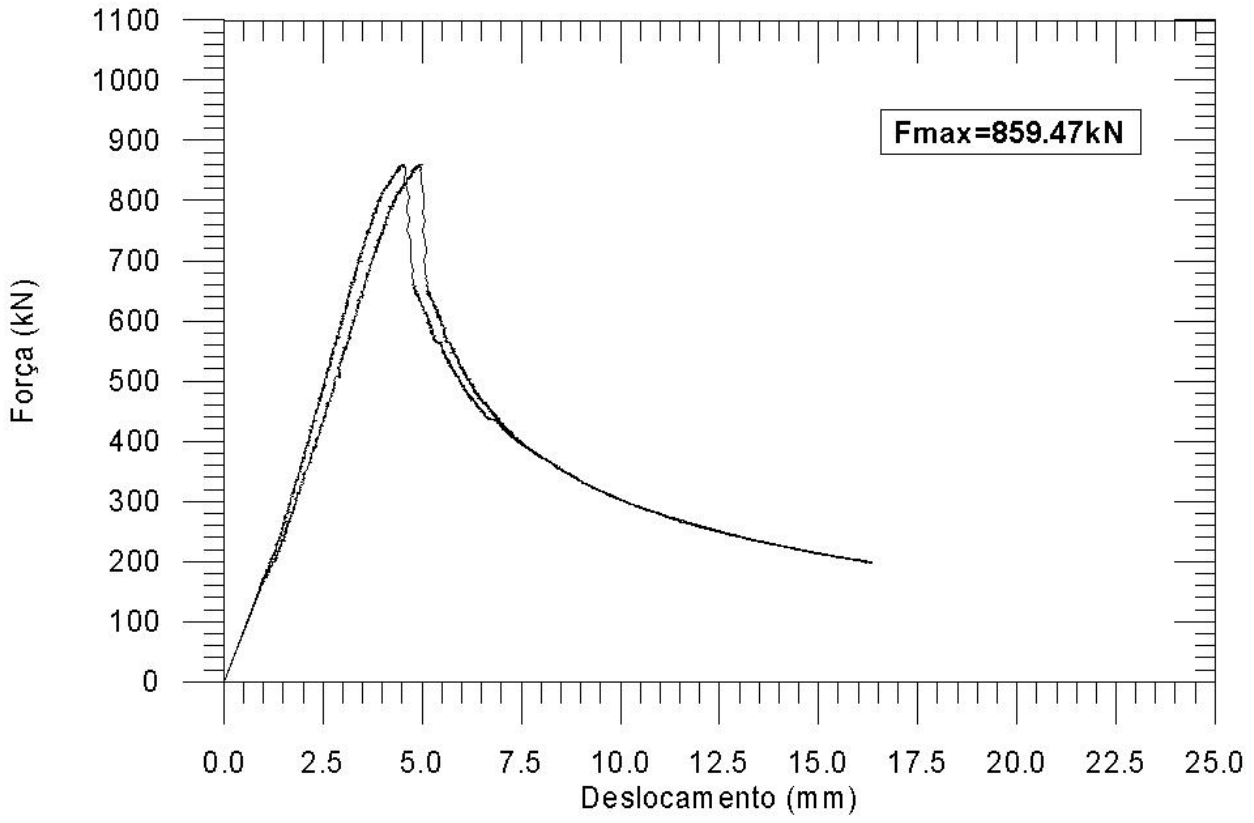

Figura B.21 - Diagramas forças vs. deslocamento vertical do pilar

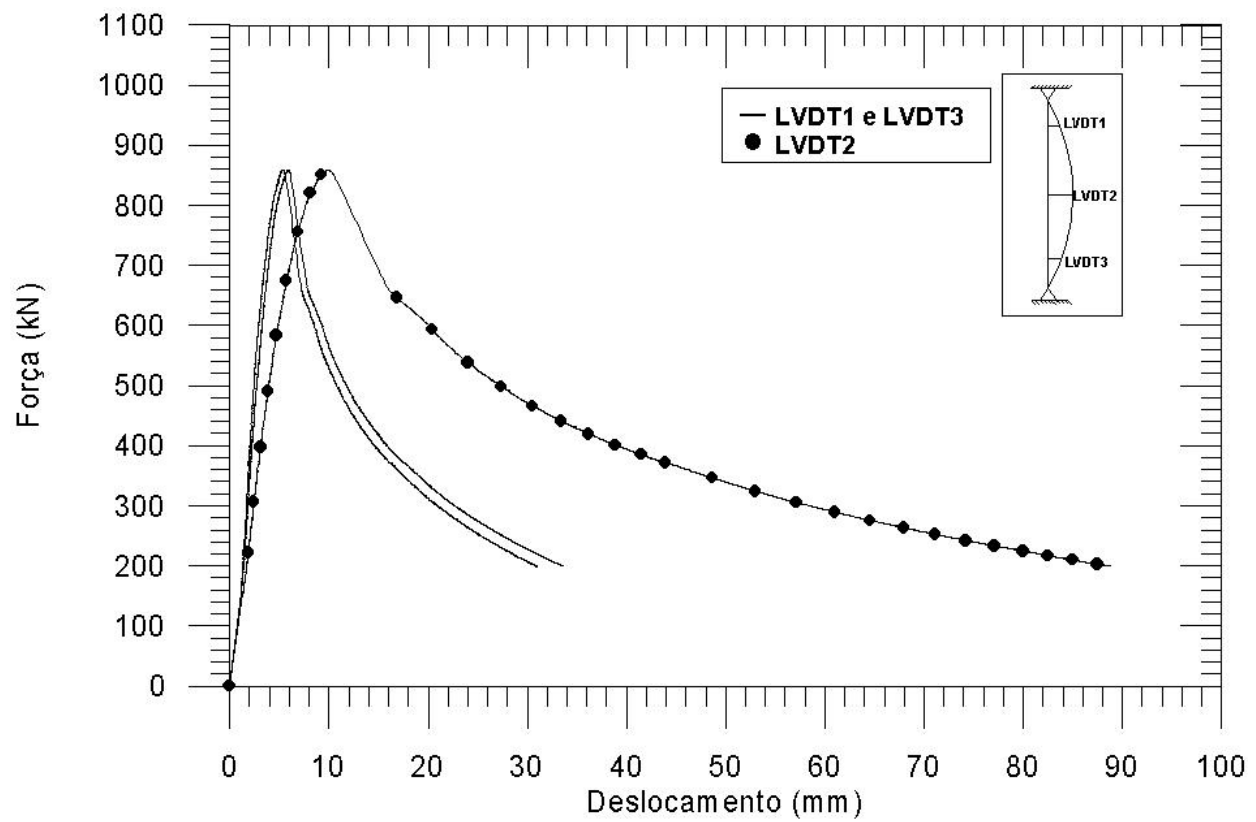

Figura B.22 - Diagramas força vs. deslocamento transversal do pilar 


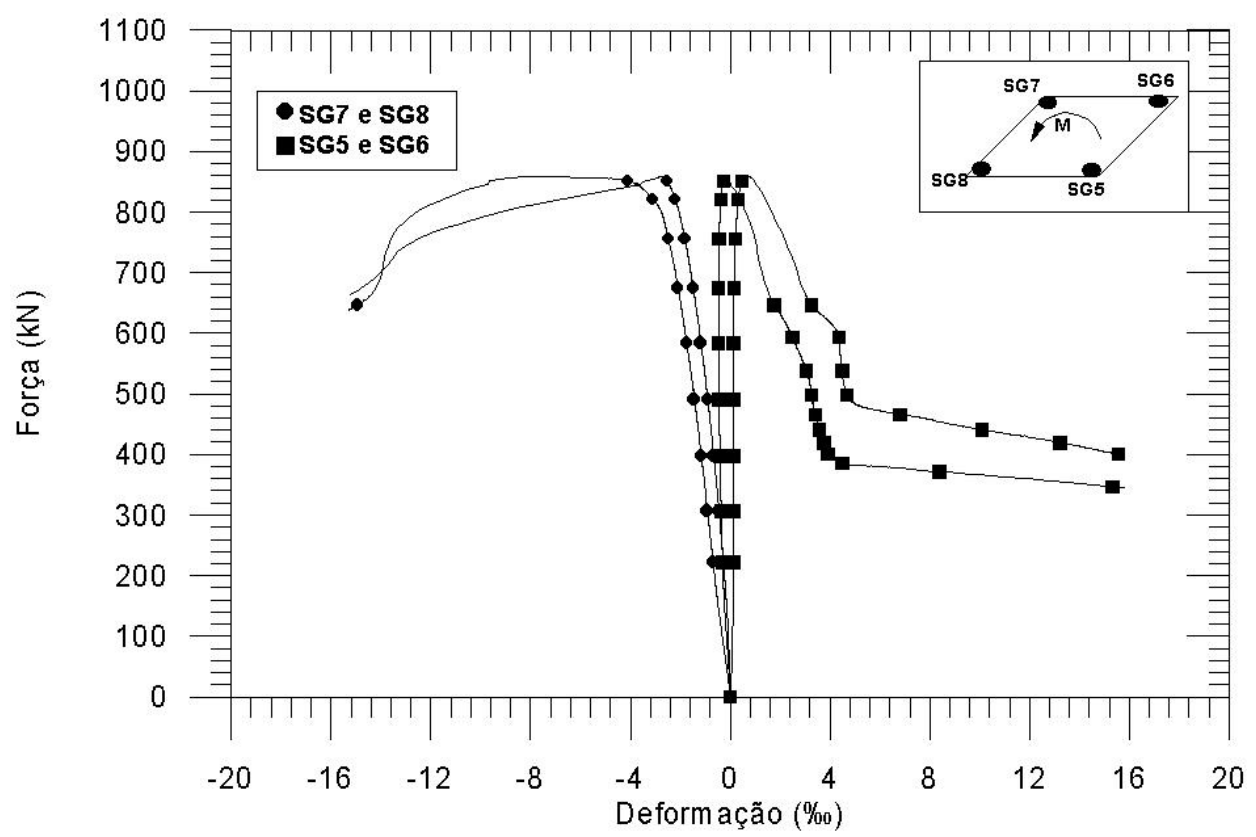

Figura B.23 - Diagramas força vs. deformação na armadura longitudinal

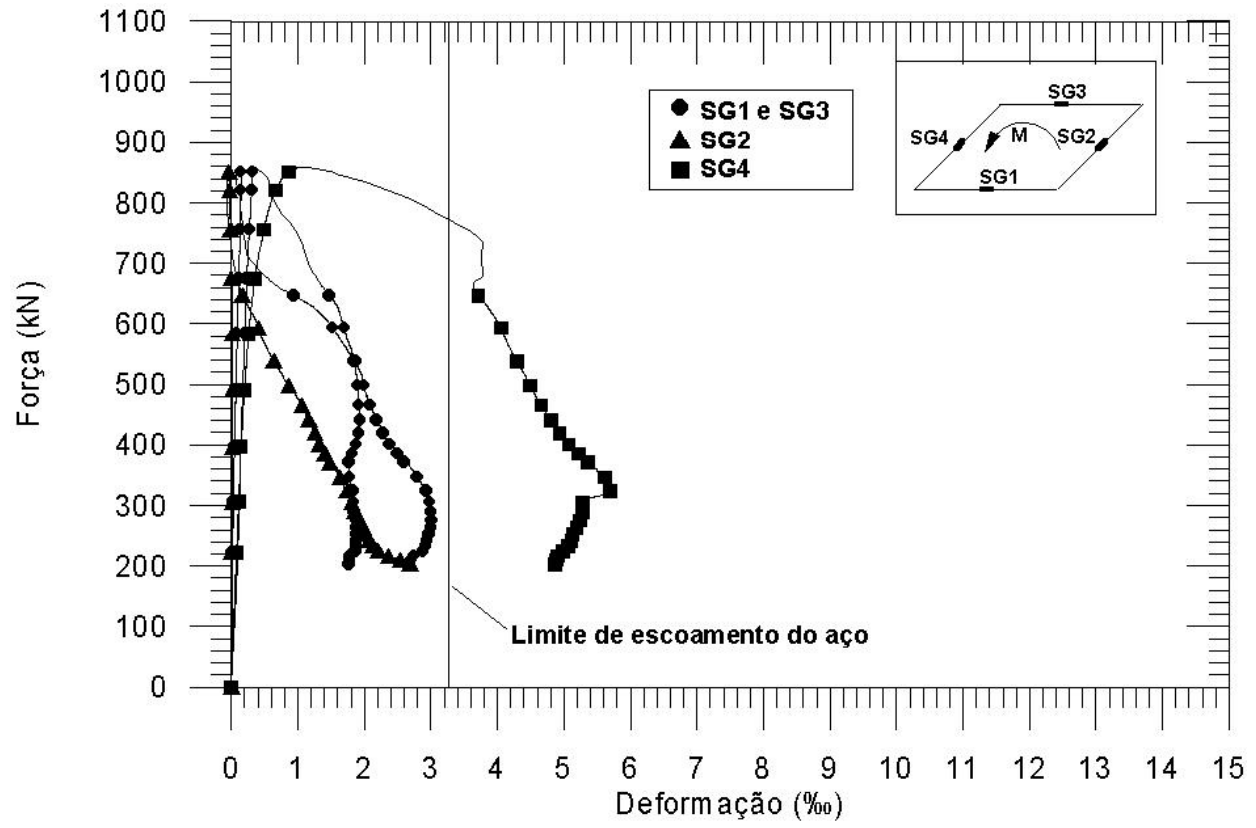

Figura B.24 - Diagramas força vs. deformação na armadura transversal. 


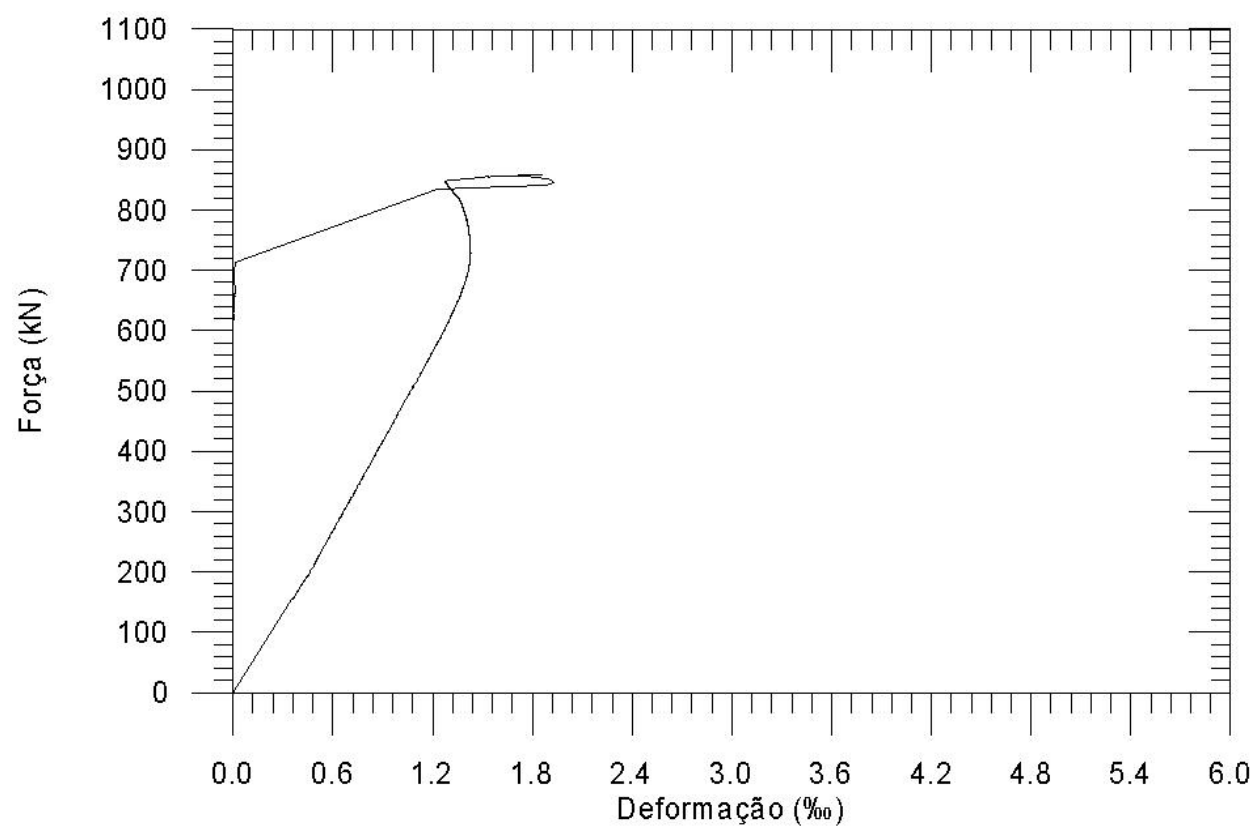

Figura B.25 - Diagramas força vs. deformação no concreto

\section{B.6.Pilar P36050}

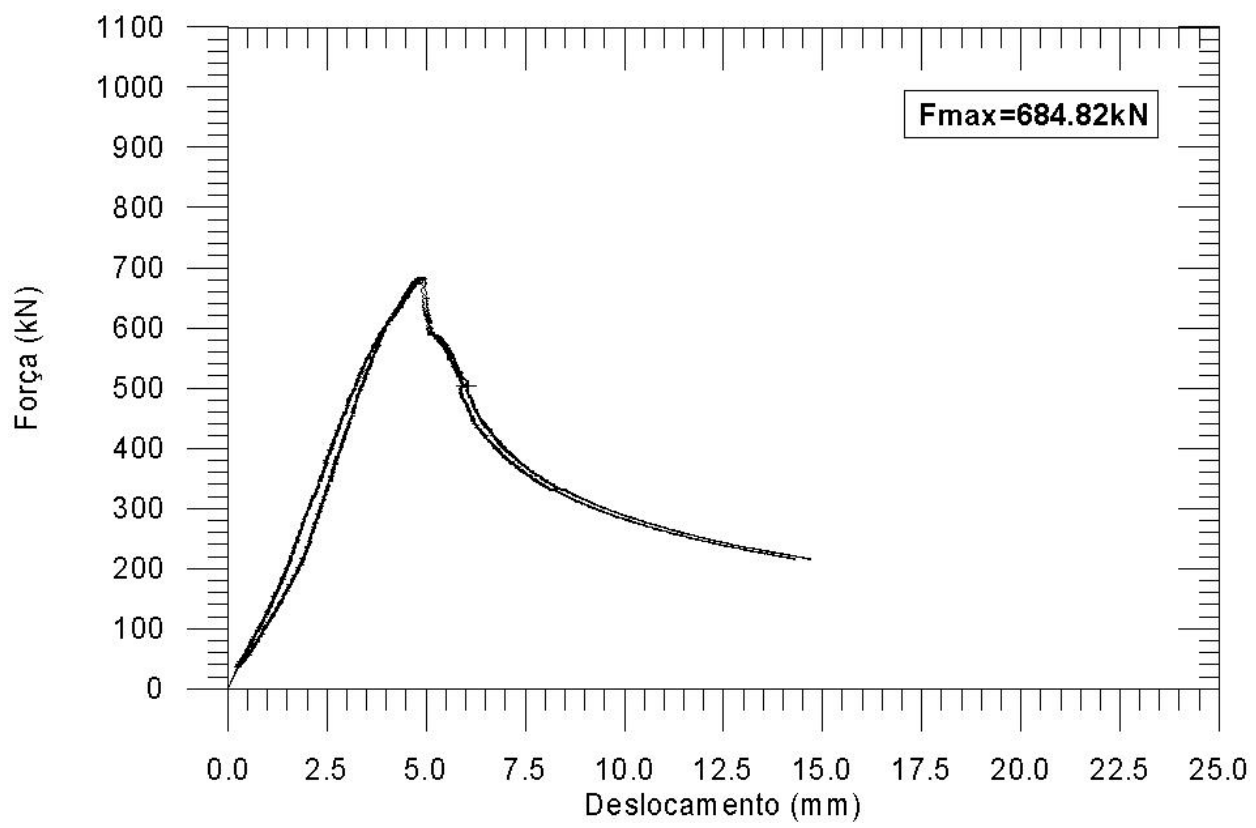

Figura B.26 - Diagramas forças vs. deslocamento vertical do pilar 


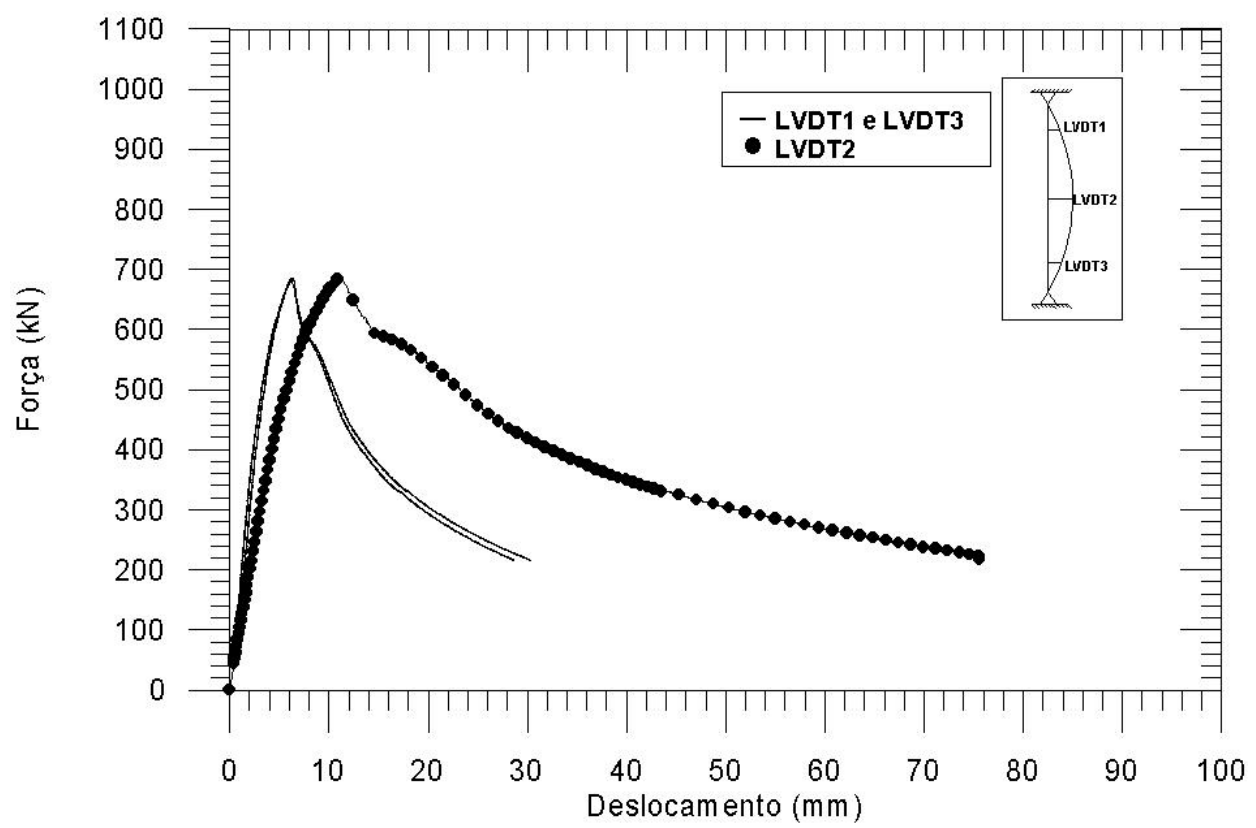

Figura B.27 - Diagramas força vs. deslocamento transversal do pilar

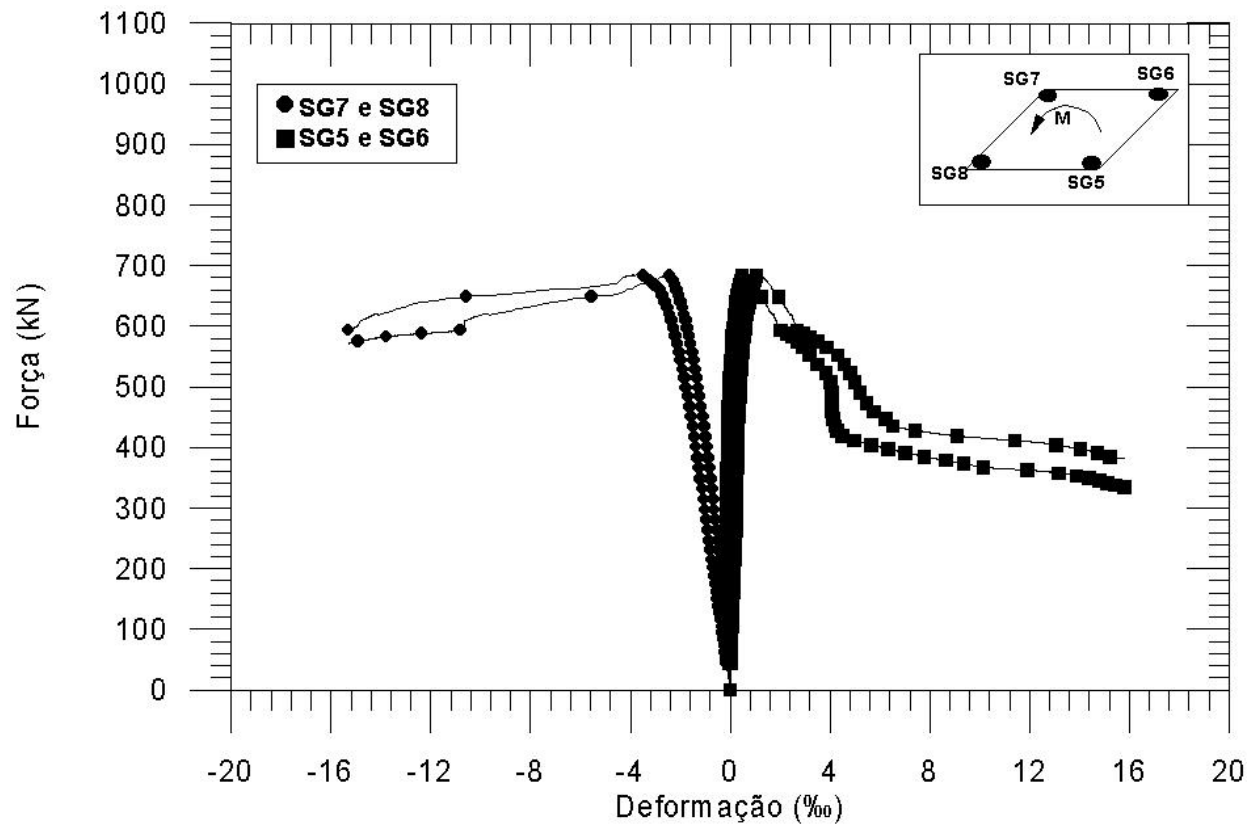

Figura B.28 - Diagramas força vs. deformação na armadura longitudinal 


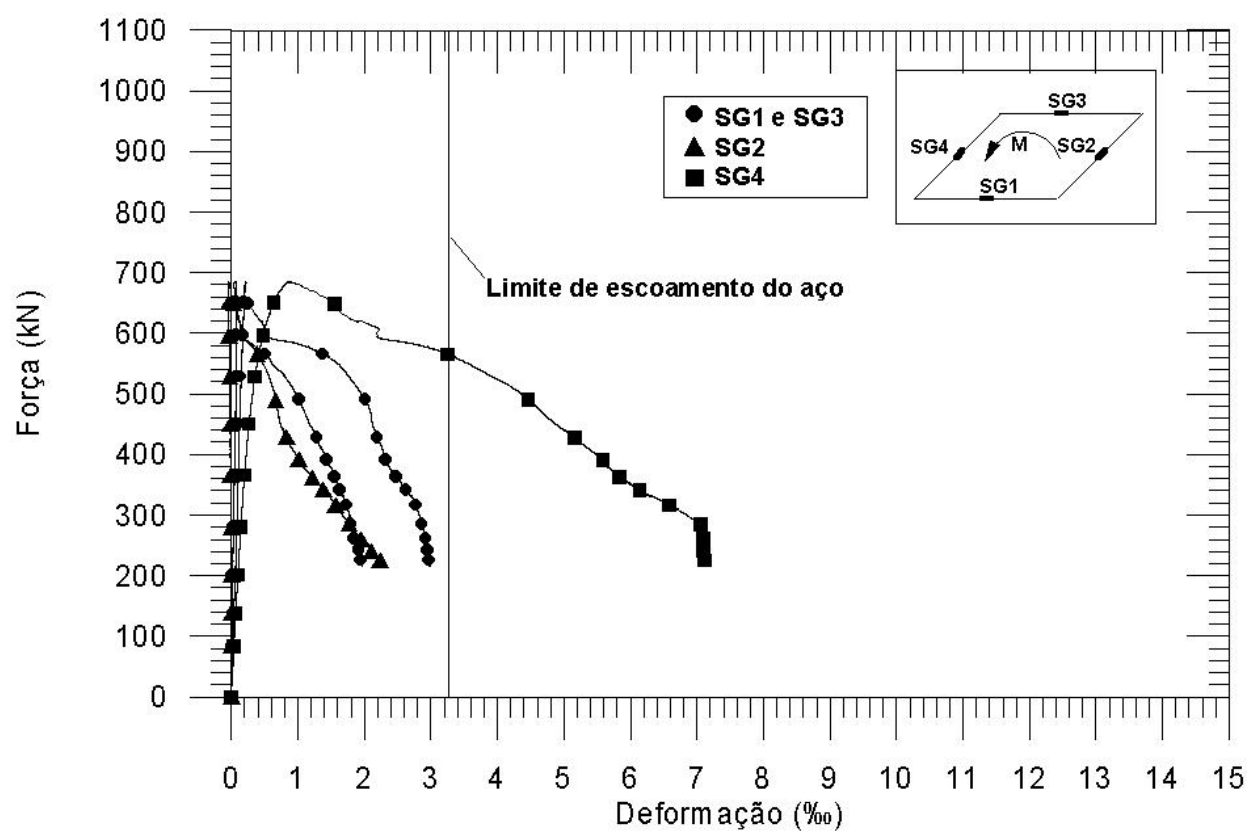

Figura B.29 - Diagramas força vs. deformação na armadura transversal.

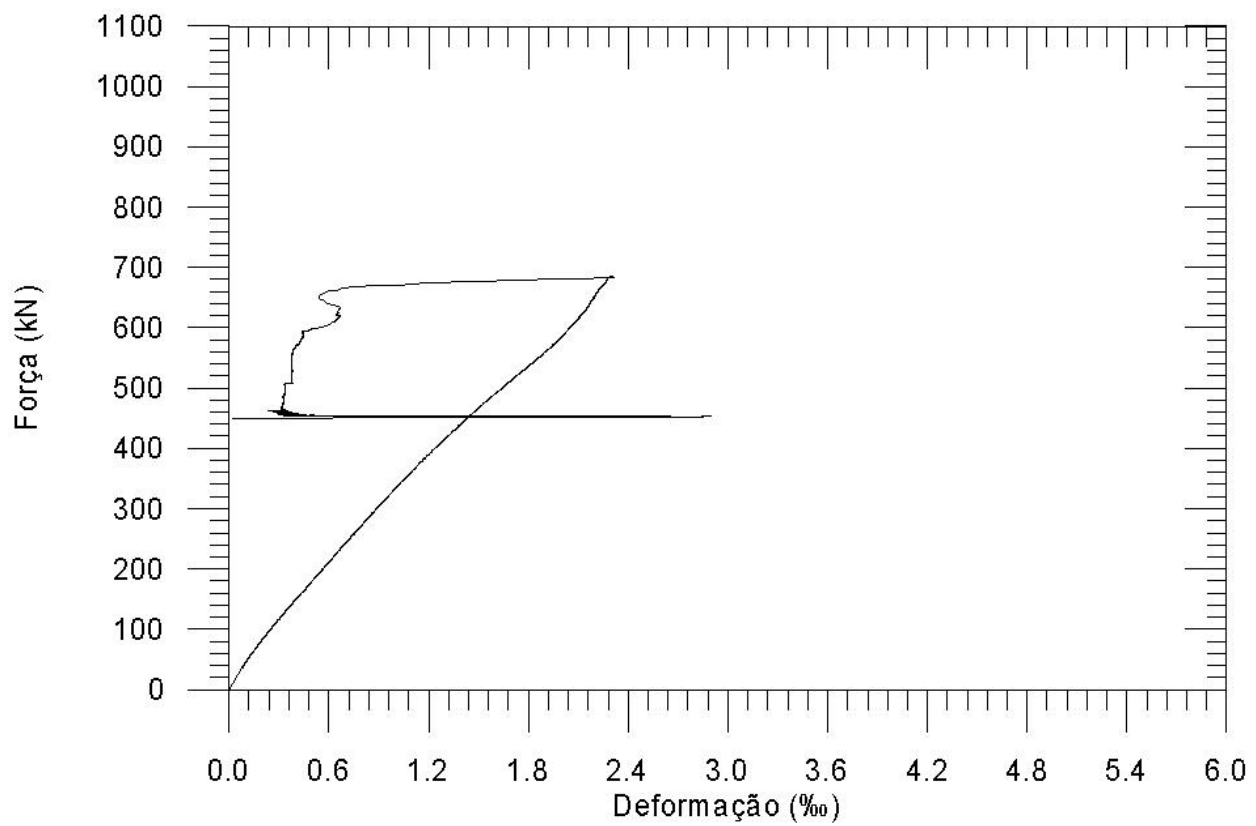

Figura B.30 - Diagramas força vs. deformação no concreto 


\section{B.7.Pilar P1601505}

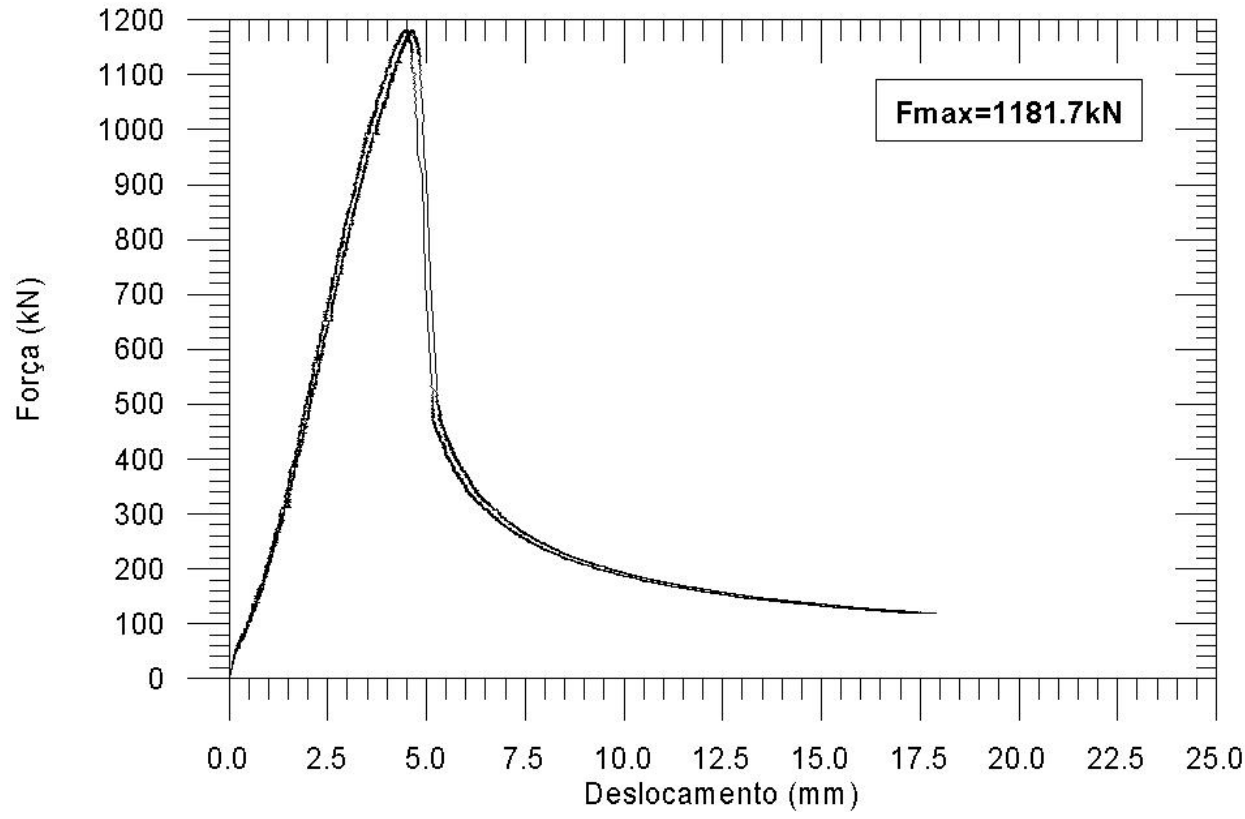

Figura B.31 - Diagramas forças vs. deslocamento vertical do pilar

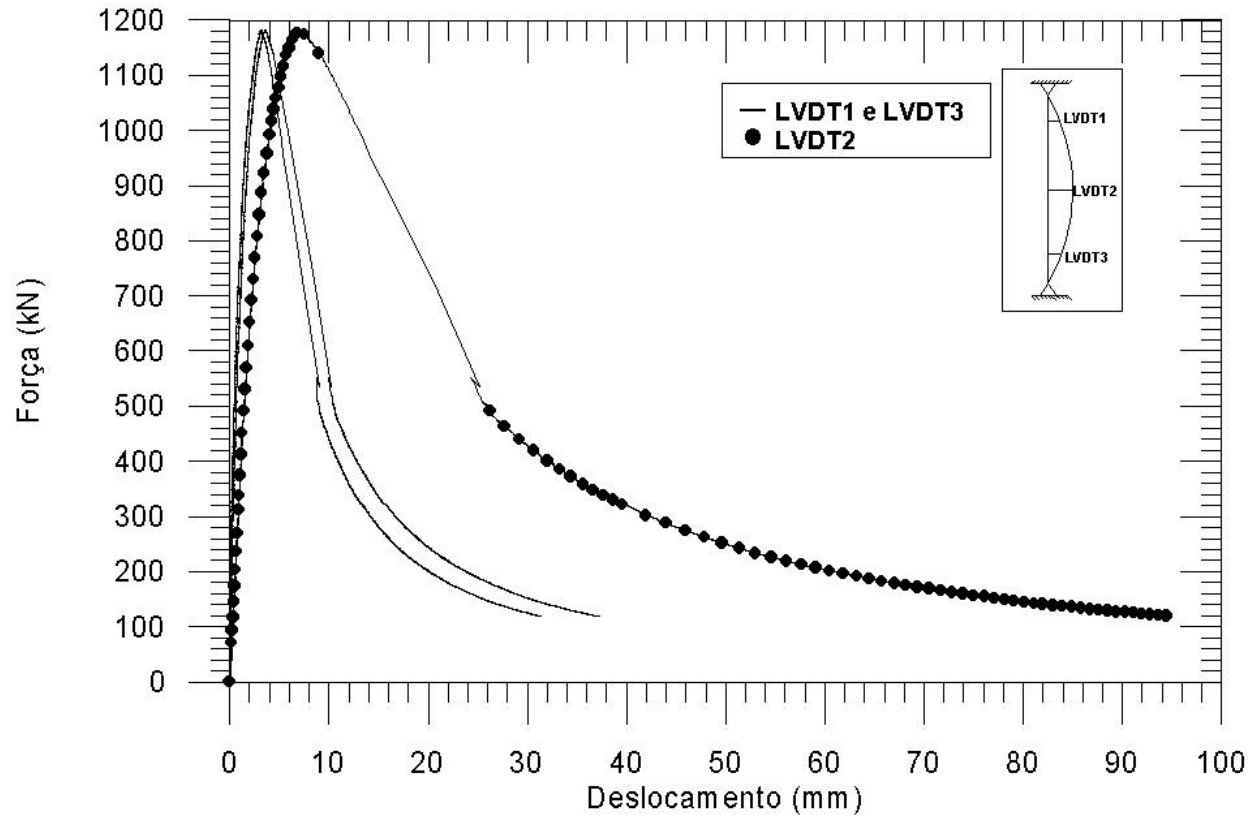

Figura B.32 - Diagramas força vs. deslocamento transversal do pilar 


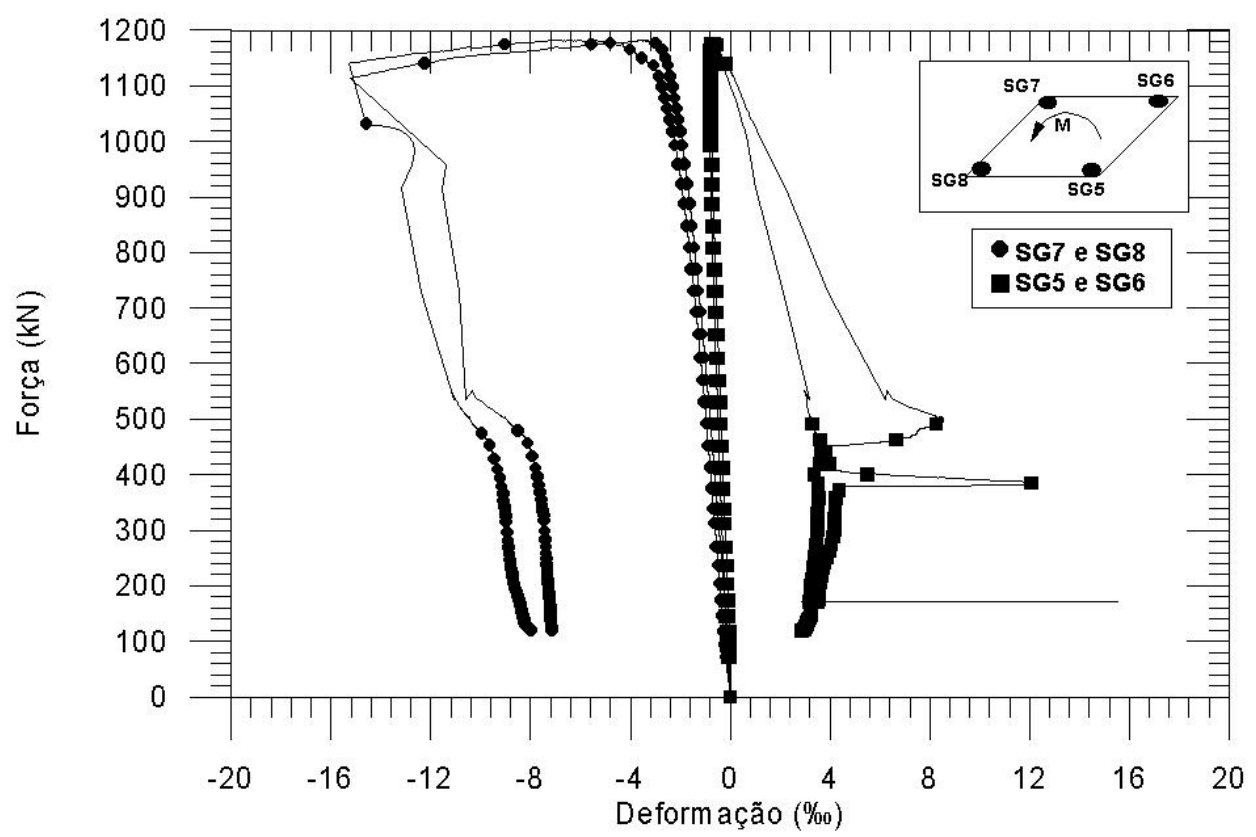

Figura B.33 - Diagramas força vs. deformação na armadura longitudinal

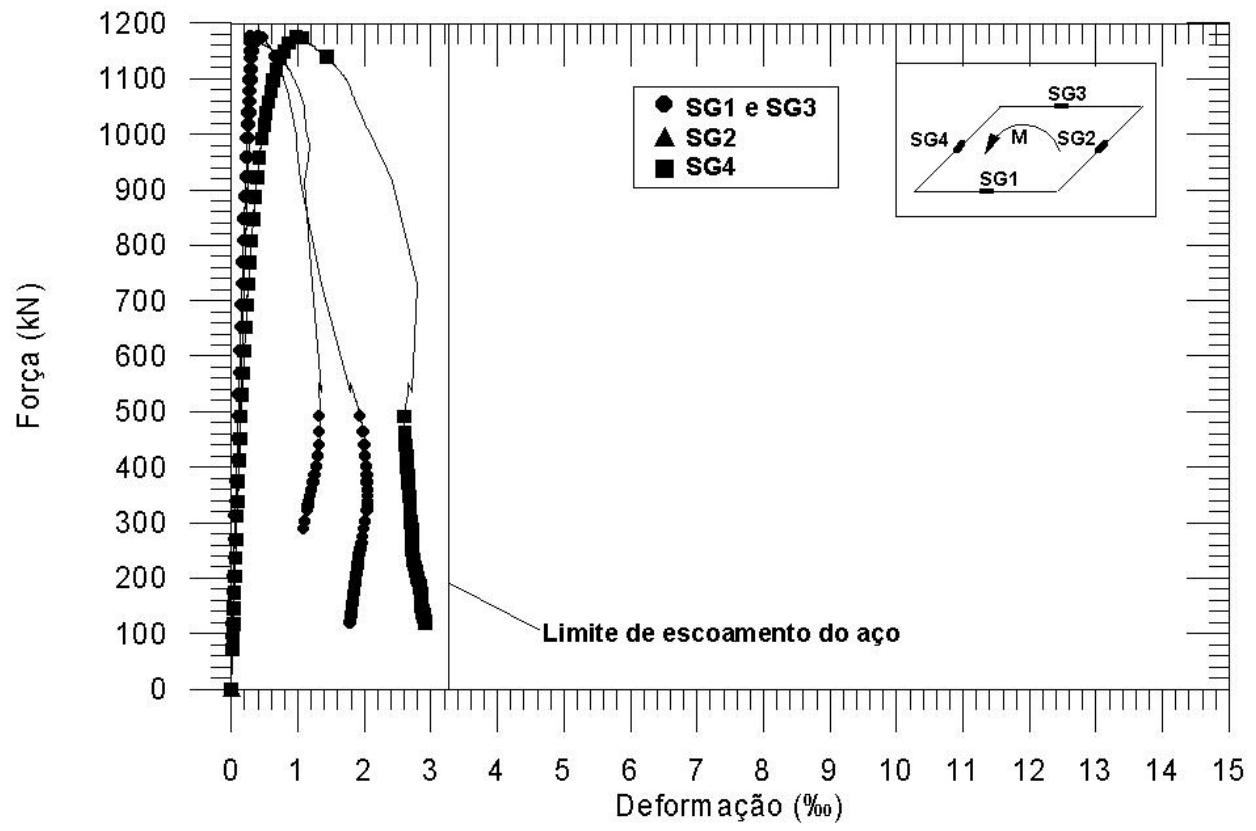

Figura B.34 - Diagramas força vs. deformação na armadura transversal. 


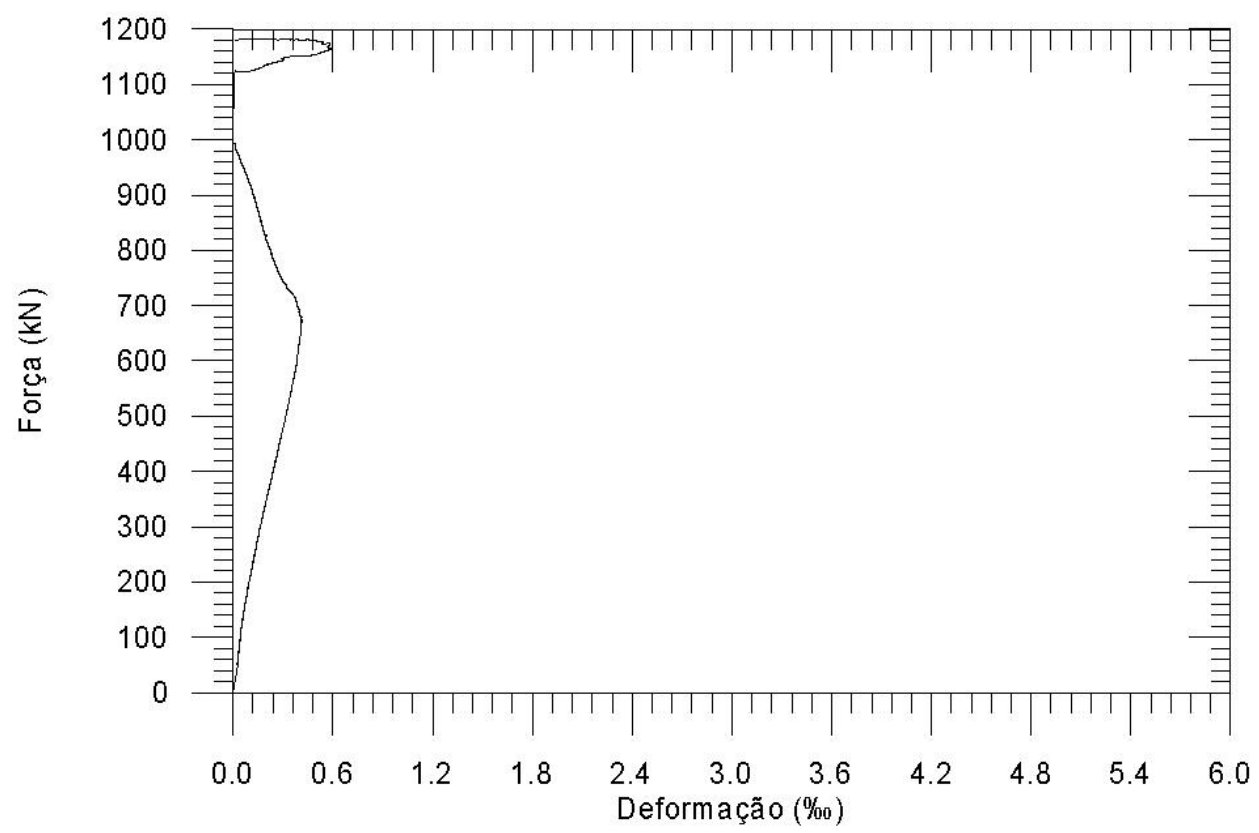

Figura B.35 - Diagramas força vs. deformação no concreto

\section{B.8.Pilar P2601505}

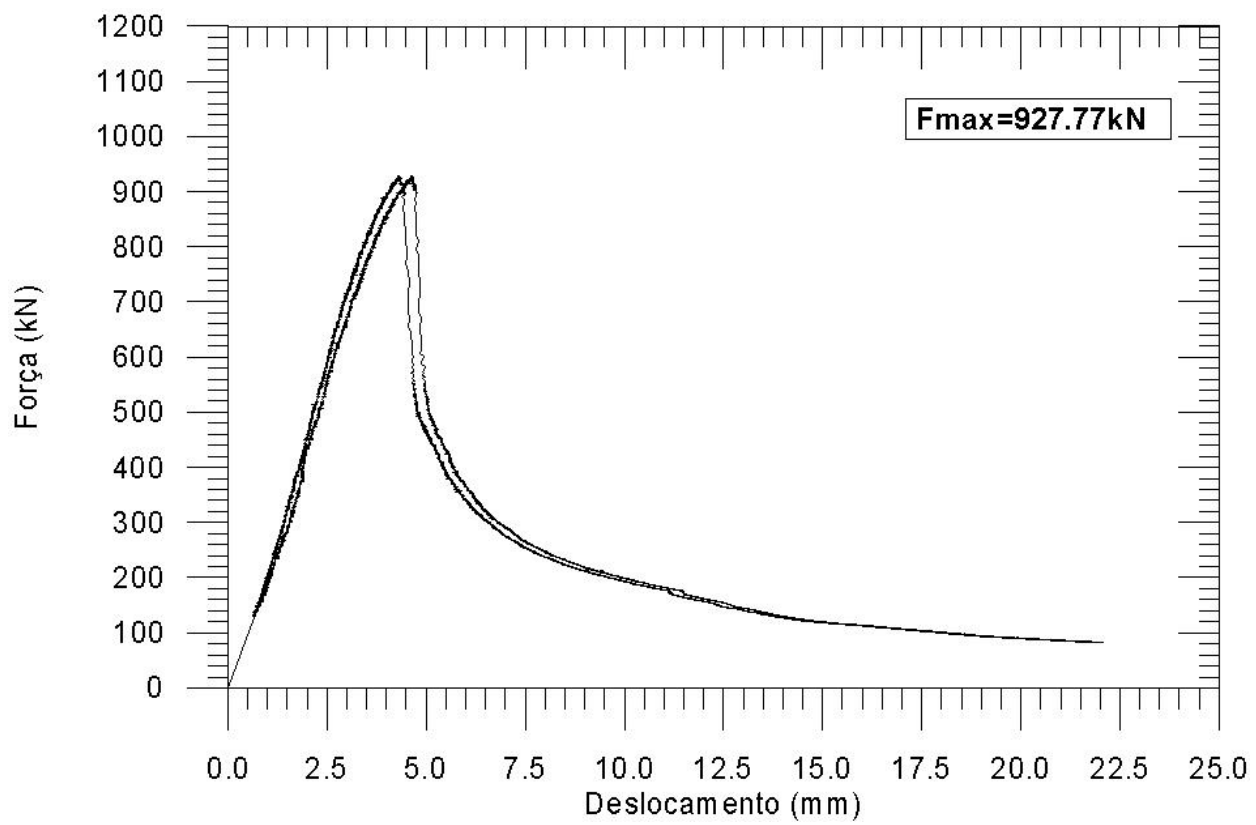

Figura B.36 - Diagramas forças vs. deslocamento vertical do pilar 


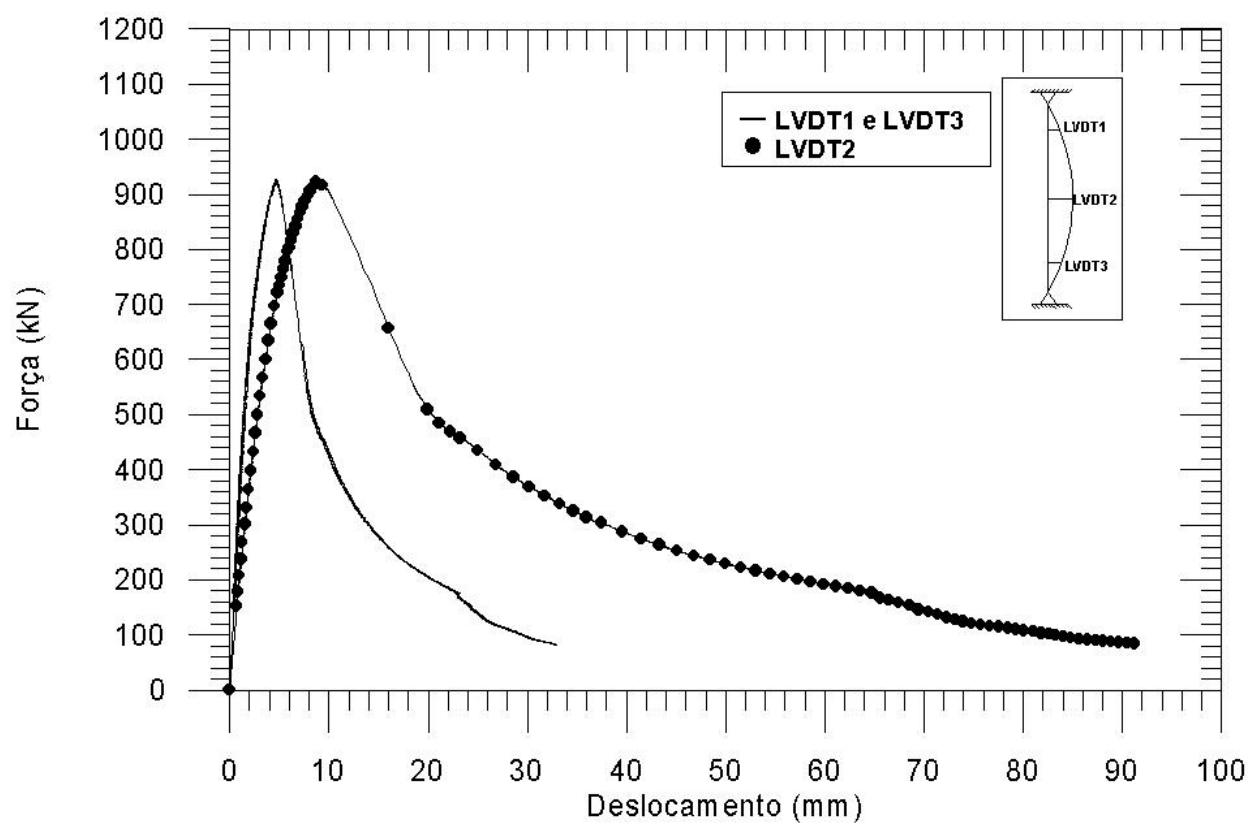

Figura B.37 - Diagramas força vs. deslocamento transversal do pilar

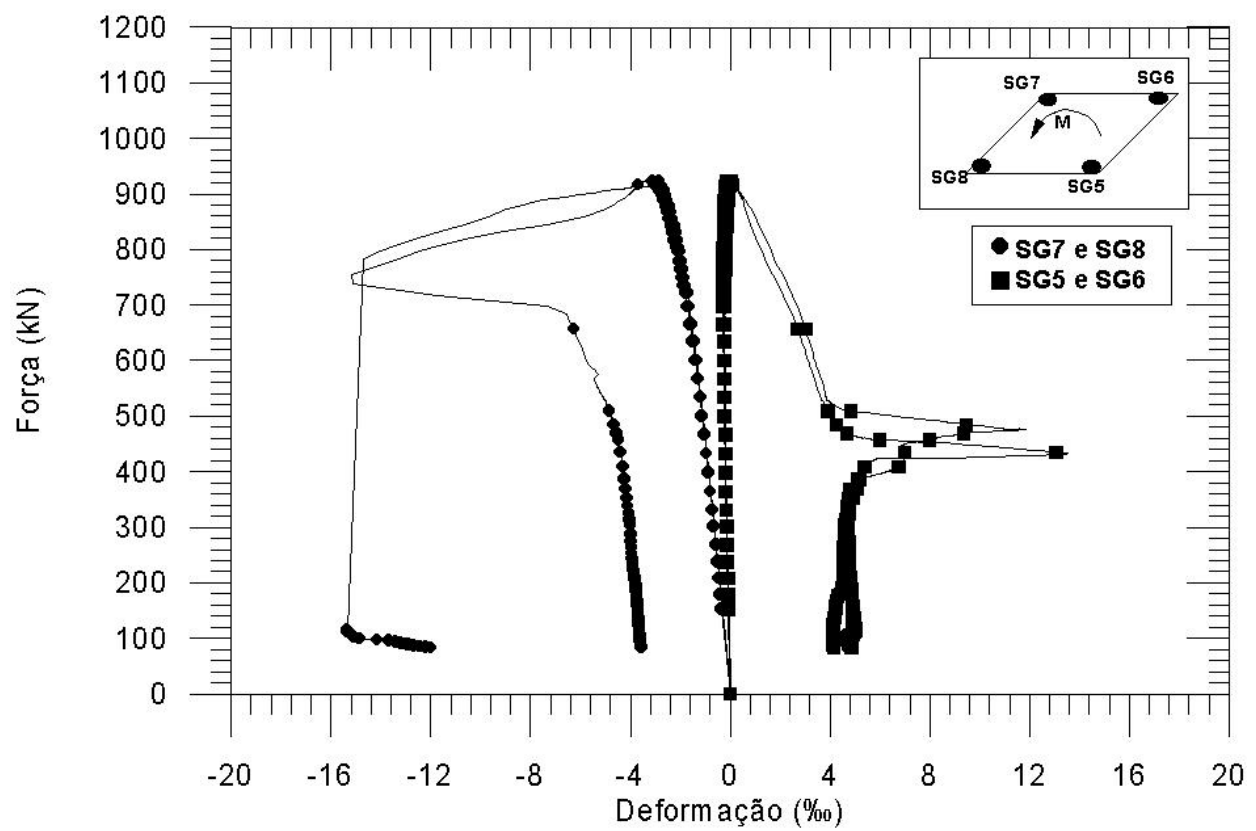

Figura B.38 - Diagramas força vs. deformação na armadura longitudinal 


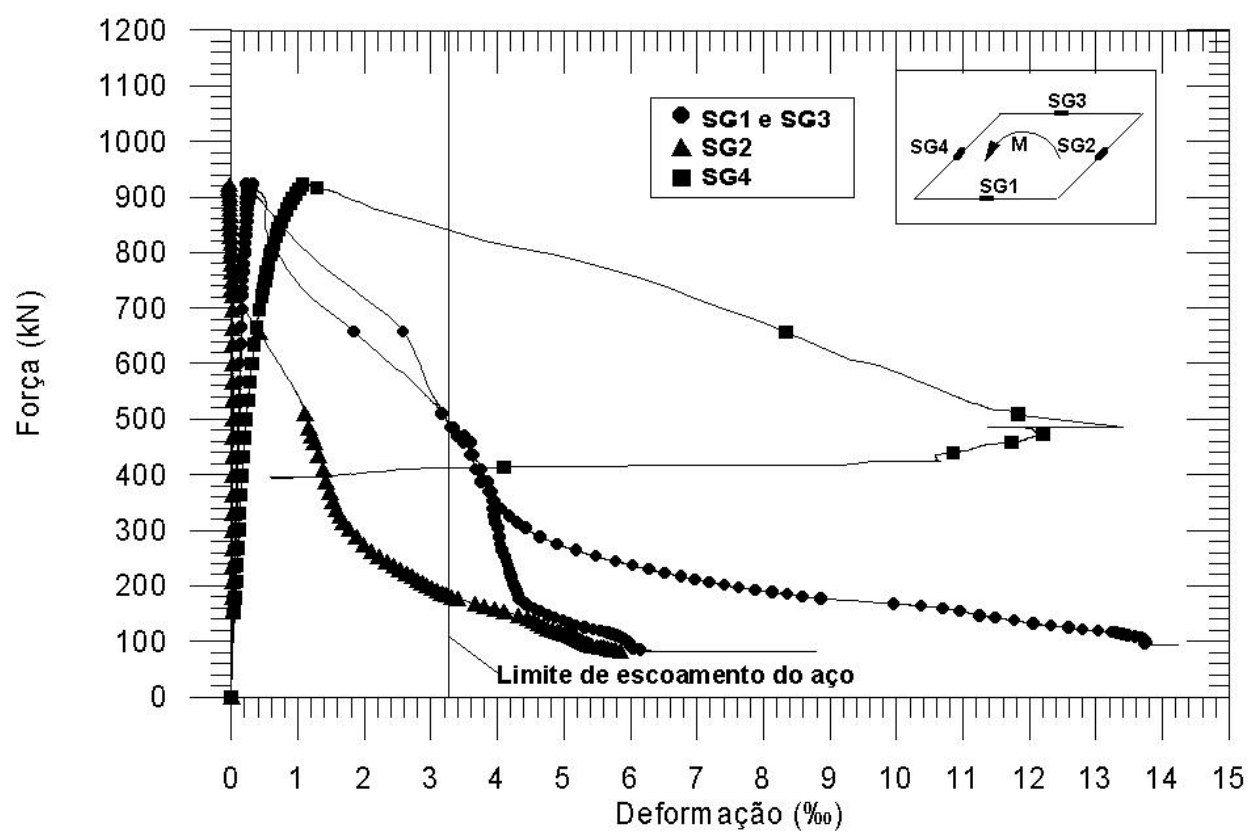

Figura B.39 - Diagramas força vs. deformação na armadura transversal.

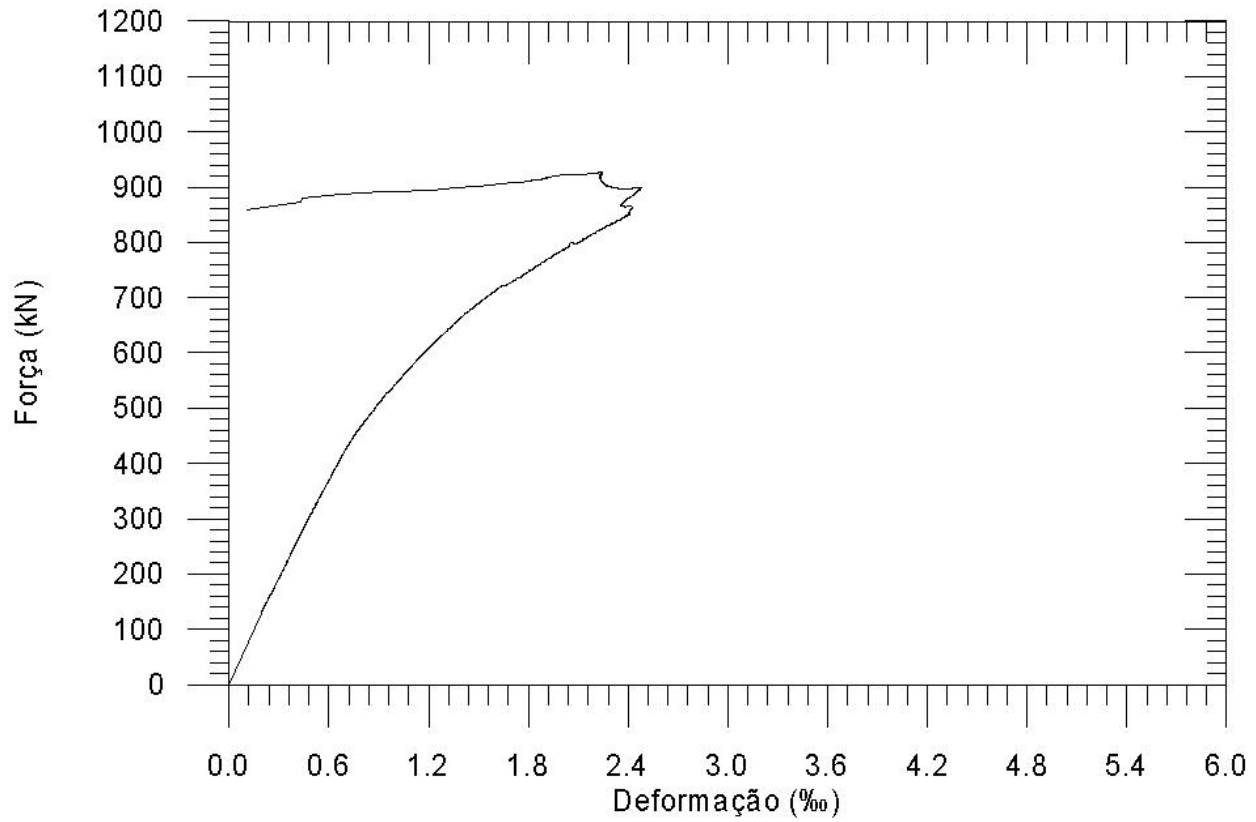

Figura B.40 - Diagramas força vs. deformação no concreto 


\section{B.9.Pilar P3601505}

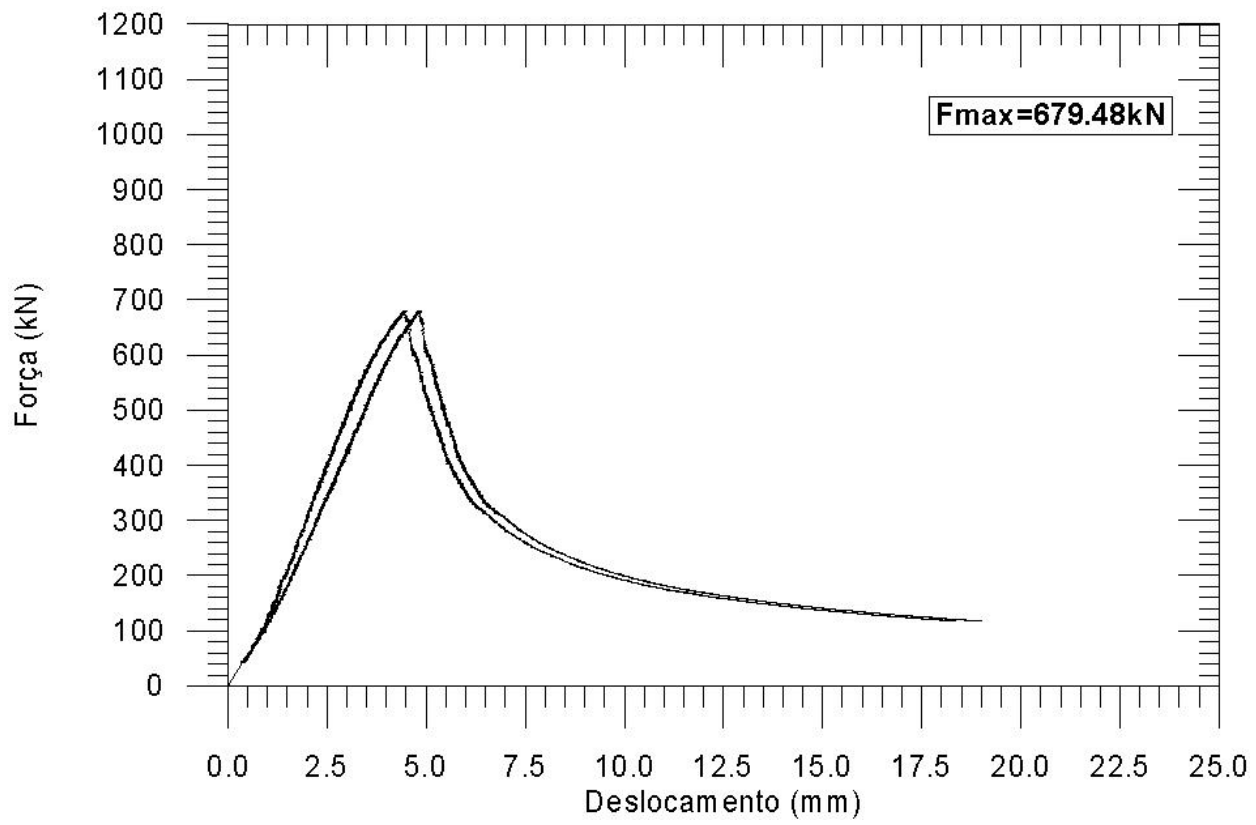

Figura B.41 - Diagramas forças vs. deslocamento vertical do pilar

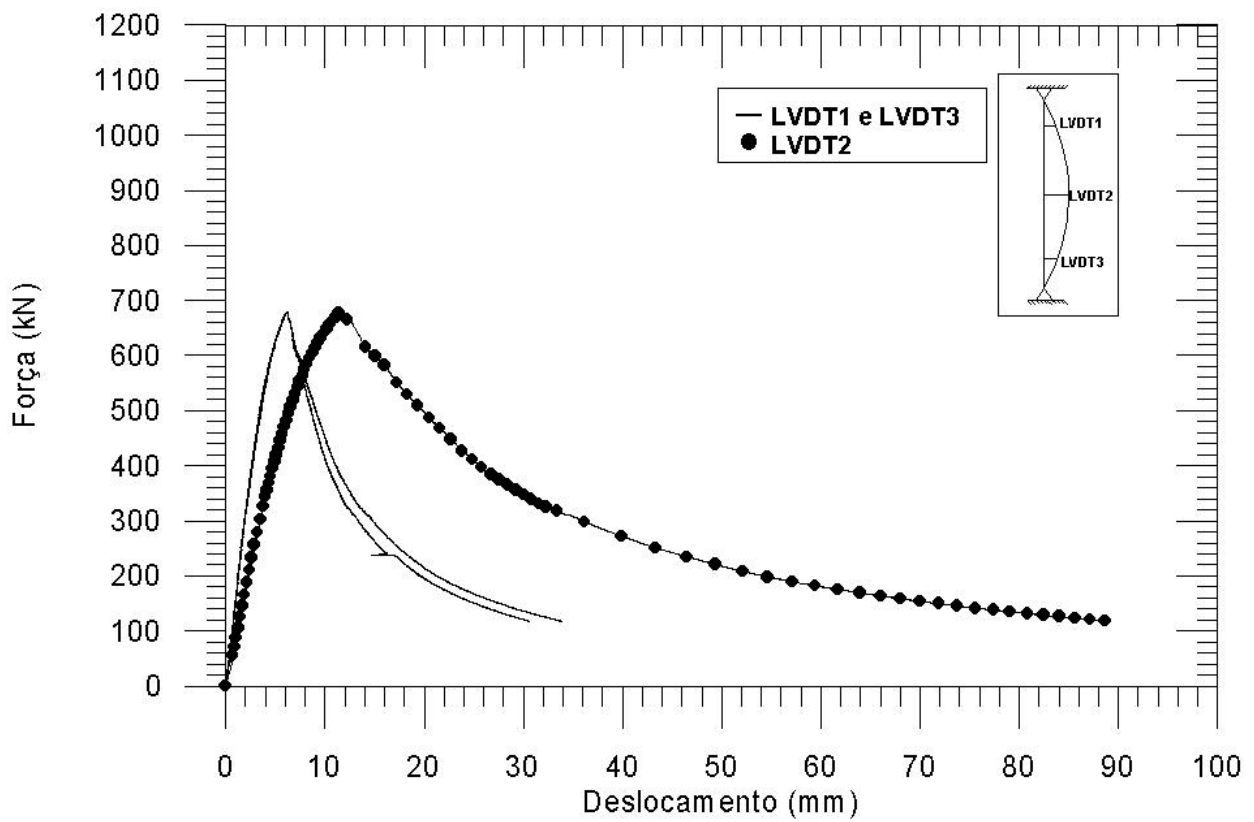

Figura B.42 - Diagramas força vs. deslocamento transversal do pilar 


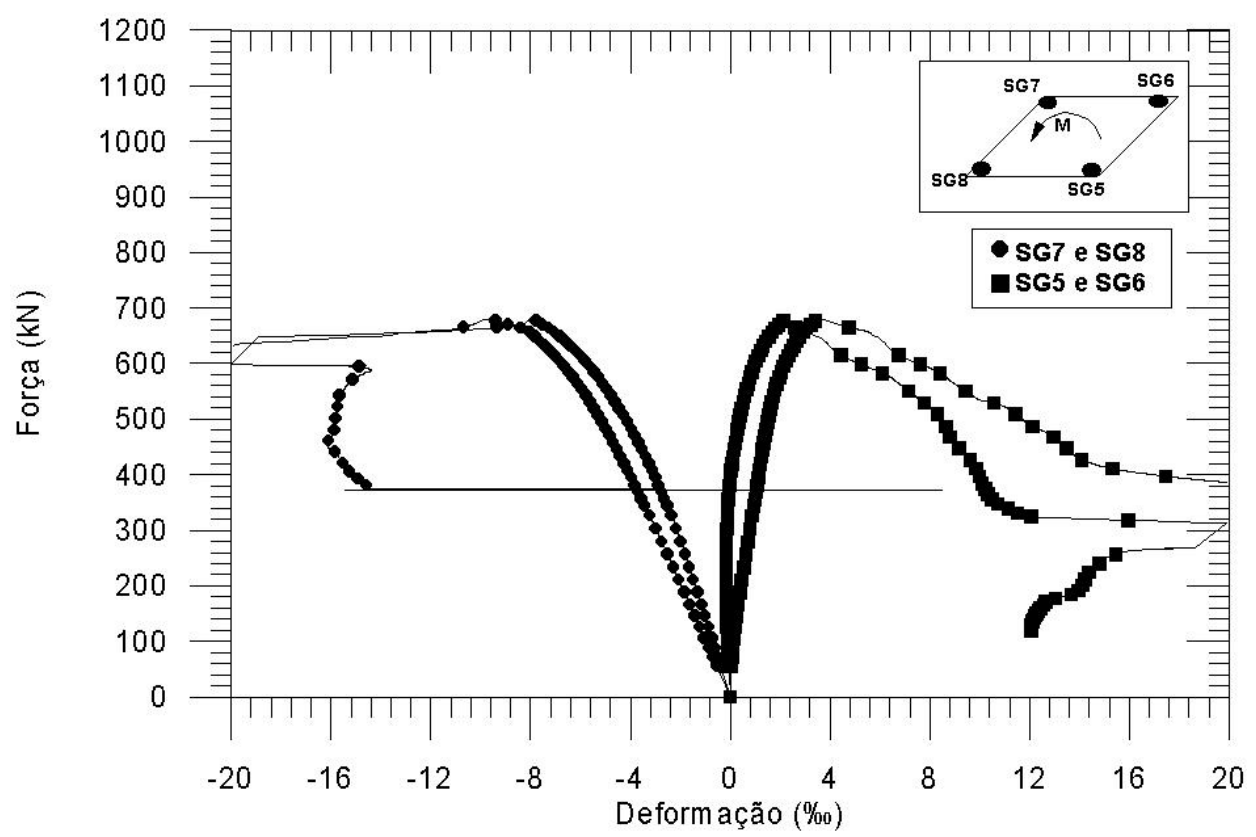

Figura B.43 - Diagramas força vs. deformação na armadura longitudinal

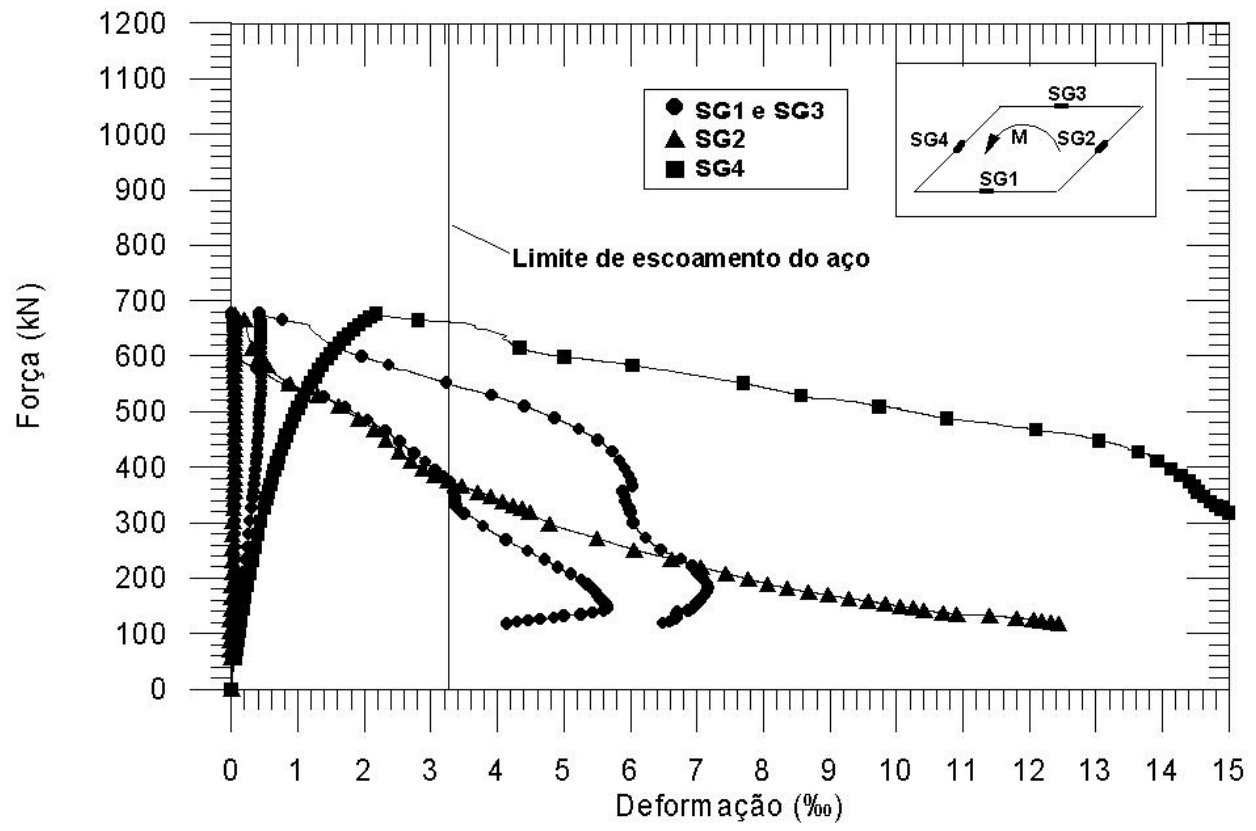

Figura B.44 - Diagramas força vs. deformação na armadura transversal. 


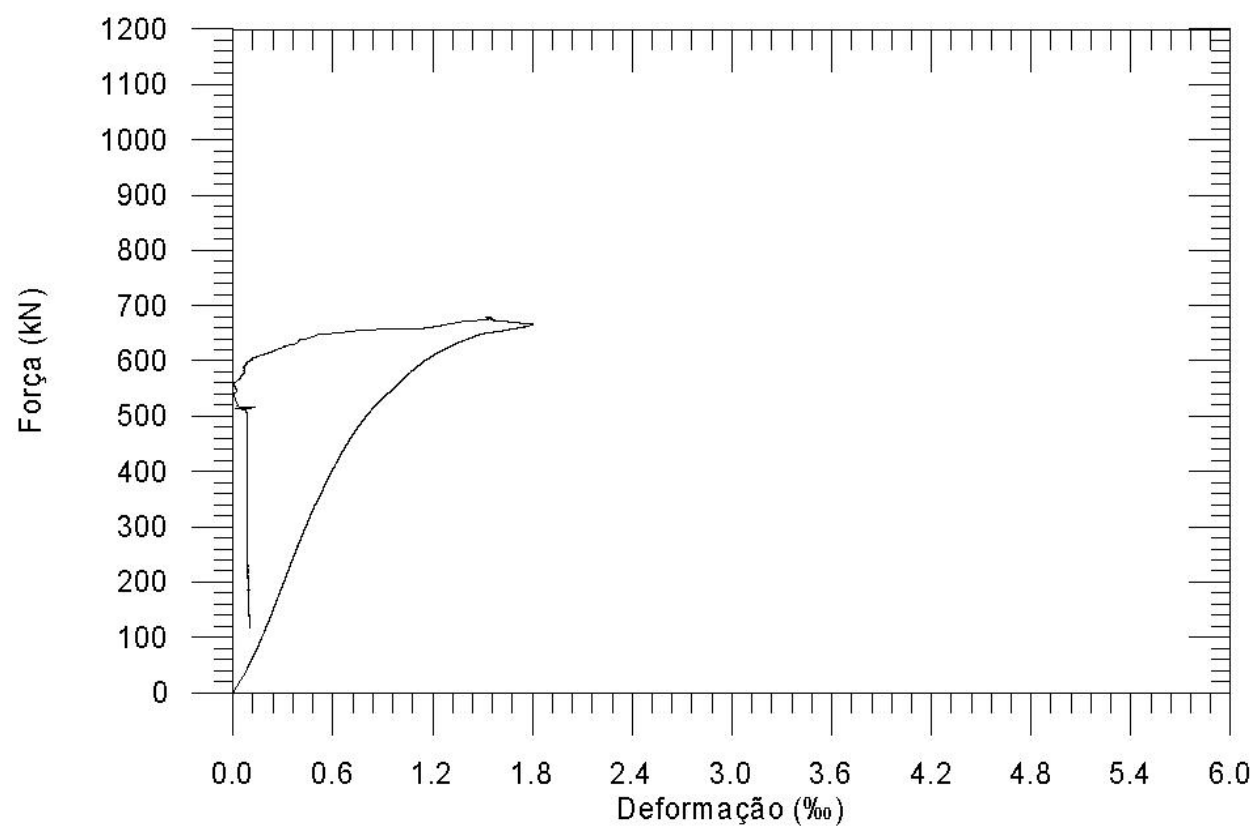

Figura B.45 - Diagramas força vs. deformação no concreto

\section{B.10.Pilar P160505}

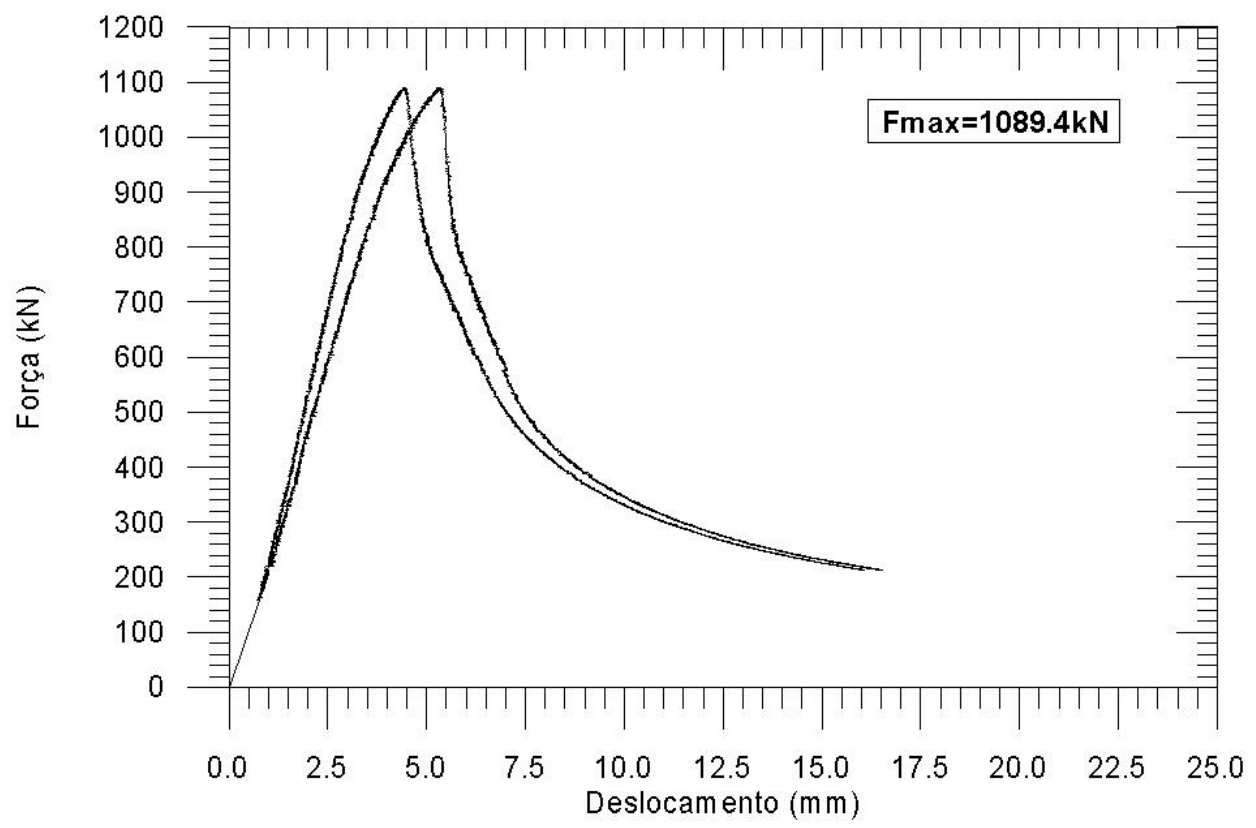

Figura B.46 - Diagramas forças vs. deslocamento vertical do pilar 


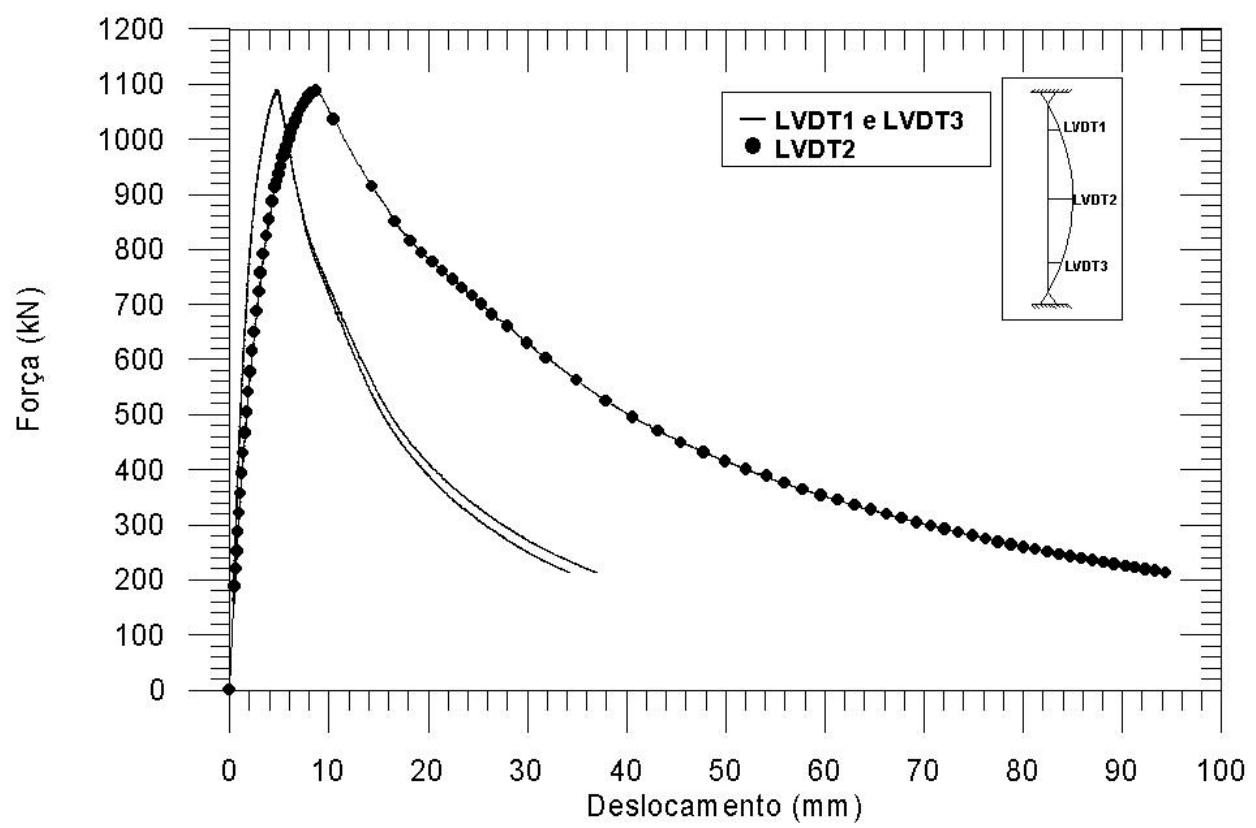

Figura B.47 - Diagramas força vs. deslocamento transversal do pilar

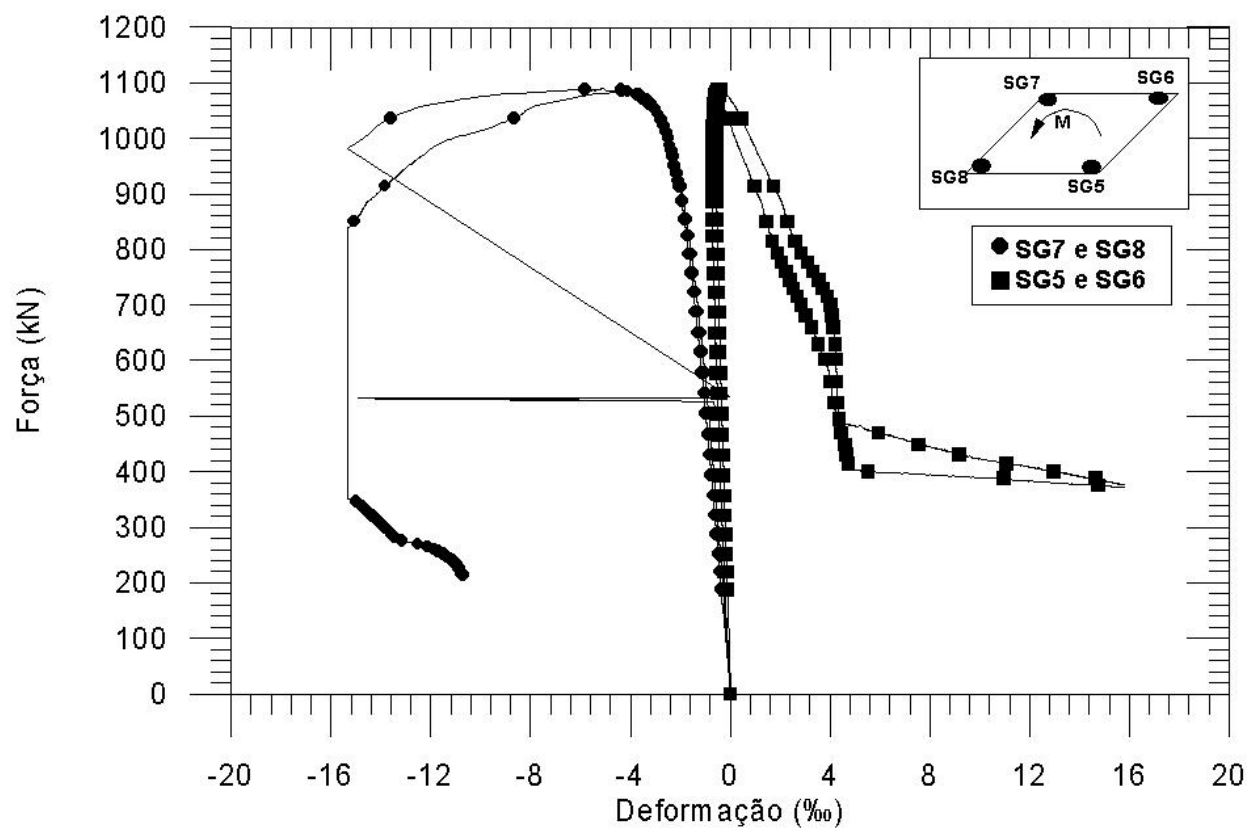

Figura B.48 - Diagramas força vs. deformação na armadura longitudinal 


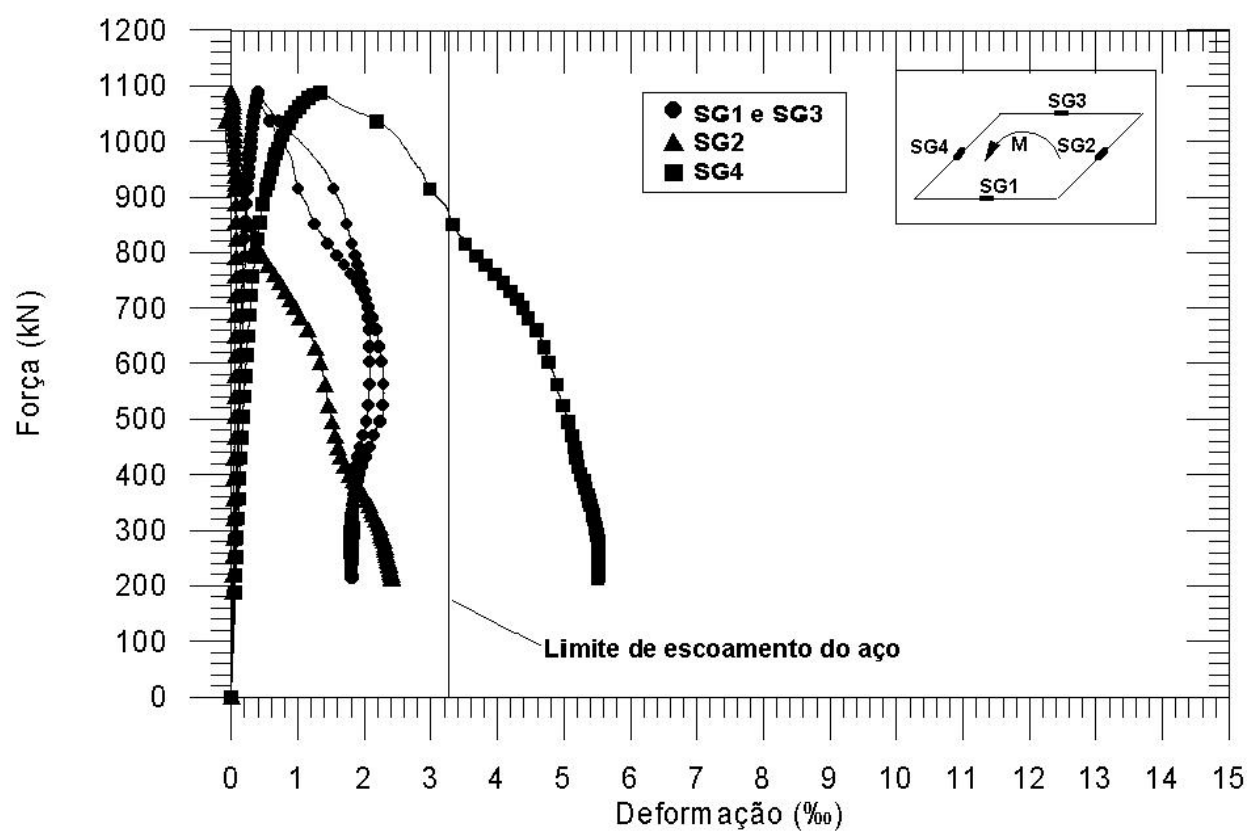

Figura B.49 - Diagramas força vs. deformação na armadura transversal.

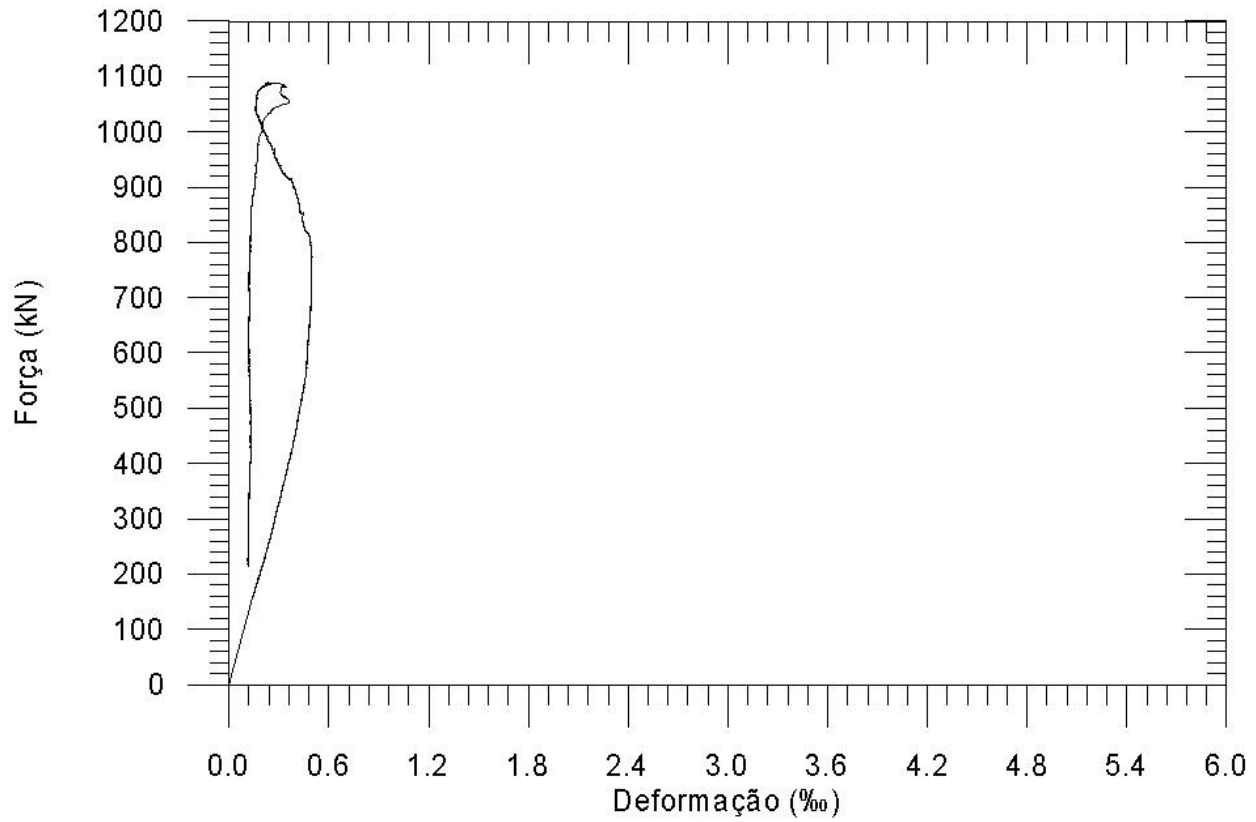

Figura B.50 - Diagramas força vs. deformação no concreto 


\section{B.11.Pilar P260505}

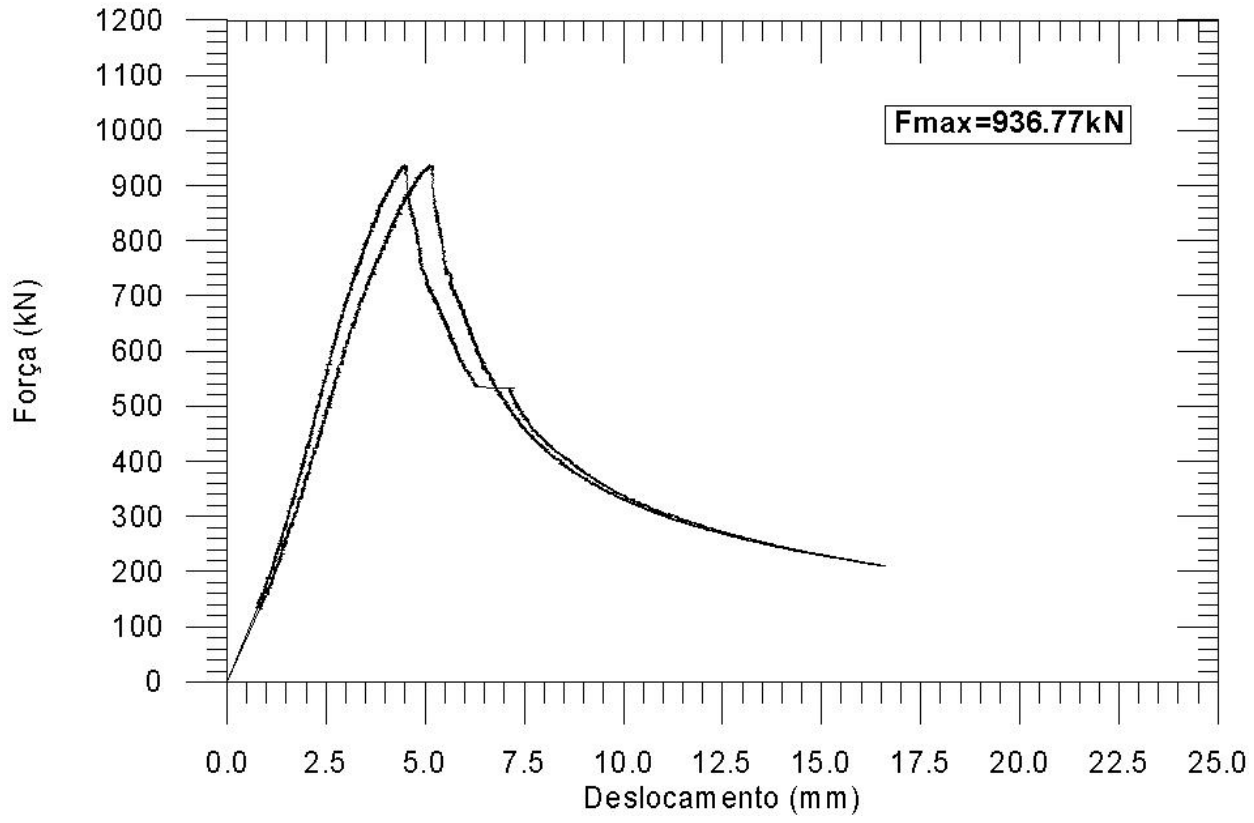

Figura B.51 - Diagramas forças vs. deslocamento vertical do pilar

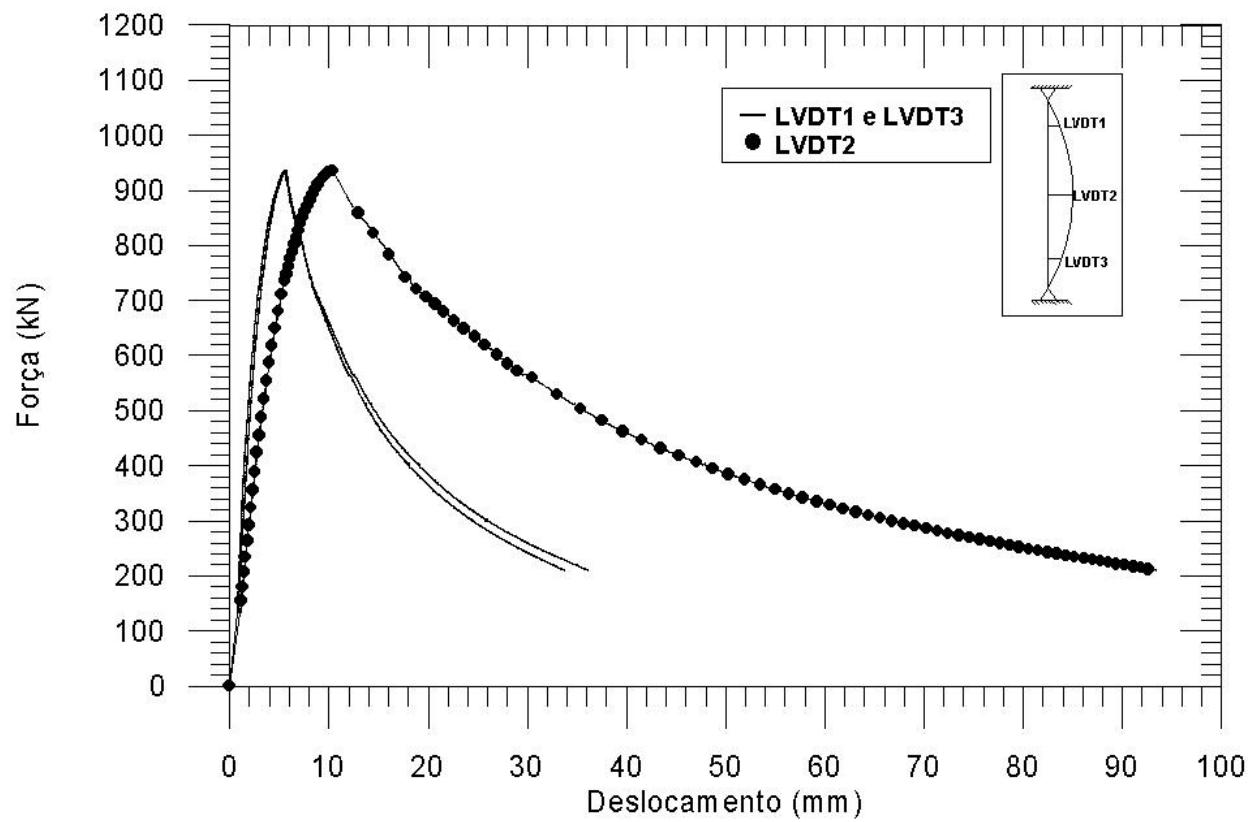

Figura B.52 - Diagramas força vs. deslocamento transversal do pilar 


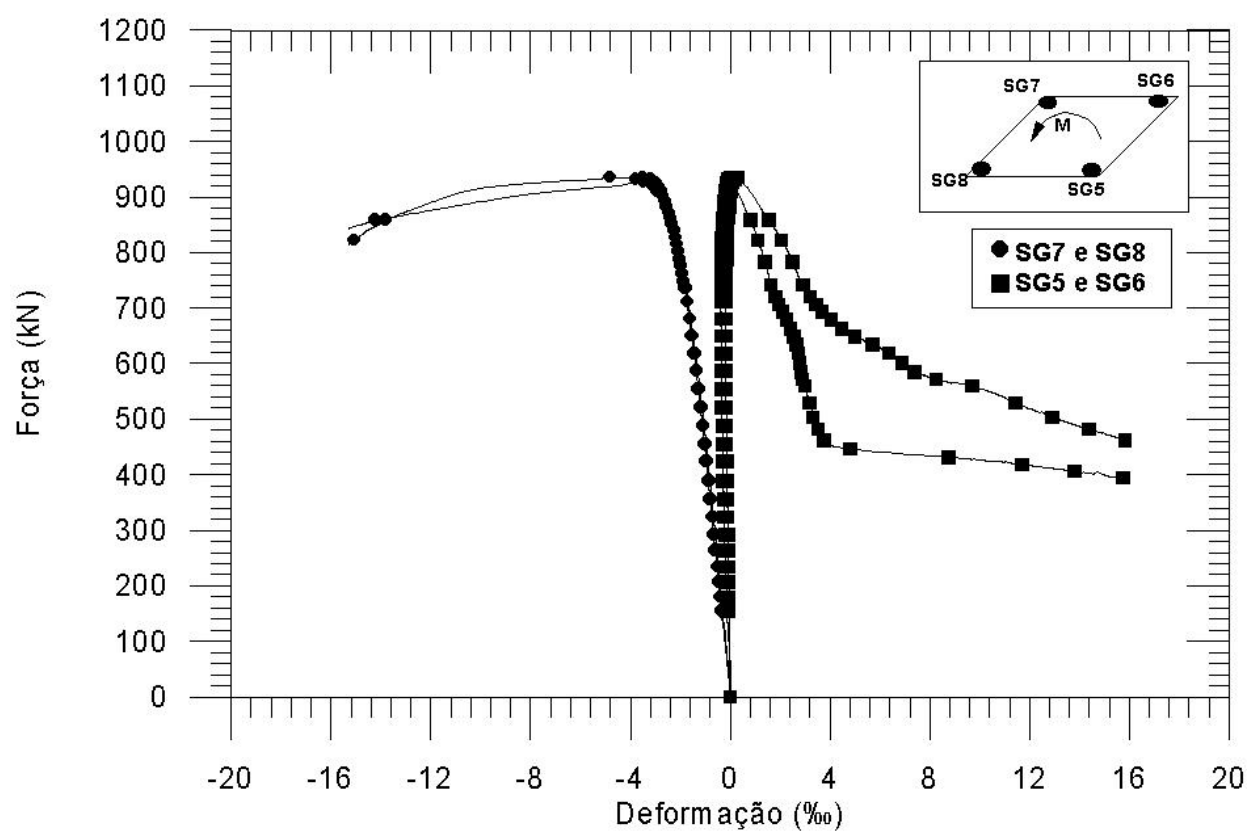

Figura B.53 - Diagramas força vs. deformação na armadura longitudinal

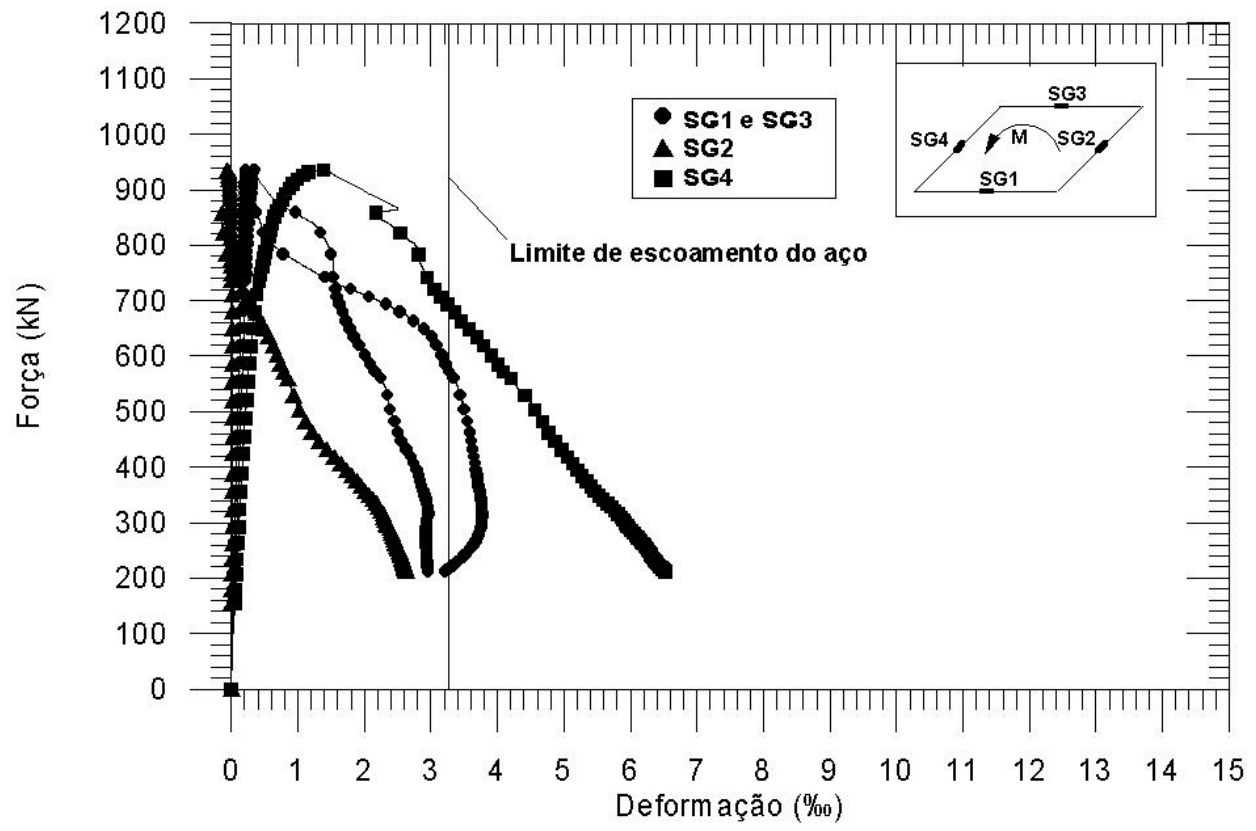

Figura B.54 - Diagramas força vs. deformação na armadura transversal. 


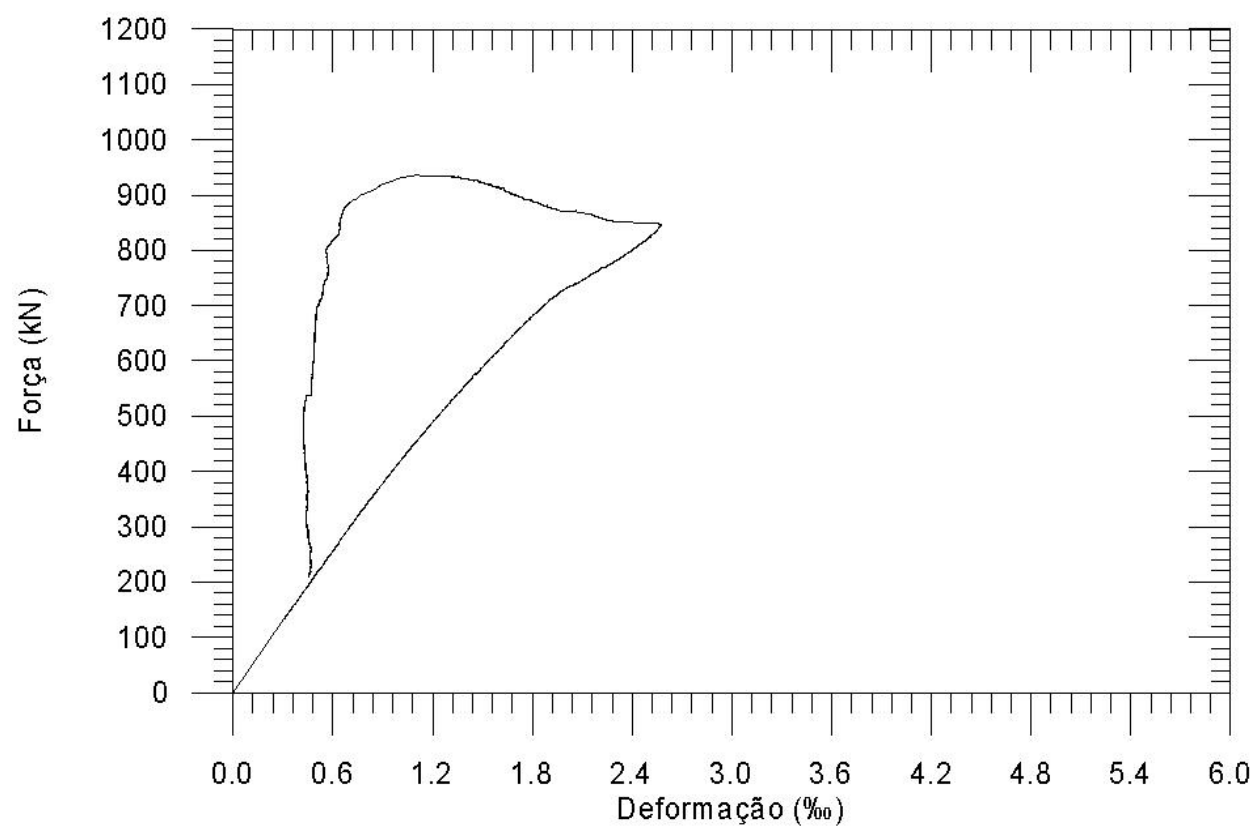

Figura B.55 - Diagramas força vs. deformação no concreto

\section{B.12.Pilar P360505}

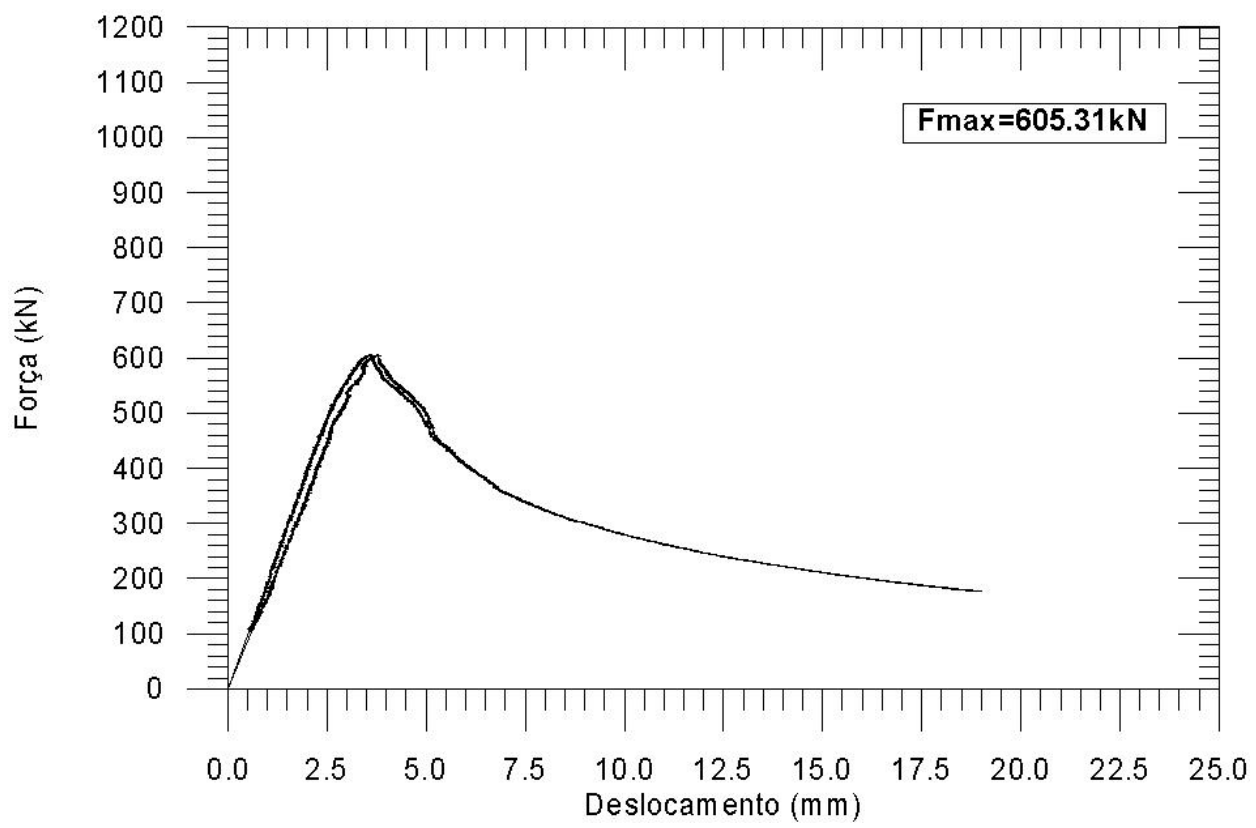

Figura B.56 - Diagramas forças vs. deslocamento vertical do pilar 


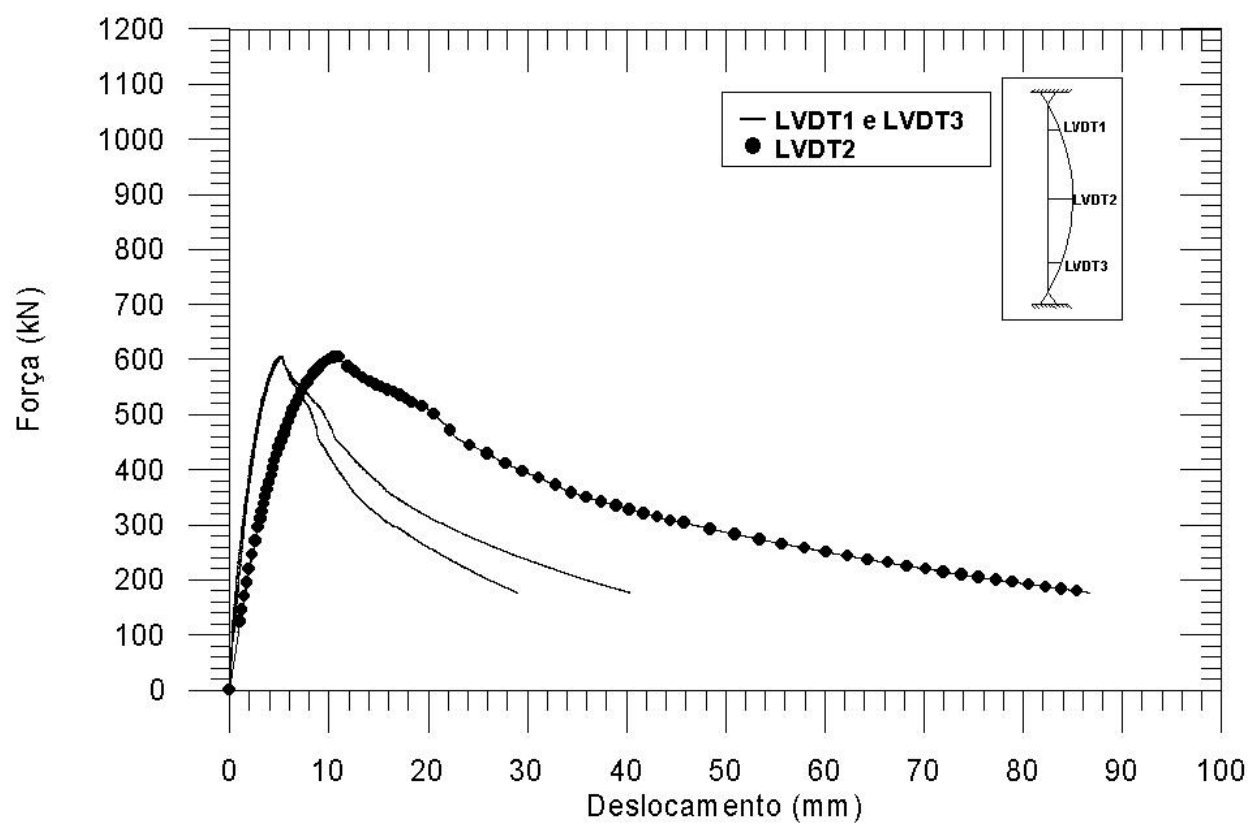

Figura B.57 - Diagramas força vs. deslocamento transversal do pilar

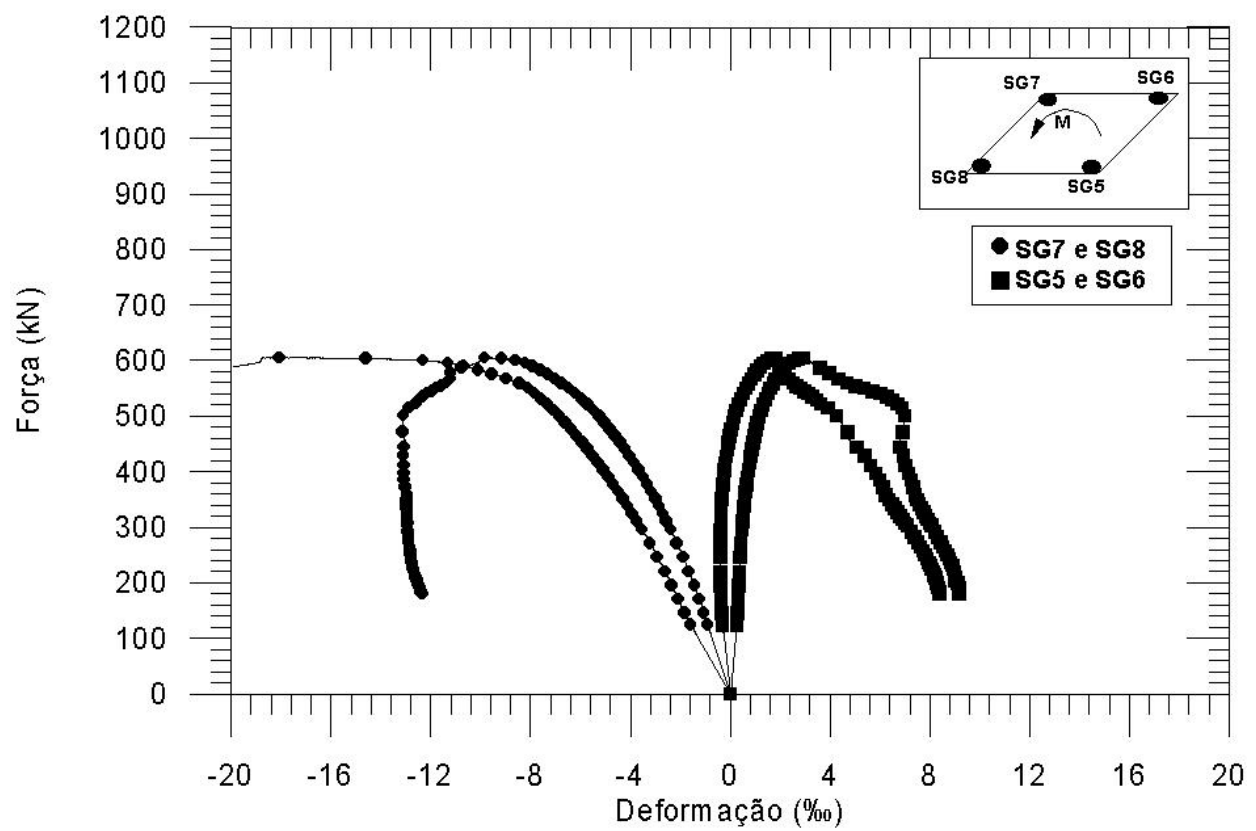

Figura B.58 - Diagramas força vs. deformação na armadura longitudinal 


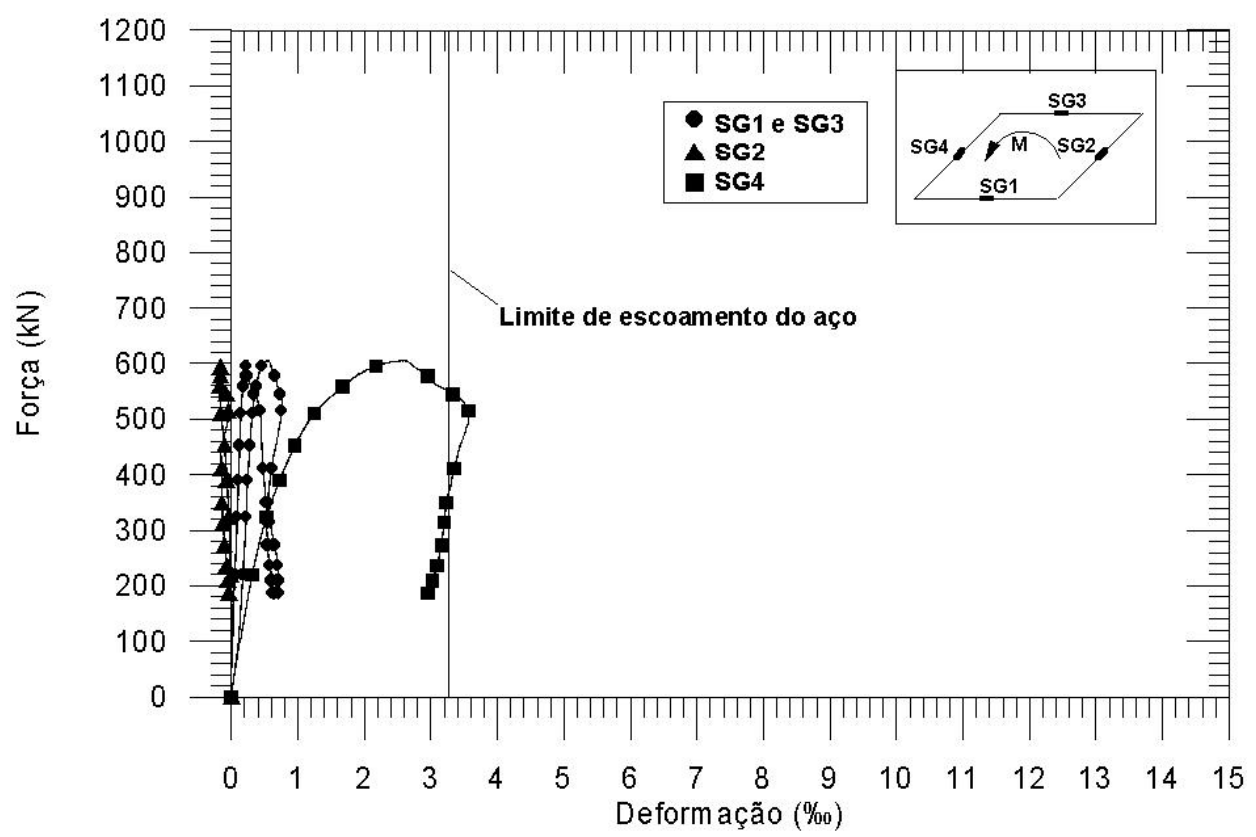

Figura B.59 - Diagramas força vs. deformação na armadura transversal.

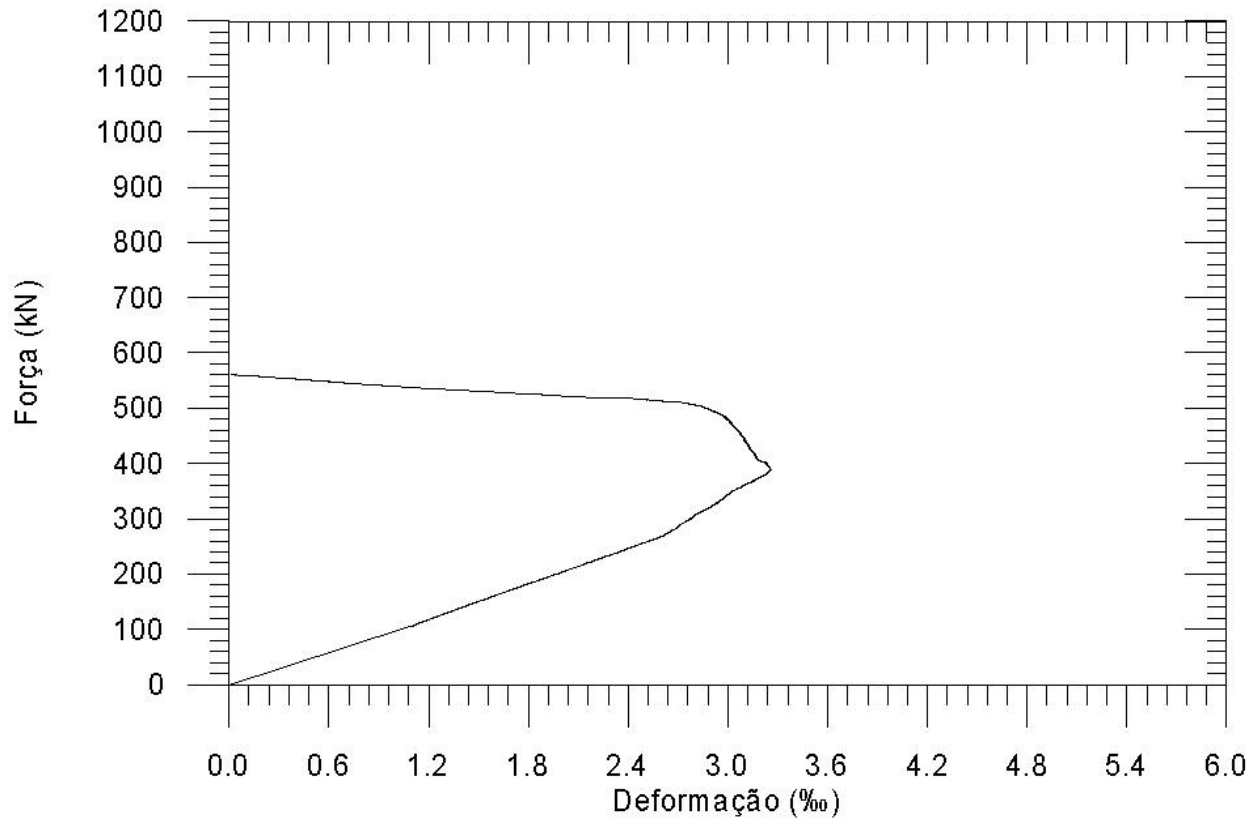

Figura B.60 - Diagramas força vs. deformação no concreto 


\section{B.13.Pilar P140}

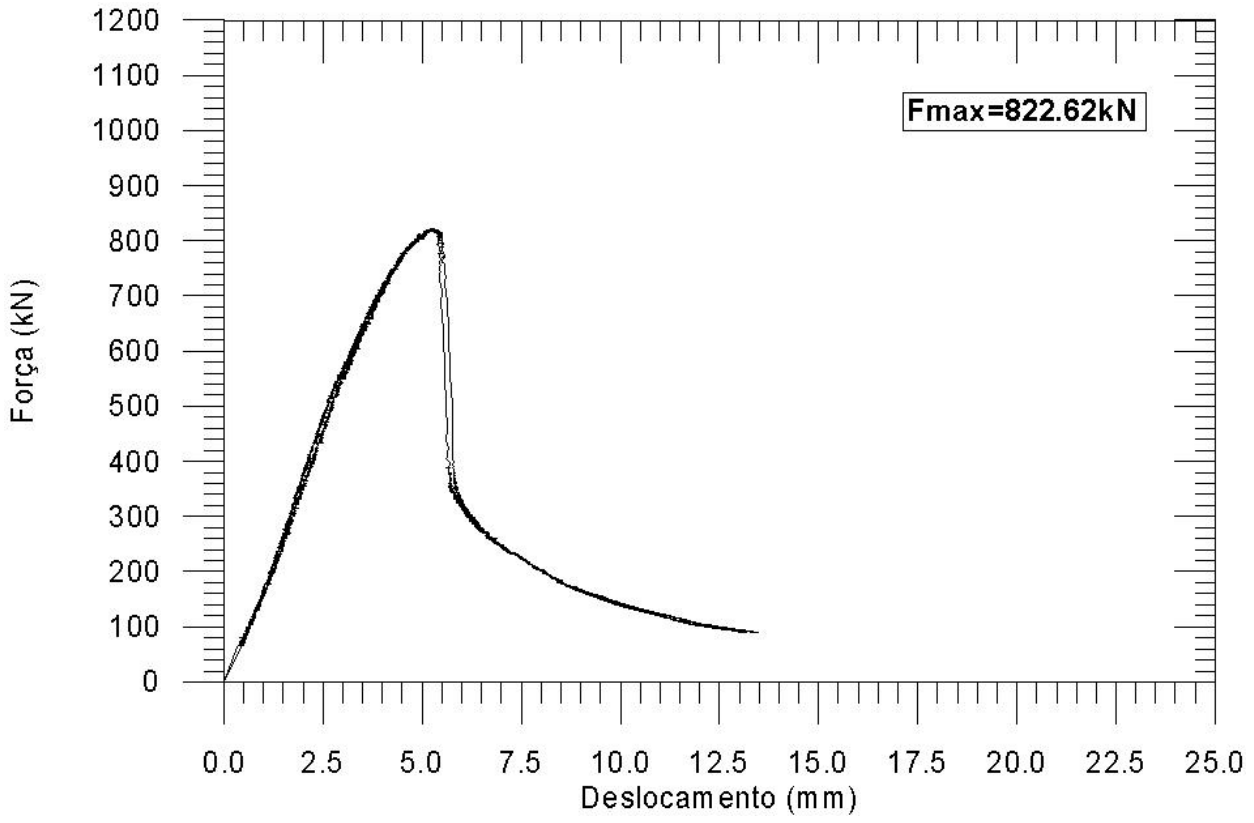

Figura B.61 - Diagramas forças vs. deslocamento vertical do pilar

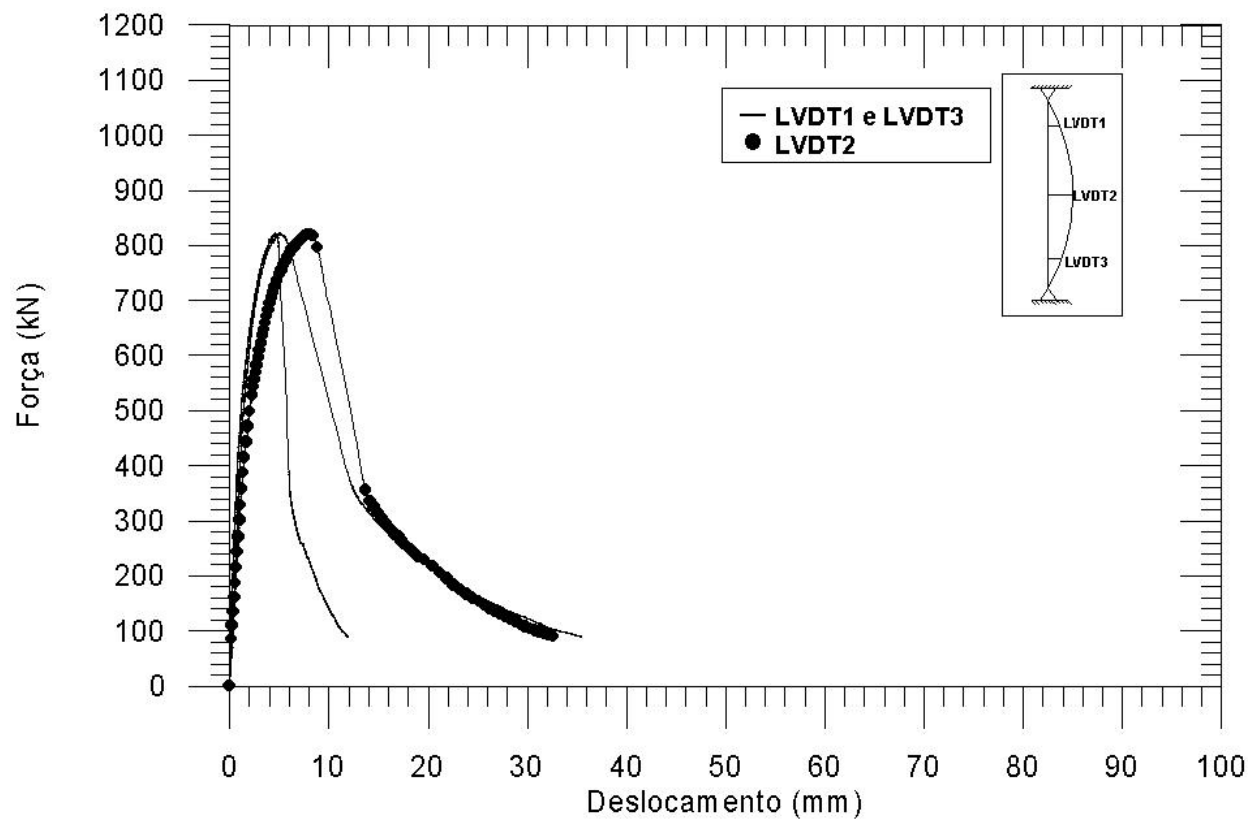

Figura B.62 - Diagramas força vs. deslocamento transversal do pilar 


\section{B.14.Pilar P240}

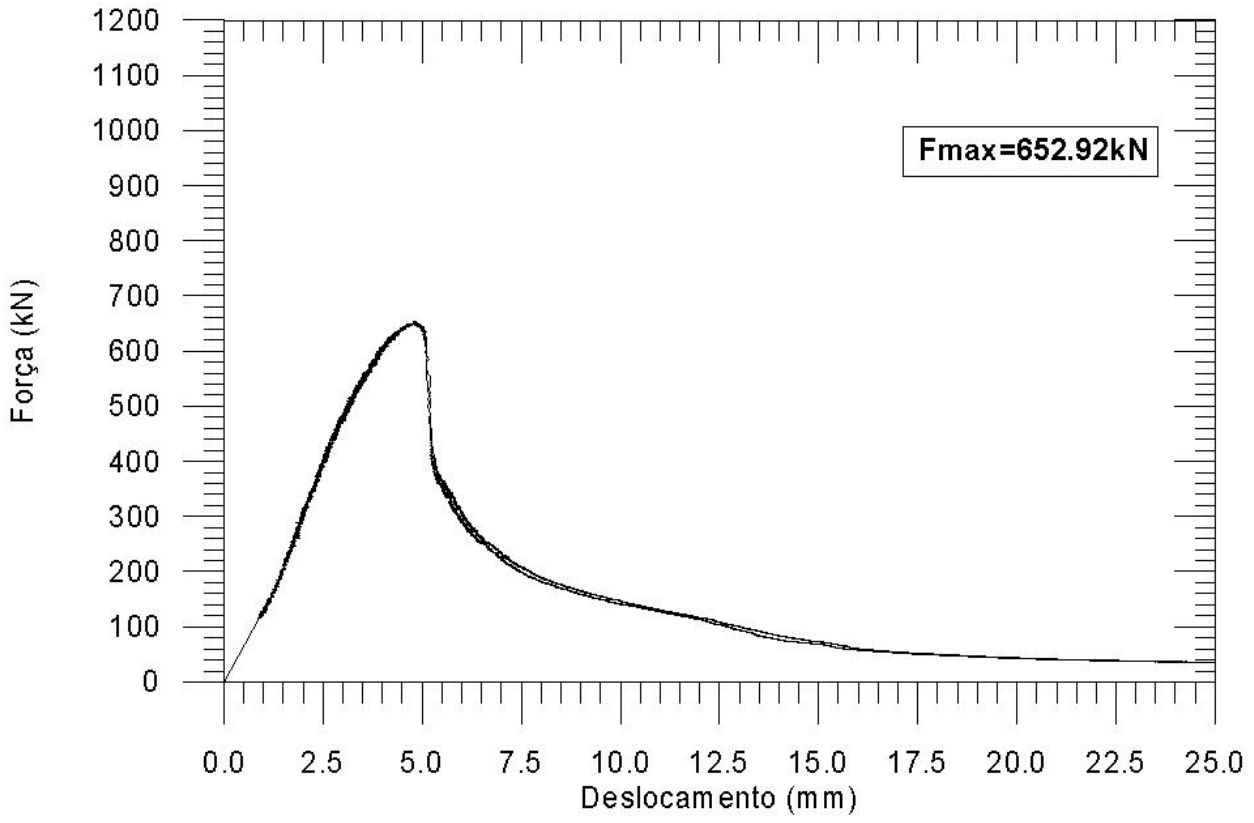

Figura B.63 - Diagramas forças vs. deslocamento vertical do pilar

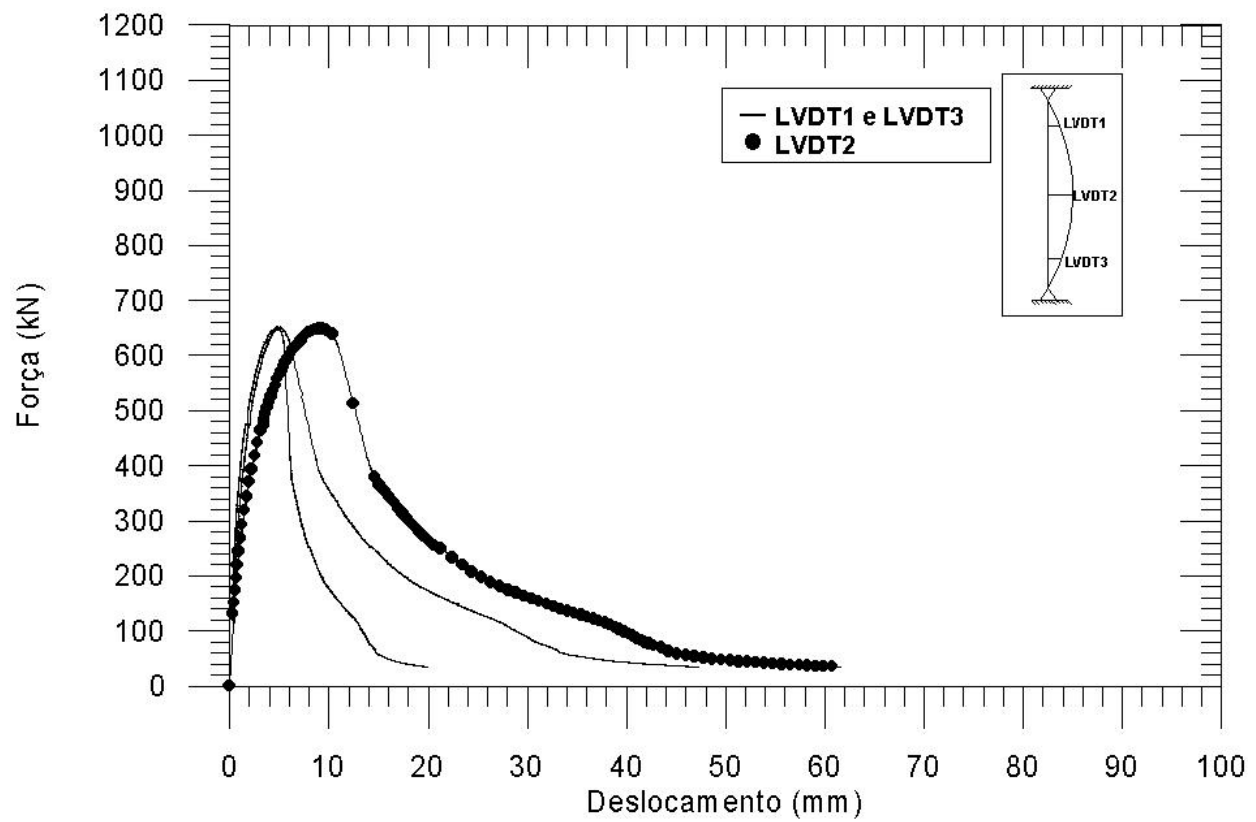

Figura B.64 - Diagramas força vs. deslocamento transversal do pilar 


\section{B.15.Pilar P340}

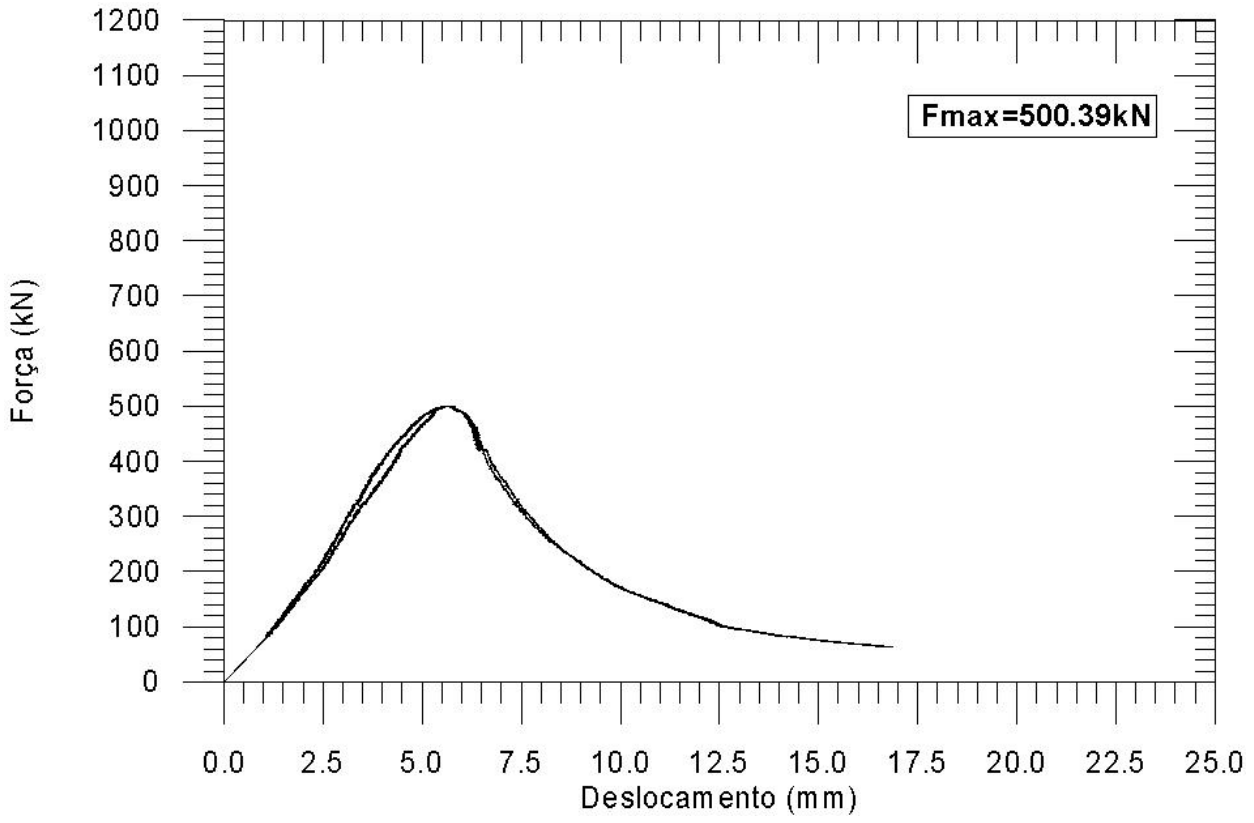

Figura B.65 - Diagramas forças vs. deslocamento vertical do pilar

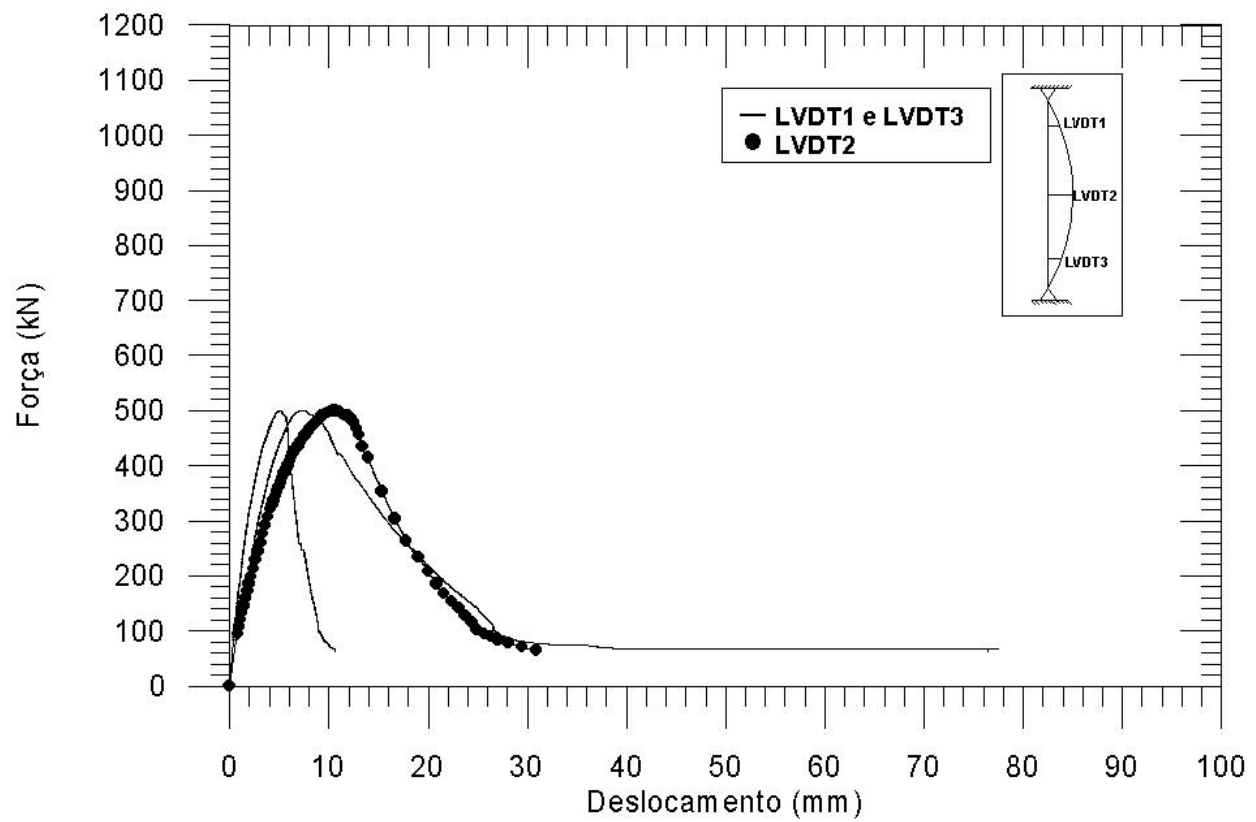

Figura B.66 - Diagramas força vs. deslocamento transversal do pilar 